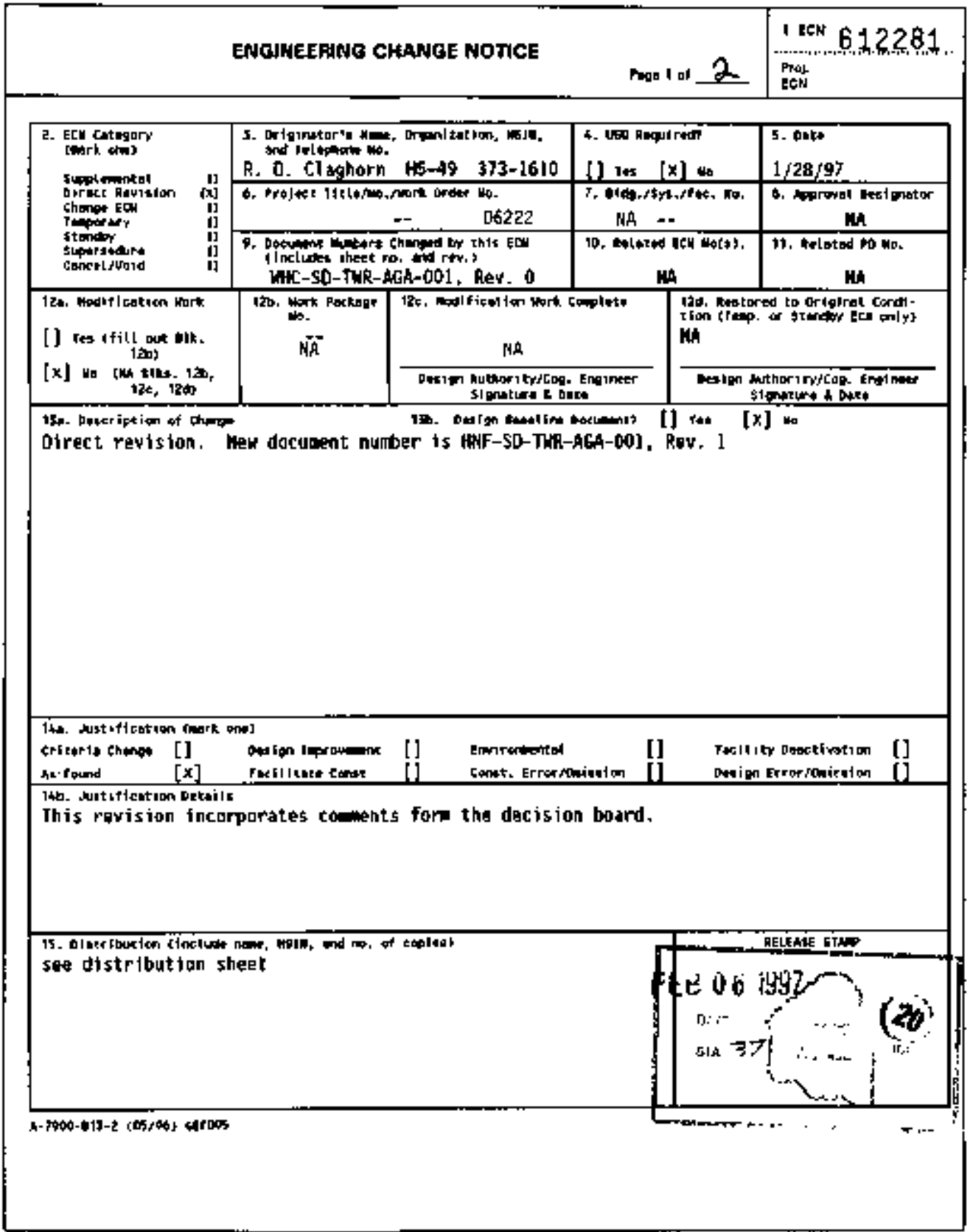




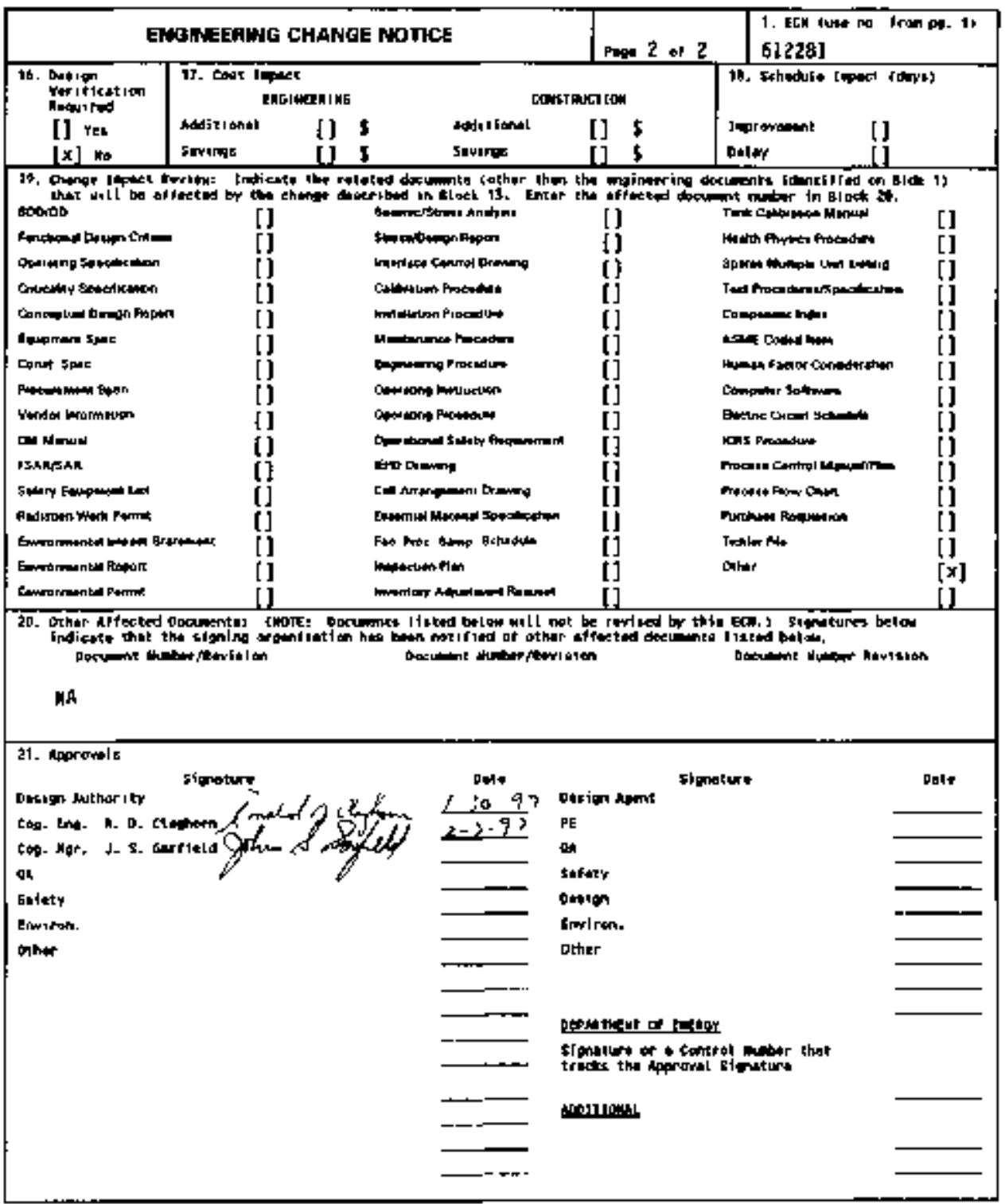




\title{
Alternatives Generation and Analysis for the Phase I Intermediato Wasto Feed Staging System Design Requirements
}

\author{
R. D. Cleghorn, J. D. Galbratth, and T. L. Salzano (Fow)
}

Mureatec Hanford Corgoration. Richland, wh 99352

U.S. Departent of Energy [ontract DE-AC06-96Rt-13200

\begin{tabular}{|c|c|c|}
\hline $\begin{array}{l}\text { ect J ECH: } \\
\text { Orp Code: } \\
\text { gak code: }\end{array}$ & $\begin{array}{l}\text { E12281 } \\
8 C 4] 0 \\
\text { Ers130010 }\end{array}$ & $\begin{array}{l}\text { WC: } 72 \text { ] } \\
\text { Charge Code: } \\
\text { Tota1 Pagos: }\end{array}$ \\
\hline
\end{tabular}

Key Mords: Alternatires Generation and Analysis, AliA, Systea besign Requirements

Mbstract: This alternatives generation and analys 1s (AGA) addresses the question: What is the destign basis for the fatilities required to stage low-level waste (LLW) food to the Phase I priyate contractors? hlernative designs for the intermed ate waste feed staging system wore developed, analyzed, and compared, Based on these analyses, this document recammends installing aixer pumps in the central pump pit of deuble-shell tanks 24J-AP-102 and 24]-AP-104. A150 recponmended is installing decant/transfer pums at the se tanks. These recommendalions have clear advantages in that they proride a low shedule impact/risk and the highest operabiłity of all the alternatives InvestIgated. This reuision incorparates toments from the dectsion board.

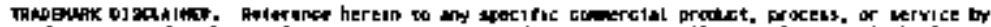

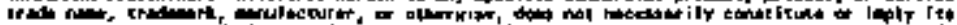

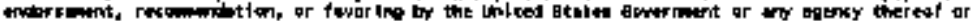
iza tontractars of mecancrietsis.

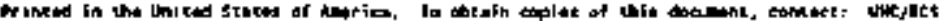

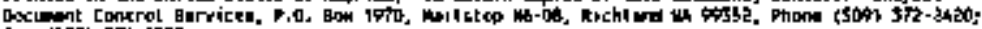

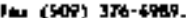
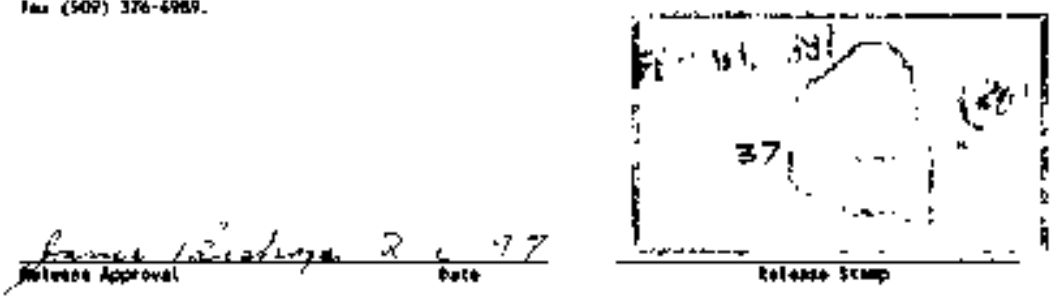

Approved for Publlc Reloase 


\section{RECOAD OF REVISIOH}

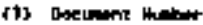

Faf-50D-TTR-AGA-001

Par 1

(2) Eitte

Alternat ives Goneration and Analysis for the Phase I Intermediate Waste foed staging Systęn Dęsign Requiromęnts

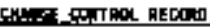

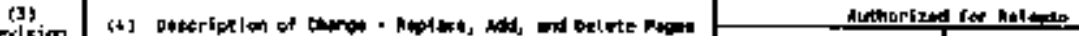

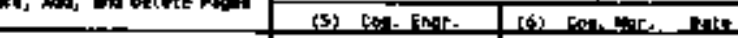

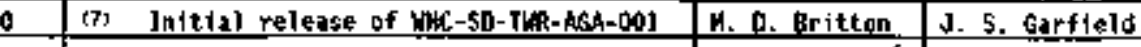

J

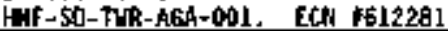


HINF-SD-TWR-ACA-00I

Revision 1

\title{
ALTERNATIVES GENERATION AND ANALYSIS FOR THE PHASE I INTERMEDIATE WASTE FEED STAGING SYSTEM DESIGN REQUIREMENTS
}

Jamarary 1999

\author{
R. D. Clagthon \\ J. D. Gtalirath \\ Nuntate Hanford Comoration \\ Richland, Washingonn \\ and \\ T. B. Salzano \\ Fhor Daniel Northwest, Inc. \\ Richland, Washington \\ Prepared for \\ U.S. Department of Energy \\ Richland, Washlngkon
}


Revision 1

\section{ACKNOWLEDGMENTS}

The authors would like to thank lise followitg couributors: $\mathbf{L}$. $W$. Shelion for deweloping the eslicuted feed batch compositions as iney exist in the intermediale waste foed thaging tanks, T. L. Welsh for determining the equations and developing the initial spreadshect on which the required numbet of samples is based, and M. J. Duchbherer for helping in the development of the sample analysis fequirements. 


\section{CONTENTS}

10 DECISION ANALY\$S \$UMMLARY

11 ALTERNATIVES GENERATION

12 CONCLUSIONS

I 2 I Eenefils of Solyds Entranument Coultrol al the Siaging Tank Versus at the Source Tanle

122 Bescfits of Buxung Versus Not Mixing

123 Bentefits of Muxer Pump Versus Pulsed-Aur Mixer

I 24 Benefits of Muxer Pumps On-Center Versurs Off-Cenler

13 DESICN REQUIREMENTS RECOMIMENDATIONS

14 DESION REQUUREMENTS DECISION

21 SOURCE DOCUMENTS 9

2 I I Tank Waste Rewedtamon System Prrwatisation Request for Proposals 9

212 Dectron Dacument for Phase I Prrvatization Trassfer System Needs 10

213 Lar-Level Waste Fat Shaging Plart

22 COMRONENTS OF THE INTERMEDIATE WASTE FEED STAGNG SYSTEM

22 I Dorable-Shell Tank Wasle Moblization Bysiem

222 I Waste Transfer System Under Domble-Shell Tantr Wuste Ręlneval

2222 Wabe Tartk Sysem Under the Tank Waste System

223 Waste Storage Syatem

224 Intcopated Iolrmedake Wagle Feed Suaging System \$ubsyblempg

30 CONSTRAINTS, REQUIREMENTS, AND ASSUMPTIONS

3 I INTERMEDIATE WASTE FEED STAGING SYSTEM

3 I I Intertrediate Wasle Feed Staging System, Constrants 17

312 Inicrmediate Waste Fred Staging System Requnrements 18

I 3 Inlermediate Waste Feed Staging System Assumptions 19

32 WASTE TRANSFER SYSTEM 20

32 I Waste Trangfer System Requirerments 20

322 Waste Trumster Syslem Assumpulons 21

33 MIXTNG SYSTEM 23

371 MLxing Sysitm Rtagunrements 23

332 Murug System Assumpilions 23

34 CHEMICAL ADDTTON SYSTEM

341 Chemical Addition \$ystem Requretpends 25

342 Chemical Addition System Assumpoints

35 SAMPLING SYSTEM 25

351 Sampling Sytken Requrements

$351]$ Modified Requer for Proposal Fead Envelopes 26 
352 Stamphing System Aggumptons 29

I 521 Projected Feed Batch Compossoons 29

3523 Esimailed Sampling and Analysis Verrabulity

3524 Confidence Level 35

I5 55 Sampltag Namber is

40 DECISION CRITERJA

41 COST 39

42 TECHNICAL MATURTY 39

43 MAJNTAINABILITY

44 OPERABILITY 40

45 SCHEDURE IMPACTIRISK

46 ENVIRONMENTAL MPACT

47 SAFETY 42

4. REGULATORY COMPLIANCE

49 PUELIC ACCEPTANCE 43

5 O DNTERMETYATE WASTE FEED STAGING SYSTEM OPTIONS AND

ALTERNATIVES GENERATION AND SCREENING

\$1 DNTERMEDLATE WASTE FEED STAGNO OPTIONS AND SCREENING

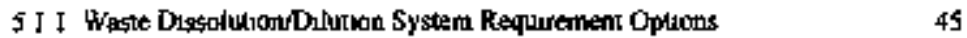

512 Waste Trensfer System Opuots 45

513 Intermedale Warte Feod Sraging Tanir Mixing Syslem Opueng 47

5131 No Muxung Optuon 47

5132 Polsed-Aur Options 47

5133 Mixet Pump Options

5134 Orher Optuens 48

514 Irtermedjale Wasle fted Staging Tank Samplung Syslem Opuons 48

52 INTERMEDLATE WASTE FEED STAGING SYSTEM AL TERNATTVES

OENERATION AND SCREENTNG

S2 I Alternative I 53

522 Alternatrue 2

523 Alternache 3

524 Alcemative 4

525 Altemative $5 \quad 55$

526 Aliemilitive $6 \quad 56$

527 Alternative ? 56

528 Allemalive 8

60 INTERMEDIATE WASTE FEED STAGING SYSTEM DESIGN CONCEPTS 59

6I WASTE TRANSFER SYSTEM DESIGN CONCEPTS

6 I I Intermeduats Wasta Feed Stageng Tank Soludt Entruartient Control

612 Source Tank Solıds Entrannent Control 61

62 MIXING SYSTEM DESIGN CONCEPTS

621 No Muxing Sysiem 


\section{HDF-SD-TWR-AGA-001}

Reveren I

622 Pulszod-Air Mixing System 62

622 I Degetiption 62

6222 Mentanabliyy

6223 Techripal Matunty 65

6224 Operabiluty 66

6225 Safely 66

6226 Cost 66

623 Mixer Pumprom-Ceqler 66

624 Mıxer Pump Ofr-Center 67

63 INTERMEDIATE WASTE FEED STAGINO TANK SAMPLING SYSTEM DESIGN CONCEPTS 67

63 I Grab Sampling Method 67

632 Core Sampling System

633 Jsolok-Type Samplitis Systern 68

64 INTERMEDIATE WASTE FEED STAGING TANK CHEMICAL ADDITON SYSTEM 68

70 TNTERMEDIATE WASTE FEED STAGING SYSTEM ALTERNAHYE EVALUATIONN AND ANALYSIS

71 COST

72 TECHNICAL MATURJTY

73 MANTAINABILITY 72

74 SAFETY

75 OPERABILITY 73

76 SCHEDULE MMPACTINISK

77 ENVIRONMENTAL IMPACT 76

7 R REGULATORY COMPLIANCE

79 PUELIC ACCEPTANCE

B D OPEN ISSUES AND ACTIONS

90 REFERENCES 


\section{HNF-SD-TWR-AOA-UNI}

Revigion I

\section{APPENDIXES}

A - MLXNG SYSTEM ALTERNATIYES GENERATION AND ANALYSIS , ... A-I

B - SAMPLING SYSTEM ALTERNATVES GENERATION AND ANALYSIS . . . B-I

C. VENTILATION ANALYSIS REPORT $\ldots \ldots \ldots \ldots \ldots \ldots \ldots \ldots \ldots \ldots \ldots \ldots$

D - WASTE TRANSFER SYSTEW ENGINEERING REPORT , . . . . . . . D.I

E - PULLED AIR VENTLATTON ANALYSIS LETTER REPORT , . . . . . . . . . E E-I

F • SAMPLING SYSTEM ANALYSIS $\ldots, \ldots, \ldots, \ldots, \ldots, \ldots, \ldots, \ldots$, F-I 


\section{HNF-SD-TWR-AOA-0OI \\ Revision 1 \\ LIST OF MGURES}

1-1 Intermedıate Waste Foed \$laging \$ystem Alternaluves 2

2-1 Tank Waste Remedianon System Phase I Ptivaluziuon Waste Feed Stagumg System I]

2.2 Anchutecture Tree wilk the Phase I Pryauzation Imermediate Waste Freed Stagugg \$yslem

5.1 Indemediate Waste Feed Staging System Subsystem OpHons 50

5-2 Internediate Waste Feed Staging System Alremalluves 52

6.1 Prylsed-Aut Muxing System 64 


\section{HNF-SD-TWR-AGA-DOI \\ Reviswa I}

\section{LIST OF TABLES}

[-[ Intermediale Waste Feed Stagiag System Altematues Decuscon Cntena Mainx

3-L Source Tanks for Phase I Pryvatizalion Feed Envelopes

3-2 Modtied Request for Proposals Enwelope Maxumum Concentralions

3-3 Medified Requesı for Proposal Feed Enyehope B Mınmum Cniena

3-4 Modrfied Request for Proposal Feed Envelope C Marumum Crrtera

3-5 Projected Intermediale Waske Feed Staging Touk (A. -102) Feed Batch Sodnum Ratros for Privace Contractor I o Percent Entrauted, Insoluble Solnds

3-6 Projected Jnkemedlate Waste Feed Sugging Tank (AP-104) Feed Bach Sodium Ratsos for Pnvate Contratior 2 O Petcenl Entrained, Insolubte Soluda

3-7 Ptopected Intermediato Wagte Feed Stagng Tank (AP-102) Feed Batels Sodiuth Ratios for Pnvale Contrater 1 I Percent tentramed, Insolubles Solrds

3-B Propected Inlermediale Waste Feed Staging Tank (AP-104) Feed Bath Sodium Ratios for Private Coptractor 22 Percent Entraıned, Insoluble Solrds

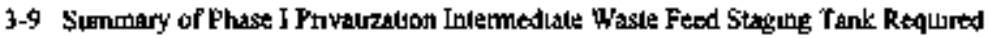
Samples with D Pertent Enttained, Inson[ub]e Sollds

3-E0 Summary of Phase I Pryalizauon Intermedtale Waste Feed Slaging Tank Requered Samples whth 2 Petceat Entrainted, Insoluble Solidt

4-1 Stokeholder Values

5.I InIermeduate Waste Feed Staginy System Alternaluves

6-I Combined Coustruction Cost of Waste Transfer ard Muxung System Coscepts 
HNF-SD-TWR-AOA-001

Revisuon 1

GLOSSARY

\begin{tabular}{|c|c|}
\hline $\begin{array}{l}\text { Abbreviation, Acromye, } \\
\text { or Tern }\end{array}$ & Correspendlng Term •r Deflnitoan \\
\hline ADA & Aur Delıvery Assembly \\
\hline ADMP & Advanced Design Mixer Pump \\
\hline$A G A$ & Altermadues Generatuon and Analyoss \\
\hline ALARA & As Low As Reasonably Achievable \\
\hline ALC & Alr Lift Circulator \\
\hline COR & Conceptual Dessgn Report \\
\hline Causlic & Soxhuar Ifydrơkide \\
\hline Constratni & Exlemilly imposed requirements \\
\hline Conuractorș" Tanks & $\begin{array}{l}\text { The DST tanks given over to ihe private contractors for use us } \\
\text { feed staging tarks in their processes }\end{array}$ \\
\hline DAP & Double Accumulator Plate \\
\hline DecantTransfer Pump & $\begin{array}{l}\text { A deep-well turbune tratsifer pump with an untake al ath } \\
\text { adjustable height (stmilar to the W-151 desga') uged to decant } \\
\text { wagle from DSTs }\end{array}$ \\
\hline Detrment & Cost of exposure \\
\hline Dilution Factor & $\begin{array}{l}\text { The ratio of the staged feed volume to the ongegnal volume of the } \\
\text { waske before retneval }\end{array}$ \\
\hline vQO & Data Quality Objective \\
\hline DST(s) & 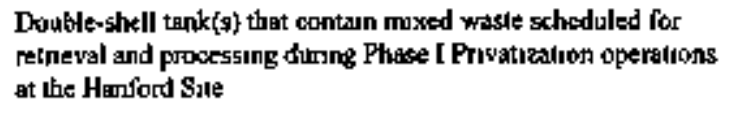 \\
\hline Exabling Assumption & 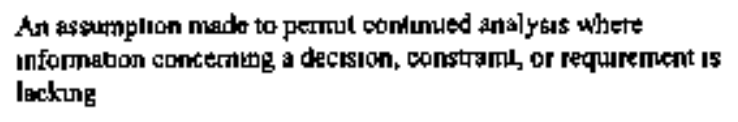 \\
\hline Eqn & Equation \\
\hline F\&R & TWRS Fumctions ard Requmements Dacuprent (Carpenter 1496) \\
\hline Feed Envelope & See Modıfied RFP Feed Ervelope \\
\hline
\end{tabular}


HNF-SD-TWR-AGA-00I

Revison I

GLOSSARY

\begin{tabular}{|c|c|}
\hline $\begin{array}{l}\text { Abbreviaton, Acronyn, } \\
\text { pr Tere }\end{array}$ & 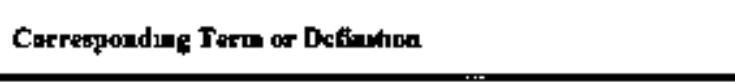 \\
\hline $\begin{array}{l}\text { Fuxed-istake Transfer } \\
\text { Punip }\end{array}$ & $\begin{array}{l}\text { A deep-well turbine pump wnth an untake al a fixed height used } \\
\text { to trangfer waste oux of a tank }\end{array}$ \\
\hline glbtopic & Sodrum Aluminste, $\left(\mathrm{NaA} \mid \mathrm{O}_{3}\right)$ \\
\hline Goco & Goyemment Ohwned $/$ Contriclor Operated \\
\hline HEPA Filler & Hugh-e[Fictenty particulate att filter \\
\hline Henford Sike & $\begin{array}{l}\text { The Department of Encrgy"g puclear site located North of } \\
\text { Ruchland, Washingion }\end{array}$ \\
\hline HEW & Hoghelevel hasie \\
\hline HVAC & Heating Venulation, and Aur Conditianang \\
\hline Insoluble Solrds & 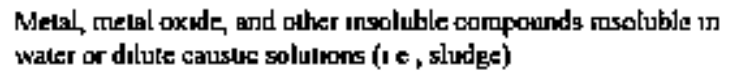 \\
\hline Iwhss & Intermediate Waste Feed Staging System \\
\hline IWFST(s) & 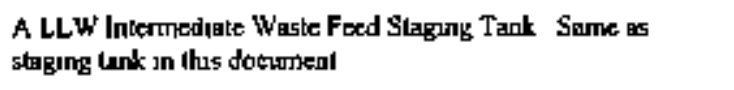 \\
\hline L.AW & Low-activity uaste \\
\hline LLW & Low-level waste \\
\hline Mixer Pump & A 300-hp pump used to mobilize solids and mix watre in DSTs \\
\hline $\begin{array}{l}\text { Mothied RFP Feed } \\
\text { Envelope }\end{array}$ & 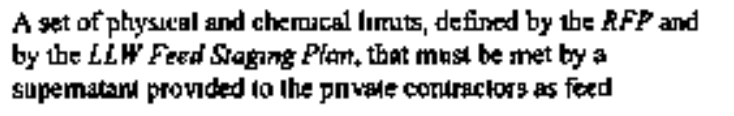 \\
\hline NGTP & New Generation Trangifer Pump \\
\hline Not-mixed & $\begin{array}{l}\text { An 1WFST mixung scenano in which the feed betch is not mixed } \\
\text { and potentally houg stratified supernatsmt layers }\end{array}$ \\
\hline OSD & Opesational Safely Document \\
\hline OSR & Operationsl Safety Requurenen! \\
\hline owvs & Operatknal Waste Volume Projection \\
\hline
\end{tabular}


HNF-SD-TWR-AOA-001

Revision I

GLOSSARY

\begin{tabular}{|c|c|}
\hline $\begin{array}{l}\text { Abbrevintion, Acronym, } \\
\text { or Term }\end{array}$ & Corresponding Term or Definilion \\
\hline Phase 1 & $\begin{array}{l}\text { The first portion of the TWRS Privalization during which a } \\
\text { proof-of-encepe demonstation is performed and additional feed } \\
\text { is processed using rejatively small-scale frocessing facilities. }\end{array}$ \\
\hline Phese II & $\begin{array}{l}\text { The final portion of the TWRS Privalization during which full- } \\
\text { scake production facilities tre operated. }\end{array}$ \\
\hline PHMC & Project Haniord Managertient Contractor \\
\hline PLC & Progerammable Lagic Controller \\
\hline PNNL & Pacific Northwest National Laboralory \\
\hline Privale Contractor(s) & $\begin{array}{l}\text { Private companies involved is the Phase I Privatization whe afe } \\
\text { contracted to constract end operate a LAW immobilizalion } \\
\text { faciliry at the Hanford Site. }\end{array}$ \\
\hline Privalization & 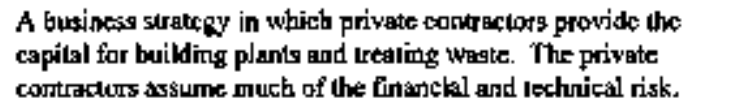 \\
\hline PSAR & Preliminary Safety Ansilysis Report \\
\hline RCRA & Resource Conservation and Recanery Act of i 976 \\
\hline Requirement & Internaly imposed timitg. \\
\hline$R F P$ & TWRS Privalizarion Request, for Propasals (DOE-RL 1996) \\
\hline RRSTD & Sodium Rationd RSDs \\
\hline RSD & Relative Standard Devistion \\
\hline Sampling Number & $\begin{array}{l}\text { The sumber of ganpies required to valfdate that a specific batch } \\
\text { meets the feed envelope citetia. }\end{array}$ \\
\hline Settled or Settleabje Solids & Solids that will setale to the bottom of Une lanks. \\
\hline Simplifying Assumption & An assumption used to make calculations or analysis eagier. \\
\hline Sodium Ratio & $\begin{array}{l}\text { The ralio of a chemical camponent concentration (jn } M \text { ) or } \\
\text { rationuctide concentration (in } B q L \text { ) to the sodium } \\
\text { Coskentration (in . M). }\end{array}$ \\
\hline Salida Entrainment & $\begin{array}{l}\text { The entraianent of sented sulids durlng relrheval and transfer } \\
\text { from the source tanks or Iransfer from the staging tanks. }\end{array}$ \\
\hline
\end{tabular}


HNF-SD-TWR-AOA-001

Revision I

GLOSSARY

\begin{tabular}{|c|c|}
\hline $\begin{array}{l}\text { Abbreviation, Acrouym, } \\
\text { or Tarm }\end{array}$ & Corresponding Term or Definithon \\
\hline Soluble Solids & $\begin{array}{l}\text { Solids that cant be dissolyed in water ot dilute caustic soluliong, } \\
\text { primarily sals of sodjur. }\end{array}$ \\
\hline Sortice Tarks & $\begin{array}{l}\text { DSTs contaiving wasle to be retrieved and uscd ag foed duripg } \\
\text { Phase I Privatianlion operations }\end{array}$ \\
\hline Staging System & Intermediate Waste Feed Staging 5ystem or IWFST \\
\hline Stasiding Tank & A I.LW' Intemediate Waste Feed Staging Tank or IWFST. \\
\hline \$iat Ratio & $\begin{array}{l}\text { A measure of the proximily of the component's sodium ratio to } \\
\text { feed envelope limit. }\end{array}$ \\
\hline Stratified Layers & $\begin{array}{l}\text { Two or wowe supernatantg with different densities and chenical } \\
\text { compositions which cause them Io loot one on top of the other } \\
\text { wilhoul apprectable mixing between the layers. }\end{array}$ \\
\hline TBD & To Bo Detemuined \\
\hline TECC & Total Estimaled Construcion Cost \\
\hline ТС & Total Inorganic Cacton \\
\hline TOC & Tolal Organic Carbon \\
\hline Tranguranic Radiomuclides & All the itolupes of americium, plutosium, and neptuxium. \\
\hline TRU & Sec transuranic radiomeclides \\
\hline TWRS & Tank Waste Remedialion Systems \\
\hline USQ & Unretulvad Safedy Question \\
\hline Well-mixed & $\begin{array}{l}\text { An IWFST mixing scenario in which the feed batch is mixed } \\
\text { until homogeneous }\end{array}$ \\
\hline wk & Week \\
\hline wTS & Waste Transler Syster \\
\hline
\end{tabular}




\section{ALTERNATIVES GENERATION AND ANALYSIS FOR THE PHASE I INTERMEDIATK WASTE FEED STAGING SYSTEM DESIGN REQUIREMENTS}

\subsection{DECLSTON ANALYSIS SUMMARY}

Thus alternaluwes generalkon and analysis (AGA) addregses the quesinon what ws the detrign hasss for the fachlites requrred' to stage low icurl waste (LLW) feed so the Phase I private comirestors?

Followng the grategy laud out by the LLW Feed Shaging Plan (Certa et al 1996), the Doubie-Shell Tatlk (DST) Waste Retrevial System and the Tank Wask \$ystem will wark logether as a sngle systers to stage batches of LLW For bie purposes of thes study, the combuned systems wll be referred to as the Intermediate Waste Feed Suagng System (IWFSS)

\subsection{ALTEKNATIVES GENERATION}

The IWFSS is mespopsshie for racelving waste from the retrevat finciton, staging the retreved waste in batches, and transfernng these feed batches to the private contractors The IWFSS uill use only some of the components of the DST Waste Retreyal Systern and the Iank Waste System The subsystems under the DST Waste Reirjeval Bystem are the DST Waste oblyzations System (jaixers and dissolution'dihulion equpment) and the DST Waste Transfer Sygien (trangfer pumps) The subsysterns of unterest under the Tank Wade Syster are the Waste Transfer Sysiem (transfer pernps, pts, and transfer Itnes), the lniermedtale Waske Ferd

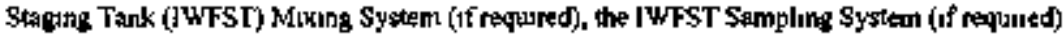
and the IWFST Ventilatuon System

The issuces and options for these systems affect each other, in perticular, the IWFST

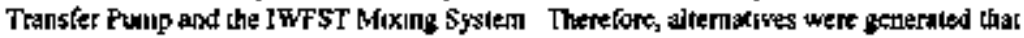
represent the corobinations of optrons for tha transfer purmp and the mixug system To rach of these alternaluves, the most apjroptiale opteons for the valve pit and the sampling and veobletron systems were added Fugure 1 - I shoms hout the optrons for these systems fit togetber inta the aliernatuves

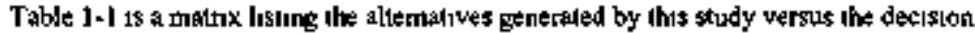
critena Ths table summanzes the differences betweer the aliemanves 


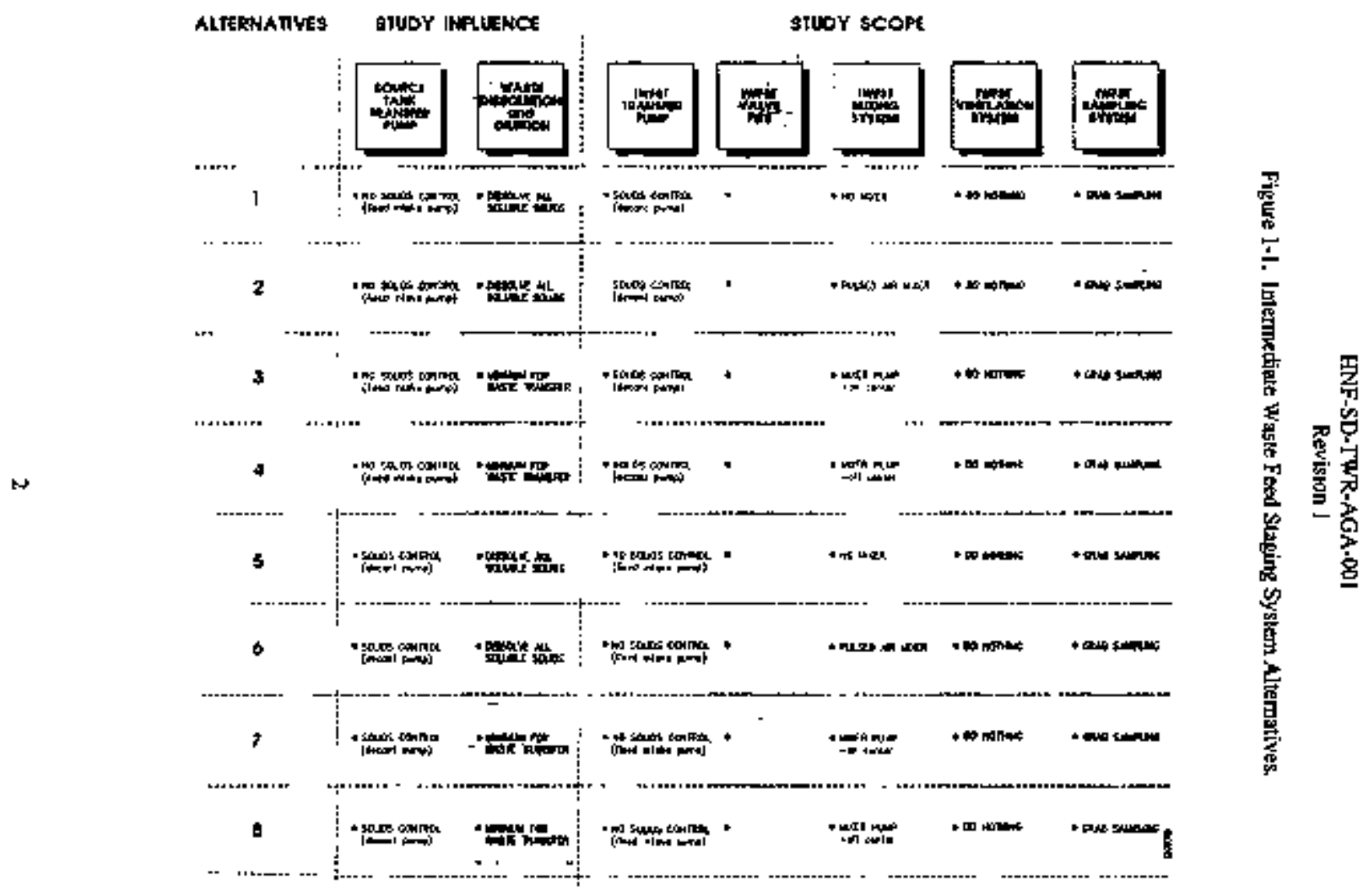




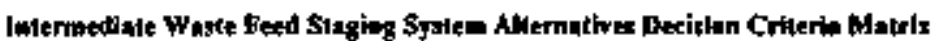

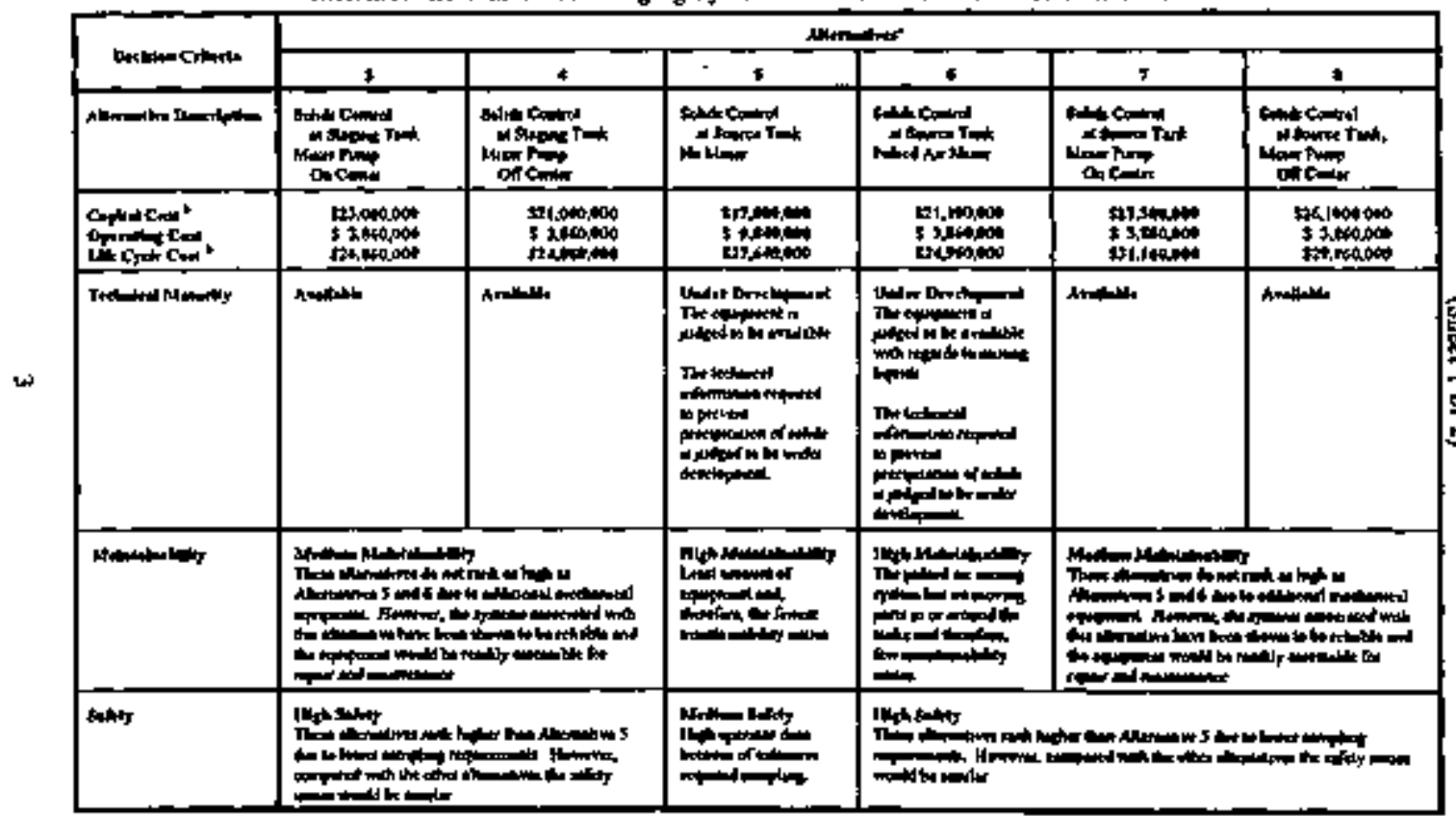




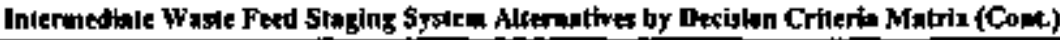

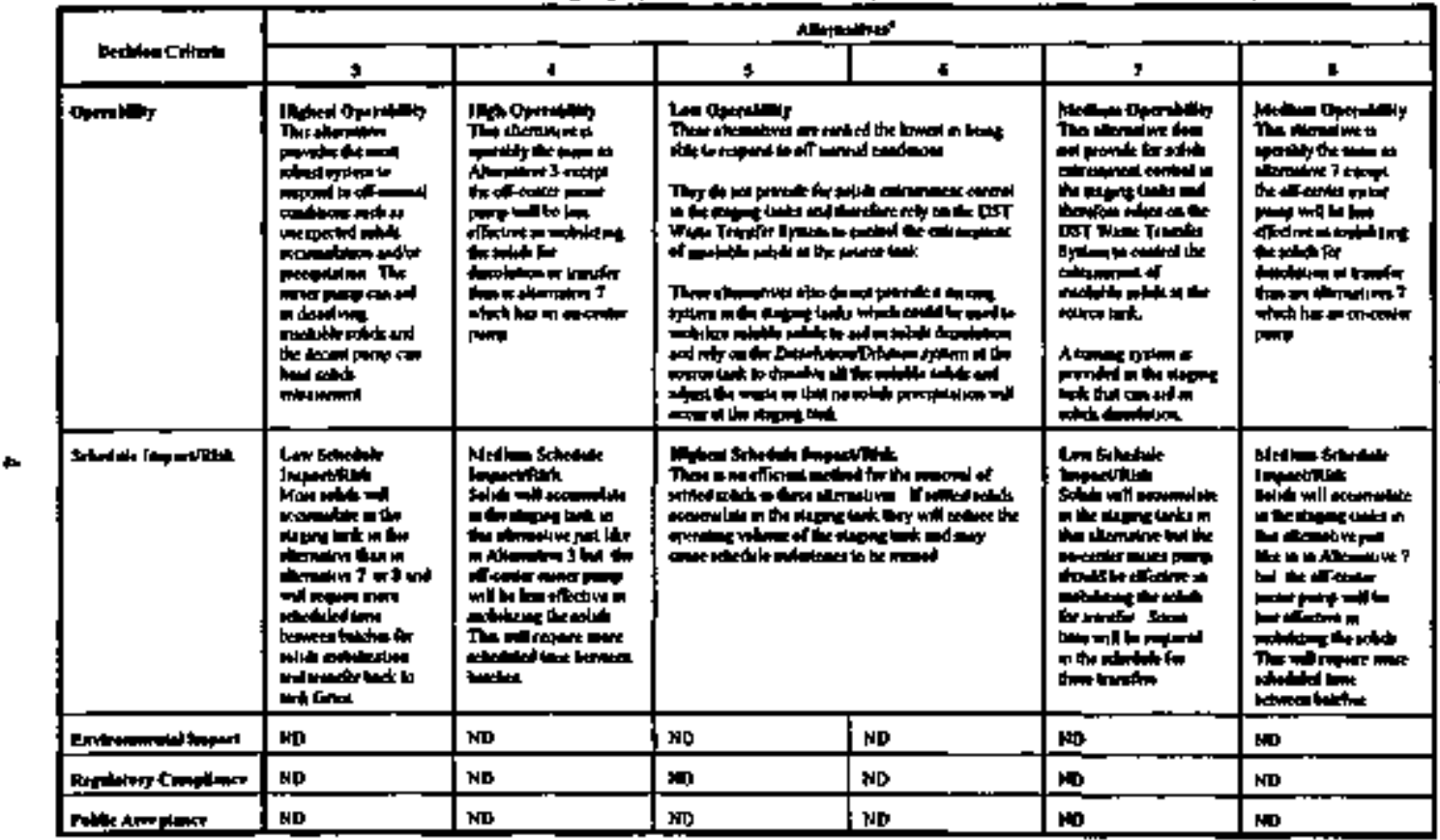

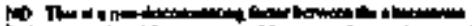

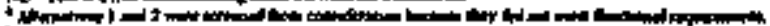

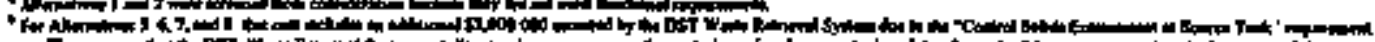

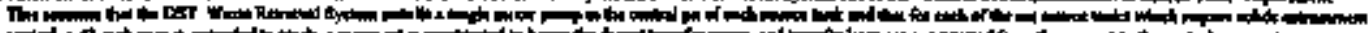

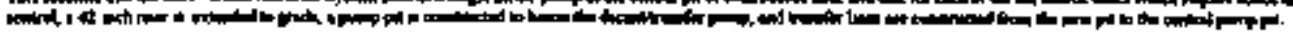


HNP-SD-TWR-AGA-OOI

Revision 1

\subsection{CONCLUSIONS}

\subsection{Bewexts of Balids Entruinment Contral at the Stzaing Tumb Verbis di line Source Tank}

A termalives 3 and 4 place control of solids entrainmenl at the staging IBrk, whereas alternalives ? and 8 have the solds entrainment control at the source lank Becmuge of this, Altermeliyes 7 and 8 ean't control the tojlowing:

- Soluble gofids ( $\mathrm{sa} / \mathrm{s}$ ) that wore not digsolved during retrieval and trans Tet or that precipitated while in the staging Iank.

- Insoluble solids unialeptionslly entrained with the retrieved supentatint andior supernatanl glumicg.

- Seftleable, disoluble solids released from the inclusions of salt crystals that were urasferred to the staging tank before dissolution.

Alterwalives 3 and 4 have the advaniage that they dan control all of these salids. Alsa, with Altermalives 1 and 4 , there is always the aption to additionally control solids eatrainment at the source tank. This can be determined on a tank by tank basis.

Fot ATternatives 7 and 8 , the cos includes an additional $85,100,0,00$ iscured by the DST Wato Retrieval System due to the "Conurol Solids Entrabment at Source Tank" requintment. This assumes that, fot etch soute lank requiting \$lids entraianicnt control, the DST Wasie

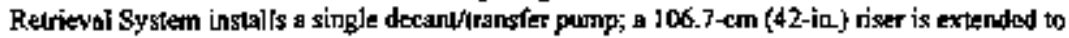
grade; a pump pit is constructed to house the decant/ransfer pump; and transfer lines are constructed from the new pit 10 the central pump pil. This assumption makes Allemative ? \$2.2 million more expensive than Altemaive 3 and Aliemative $\$ \$ 3.0$ millian mote expensive than Altemative 4. This assumption makes Altemalive $7 \$ 4.3$ milion mort expensive then Alemalive 3, and Alternative 85.1 million more enpensive than Altemative 4. Without this assumption, Allemative 7 is $\$ 0.8$ million chespet than Altenkative $I$ and Alternatives 4 and 8 $\cos$ the saute.

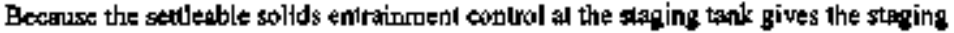
system a highter opperability and a lower cost, it is reconnmended thal the contral of gettroable solids entraltument be placed on the stogimg tanks.

\section{2 .2 Benefics of Mitring Venus Net Mixing}

Alternative 5 (co mixer) is the only allemstive where a mixing mystem is aot put is the staging tarks. The capital cost tor a mixer pump on-center, a mixer pump off-tenter, and a 
HNF-SD-1'WR-AGA-0 O I

Rerision 1

pulged-ayr \$y5dem are $\$ 67$ mellion, $\$ 64$ mallon, and $\$ 55$ million, respeci|vely (see

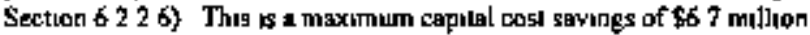

If the thoged waste as not actryely moxed, the assumption of homogenerty cannot be mide and the number of samples requited to viludate the feed bach incresces The thereased

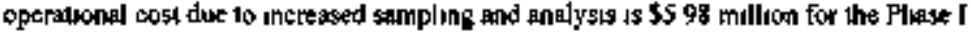
operalkonal period (sce Tabla ?.I)

The maxımum capital cost savings of not ustalling a mixet pump system is nearly offist by the increased operational cost for increaged sampling Problems with settled solıds

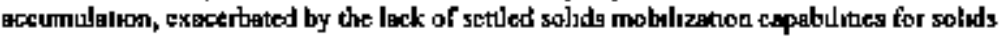

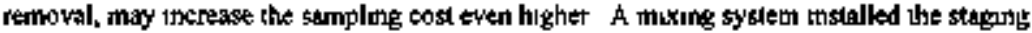
lanks for Phese I could also haye the same kind of operalional cosi savings durug Phase II Also, because of the increased sampling, operator doses recetved are higher

Bectuse mixing the slaged wasle prorides the staging system with highter aperabilily. lower schedule impactirisk, and highet safery, mixing the staged waste is recommended

\subsection{Bonefite of Mree Panp Vernut Pulsed-Air Mititr}

In conirast to Aliemadıves 3, 4, 7, and B, Altemative 6 instal]s a single 9] 4-cm (36-in) pulsed-aix mixer भा the saging lanks The nperabilsty of this allemague is rectured because the pused-aur muxer bas not been demongtraled to be ceppoble of mobalung setted solide, whuch makes it more difficult to femove the setted soljds Also, the pulsed-air mixing system cannot be used to mobilize goluble sol]ds 10 ard in solids dissoludion and mugt rely on the Drssolutoon/Dilubon System al the source tark to dissolve all the soluble solıde and adjust the waste co tha so sobds precipitation sill occur at the stagug tank The techneal unformatoon to do the is not sturently ayalable bul us under development

These is a capilal cost savinges rssoctaled with the polsed-atr muxer in the stagng tanik ralher than a muxer pump The pulsed-air mexer is $\$ 12$ millon find $\$ 09$ mullon less expen, ive

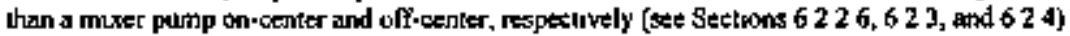

Because of the uncreased operabuluty and decreased schedule impactask the muxer punps

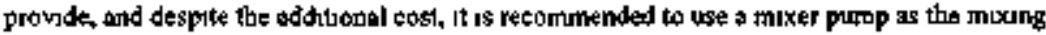
systemk in the siapneng tank

\subsubsection{Bedeflts of Mixer Puaps On-Center Versus Off-Center}

Altemaluyes 4 and 8 are nearly ddenilcal to Alremauves 3 and 7, respectively, excepl that

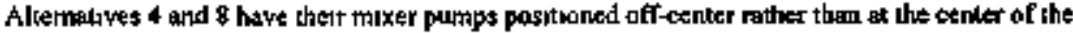
lank the could dramatically Jeduce the atagug system's ability to effectively mabiluze the

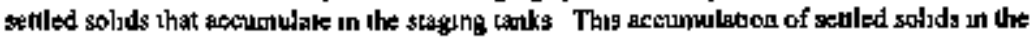


saging tank will be most pronounced in Alkmairyes 3 and 4 where the endrannedt of solds is not coutrolled at the source tank

The only benefit of hevirg the mixer pumps off-center ig a decreaged cust (cospulal) of $\$ 20$ millian between Alternitives 3 and 4 and $\$ 12$ mulien between Altematives ? and \& (see Sections 6226,6 23, and 624) Because of the uncreased operability and decreaged schedule impaxtinsk, usıng on-sedier mixer pumpts in the stadying tanks is recommended

\section{DESIGN REQQUIREMENTS RCCOMMENDATIONS}

Aliernativa 3 is the recommended alteniative It theludes the following

- Solids entrannrient control at the slaging lamk

- A mixing system (roiher than no muxing system)

- A mixer purno (ralher than a pulsed-aur mixar)

- An on-center muxer purap locatıon (rather then off-cemier)

Clear advaniages to thus allemalite ate that it has the following

- Highest operabslity

- Low schedule impactinsk

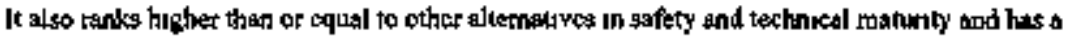
cost just above the average

\section{A DESIGN REQUIREMENTS DECTSION}

This docuraent does not contan a decision on thes system A netw dectson boerd will be convened in fiscal year 1997 to make a dectsiton 
HNE-SD-TWR-AGA-OOI

Revision I

This pase inkentrondly left blank 
HNF-SD-TWR-AGA-C01

Revistón I

\subsection{PROBLEM STATEMENT}

This AGA process addrestes the following question:

What is the desien thasis for the facilities required to stage LL W feed to Phase I priyate coniractors?

The term "Fhate I private conteactors" refers io DOE's two-phased approach to the remediarion of Hanford'g tank waste. The Tank Waste Rentediatlon Systew Mistion Analysis (WHC 1996d) gtates that the mission of the Tank Weale Remedialion System (TWRS) is to merrage and immobilize for dispasal Hanford adiodeclive waste in a safe, costeffective, regulatory compliaul, and environmentally sound manner. The physical systems required in perform the mission will be scquired through a combination of privaleby-ownedropesated and

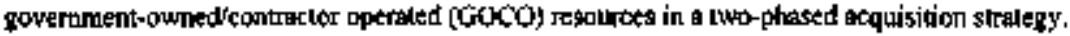
During the first phase, GOCO resturces will sigge waste from DST as feed to the twe private conlraclars. The ptivale contractors will then demonstrale pretreatmenl of the LLW by separatiog radiomuclides from the waste liquids and then irmmobiliziag the resulting low-activity wraste (LAW).

\subsection{SOURCE DOCUMENTS}

Section 3.0 provides detalls on the constraints and assumplioas used for this andysis. To elaborale on the problem statememt given above, this section will review the upper-lesel

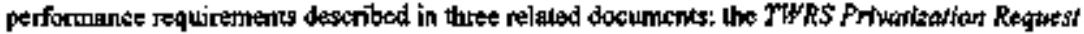
for Proposals (RFP) (DOEE-RL 1996), the Decition Docunent for Phase I Privatization Fransfer Syatery Needs (Gelbraith el al. 1996) and the LLW Feed Sraging Plan (Cerla el al I996). The significance of each of these doetuments it diselossed below.

\section{1.l Tank Weste Remediotion System Prinotization Request for Proposts}

The TWRS Privatization Request for Proposals (RFP) (DOE-RL 1996) identifies the gervices thal DOE will provide to the private LLW ireament condracters. Thds AOA specifically adtireses the development of destght reguirements for a system that will enable DOE 10 stage suffictent quantities of wasle feed and prowide composition information before transfer to the privalo contuactors. In ascondance with the ARP (DOE RL 1996), operotiont control of DST 241-AP-106 and 241-AP-108 will be transferred to the privale contractors for their use as feed lanks (coutractors' tanks). 
HNF-SD-THR-AGA-0OI

Revision 1

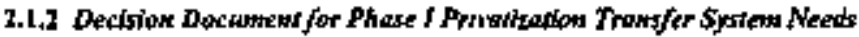

The LLW feed Slaging Pian (Ceria et al 1996) recammended usung the Ipdiroc \$laging As Soon As Possible siaging strategy that requires mo imemediate waste feed tlaging lankg (IWFSTs or staging tanks) The term "intermediote" refers to the Jact that DOE will use these

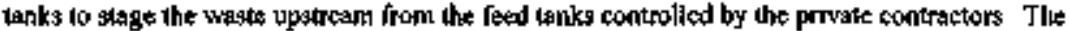
LIW Feed Saging PJon (Cerla et al 1966) also recommended using DST 24I-AP+102 and 241-AP+104 as the stinging tanks The decision to arocept the recommended stralegy ind use 241-AP+102 and 241-AP-F0d as the slaging latks is documented in Decsion Document for Phase 1 Pinvatı zarıon Transter \$y5tem Needs (Galbratth et a| [996)

\subsubsection{Low-Level Wavie Feed Staging Plan}

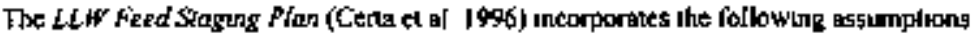
regarding the proposed intermediste watsle feed slaging system

- The DOE, as repregepled by the Project Hantord Managereat Contractor (PHMC), wall demorgtrate that the delivered waste mests the composuliontal fead envelope

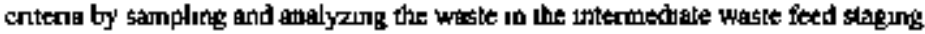
tanks

- The samples axd the analysus of waste in the intermediale singing tanks will also satasfy regolatory requirements (if any) imposed on the PHMC before the transiter of the wasie to the contractors lank

- The PHMC contractar unll providg the waste batch composstuon befare trangfel 6 the controctors' lanks

Fotlowing the surategy lard out by the LLW Feed Stagrag Plon (C)ertia at al 1996), the DST

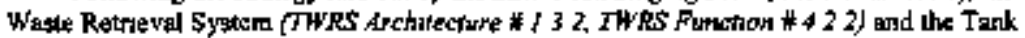

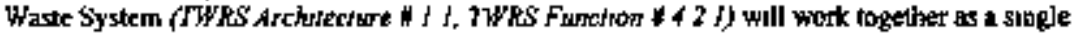
system lo stage balches of LLW For the purposes of ikls shady, the combored gystems will be referryed to as the Intemediale Wata Fead Staging Systen (IHFSS)

\subsection{COMPONENTS OF THE INTERMEDLATE WASTE FELD STAGING SYSTEM}

In the TWRS Privaluzation Phase I Waste Feed Stapung System (sec Figure 2-1), superatant ato salt slurty waste kill be retreved franl select DSTs (scurce taniks) The relreved wasle wnil be diluted and socro or all of the boluble solods will be ditsolved The resultung wagte will be irantfierred to a tagging tank Waste is the stagug lanks unll bo

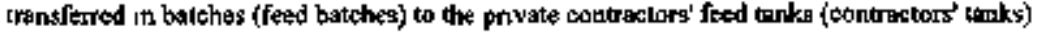

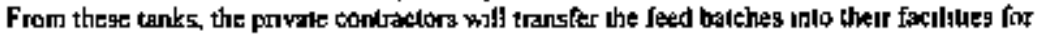
LLW pretrestmenl and LAW amumobulization 


\section{TWRS PRIVATIZATION WASTE FEED STAGING SYSTEM}
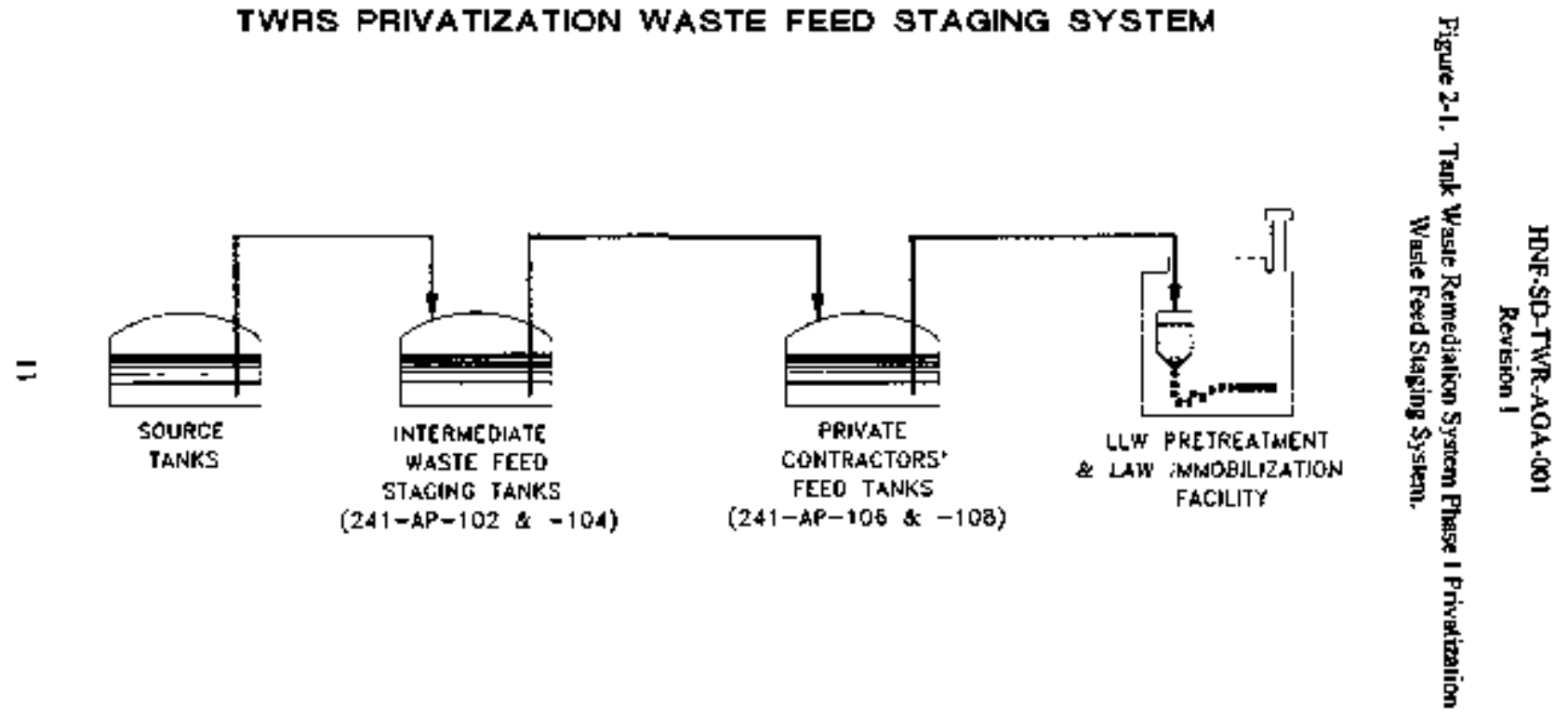
The IWF\$ is responsable for recelyog waste from the retneval funcuon, stagng the reinesed wrale in batches, and transferring these foed batcheg to the contractors' lanks The IWFSS will use ouly some of the components of the DST Waste Retroval and Tank Waste Systems The systems of uterest gre strown on the atehulecture trete in Figure 2-2 The subsystems under the DST Waste Retrevial Sy5tem are the DST Waste Mobulization System (miners and digsolution/dilution equpment) and the DST Waste Transfer Sysiem (trangier permps) The subsyglems of interest under the Tank Wasle System are the Waste Trangfer System (transiter pumps, piss, and transfer lines). the IWFST Muxing \$ysterr (If requnted), the [WFST Sorpo]ng Sysiem (if required) and the IWFST Ventilation System Issues and optons for each of these subsystems are discussed below

\subsubsection{Doublt-Shell Tank Waste Mob-lizatuon Sysitem}

Some of the wasle idenified in the LI.WF Feed Slaging Plan (Certa et al 1996) w'li tequire equiprent thal is designed to brealk up and dissolve solubte solds chal ade currenuly wnthen the selected source tants so that the waste can be pumped through the Waste Transfer Sygtem desconbed is Section 222 below For the purposes of this study, il 15 assumed that standardaed mikess will be used only where it is heceggary to achieve conough foed to meet the feed guanulty

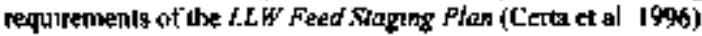

Because of issues with the release of flammable gases (1 \& , hydrogen and anmonia), the DST Wasto Retnes'al System may be raquired it mux the shudge before the supernatant in soms lanls cas be retneved If thus is the case, it is assumed an appropnislely tong settling penod would be observed aftes thutting off the wixer pumps and before slartung the decantitansfer pumps Onher wbjechives as5ocated bash a iniker, guch as the termital clean out of DSTs, ale not within the scope of this ankalysis

The LLLV Fead Sragung Plan (Certe at al 1996) shows that most of the retneved wask will requre some dissolution of soluble solids and dtlution of supernatenis al the source tank to make the waste pumpable using standard lank farm equipmeat Thus dissolution'difution is intended to reduce the specific arsuity and viscosity of the transferned waste that also complres whth the Flammable Gas Rule in the Waste Conapabulity Dada Quality Objectrves (DOO) (Fowler 1995) Thus wilh uncrease the turbulence in the trantfer lines and reduce the poiential for solids collecting and plugging the system This system could atso be used to drsolve all of the solnble solvds before the waste is iransferred umo the staging tanks and I0 adjush the superoatant composition to prevent precipulation in the staging tank 
HNF-SD-TWR-AOA-DO]

Revision L

Figure 2-2. Archilecture Tree wilh the Phase I Privalization Intermediate Wara Feod Staging Svgtem.

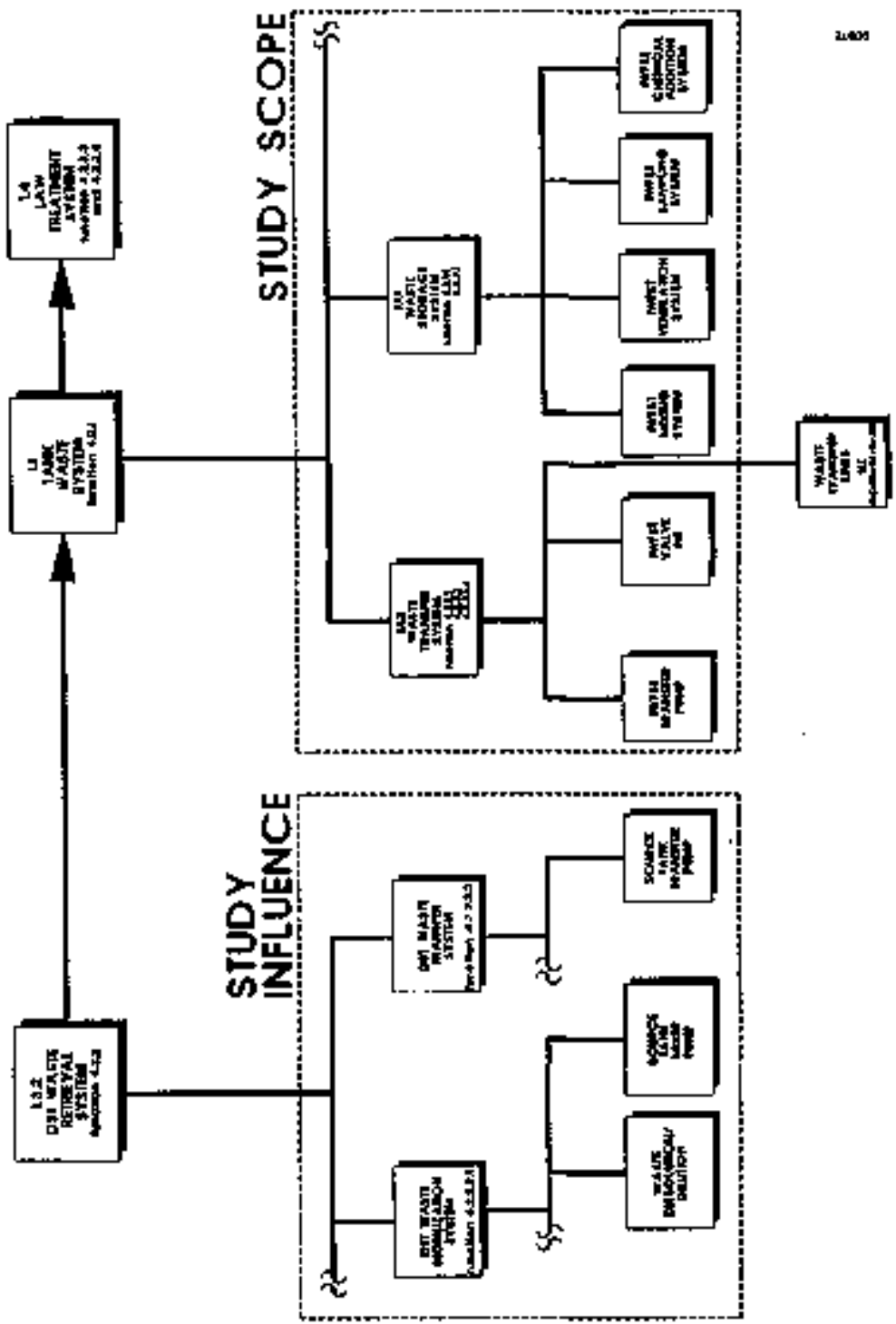


HNF-SD-TWR-AOA-OOI

ReYision I

\subsubsection{Wagte Transfer System}

The Waste Transfer System (WTS) Includes boh the WrS under the DST Waste Retreyal System and the WTS under the Tank Wasle System

2.2.2.1 Wagte Transer System Under Doable-Shett Tank Waste Retrleval. Aficr the wastes have been mobuluzed, the hanster punps wihn the xource lanks will bo requed to grove waste

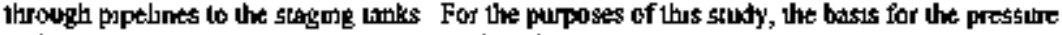
and velocity required to push the waste woll bo that sclected by a decasion on the Dectstion Dacament for Phase if Privatzatian Transfer Systeas Needs (Gralhrath et at 1996)

It may be desisble to locale the amake for some of the tronsfier purnos such that mosi (If not all) of the tusoluble soltds (I e, sludges) wihin the souree lanks are left behind 11 would be desorable to leave the sidudgeg behied in that the DDE is cominitted lo provide a waste fecd to the privale coniraclors with no more than five valume percent (setikeable) solids The study will Jdenlıfy the cost and bendits of controllung the conount of insoluble solids entranted (soleds eniratnmeri) and subsequently transferted to the staging tanks

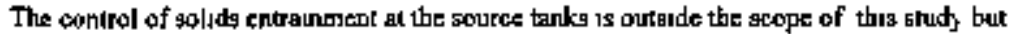
is unvesugaled on enough detaul to define interfate requrements pertainung to the solsds endranent opntrod

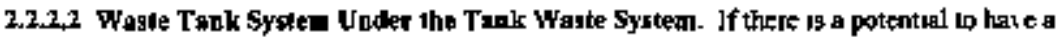

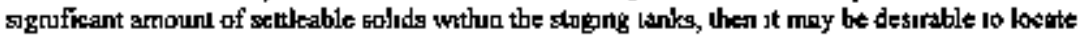
the intake for the trensier pumps such that most (If not al]) of the tusotuble, setuleable soluds within these inoks are kif behind This study will idcentify the cost and benetits of localing the transfer pump inlake al the end of a nexible hose posilıoned al a pounl abowe the settled solids in the source tank

The papetines thal will serve as lhe tangfer rotuta from the source lanks in the staging lanks rere selected in the Dewssom Dacument for Phare I Privatwation Transfar System Needs (Oalbrath et al 1996) Appendex D, Wate Transfer \$josem Engrintering Report, analyzes oplians for connesung the pupelines wyth tive lWFSTs

\subsubsection{Waste Storage Systen}

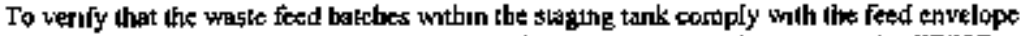
cnkera, a number of samples have to be iaken fmom the skaging tanks The ussue on the JW Sanping Sysiem is what type of smpling gystem ig best suited tor the Phase I feed batch gampling noeds

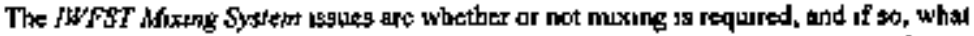
type of urixing system should be used and where in the staging tank sbould it be localed Factors affecting the mixung ussue include the benefits in muxng potentally suratufied ligud layers (i *, 
HNF.SD-TWR·AGA·00l

Revision I

blend wasle from two or more sourte tanks or blend waste with additives used for chemical adjustments of the waste), ditsolying soluble soditum salts that did not dissolve durisg retrieval and transfer from the source lanks, redissolving precipinated salts (e.g. gibbsite), reducing sampling and apalysis requisements by craating a harmogenous solution, and romaving probletralic Jiquido (e,g., Alushing the heet during Ervvelope changeg) and sealed solids (i.e., tank clean aur).

Depending on the mixing system used, upgrades to the TWFST Ventthation System may also be required. Ventilation system issues will also be investigated for alternatives where it is required.

The issue with the IWFST Chemicts? Adtifian Sygtem is how la best integrate it in wilh the other WTS subsysterns.

\subsubsection{Initgrated Ib1trmediale Waste Fet Suging Systew Subyystems}

Because the issues and optipns for these syslems elloct etach other, it is not feasible to consider each bystem indivitually. Therefore, dlemsliyes have been generated that tepretent the mosl plasusible combingtlous of options from the Waste Trangfer and Mixing Sygleras. To each of these altematives, the most appropriate options for the Sampling and Verdilation Systems were added before the alteroative wro analyzed.

A teparate study in Appendix D compares valve pit altematives in the Wagle Transfer System (Under the Tank Waste System). This study algo analyzes optiong for the connecling of lle pipes with the tarks. 
HNF-SD-THR-AGA-101

Revision 1

This pape intentionally left bank. 
HNF-SD-TWR-AGA-00L

Revision I

\subsection{CONSTRAINTS, REQUIREMENTS, AND ASSUMPTIONS}

\section{J INTERMEDIATE WASTE FEED STAGING SYSTEM}

\subsubsection{Intermediate Wuste Feed Staglng System Cousaraints}

The Intermedate Waste Feed Slagmg System wall conform to al of the following regulanory documents

Consiraints are requirements that are umposed by an exlemal organizalion The design, operption, and maintenance of the LWFSS are arfected by slate and federal requlackons, agreements, DOE Orders, and WHC requirements In adithon, there are gondetines and specificalrong that set forth engunteng tequirements deemed necessary for safe design and construction of the systert The requirements and guidelunes presented in these orders, regulations, codes, and agreements must be followed when designing and unstalling a moxitig system The format below establushes a hierarchy unio the lasted documenus is be used diring the defimituve desagn stage of the ILFST upgrades

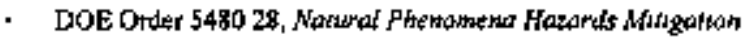

- DOE Order 5820 2A, Radioscture Waste Management

- DOE Order 6430 IA, General Design Crutera

- WAC 173-303-640, Dengerous Waste Regufotwons, Tant Systems

- WHC.IP.1043, WHC Occupanonal ALARA Progrant (WHC 1995)

- WHC-SD-GN-DGS-3001 I, Radielogkal Destge Grde (WHC 1994)

- WHC-SD-TP-SARP-00I, Sample Prg Transpart System Soffety Analysts Regari for Packarging (Onsste) (Carlstroun 1995)

- WHC-SD-WM-SARR-03I, \$afery Analysss for Push and Rosary Made Core Samping (Mt:liken 1995)

- WHC-CM-2-14, Hazardous Morereal Packaging and Shappung (WHC 1992a)

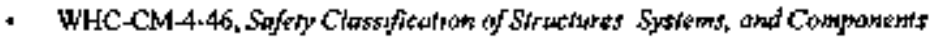
(WHC 1992b)

- ASME B3! 3. Process Pipnig 
HNF-SD.'TWR-AQA-001

Revision I

\subsection{2 lnterwediale Waste Fred Stuging Systen Requirenents}

Any long-length equipment instilled un the sugung tanks (t $\mathrm{g}$, zuxer puraps, transfer pumps, thermocoupk irets) mut be designted io fil in the bunis contaners developed under the Long-Length Conlaminated Equpment Disyosal Program In additon, the equpuent weigh!

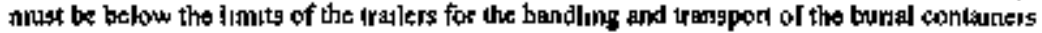
The design information for the lang-length equiprneal can be found in the following documents

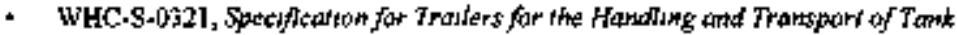
Fapms Lang-Length Comamsmated Eguspontent (MaCommick 1996)

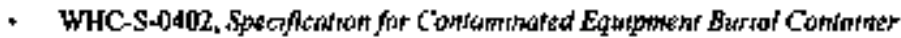
(McCornntk and Edwards 1996)

The RFP (DOE-RL, 1996) and amendments ident,fied the services that would be pron kded to the poyale contractors The followng are those servect thal would be provided by the IWFSS

- Stane and deliver sufficient quaninieg of waste feed to the contractors' Ianks

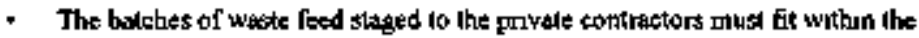
modified RRP feed exvelopes?

- Provide compostion unformatien before the transfier to the contractors' lanks

The RFP (DOE-RL 1996) also stalcs that

- The feed tanks for ponvate contraikars 1 and 2 will be 24I-AP. 106 and 241-AP-108

and the Decislon Doctwenr, Low.Level Waste Feed Staging Stratedy (WHC i996e), has decuded that

- Two imlermediate wast feed sagung tanks are requend la implenem the LLW feed Slaging Plan

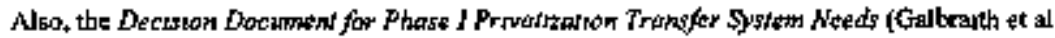
1996) decided that

- DST 24I-AP-102 and 24I-AP-104 whll be the LLW Intermediate waste foed sal alung lanks for Phase I

The RFP (DOE-RL 1996) lost the follawng as a performance requltement 
- Minimaze the usage of sodium compounds (e B, sodium hydroxide, sodium nutrie, floosdes, and sulfates) that could uncrease the volume of inmobslized LAW and Imrrobiluzed HLW

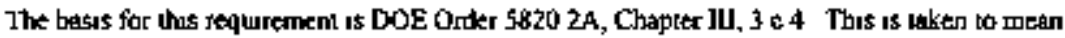
got only mindmizmg the use of sodum betang hquads, but monimizing condilions that will tequire future uge of 5odium bearng solutions Other constrauls on the IWFSS listed in the

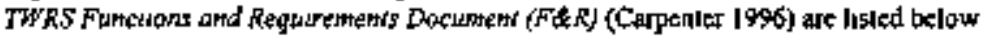

- Esriwated TWRS Projecr Schedule The IWFSS must support the TWRS project schedwe Ptopf-of-Concept opcraliong wall bo fiem hune 2002 through June 2007 . with $\mathrm{DQE}^{+}$g optron bexiesd processing through Juse 20] 1

- Chemrcof Concentrapung Limts The IWFSS systems inderfacing with the waste sources mugl be capplite of handing waste with the chempal concentrations specified m OSD-T-15]-00007 (WHC 19466)

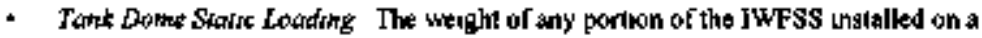
lank shall be limited by the statsc dome looding design haris specified in OSD-T-151-00007 (WHC 1996b)

- Temperature - Non-Aging Waste DST Waste The IWFSS must be capable of handling waste wath a theximum temperature of $82^{\circ} \mathrm{C}\left(180^{\circ} \mathrm{F}\right)$ as apecified in WHC-SD-WM-OSR-016, LCO 322 (WHC 1996a)

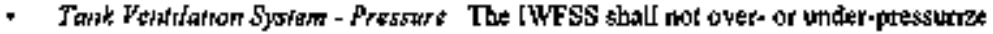
the Iarks based on the Jimis specified in OSD-T-151-0000? (WHC 1996b)

\subsubsection{Intermedinte Wasit Fetel Slaging Syblem Astumptiong}

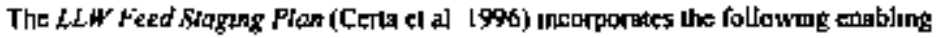
assumptoons regrording the IWFSS

- The startıng dake for fect staging transfers is Oclober 1, 2000 (Certa el al 1996. parge 3-I)

- The DOE, as represented by the PHMC, will demonstrake that the deliveted waste mets the composiluonal envelope criletra by sampling and analyang the waste in the intermęlait waste fied staging tankg

- The simples and the analy sis of waste in the stacing canks will also salisfy regulatory sequirements (if any) imposed on the PHMC befoce the Irangfer of the wasle to the contraciors' lanks 
HNF-SD-TWR-AOA-DOO

Revision I

- Not all of une DST wasle compositionas fall willin a modified RFP feed envelope. The tarks blat contain waste winhin a designated envelope and are scheduled for staging are referrerd to as spurce lanks and are bisled in Table 3-1. Somo of these are subjecl to change as envelopes crolve and OWVP's are revised.

Table 3.1. Source Tanks for Phasa [ Privalizalion Feed Envelopes.

\begin{tabular}{|c|c|c|c|}
\hline Envelope & A & B & C \\
\hline \multirow{5}{*}{ Tank } & $241-A N-103^{2}$ & $241-A Y-101^{\circ}$ & $241-A N-102$ \\
& $241-A N-104$ & & $241-A N-106$ \\
& $241-A N-105$ & & $241-A N \cdot 107$ \\
& $241-A P-1041$ & & $241-A P-107$ \\
& $241-A P-106$ & & \\
& $241-A W-10]$ & & \\
\hline
\end{tabular}

'It is assumed that this tark waste will be concenirated or blended with a more concentrated waste 10 macet the minimum sodium limit of 3.0 M.

II ig ascsumed that these tank. wastes will be diluted of bended wilh kess concentrated wastes to meet the maximums sodium limit of I $4 \mathrm{HF}$.

The location of this waste may change.

\subsection{WASTE TRANSFER SYSTEM}

\subsubsection{Warte Transfer Bysten Requiremesly}

The LLW Feed Staping Plan (Çerta ex al. 1996) lisis the following bet feed makaup and delivery requirements.

- Rexeive a batch of waste unaferred from one or mare source DSTg via the recommended trantiter system uggrade Altermative $\mathrm{K}$ (see Galbralth el $\mathrm{\theta}$. I996, LLW Option 4, HLW Option 3).

1 Teansfer the suxematant and solids (if the solids content and composition is acceptable) to the contrackors' tenks. The transfer setup lime ghould be consiatent with the feed delivery shudy's recommended case (Certa ed al. 1996) and nominally take olve day.

- Transfer the supernalanst to the contractors tanks kedving all or some of the serted solids behind (if the solids conleal and composition is unsaceptable). The lime needed 10 settle out soljis should be no longer than 30 dsys. The transfer setug time 


\section{HNF-SD-TWR-AOA-001 \\ Revision I}

ghopld be consigten with the foed delivary shudy's recommended case (Certa et at. 1996) and arminally lake one day.

- Pump transfers tale should be $0.76 \mathrm{ML} / \mathrm{day}$ (140 gat/min $)$.

- Follow ench feed delivery transfer with a line fhugh of 1.5 line wolurnes.

- The liquid beel remaining in the saging tank after the leed baltb hat bern transferred to the contractors' tanks should to po more then $0.10 \mathrm{ML}$ (I0 in.).

- Trunsfer the staging taink's entire contents (excluding the heel) to anpither D\$T if the whasle is oul-of-specification ofl must be removed or bet aside for later disposition.

- Remoyc problematic (due tr guaruity, conposition, or physical properies) solids thal were intentionelly or intadvertently resieved and transferred from the sourve DSTs or that precipitated during or after the tranafer. These soljds would be transferred to another DST for furture processing.

\subsubsection{Waste Trunter Systew Assunptions}

There are two typeg of golidg of concern 1o the Wastr Transfer System: solutwe soljog -5alts that were pod dissolved during retrieval and trangfer or that precipilaled while in the staging tank; and insoluble solids-amecol and melol oxide sludges ond other compounds thet will not dissolve in water or dilute caustic solutions.

The waste phase the golids are associated trith divides the solids into two classifications: surperded and sealled. The suspended solids consist of undissolved soluble sollds or insoluble solids too small to sertle out of the supemslapl. \$uspended soluble solidg can be dealt with by dissolving them either during retrieval and transfer or durting mixing in the staging tanks. If the soluble solids are not distolyed, bey will likely foll to the botton of the tank where thelr transfiet will be contrailed wilh the rest of the sentled solids. Susperded insolubte solids are not realisdically separabie from the revieved supernalanks and sluries. Therefore, controlling the urangfer of the se solids from the sourse lanks to the staping tanks, or from the staging tanks io the contrattors' tanks, is not feasible.

Senled, or sertlesble, soleds are those solids that seake 6 the botton of the tank. The setuled solids in the singing tanks are expetied to be prtmarily insolubte solids from sorree tank siludge loyers entratied during the reyrieval and Iransfer proctss. If adequate mixing and digsolution are net performed, the settled solids in the staging tank may very well include a sizeable amount of solubłe solids.

The following are enabling assumptions used for the waste Transfer System in this study. 
HNF-SD-TWR-AGA-001

Revis|on I

- The DST W Bste Trang fer System under the DST Wesle Retreval System will dilute the setneved wasle (If required) and dissolve soluble soluds in the retneved waste before the waste is transferred into the slaging lanks

- Retrjeqal thi]] trangfer some undissolyed solubje solkds ko tha staqing lanks if not requixct to disso|ve all the soluble solrds Furher dissolution may requnre the adther of dilute caustic tolution and beal It may also require the addilitn of cuncentrated tausic solution wadjugr the hydroxide concentralson of the transferted waste to avord precipilation of soltds

- In order to fall belaw the maxumum five volume pertent (setksab]e) solds os required by the RFP (DOE RL I996), the Waste Transfer System needs 10 actlyely confrot the enurannment of 5001 ids in the transitered waste

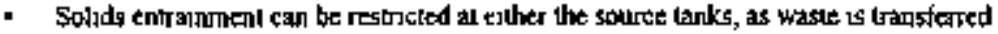
to the staging lanks, or at the slaging lanks, as the feed bacthes are irantfermed to the tontraclors' tanks

- One sew generation Rex-and-fosl-tntake decantitransfer pump, erther in each source

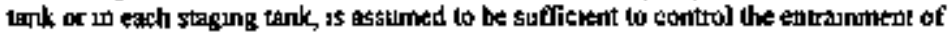
solds to below the mexumum five solume pertenl (setileable) solrds required by the RFP (DOE RL 1996)

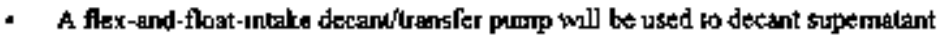
durnng waste transfers where the control of solds entrainment is required

- For transfers where the soluds entrannment is not controlled, a New Gencretoon Transfer Pump (NGST) or equyaleal woth a fixed-inlake wall be used

- Five gource tarks (24 I-AN-103, 24I-AN-105, 24I-AP-104, 24:-AP-106, and 241-AP-107) have no or very little waste excluded from retrieval (sealed insoluble solids) and are scheduled for complete retreyal (Certa el al 1996) These tanks will have NGTP's or equivalent instilled

- Sux source tanks (24l-AN-102, 24I-AN-104, 241-AN-106, 24l-AN-I07, 24 I-AW.101, and 24I-AY.10I) have waste excluded from reineval (settled insoluble solws) and are scheduled for selectrve retreval (Certa el al 1996) Theretore, decanlitrangfer purmps would be installed on whese tarks when sol ids entratament control at the souste tank is requited

- If soluds entraparam is not contralled ad the sourte tank, settleable solds will enter the staging tankg and accumulate The aceumulated settied solids may IImit the useable volume of the tank and requare removal betore the completion of Phase 1 Pryalization The accumuladed soluts will eventually have to be removed, if not in Phase ], then in Phase II 


\section{Revision 1}

- Addition of a new pit on the stagting 1anks will not exceed the dome limil of Une tanks. It is assumed that the wejght of ibe pit will be less than the wejght of the soll remoyed.

\subsection{MAXING SYSTTEM}

\subsubsection{Miung Syatem Requirements}

If a mixing system is used in the [WFSS, the followide are requirements for it.

- Hear Gereration Limtit. Tho mixing gystem will be limiled to a totol thermal input load based on the lank operating limitg of $20.5 \mathrm{KW}(70,000 \mathrm{BTU} / \mathrm{h})$ radiolytic heat generalion and a maximum solution temperature of $49^{\circ} \mathrm{C}$ ( $\left.120^{\circ} \mathrm{F}\right)$. A ventilation system for adding a 300.hp mixer pump is addressed in Appendix C.

- The time allocated far mixing the batch should bo consistent with the $L L H^{\prime}$ Feed Staging Plar (Cerla el al. 1996) and requine no mose than 14 days with a median of 7 days or an equivalenl distribution.

If mixer pumps are instalied in the slaging tanks, instrumentalion wo monitor andfor control the folkwing premetest shall be designed and instalked untegs exigling tank instruments can be vtilized:

- Monitor tank lesel, Iemperahure (wasle and vapor space), pressura (vapos space), and gas coneenirations.

- Delemine the extent of mixing effectiveness.

- Monitor mixer pumig mokor arroperage, tpsh, and kemperahure.

- Monicor temperatures of mixer pump drive and bearing components.

- Monilor mixet pump bearing seal lubrication waler Dow rale.

- Measure vibration of the mixer purap assembly.

\subsubsection{Miring System Assumptions}

The following are enabling asaumplions used in this stody for the Mixing System. 
HDF.SD-TWK-AGA-001

Revisión I

- One 300hp anxer purap in edch staging tank will adequately max the foed baicli to dissolve soluble sodurm salts that esiher dud nor dissolve dunge retneval and transfer or that precipitaced after trassier $\left(e \mathrm{~B}\right.$, gibbsite $\left.\left(\mathrm{NaA} / \mathrm{O}_{2}\right)\right)$

- A single 300-hp mixer puchp can actively mix the waste in the staging tank for 75 hours per weck before the waste lemperature reaches $82^{\circ} \mathrm{C}\left(180^{\circ} \mathrm{F}\right)$, the maxımum allowable wasle tentperilure

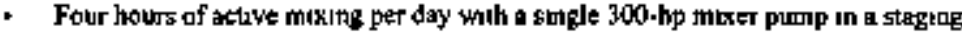
tank can be done before the venulation system is overloaded

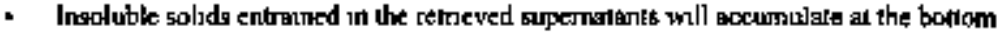
of the staging lanks of no solids eniranmem combol is place at the source tank

- If solyds eniranment is not restreied an the sounce tank, a mixing system capable of

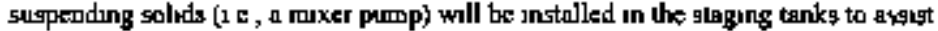
in removat of accumulated soinds

- Pulsed-air systems are generally used to mux loqud not motrann solnds Beçause of lack of data, a single pulsed-aur system in exch sliging tank is nol dessumed to be capable of suspeading solids adeghately for solids temoval

- One 300-hp mixer pump un each slageng tank is adequale for mantreining soldds in

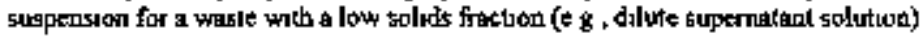

- Soluble solids that were not dosodved dunng retneyal and transfor to the staghag tank or that precipitaled dunag or after trangfer bo the slaging lank may setule and accumulate at the bottom of the slageng tanks Wilhoul the snclusson of the chemicols in these precenplatiod solids the feed batch may not meet the modified RFP feed envelope

- Analyss of the impact of the mixer pump yet forces on existung or added inderibl tank equepment is beyond the seope of thus study

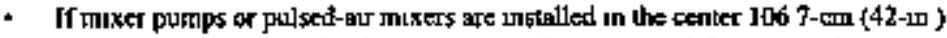
noers on the 5 thag removed and replaced 
HNF-SD-TWR-AGA-(001

Revision I

\subsection{CHEMICAL ADDITMN SYSTEM}

\subsubsection{Chemied Addltion Syslem Requirements}

The LLW Feed Slogling PJan (Çerta et al. 1995) tists the following as a feed makeup and delivery requirement.

- Provide for a Oush or odher mesins to remove of dilute pokentially problematc supenatint heels before swilching feed envelopes.

\subsubsection{Chemieal Addition System Assumption}

Atgumplions made for the Slaging Tanl Chemicd Addition System ant:

- The mobile chemical addition sjagern scoped for Projext W-2II will be sufficienl for the needs of the IWFST Chemical Addition System.

\subsection{SAMPLNNG SYSTEM}

\subsubsection{Bampling System Requirtatents}

The LLW Feta Staging Plas (Certa et al. 1906) lipes the following Sampling \$ystem requirements.

- Take the proper mumber, kecalion, oud type of smples to:

- Insure that the waste composition mects the modified RFP feed envelope

- Salisfy segulatory requfrements, If any, for delivery of and slorage of waste to the private contractors

- Satisfy the OSD and waste corrpalibdlity DQO for transfer atd gtoraga of waste in the stagleng tank

- Establish the ofticial composition of the waste for assegsing the private contractor's performance

- Eistablich the quantty of sodium delivered to the private contraclors. 
- The time needed to obtain samptes and deliver them ta the laborgtery should be consirkent with tha feed delivery study in the LLW' Feed \$taging Flan (Cerla el al. 1996, Appendix E) bond nombally tequire 2 days

Other requirements on the Saupling System are as follows.

- The gystem must be able lo obtain the requirad samples through tank-lop rigers wilh sominal djamerers of between 10 and $30 \mathrm{~cm}$ ( 4 in. and 12 in).

- Retrieved anmples and associated hardware must fit in the existing Hantord hot cell Faxilities.

- The stielding desigr criteria in the Radiologicel Design Guide, Section 7.0. (WHC IS94) will be uged to determine the shielding requinsments for the gampling sy!dem Shiekding shall be designed of liatil the otal whole body dose to less than $5 \mathrm{mSv}$ per year.

35.1.J Modined Regues1 for Proposal Feed Envelopes. The LLW Feed Staging Plan (Certa et al. 1996) recommended several modifications to the feed cravelopes detailed in the RFP (DOE RL 199h). The modifed RFPP Fead Envelopes tnclude the following requirements.

- The modified RFP waste fed envelopes are mutually exclusive (i.e., exch waste cen fall into only one feed envekope).

- The feed delivered to the contractors' tanks stall have no thort than five volume percent of (setlesble) solids.

- Volume percerd settled (or settieabde) solids will be measured by Method 2540F, \$ettleable Solids (Greenberg el all 1992).

- Tartk Farm Opcralions specifteations given in the Operating Specifications for the 241-AN, AP, AW, AY, AZ, and SY Tark Farms (OSD-T-151-00067) will be met.

- The sodium molarity is defined to be between 3 and I 4 molar.

- The concentrition requirements for all olber constilueats are given as ratiog to the sodium torkentration. Table 3.2 lists the maximum conglituent concerrirations for each feed envelope. Table 3-3 lists the Enyelope B minimum ariteria and Table 3-4 has the Envelope C minimum crileriz. 
HNF-SD-TWR-AGA-001

Revislon I

Table 3-2. Modilied Regarest for Proposals Enyelope Maximum Concentraions. (2 Shets:)

\begin{tabular}{|c|c|c|c|}
\hline \multirow{2}{*}{$\begin{array}{c}\text { Chemical } \\
\text { analyle }\end{array}$} & \multicolumn{3}{|c|}{ Maximum Ralio, andyte (mole) to sodium (nole) ' } \\
\hline & Envelope A & Envelope B & Epvelope C \\
\hline Alurninuाt & 0.19 & 0.19 & 0.19 \\
\hline Barium & $0.000 \mathrm{l}$ & 0.0001 & 0.0001 \\
\hline Calcium & 0.04 & 0.04 & 0.04 \\
\hline Cadmim & 0.004 & 0.004 & 0.004 \\
\hline Chloride & 0.037 & 0.065 & - 0.037 \\
\hline Chromium & 0.0069 & 0.02 & 0.0069 \\
\hline Fluoride & 0.091 & $\$ .2$ & 0.001 \\
\hline Inon & 0.01 & 0.01 & 0.01 \\
\hline Mercecury & 0.00001 & 0.000001 & ㅁ. 040001 \\
\hline Posasgium & 0.18 & 0.18 & 0.18 \\
\hline Lanthanum & 0.000008 & 0.00008 & D.00000s \\
\hline Sodiumn & 1 & 1. & 1 \\
\hline Nicikel & 0.003 & 0.0007 & 0.003 \\
\hline Nitrice & 0.38 & 0.38 & 0.38 \\
\hline Nitrute & 0.8 & 0.8 & 0.8 \\
\hline Hydroxide & 0.7 & 0.7 & 0.7 \\
\hline Lead & 0.00068 & 0.00068 & 0.00068 \\
\hline Phosphate & 0.038 & 0.13 & 0.038 \\
\hline Sulffate & 0.0007 & 0.07 & 0.02 \\
\hline Imorranic carton & 0.3 & 0.3 & 0.3 \\
\hline Organic carbon & 0.06 & 0.06 & 0.5 \\
\hline Uranium & 0.0012 & 0.0012 & 0.0012 \\
\hline Radionuclide & \multicolumn{3}{|c|}{ Maximum ratio, radionuclide (becquerel) to sodium (mole) } \\
\hline Transuranics & 6.00E+05 & $6.00 E+05$ & $3.00 \mathrm{E}+06$ \\
\hline${ }^{1+}$ Cessium & $4.30 E+09$ & $600 \mathrm{E}+14$ & 430E+09 \\
\hline ragirontium & $5.70 \mathrm{E}+07$ & 5. $70 \mathrm{E}+0\rangle$ & $8.00 \mathrm{E}+10$. \\
\hline
\end{tabular}


HNF-SD-TWR-AGA-001

Revision I

Table 3-2. Modified Reguest for Propospls Envelope Maximum Concenurations. (2 Shetets)

\begin{tabular}{|c|c|c|c|}
\hline \multirow{2}{*}{$\begin{array}{c}\text { Chemical } \\
\text { gualyle }\end{array}$} & \multicolumn{3}{|c|}{ Maximum Ralio, antalyve (mole) to sodium (mole)' } \\
\cline { 2 - 4 } & Envelope A & Envelope B & Envelope C \\
\hline "Technetium & $7.10 \mathrm{E}+06$ & $7.10 \mathrm{E}+06$ & $7.10 \mathrm{E}+06$ \\
\hline
\end{tabular}

' Shaded numbers highlight differethes beturen the fied envelopes.

Table 3-3. Modified Requess for Proposal Feed Eave]ope B Minimum Criturits

\begin{tabular}{|c|c|c|}
\hline \multicolumn{3}{|c|}{ At least one of these limitg must be satisfied. } \\
\hline Analyte & $\begin{array}{c}\text { Minimum } \\
\text { Analyte:Na Rato }\end{array}$ & Unils \\
\hline Chloride & 0.037 & molimot \\
\hline Chromíum & 0.0069 & molimol \\
\hline Fluoride & 0.091 & mol/mol \\
\hline Phosphate & 0.038 & molimol \\
\hline Sulface & 0.0007 & molinwol \\
\hline${ }^{1+{ }^{\top}}$ Cesium & 4. $3 E+09$ & Bq $/ \mathrm{mol}$ \\
\hline
\end{tabular}

Tathe 3-4. Modified Request for Proposal Feed Envelope C Minimum Criteria

\begin{tabular}{|c|c|c|}
\hline \multicolumn{3}{|c|}{ Must be satighiedt. } \\
\hline Antlyte & Minimum TOC:Na Ralio & Usits \\
\hline TOC & 0.06 & mol C/mol Na \\
\hline
\end{tabular}


HNF-SD-TWR-AGA-0OI

Revision 1

\subsubsection{Sampillag Sysiem Atsumptiond}

The following are assumptions made for the Sathpling System.

- Before slaging a feed batch, the source lanks will be sanpled and characletized. The comprostiton of the waste as well as the existence of sigpificanlly different 3queous Injers in the tank will be determined. The waste dn the soures tank will then be assigned to one $n \mathrm{r}$ more feed batches of a specific feed envelope.

- A saligical woldation of the feod bake's cherded and phytical characleristics will be needed to support the claim that the DOE and the PHMC contractor have fulllled their obligation o provide LLW Exed within the prepcribod focd envelopo. This stalistical yalidalion will requive that each feed bakeb be sampled while in the staging lank and that the saruples be analyzed.

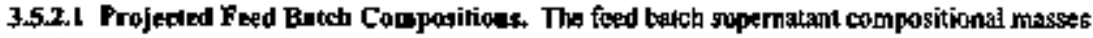
(as they will exis in the intermediale wate feed slaging lanls) are based on the Projected

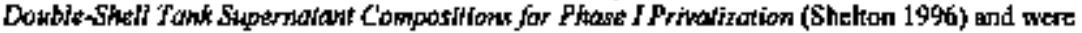
ealculaled for, althongh not published in, the LLW Feed Staging Plan (Certa tt al. 1996). (Sec Appendix F) In calculating the lotal composition of the feed balches, an eslimale of the composition of insoluble sotids entuained in the supermagtanl iq added to the supematant compositional masess. In this alculation, it is assumed that:

- The solids entrained during relrieval and transfer bave the same composition as be bu|k solids in the souree tank.

Becouse not all source tanks haye solids composition data, it was assumed that:

- Onby the source tanks with solids composition dats bave solids that add to the composition of the keed bakh.

Appradix F provides a moss desailed tiscussion of the equations and assumplions used in ealeulating the projested feed bakb compositions.

The composition for components is lisled as a ratio of the componerst concentralion to the sodium concentration (sodium ratio). The value listed for sodium is the sodium concentration in moles per liter.

Tabies 3-5 and 3-6 show the projected toul feed sodium ration for Privale Contractors 1 and 2, respectively, for the zero percent enurained (settleable) solids case. Tables 3-7 and 3-8 show the projected total feed sodium ratios for Private Coatractors 1 ind 2, respectively, for the two percen entrained (setileable) solids case. The kotal feed batch sodium ratios for the one, three, tour, and five percenl cnurained (settleable) solids cages can be lound in Appendix F. 
Table 3.5. Projacted Imermediate Waste Feed Saging Tank $(A P-102)$ Feed Bach Sodum Raios for Privale Contracior 1; 0 Percent Emtrained, Ineoluble Soljo.s.

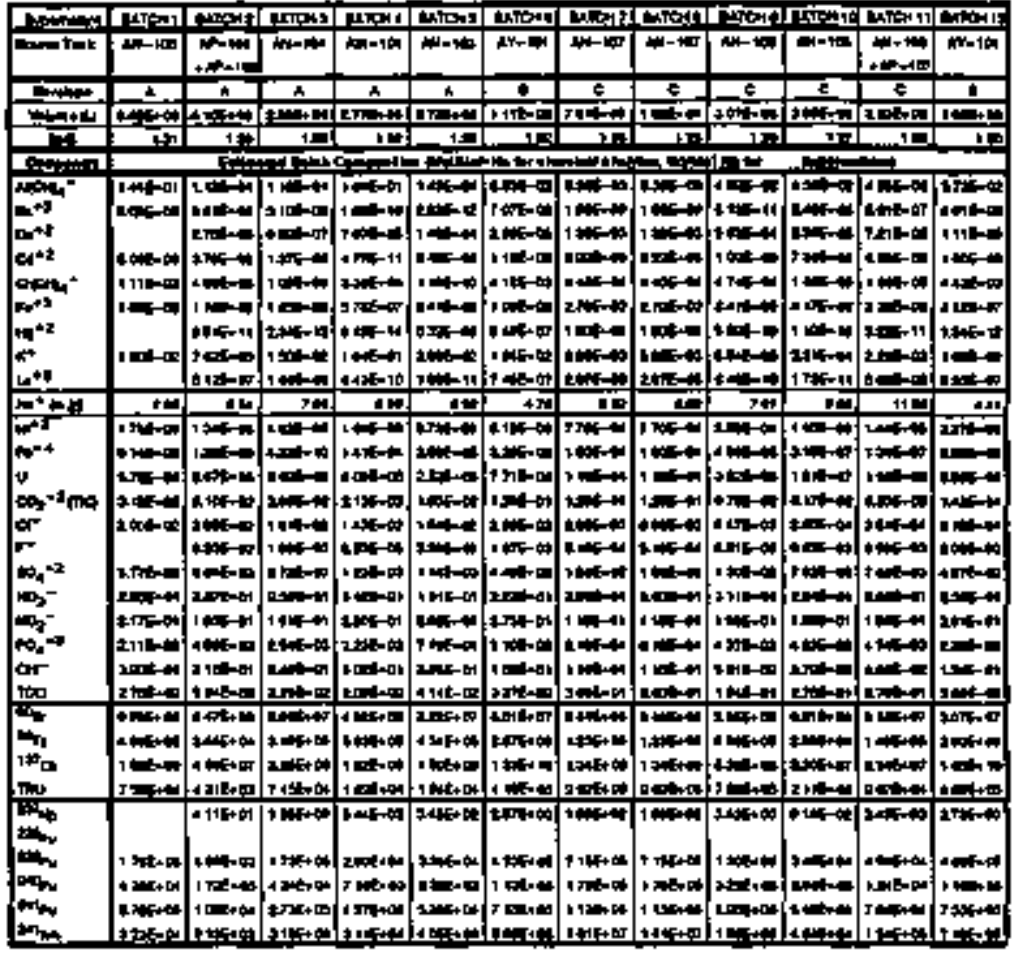




\section{HNF-SD-TWR-AGA-OOD \\ Revisión I}

Table 3-6 Proyected Intermediane Waste Feed \$lagme Tank (AP-IO4) Feed Bach Sodivm

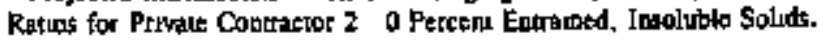

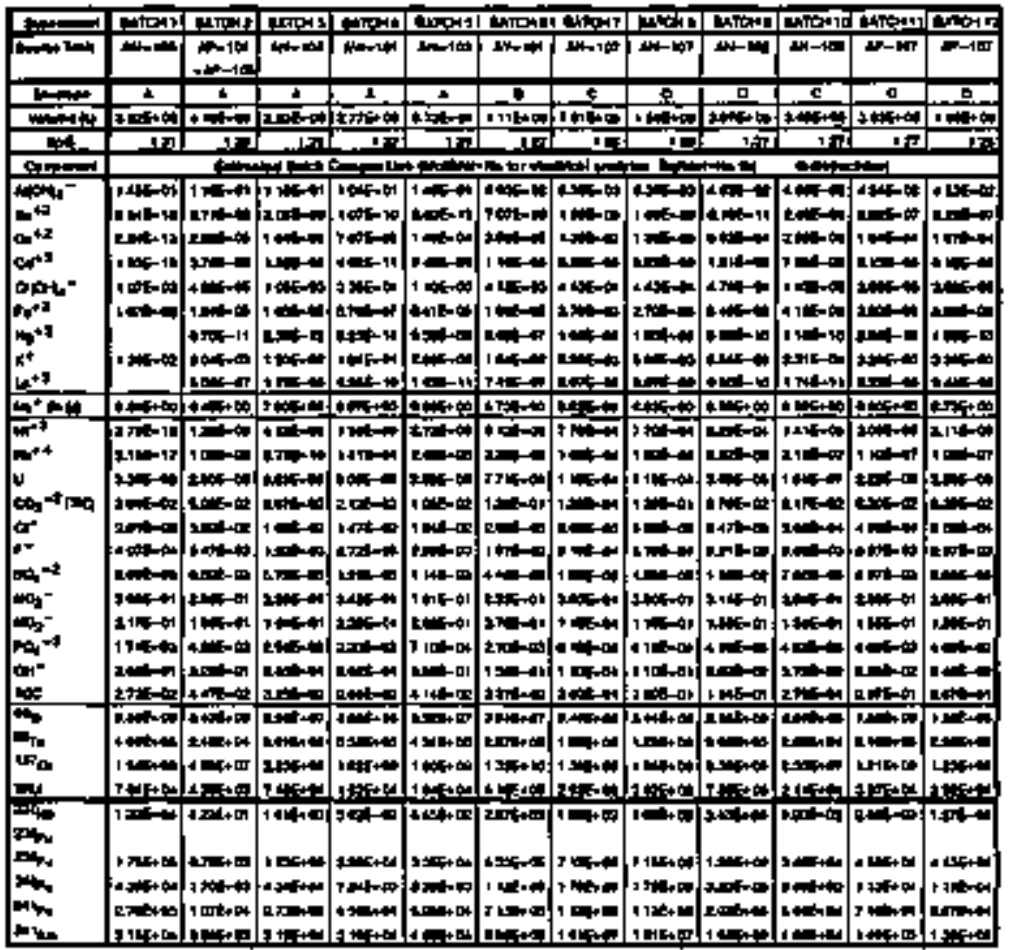


Tablo 3-7. Projected Inlermedrafe Waste Feed Staging Tank (AP-IUC) Feed Barch Sodnum Ratios for Privare Concractor 1. 2 Percept Entrained, Insoluble Solrds.

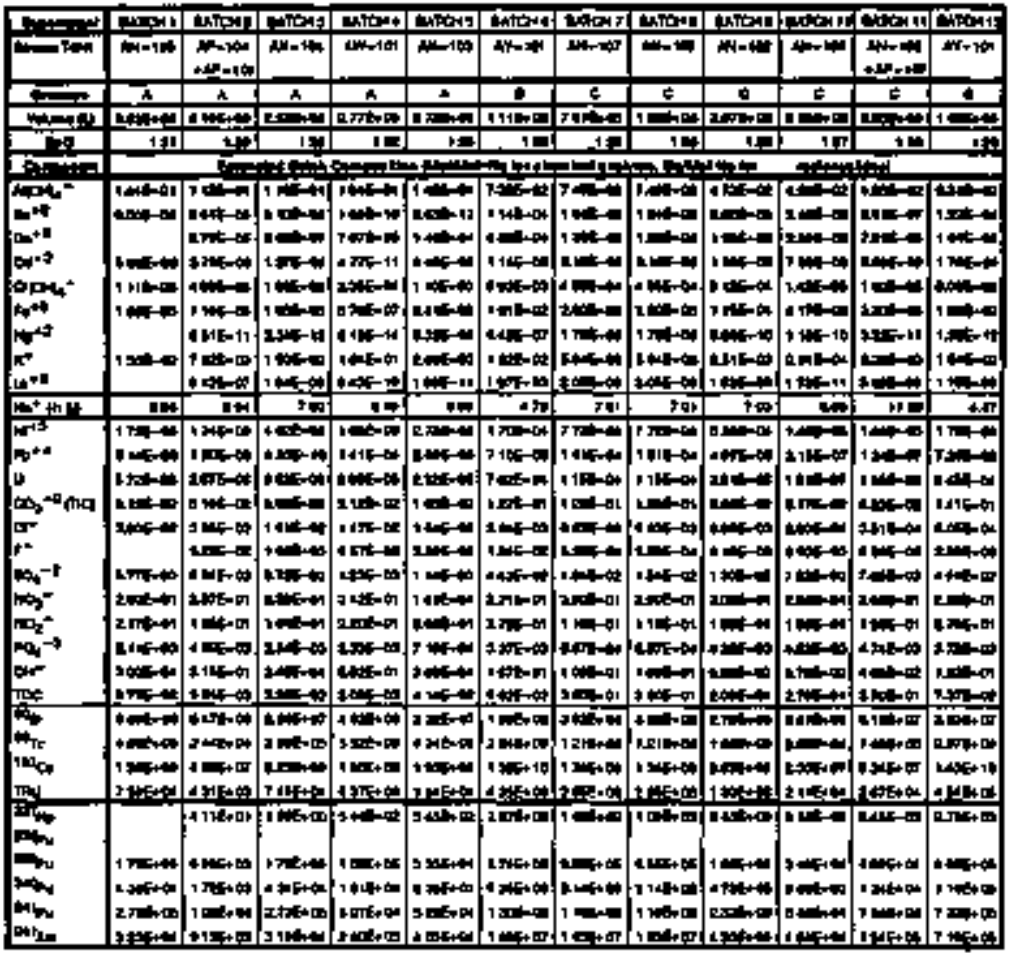




\section{HNF-SD-TWR-AGA-60I \\ Revision 1}

Table 3-8. Projected Interarediate Waste Feed Slagung Tank (AP-104) Feed Batch Sodiafit

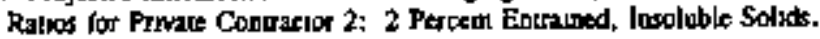

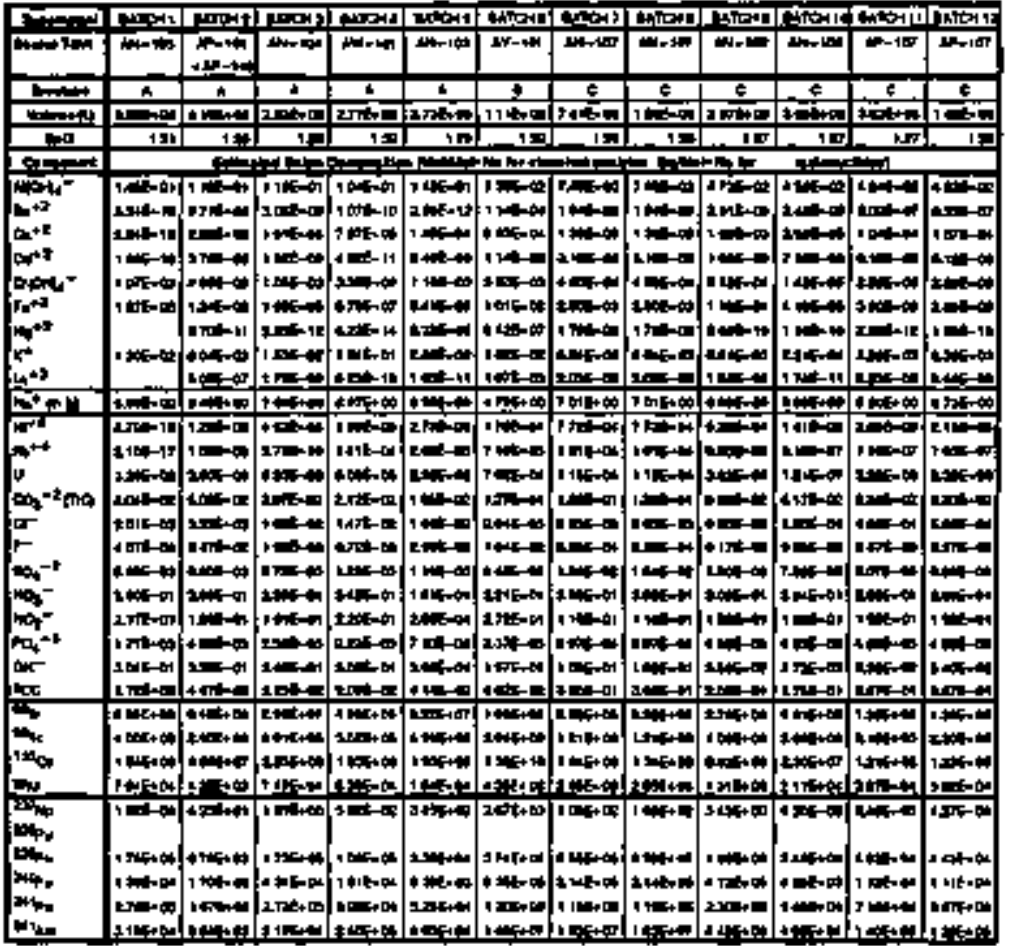


3.5.2.2 Waste Variability and Sawplifng Locations, The intention of stmpling fs to oblain a set of samples that are representaliva of the entira feed bath. Therefore, amples should be taken in such a way as to account for the compositional variability betweet gupermatanl phases.

Loterd Vartability. The tantal variability is the varisbility tn the composition of samples taken at the same wate beight bud diflerent lateral kosajous in the tank (i.s., at different risters). Fơ supertalants it is agsumed that:

- Different phases in the wagte oceur becente of different densities (assumably arising form different compositions)

- Fach pbase has a single source and is homogeneous

- Each phase is level laroughout the tank.

From this and from past experieace, it is couchuded that:

- The lateral yariablity for supernacants is very low (below analytical eror).

Therefors, the following requiramert on sampling is dertved.

- All the batch samples will be taken from a siagle tiser ot each staging tank.

Vertical Varinbility. Vertical variability is the variability in the compoginion of samples taken at the gampe lateral locetion (i $e_{7}$ riser) but al different waste dephth. If liquids with different densities (and ostumably different composilions) wre odded logethet in a feed batch, stralified superthatont layers may form unless there is adequate mixing. Potential sources of siratifled layers ano as follows:

- Adding a new bouch to the heel from a prevlous bateh

- Combinirag wastes fiom difictirnt soukco tanks

- Sequentially removing different phoses of waste from a sivgle source lank

- Adding chernicalg to adjust 1 feed batch composition.

Because in is quite probablo that suraified sppertatants will appear without adeguale mixing:

- Vertical qariatriltty is considered to be the most probable source of sample variability.

Therefore, the blowing requirement is detived.

- Samples will be taken at geveral differtent heights in the wiste. 


\section{HNF-SD-TWR.AGA-DOJ \\ Revisiond I}

3.5.2.3 Estimated Sumping and Analysis Variability. In calculading the mumber of samples that are needed lo verify that a feed baich mete the feed envelope criteria, an estimate of the andytical enor and sampling varitbilicy is needed. The calculations in lkis study use telative standerd deviation (RSD) values that combine the analyrical fror and sompling variabilitics. These RSDs were deterroined from the mean concentration, the variance of the mean, and the aumber of garple localions reported in previous sarupling and analygis mports for supesnakant characlerization (Simpson 1994a, Welsh 1994a, Simpson 1994b. Welsh 1994b). These valups are applicable to the supertatant. When solids are added to the feed batch comporition, it is assumed that:

- The RSD valaes for the supernntanis are valid for the tolal feed bach composition that includes the composition of entrained solds (slurdges).

The "not-mixed" scentrio assumes that the slaging lauks are not upgraded wilh an welive mixing sygtera. The "well-mixed" secanio assumes the staqine tanks are upcraded witb aclive miking systems çapable of mixing stratified liquid layers ink a homogenous mixhme.

\subsubsection{Coundense Lavet. It is assumed ihat:}

- Ninety five percent confidente intervals ane noedkd tor both types of eror (j.e., false positive and folse negalive) 10 yoljdele that a feed batch meets the feed envelope eriteria.

- The componerit cancentrations are nombally distributed around the mean

3.5.2.5 S*wpling Number. The numper of samples requircd lo validato a specific foed batch (ampling mumber) for each component wrs calculated. Table 3.9 snmminizes the number af amplea required toc each feed balch validation for Privale Contraclors I and 2 for the zeto percent entritided insoluble solids case. Table 3.10 summarizes the number of samples regutred for each feed batch yalidation for Private Contractors I and 2 for the twa perocnt entrained insolnb|e goljds case. 
HNF-SD-TWR-AGA-001

Revision 1

Table 3-9. Summary of Jhase 1 Priyatizaliont Intermediate

Waste Feed Staging Tank Required Samples wth

0 Percen Entrined, Insoluble Solids.

\begin{tabular}{|c|c|c|c|c|}
\hline \multirow{2}{*}{ Batkh } & \multicolumn{2}{|c|}{ WellWixed Sctomita } & \multicolumn{2}{|c|}{ Now-Xiked Serentrib } \\
\hline & Contratur I & Ctentation 2 & Codotivier 1 & Contration $?$ \\
\hline 1 & 3 & 3 & 7 & 7 \\
\hline 2 & 8 & 5 & 47 & 34 \\
\hline 3 & $\mathbf{3}$ & 3 & 7 & 7 \\
\hline d & 3 & $\mathbf{3}$ & 4 & 4 \\
\hline$s$ & 3 & 3 & $s$ & 1 \\
\hline 6 & 3 & 3 & 9 & 9 \\
\hline 7 & 19 & 19 & $\$ 9$ & 89 \\
\hline B & 19 & 19 & $\$ 9$ & 89 \\
\hline 9 & 3 & $\$$ & 10 & 10 \\
\hline 10 & 3 & 3 & 4 & 4 \\
\hline JI & 3 & 3 & 5 & 4 \\
\hline 17 & 4 & $y$ & 15 & 4 \\
\hline Todel & 74 & 70 & 291 & 266 \\
\hline $\begin{array}{l}\text { Scanmiv } \\
\text { Tolal }\end{array}$ & & & & \\
\hline
\end{tabular}


HNF-SD-TWR-AGA-[0]

Revigion 1

Tabk 3-16. Summary of Phase I Privatizalion lolemediate

Waste Feed Slaging Tank Required Semples ainh

2 Percent Entrainced Insoluble Solids.

\begin{tabular}{|c|c|c|c|c|}
\hline \multirow{2}{*}{ Bented } & \multicolumn{2}{|c|}{ WeIl-hated Sctindo } & \multicolumn{2}{|c|}{ Not-Mred Serentrip } \\
\hline & Contantrin I & Chritrecker? & Comtracku 1 & Controctof 2 \\
\hline$I^{*}$ & 5 & 3 & 7 & 7 \\
\hline $2 *$ & $\downarrow$ & 3 & 47 & 4 \\
\hline $3=$ & 3 & 3 & 7 & 7 \\
\hline $1 \times$ & 3 & $\$$ & 4 & d \\
\hline$\$$ & 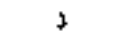 & 3 & $\$$ & $\$$ \\
\hline 6 & Fonled & f ulted & Falled & Pm|ed \\
\hline$\vec{t}$ & 21 & 21 & $10 \mathbf{2}$ & 102 \\
\hline 自 & 21 & 26 & 102 & 1012 \\
\hline 9 & 3 & 3 & 10 & 10 \\
\hline $10 \cdot$ & 3 & 3 & 4 & 4 \\
\hline $11^{2}$ & 3 & 3 & 5 & 4 \\
\hline $12^{*}$ & Faulad & 3 & Fanled & 4 \\
\hline Todn ${ }^{5}$ & $\pi$ & $\pi 4$ & 290 & 286 \\
\hline $\begin{array}{c}\text { Scending } \\
\text { Todnt }\end{array}$ & \multicolumn{2}{|c|}{ 1] } & \multicolumn{2}{|c|}{585} \\
\hline
\end{tabular}

" Ho collids dala wuilable for these biches

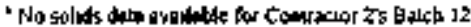

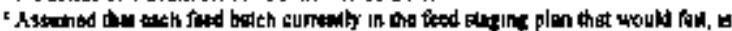

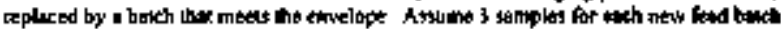




\section{HNF-SD-TWR-AOA-ODI}

\section{Revișion I}

This pege inlentiondly left blank. 
HNF-\$D-TWR-AGA-001

Revision I

\subsection{DECISION CEITERIA}

This section idextifies the performance measures thal are used to difteredliake betwren alternatyeg. It is important to node that the performante meatures nepregent a mixture of quartilalive and quslitaive factors. Some of the performance measures, such ag cost, represent difeclly raeasurable variables. Other performance measures, such as operability, are muxh mote dependent on the judgement of experienced enpineers. Although this study foetuses on the more tangibte and irameblately visib]e perfomance measures such as cost and schedulte, it should be noted that some of the less tangible performance measures, suxh at operability and safety, can carry heavy hidden cost axd perromance penalties (c-g. . unplanned shutdowns due to equiprnear failutes and the need to changeous in-tank equipenent on a greater frequency).

\section{$4.1 \operatorname{cosT}$}

$r_{0}$ the extent practical, the system, equiprant, or conponent will be evaluated with respect to cespital and operating ife-cycte costs.

\subsection{TECHNICAL MATURITY}

The tectinical maturity of a process, system, or piece of equipment can be tasessed in temis of the following maturty hieranthy (given in descenditig ordet of preference);

Availabe:

- Techrologies that are applice on a production scale in the nucless industry.

- Techwologies that are applied on a production scale in a conventional commercial industry.

Field Testing:

- Technologies that have been demonstraled on a "hot" or nuclear pilot scate using actual tect materials.

- Techrolegies that tave been derconstraled on a "cold" or non-maclear pilot scale using simulated feed malerials.

Prototype:

- Technologieg that have been demonsualed on a hox" or muclear bench scale using actual feed mantriels. 
- Techunologies thal heve been denonstraled on a "could" or don-nuclear bench siale urog anmulatepd feed materisls

\section{Vodkr development}

- Technologjos that are suppoined by studies waich are backed by berab scale experureals

- Technologies thal are suppoted bv conceptual shudies that are not backed by bench 5çale experments

\section{Unavalable}

- Technologies that are not avalkble for use

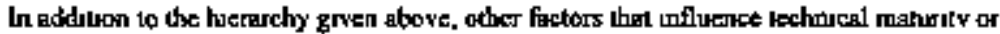
Iechoblogy assurtanct incluxk, (1) maxicaieng flexibulty (adeptabylily for new technologies or mission change). (2) design flexubility of adaptabllity for incorparatiog impraved texhnologr. and (3) awouding tegulalory uncertaiaty

\subsection{MAINTAINAGILITY}

The mantainability of a syglem car be assessed by evaluaing the complexity, reliabulity,

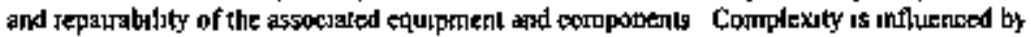
factors such is the level of trounmig required to perform mountentinse on the equapmint, the nood for specisl or uniche lools or procedures, design gualinies such as features that ense repalir, standardized parts and provisions for ipoubleshooung Reluablity can be derently messured by

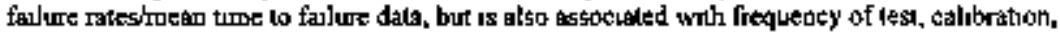
and pretentuve manteriance procedures Another key measure of reliabulty is the impacl of Saulutes on the process, including recovery at downtime followng a taulure Reparability is Infivenced by wotk space factorg (interterences, confined work spaces, the ), location of the equipment, means of repeur or replacement (cemole or contact manlectabes), number and type of personnel requited lo stpport ispars, pre-mantenance preparalion requirements and post. mawienauce impacts such as quanilies and types of wastic produced and functional test

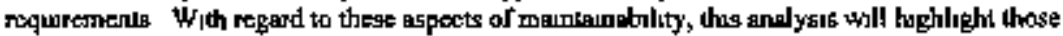
characlenstucs thal are slgtuficandy differend belween tbe allematives

\section{A.A OPERABILITY}

Operabiluty of a system is mostly a qualilative measure of the unherent complexuly of a system that unfluences other aspexis of operobilily anch as the following 
HNF-SD-TWR-AGA-COOI

Revigion I

- Startup and Sbutsown of the System. This is an important operatility issue since most upter conditioths occur during startup and shutdown when the system is is a state of flux and ungeady stane conditions are prevalem. This is heavily influenced by the number of sub-systems or unil operalions involved.

- Process Condrot. Operability wilh regard to process control is influtenced by the number and type of ptocess control points (ischuding process samples).

- Troubleshooting and Response to O/f.Normal Condilions. This factor is influenced by the diversity of sysiems and equipment. Systems that use simple, malure technologies and equipeneal are fawored over nowel and unique technologies and equiprent for which there is little operating experiessce.

- Operator Interfaces. This aspect of opesabitity is infuenced by such factors is the kevel of tratindng required to operate the systrm and be degrase, type, and frequency of operuter interaction winh the system.

With regard to these aspects of aperability, this angalysis will highlight those chacacteristics that are sigaificantly different between the altematives.

\subsection{SCHEDULE IMTACTRISK}

Schedule impaclirisk will be assessed relative $\omega$ implementalion of a given alternative. \$chedules oo be considered tre]ude start-up, production, Tri-Party Agretement, and ocherr inlemally (WHC) or exletnally (DOE, regulabry, stakeholder) diven schedules.

\section{S ENVIRONMENT AL DMPACT}

The cavironmental impacts of a system can be assessed by evaluating the following factor:

- Gaseous eflluent generation

- Secondary dangerous waste generalion

Gaseows eflluent generation is defited as the rate of emission of regulatod pollutants, both radioactive and nonsationctive. Ideally, emission rates should be kept as low as reasonably achievabje (AI,ARA). The degree of tteatmenl required to meet airbome effluent discharge limits is also a fector thal should be examined in comparing systems.

Secondary dangeroug watst generalion is thefinted as the quantity of wastes (theluding mixed wastes) generaled as a result of the primary proceseing operation. Secontary dangerous waste gentetalion should be minimized as much as possible. The extent of in-plant secondary 
waste trealment facilities and dangerous wasle packaging and storage and accumulation areas are factors thal should be considered when cemparing syalems based on secondery waste generalion.

\subsection{SAFETY}

To the extent practical and meaningful, altcralives should be compared on the bases of associaled hazards and implicalions for ongihe/of'site safely, worker safety, and mission and properly protection. Topical areass for consideration include the folltawing:

- Hazards

- Introchuctionj/ereation of hazands

- Ease of harard mevealion

- Ease of hasard mitigation

- Offsitolonaine safcty

- Hazard calegorization

- Safety class

- Performance category, or seigmic criteria

- Ratiological rísk acocptance criteria pompliance

- Toxicological risk soceptance criterio compliance

- Procegs and industrial safcty

- Health physlcs requirements

- Compltance wilh DOE 6430.1A and telaled indugtry standatds

- Mission and Property Protecilon

- Potemial for accident propagation and impacts to otber facilinies

- Potemial imparts due to accidents initialed at other tacilities

- Impliculions for recovety from accidents expected to nocrur during the lifeltime of the mission.

\subsection{REGULATORY COMPLIANCE}

The regulatory cornpliance decision criterion includes conshderation of regulatory compliance, permitting, amd complexily issues. Permitting requlfentents should be evaluated baged on the following factors: (1) number of yermils required or modified, (2) completín of required permining documedtalion, (3) poledlially required pemils or approvals that ane unique 
HNF-SD-TWR-ADA-001

Revisión I

wo the sysaem being exanined, (4) reguladory obstackes, and (5) impacls of permiding acliyjtes on the project schectule.

\subsection{PUBLJC ACCEPTANCE}

This section considers the acceplability of an alkernalive relative to exprossed beakeholder values and concernt. These performince measures hase evolyed from a previous TWRS Leadership Council and were used in previous antalyses (Boomer et at. (999) and a TWRS Decision Board that was eslablighed in 199410 recommend a TWRS facility configuration. The performanke mensures were selecied to bound and consolidale the various stalkeholder valuts (see Table 4-I). 
HINF-SD-TWR-AGA-D01

Revis|an !

Tabke 4-I Stakeholder Values

\begin{tabular}{|c|c|}
\hline Stphefholder valuc. & 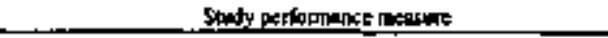 \\
\hline Freded the Colunibst Rintr & 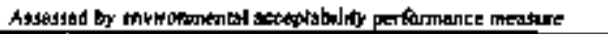 \\
\hline 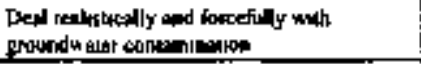 & Nod applocoble to this findy \\
\hline 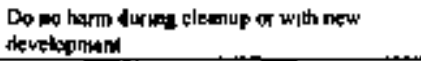 & Assersed by sete tod lociboa of fralilies \\
\hline 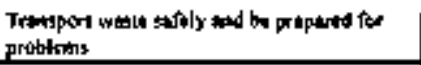 & Non *absed \\
\hline 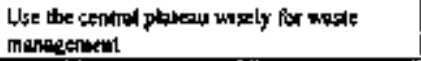 & Nod applocable \\
\hline Clen up ares of high folure ure vale & Non arsessed \\
\hline 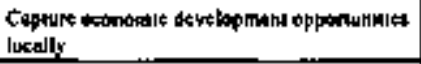 & Non tassesed \\
\hline 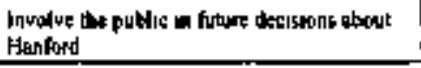 & Jthic gudy will be arualable to the putilic \\
\hline Prolted the orvuroment & 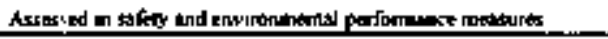 \\
\hline 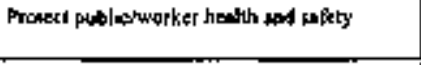 & 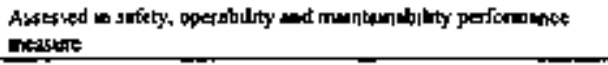 \\
\hline 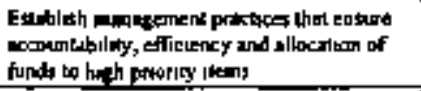 & Kat actessed \\
\hline 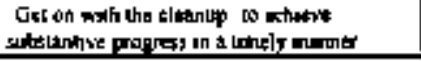 & 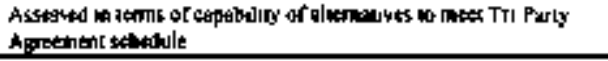 \\
\hline 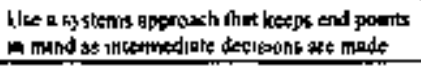 & 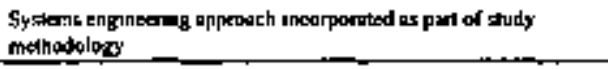 \\
\hline 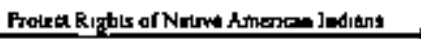 & Nol aystod \\
\hline 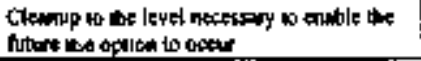 & Nod mserged \\
\hline Entuad Cumplance & 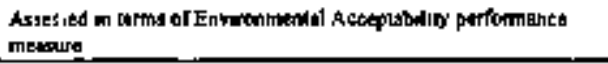 \\
\hline 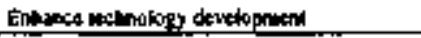 & 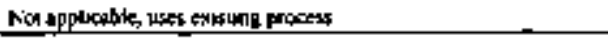 \\
\hline Reduct Cost & 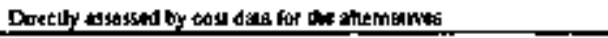 \\
\hline Impropyg yeate mengcemen! & Nol apsesped \\
\hline Uat Mulume Tethriolotiks & 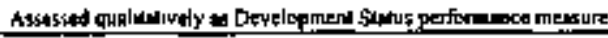 \\
\hline Enbeoce public acceptare & Mal a ressed \\
\hline Use open and for processed & 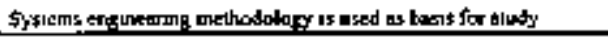 \\
\hline Increas eflenency & 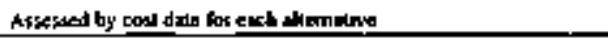 \\
\hline
\end{tabular}


HNF-SD-TWR-AGA-001

Revision I

\subsection{INTERMEDIATE WASTE FEED STACING SYSTEM OPTIONS ANH ALTERNATIVES GENERATION AND SCREENJNG}

In the following sections, the different itions for each system are tiscusted and gcreened Then a set of optrons, onte from esch system, is assembled co produce in allemathe All the 3|termatyves nopt screened meet all the consuraints and requirements Istes in Section 30

\section{S.1 INTERAIEDLATE WASTE FEED STAGING OPTIONS AND SCREENING}

Options were generated for the Waste Transfer System, the IWFST Mixing System, and the IWFST \$amptmg System by informal brainstomnar and documented in meeting mimates (Galbrarth 1996)

\subsubsection{Weste Dissolution'Ddution Bystem Recyimenent Options}

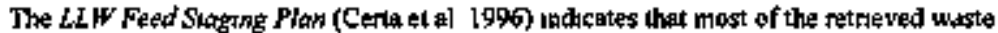
will require 50me tissolution of goluble solids and dilution of supemitantg at the gource 1ank io make the washe pumpatbe using standand tank farm equanoent Thus system is autside the scope of this study but is thvestugated in enough detal 10 define inderfare requirements

Dbgokve all Soluble Solldg. This oplon would require that the Warle

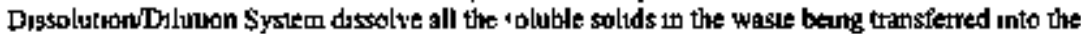

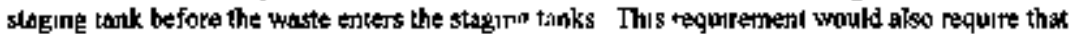
the transferred waste's hydroxide concentration be adjusied to arovd precipialion of aluminum salis in the stagting tank

Dirsalve Munimug lor Waste Trassier. Thus is the "ho requirement" epuron Although

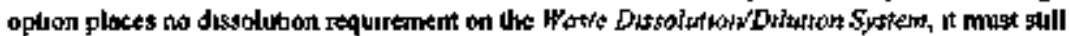
dissolve the munimum soluble solids necessary for the nagste transter. This is requured by the Waste Pumpability Rule

\section{1+2 Waste Transfer System Optian}

The purpose of the Wasle Transiet Sygiem (WTS) is lo move wasle from the gource tanks to the staguse ianks and then to the contractors tanks Ode of the consturaints ot the WTS $n$ that the feed batches sent to the private conttactors must contaln vo more than five valume perreenl settled solids Because of this, the issue for the Wasle Transfer Systern is bow and where to conirol the solids content of the feed batches Thus issute whil] dekermitse whal type of

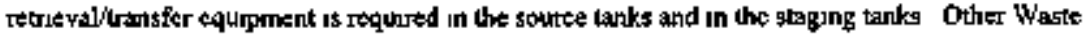

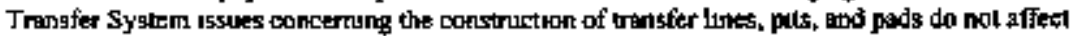
tasures in the other systems and are discussed in Appenolix D 
The pump syskems under consideration are pearly bdenical except for their antake The Gxed-intake trangfer pump is installed wnth is inlake fixed at a spenific benght and will remove al] layers abowe ts untake poum Sunce ths sysem is used more ofter at the Hanford Site, it $x$

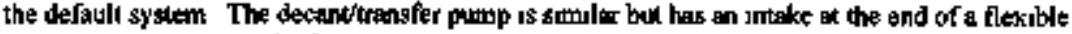
hose Ths makes il useful for selectavely decanting supernatamts from an upper or mid layer and for the mernovat of supermatant heels, if required

The solpls entrumment conirol can be placed gither on the souree lank, of the staging lank,

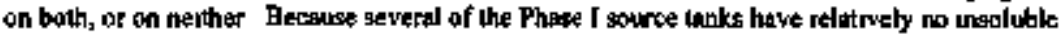
solids and are planned tor compleve retneval, the fixed-intake transfer pumps will be inetenlled regardless of placing the solids limating at the source tank ar not From this, four counbrituons of urinsfer pumps develop atd are discussed below

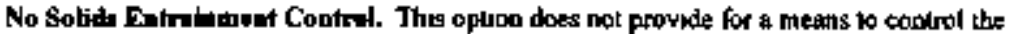

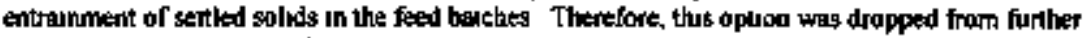
consaderation because it did not meat the enilera of providug feed betches wrth kesa than 5 wodume pereent solids

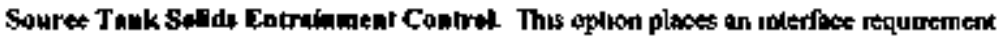
of controling the entramed solutsisludges to a mimenura on the DST Waste Retreval System It

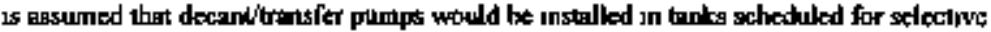
retheval These lanks (1 e, AN-102, AN-104, AN-106, AN-107, AW-101, and AY-101) conlan setiled solids (sludge) layers that the $L[W$ Feed Staging Plon (Certa el ad (996) excludes from retneval Fixed-ingle triesfer pumps would then be installed un source tanks contannig no or very litile sludge and thol are iherefore sebeduled for cơmpleke retheval f $1 \mathrm{e}, \mathrm{AN}-10 \mathrm{~s}, \mathrm{AN}-105$, AP-104, AP.106, and AP-IOT)

The roks associaled with this opiren are that some insohable golids may exist in the laniks

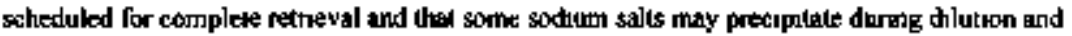
Iransfer to the staging tank

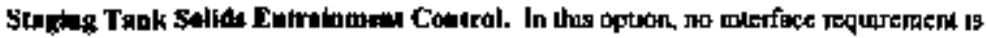

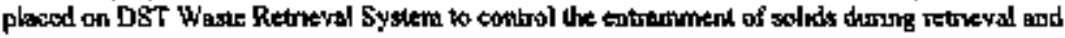
transfer Assumably, Fixed-inlale pumps would be inatallod in all the source tanks Ths option

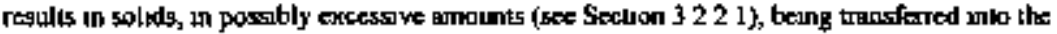
stagng lanks In the blagene tank, the entromed solds would be allowed to settk into a supematant and settled solids byers A rngle decantitransfer purnp installed in wach of the staging tanks would be used to decanl the sapsersilanis from the setiled bolde layer

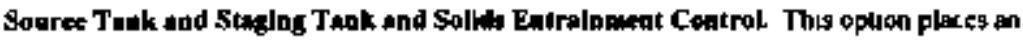
interface requrement of controlling the anirained insoluble solids ks a minmoum on the DST Waste Retneval System Transfir pumps wruuld be unstalled in sourse uanks in the same fashion as staled shove far tha Sowce Tank Solids enfrovanert conirod opion A single decant'trangfer pump woustid be mstalled un each stagiag tank Adding the solids entranument control at the source lanks adds approximately $\$ 5,100,000$ wo the diernalives 
Thus option was dropped from further cunsuderathon bocaule it is assumed that decantituansfer pumps enther in source lanks or no the dlaging lonks is sufficient we controd the

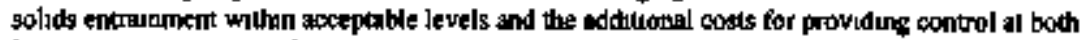
locahrong is nol whranted

\subsection{Intermedtate Waste Foed Steping Tank Mtxing System Options}

The poralary purpose of the IWFST Mixing System, if needed, is ko blend strutufied liquid layers mo a bomogenous maxtume Strahfied kyers in the stapng tank may arse from the loyer-by-loyet trenster of sowere tanir supernalants, the aldibonal wagtes from two ot more sourtes tanks ino a single balch, or from the addilon of chermicals (bJend additrves) to reformulate the batch

5.13.1 No Mirieg Option In liss optoon, no mixers are installed in the staging lanks This

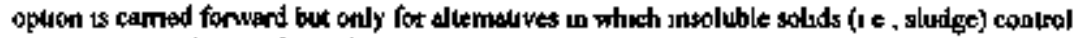
al the source tank is performed

5.1.3.2 Polsed-Air Oploms. Thete concepts wroduce repod aur pulses at the botton of the tank to creare a toroldal current (upurad in the center atd dowmwrard near the edges of the canks) to veracally mix busafied Jequad leyes in the tank The pulsed-aur method may mix stratified liquids layers bull this has not been demonstriled wnth a Hanford waste Alan, $n$ is not knoun

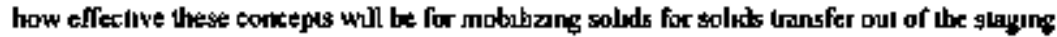
tanks

Pulted-Air Mfier - Sinde Uoùt. The single unut pulsed-alr opluon uses a single undt installed in the lank through the 1067 - $\mathrm{cm}$ (42-In ) nser in the central put Thus single unt is

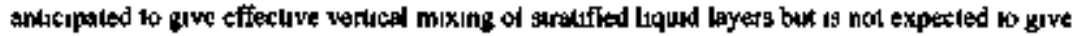
the lank waste enough motrentmm bo adequately mobslize solids for temoval (Powell and Hymas 1996) Insufticient dala exist to make thes determmituon Therefore this optuot will only be cartied Jorward for alterratuves that do nol require solids resnoval from the staging lanks

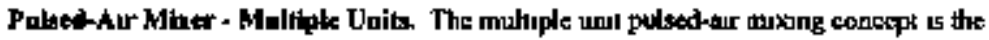
same as the single unil concept plus the addition of thre stratier air pulse systems itstalled in

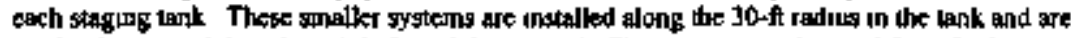
used to better mobulize the soluds for soleds removal Thus option wats dropped from further considetaion because it has not been demonsicaved that multipte units will improve the vertical

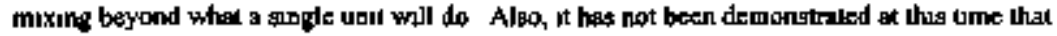

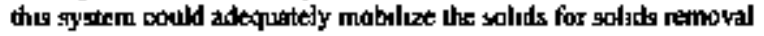

5.1.3.3 Mhrer Puep Optiona. The Muxer Pump opt|ans cougst of highncespacily low-hesd 300-hp punge whth closely-speced suction and diecharge ports They are desugnel to raciraulate the flunds withun an undergtownd radioustive waste tank to wchiveve mobilizalion and inixing of waste sludee ond supernale Mixer pumps are key ta retroval systems such as the Project W-2] I. Inutual Tank Retrierdid Systems (Ruck 1995) 
Mirer Pump 0n-Center. This option uses a single mixer pump of the style developed by

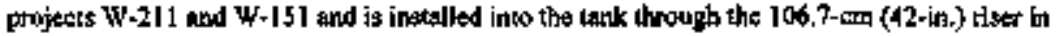
the centel pump pit.

Mitrer Pamp Off-Cnates. This option uses a strgle mixer pump of the style developed by projects $W-211$ and $W-151$. The rrixer pump is installed into the lank through existing $106.7-\mathrm{cm}$ (42-in.) construction riser on a $6.3-\mathrm{m}$ (20-ft 9-in-) radius. This riser is exteodod to grade and a pad is consinucted log the system.

Double Miner Pueps Ofi-Cenier. This option uses twa mixer pampls of the style developed by projects W-2I land W-15I. The mixer ptampg arc installed inlo the tank through existing 106.7-em \{42-in. $\}$ construction rigers an a 63-m (20-ft 9-in) radius. There two risczs are al 90 degrees from each other and are below grade. This optton was diopped due to its high sust and the belief that two off-cerster pumps 90 degrees apposed will not perform apporectiably better that a single mixer pump on-cepler. This has been demongurated in 5cale-model, muttipte. mixer putup tests perfortaed by PNNL, for determizing mixer pumpefficiencics.

\subsubsection{Dther Optlons. Other options thal were discussed include the following.}

Medified Slurry Dlstributor \$ystem. This system would use a transfer pump to move the waste from the IWFST to the AP valve pit and back to the tank through a shury digtributer with a moveable discharge nazzle. The olurry distributor would sindy the recirculated waste aver the surface of tbe tank contents to provide mixirg of the waste. Slunry distributors bave been widely used at Hanford to distribute the heswer slurrites in tho wagle, but sol as a mixing gystem. This system uruld reed o be tested and evaluated for dissolving and mixing efficiencices in scaled modelg before it would be feasibie in the stingian tanks. For this reasont, the Micodifiel Slurry Diatributor Systerc was screened from funther evaluation.

Mechapleal Aqfiaters. Mechanical agitalion is not generally censidercd feasible for mixing 3,785-m3 (1- Mgal) tanks. Therefore, this option was removed from further consideration.

\subsubsection{Intarmedinte Waste feed Staging Tank Simpling System Optlons}

The purpose the IWWFT Sampling \$ystem is ov valindate that the feed batches meel the modified RFP feed envelope limitt. The sampling system concepts considered in this study were as follows.

Grab Sanpling. Thus concept is the "batile-on-a-string" metbod frequently used at the Hinfard Site.

Core Senpling Sytem - Siallonary. This concept involves the permenenl placement of a core sampling sysiem, of the type currenlly tused at Hanford, onto each staging lank. 
HNF-SD-TWR-ACA-[OO1

Revision I

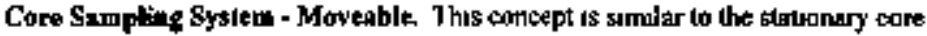

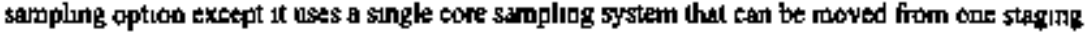
conk io the ather on a ral system

Lodok'-Type Sanpling Sysiem. Thi woncept uses the conceptual design done for the Grout Dispogal Program that Jocales a sampling facilty withn the AP Tank Fam and pulls \$Buples trom a fecirculation loorp locared in each taik

\section{$\$ .2$ INTERMEDIATE WASTE PEED ST AGING SYSTEM ALTLRNAT]VES GENPRATION AND SCREENING}

Figure 5-I shows each of the IWFSS sulosystems from the TWRS Architesilute Tres in

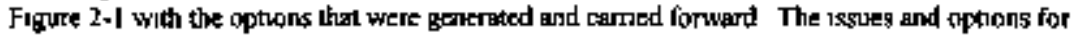
these systems aflect each other, in parucular, tae IWTST Transfer Pump and the IWTST Mixing Sysicm Thereforc, alkenatives were generated lhal neprescant the combinations of opilions for the tragsfer pump and the mixing system Table 5-1 ghows this a] ternatives gencation

To each of these alternauves, the wost uppropriate ophons for the valye put and the samplıng and venulatiun systeres were added Figure $\$-2$ shows how the opdions for these systems 61 logsther inio the altem:sines

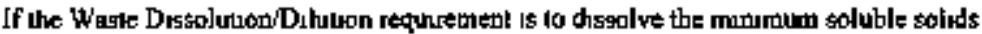
for the wrate trantefer, some soluble soluds may be unirodoced wio and seftle to the bottem of the stacing lank If no method of mobilızing the soluble solids is ayahabit, soluble sodinm sqlis nasy be umientionally excluded from fized batches that could cause the bakebed quantity of sodnum lo

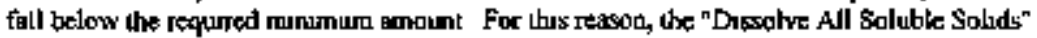

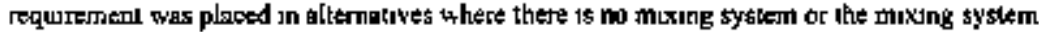
does not mobnlze solvds (1 e, the pulsed-ait mixer)

']polok is a registered urademark of Ben E Haeger, Yorkville, IL 

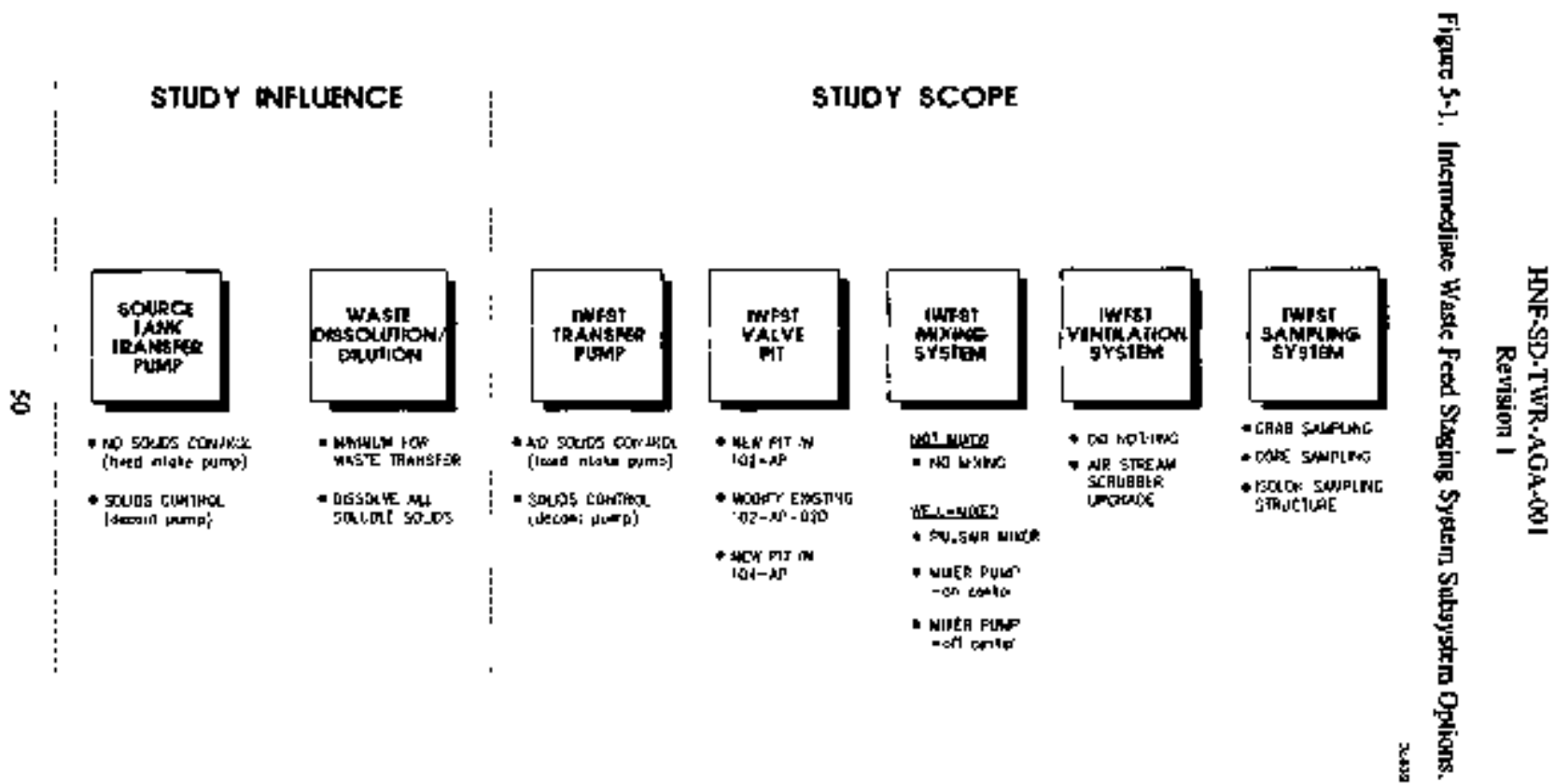


\section{Revigion !}

Table 5-1. Tntemedtialm Waste Feod Staping Sycsong Altematives.

\begin{tabular}{|c|c|c|c|c|c|c|c|c|}
\hline Alaprutives & I" & 24 & $3 *$ & 4 & $s$ & 6 & 7 & 8 \\
\hline \multicolumn{9}{|l|}{ Wased Traprer Systim" } \\
\hline \multicolumn{9}{|l|}{ No solide entringuent control' } \\
\hline Sollds coprinumend cpotral a IWFST & $\mathbf{x}$ & $\mathbf{x}$ & $\mathbf{x}$ & $x$ & & & & \\
\hline $\begin{array}{l}\text { Solids entrginmen control a Source } \\
\text { Tank }\end{array}$ & & & & & $\mathbf{x}$ & $\mathbf{x}$ & $x$ & $x$ \\
\hline \multicolumn{9}{|l|}{ 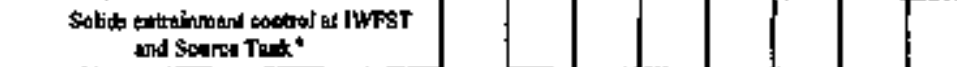 } \\
\hline \multicolumn{9}{|l|}{ INFST Mixing $\$$ ytem } \\
\hline No Miketr & $x$ & & & & $x$ & & & \\
\hline Pulsai Mixer • Single țpil & & $x$ & & & & $x$ & & \\
\hline \multicolumn{9}{|l|}{ Pultair Mixer - Audiplo Undu" } \\
\hline Mixer Pump OnuCenta & & & $\mathbf{x}$ & & & & $\mathbf{x}$ & \\
\hline Mhet Pump Ort-Cenes & & & & $\mathrm{x}$ & & & & $x$ \\
\hline \multicolumn{9}{|l|}{ 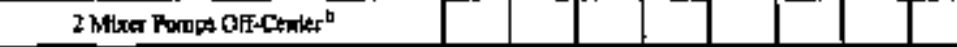 } \\
\hline \multicolumn{9}{|l|}{ Mpodified Slurry Eisulbutor" } \\
\hline Mechroked A pitwors ${ }^{8}$ & & & & & & & & \\
\hline
\end{tabular}

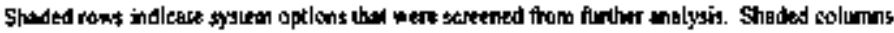

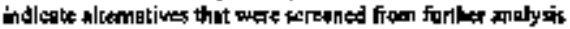

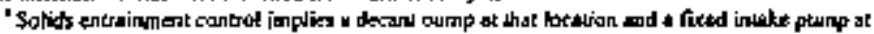
the otber locelion untess otharyitet specilled.

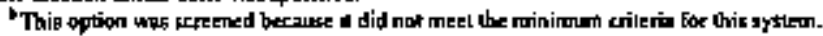

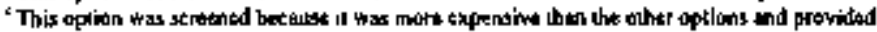
eithes no of malnal additlornl benefiks.

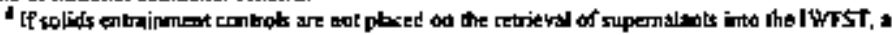

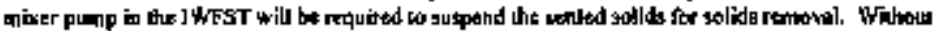

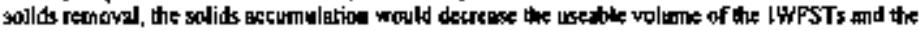
schentule wapuld be mikepd.

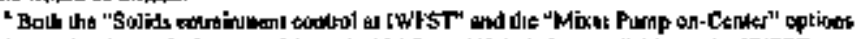

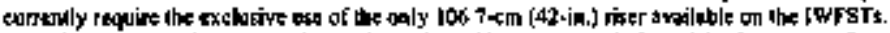

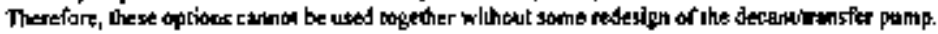




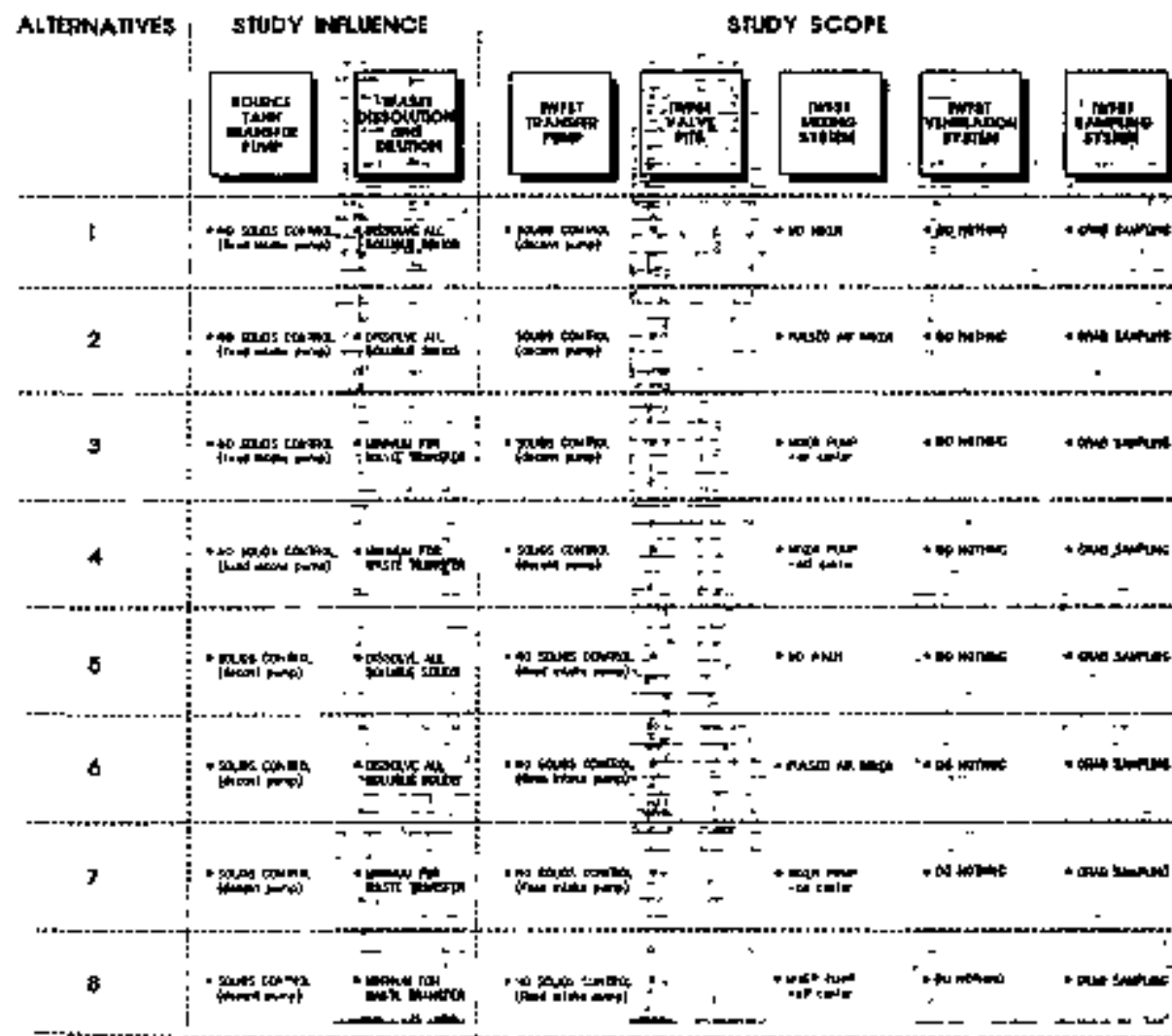




\section{Revision 1}

\section{2,1 Altarnativiv I}

Alıernative 1 combines the fotlowing options.

DST Retrlewal InIerface Requtrements.

- Na source tank solids emtraitument contod (fixed-intake irangfer pumpe in al1 source tanks).

- Dissolve all the soluble solids.

\section{lWFSS Option.}

- A decantitastsfer pump in each IWFST (Solids Entrainment Control).

- A new valve pil on AP-104.

- No mixes pump in each [WFST.

- No ventilation upgorades

- A grob stumpling system.

If Uxe solids entrainment condrat in nod performed al the source unk, insoluble soltds (Le., aludges) will be thlrained and transferred to the staging tank where they will settle to the tank bottom and accumulate. Withost the removal of these solids, they will reduce the ugeable volume of the tank causing the schestule is be impacted. Therefore, this altermative was screened from further cansideration.

\section{2 .2 Alerasthe 2}

Alternalive 2 combines the following options.

\section{DST Rearieval Interface Requirtmedis.}

- No source tank solide entrainerest conlrol (fixed-intake transfer punps in all source (19aks).

- Dissolve all soluble solids 


\section{TWFSS Options.}

- A deantitansfes pump in each IWFST (Solids Endrainmeat Contral).

- New pits on AP-102 and AP-104 (106.7-cm [42-in.) rises) for the decam/leansfer pumps.

- A pulsed-air mixer on-center in each IWFST.

- No ventilation upgrades.

- A grab sampling system.

If the solids antrainment contral is stal performed ar the source tank, insoluble solids [i.e., sludiges] will be mutrained and transferred to the staging lont where they will oettle bo the tank borlown and ocemblate. Without the removal of these solids, they will reduce the useable volume of the tank calusing the schedule lo be inpacted. Therefore, this allemative wats streened from further consideration.

\subsubsection{Alierwithe 3}

Alternative 3 combines the following options.

DST Redrievil Imierface Requiremento.

- No source tank solids entrainment conurol (fixed -intake transfer purmps in all source tanks).

- Dissolve tho minimum arount ol solidg to meel wase transfer fequirements.

\section{lWFSS Options.}

- A decantitransfer purru in each 1WF\$T (Solids Entrainutaent Control)

- New pits ou AP-102 and AP-104 (106.7-cm [42-in.] riser) for the decant/fratsfer pamps

- A mixer pump an-senter in each IWFST.

- Na ventilation upgrades.

- A grab garnpling system. 


\section{Revision I}

The decanuitransfer pump requires a 106.7-em (42-in.) riser. The only 106.7-emor (42-in.) riser availabte on the tanks is gt the center where the mixer pump would be located. $A$ spare 106.7-cm (42-in) risere on \& 6.3-m (20-ft 9-in.) radius will be extended to grade. A pil will be added to contain the pumpa and jumpers and new waste transter lines witr be rouled to the central pump piL

\subsubsection{Alnemative 4}

Alternarive 4 combines the following oplions.

\section{DST Retrievol Jnteriace Requirzments.}

- No tource tark solids enktainment control (fived-intake cransfer pumps in ell tource Lanks).

- Diggolye the minimum amotut of solids is mete waste trantfer requirements.

\section{TWPSS Optious.}

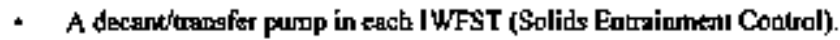

- The decantitransfer pumps wilt be intaglked in the 241-AP-02A and 241-AP-04A central mump pils.

- A mixer pump off-center in each LWFST.

- No ventilation upgrades.

- A grab sampliag system.

\subsubsection{Alteruatives}

Alterative 5 combines the following aptions.

\section{DST Retrieval Interface Requirtmedts.}

- Control solids entrimment (decandiranter pumps in gix source tanks, tixed-itjake iransfer pumps in the five olher source tanks).

- Dítsolve all the soluble solids. 


\section{IWESS Optiant.}

- A fixed-iblake iransfer pump in eacb IWFST (No Solids entrainment control)

- The AP-102 transfer pump will either be installed in the 24 L-AP-02D pit or the central pump pit. The AP-I04 pump wil either be inglalled in the central punp pil ar the aew waste tansfer value pit.

- No mixer pump in each IWFST.

- No vertilation upgrades.

- A grab sampding syskem.

\subsubsection{Altertalive 6}

A|temalive 6 combines the tollowing options.

DST Retrieval Interface Reguiremente.

- Control solids entrainaend (decartitransfer pamps in six gource lanks, fixed-intake transfer puraps in the five olher source (anks).

- Dissolve all the soluble solids.

\section{JWFSS Opdions.}

- A fixed-intake trantier punp in ench IWTST (No Solids entrainment control)

- A netr pil on AP.I04.

- A pulsed-air mixer on-center in each 1WFST.

- No ventilation upgrades.

- A grab sampling systets.

\subsubsection{Altermethe?}

Ahernative 7 combines the following aptions. 
HNF-SD-[WR-AOA-0OI

Revision ]

\section{DSTT Retriteval Interface Requiremenls.}

- Control solids entraitument (decanduantfer pumps in six source tanks, fixed-intake Iransfer pumps in the live other scurce tanks).

- Dissolve the minimum amount of golids Io meet waste transfer requirements.

\section{IWFSs Dptions.}

- A lixed-intake iransfer pump in tixh lWFST (No Solids entrainmenal tontrol).

- A new yalve pit in APr 104.

- A roixer pump on-cenler in each JWFST.

- No ventilations upjesdes.

- A grab sampling system.

\section{2 .8 Alternetive 8}

Alterative 8 tomblose the following optunts.

DST Retrikval Rpterdace Requirearats.

- Control solids entraiomen (decant/ransfer pumps in six source tarks, Exed-intake transfer pumps in the five other gourec canks).

- Dissolve the minimum anotmi of solids co meel waste trabsier requirentents.

\section{[WFSS Options.}

- A fixed-inlske transfer pump it each IWFST (No Solids entrainment comtral).

- The trangfer pumps will be instalked in the 241-AP-02D pil and 24L-AP-04A central pursp pit.

- A mixer pump off-center in esch IWFST.

- No vemilation upgrades.

- A grab campling system. 


\section{HNFF-SD-TWR-AOA-001}

Revision ]

This page intemionelly left blank. 
HNF-SD-[WR-AGA-OD]

Revișion l

\subsection{WNTERMEDLATE WASTE FEED STAGING SYSTEM DESIGN CONCEPTS}

\section{I WASTE TRANSFER SYSTEM DESIGN CONCEPTS}

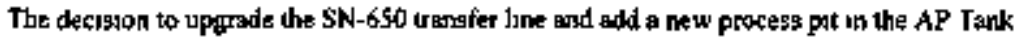
Farm has been made (Gialbrath et al 1996) An Eiganeterng Report is prescniced in Appendix D Ihat proyides three opions for instell]ng a trassfer put in the AP Tank Farm Option I would add

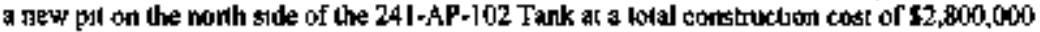
This 19 equivalent 10 Altemitive $K$ as presented in LLW Feed Bragutg PJart (Certat er al 1996) Optuon 2 looked al using the existung 241-AP 02D Pump Pri at a wolal constructson cost of S1,900,000 Opeion 3 would add a new put on the 24l-AP-l04 Tank sumlar to the 24]-AP-02D Puinp Prt al a lotal construcion cost of $\$ 2,7 \$ 0,000$

Option I meets all of the requurements for the transfer sysicm Optaon 2 was not preferred

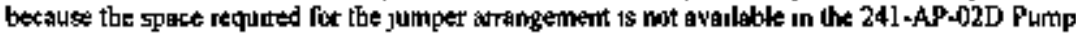
PIt In 3dd11ion, the topography of the iransiec gystem in Option 2 dees not meet the requirenseph of Altemative $K$ Opton 3 meels al of the requirements for the transfer system However, in order for Opturn 3 to manalain the topography requirements of Altemabie K. the Dew pit needs or be separaie from the decandiliansfer purap If the pump is locaced in the same pit, a wall separating the pump discharge jum|ser arrangement fomt the HLW feed jumper arrangement would be needed (Sec Appendex D)

Optien I and Ophon 3 are almost ddemital in each of the deciston criterna used All of the requiremienls of the trantier system, theludug the ropagraphy are met and the casts are similar Hourever, Optron 3 is the prefered option because the new put on the stagng tank would allow access in a 305 -cm (12-1 ) ग5er This pul could be used in the future for m-tank equipmem where a's the pit is Option I could anly be used for the scope of Phase I Privatizion

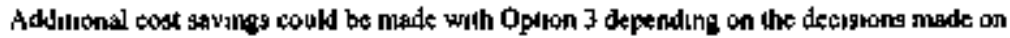
soluds entrainment control and the mxing syslem Suze and specific location of the dew purtep pit could be optinized with the upgrakes required for these other systems Houtever, these posshble cost savings trould be addressed dunng the de fienture degign stage and do not affect the decisons to be made here

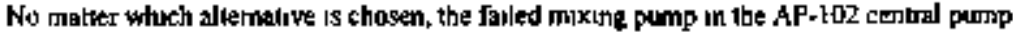
pit and the slurry distribulor in the AP-I04 central pump pit would noed to be removed In addilion, the exigung trangfer pumps and thermocouple irete would need to be removed The cosi foc teraoval and disposal of this equpmeal is approxirnately 55,500,000 (For the no mexer a|tematives, 11 is assumed that the existing therteocoupte uees will not be removed For this sase, the cost far remroval and disposal of the remalning equiprient would be appoxunately $33,900,0(90)$ Thus uncludes $\$ 2,900,000$ for treethouse and support costs and mmobslization

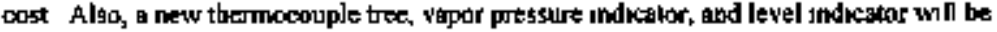
required in each slagemg tank The lotal costs to purchase and install this equiproen is both of 
HNF-SD-TWR.AOA-OOOL

Revison I

the staging tanks are approxmately \$260,000 These costg need to be added to the cosis provided belpuw

\subsection{J Intermediate Waste Feed Sagung Tank Soluds Entraingent Cantrol}

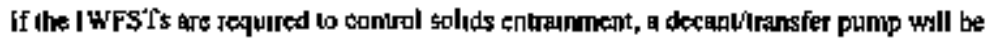

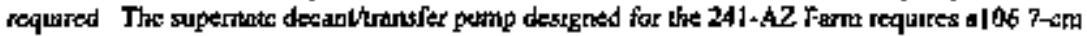

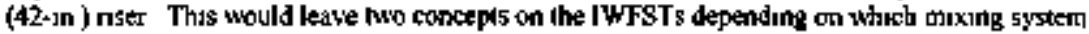
concept is chosen

The first concept would be id use the $106,1-\mathrm{cm}(42-\mathrm{dn})$ neser in the central pump pil This would coineide with Opton 1 in the Muxing 5ysiem AOA (Sex Appetidix A) The muxer pumpg would be placed off-center and the new decanthransfer ptamp would be in the central pump pil

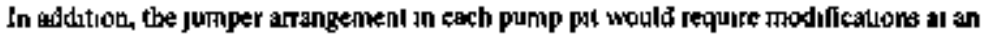

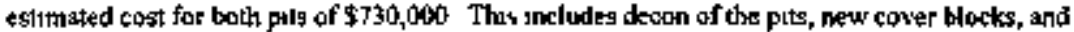
removal and dusposal of the exusung jumpers The cost of iwo new decantitanster pumps would

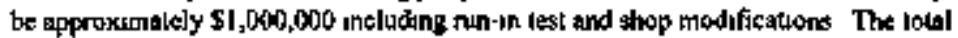
constinction cost for this concept would be approxim:ately \$4,400,600 This uncludes $\$ 1,200,000$

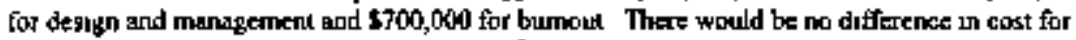
this concept of the decenuliransiet pump (or a fixed-intake pump) is installed ton a 50 5-cm (12-un ) nser in the central pump pit Currendy a decanlitranster pump that uill operaie wath a mixing system has not been depgned that will fit in a 30 5-cm (12-un) nser

The second concepl would be ta add a ncw punp plt above the off-center 106 7-cm (42-in) nster This conncides with Option 2 is the Mi cing Syserv ACiA (gee Appendix A) that uses the central purnp pit 106 ?-cm (42-10 ) neer for the taxixer pump. The would require a new pump pit ard a new transfer line between the neth pul and the cental pump pit at an esumaled cost of \$1,700,000 for both stiegng tanks This includes rerouting of exising trabsfer lues and insurumerix an links, and a new core dnil in the 24I-AP-04A Cerriral Pump PIt in addihon, the

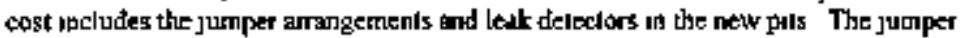

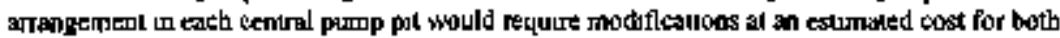
pis of \$910,000 This includis decon of the pals, thew cover blocks, and nemoval and disposal of the exusung cover blocks and Jumpers The cost of two new decanditangler pumps woukd be approxianatcly \$ 1,000,000 uxcluding run-m test and shop machficsluons The total contruction cost for this conctpl trould be approkimately \$6,100,000 Ths includes $\$ 1,200,000$ for desigh and manayement and $\$ 1,300,000$ for burnout The difference un cost tor this conpepl if the

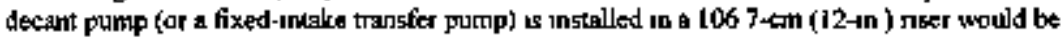
approximately $\$ 850,500$ 


\subsubsection{Source Tank Solids Entr inmeat Contral}

If the source lank is used to control the sollds, the staging tanks would not require a decant pump. The sloging larks would just need to be equipped with a standard fixad-intake trangfer purmp to feed the coniractors" tanks. The New Generatlon Transfer Pump. (NIBTP) or equivalent is assumed to be used. The NGTP can fit in a $30.5-\mathrm{cm}$ ( 12 -iti.) diamoter niser in the centsat pung pll or in the 241-AP-02D Purap Pit andd a new pamp pit atoove riser no, 13 (30.5-cm [12-in.]) on the 24I-AP.104 Tank. The location of the pump will depend on the concept chasen for the mixing system.

If Option I (Mixer Punp Off-Center) for the mixing system is chosen, lhe NGTP could be located in the cents installing the uransfer pump would be the same as une cost for installing the decall pump in the central pump pit. The tolal constuclion tost of this concept wobld be opproximately $\$ 4,400,000$. This ircludeg procuremenI, design, removal and installanion of jumpers, and bumoul costs.

If Option 2 (Mixer Pump On-Center) for the mixing system is chosen, the NGIP could be loceded in the 241-AP-102D Pump Pit and in a new pump pit on the 24I-AP-104 Tank (goe Appendix A). The new pump pil and transfer line woold have a holal cost of approximately 5830,000. A new jumper aurangement in the ventral pustop pit on the 241-A.P-104 Tark would be around $\$ 460,000$. If the cost for degien and bumoul are included, the tolsa construction cost for this concept wottd be approximnlely \$S,300,060. Thig ineludes procurement, design, and bursout costa.

\subsection{MIXING SYSTEM EESIGN CONCEPTS}

Table 6.I summarizes the combined costs and concepts for the whete transfert and mixirg systerns. The combined cost includes the asociated equipment removal and preenhousersujport costs. Details of the wagte transter gyglem design concepts were addressed in the previous section. Details of the mixisg sysern design concepts are in the following rections.

\section{2.] No Mixing \$ysted}

In this concepl no mixer pumps ane installed in the staging tanks. The detant pump or fixed-intake pump could be loented in the ceplral pump pit of the staging tanks (see Apjendix A). The cost associaled with installing either of these pumpe would be the satte as the cost for installing the decant pump in the cearal pump pin (see Section 6.1.2). The total construction cost of this concept wonld be approximalely $\$ 4,400,000$. This includes procurement, design, rethoval and instaljation of jumpers, and burnoul costs. If the cost for equipmerit removal and replacement is included, the total construction cost wortd toe approximately $\mathrm{SB}, 300,000$. 


\section{Revigion 1}

\subsubsection{Pulsed-Aur Mixing Syuten}

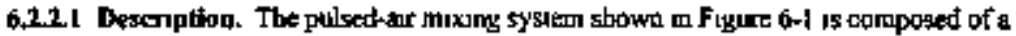

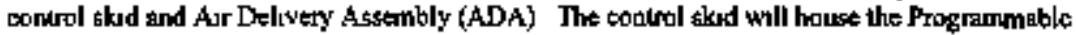
Logit Controller (PLC). Operator Ioterface Tertinal, and the arr comptessof A turable aur hose Will then run from the control skid to the central pump pit(9) on AP-102 and AP-104 The alr

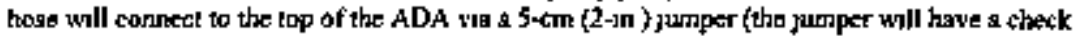
valye to prevent bark flow) The ADA consists of a 14 3-m (47-ft) long 5-cm (2-1n ) schedule BO stantitss sieel pepe, with a Double Accumulator Plale (DAP) weelded to the end A DAP is rasde up of two stainless gtect plates (gize of plale us dependant of niser diameter) The plates are anenied so that one ug drecily above the other with about o 2 54-cm (l-sn ) space separating them 
Table 6-1. Combined Consinution Cost of Waste Trangfer and Mixing System Concepts.

\begin{tabular}{|c|c|c|c|c|c|c|c|c|c|}
\hline \multirow{2}{*}{ Conpopt } & \multirow{2}{*}{$\begin{array}{c}\text { Cost } \\
\text { ts } \\
\text { willos }]\end{array}$} & \multicolumn{8}{|c|}{ Alatentive } \\
\hline & & 14 & $\mathbf{2}^{*}$ & 3 & 4 & 5 & 6 & $\tau$ & $\$$ \\
\hline \multicolumn{10}{|l|}{ SN-690 Trumier Spated } \\
\hline Oplian I er Optiran 1 & 24 & $r$ & 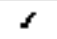 & 1 & $\checkmark$ & 2 & $r$ & 7 & $\gamma$ \\
\hline Opdltक 7 & 19 & \multicolumn{8}{|c|}{ 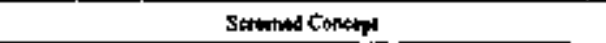 } \\
\hline \multicolumn{10}{|l|}{ No Mididas Syurm } \\
\hline 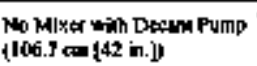 & $\mathbf{s} 3$ & 1 & & & & & & & \\
\hline 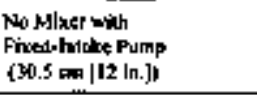 & \pm 3 & & & & & 2 & & & \\
\hline \multicolumn{10}{|c|}{ 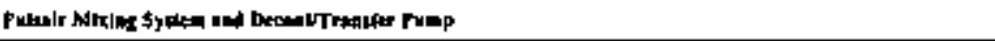 } \\
\hline 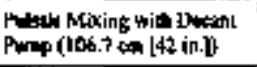 & $1244^{\prime}$ & & $r$ & & & & & & \\
\hline 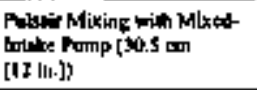 & 11.6. & & & & & & 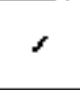 & & \\
\hline \multicolumn{10}{|c|}{ 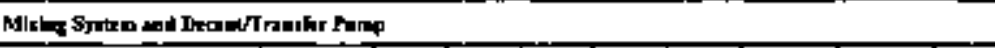 } \\
\hline 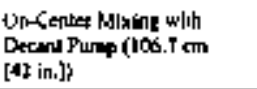 & It6 & & & $\checkmark$ & & & & & \\
\hline 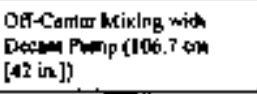 & 16.6 & & & & $\checkmark$ & & & & \\
\hline $\begin{array}{l}\text { On-Center Middine with } \\
\text { Fived Imlate Pump } \\
(30.5 \text { [ } 12 \text { in.] }\end{array}$ & It.t. & & & & & & & $\checkmark$ & \\
\hline 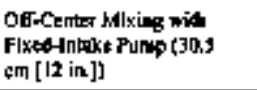 & 16.6 & & & & & & & & $\checkmark$ \\
\hline 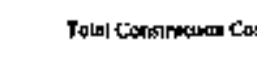 & (5 mialon) & 11.4 & 292 & 21.4 & 19.4 & 11.1 & (14.0) & $\underset{(30.2)}{20.6}$ & 19.4 \\
\hline
\end{tabular}

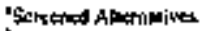

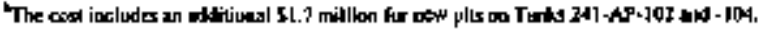

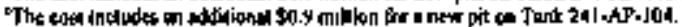

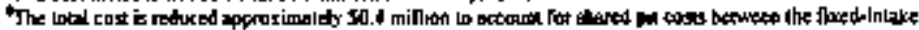

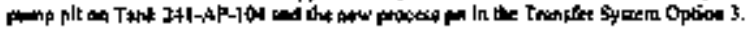




\section{HNF-SD-THR-AGA-AOI \\ Revision ?}

Figure 6-1. Pulsed-Air Mixing Syatem.

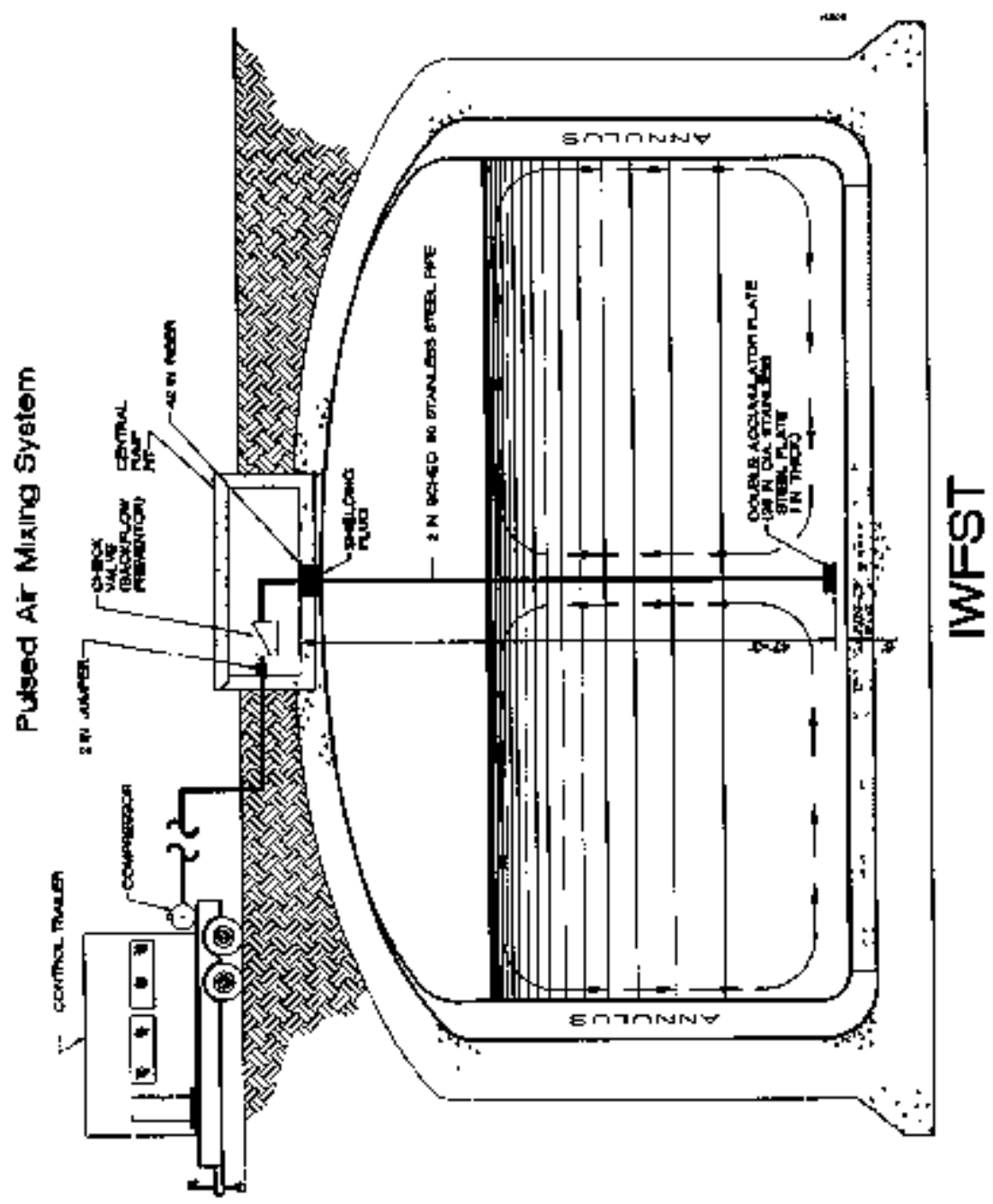


The cantept betund a pulsed-air mixer is very sumple Ar, supplied by the comptessor, is pulsed through the ADA when the aur reaches the DAP, it is lowsed in a raclal direction The alr regrougs durectly above the DAP to form a targe oval bubtle The bubble rapudly travels upwarda, due to broyiant forces, to the top of the nasce, pullits the besvy guperialanl up wrth it Al the top of the supetnalanl, the bubbte burstr volemthy, and energy is telessed from the bubble

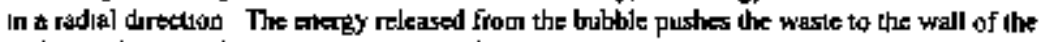
tank At the wall, the supematant is pulled to the bottont of the tink by granty Thus cycle is

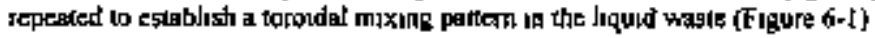

Installatuon of the pulsed-ar mixing system will be at followt A shrelding plng will be labricaled on the lop end of the ADA, which will then be lowered unto the resr, as one ngid unit, by a crant The ar line will then be atisched All shielding and contasnmenl stnuciutes for construction will be used as required (these ars reflected in the cost esumale)

For the staging tanks, there are two oplions for implementing the pulsed-aur thixer systert Opt|on I consistg of a singte DAP (9I 4-cm [36-in] dismeter) thstalled through a $106 \mathrm{7} 7 \mathrm{~cm}$

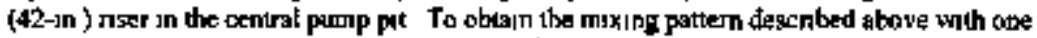

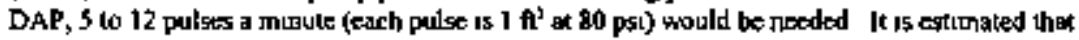

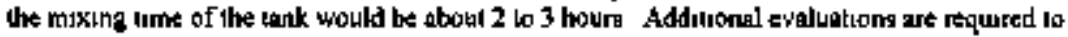
determine the pulse frequency and interactions unth the tank suructure

Option 2 is io install throe 25 4-em (10-an) DAPs through a 30 5-em (132) spare nser located on the outet tadius of the link The uperaltan of the 25 4-cm (I0-In ) Daf's would be integraled whth the operation of the centrally lacated 9/ $4 \mathrm{~cm}$ (36-th) DAP Added DAPs will increase the cosl by opproximaleby I0 percenl per DAP This method is predicted to mobilize more solids off the boitom of the lank thand the previous method Thus opture as well needs to be demonstraled to vernfy the peroormance of the system in a $3,785-\mathrm{m}^{3}$ (I Mipal) tank

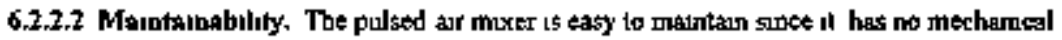
parts un the waste tanks The syytem consssus of a bong pupe welded to a DAP Otce the pipe and DAP anc installed, thare is no need for taumlenence in the tanks The only mechanical parts of

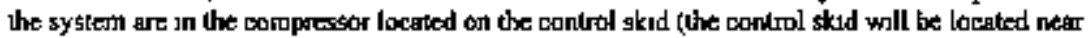

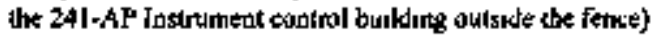

Ventulalion effects due to a pulged enr mixer ware evaluated As an upgrade to the IWFSS, de-eatrantment devices were investigated The evalualion concluded that fhuldics devices, which are currently used in the uuclear itdustry for de-entranment and are inexpensive and compact, would fulfill the requirements of controlliug erosol particleg generated by the pulsed-aur muxing systerc Flundics devises have no mechancal parts, and lierefore are very low malutenance The

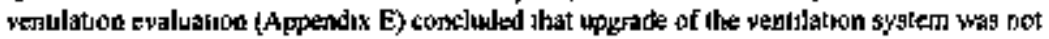
watranted based on a life-cycle cust companson of scrubber toglallation versur HEPA filter

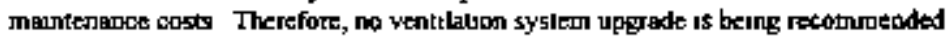

6.2.2.3 Tochnicol Maturnty. The purpose of the pulsed-air mixer is to mux stratufied superialant, then the utility of a polsed-aut miket has been demonstratod comoncresally Pulsed- 
Revision 1

air mixers are used extensively in the petrocticmical indusiny, along with many other industries to mix various types of viscoul filuids.

If solids need la be removed from a lage flet bottom tank, then a pulsed-air mixer is nol technically matured. Pacific Norhwest National Laboralories (PNNL) has conducted research on a pulsed-air mixing system for solid suspensiot. PNNL concluded that it was not feasibte is use pulsed-sir mixing for removing studge of the bottom of a flal bottomed tank, but believes that pulsed-air mixers can mix stratified supernikants lite those in the IWFSTs (Powell and Hyorst 1996). PNNL plans to do thore leslmg in FY 1997 on this subject as funding is ptovided by DoE's EM-50 Office of Seience and Technology Developmetsl.

6.2.2.4 Operability. The pulsed-eir mixer will be caatralled from a control room mounted on a bkid. A PLC-based controller with an Operator Inderface Taminal will control the system. Once the PLC is set up, tho personstel are requited to operate the system, only mutine surveillance would be required.

6.2.2.5 Sufty. The pulsedair mixing syslem is in Intrintically safe degiga and can be operaled in a flammable gag entisonment. The control system as desigened providks for a near zero wobalbility for over pregsurization of the tank. To increase the safety of the mixer even more, it will be tied inlo a pressure sensor on the tank we insure thal an pressirization of the tank occurs.

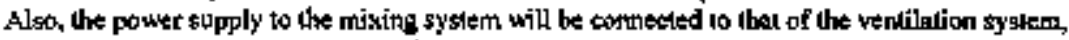
so that when the ventilation sygater, gbuts down, the pulsed-sir mixer will automatically shut down. Another (porential) safety advantage is thax pulsed-aif mixing technology does not add heat to the lark.

6.2.2.6 Cogt The rough onder of a magnitude cost estimate is provided in Appendix A. The cost estimaleg are for both of the slaging tanks.

Option 1, single ADA installed in the central pump pils estimaled to cost \$5.500,000. This cost does not include Other Project costs guch ox CDR prep, PSAR, and startup readiness review

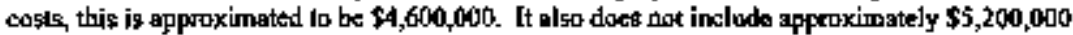

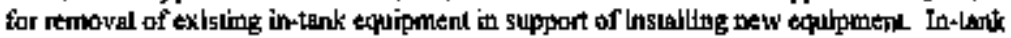
equiptentent to be removed itreludes the failed mixer pump is AP-102, the slury distributor im AP.IOd, the transfer pumis from both tanks, and the thennocouple trees from both tanks.

Procurement took into account the cost of the pulsed-air coutrol system (control trailer. PLC conuroller, soffware and compressor) and toro decant'onasfer pumps (one for each staging 1ank). It was assumed thal only one control sybter and compressor were needed to operiste the mixing systems of both of the staging tanks.

\subsubsection{Miner Puspo On-Cewler}

This concept coincides with Optton 2 in the Mixing Sygtem AGA (Appendix $九$ ). The mixer purps would be locsted in the $106.7-\mathrm{cm}$ (42-in\} riaer of the central pump pit. The total 
construction cost for this concept is approximstely 56,760,000. This includes procurement of the pumps and coutrol systens, design, fabrication, and bumout cosis. The cogts of the mixer pumps and couttol system ate approxinately $\$ 2,300,000$. Upgrades to the row water supply and addition of a nitrogen bortle 5tation accourst frir $\$ 400,000$ of the total casts. In addition, the costs for degign and burnout accouml for a total of $\$ 2,900,000$.

\subsubsection{Mlxer Pump Orf-Cewter}

This concept coincides wilk Oplion I in the Mining System AGA (Appendix A). The mixer punps would be loceted $6.3 \mathrm{~m}(20 \mathrm{f}, 9 \mathrm{in}$ ) off-center on a new conerete pad. The holst consenuction cost for this concept is approximalely 56,400,000. This incluates procturented of do pumpg and control systens, design, fabrication, and bumoul cosis. The costs of the mixer pumps and control system are approximately $\$ 2,300,000$. Upposedes to the raw waler rupply and atddition of a nitrogen borle station $\$$ ceount for $\$ 400,000$ of the tola costs. In addition, the costs for design and bumout account for a total of $\$ 2,900,000$.

\subsection{INTERMEDLATE WASTE FEED STAGING TANK SAMPLING SYSTEM DESIGN CONCEPTS}

\subsubsection{Grab Sarapling Meibad}

The grab sampling system consists of a bonke, stopper, weight and wire rope. The bottle is lowered into the wrste media where the sample is taken. This sampling method is the easiest to do, however, the suctess of the method is higtly dependent on the skill and experience of the personthel taking the samples. In addition, the grab sampling methad is the most susceptible to being delayed by weather conditions. This soncept coircides with Option l of the Sampling System ACSA (Appendix B). For the "well-mixed" waste scenario, this concept would have a total estimaled cosl of 53,860,000. However, for the "nol-mixed" waske sceuatio, this concept would have a total estimaled cost of $\$ \%, 840,000$.

\section{3 .2 Cort Suntping Sysieb}

The core sampling system consists of a spectially destgned and equìpped core sampling touk. However, the sampling equipment could be moumied on a skid. The sampler is loaded into the drill string and the dril] string is pushod through the waste using a dill rig. This sampling method is common on the Hanford Sile and has been shown to be very rethable. This coucept rodecides witt Option 2 of the Sampling System AGA (Appendix B). For the "wetlmixed" waste gocenario, this concept would have a total estimated cost of $\$ 12,670,000$. This includes the capital cost for a new core sampline lruck or stid of $\$ 5,750,000$. However, for the "not-mixed" waste scenario, this coneept wauld have a toloi estimited cost of $\$ 18,540,000$ incluting the cost for a new core sampliag inuck ar skid. 


\subsection{Isolok-Type Sampling Syuten}

This concept uses the conceptual design dane for the Groul Disposal Program Ihal locstes a sampling facility vithin the AP Tank Farm. "The facility uses an [Folok'-type sampler system that can obtain representztive samples of the feed batches in the torging lonks. This correept coineides with Option 3 of the Sampling System AGA (Appendix B). For the "well-miked" waste scenario, this concept wowld have a total estimated cost of \$12,970,800. This includes $\$ 11,250,000$ in capital cost for the sampling facility. However, for the "well-mixed" waste scenario, this concept would have a wiol estinated cost of $\$ 16,906,000$ inclenting the cost for the sampling faxility.

\subsection{INTERMEDLATE WASTE FEED STAGING TANK CHEMICAL ADDITTON SYSTEM}

For the addition of chemicals to the staging tanks, an estinate for a chemical addition system has been obtained. This costimate is based on a canstic supply system but will also hrve the capability to hardle otber chernicals that may be required. This estimate was costed from the cherricil addition system stoped for the W-211 Project. The facility consigts of a mobile hot waler boiler system, a louck unloading station tor $\mathrm{NaOH}$, an in-lion static mixer, and a flubh lank The boiker system wowld provide hol walex that would be mixed with the supplted $\mathrm{NaOH}$. The system would alto provide Elushing of the Iransfert lines ofter a 1ransfer. No layouk of the system has been dowe, however, site imptovements uowld include fransfert lines for $\mathrm{NaCH}$ and diluted waste, electrical and insirumenlation distribution systems, and utility upgrads. The total construction cost for the crualic supply system is approximately $51,600,000$ thesed on the design from Project W-2II. 
HDF-SD-TWR-AGA-001

Reviston I

\section{INTERMEDLTE WASTE FEED STAGENG SYSTEM ALTERNATIVE EVALUATION AND ANALYSIS}

This section evaluales tach of the allemstives catried forward in Section 5 according to the performunce measuras described in Section 4.

\section{$7.1 \cos T$}

Iabte 7-l surnmarizes the costs agsocialed with cach of the aliematives selected for detailed evahuation. All costs are in fiscal year 19\%6 dollarg.

The life-cycle costs tor this evaluation focused on sampling costs and capital corsts for required upgrades to existing tant fann systerns. The capital cost estimates include the cos! assocjaled with the rempoval of pxisting in-lank hardwate thet has erither failed or will no longer be used in the foresesble future. It dlso includes the cost of extending existing 106.7-cm (d2-in.) risers lo grade on source tanks tequiriog decanthratsfer pumps. Cosis nol inthded are the removal of failed equigrnent (i.c., mixer and urangfer puraps) during the Phage I operationtal period of five years.

Alterualive 3. The life-cyele cost of Altemative 3 is estimaled at 527 millind. This is i glightly hogher cost than mogt of the gilematives and is a result of constnucting new transfer pump pits on 106 . 7 -cm (42-in.) risers for the decantutuansfer pump and sew transiter lines from the pits 10 the respective centrad pump pil. This ahesnative would not use the existing obD pil on Tank AP +102 .

Altemative 4. This allemalive has a tife-cycle cost of $\$ 25$ million and is the kruest cast of all the altematives evaluated. This is less than Altemative 3 due to the fact that the mixer punp is insts]led of an off-center pad raber than in the central putap pit. This oltercative also doetn'I roquire new waste trasgfer lines. The decantitransfer pump is installed lhough the existing 106.7-cen (42-in.) riser in the central pump pit and uxes the existing wasle transfer system to Iransfer waste to the DSTs.

Altermative 5. This altemative has a life-cycle cost of about \$28 million. The andy capital assucjated with this altermative is that required to remove existing equipment tan existing fieiled mixer in AP-I02 for example). Therefore, this ailemative has the lowresl capital cosl, aboul \$18 raillion, of all the atematives evalualded. The rectuetion in capilal, however, is completely offset by the highest operaling cost ( $\$ 10$ million). The higher operating cosis ors due to the addittotat sampling that would be raquired to demonsirate compliance with contract specifications. 
Table 7-I. Jnlerunediate Waste Feed Staging System Altentative Cost Surnmary. (2 Sheets)

\begin{tabular}{|c|c|c|c|c|c|c|}
\hline \multirow{2}{*}{$\operatorname{Cos}$ acmpones } & \multicolumn{6}{|c|}{ Ahtpentes: } \\
\hline & 3 & $d$ & $\mathbf{s}$ & 6 & 了 & 8 \\
\hline \multicolumn{7}{|c|}{ DST WASTE RETRICVAL SYSTEH REQUIREMINTS } \\
\hline 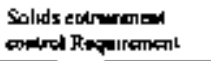 & Pa Solnts & $\begin{array}{l}\text { No Solids } \\
\text { Toptoph }\end{array}$ & $\begin{array}{l}\text { Camral } \\
\text { Sold }\end{array}$ & $\begin{array}{l}\text { Caniral } \\
\text { Solıd }\end{array}$ & $\begin{array}{l}\text { Comnal } \\
\text { Solnt: }\end{array}$ & $\begin{array}{l}\text { Cahirot } \\
\text { Salba }\end{array}$ \\
\hline 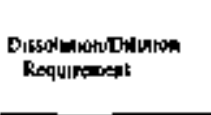 & $\begin{array}{l}\text { Meimum For } \\
\text { winde Transer }\end{array}$ & $\begin{array}{l}\text { Minimus fipr } \\
\text { Wate Tronsiet }\end{array}$ & $\begin{array}{l}\text { Dassalyn } \\
\text { Berort } \\
\text { Waste } \\
\text { Trtesta }\end{array}$ & $\begin{array}{l}\text { Desalya } \\
\text { Befort } \\
\text { Worte } \\
\text { Trufer }\end{array}$ & $\begin{array}{c}\text { Mluninue } \\
\text { For } \\
\text { Whate } \\
\text { Trunder }\end{array}$ & Wiate Trankfar \\
\hline $\begin{array}{l}\text { Punp Pu Culpl } \\
\text { ITECCX }\end{array}$ & $\mathbf{5 0}$ & $\mathbf{5}$ & $\mathbf{s}, 1004000$ & $\$, 100,000$ & 55,1001000 & $\$ 3.100 .000$ \\
\hline \multicolumn{7}{|c|}{ IWPST WASTE TRANGPER AND MLXNG SYSTLMS } \\
\hline Trusster Punis Optam & 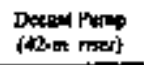 & 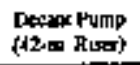 & $\begin{array}{l}\text { Flyed Iniake } \\
\text { Punfe }\end{array}$ & $\begin{array}{c}\text { Flxat-Intast } \\
\text { Pump }\end{array}$ & $\begin{array}{l}\text { Fixedinlalist } \\
\text { Pump }\end{array}$ & $\begin{array}{c}\text { Fixed-1nislde } \\
\text { Pumfe }\end{array}$ \\
\hline Mning Syatem Gplioo & $\begin{array}{l}\text { Mixer Pump } \\
\text { On-Cenur }\end{array}$ & 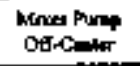 & $\begin{array}{c}\text { No } \\
\text { Mfoer }\end{array}$ & $\begin{array}{l}\text { Pulaed Alt } \\
\text { Maer }\end{array}$ & $\begin{array}{l}\text { Mast Remp } \\
\text { DenCenber }\end{array}$ & 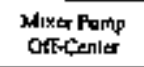 \\
\hline $\begin{array}{l}\text { Truster Punpildker } \\
\text { Catid (JECC) }\end{array}$ & $\$ 18,600,000$ & 314600000 & $58,300,000$ & $\mathbf{3} 11,600,000$ & sI7, $\mathrm{B00}, 000$ & $\mathbf{s} \mid 6,600,000$ \\
\hline 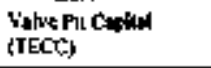 & $\$ 1,800,000$ & $\$+\infty, \infty)$ & $\$ 2,800,000$ & $\$ 2,600,000$ & $\mathbf{s t}, 00,000$ & $\$ 2800.000$ \\
\hline $\begin{array}{l}\text { Totol Trusph } 4 \\
\text { Miking tystem Capulal }\end{array}$ & $\$ 1,400,000$ & $\$ 19.60,000$ & $\$ 11,100,000$ & $514,400,000$ & $500,600,000$ & $\$ 19,40,0,000$ \\
\hline \multicolumn{7}{|c|}{ IWFST CHEHICAL ADDTTKN SҰSTEK } \\
\hline 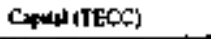 & $\$ 1,600,000$ & $\$ 1600,000$ & $51,600,000$ & $51,400,000$ & $\mathbf{5}], 000,000$ & $\$ 1,600,000$ \\
\hline \multicolumn{7}{|c|}{ nATST VENTILATtON SYSTEM } \\
\hline Domron & Not Resumed & Nok Rsquira & Nor & Xian Repinted & $\begin{array}{c}\text { Nent } \\
\text { Requered }\end{array}$ & Not Ftequared \\
\hline \multicolumn{7}{|c|}{ IWFST SNNPLING SYSTEM } \\
\hline 07माभा & Grab & Ginab & Cab & Grab & Grab & Gnb \\
\hline \multirow[t]{2}{*}{ Copilal } & 50 & 50 & 50 & to & $\$$ & $\infty$ \\
\hline & & $\begin{array}{c}\$ 1,320,000 \\
5530,000 \\
\$ 120,000 \\
560000\end{array}$ & $\begin{array}{l}\$ 1,320,000 \\
\$ 1,380,000 \\
\$ 1,0 \$ 0,000 \\
5180,000\end{array}$ & $\begin{array}{l}\$ 1,320,000 \\
\$ 530,000 \\
\$ 520000 \\
\$ 60,000\end{array}$ & $\begin{array}{l}51,320,000 \\
\$ 530,000 \\
5320,000 \\
\$ 50,000\end{array}$ & 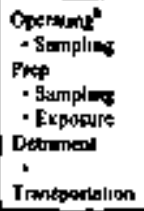 \\
\hline
\end{tabular}


Table 7-I. Intermediate Waste Feed Stagiog System Alemative Cos Summary. (2 Sheets)

\begin{tabular}{|c|c|c|c|c|c|c|}
\hline \multirow{2}{*}{ Cost sompouent } & \multicolumn{6}{|c|}{ Altermpwer } \\
\hline & ; & 4 & 5 & 6 & $?$ & 1 \\
\hline 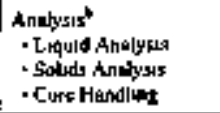 & 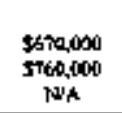 & $\begin{array}{c}5670,000 \\
5760,000 \\
\times 1 / 4\end{array}$ & $\begin{array}{c}52,400,000 \\
52,710000 \\
100\end{array}$ & $\begin{array}{c}\$ 670,000 \\
\$ 56,000 \\
\text { Wish }\end{array}$ & $\begin{array}{l}560,000 \\
\$ 50,000 \\
\mathrm{JNA}\end{array}$ & 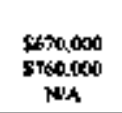 \\
\hline Simpldng Sy=10 Todal & $5,860,000$ & $53,060,000$ & $59,5 \% 0,000$ & $53,050,000$ & $53.760,000$ & $13,160,000$ \\
\hline \multicolumn{7}{|c|}{ ALHERAATNE TOTALS } \\
\hline Capted (IECC) & $523,000,000$ & $\$ 1,000,60 \times$ & $517,600,0,001$ & $8 \mathrm{~s}, 100,000$ & $5 \% .000,000$ & 526.100 .000 \\
\hline Optorimine & $\$+\$ 60,000$ & $53,060,000$ & $59,840,000$ & SI, 960,000 & $\mathbf{S J}, \mathbf{9 0 0 , 0 0 0}$ & $\$ 3, \$ \infty, \infty x 0$ \\
\hline Tolated & $526,8 \leqslant 00000$ & $524,860,000$ & $527,650,000$ & $524,960,000$ & $81,160,000$ & 599,964000 \\
\hline
\end{tabular}

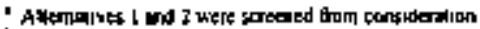

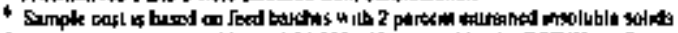

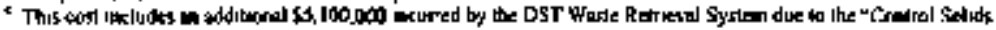

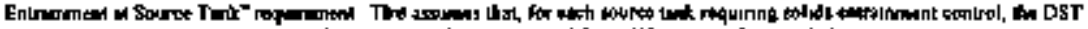

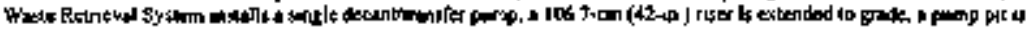

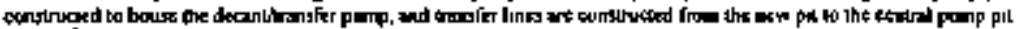

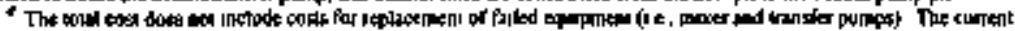

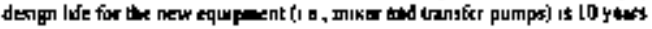

Alteruative 6. This alternative has a life-cycle cost of $\$ 23$ million. This altenative uses a pulsed-air mixet which is considerably' less expensive than the mixer pump system. The configuration selected for this altemat|ve uses the existing $106.3-\mathrm{cg}$ (42-in.) riser in the central pump pil for the mixer. The tixed-intake transfer pung is lostalled through a $30.5-\mathrm{cm}$ (12-in.) riser.

Alierualive 7 . This altemative has a life-cycle cost of about $\$ 29$ million which is the highest cost of all the alematives evaluated. This alternative is similar to Alternolive 3 with the exception that it uses a fixed-intake trantfer pump, whlch can be installed in a $30.5<\mathrm{cm}$ (12.In.) iser.

Altermative 8 . The handwac for this alomalive í the sume as for Alterdative 4 except thel fixed intake transfer pursps are tnstal]ed in tht AP-L02-02D pil and AP-I04-04A cetural pump pit inssead of the decantitransfer pumps. The life-cycke cost for this alternalive is $\mathbf{\$ 3 0}$ million.

\subsection{TECHNICAL MATURITY}

Allemobita 3, 4, 7, and \&. The itchtical raturly of the transfer pump and mixer purpp systems ags:0eiled with these altematives is bigh. They all have boen applied at the Hankord Sike. Mixing systems configured in this matwer have been used in two previous situations, 24)-AP-102 Grout Feed Tank and 24I-\$Y-101 Tank Mitigation. The Grout mixer failed aller several riecks of aperalion the the facl that the pump motor was submerged made it very 
difficult to tepair. The design and deployment of the 241-SY-10I mixer was based on the lessons learned froot the Grout Progran and the results were judged to be succestful.

The projected effectiveness of mixing mulltans of litert (galkons) of liopuid waste using subnerged jets, towever, is difficult to calculate. Hence, the camera installed as patt of the propaged tank quodificatiops is intended to give operators a qualitalive feet fot mixing effecliventess.

Alteractive 5. This aftemative toes not povide a mixing system or any equipment linel uses a qovel concept. Therefore, the technical gaturity of the equipment is judged as "ayailabse."

The uncertainty assotjaled with the entraimment and precipilation of solids is judged to be high so 11]is altertative has the leasl centainty abuur readily demonstrating compliance with contact specifications. Therefore the technical information required la make this alternative viable is judget o be "under developrocent"

Allernaliwe 6. The technical maturity of a pulsed-air mixing system hes been proven and used in the perrochemical iadustry, along with many other irchutries, to mix various types of fluidg. Therefore, with regard to the mixing of liquids, this altentative is judged to be "ayailable."

The suspension of solids, however, is another matter. The deployment of pulsed-air nuixers in large diateles, flat botwom tanks has no been demonstrated (Powell and Hymas 1946). A limited number of additional air dejivery devices could be installed wilhin the staging canks w enhance the supension of soljds but the effecliveness of that configuration is still umcerain. Therefore, with regard to the suspentsion of solids, this technology is sill "under development."

\subsection{MAINTAJNABILITV}

The design requirement on new mixer and transfer pumps is foc a ten-yess operational life cycle or 5,000 operitional hours.

AHerbathes 3, 4, 5, 7, and R. Allermatives 3, 4, 5, 7, and 8 are judged wo equal in this criktion. The gystems that are provided are al] common to the Hanford Site and minimal addinional training will be required of personnel In addition the gystems have bees shown to be reliable in othe spplicattons.

Alterustives 6. With regard to muintainability, Alternative 6 is diffenent from the odher altemalives that bave mixing systems. With a pulsed-eir mixing sytem. there tre no moving parns in 1]e fanks. The air conpressor required to create the air pulse is locoted away from the tank. Further, this aliemative uses a control system that is kecated on a akid oulside the 241-A.P intrometol build'mg. 
HNP-SD-FWR-AGA-OBI

Reviskn !

\subsection{SAFETY}

Alternutives 3, 4,5, 7, and 8. Alternative 3, 4, 6, 7, and 8 ere judged to equal in the critenon

Alfernative 5. Alieniative 5 doeg not employ an active muxing system This incteases the probabslity that the superngtand will form strolified leyers and will require a nore intense 6ompling efFort to demonstrale the the waske comples with contract and (porgibly) regulatory specifications This increase in sampling opelations incieases the cadiation dose recerved by the operators

\section{IS OPERABILLITY}

Alternatives 3 and 4. Alternalives 3 and 4 both provide the IWFSs wnth High Operabersty The

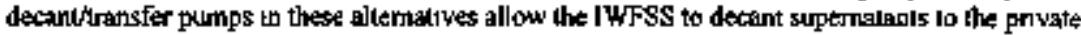
contractors even after excesgive solnds have been transferred into the staging tank And, whth the moxer pump to entran the gettied soluds, the settled sohds can be trangferred back to the lank farms

Also, bolb of these alternatwes, as well as Aliemaryves 7 and 8 , have a mixer putmp that can

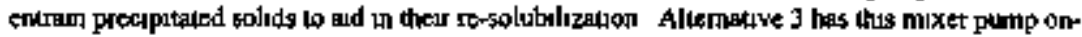
cender and provide the [WFSS the most robust tystem to reapond to off-normal condtaens Alteritative 4 is ogerably the same as Alterralive 3 except the off-center moxer pump will be less effective un moblizents the solids for distolution ot transfer

Alempatives 5 and 6. Altergatives 5 and 6 are ranked lowest in being able to respond to o1f. nomol condilions and so frovide the IWFSS with Low Operabslsy. They do not prouda for solids entranneat coulrel in the stagusg takk, and therefore rely on the DST Waste Transier

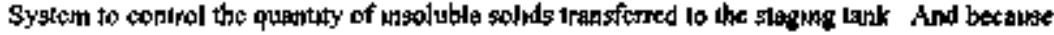
these alterualuveg do not provide a muxiog system in the staging tants, they also rely on the DST Watete Transfier Systen to dissolve all the soluble soluds before they enter the slaging tanks and to adjust the waste composition 50 that preciptialon wilJ not occur

Alterualives 7 and B. Alternotives 7 and 8 are ranked betureen Altemdives 3 and 4 and 5 and 6 in being able to respond to off-nomal conditions and so prowde the IWFSS with Meditur Operabrity Altematives 7 and 8 do not prou ide solds emirumineat controt in the stagog tanks and therefore, like Alterative 5 and 6, rely on the DST Waste Transies System to control the

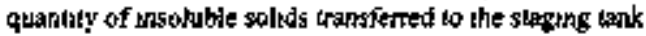

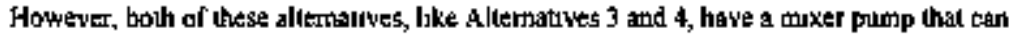

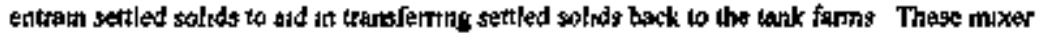

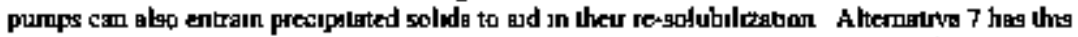
mlxet pump on-teniet, prowidung the IWFSS mith a more tobust gystem than the off-center muxess in Alkertalsve 8 


\section{HNF-SD-TWR-AOA-00I \\ Revigion I}

\subsection{SCHDDULE DMPACTRISK}

Alt of the alternativer evalualed can be made wo suppon the Phase I Privalization schedule and the Tri-Party Agreement milestones. Some allemalives, houreser, have a grealet risk that othess of not meeting coulractual requirements on the sehedule. The construction / startup activity, the operationsal selnedule, and the operacional risks for each eqai uated adtenalive are discuserd bekw.

Ahernative 3. The construction aclivity for this altermative is mote complex than the olhers. Upgrades to be central purmp pit for installation of the mixer systed will require an extensive rework of the jumper configuration. Additionaly, new transfer punp pits mus be constructed aver existing 106.7.cen (42-in.) risers. These risers must be exiended to grade level. New waste Iransfer lines will be rouled to the central pump pit.

With regard is the operational schedule, this altermative will allow for an expediled

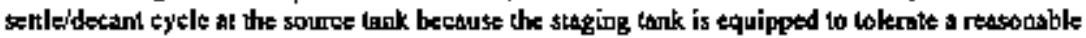
quastity of solids. Therefore, the liquid waste from the source tank can be iransferred shorly after the mixer pumps have stopped. This al iernative, however, does not require that the retrieval systern dissolve all be soluble solifts or to adjust the retrleved waste's hydtoxide concentration to prevent precipitalion al the staging tank. To dissolve aluminum salts or to prevent thern from precipitating, hydroxide additions at the staging tanks may be required either during or shortly after the lank has beeg filled. Otherwise, a significant amount of sodium may be left on the bollom of the sloging tomk.

With regard to operational risk, the centrally localed mixer pump conficuration is judged to provide the bes situation for mobilizing solids if it becomes necessary. This altemative also uses a decartitrantfer pump syglem at the staging tank that is justged to reduce the probability that a significant amount of solids will be tronsferred wo the contratars' tanks.

Alteramive 4. The construction agtivity for this allemative is simpler than for Altermative 3. The renwry of the central pump pit is less extensiye in that the installation of a decarititenthefer pump is less obtrusive than the installatlon of a mixing plump. The construction activity is still commilex int that it mequires the extension of an existing $106.7-\mathrm{cm}$ (42-i0.) riser to grads and consinuction of a mounting posd for the mixer pump instaltation.

The operational implicalions for this allemative are similar to that given for Alternative 3. This sygtern is jurdged to be adequate for the mixing of liquids. But with a mixer pump installed off-center in the lank, this configuration maty not be as efitient al suspending solids in the staging tank. Past studies have shown lhal the energy of a submerged jet form these putaps dissipates rather quickly and is not litely to seach the othes side of the tomk.

Aliernathe 5. The cousuruction aclivity for this alternatise is much simpler than for the other alterartives presented in this analysis. This it no mixer syotem to install and the ube of the fixedintake transfer purmp also simplifies the desipn. Therefore, this configuration results in a minimum amount of conginuction activity. 


\section{Revisiunt ]}

The operational inpact of this alterpative, however, could be severe. The increased postibility that the supernatunt will form strotified layers will require a more intente samplimg eftort lo demonsirate that the waste coptipties with contracl and (Dogribly) requlatory specifications. Using evaptrator opergitions and the farmer Graut Disposal Program as poinus of referente, the sampling athd validation of a waste feed can hold up optralions for mondhs.

Alleruative 6. The required modificalions to the existing tank system are small compared with those for ahernalives installing a mixer pump sy'skem oth-cenuler or off-cebler. Therefore, constourtion and startup milestones sbould be eatily met with this altemative.

Operationally, thig allemalive presents some advanlageg and digadvantages. Since this allerrative uses a pulsed-air mixing sygtem walh a foxed-intake transfer pump, the sette/decant cycle at the spurce tank must be perforesed with oxore cere than that required for the outher alematives.

Alternalive 7. Since it's similar to Altemalive 3, thig alternalive will present similar complexities in construction and Elarfup. The rixer system is bcated in the central pump pit that

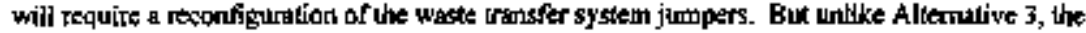
wasle trunsfer system at the staging lank useg a fixed-intake trangtert pump that ust tho $02 \mathrm{D}$ on 241-AP-102 and a 30.5.cm (12-in.) rigar in the new valve pit to be localed on 241-AP.104. Therefare, construction and startup schedules should be easiet bo mest with this alternative.

This alternative is also operationally similar to Alternalive 3. None, however, that the contirol of the insoluble solids at the trurce 1onk reduces the issue of insoluble solids bur does not reduce the potenlial for soluble solids from bxing transferred hito or precipitadting in the stanging tanks. To dissolve alundaum salts or to prevent them from precipitating, hydroxide addittous at the staging ranks may be required either during or shorily affer the tank has been filled. Ohherwise, the fixed-ialake for the transfer purap at the staging tank would transfer these sohuble solids froan the staging tank to the condractore' tinks.

Wilh tegard to eperational lisk, the cerlecred mixer pump provides a means of preventing or mitigating a problem associated with the actumulation of solids.

Alemantive 8. The construstion and stertup aclivity for his alternative is similar to Alternative 4 with the exception that it uses a fixed-intake transfer purnp at the graging tank. Therefore, the congtruction and startup sethedule should be easily met with this alternative.

Operaliotally, this altemative is similar to Alternative 7. This altemative, however, installs a mixes pump off-cemter on the slaging lank. This configuration is judged to be less effective in mobilizing the settled soljits on the far sdde of the tank If the mixer system cannot mobilize the settled solids, it will hoo be abje to support the digsolution of soluble oolidg or the removal of the insoluble ones. 
HNF-SD-TWR-AOA-BOI

Revision 1

\subsection{ENVIRONMENTAL IMPACT}

All the ademaxives are juxged to eulual in this eriterion.

\subsection{RZGULA'TORY COMPLLANEE}

All the afienarives are judged to equal in this cricerion.

\subsection{PUBLIC ACCEPTANCE}

All the altermative are judged to be oqual in this criterion. 
Revision 1

\section{\$.) OPEN LSSUES AND ACTIONS}

Open issucs that have been idenufied by this study are as folkows

- Iopact of Famenable Gas Relense: Retreval of teverd of the source lanks may be impacted doe to the Wagle $T$ ank Safety Watch List stapus The issuce is releard to the

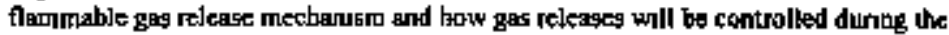

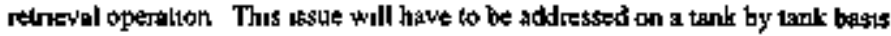

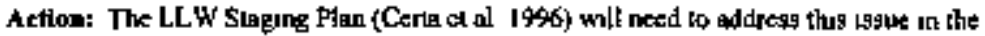
next resision The Unresolved Saftety Queshion (USQ) process will be the mechanism to resolve this issue

- Centrol or Settienbite Solpds: Controiling the selileatle golds at the source tanks may te operatuonally difiteult The two bypes of soldd ko be deall with are undisolved, soluble salits, ath setleable, insoluble soluts In order lo cantrol the Iransfer of undtssolved, soluble solids at the soumce lank, complete dissolution is required Furthernore, the chemical composition of the supemalant may need

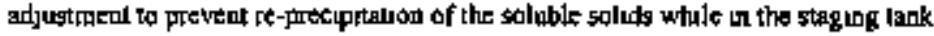
The transiter of setleable, wsoluble solids sen be controlled al the source tank by utsliang a new generation decant'trassfer pursp. If muxers are used to the source lanks, required settling IIme dala are aceded

Actipa: Adentional sampltag and andysts of the propobed saurce lanks is needed to delermme whal sontrots must be imposed during the tetrevel and transfer aperation to lirut insoluble soluds from reaching the stagutg tank ard soluble solds from precopilating

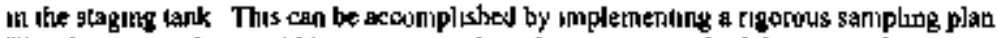
The altemate to this would be to increake the volume percent of soluds that can be transferred to the private contraciors thas would require negooathons between DOE and the private contractors

- Sampline Xnmber: The samplung number calculated in this analy ysis delermined the number of gamples required to valjdate thal the feed balch meets a specific toed

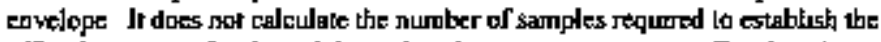
official quantiry of sodium delivered to the pnvale contectors For this, the accuracy for the mass of 5odiom transitered (c $\mathrm{g}, \pm$ five masss perceenl) and the confidence level for thus measurement (e g. 95 perceni) needs to be slipulated Higher securacy wal] reduce the uncertainty in the quarinty of sodnum transferred and may reduce the cost 10 DOE for the mivate contraciorn to immoblize it, it the pnyate contractors aTe pald on the basss of the bighest possuble sodium quanity un the fied betch (nomenal mass plus the uncertanty) 


\section{HWF-SD-IWR-AOA-ONT \\ Revision I}

Action: Both the accuracy and the confidence level noed to be evaluated aissinsl the ircteased cost of sampling and analysis and will require acpotiations between the DOE and the privete contractors. 


\section{HNF-SD-1 WR-AGA-0OI \\ Revison I}

\subsection{REFERDNCES}

ASME B31 3, [996 Edilion, Process Plping, Amerkan Society of Michanucal Englneers

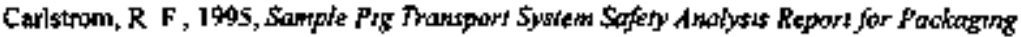
(Onsus), WHC-SD-TP-SARP400], Rev 00, Wesinghouse Henford Company, Ruchland, Washinglon

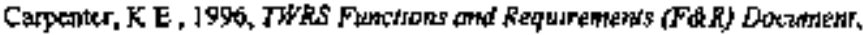
WHC-SD-WhM-FRD-020, Rey 0, Westunghouse Hanford Company, Ruchland, Washinglon

Certa, P J, W H Grams, C M Mcçonville, I, W Shetton, and E J Slatheng, 1996, Low. Levet Faste feed Siagung PJom, WHC-SB-WM-RPT-224, Rev 0, Westunghouse Hanford Company, Rabland, Wabhungton

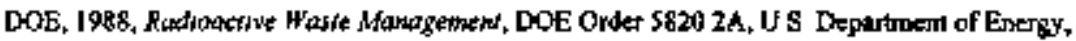
Washington, D C

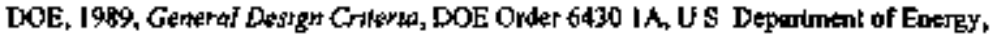
Washington, DC

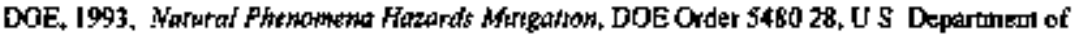
Energy, washugton, $\mathbf{D} \mathbf{C}$

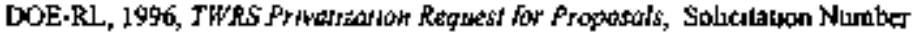
[DF-RP166-96RL 13308 (Fabruary 1996), US Department of Energy - Ruchland Operations iffice, Richland Waghugton

Fowler, K D, 1995, Data Quatry Obrectres for Tamk Farms Waste Compatrbuluty Program, WHC-SD-WM-DOQ-001, Rey I, Wesinghouse Hanford Company, Rucbland Washungson

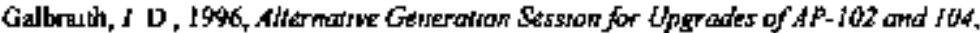
\{merung mubules, Jurse 13), Wesunghouse Hanfötd Company, Richlimd, Washington

Galbranth, J D, T B Salzano (JCF KH), and J R Nichalson (ICPF KHD, 1996, Decusron

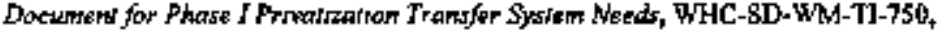
Rev 0. Wesimghouse Hanford Company, Ructland, Washunglan

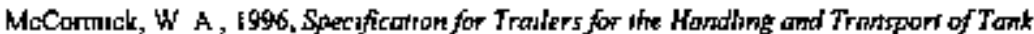

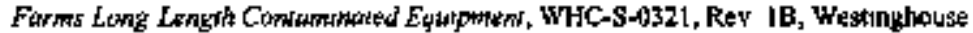
Hanford Company, Ruchland, Warhangton 
MeConsick, W A and W S Edratds, 1996, Specsfication for Contamanatod Equipmoni Barral Contomer, WHC-S-0402, Rev 0B, Wextinghouse Hatford Company, Ruchland, W'ashington

Milliken, N J, 1995, Safety Anolysus for Prash-Mode and Rovary-Mode Core Sangling, WHC-SD. WM-SARR-43I, Rev 2, We, dinghouse Hanford Company, Ruchlaud, Washington

Poutl, M R and C R Hytuas. 1996, Retnekal Proctss Development and Enhamiements FY96

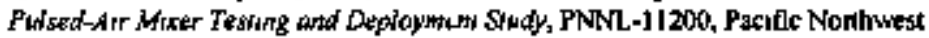
Natıonel Laboratones, Ruchland Wastingtod

Preck, C A, 1995, Enguneerng Repor, Imual Tank Retteval Systems, Tank 2d1-SY.102 Waste Coolung Evaluation. Project W-21I, WHC-SD-W21 1-ER-002, Rev 0, Westinghouse Hanford Company, Ruchland, Waghington

Simpson, B C, 1994a, Tamk Chatractertatrost Report for Double Shell Tank 24I-AP.j0S. WHC-SD-WM-ER-358, Rev 0, Westinghouse Hapfotd Coumany, Ruefland Waghington

\$ırapson, B C, 1994b, Tamk Characierization Repurt for Double Shell Tant 24IAAP-J 02, WHC-SD-WMA-ER-360, Rev 0, Westmghouse Harford Compeny, Ruchland W/ashingtom

WAC 173-303-640, "Dangerous Waste Regulaluons, Tank Systems," Washugfon Adminushative Code, as amended

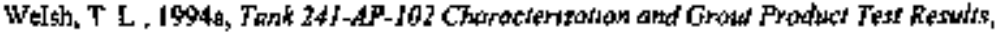
WHC.SD-WM-TRP-168, Rey 1, Westinghouse Henford Campany, Ruchland Washugion

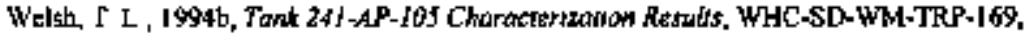
Rev 0, Wesunghou Itanford Company, Ruchland, Wasturgtan

WHC, 1992a, Hazardous Matenat Packageng and Shppong, WHC-CM-2-14, Westunghouse Hunford Compeny, Ruchland, Washustiont

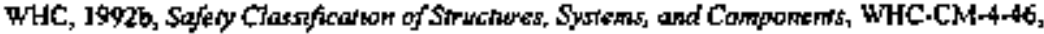
Wesanghouse Harford Company, Rucliand, Washington

WHC, 1994, Radologreal Desugn Gurda, WHC-SDGN-DGS-30011, Rey 0, Westinghuse? Hinford Company, Ructland, Washington

WHC, 1995, WHC (dectpattona' ALARA Pragrom, WHC.JP-1043, Rev 0, Westitghouse Hinford Company, Ruchand, Washanglon 


\section{HNF-SD-'TWR-AOA-001}

Revision I

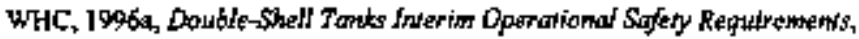
WHC-\$D-WMM-OSR-016, Rev, OB, Westunghouse Henford Company, Richland, Washington

WHC, 1996b, Operwing Speciffcowions for she 2AH-AN, AP, AF. AY. AZ and SY Tank Farm, OSD-T-151.00007, Westinghouse Hanfond Company, Ricbland, Wobingkon.

WHC, 1996, TWRS Functions and Requircments (F\&R) Document, WHC-SD-WM-FRD-020, Rev. 0. Wealinghoute Hantord Company, Richland, Washington

WHC, 1996d, Tank Waste Remtediation System Wission Analysis, WHC-\$DD-WM-MAR-00B, WHC-SD-WM-TRPA168, Rev. 0, Westinghouse Hadfond Counpany, Richland, Washington.

WHC. I996e, Declalan Docpment, Low-deved Waste Fead Saging Strategy, Westinghousc Hantord Corpany, Richland, Washingion. 
HNE-SD-TWR-AOA-ODI

Revision I

This page lintentlonally left blank. 


\section{APPENDIX A}

\section{MIXING SYSTEM ALTERNATIVE GENERATION AND ANALYSIS}


HNF-SD-TWR-AGA-DOl

Revision I

This page irkentionally keft blank. 
ENF-SD-TWR-AOA-ODI

Revision ?

APPENDLX

MIXING SYSTEM ALTERNATTVE GENERATLON AND ANALYSIS

\section{AI." DECISION ANALYSIS SUMMARY}

This altermative generation and analysis (AGA) report provides information for the Loutf.mel Waste Fetd Staging Plon (Cetla 1996). Thit AOA evaluates what infrastructure upgrades ho the intemmediate waste feed staging tanks (TWFST) are necessary to support a mixing system. Tanks $24 t$-AP-102 and 241-AP-104 have been designated as the IWTSTs (Galbraith el al. I9969).

Section A I.0 meludeg a desctiption of the options evalualed and discusses the comparison of the oplions to the decision criterin Sextion A2.0 desils the moblar gtatement, and

Section A3.0 disenseses the constraints and assumpliots for the analysis. Section A4.0 provider the detailed analysis of the options, and Seclion AS.O provides the document references. Cost extimales are included in Section A6.O.

\section{Al.d STATEMENT OF THE PROBLEM}

What type of mixing system thould be used in the [WFSTs to support the staging of bow-setivity waste (LAW) for Phase I privalization?

\section{AIZ DECISION ISSUES}

\section{A] 2.1 Dpen lssures}

One mixer purnp is assumed to be adequate for maintaining solids in suspension fint a waste with a low solids fiaction. This is based on the fast thal po dudgeg will be present in the feed ataging waste. In addition, the waste feed envelopes specify the the insoluble oolide fraction will not exceed 5 vol\% of the praste transferrad (DOE 1995).

One decant pump is atsumed to be required in each IWFST. This is required if the solids fraction is inadvertently exceded duriag relricval of the rource doubde-shelt lanks (DSTs) (Certa 1996). A 106.7 -cm (\$2-is.) riser is required for the decant pursp with the load senting wincth. The winth mechandson is required to elindinate the whipping wethon applied to the decant purrop Juating the operation of a mixet pumap. If the thixer pump is aot used, the winch

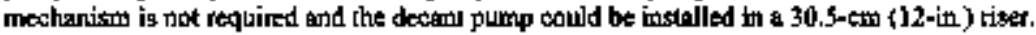
This would reduce the upgrades needed to the IWTSTs. 


\section{HNF-SD-TWR-AGA-ONI \\ Revision I}

\section{A1.2.2 Scope}

The objeclive of the Phase $\$$ privalization is to deliver LA $W$ and $F L W$ feed to the Phote $I$ private Dontraclars for vitrification. This reporl andowses the mixing requirements for the IWFSTs and the upsistes roquired to support vacious miximg oystem options.

\section{A 1,3 DESCRIPTION OF OPTIONS CONSIDIMED}

The tonk condents will be mixed before transferring the waste to the [WFSTs. However, the mixing sysiem must be capsble of mobilizing any solids that may be intentionally or inadvertenkly gettled in the IWFSTs. Based on successful retrieval operatlens at other U.S. Depertment of Energy (DOE) sites, mixce pumps ware selected for Project W-2] 1 (Riteck 1996) as the appropriate technology to temove setled soltds and ate, therefore, selecied for the JWFSTs.

\section{Al.3.1 Beskeround}

Project W-] II chose mixer pumps as the planod method of wagle retrieval, based on enginecring techwology ghudics, past experience with hydadalic sluicing at the Hanfort Sike, experrience with mixer pumps at the Savannah Rive Pleml, and by the reconnibendations from two engineering stodies. Mechanical mixers, sluicing, ultrersonics, and sir'vapor jets were also exsmined (Shaw 1992). Safety, versalility, schedule, and cost considerations were the principal factors that led to the choice of mixer pumps rather thean hydraulic glmicing nozzes. Several studies (c. g., RHO 1984, Lawler I986a and b, Stegen 1986) have conchoded that mixer pumps would be the preferred method for thary tetrieval applleathons. Most of the studies done previously there concerned with retrieval of solids, not in maintainitg solids it guspengion as is the case with the I'W'FSTs. However, the advankages of mixer fumps over sluicing and meechenical devices ideruified in these reponts are applicable ta the IWFSTs. In thetse reports, the prineipal advanlages of mixer pumps were idendified (Walers 1994) as follows:

- Mixer pumps can proudde a ulyfontly mixed feed streant

- Provide the option to perform in-lank washlag and processtng of solids

- Do not requise sipniticanl upgrades or addition of waste tratsiete lines

- Requito less equipment and operator action in the tank farm

- will result in lowstr oxerator exponsure (at-low-as-reasonably-achievable [ALARA]).

In addition, the conceptual design ferhureg of the fecd lexks for the Grout Trealment Facjlity included mixer pumps. Several wasto mixing system options were examitued for the Grout feed tank and a mixer peung was chosen (Lubler 1954). The main funcion of the grout 
tanks was to maintain solids is suspensios and well-mixed prior to waste feed sampling and during feed transfer to the groux process. This anatches the function of the mixiag system requirad for the rWrsts.

\section{Al.3.2 Mlxiog Syutem Optipas}

One mixer pump will be required in ench IFFST. The basis for this is that the monluble solids traction of the waste feed envelopas will not exceed five volume percert af the waste (Telysfered (DOE 1995). The advanted desiga mixer pumip (ADMF) is asgumed to be osed. The pumps will be installed through existing $106.7-\mathrm{cm}$ (42-in.) riser penetrations. The effect of additg a 300 hp wixer pump on the JWFST ventilation system it addressed in Appendix C.

One decant purmp will be required is each JWFST (sce Section Al.2.1). The exigting trumsfer purnps will be replaced with the new supetnile decaml pump. Decant pumps are required to leaye some ox all of the solds behited if the solids fraction is out-of-spectfiedion (Certe 1996). This would oceur if too many solids were inadvertently retrieved and transferred from the source DSTs, or precipilated during or after the transfer. The pumps will be installed through existing 106.7. $\mathrm{cm}$ (42-in.) riset penetrations.

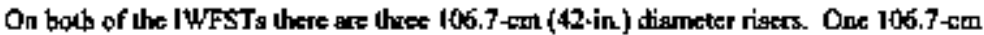
(42-in.) riser is localed in the centsal pump pit. On tank 241-AP.102 a fieled mixer pump is loested in this riser and the transfer purpp is localed in the 241-AP-02D pump pit (30.5.cm [12-in.| riser). On lark 24l-A.P-104 a slurry distributor is localed in the central pump pit 106. 7-em (42-in.) riser and the Iansfer pump is lacated in a 30.5-cm (12-in) riser in the cerstral pump pit The oller two $106.7-\mathrm{cm}$ (42-m) risers are loculed $90^{\circ}$ apart on a $6.3 \mathrm{~m}$ (20 f. 9 in.) radilus. These two rters are lisled as spares on both tanks.

There where tuo optiong considered for instal]ing thixer pumps in the ITFSTs. Oplion 1 is to locate the quixer pump in tiser no. 5 (106.7 $\mathrm{cm}[42$ in] ]), off-centered on a new concrete pid. This option uses ine design from Project W-2I l thal places the miker pumps on slabs al grade (Rjeck 1995). Mixer pump foundadions will be reinfonced concrete glabs $2.7 \mathrm{~m}$ ( 9 fi) by $2.7 \mathrm{~m}$ ( 9 f) and 0.3 m ( $1 \mathrm{ft}$ ) thick placed $15 \mathrm{~cm}$ (6 in.) below gade. High pressare spray rígg will be fatricated and inglalled ot lop of exch of the mixer purng risers for fisture decoutamination of the mixer pumps as they ate wirthdrawn from the lank. The dexant pump would be located in the

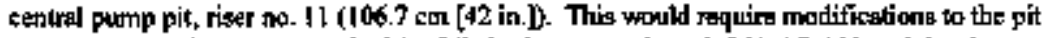
arrangement including removal of the falled mixer pump in tonk 241-AP-102 and the slurry

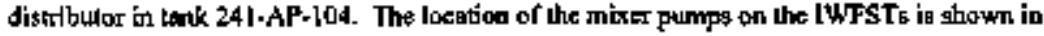
Figures A1-1 and A1-2 for lanks 241-AP-102 and 241-AP-104, respectively. A typical cros:section of the stab and mixer pump assembly is ghown in Figure Al-3.

Option 2 is $\mathrm{k}$ locate the mixer purip in the $106.7-\mathrm{cm}$ (42-[m) ther of the central pump pit, riset no. 11. This optoth tases the design from Project W-2I that places the mixer pamps on the cover bloxks of an existing pil. The mixer pumps would be supported on the cendral pump pit by a kotd distribution fiture astembly. High pressure gprey rings would be fatricated and ingtalled 
within the centrol pump pit for funure decontamination of the mixer pumps as they are witbitrawn from the lank. The decant pump would be locsted in riser no. 5 (106.7 $\mathrm{cm}$ [42 in. ]). This would require a new pump pit and trangfer line an the JWFSTs. The pump pits would be appoxinualely

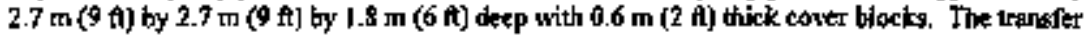
lines gould be double cocased with a 7.6-im (3-in) diameler staintess steel primery encased in a I5.2-cm (6-in.) diemeter carbon steel secondary and be tpproximetely 6.4 in (21-fi) in length. In addittas, this optlon woukd nequire modifications to the central pump pit arrangeneml inclnting a new 7.6-tm (3-it.) nozzlo in the central purap plt of tank 241-AP-I04, and semoval of the friled mixer pump in tank 241-AP.] 102 and the slunty distributor in lank 241-AP.194. Also, new cover

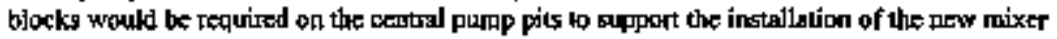
permps. The location of the crixer permps on the IWFSTs is atown in Figures A.1 - 5 and A1-5 for tariks 241-AP-102 and 241-AP-104, respectively. A lypical cross-section of the central pump pil and mixer pump aggembly is shown in Figure A1-6.

\section{A1.4 DECISION CRTTERIA}

Decision criterit consists of information used to dhtthguish preference andong the optons considered. The list of dectston criteria specified in the draft decision plan are not alt needed in evaluating the mixing options. The criberia to be used are described in Sections A 1.4.1 through A1.4.5.

\section{A1.4.1 Cast}

The gystems will be evaluated with respect to developuental costs, project capitol costs, operating costs, and disposal cosis.

\section{A1.4.2 Schedule}

The schedule impactrisk will be assessed relative to implementation of a given option. The DOE has developed a planning schedule with a starl date of furre 1, 2002, for the operations of Pbase I facilities. 
HNF-SD-TWR-AGA-OOI

Revision 1

Figurs Al-1, Mixer Pump on Slab: 241-AP-102.

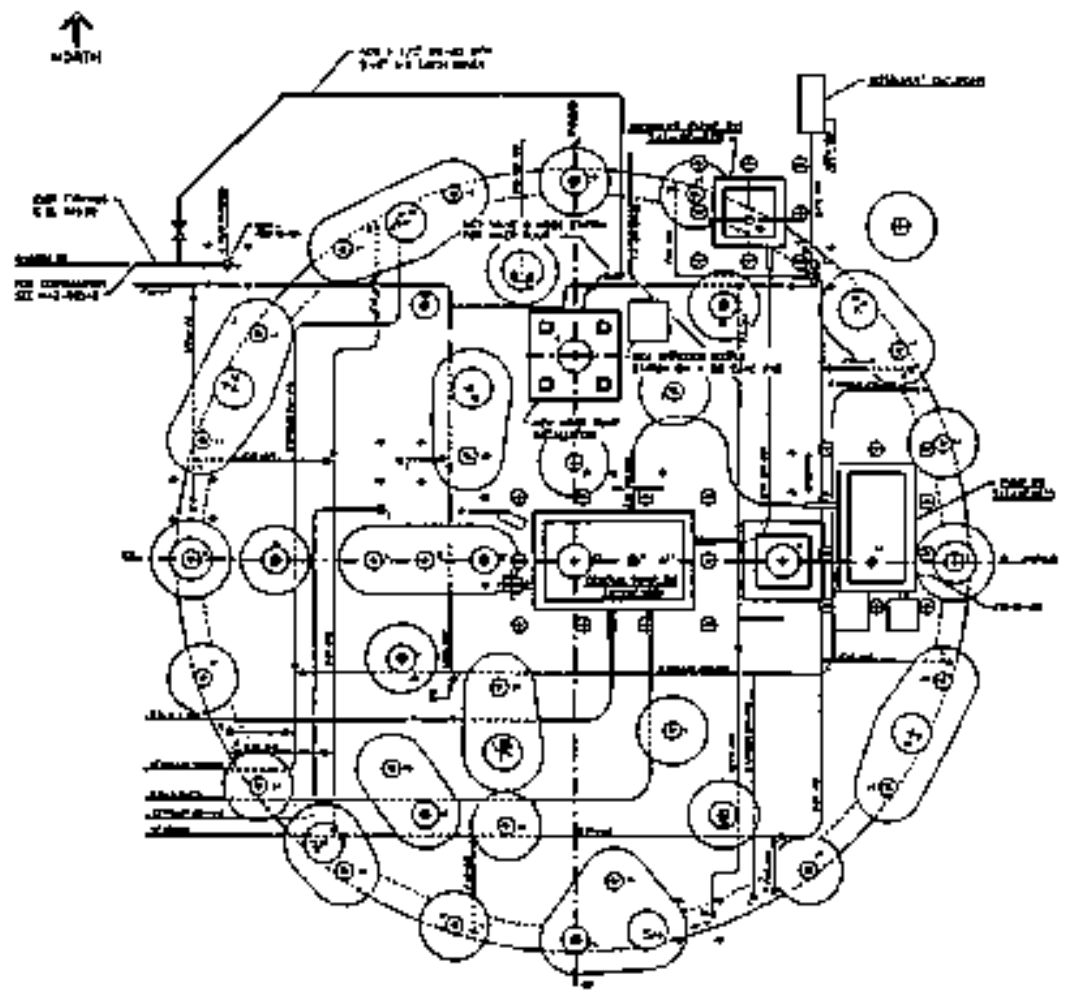

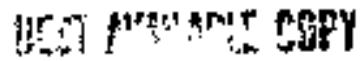


Figure A1-2 Mixer Pump on STab 241-AP-104

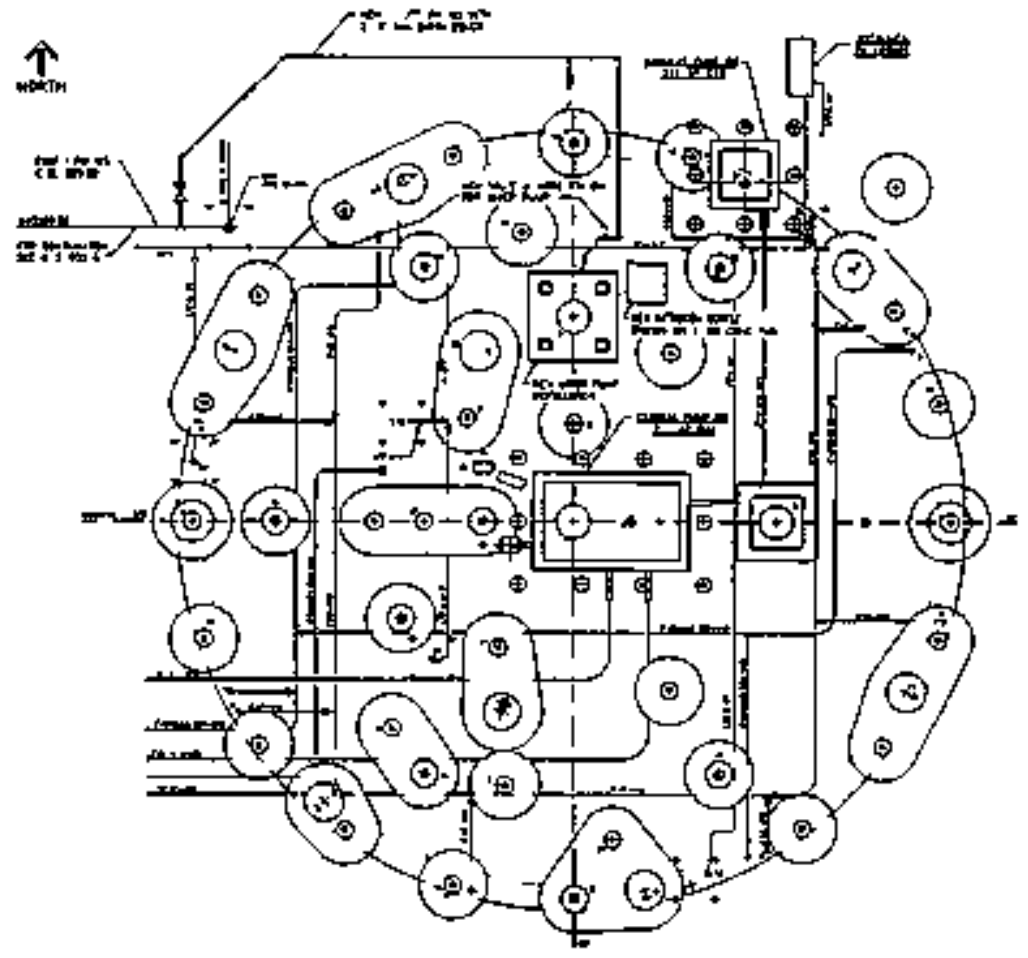

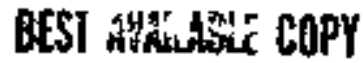




\section{HNF-SD-TWR-AGA-001 \\ Revision 1}

Figure A1-3. Mixer Pump on Slab: Assembly.

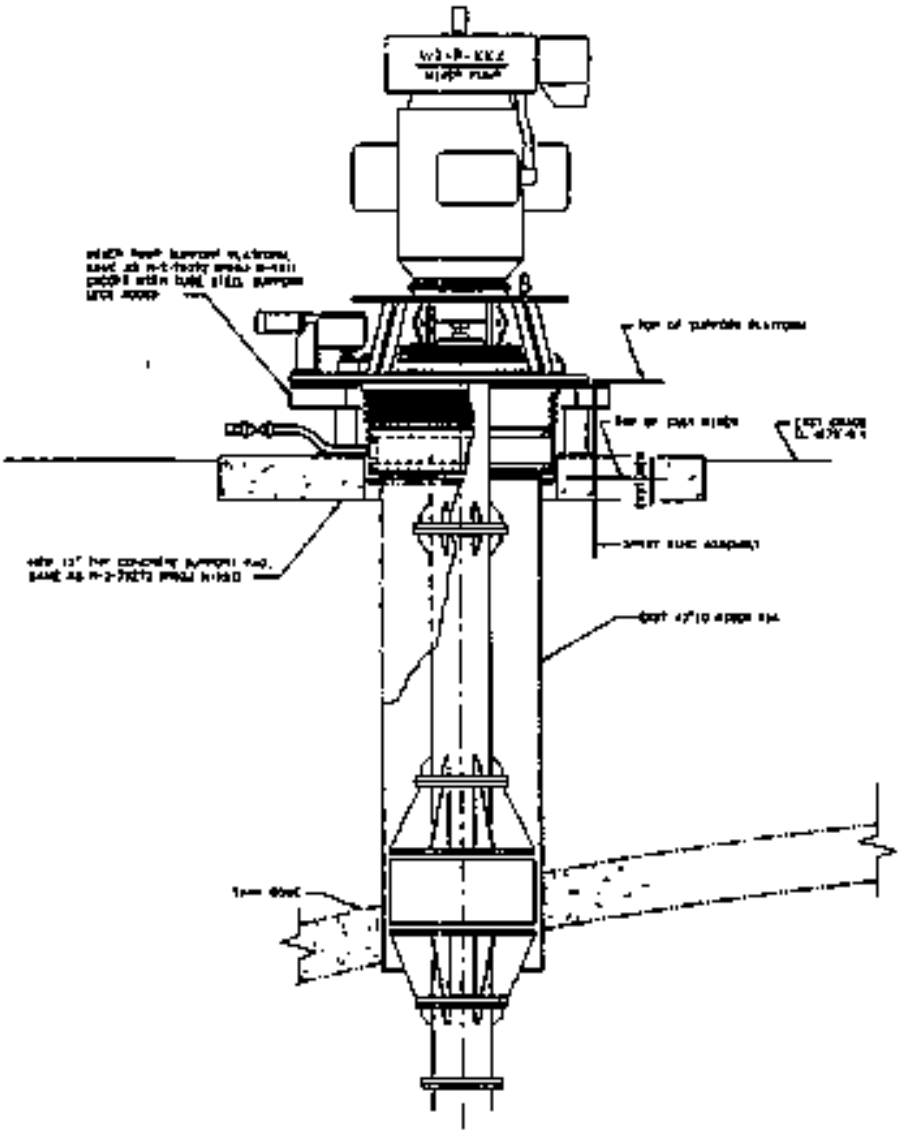

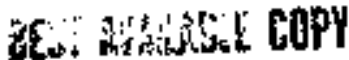


ENF-SD-TWR-AOA-OUI

Revision I

Figure Al-4. Mixer Pump above Central Pump Pit: 241-AP-102.

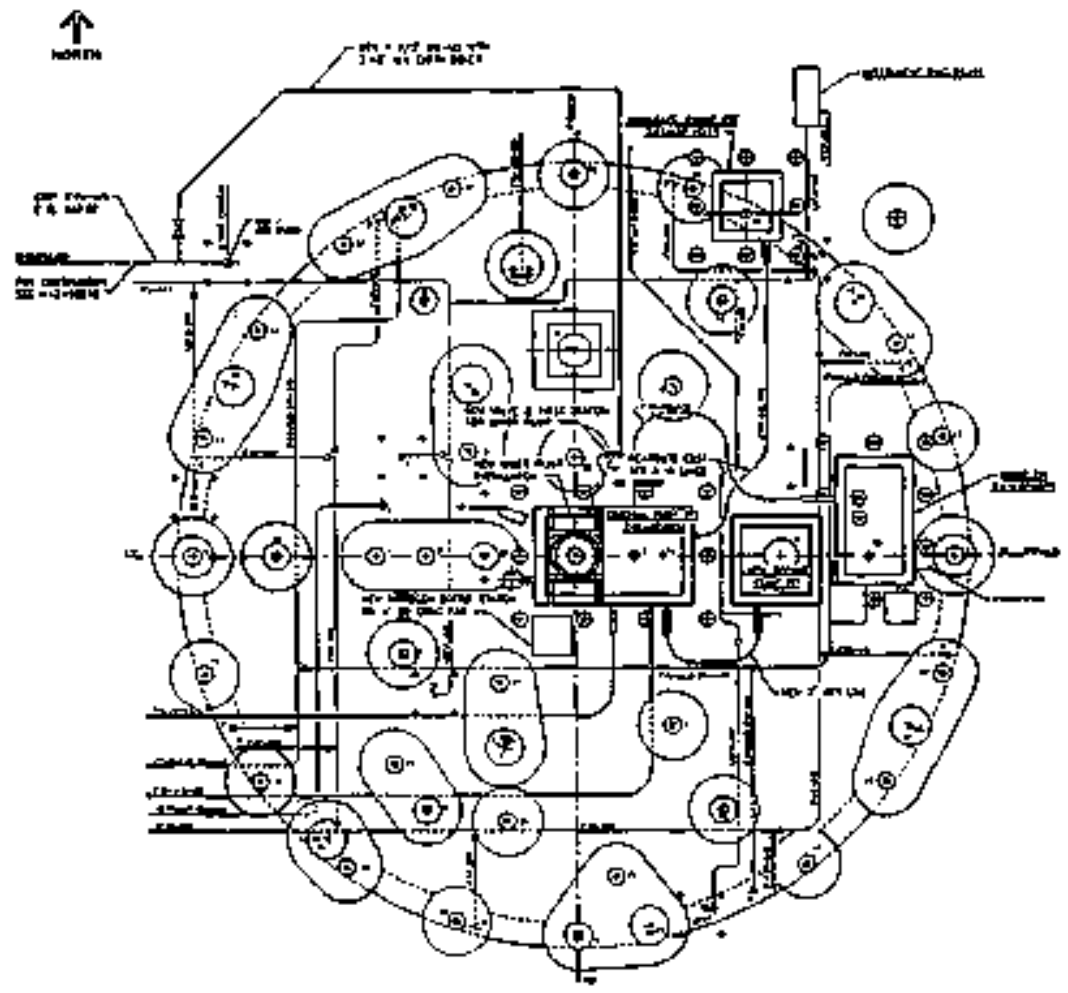

BLF AHABABE COPY 


\section{HNF-SD-TWR-AGA-0OI \\ Revlsion I}

Figure Al-5., Mixer Purap abrove Centual Purnp Pii: 241-AP-104.

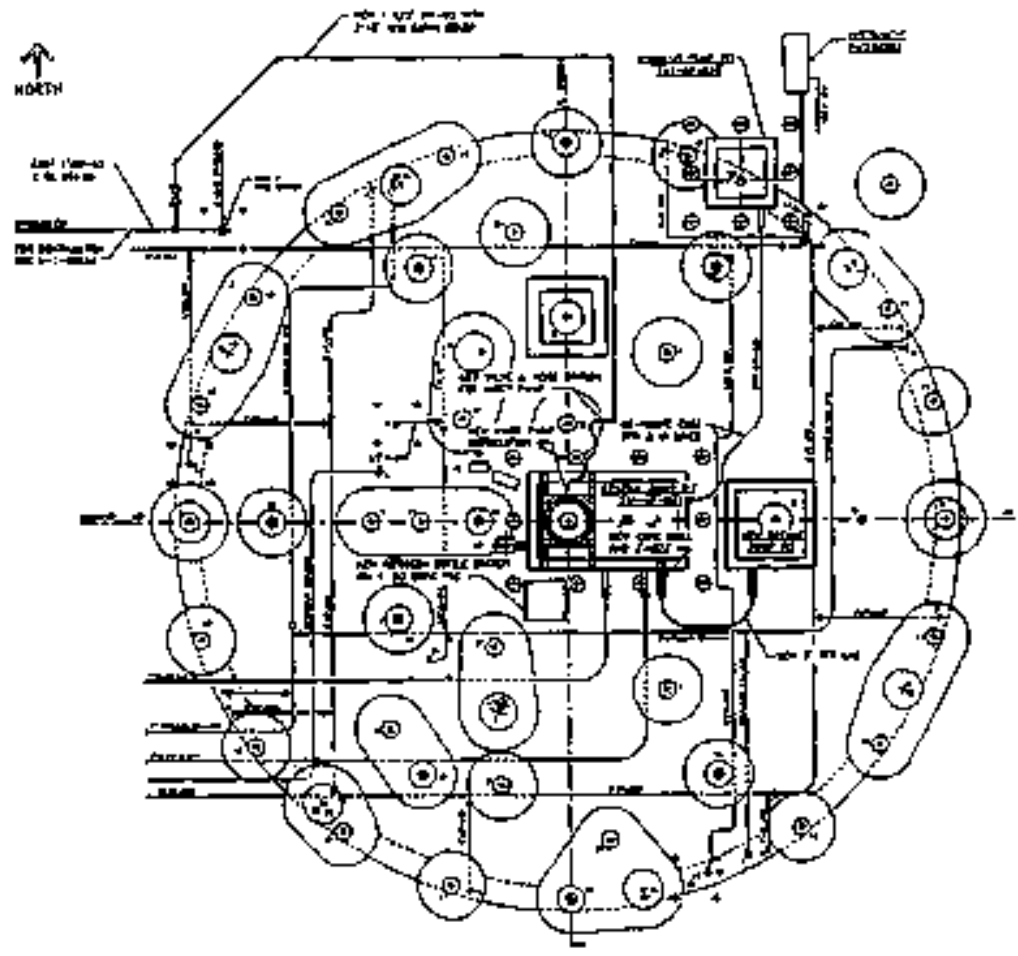

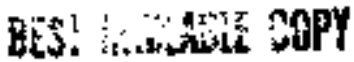


HWF-SD-TWR-AGA-D01

Reytsion I

Figure A -6. Mixer Pump above Central Pump Pil: Ascenbly.

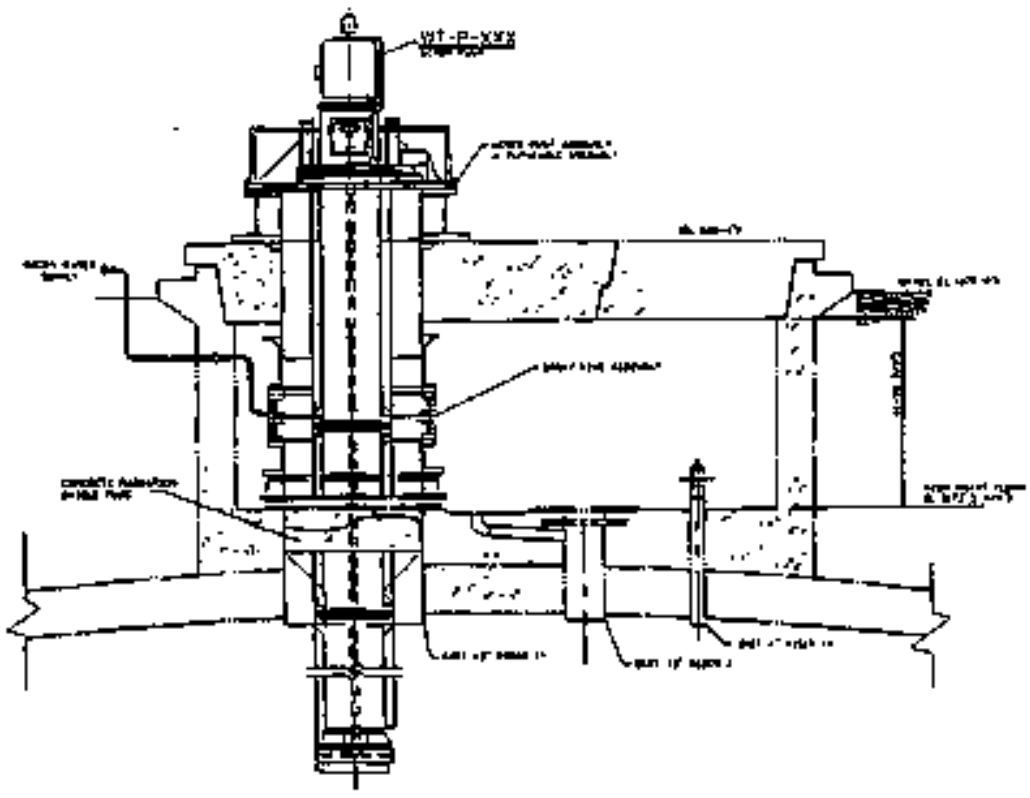

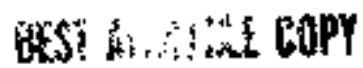




\section{At.4.3 Maintainabilly}

The frainlainability of a system will be assegeed by evalualtag the complexity, reliability, and repairability of the associared equiprnent and copnponents. Complexicy xill addtest any training requiremerses for operation personnel, the need for special tools or procedutes, and design clualites such as features that ease repair. Reliability will addrese calibration and preytentive maintenance procedures along with impacl of failters. Repairability will addregs the location of the equipment, the means of repair, and the number and type of persontel required to support repeirs.

\section{At t,4 Techical Maturity}

The technical maturity of the syskem will be assessed as io wether the system has been applied at the Hanfori Site or commeselal ladustry, and if the system has been tested experimental ly by beneh scale experiments.

\section{A],4,5 Performanes Requiremants}

The mixung system muss be able to perform the folkwing (Certa 1996):

- Blend waste fropl two of more soluce DSTs

- Provide a homogeneous feed to the priqale contractors

- Dissolve soluble galts that did not dissolvo during nelrieval and transfer from the spowe DSTs

- Dissolye solids such as piobsite that may have precipilated during metrieval and transter

- Support chemical adjustment of the waste $\mathrm{NaOH}_{2} \mathrm{NaNO}_{n} \mathrm{NaNOO}$, and $\mathrm{H}_{2} \mathrm{O}$

- Support samplitig protocod.

The transfer pump must be abla to perform the following (Certa 1996):

- After delivery of a teed balch to the private contractors, the liquid beel remaining in the lWFSTs should be no more than 0.10 ML (25 cm |10 in.]) of waste. 


\section{Af.5 OPTION EVALUATION}

A tradified slury distriburer syskesn was suggested. This would purmp the wagle to the 241-AP valye pit and back through a slurry tisuributor with a discharge nozzle. Slury distribulors have been widely ured at the Hanford Site to ditribure the beaviet sluties ialo the tanks, bul not as a mixing system. This system woukd need to be tested and evalualed in tcale models to verify that the sygem could perform sulisfactorily in the IWFST?. Therefore, the madified slurty distribntor syglems was screented from further evaluelion.

The pulsed air mixing system was also suggested. Studies have been dose on this for retrieval, but not for just mainuaining solid suspeasiont. This technology appears to be timple and warrants further consideration. However, al his time the technology has nol been prosen or used with the waste in questiot. Therefore, the pulsed sir mixing system was screened from furthet evalualivit.

The analyses of the no mixer pump oprions haye been summarized in a tabular forth it Table A1-1. Since the Iwo oplions involve the gande equiptaent, the decision criteria of maimainability, lechnical maturity, and pertormante reculraments will be the same. The main driver in selectipg the preferred oplion will be based on cost and schedule. 
Table Al-1. Matrix of Mtxer Pump Opaions by Decision Crileria.

\begin{tabular}{|c|c|c|}
\hline \multirow[b]{2}{*}{ Decision Criteria } & \multicolumn{2}{|c|}{ Option } \\
\hline & $\begin{array}{l}\text { Oplion ] } \\
\text { "Whixer Punp on Slab" }\end{array}$ & $\begin{array}{c}\text { Option } 2 \\
\text { "Mixer Pump abuve Centsal } \\
\text { Pump Pio" }\end{array}$ \\
\hline Cogl & $\$ 16,600,000$ & 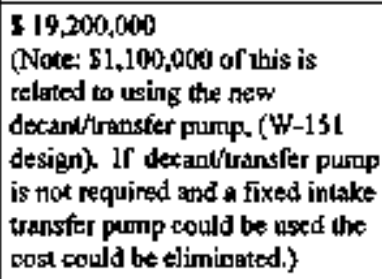 \\
\hline Scherctule & 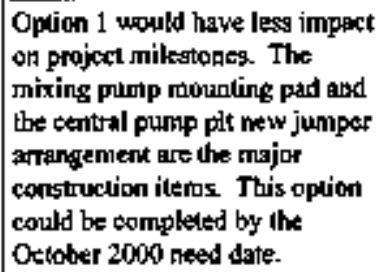 & 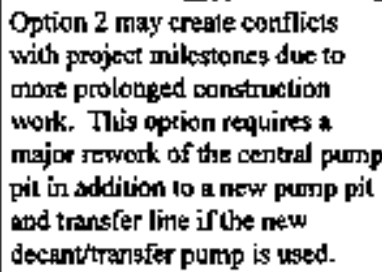 \\
\hline Mainlaitability & 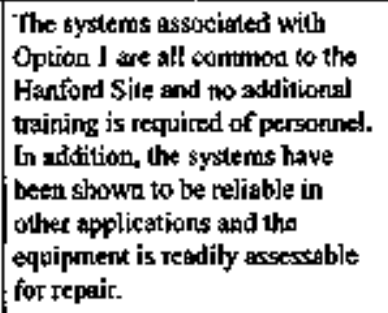 & Sarue as Oplion 1 \\
\hline Technical Mahrity & 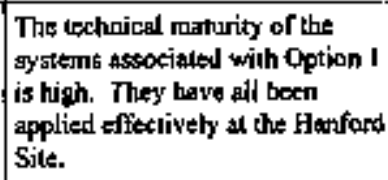 & Same as Option 3 \\
\hline
\end{tabular}


HNF-SD-TWR-AGA-DO1

Revision I

Table A L-1. Matrlx of Mixer Pump Optons by Deciston Criteria

\begin{tabular}{|c|c|c|}
\hline \multirow[b]{2}{*}{ Decision Crileris } & \multicolumn{2}{|c|}{ Oplion } \\
\hline & $\begin{array}{c}\text { Oplion 1 } \\
\text { "Mixer Punp on Slat" }\end{array}$ & $\begin{array}{c}\text { Option 2 } \\
\text { "Mixet Pump above Central } \\
\text { Punp Pit" }\end{array}$ \\
\hline $\begin{array}{l}\text { Performance } \\
\text { Requiremethls }\end{array}$ & $\begin{array}{l}\text { Mixing performance could be } \\
\text { demituished with this oprion do } 10 \\
\text { the off-center lacation. }\end{array}$ & 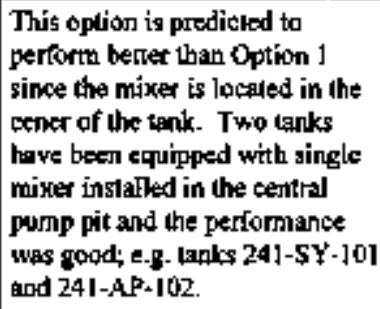 \\
\hline
\end{tabular}




\section{A2. PROBLEM STATEMENT}

The objective of this AGA report is wetermine the best option for installing a mixing system in the IWFSTs. Tank 241-AP-102 wat modified tor the grout propratrl and eurrently has an agitation sygtept and a news tranefer pump pit. The capabilities of these modifications $b$ support the miximg requiremenls for the lWFST thesds to be addressed along with the upyrades required for conkl 241-AP.104.

This AGA will investigate optens for the mixing of the JWFSTs and determine the modifications required 10 install these systems. Preyious analysis of mixing 5ystems will be tused to screes options and a preferred option will be selected. The criteris for dectemining the best optlon witl be based primarily on cogl and technicat maturity of the mixing system. 
HNF-SD-TWR-AGA-O0I

Revision 1

This pege intentionally left blank. 


\section{A3.0 CONSTRAINTS AND AESUMPTIONS}

The JWFST mixing system would be considered pant of the Share Managed Tank Wastes Function 4.2.1.1 (W/HC 1996). This 'includes the mobilization'suspension of tank waste solids, miror chemical ajustments, and in-tank Webujing and fort siaging.

The performance requirennermta identified in Function 4.2.1.1 that pertajn to the mixing sysiem are as follows:

- Estimoted TWRS Project Schedtle

The ruixing sysiem must support the TWRS project scheatule. Proof-of-Concept operaliotss will be from June 2002 through Jume 2007, with DOE's aption of tatend protessing through June 2011.

- Chemiral Cententrations Limits

The mixing sybetm sygtems interfacing with the waste sources must be capable of handling waste with the cbernical concentralions specified in OSD-T-151-00607 (WHC 1996a).

- Heat Gemenation Limit

The mixing systers will be limiled to a total thermal input load based on the latk venlilation system cooling capseity. This ventijalion anslysis for addine a 300.hp mixer pump is addregsed in Apperdix c.

- Tank Dane Static Loaditug

The weight of eny portion of the mixing system installed an a tank riser will be limited by the stalic dome loading destign limits specified in OSD.T-151-00007 (WHC 19969).

- Tank Ventilation System - Pressure

The mixina gystem will not ovet of under-preaburize the tants based on the limils specified in 0SD-T-151-00007 (WHC 1996a). 
- Tempenoture - NomAging Ware DST Waste

The mixing system must be espatie of handling waste with a maxumurg temperature of $82^{\circ} \mathrm{C}\left(180^{\circ} \mathrm{F}\right)$ as spectitied in WHC.SD-WM-OSR-016, LCO 322

(WHC 1996b)

\subsection{CONSTRATNTS}

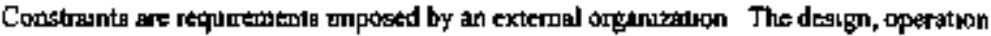
and mantenanke of the IHFST mixing system are affecied by state tond federal regulations, agreements, DOE Onders, and Westugghouse Hanfiod Company (WHC) requrements In addilion, there are guidelines and specuifcalsons thal set forth engpoering requinements doemed pecescary for 5afe dessign mod construthon of the mixung sygtem The requirements and gundelites presented in these orders, regulaions, codes, and wejeements must be followed when

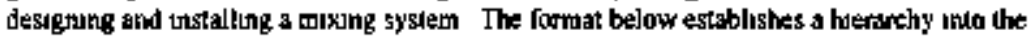
Insted docuenents 10 be uged during the definutive desugn stage of the IWFST upgrades

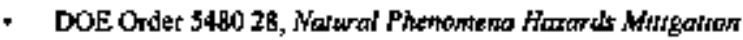

- DOE Onder 5820 2A, Radhoatime Waste Martagement

- DOE Order 6430 IA, General Design Crierta

- WAC 173-301-640, Damgerous Watte Regredans Taht Sysiems

- WHC-1P-J013, WHC Occmpartomal ALARA Program

- WHC-SD-GN-[XGS-30011, Radrofograd Dengn Gude

- W/A-CM-4-46, Safect Classificatoon of Structures, Systents and Comporents

The long-length equipuert must be designed is fit in the bunal containers developed under the Long-Lengh Coulsminated Equipment Disposal Prograpl In adidrion, the equipment weight must be below the limus of the tralers for the handling and tritisport of the bumal contancers The degign information for the bonz-kenglh aquafmenl ara be found in the following documents

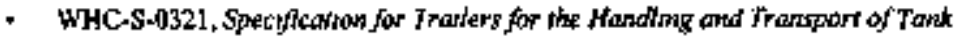
Forms Long-Length Contantenated Equponent

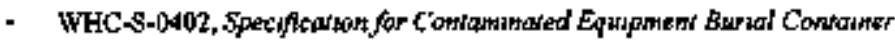

Instrumentatwo to momtor and/or contiod the followmg parameters will be designed and ingialled unless exubung tonk insinuments can be used 


\section{HNF-\$D-TWR-AGA-001 \\ Revision 1}

- Monitor tank level, teraperahuee (wagle and yaper space), pressure (yapor qaxe), and gens concentrutions.

- Detertinine the extenl of trixing elfectiveness.

- Monitor mixer pamp motor anperace, rpon, and temperature.

- Monilor temperatures of mixer pump ddve and bearing componenis.

- Modilor mixer pump bearing/seal lubricalion water flow rale.

- Mesare vibratiod of the mixet punp atsembly.

\section{A32 ASSUMPTIONS} ophiong:

The folkwing sagumptions have been nado in the andysis of the IWFST: mixing systeth

- Anelysis of the inpact of the mixer pernp jet foteet on existing or added internal tank equipment is beyond the scope of this report.

- One mixer pump in each I WFFT will provide adequale mixing of the slurry/supermate wask to be staged.

- Decap1 pumpigs will be required to transfer the supetnale to the privale comtractor's feed tank If the quentity of tolrds is out-of-specificotion (Certa 1996).

- Addition of a new pit on the JWFST 3 wi]1 not exced the dome limit of the tanks. It is assumed that the weight of the pit will be less than the veight of the goil removed. 


\section{HNF-SD-TWR-AOA-001}

\section{Revision I}

This page intentionally ken blank. 


\section{A4.0 ANALYSIS OF OPTIONS}

This section documents the medhodology used to generale the options and documents any options that were screened. In addition, this section determines how uell an optlon satisfies each selection criteria.

\section{A4.J GENERATION OF OPTIONS}

The options for the mixing system were developed by irformal brainstorraing and documented in meeting minules (Galtrodth 1996b). The uptions generated for the mixing system consist of the fallowing: Mixer panp system, ptilsed air rrixing systoth, and 1 wodified shurry distributor systern.

The mixer pump system consists of high-capacity low-head pumps with elosely-spaced suction and discharge ports They ane designed to necirculate the thuids withill a radionetive whste tank to athieve mobilizatlos and miximg of the wote. Mixus pumps are key to retrieval gystems such as the Project W-2II, "Initial Tank Retrieval Systems" (Rieck 1995). The mixer pump systems to be addressed will include concepts developed by Projects W-2II and W/.151. This incitudes mototìng the mixtr pamps on top of the temiral purop pit and on a concrele slab.

A pulsed air mixing system is curtrenty being eqaluated by Pacitic Northwest National Laboratory (ENNL) for use in shodge mobilization. This system mixes the waste by generaing large oval-shaped bubbles of compregged air that are sequentially introdaced under large actumularor phales al the bottom of the tank. The consecunively thered pulses quikkly tise in a controlled scoutence to the top of the lank, foreing liquids to circulate from top to botion crealing B vertical flow pahtern.

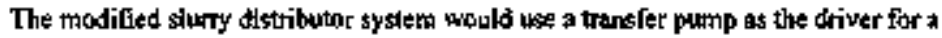
reciteulation system tied to a satury distributor. The slurty disinibulor would spray the recinculated wagle over the surface of the tank contends to provide mixing of the waste.

\section{A4,2 SCRREENING OF OPTIONS}

The options generaled can be Inittally schented against the crilaria of technical maturity. The pulsed air mixing system appears to be simple and wartants further consideration. Howtever, at this time the techrology has not been proven or used with the supemote wate in questiont, ot in a othe mijlion gallon tanl. Therefore, the pulsed air mixing sysyen was gereened from further evaluation. In addilion, the modified slurry distributor system would doed to be lested and evaluated in scaled models before it would be fesible in the IWFSTs. Therefore, the modified

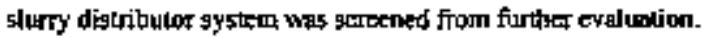




\section{HNE-SD-TWR-AGA-ODI \\ Revislou I}

\section{Ad3 ANALYSIS OF MIXER PUMP OFTIDNS}

The adalyses of the two mixer purre optione have been summarized in Table AI-1. Since the two options involve the same equipment, the dexision sflterda of mainlainability, technical pasturity, and performance requirements will be the same. The main driver in selecting the preferted option will be based on cost. This section provides a detalled description of the upgrades required for these two options and the cost associated with each upgrade. The costs are taken Irom the estimates provided in Seclion A6.0.

One raixer pump will be requined in each IW/F $\$$ T. The initial cost of the ADlHP including tun-in lest is approxdmately $\$ 760,000$.

One decant pump will be requirad in each JWFST. The existing transter pumps will be replaced with the new supernete decant purnp. The initial cost of the decant pump includtug num. in test and thop modifiegtions is approximately $\$ 510,000$. If the winch mechanism is not required, the cost would be approximately $\$ 450,000$.

A nitrogen bonte station will be required for each of the mixer pemps for the gas-seal

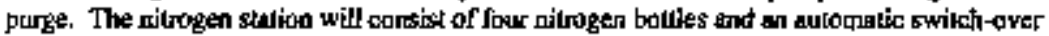
manifold (with pressure megulalox, pressure safety valwe, pressure iddicators, thd check valve), that will automalically 5witch from the old bottle to the new on low pressure. A standard "K"

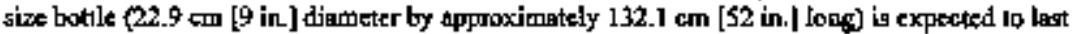
approxitnalely 30 days before being surtomatkally switched over to a new bonle. The cosis io install a ritrogen bottle station in boh of the IWFSTs are approximately $\$ 120,060$.

The failed rixing pamp and the slurry distribstor for tank 24l-AP*102 in the central puesp

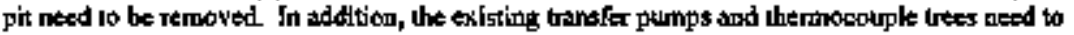
be removed. The cost for removal and disposs of this eqoipment is approximately $\$ 5,500,000$. This includes \$2,900,000 for vreenhause and gopport cost phus irmobilization cost.

A thew thermocouple tree, vapor pressute itdicaloc, and level fudicator will be required in each IWFST. The lotal cost lo putchase and install this equipment in both of the IWFSTg is approximately $\$ 260,000$.

\section{A43,1 Option 1}

Opeica $I$ is to locste the mixer pump in riser no. $S$ (106.7 cm [42 itt]). off-centered on a Hew concrete pad and locate the decant purnp in the central pump pil riser no. 11 (106.7 $\mathrm{cm}$

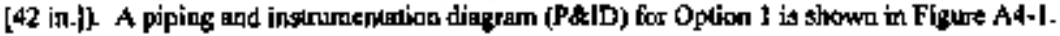


Revision I

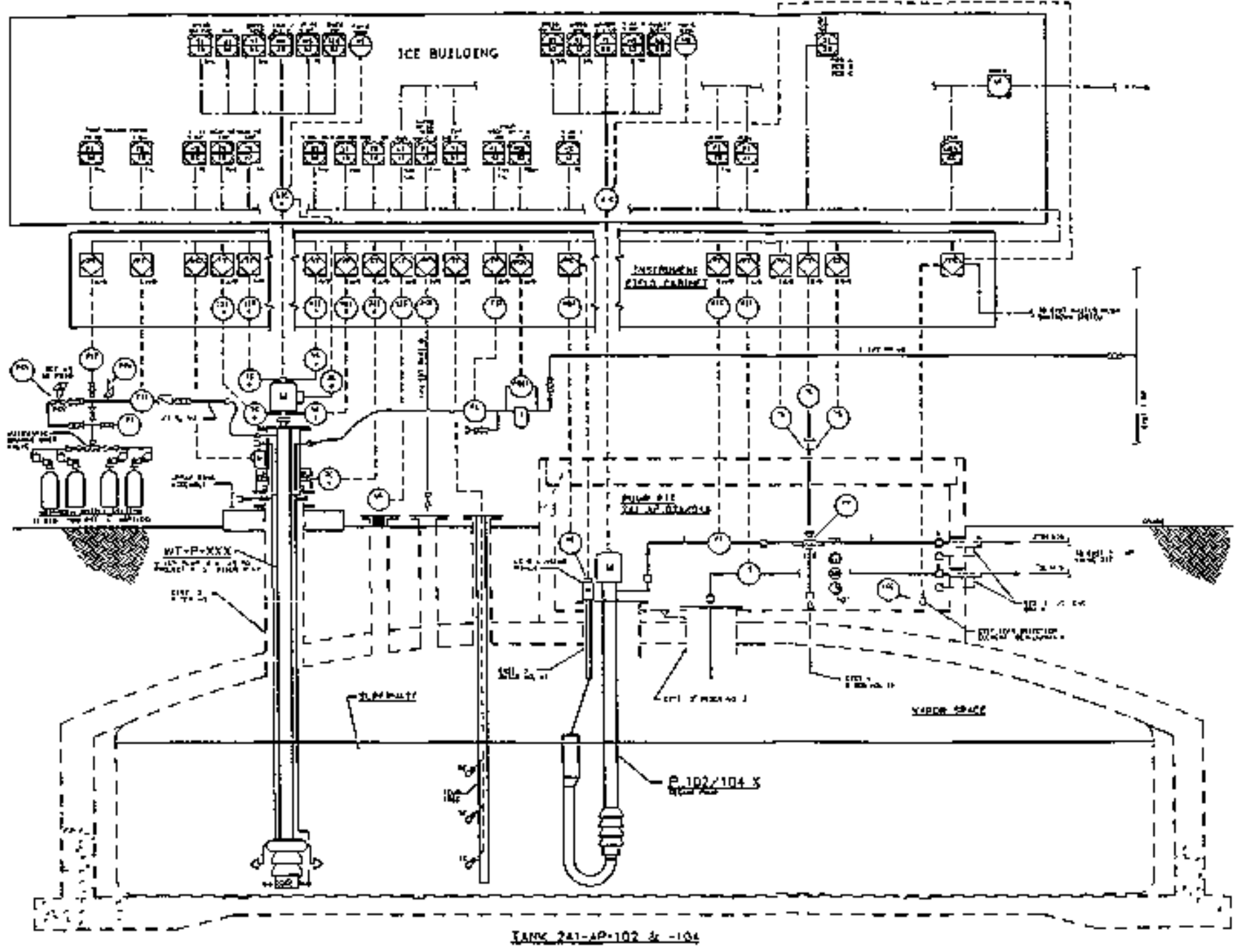

Figure Ad-I. Pfpung and instrumentation Dageran far Option I téczino

$\overline{\overline{Z n-}}$ ב-

ב-ב nimi-

$\rightarrow-0 \quad 0 \mathrm{max}$

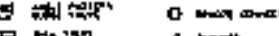

它

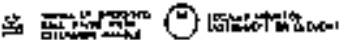

星 可访地

d univere By

a)

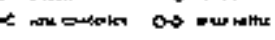

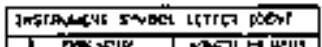

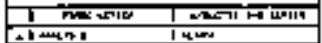

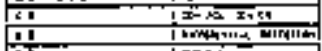

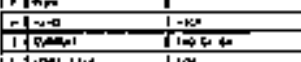

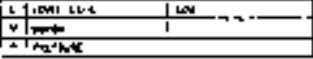

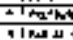

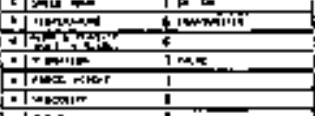

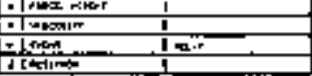

LINE OSMI FISAT'ON

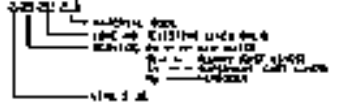

NoTES

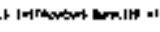

s.

i 5

A-2S/A-26

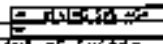

bis

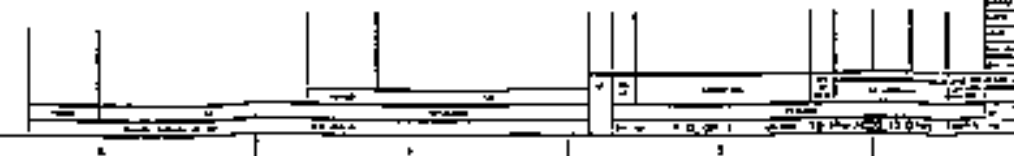

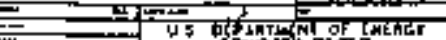


HNF-SD-TWR-AOA-0OL

Revition 1

The work associaled with Option I inclodes the following items for each of the IWFSTs:

- Purchase of oofe ADMP and one gupernale decant/tratigfer pomp.

- Install appoximadely $23 \mathrm{~m}$ (75 fl) of new 3.8-cm (1.5-in) row water line includiag a tewy yalye and bose station.

- Extend the ]06. $7 . \mathrm{cm}$ (42-in.) riser and ingtall the mixer pump foundavion. Thds will be a reinforced concrate slab $2.7 \mathrm{~m}$ (9 f) by $2.7 \mathrm{~m}$ ( 9 fi) and $0.3 \mathrm{~m}$ (I ft) thick placed 15 un (6 in) belowgrde.

- Patricate and inglall a high pressure gpray ring on top of the mixer pump riser for future decontamination of the mixer pump os it is wilhdtaw from the tank.

- Install a nitrogen bottle station for the gas-sesl purge of the mixer pumap.

- Modify the ecntral purap pit jumaper arrangerdeal as showe in Figure A4-1.

- Renove the faited mixer pump in the central pump pil (tank 241-AP-102 only).

- Remove the slurry distributor in the central pump pit (tank 24;-AP-104 only).

The 1otal cosl for the uork induded in Option 1 is anproximately $\$ 16,600,000$. This includes $\$ 3,000,000$ for design and managermemt, and an estimaled burnoul cost of $\$ 1,700,000$

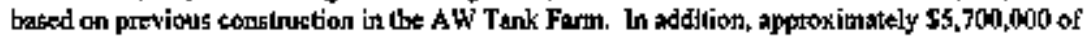
the total cost for Option 1 corresponds to upgrades for adding the mixer pumps. The toial cost for Option l that corresponds to upgradeg for adding the decent pumpg is approximatcly $55,200,000$. There would be no difference in the cost for this aption if the decind//ransfer pumps ware installed in a $30.5 \mathrm{~cm}$ (12-in). riser in the cenural pump pil.

\section{A4.3.2 Option 2}

Option 2 is to locate the mixer pung in the 106.7-cm (42-in) riser of the central pump pit, rise so. $1 \mathrm{l}$ (106.7 $\mathrm{cm}$ [42 in.] ) and kesule the decant purap in a new pump pir above riger no. 5 (106.7 eng (42 in. D. A 9\&ID for Oplion 2 is shown in Figure A4-2.

The work astociated with Opton 2 iscludes the following itteng for each of the LWFST:

- Purchase of one ADMP and one superrate decant/uransfor pump.

- Inșall appoximalely 29 a (95 ft) of new (3.8-cm [1.5-in.]) raw walet line lectuding a rew yalve and bose thation.

- Install the mixer pump on the cover blocks of the ceniral punp pil. This will require ite repliscement of the exietisfg caver btocks. The central purmp pil cover blocks are 


\section{HNF-SD-TWR-AGA-QOOL}

\section{Revision 1}

$0.6 \mathrm{mo}$ (2 fl) thick and cover an area that is $5.0 \mathrm{~m}$ (16.5 fi) by $3.2 \mathrm{~m}$ (10.5 ft).

- Fabricate and indall a riser exirnsion and high pressure spray rimg wînin the central pump pit. Sex Figure Al-6 for a lypical cross-section of this assembly.

- Install a sitrogen borle stalion for the gat-seal puge of the mixer pump.

- Core drill and inglal a new $7.6 \mathrm{cn}$ (3-in.) PUREX nozzle in the central pump pit (tank 24]-AP-I04 only).

- Modify the central pump pit jumper arrangement as shows in Figure A42.

- Install a new parmp pit en the I06.7-cm (42-in.) nigar no. 5. The pump pit would be

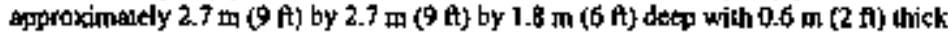
sover blocks. The pit would inelude as stoteless steel liner.

- Reroute the existigg transter line and insinumeat air libes that interfere with the installation of the new pump pit.

- Install a new transfor tine between the ceptral pump pit and the new pump pit. The transfer líne would be doubde encased wilh a 7.6-em (3-in) diamater staínless steel primbry entested in a 15.2-tm (6-in.) dikanteter carbon steel secondary and be approxlmately 6.4 mo $(21$ f) in lenghth.

- Fabricale and instail] a jumper amangenent and keak delector in the new pump pil as shown to Flgure A4.2

- Remove the failed mixer pump in the central pump pit (tank 2d 1 -AP-102 anly).

- Remowe the tiurry distributat in the centrat puntp pit (tank 241-AP. [04 only).

The total cost for the work inctuded in option 2 is approximatedy $\$ 1,2000,000$. This includes \$2,600,000 for design and management and an estiutated bujmout cost of $\$ 2,800,000$ based on previous construxion in the AW Tank Farm. In addiltion, approximately $\$ 5,600,000$ of the tolal cost for Optlen 2 contesponds to upprades foc adding the miker purnps. The tolal cost for Option 2 that corresponds to upprades for adding the decapl/trantfer pumps is appoximately

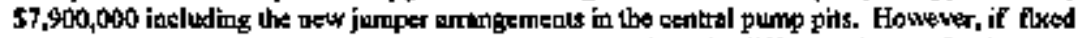
intake transfer pumps are installed in a $30.5-\mathrm{cm}(12$-in.) riser, the difierance in cosl for this option would be approximately $\$ 1,100,000$. 
HNF-SD-TWR-AGA-001

Revision I

\section{AS* REPERENCES}

Carpenter, K. E., 1996, THRS Funcilons atat Requirements Document, WHC-SD-WM-FRD-020, Rev, 0, Weatinghouse Hanford Company, Richland, Wastiriquon,

Ceri, P. J., 1996. Low-Lewt Wosre Feed Sraging Plan, WHC SD-WM-RPT.224, Rev. 0, Westinghouse Hanford Company, Rictland, Washingion.

DOE, 1988, Radionative Wasta Management, DoE Onder 5820.2A, U.S. Department of Energy. Washington, D.C.

DOE, 1989, Gereral Design Criterka, DOE Order 6430. IA, U.S. Departmeat of Energy, Washington, D.C.

DOE, 1493, Neriural Phenomera Hozards Mfitigation, DOE Onder 5480.28, L.S. Department of Energy, Washington, D.C.

DOE, 1995, TWRS Privaritation Requests for Proposoils - Draff, Solloilalion Number DE-RP06-96RL13308, U.S. Deparunent of Energy, Richland Operations, Richland, Washington-

Oalbraith, J. D., T. B. Salzano, and J. R. Nicholson, 1996a, Decislon Doctiment Kor Phase I Privatizerion Trantsfer System Needs, WTHC-SD-W/M-T1-750, ReY, 0, Drat, w/estingbouse Hantord Company, Richland, Washinglen.

Galbraith, J. D., 1996b, Almernative Generattun Session for Upgrades of AP. 102 and J04, Meeting Minutes, daled Junc I3, 1996, Wegtiaghonge Hanford Company, Rjchland, Washington.

Lawler, J. H., 1984, Grout Fied Tank Miker Worting Papers, SD-RE-T]-127, Rev. 0, Rockwell Hanford Operalions, Richlaxd, Washinukon.

Lawler, J. H., 1986a, Dowble-Shell Tank Wasie Retriewal Technology Program Plom, SD-WM-TPP-G09, Rey. 1, Rockwell Hanford Operations, Richland, Washiogton.

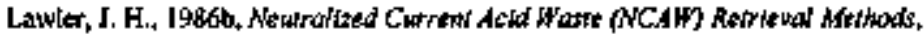
SD-WM-T-23I, Rev. 0, Rockurell Hanford Opcrations, Richtand, Waghinglon.

MeCormick, W. A., 1996, Specificarion for Thaifers for rat Havaling and Thantppart of Tank Farms Long-Length Comtonninated Equipuent, WHC-S-0321, Rev. 1B, Westinghouse Hanford Company, Rlehland, Washingion. 
MeCormick, W. A., and W.S. Edwards, 1996, Spectfication for Contanimiled Equipment Burtol Contaider, WHC-S-0402, Rev, 0B, Weatinghouse Hantord Company, Richlond, Washlugton,

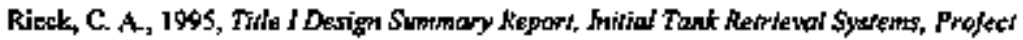
W-211. WHC-SD-W21 l-TDR-001, Rev, 0B (Supplement 2), Westinghouse Hantord Company. Rdehland, Washingtor.

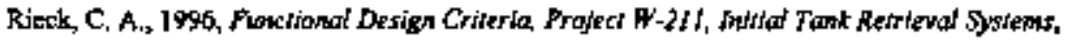
HWC-SD-W21 1-FDC-001, Rev. 2, Westinghouse Hanford Compary, Richtard, Washidegloth

RHO, 1984, Hanford Warle Managenent Plar, RHO-WM.PL-S, Rev. 2, Rockwell Hanford Operations, Ridulard, Washingion.

Shaw, C. P., 1992, Mirar PLanp Study for Project WISt, WHC-SD-WM-ES-195, Rev, 0, Westinghouse Hanfard Corqpany, Richlond, Wastington.

WAC 173-303.640, 1990, "Dangerous Weste Regulations, Tank Systerts," Washtngtort Adwintighowtue Cade, as amended.

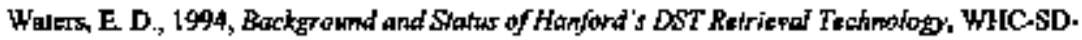
WM-TI-593, Rey, D, Westinghouse Hanford Company, Richland, Washingtou.

WHC, 1992a, Safey Clossifficatian of Siructures, Systems, and Canponents, WHC-CM-4-46, Westinghouse Hanford Company, Richloond, Washington.

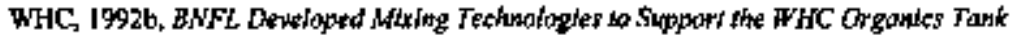
frogram, TRAC-0748, Rev. l, Wertinghouse Hanford Company, Richlind, Washington.

WHC, 1994, Radrolegical Destgen Gudde, WHC-SD-GN-DGS-30011, Rey, 0, Westinghouse Hanford Company, Richland, Washingtop.

WHC, I995, WHC Ocoupationsal ALARA Progrant, WHC-RP-1043, Rev, 0, Westibphouse Hanford Cosapeny, Richland, Washingtor-

WHC, 1996a, Operating Specifications for the 24I-AN, $A P, A W, A Y, A Z \& S Y$ Tant Farts, OSD T-151-400k7. Westinghouse Hanford Campany, Richland, Wathington.

WHC, 1996h, Dowbie-Sheil Tanks Interim Operational Sofety Requirenterts, WHC-SD-WM-OSR-0I6, Rev. 0B, Wertinghouse Handord Coenpany, Bichland, Washingolon. 
HNF-SD-[WR-AOA-00I

Revision 1

A6.0 COST ESTIMATES

$A=33$ 


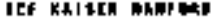

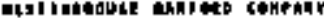
10i no 24105 ind

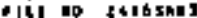

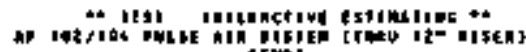

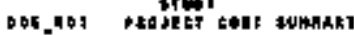

Vut 1 pI

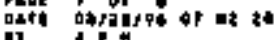

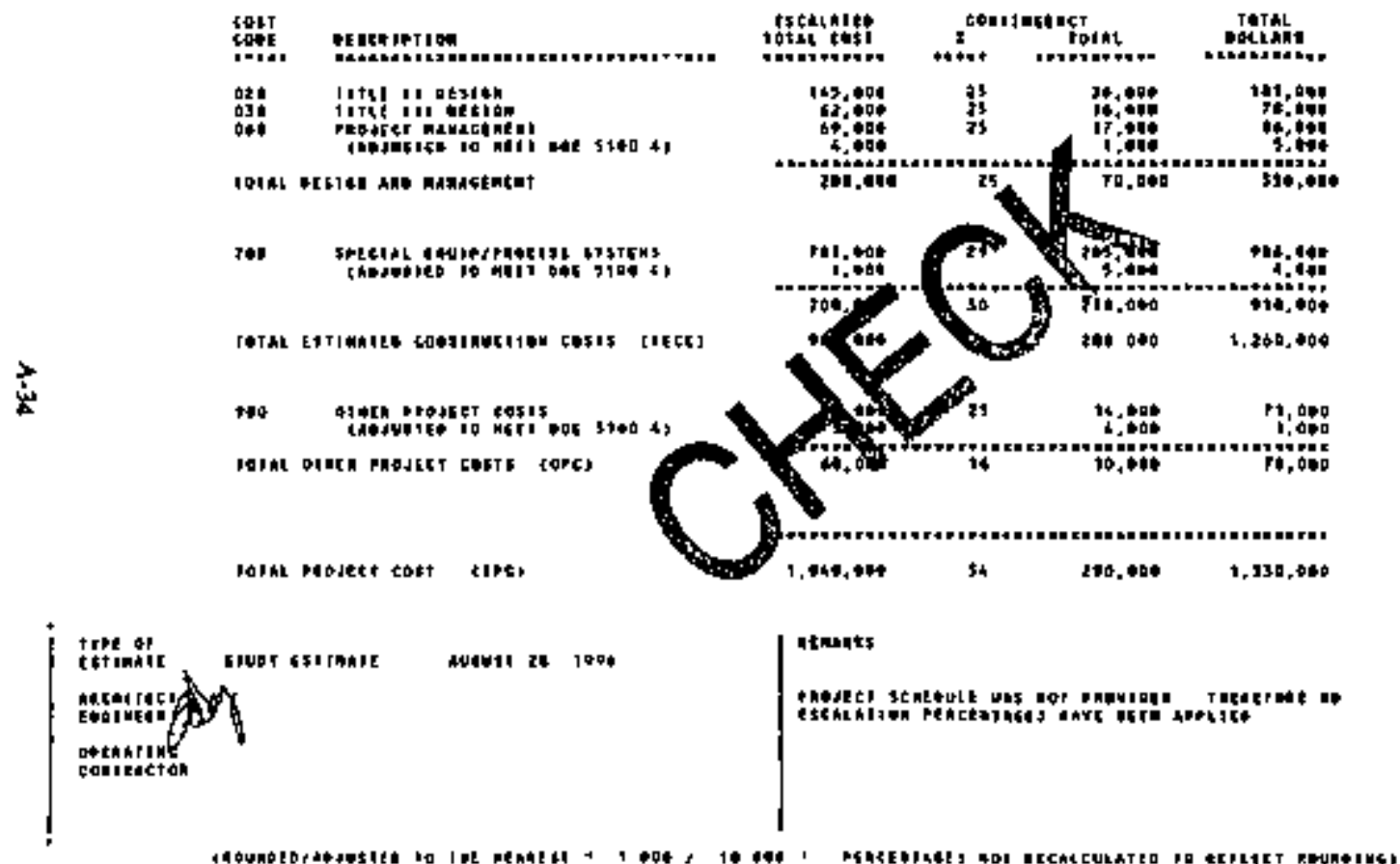




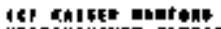

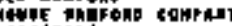

To.

\section{WhA NGEE FTTIDA}

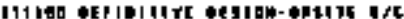

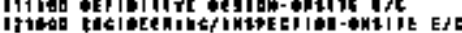

suprotil 1 zestereniut

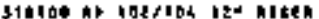

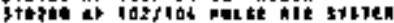

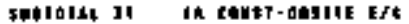

grabto tohl he tete-tots

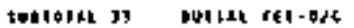

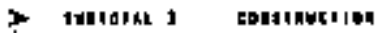

us

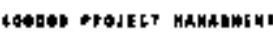

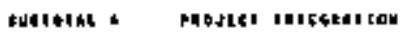

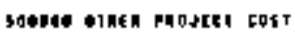

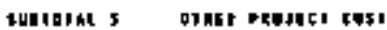

aneset 101k

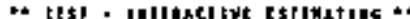

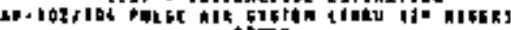
gor
Bakt a ar a

Thit

\begin{tabular}{|c|c|c|c|c|c|c|c|c|c|}
\hline Lation & 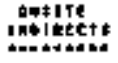 & 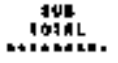 & $e_{x}^{\text {enta }}$ & & 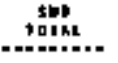 & $\sum_{1}^{t+\infty}$ & $\begin{array}{l}\text { alets } \\
\text { toikt }\end{array}$ & 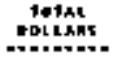 & \\
\hline $\begin{array}{l}\text { Ispoth } \\
\text { bidot }\end{array}$ & $\bullet$ & 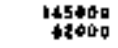 & 0.4 & a & $1+4 \%$ & as & 94250 & 1013s: & \\
\hline 207004 & $\bullet$ & 201000 & $\bullet .00$ & $\bullet$ & 24regs & 23 & 31750 & 230 & \\
\hline $\begin{array}{l}24 \$ 110 \\
420112\end{array}$ & 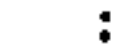 & $\begin{array}{l}\text { J4sfil } \\
\text { 124112 }\end{array}$ & $\bullet, \bullet 0$ & $\bullet$ & $\begin{array}{l}2+\$ 2109 \\
+26112\end{array}$ & 70 & Pasht & $\begin{array}{l}5 \times 10153 \\
155445\end{array}$ & \\
\hline 491601 & 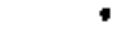 & 401601 & 1.48 & $\bullet$ & 491641 & 21 & 202177 & gerer4 & \\
\hline of & $\bullet$ & 9310 & $\bullet . \bullet 0$ & - & $\$ 319$ & I* & 2056 & 12371 & \\
\hline Q311 & $\bullet$ & $\$ 310$ & $\bullet, \bullet$ & $\bullet$ & 759 & 34 & 2856 & 12175 & \\
\hline Jo11: & $\bullet$ & 101180 & $1, * 0$ & $\bullet$ & To1120 & 27 & 205233 & 946153 & 5 \\
\hline souta & 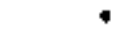 & \$raष0 & $\bullet, \uparrow 0$ & $\bullet$ & crops & 23 & 17250 & Db234 & \\
\hline botat & $\bullet$ & 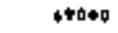 & $\bullet, \bullet 0$ & 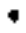 & atene & es & 17230 & 04250 & \\
\hline 32508 & $\bullet$ & $31 \leqslant 02$ & $\bullet .00$ & $\bullet$ & 57402 & 15 & 14331 & 71753 & \\
\hline 12607 & $\bullet$ & sropz & $\bullet \bullet \mathbb{0}$ & $\bullet$ & 57442 & 13 & $\mid+3>1$ & risst & \\
\hline
\end{tabular}

(60)

$1,034,523$

t, 134, 31*

$\bullet, \bullet$

$1,054,52$

205.504

1.313 .14 


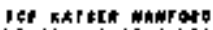

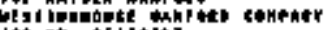

Jot nt. 24ititit

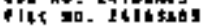

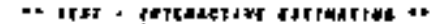

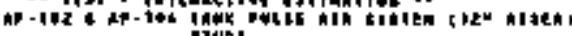

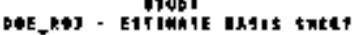

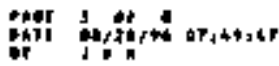

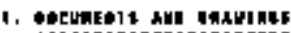

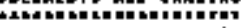

pectumets; 5 ;

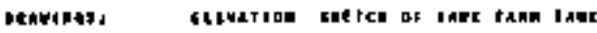

2. Whe hith pres

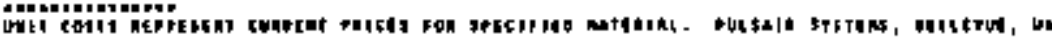

3. LAneh nired

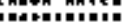

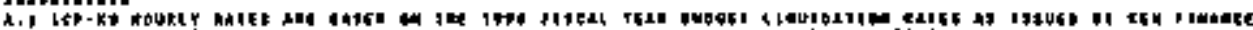

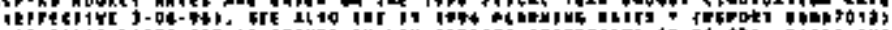

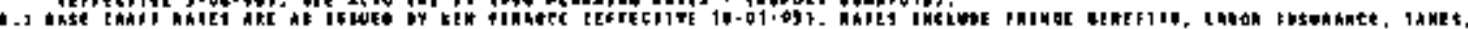
trore

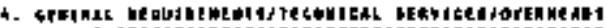

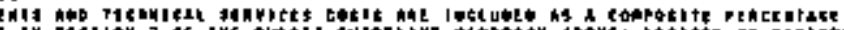

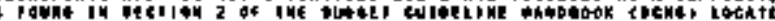

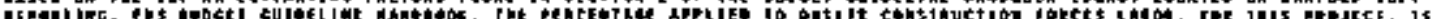

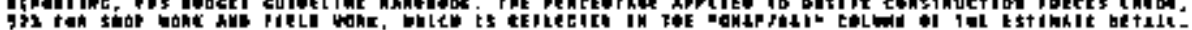

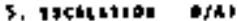

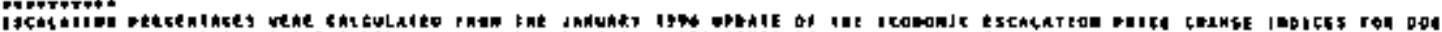

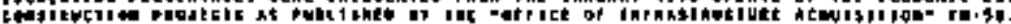

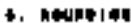

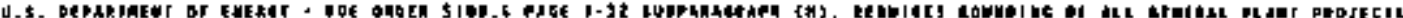

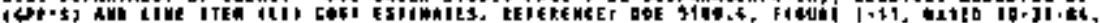

I, shmarts

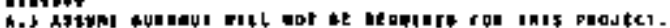

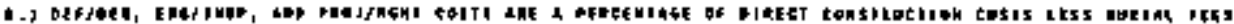

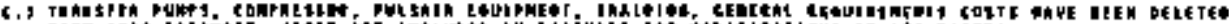

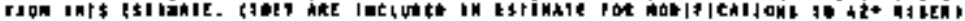

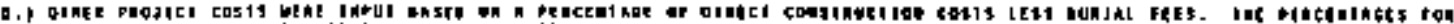

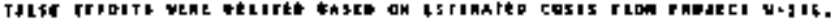




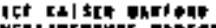

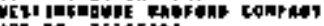

jon no, 24165 ind

$\cos 1$

COBE JWH

DEFCIPILA

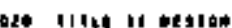

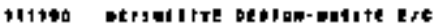

folde eze rirec II besiat

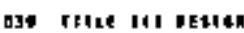

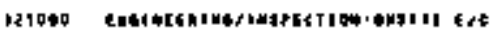

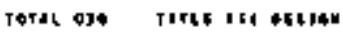

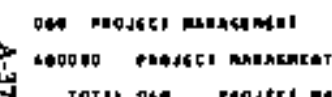

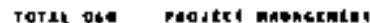

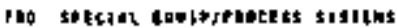

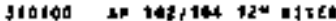

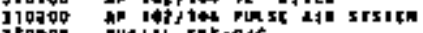

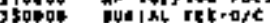

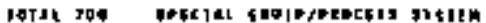

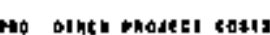

gnopolo ot ace rhedel tad

Told top arate phedet casis

phatef t\#1aL

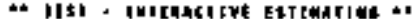

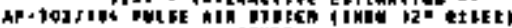

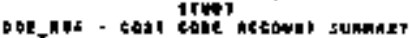

Mat 4 of

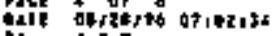

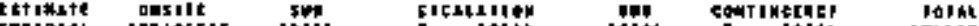

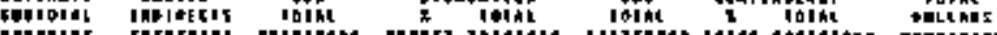

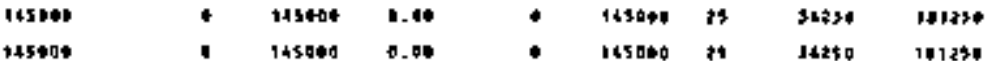

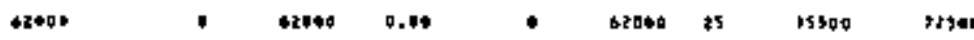

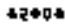

12448

, 4

I214t

15sed

ryse

+pgen

doth

67040

Q, 早

$\bullet$

botop is 11246

14350

a $6+040$

จ. 1 *ै

d*to

11240

2454t4

$42+117$

4 ร43109

54309
$42+192$
1594

D.8.

中

TA1EA

a. 的

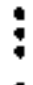

265406
+26117
$7 \$ 19$

rQ1120 29

7454t

17 Pej:

14t

atom

250459

331947

125

404353

37+

a 7740z

4.40

0

if*ez ts

14351

rots

ว Tम4

57402

a. ô

stres as

16251

P1351

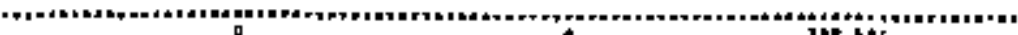

$1,016,528$

$1.054,012$

$\bullet .10$

$1,0,16,321 \quad 20$

2ats, 36

1, 323,104 
Itt kspita estrib

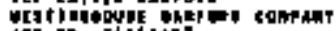

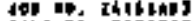

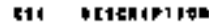

comolitustion

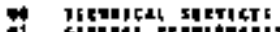

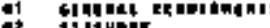

13 1111 inent

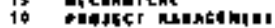

tatek consinucicion

modtca rathe

مل
At IEs1 - Inretactiod csildinige at

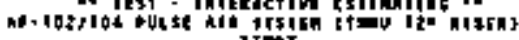

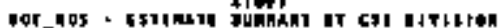

pate 3 at to

til

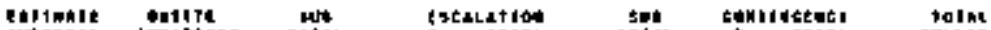

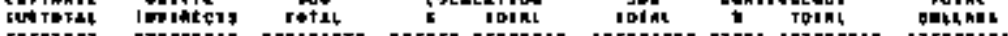

\begin{tabular}{|c|c|c|c|c|c|c|c|}
\hline 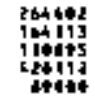 & : & 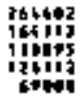 & $\begin{array}{l}0.00 \\
0.00 \\
0.00 \\
0.00 \\
0.00\end{array}$ & $\begin{array}{r}265402 \\
166113 \\
1+41175 \\
12+112 \\
64010\end{array}$ & $\begin{array}{l}23 \\
27 \\
30 \\
35\end{array}$ & $\begin{array}{r}66141 \\
4131 \\
13244 \\
123 \pm 1 \\
17234\end{array}$ & 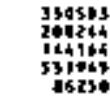 \\
\hline 024,522 & to & $92,4,32$ & 0,0 & 1.054 .522 & 21 & 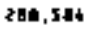 & $1,525,104$ \\
\hline
\end{tabular}

$$
\text { (1) }
$$

$1,052,58$

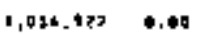

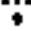

रहE, 5 14 
141 KhIste adurang

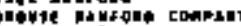

ite no, lot 61 int

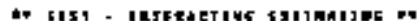

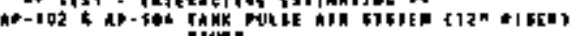

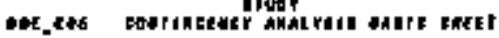

mat 4 if

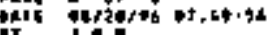

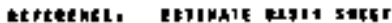

intet 3 af

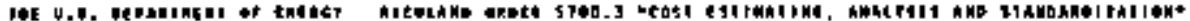

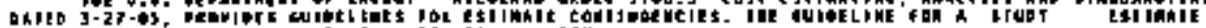

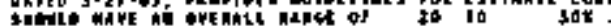

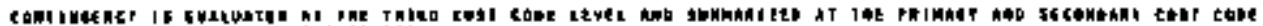

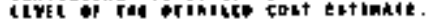

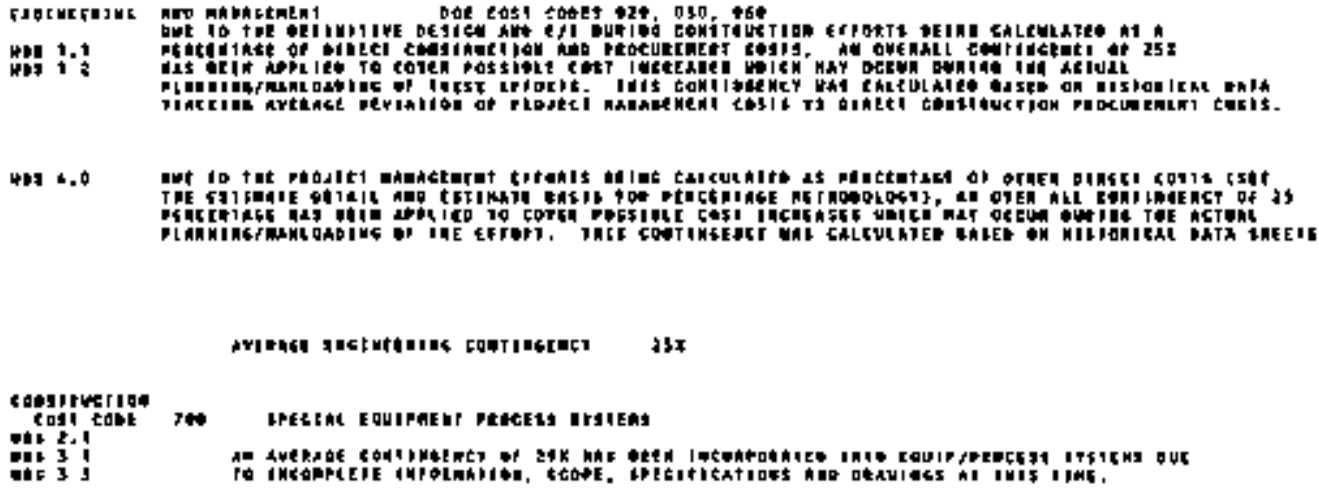

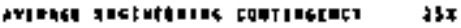

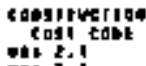

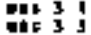

76

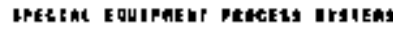

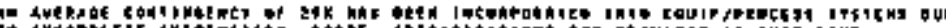

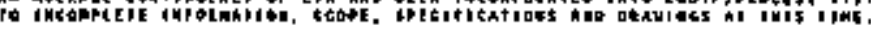




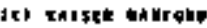

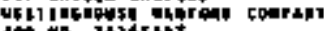

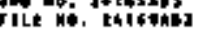

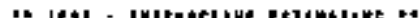

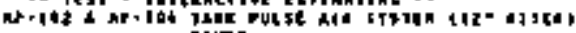

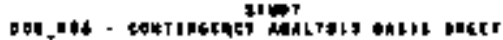

Phice $y$ ar

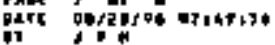

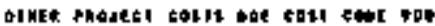

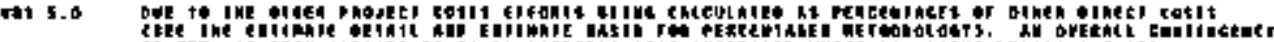

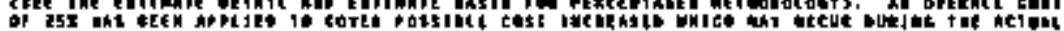

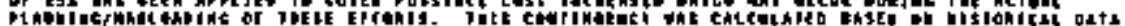

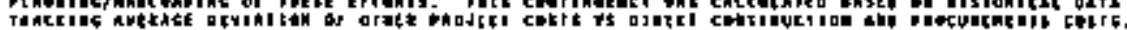

然

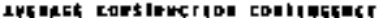

そ早政

ArEAAGT MODJET CHUIJEGHST

201 
I5f whr cth anderent

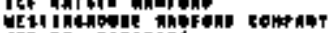

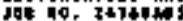

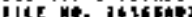

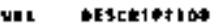

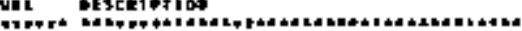

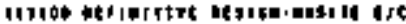

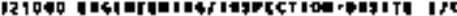

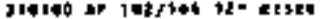

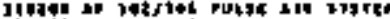

J)

tototo mojet whinendet

DHoptri kathl

$1 .+14,522$

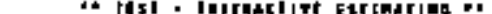

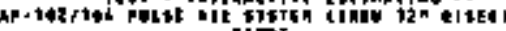

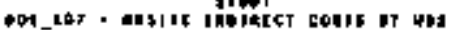

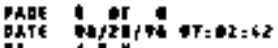

dite art?

\begin{tabular}{|c|c|c|c|c|c|}
\hline 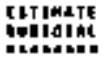 & SenIMAEI & 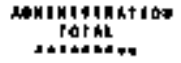 & $\lim _{t \rightarrow \infty+\infty}$ & 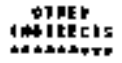 & 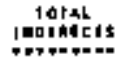 \\
\hline 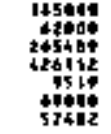 & $\begin{array}{l}4.01 \\
1.06 \\
0.06 \\
0.06 \\
0.06\end{array}$ & $:$ & $\begin{array}{l}0 \\
0 \\
0 \\
0 \\
0 \\
0\end{array}$ & $\begin{array}{l}: \\
0 \\
0 \\
0 \\
0\end{array}$ & $\begin{array}{l}0 \\
0 \\
0 \\
0 \\
0 \\
0 \\
0\end{array}$ \\
\hline
\end{tabular}


Itf resile what ot:

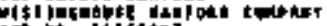

Itit, jol64hoj

Ateoun

anisin

DH 1ERIFIA

Cunbin by

111104

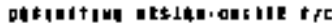

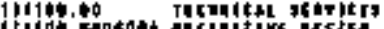

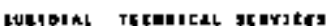

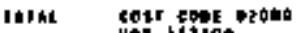

yes bitot

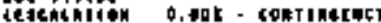

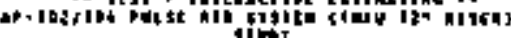

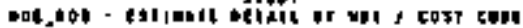

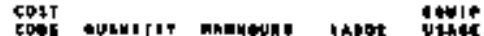

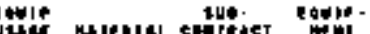

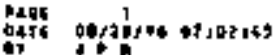

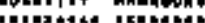

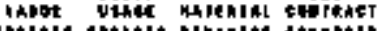

ontr, Ioling

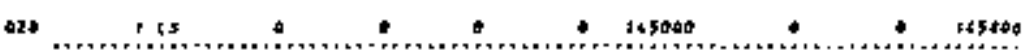

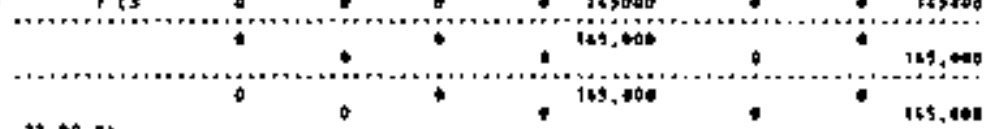

t)

1.

.

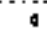

$\frac{1}{1}$ 


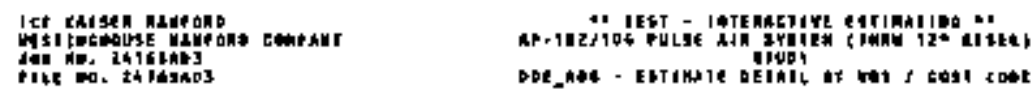

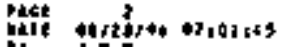

it

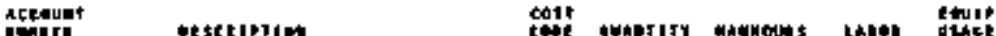

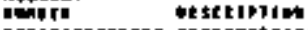

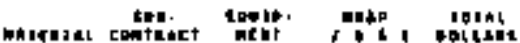

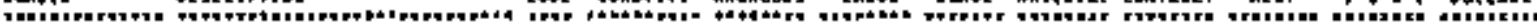

921006

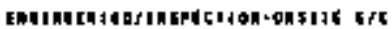

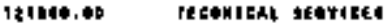

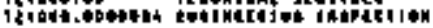

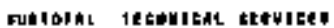

I I I I

tos 1 tont 12900

rectikita.

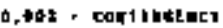

$\$ 54$

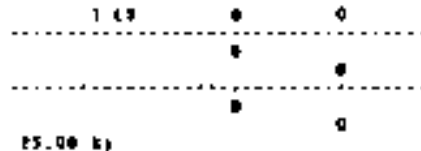

\section{....}

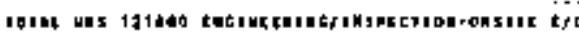

t5. I. 1

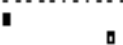

a

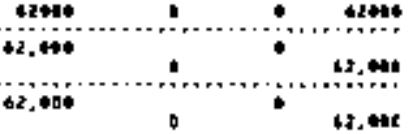

47. Ane

tr

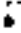

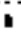

a)

o 


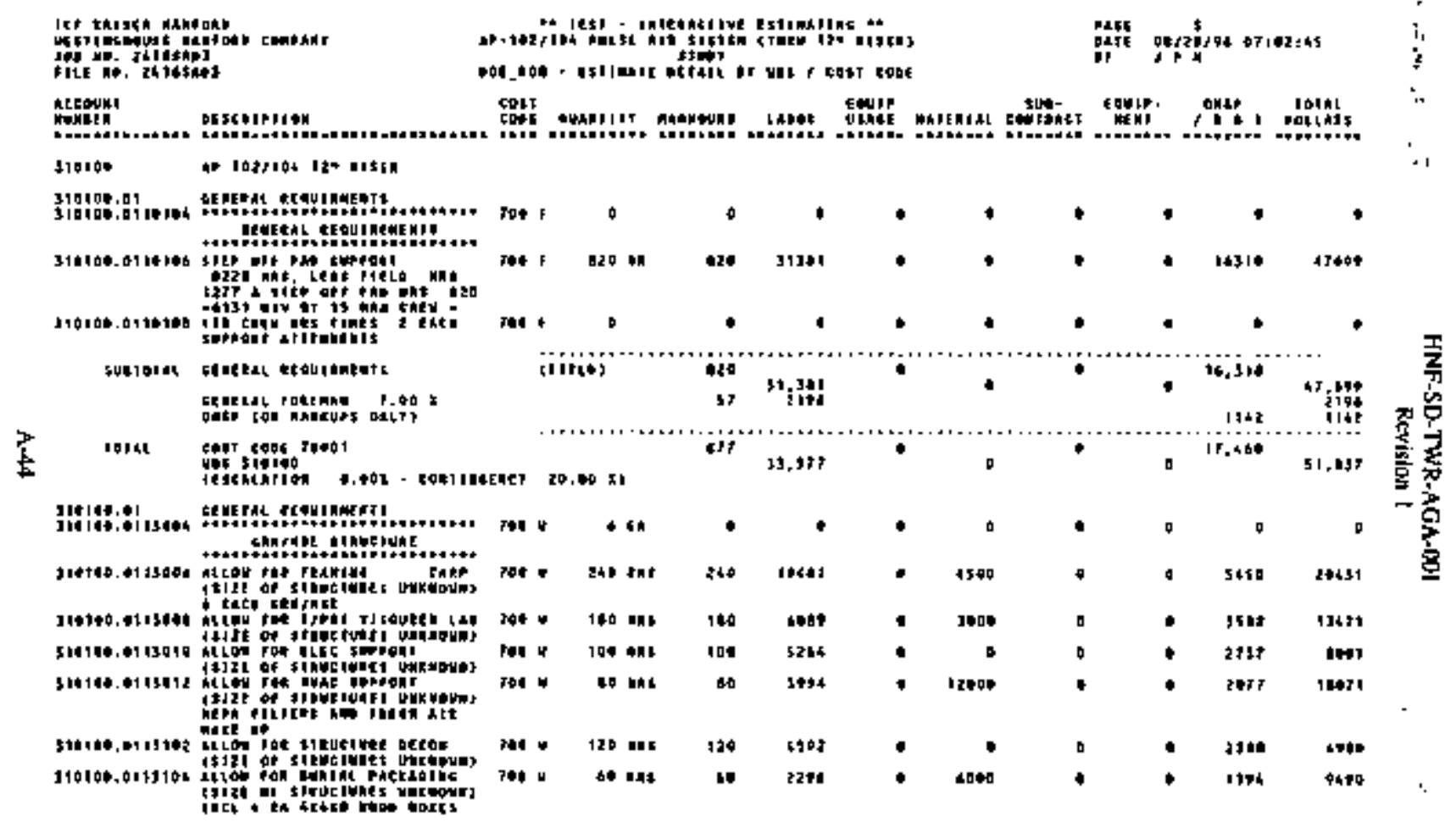




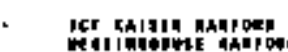

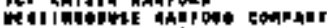

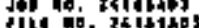

\section{uttwbI}

unhete DEMEAIPTIO

$\rightarrow \infty+4$

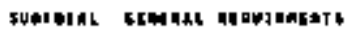

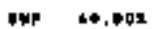

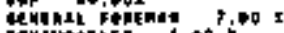

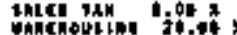

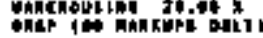

tol he cosic cote 70061

itctiol

D.tat - contigedef 10.04 W
59H WUAB ELE 4.00

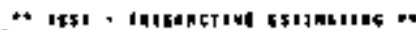
AC.

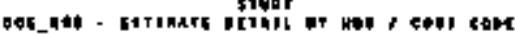

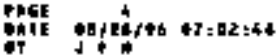

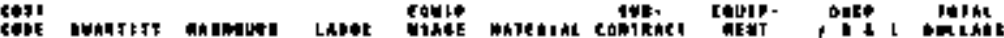

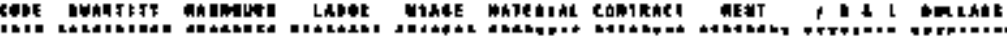

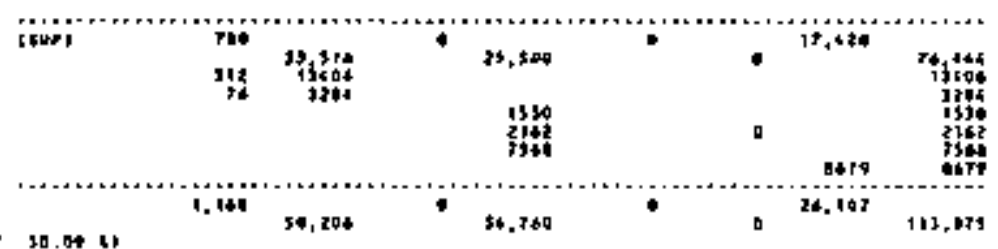

Jithe.

stlemotr

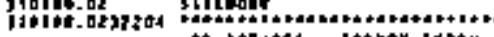

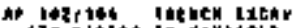

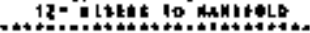

in \$10

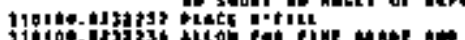

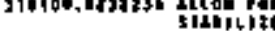

SUICIDA

\begin{abstract}
sialit:
\end{abstract}

\section{cr to.tet}

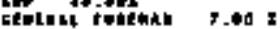

çasimasios 5

thet tip

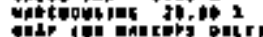

IoThk cost coer fotos?

wat Jitiot

crtcalition

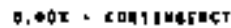

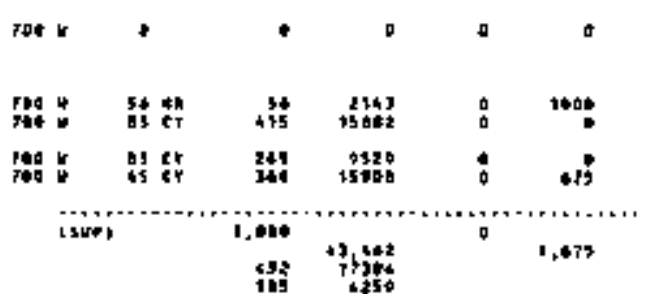

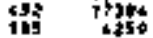

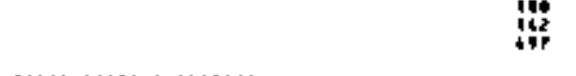

$50,0 \bullet \mathbf{x}$
$1,41 \%$

c), 146

2,614

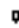

D

a

$\rightarrow$

1110

5278

$\begin{array}{ll}1055 & 14464 \\ 012 & 24055\end{array}$

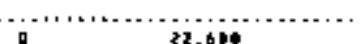

2.600 का, r5?

$11234 \quad, 1+894$

\$1,

(n)

101,975

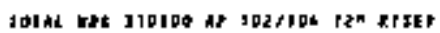

1.241

14t,

$\downarrow$

98. 175

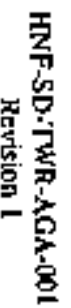

$45,+60$ 


\section{IE) ChIILt waycane}

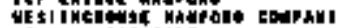

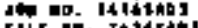

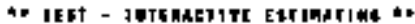

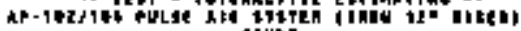

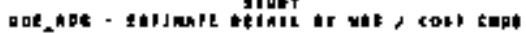

ritr and Ttiosites

Cas I

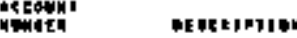

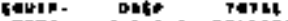

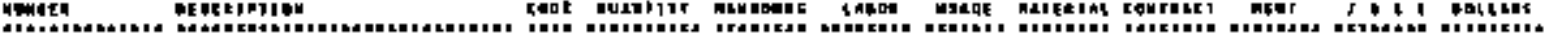

\section{J102 中o}

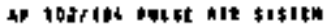

$3+5204,19$

HEFingent

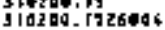
nt $102 / 104$ int

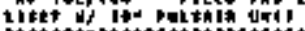

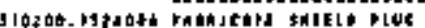

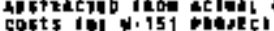
11,

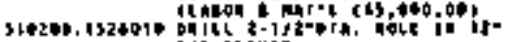

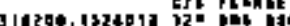

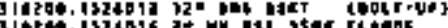

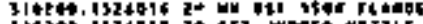

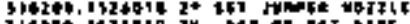

31t20. 13240

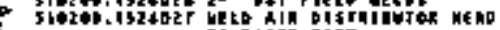

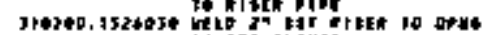

I 12* findes

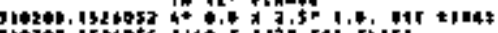
jor

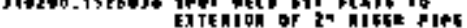

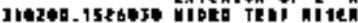

solrelat meendelent

ne ne kal tettwing r.to $x$

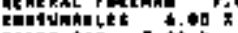

Tains tax a.

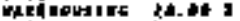

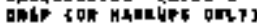

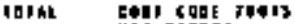

Hod 30030

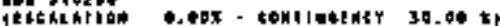

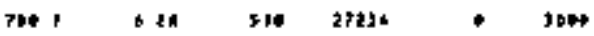

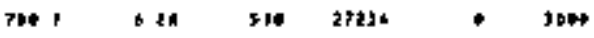

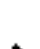

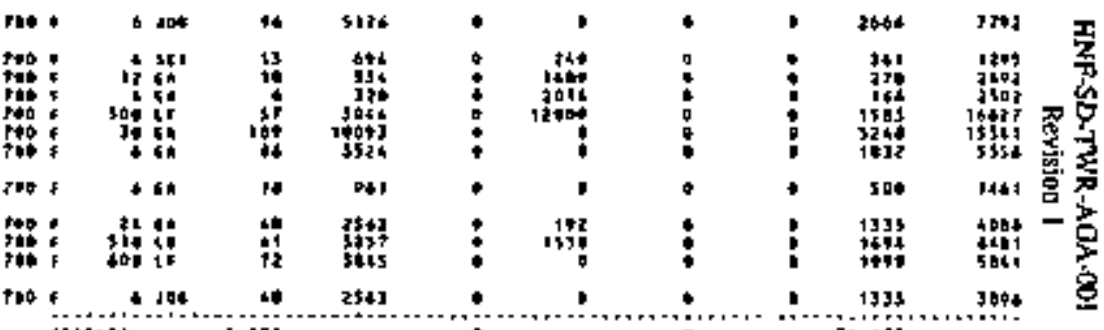

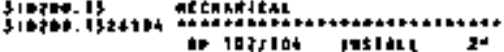

atengitta

creas 1,194

43 41,756

24,494

Jis 193

1210

446?

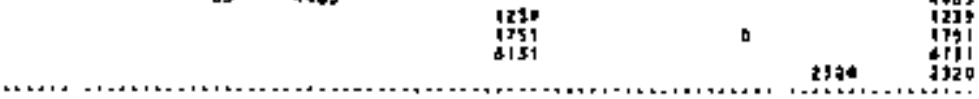

$\lim _{102}$

$1,27 T$

46,271

19,800

is, 6 ts

$159,47 \mathrm{~F}$

iv 10zrlat

rot $n$ 


\section{ter calish unpoto}

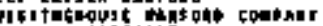

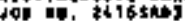

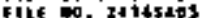

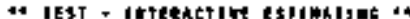

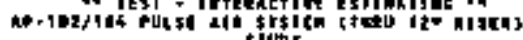

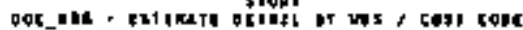

back phitros pio214b atteloti beschinition

MIEK HAIR OIETE I HA MAT

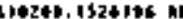

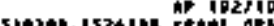

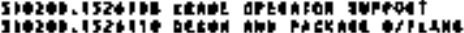

cers.

cerce

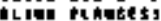

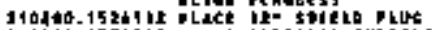

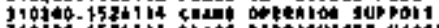

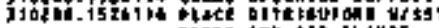

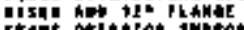

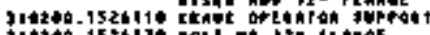

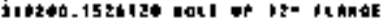

surtrolAL netwhelent

7.

100,0

CEALAL FonkAM $t, 4$

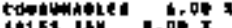

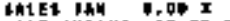

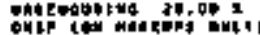

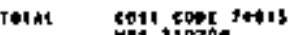

4011070 Crizhinito

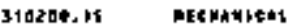

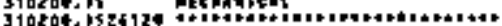

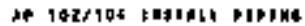

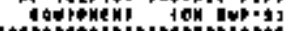

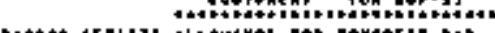

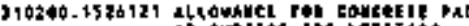

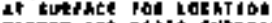

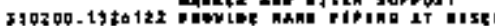

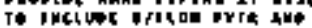

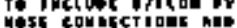

Me

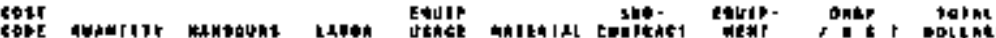

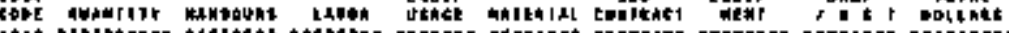

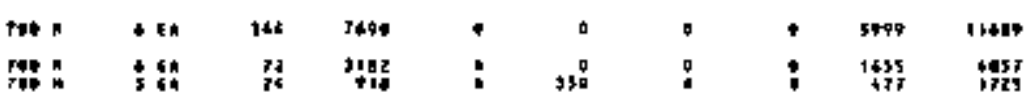

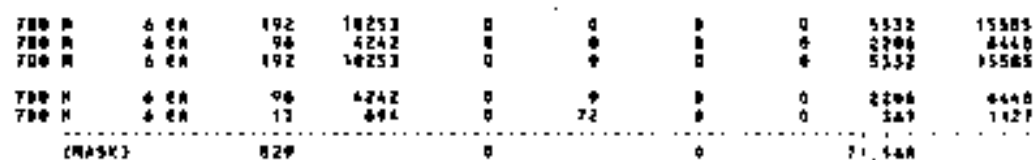

\section{tonsixy}

24

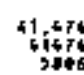

452

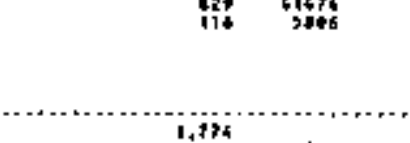

30.00 51

a1, t54

rop

7ot*

rab

40

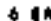

4 rt

It

5

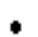

20

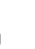

\section{Itod}

17ด16

JP
142 2t

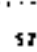

sto

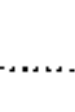

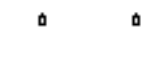


Itf Khlsti utor met:

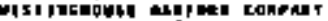

dan 10. $2614 \$ 147$

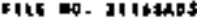

\section{intedun}

Yremith

hestrinilen

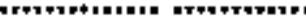

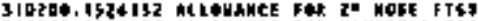

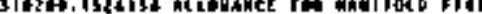

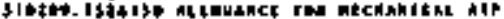

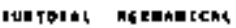

3wy te the

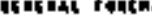

r.po 1

cencuarents 1

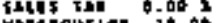

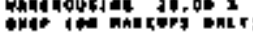

Torint

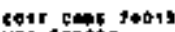

11 1 intio

trichirion

D. Des

toulintentr

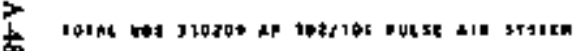

(ant

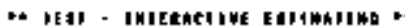

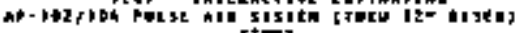

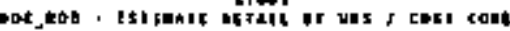

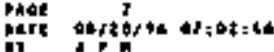

\section{Exज1}

201.

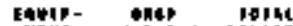

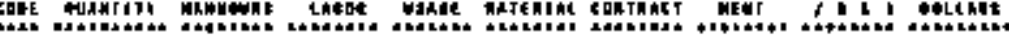

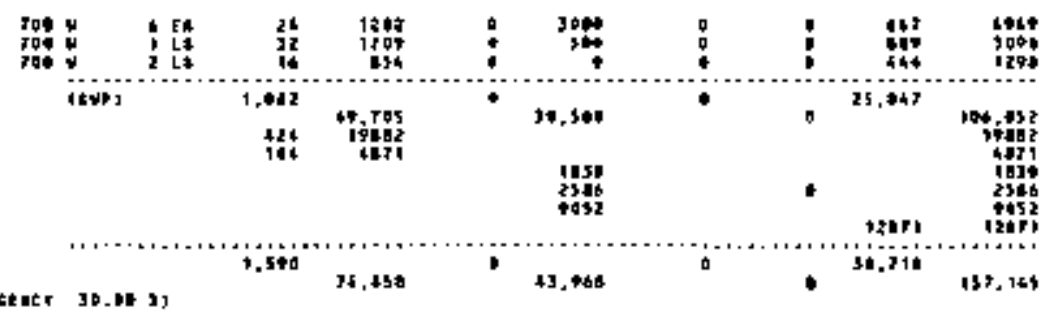

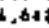

$t+1,6+3$

It, gat

8

120, 14

424,110 


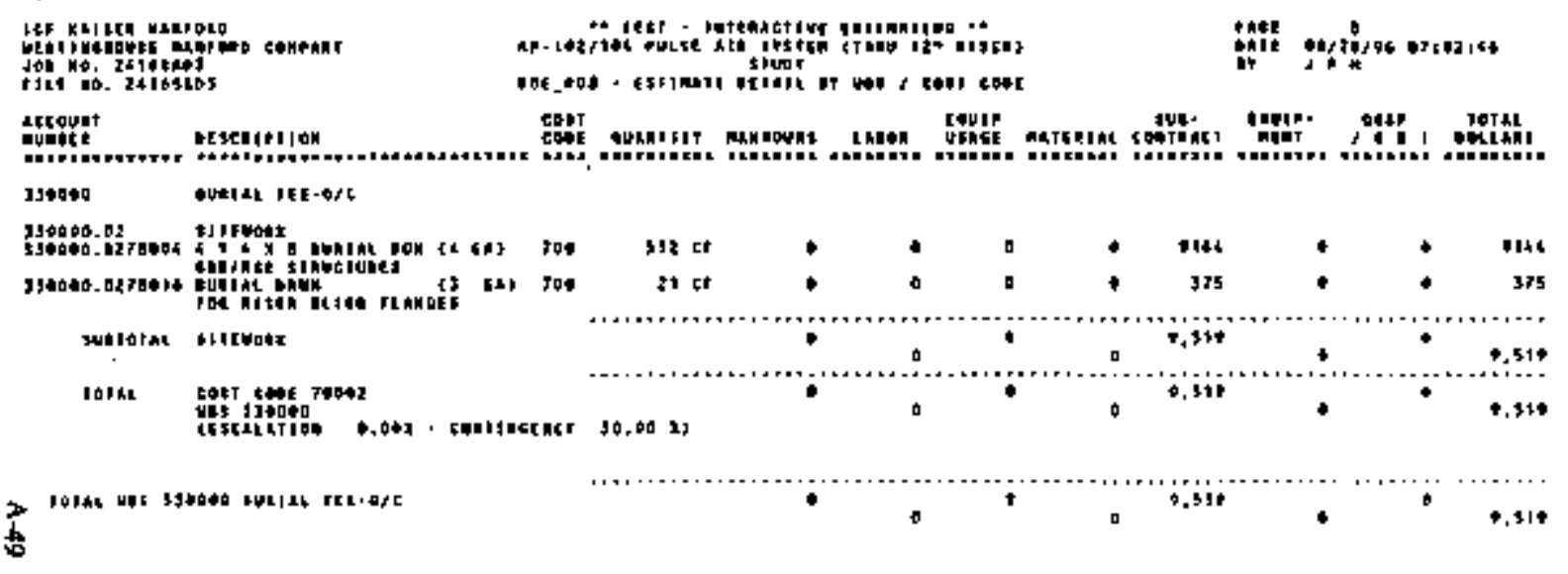


JCF Whis5 nerone

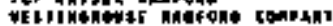

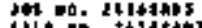

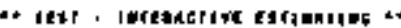

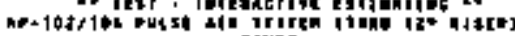

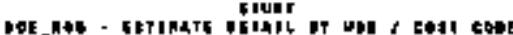

\section{eczourr}

actint

ctscatipan

tobebs pasjer mamanomen

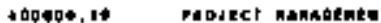

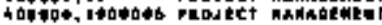

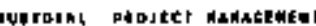

101 int

Cos I che derte

DIT tothat liçitician

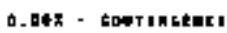

$\cos 1$

thu it

niterint contict

mate

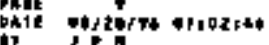

Enerp, towlo Iorkt

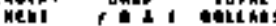

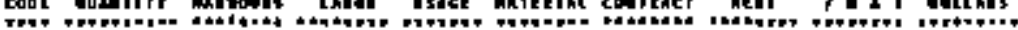

$\bullet$

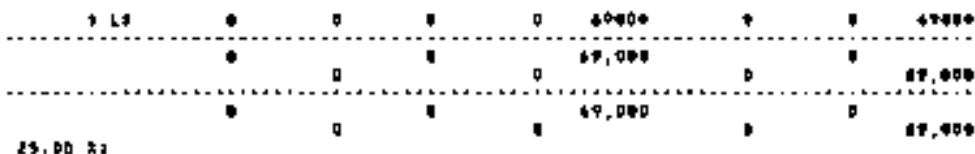

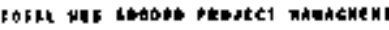

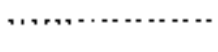

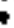

口

b) beto

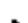

69, 006

㤎 


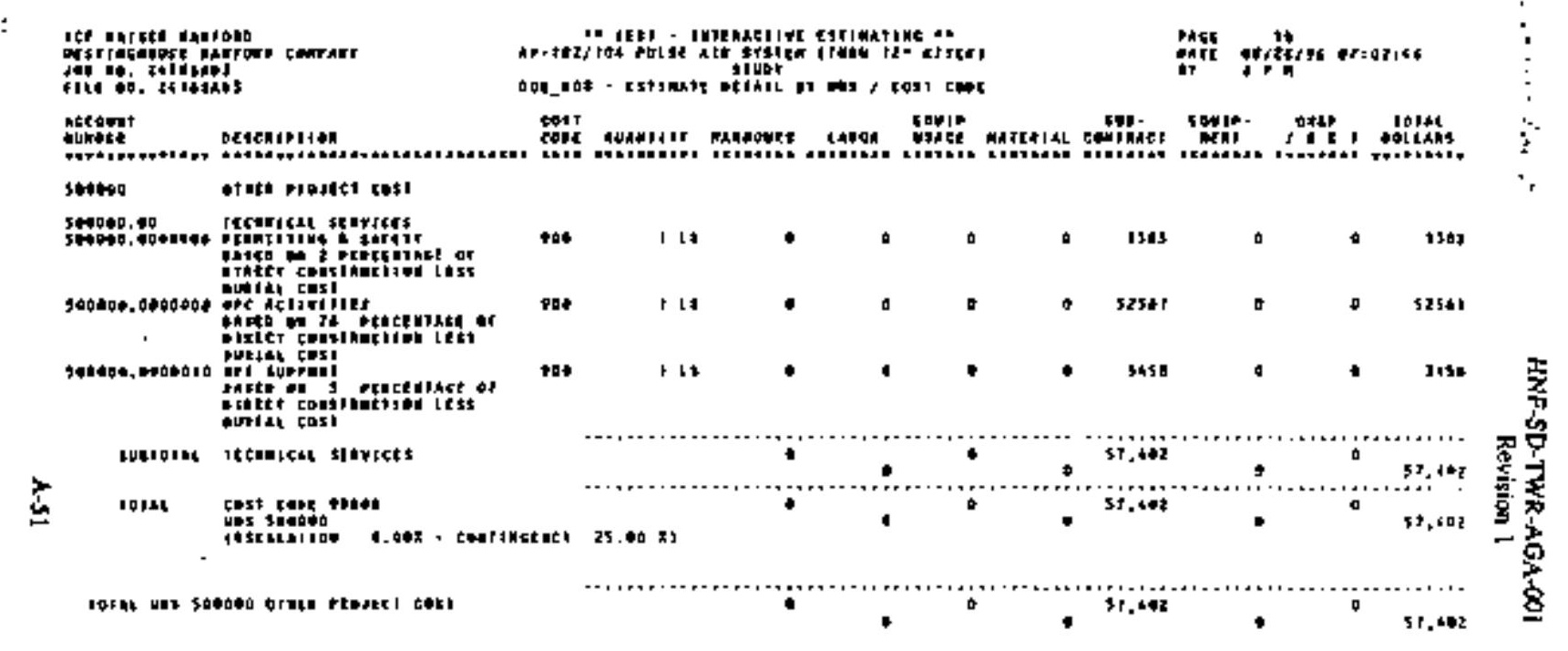




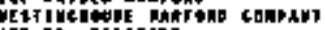

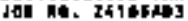

inttedcriva dirimaige ot

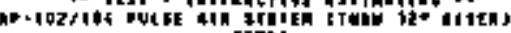
$5 T$.

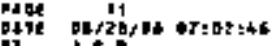

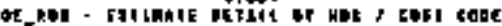

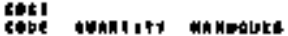
QRetiniption

crr are

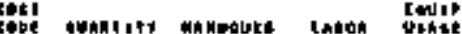

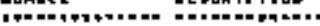

netort goline

:110

504,524

-

13,504

pontr - aid
and 14124

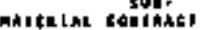
10 I 14 matr.

(1)
242,021

197.77

1, 154,52 
I5f RAILE WhAPR:

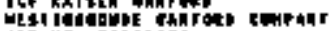
tol ino 74 istixt

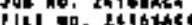

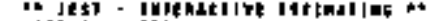

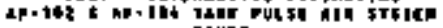

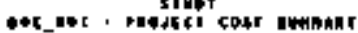

Dhat 1 of

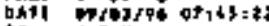

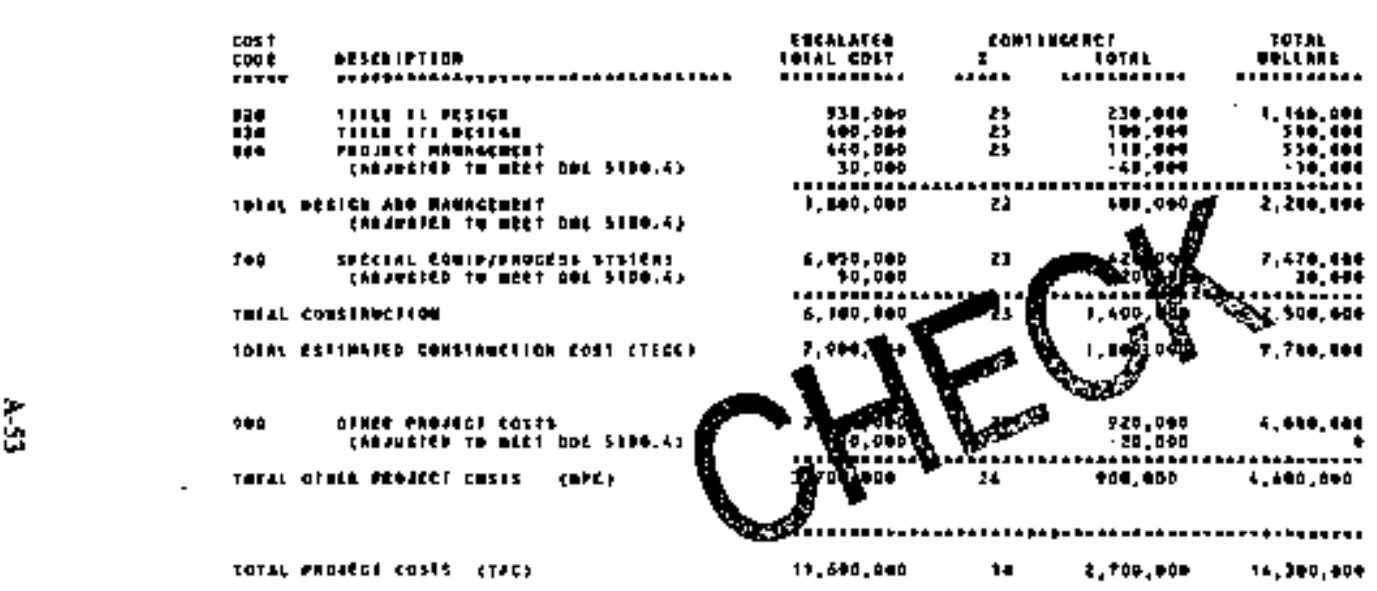

TEAHRR \$:

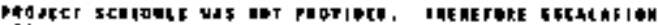

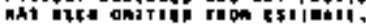

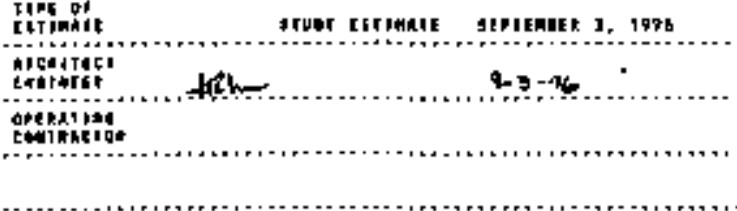

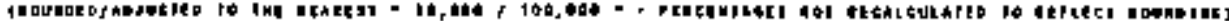


tTP KAjeIt Mand oed

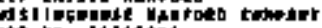

tou a

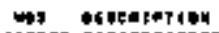

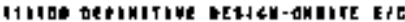

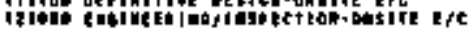

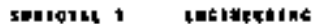

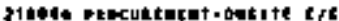

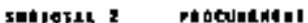

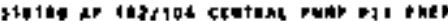

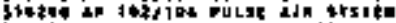

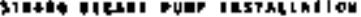

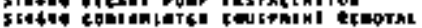

2.

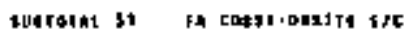

is sjogto nutial Iet-ert

sueteral 51 Whide ite-ert

suerosat $g$ tonsiletilda

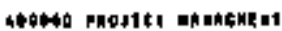

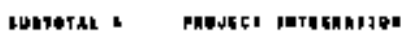

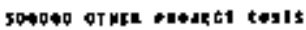

LUtTerab s ateth orobet tust

- vaefer relut

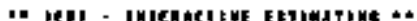

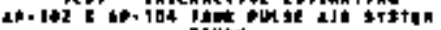

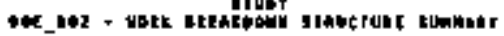

vate to of

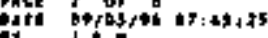

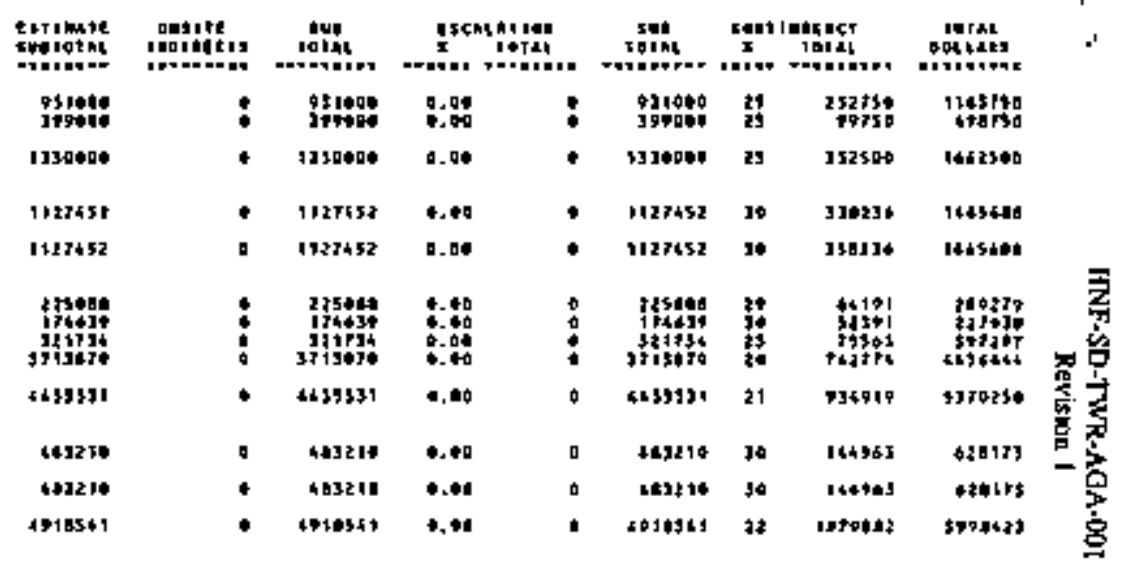

4150to

- taber

- 165890

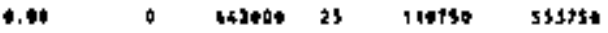

- 14toted

1. DP

430er $\quad 5$

110750

553750

36.r40.4

- Jatopo

4. 4.

19734

434ars:

stronde

1. 16

11750

\{340730

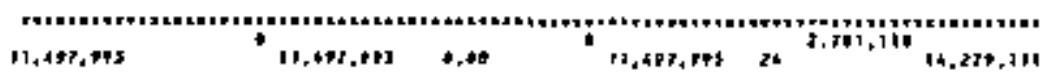




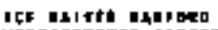

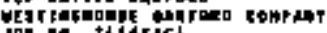

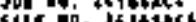

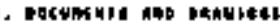

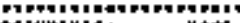

Henimial Mot

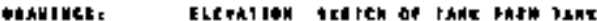

2. Wallolins onites

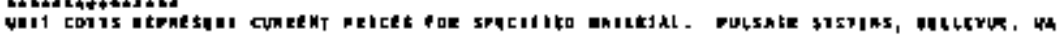

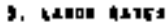

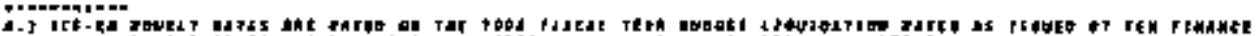

cEFicilite 5-

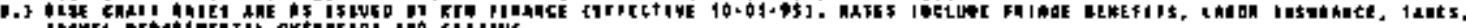

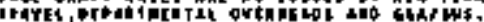

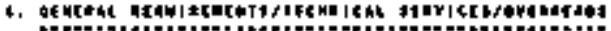

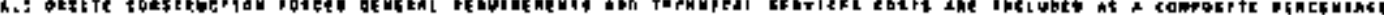

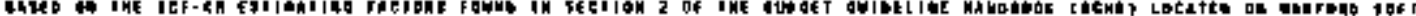

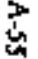

3. Istakirion Has

L. Meurtion:

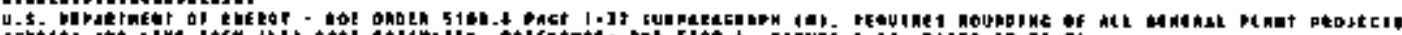

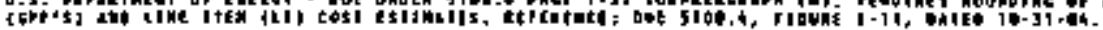

T.

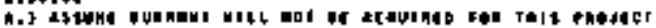

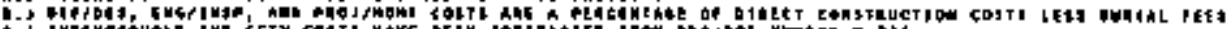

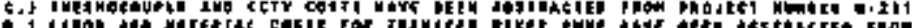

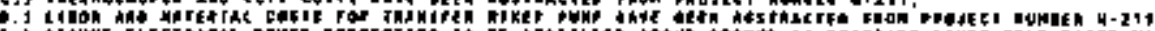

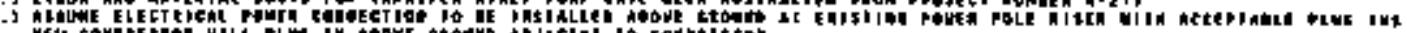

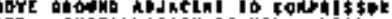

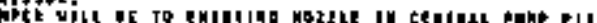

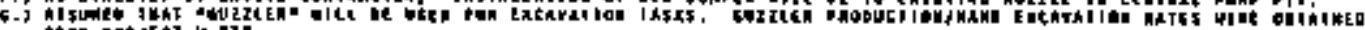

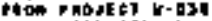

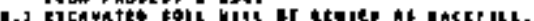

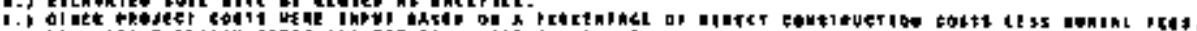

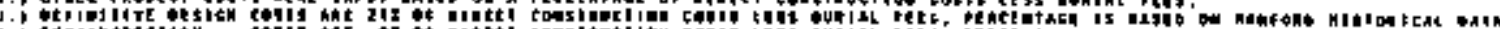

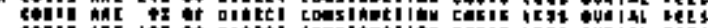

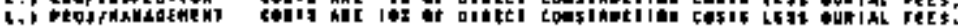




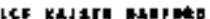

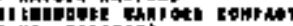

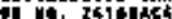

il.

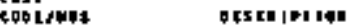

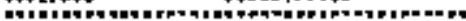

43* IIILA II BRIEA

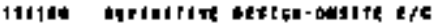

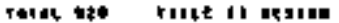

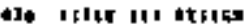

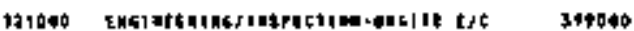

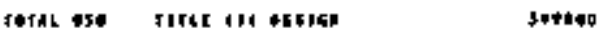

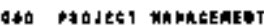

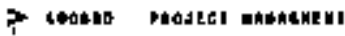

d

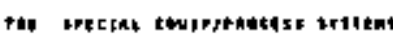

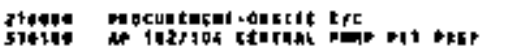

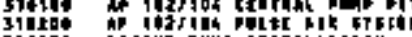

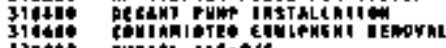

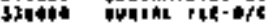

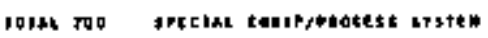

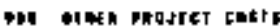

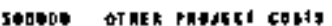

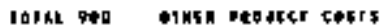

pudiel lathe

\section{0}

445006

1127437

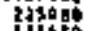

11659

5रा194

3715476

1443405

341009

34 1700

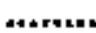

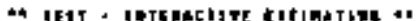

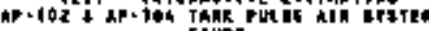

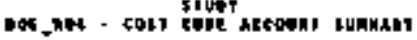

Phat 4 of

in

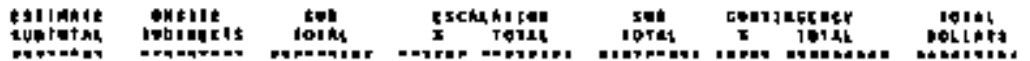

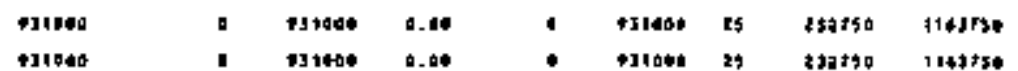

131406

$\rightarrow 110$ 24

zotad $1101+5$

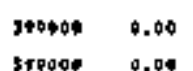

31010 25

99750

49015

soraed is

14750

4torse

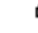

D 56rprea

- scrther $\bullet, 4$

\subsection{0

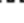

Ststén 2

(1) Jol 2

114190

\$4350

4434

140 iso

531750

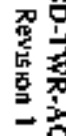

\begin{tabular}{|c|c|c|}
\hline 0 & 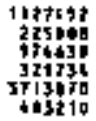 & 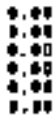 \\
\hline 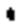 & 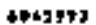 & $\bullet, \bullet 1$ \\
\hline
\end{tabular}

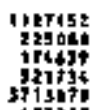

40310

$4045 * 4$

30
30
30
30
30

5.

23.751

4t+1 1

12)

P42

Itditi

$161+110$

$19+34 t$

itiotion

217950

st?

1656444
628173

rated II

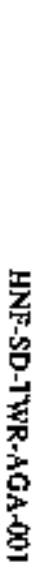

$11,47,945$

$11.67,403$

0.

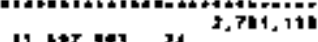

$16,270,111$

rise

45 retse 


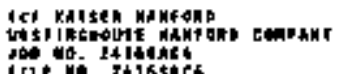

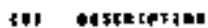

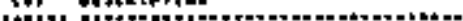

censtivit If od

to tetwitha traters

is sivetion

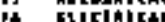

it mirihirat

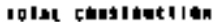

pousct rajel

in

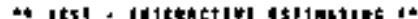

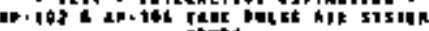

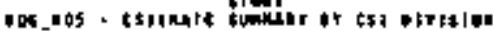

Phe 5 of a

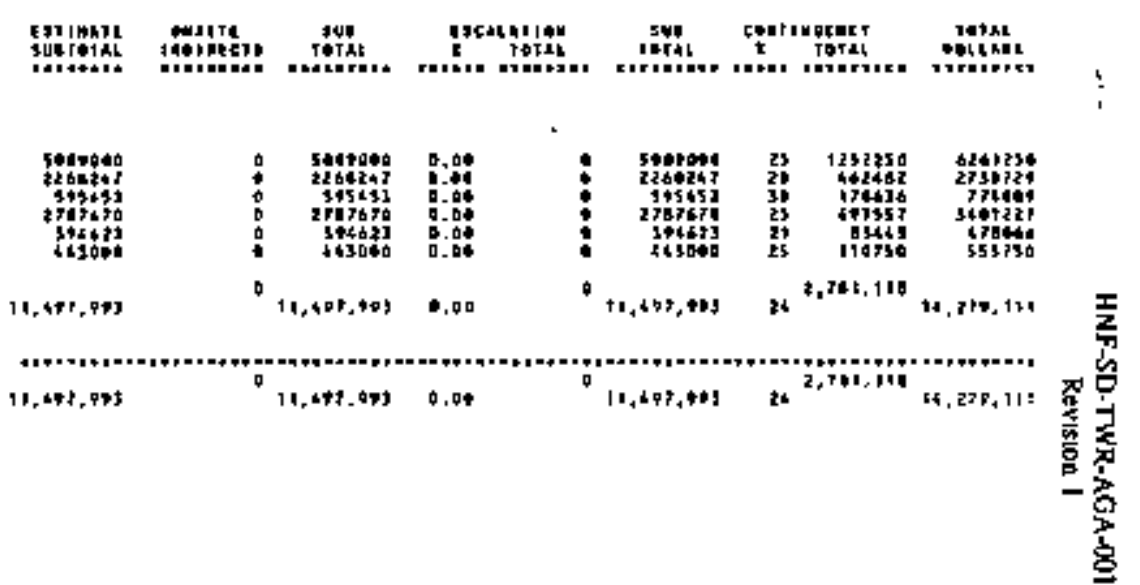




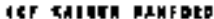

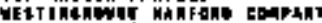

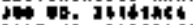

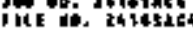

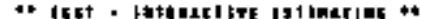

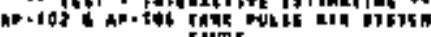

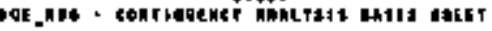

Th\$s ot $40+149196$

Merenz

PADE as or

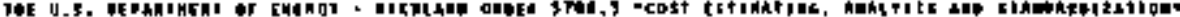

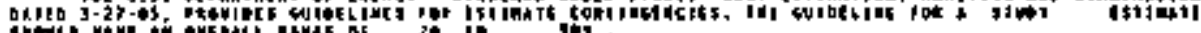

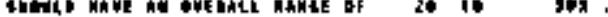

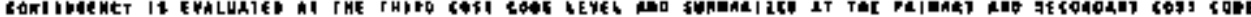

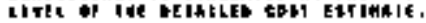

空

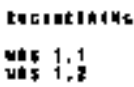

vats.t.

vestistion top

14: 2.5

int 1

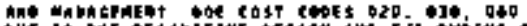

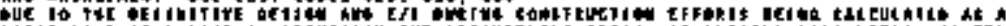

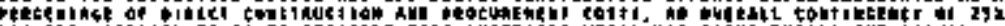

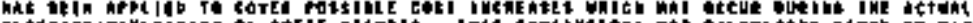

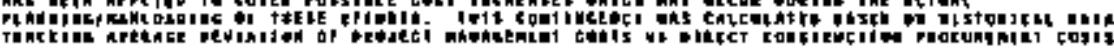

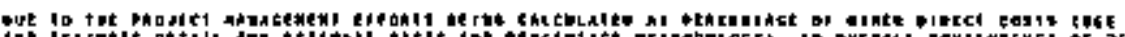

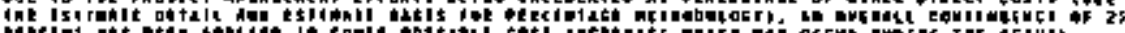

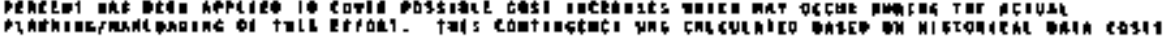

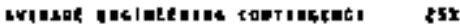

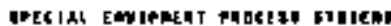

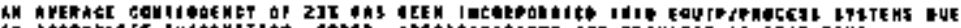

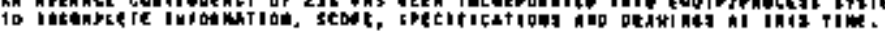




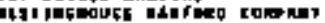

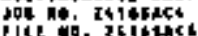

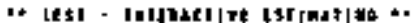

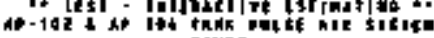
\$IVम, rast

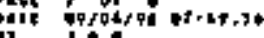

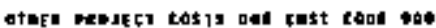

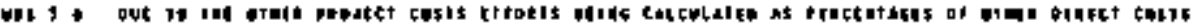

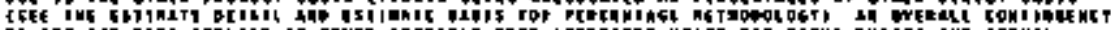

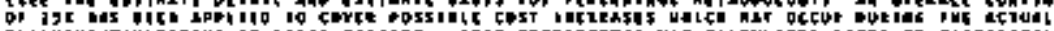

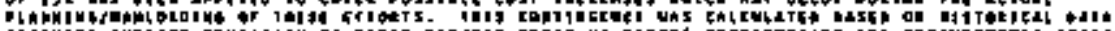

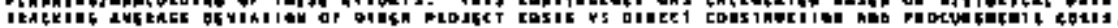

$\underset{0}{\mathrm{c}}$

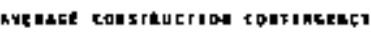

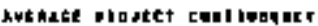

232

$3+t$ 


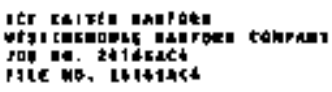

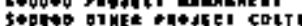

Nedes Iathe

交

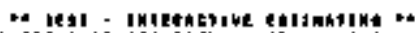

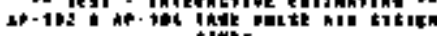

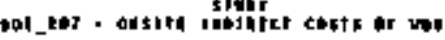

\begin{tabular}{|c|c|c|c|c|c|}
\hline 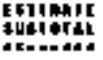 & 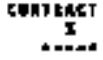 & 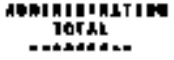 & 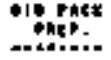 & 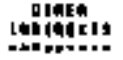 & 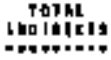 \\
\hline 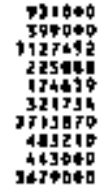 & 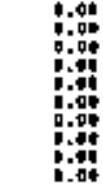 & $:$ & : & 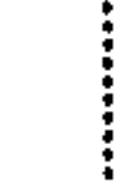 & \\
\hline
\end{tabular}

$0,21,64,041$ in 
ICF ESILEN maniodo

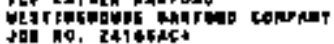

jice iso

\section{Açrene1}

autecte

reschini ian

$+4$

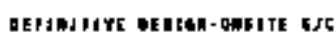

li1 in rethniest anyiets

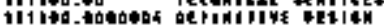

contathe Iethaseh tinylert

relas

CDEt twa crat

tercilition

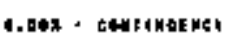

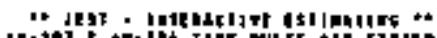

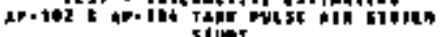

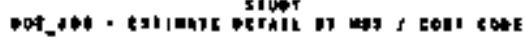

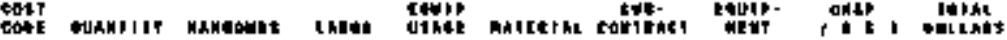

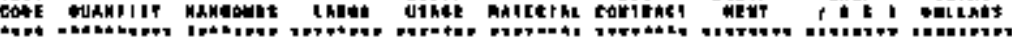

PhGE

CErmition

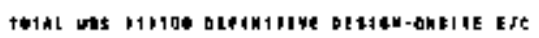

Q2*

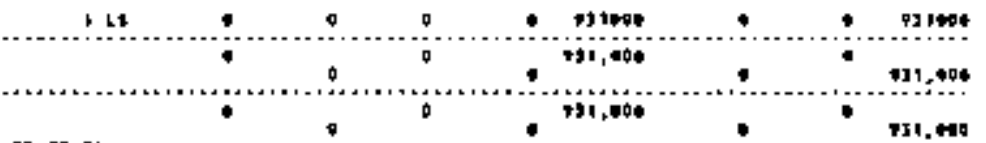

21,005

TI.40
11,04 n
ธ

then 


\section{ICt thisit Wantens

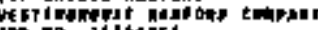 100 vo. Titithes

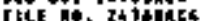

\section{nscDink \\ necinth \\ TH sceiplise}

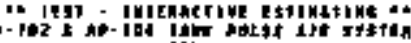

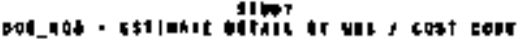

\section{CA1}

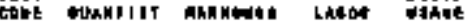

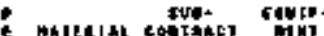

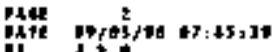

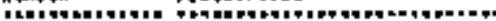

1214:4

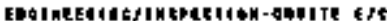

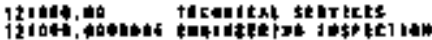

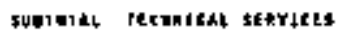

Q10

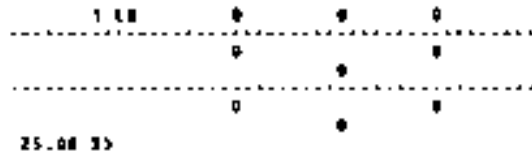
$30 \rightarrow 000$

\% s......... ini 1210 in

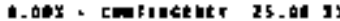
540.044

$\ldots \ldots$

.

- j+14006

\section{rap coter b3to \\ 1014} (risalitian

ist

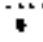

149,048

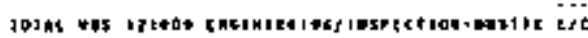

点 


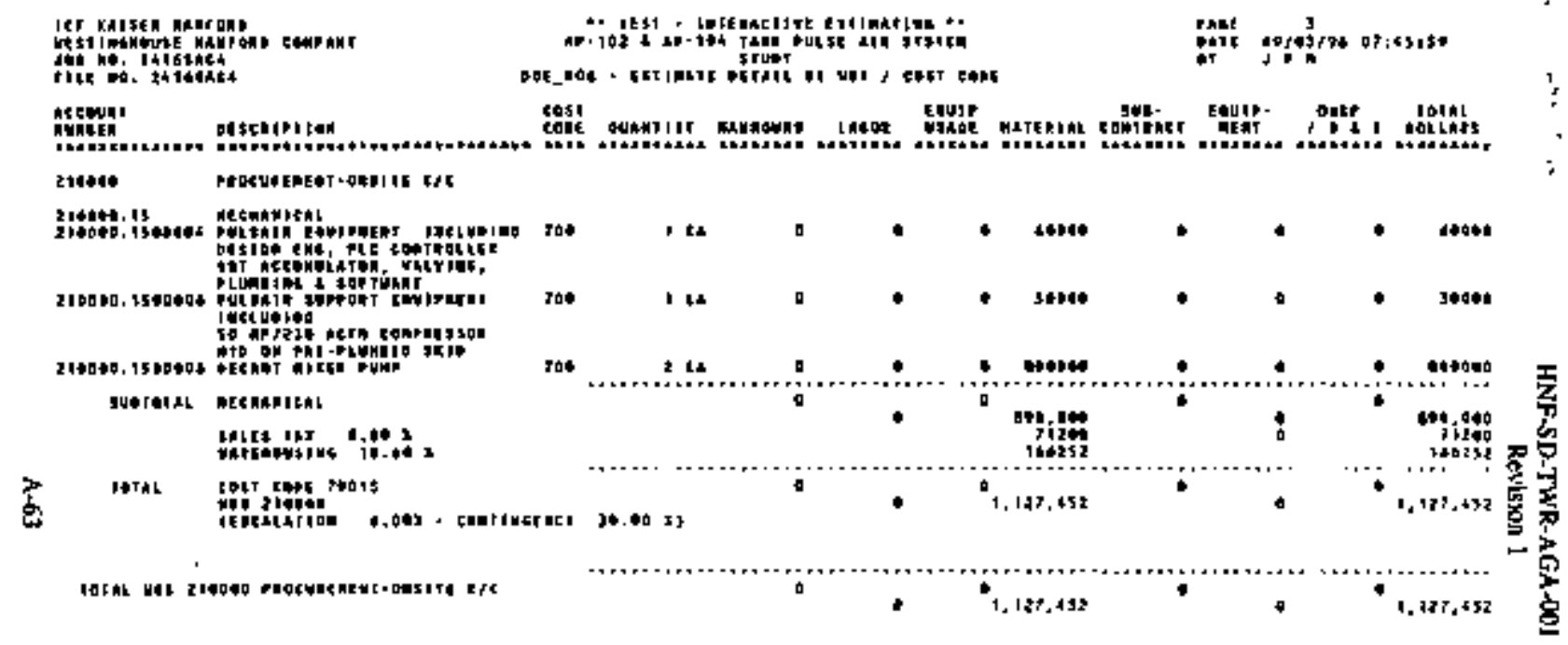




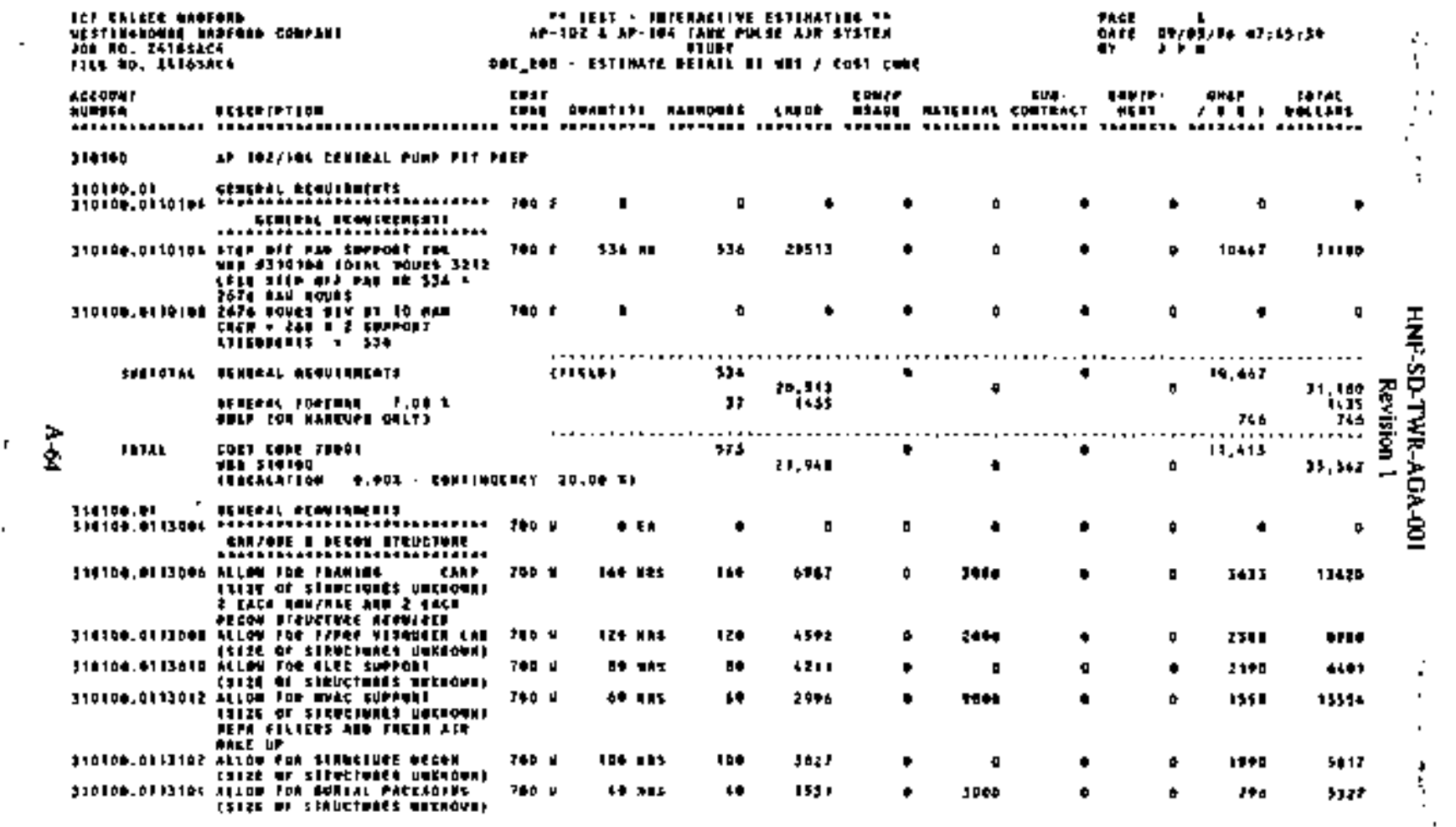


Icr lacise mayedt

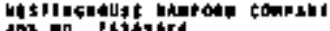

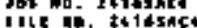

\section{uecount}

atum 6 h

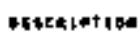

Crickiot ion

IMCL 2 ES IKGME wOS LBMEI

IELIGTHE

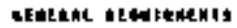

smit 40, net.

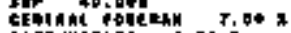

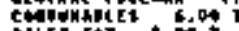

EAt IT ThP

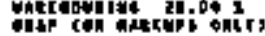

I*1

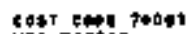

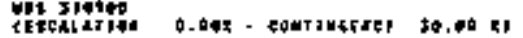

grolotiof

giging.07

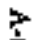

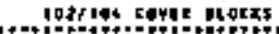

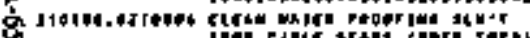

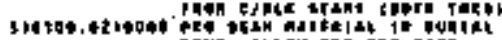

How Al cor roh anc rach

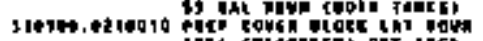

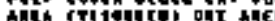
Hoir ThMe

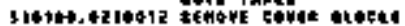

(2)

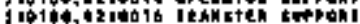

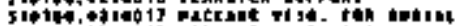

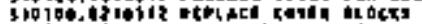

sidice.

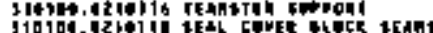

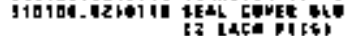

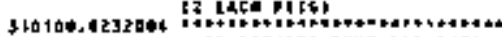

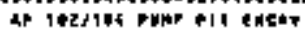

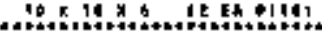

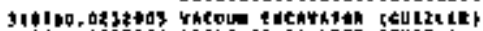

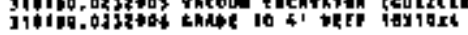

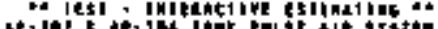

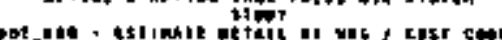

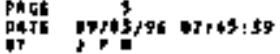

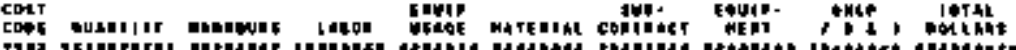

(160)

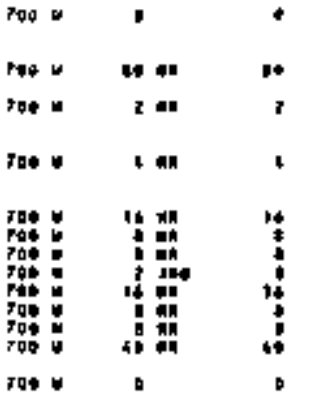

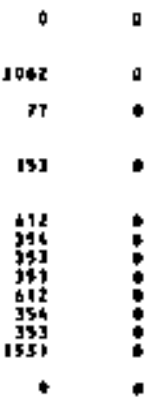

$\operatorname{rog}:$ it

1




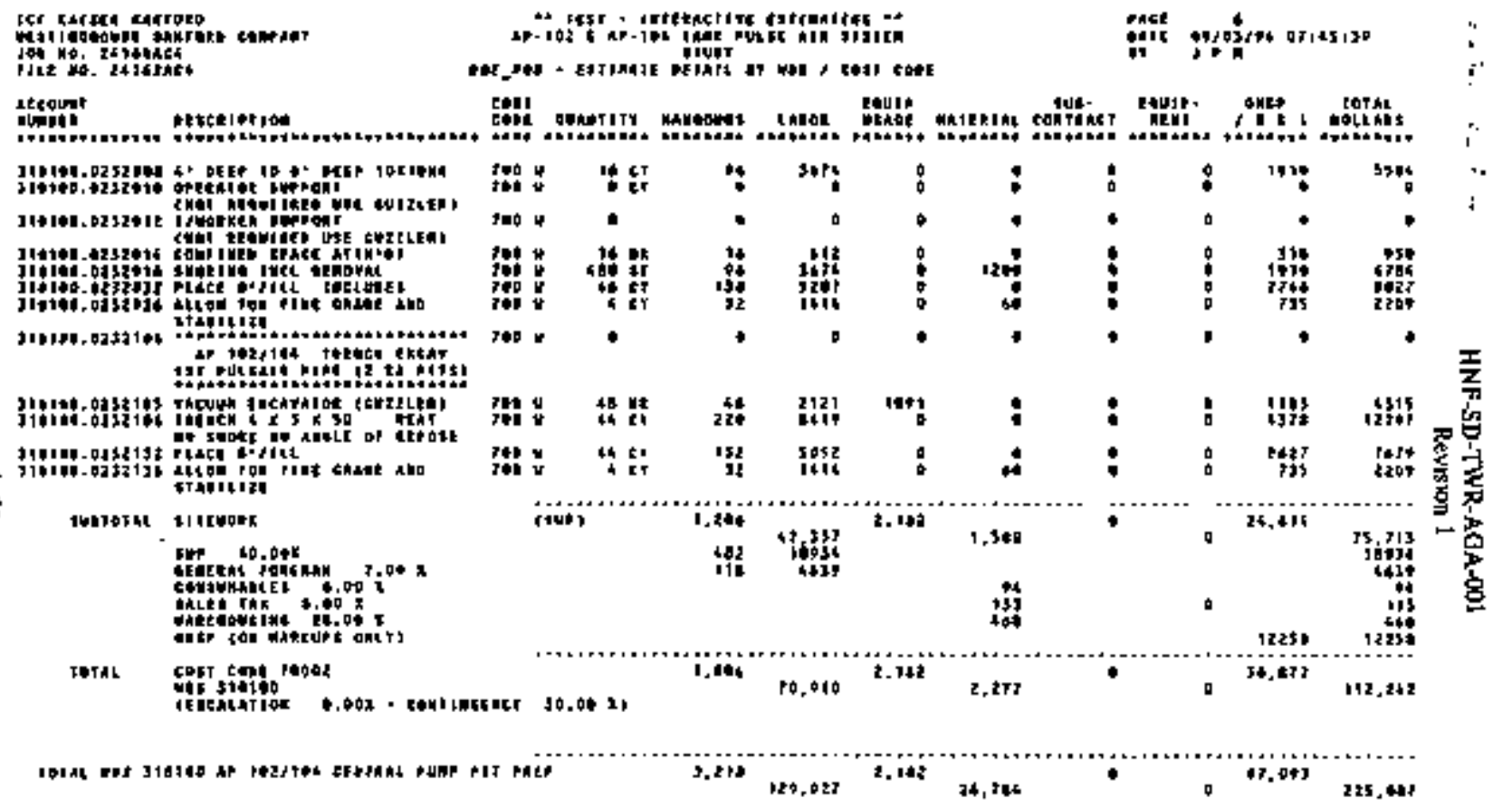




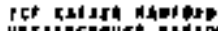

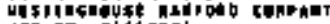

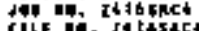

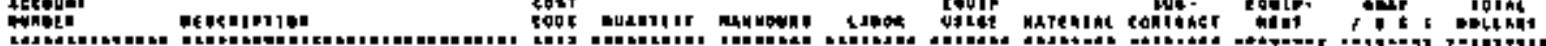

ab.102

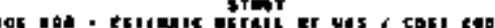

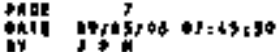

310200 ho iefriat ruç\$ nil araien

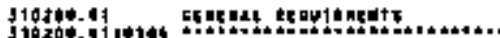

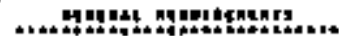

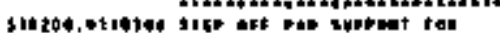

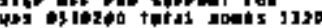

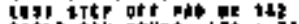

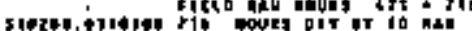

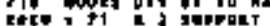

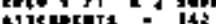

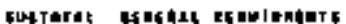

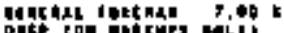

a

co51 con Ttot 1

जba Jingto

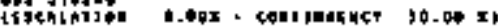

rot

rot , 162 at

$1+2$

rod

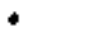

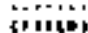

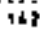

4

$+$

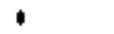

2424 1240

Jib24, 15

Ienticicts

hive

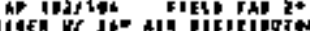

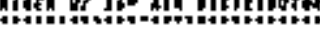

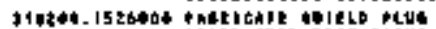

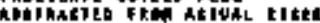

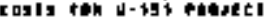

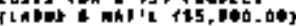

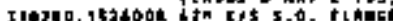

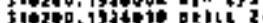
gers matrst

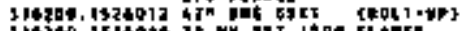

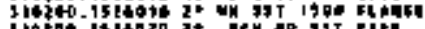

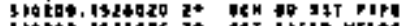

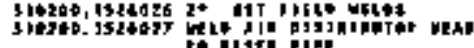

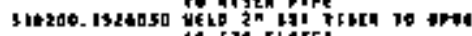
in cic ringse

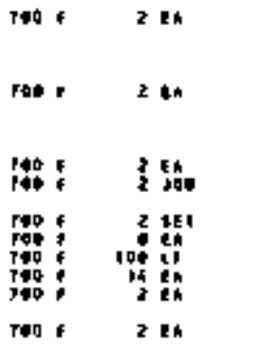

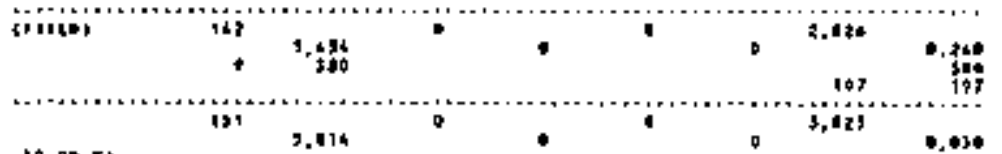

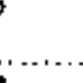

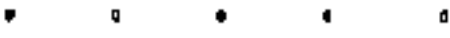

1040

$\bullet$

475

1434

$1 \mathrm{ras}$

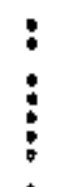

 


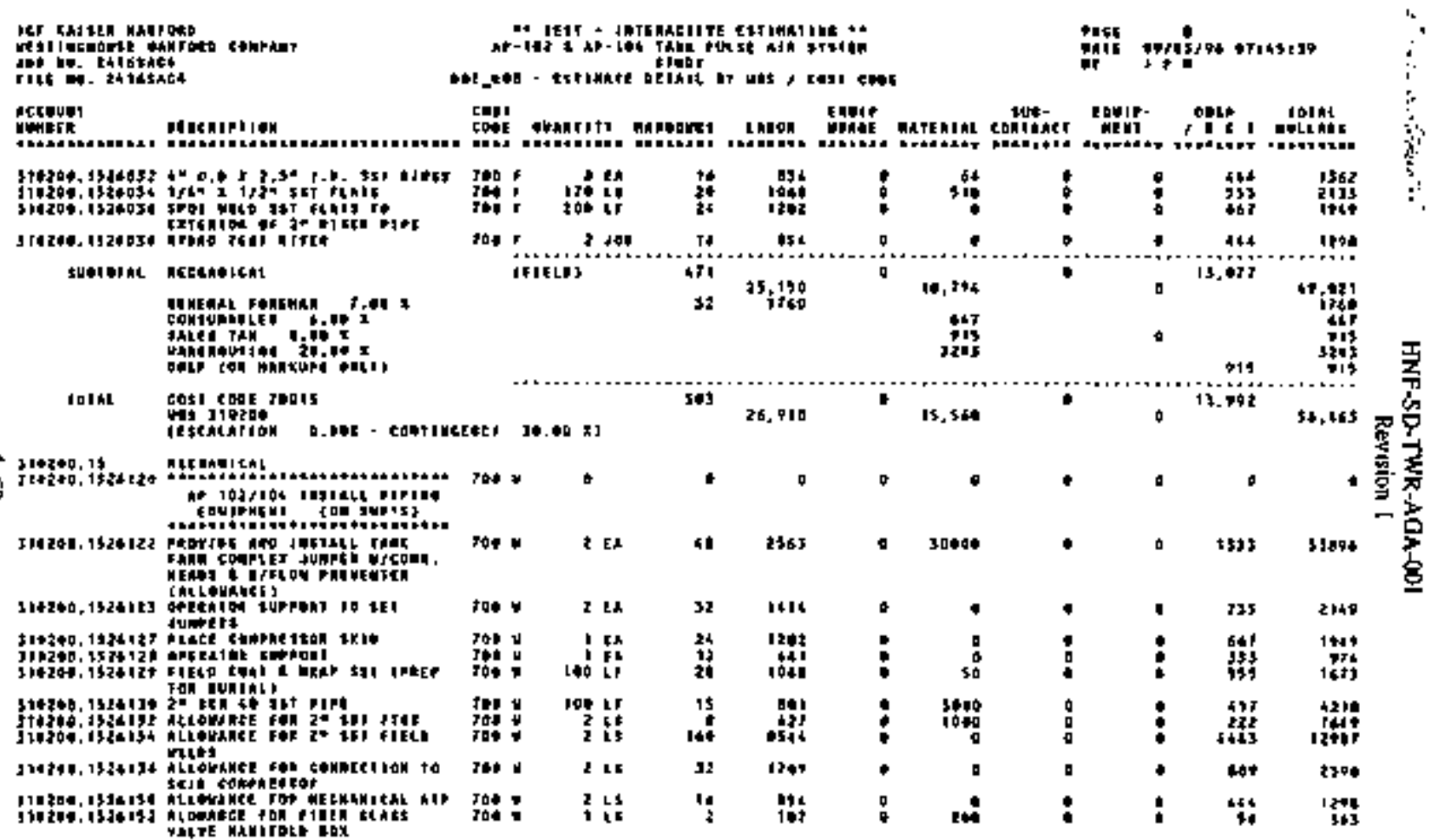




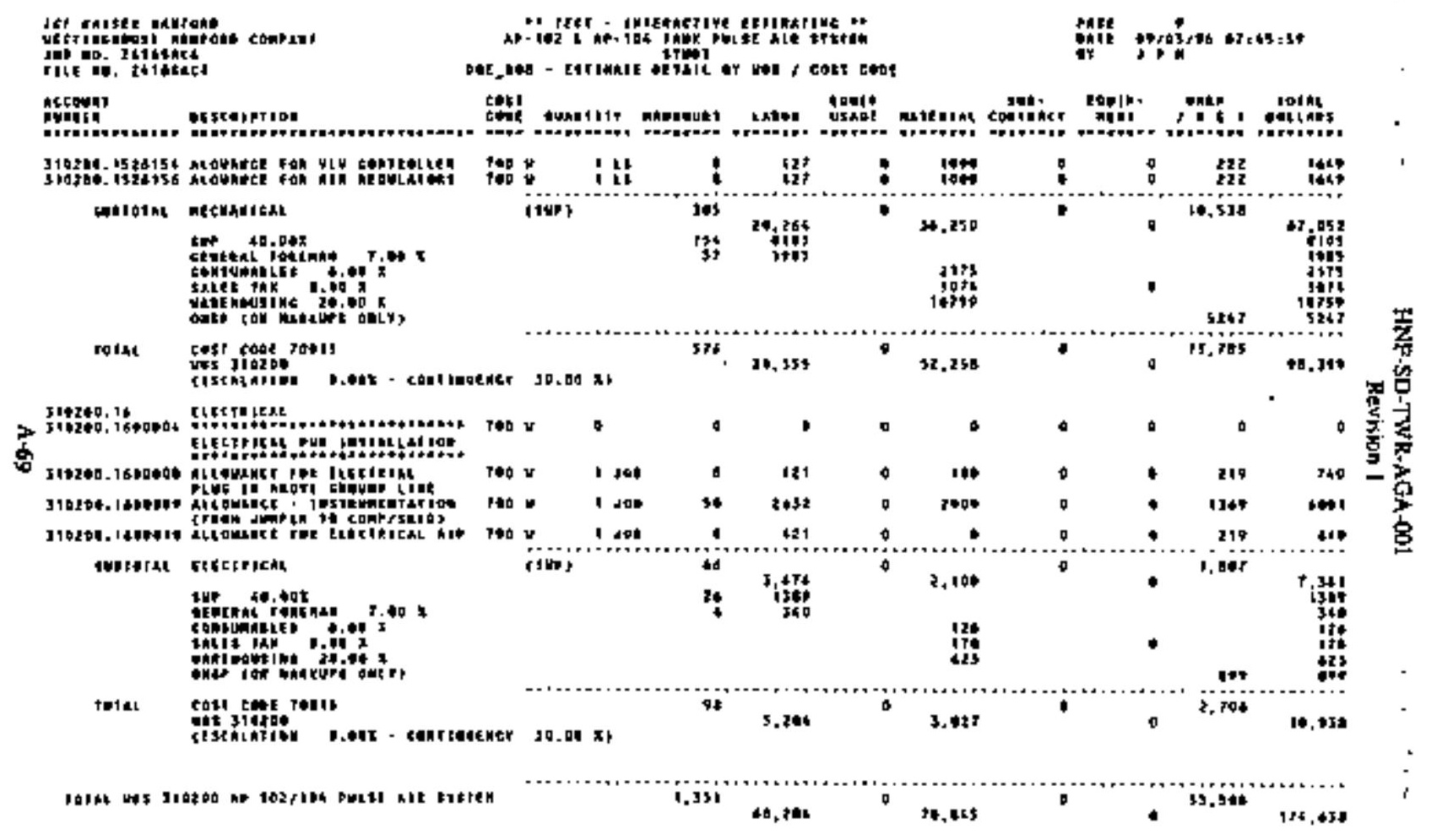




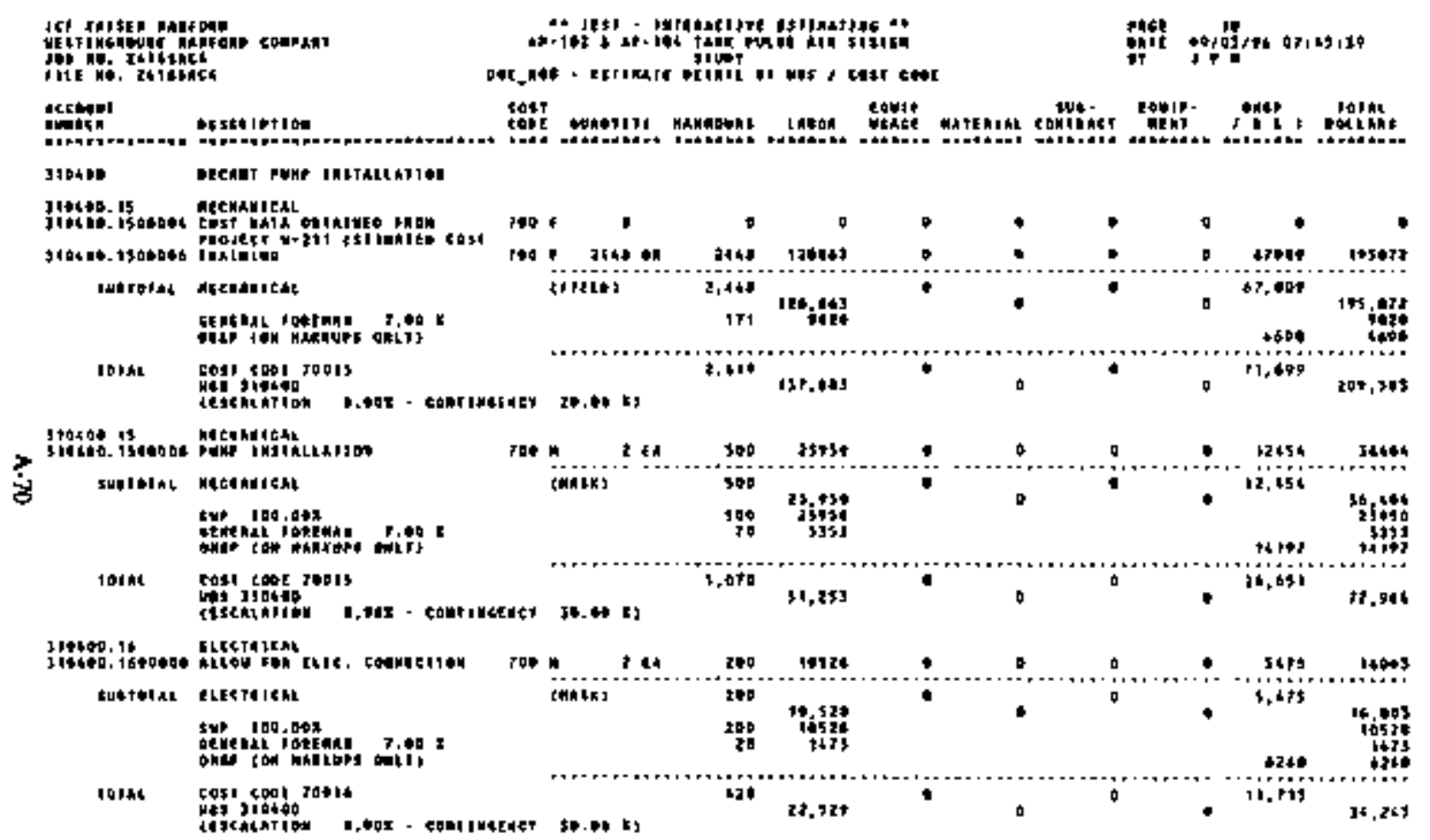




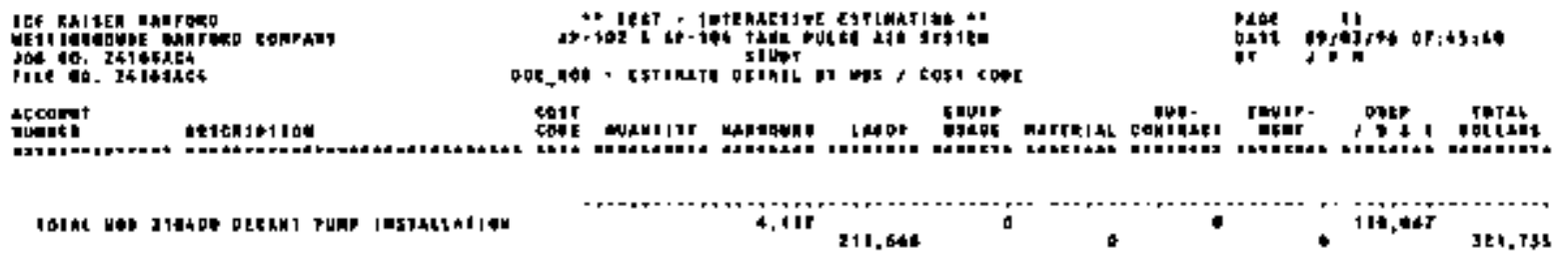




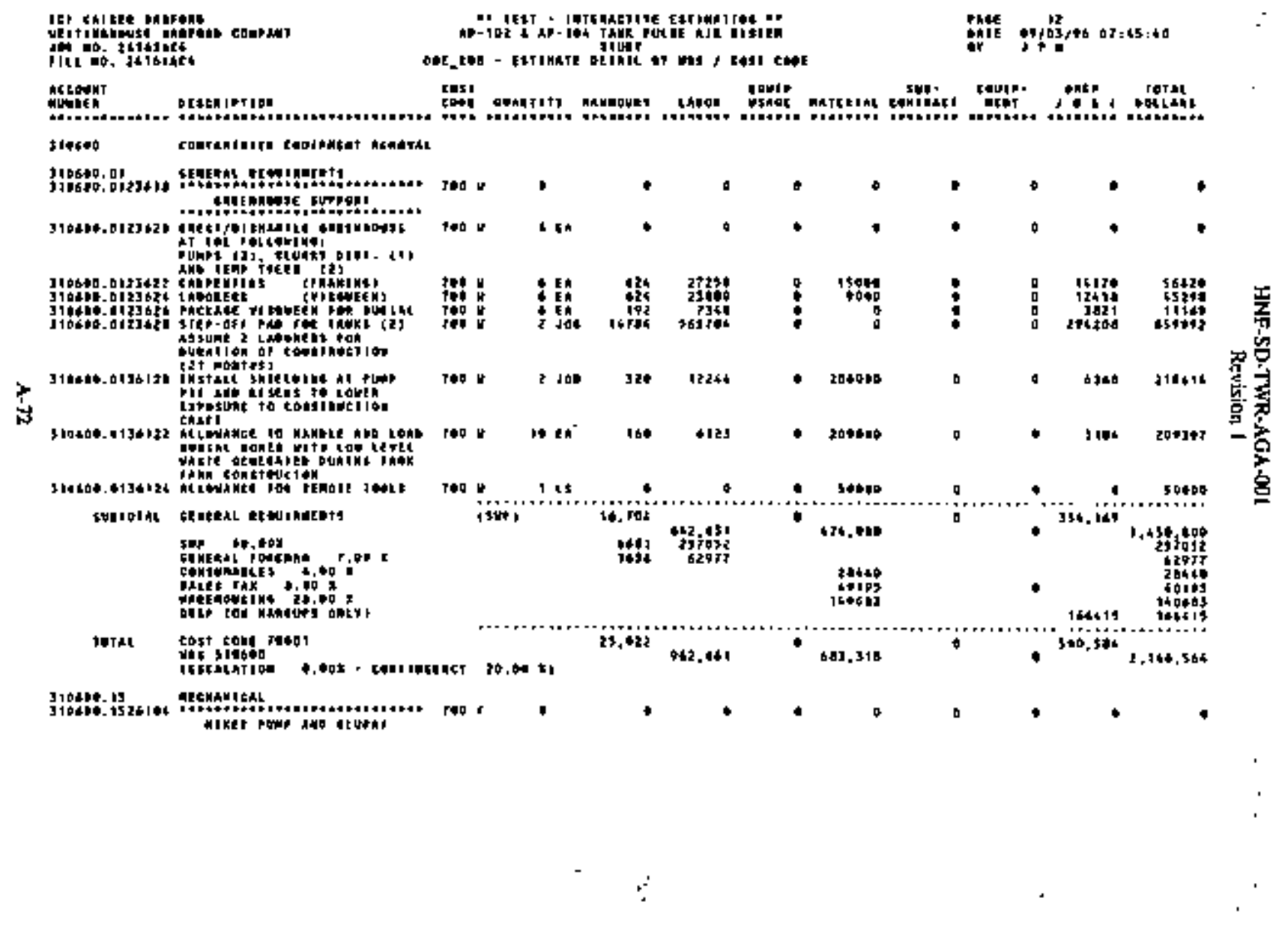




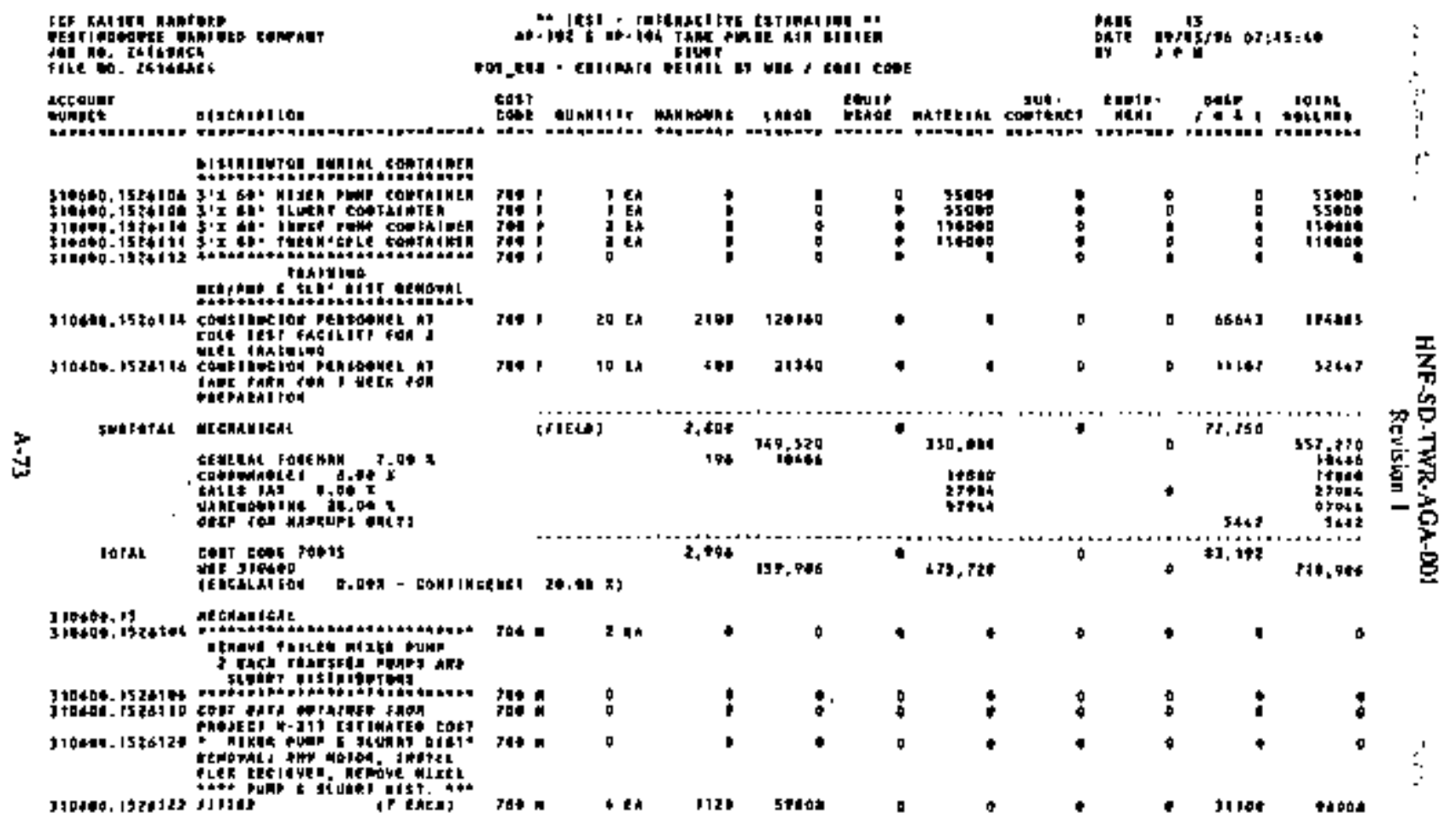




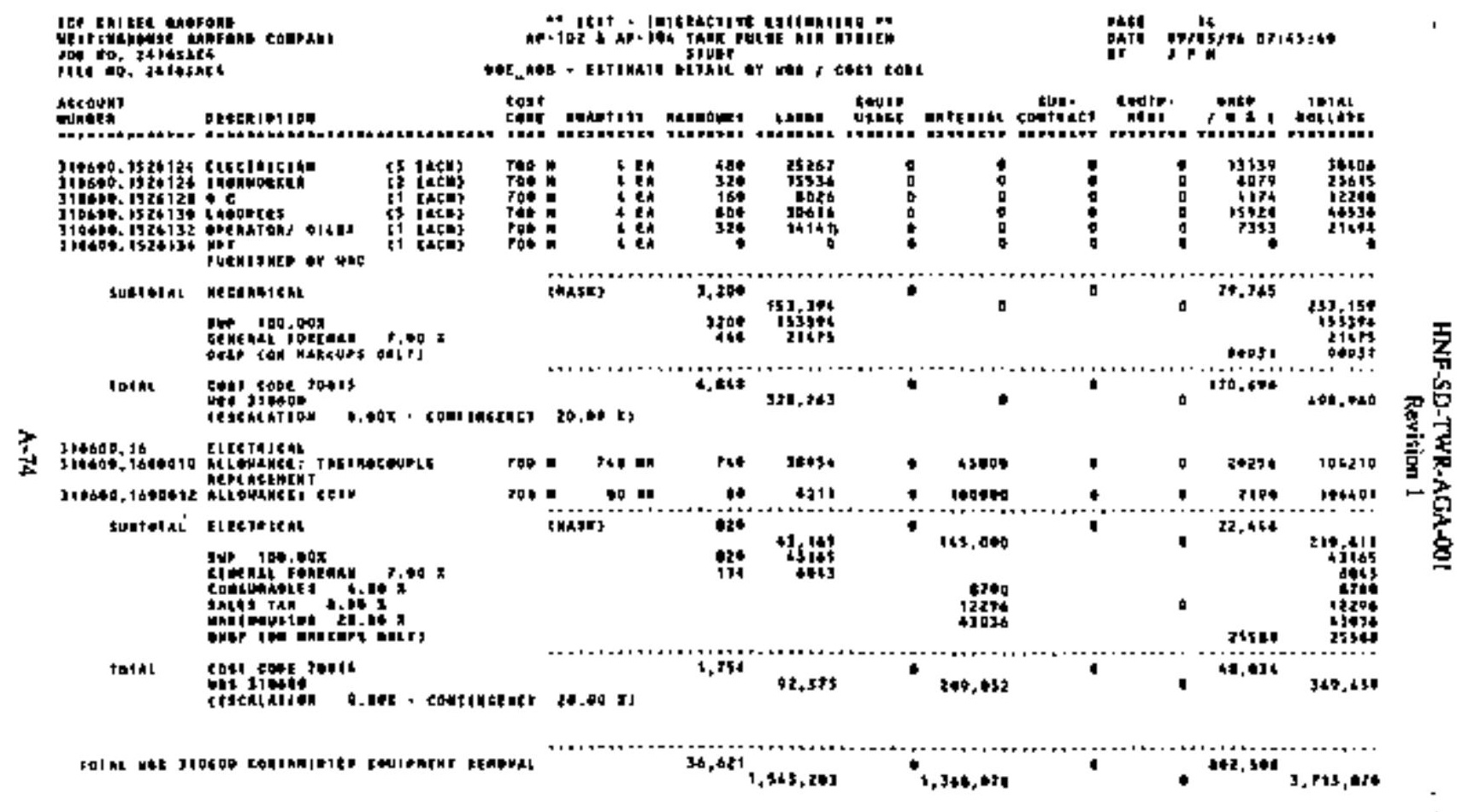




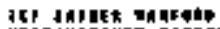

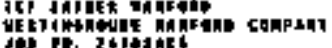

ing

ACEPuTl

Munip 5

Qtextit tot I tor

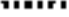
nutial ref - QRE

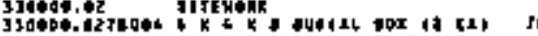

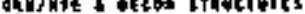

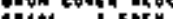

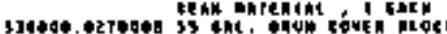

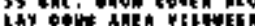

1) LAY ENEC

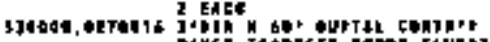
Mingh, TAM

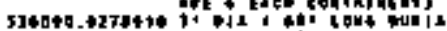

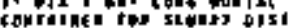

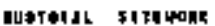

诂

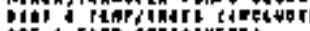

\section{So11 5005 topt}

Ca11

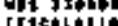

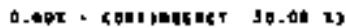

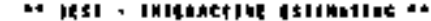

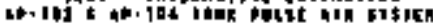

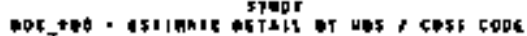

OAGE

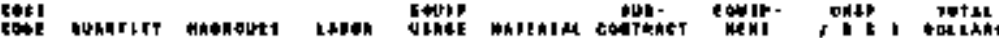

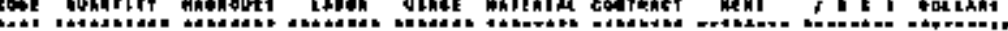

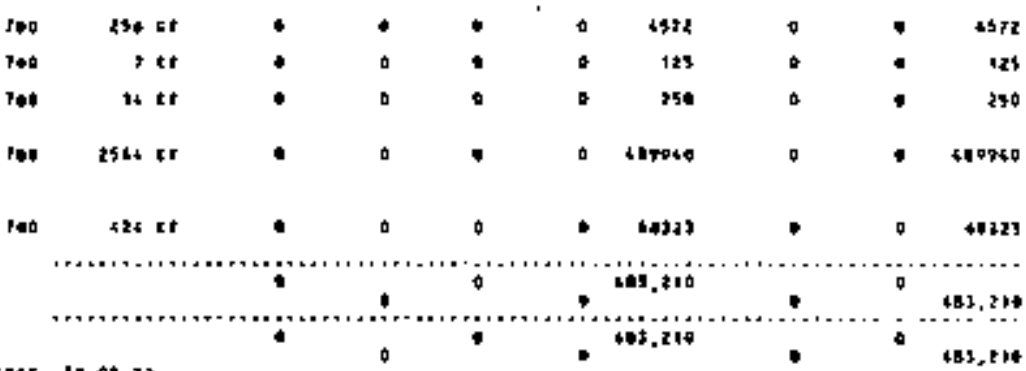

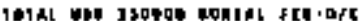

\% 


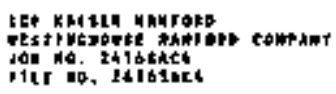

15egunt

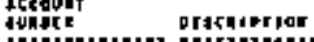

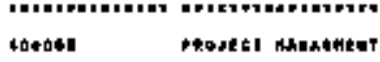

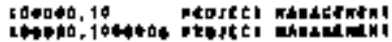

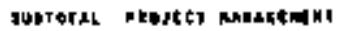

141

CQ11 chan \$4 17

erted

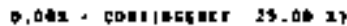

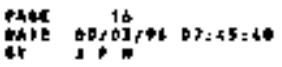

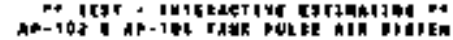

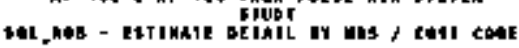

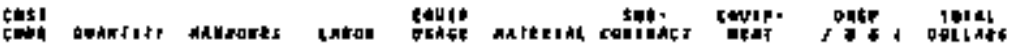

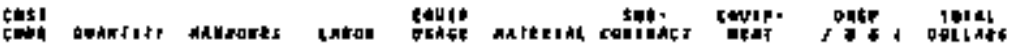

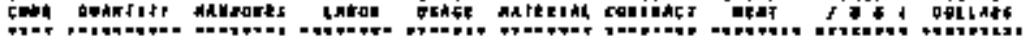

, n,

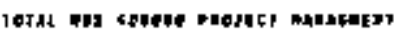

桨 


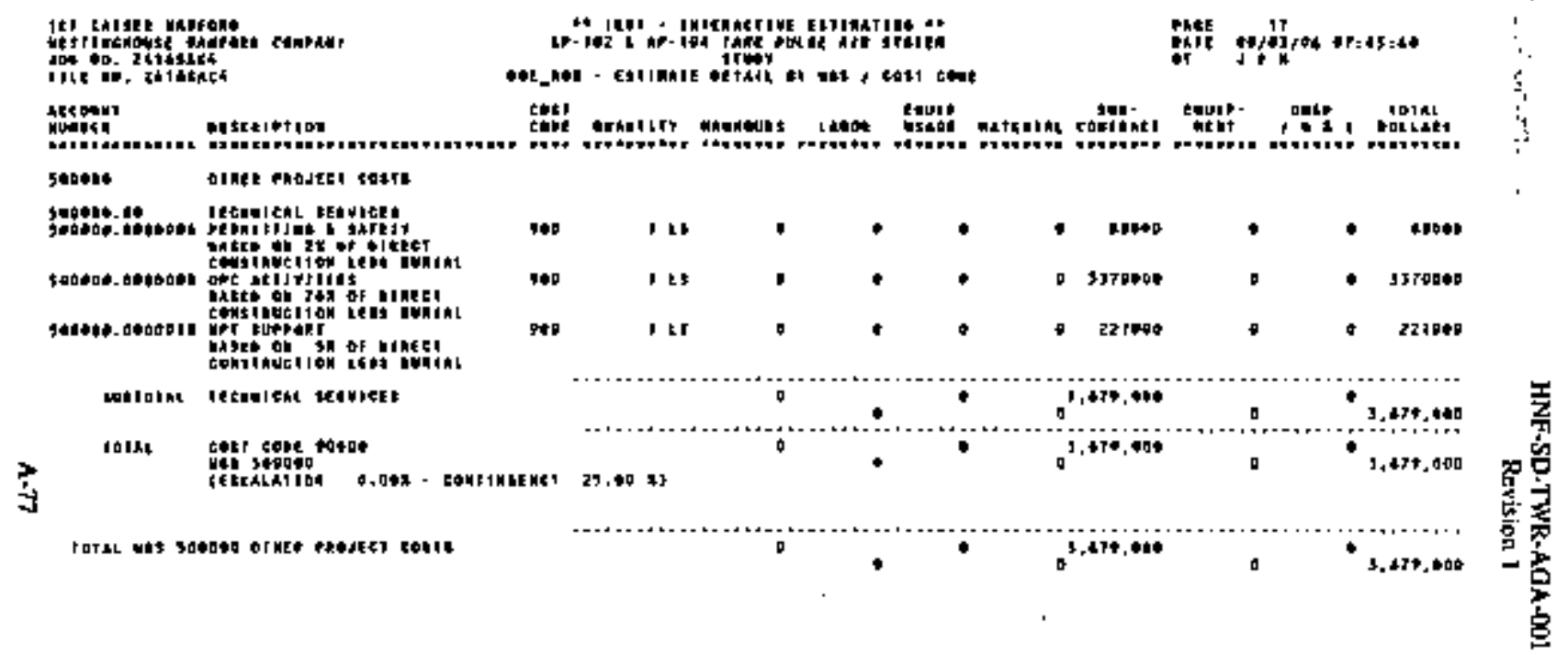


ICF AAILE Mhareht

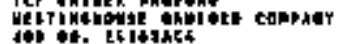

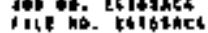

Meçauri

4⿻1日)

percestation

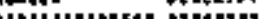

MrtakE te1k

$0,93, r+2$

$2,303,141^{3,013,210}$

$1^{3,015,177}, 1,407,1+2$

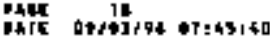

$4 \%$

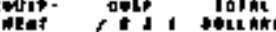

Ap-10i to

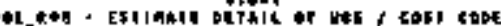

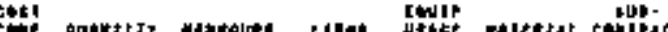

That

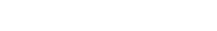

$\frac{5}{2}$ 
HNF-\$D-TWR-AGA-0OL Revision 1

\section{APPENDIX B}

\section{SAMPLING SYSTEM ALTERNATIVE GENERATION AND ANALYSIS}


HNF-SD-TWR-AGA-00]

Revisken ]

This page intentionally left blank.

B.2 
HNF-SD-TWR-AGA-001

Revison 1

APRENDLX B

SAMPLENG SYSTEM ALTERNATIVE GENLRATION AND ANALYSIS

\section{BI.0 DECISION ANALYSIS SUMMARY}

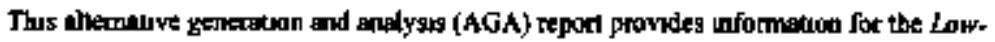
Lewt' Waste Fotd Staging Plan (Certo 1996). Thr AGA evaluates what Infragtructhere upgrades wo the intenmedrate waste feed staping tanks (IWFSTs) ate necessary or support the samping sysicm Tanks 241-AP-1 iot and 241-AP-104 have been designated as the [WFSTs (Oalbrath at al (996a)

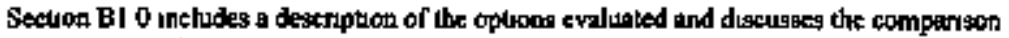
of the opions to the decision wrent Section B2 0 deliris the problem statement, and

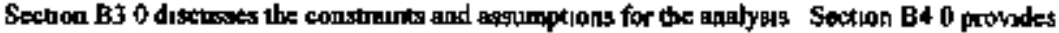
the detaled analyss of the options, and Section B5 0 provides the documbent references

\section{BI.I STATEMTNT OF THE PROBLEM}

What type of garopling systew should be used in the IWFSTs to support the staging of lowacuvity wask (LAW) for Phape I pnvalzation?

\section{B] 2 DECISION ISSUES}

\section{B1.3.1 Open lanwes}

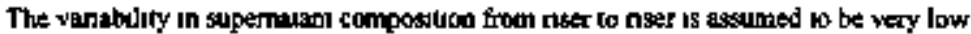
(below analytucal arror) For thes reason and becaluse of the cost of multaple samplung locations, tatch sampkes frow each I WFST will be taken fixm a sungle riter

The aumber of samples required is based on a nomnal estanate of 2 percend solids For the

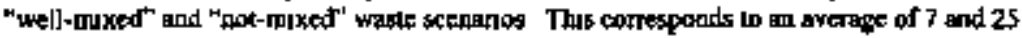

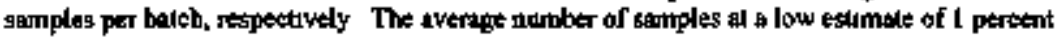
solits for the "well-gixed" waste scedano also was seven Bowever, the average number of

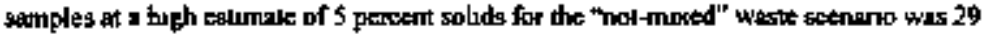

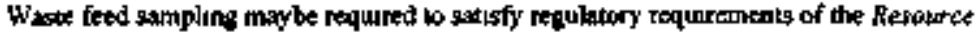
Conservation and hecrwery Act of 1976 (RCRA), the Entrionmental Protection Ageney (EPA), and the Weshiagion Depariment or Eootogy Present regulations roquire all wasles to be 
sampled and analyzed with tatuchely low dotection kevels. To achieve the mathdoled detection

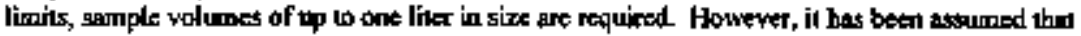
the levges somple requined from the JWFSTs will be 100 mil. If the one ling sample size is required, the results of this AGA may be inaxcurare.

\section{B1.2.2 soper}

The objective of the Phaso I privatization is to deliver LAW and high-level wagds (HLW)

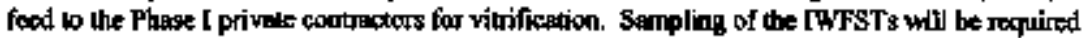

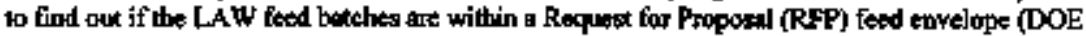
1995). This ripont addresses the eampling requirements for the IWFSTs and the upprades requiked to suppoct verious sampling system options.

\section{B1.3 DESCRIPTKN OF OPTIONS CONSIORRED}

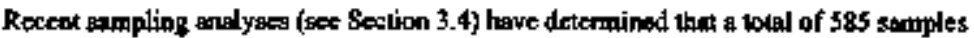
nould be recpufied for the "not-mixed" waste scentrio. This is based on a nominal extimate of 2 petcenl solids and corresponds to an ayerage or 25 samples per buch. For the "well-mixed" wagte scenario, a tolol of IS1 samples would be roppired at the nominal extimate of 2 percent

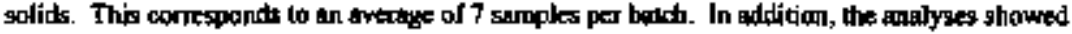

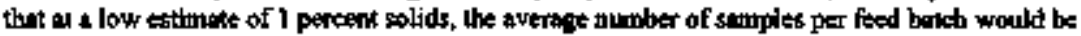
7 for the "well-mixed" waste scenario. The high witumate of 5 percenl solids corresponded to an average of 29 smples per batth for the "not-mixed" waste scengrio. The ample size is asgumed

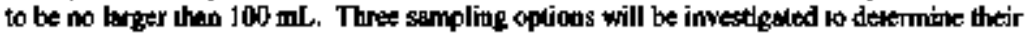
adequacy in meeting the sampling roquirements stented.

\section{B13.1 Option 1 - Grab Swepler or "Betile-01-1-Strin:"}

The current method of stinplias stpernotand in the DSTs is the gob sampler or "Battle-an-

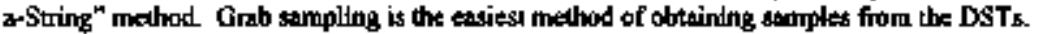
The system comprises a batile, siopor, weight and wipe rope. Two types of boltles are used: (1) a wide douth (125 mL) botde for sampling bo visposity sludpes and (2) a antow mouth ( $120 \mathrm{~mL}$ ) bottle for liquids (WHC 1946c). The stmple bottle wembly it altown in Figure B1-1. Priparallow for obdaining a sample involves prestriaging the bottle and its rubber stopper with the approptite lengths of wime rope. This sampliag method ang obitain samples within $13 \mathrm{~cm}$ (5 in.) of the bottom of the tank. A plove bae or odhe contuinmend structure to place over the designated sample riser on the tank. The sample pis (Carktrom 1995) is placed ingide the contiaes of the glowe bag. 
Figure BI-1. Grab Sample Bottle Assembly.

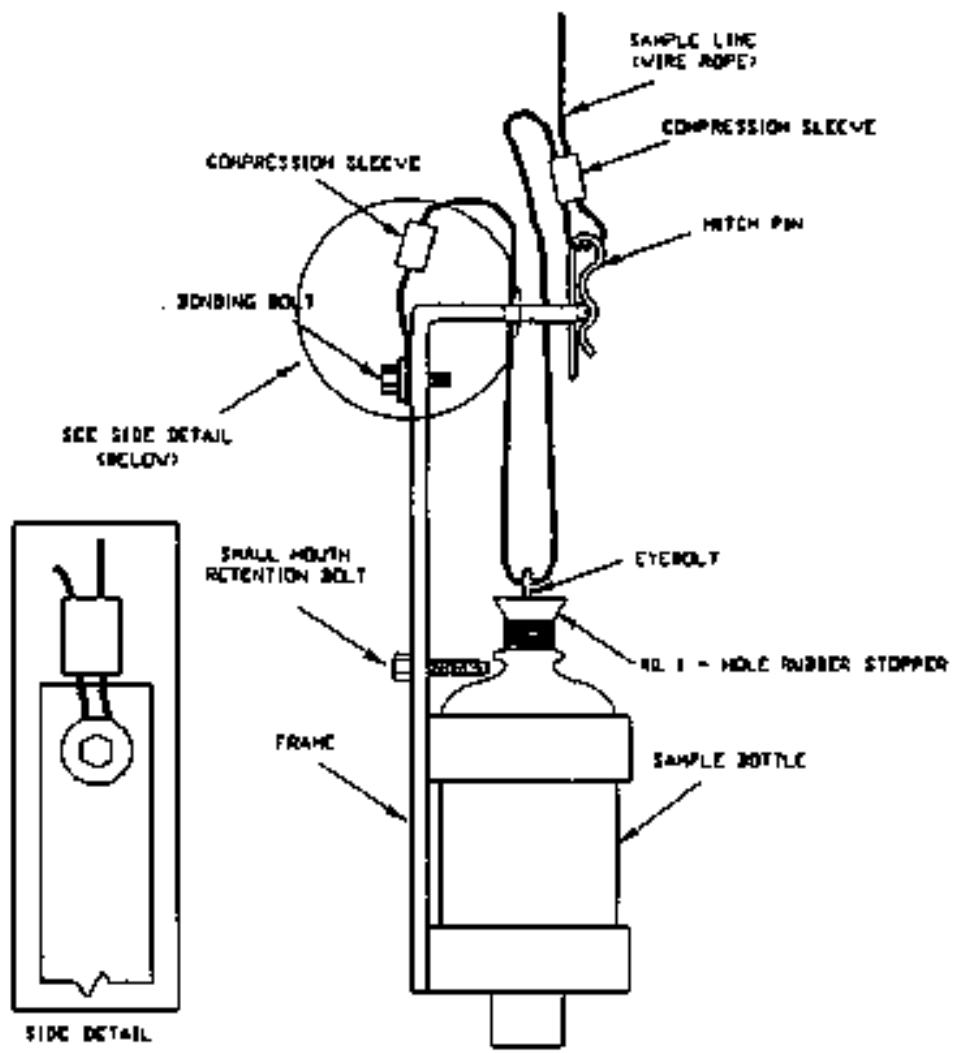


To obtan the sample, the cover is femoved firoth the nser The sample bottie va the sampler carner is lowered to the approprave depth and held for several seconds Then the rubber stopper is removed by jerking on its wire rope The botle is allowed sufficnetl tutie to fill, and then is pulfed back to the upper portion of the nocr The bolle is ralsed $\mathrm{k}$ grade level, bul not remryed from the nser The nabber stopper is removed and deposect of appropratoly After sunvey ing the sample to dekermane extremily dose nues and contact radiethon readings, the sample botule is capped onth the screw-on lid [1 ts then kowered a stoct distance down mo the

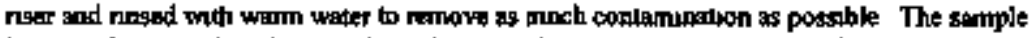

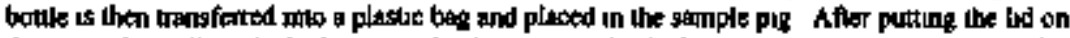

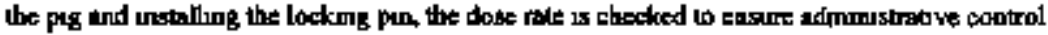
limits asedected wrth handing and transporing the pig are not exceeded The tiser cover is then reingtalled on the nser and approprate bousekeepung completed restonng the tank farm to narmal optrotronal comition

Fart of the sompler induced bag for the grab sampler anc as follows

- Matenal collected in the burte may be contamminted by malenal from adjacent elevations the io the novement of the sampler when the stopper or cork ts removed

- Simples collected ine thol cutrently lemperilure controlled (except freeze protection) ufter remowal from the tank

\section{B1332 Optina 2 + Care Suppter}

A spectally desand and equppet core sampling truck is currently used to obtoun samples

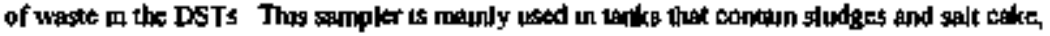

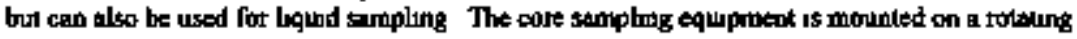
plations on the corse samping inuck The core sampling trock is shown in Figure B1-2 The

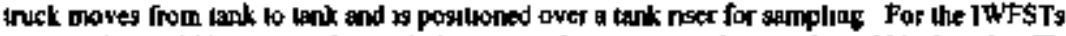
the gampler could be mounted on 1 skad or a complete sore semplunt truck could be bougha This analysis will debufy the cost of a new sampling truck separaie from the cost to perform the feed batch stroples

The maxumum volume for thes sempler is $300 \mathrm{mll}$ for lequids and semples can be obeaned withn $75 \mathrm{~cm}$ ( $3 \mathrm{~m}$ ) of the bottom of the tank The core sampling truck is equipped wrth many

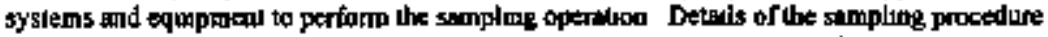

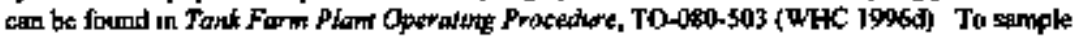

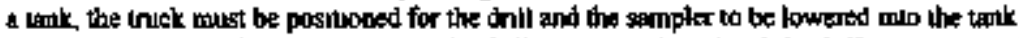
penetration A samples is inserted into the dnil stinng core burjel and the drill strute is atrached to the cort barret The dill sting is lowered into the tank and additional sectrons of dinll string

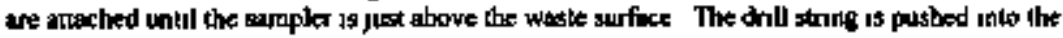
waste to obram the sample 
Figure Bt-2. Coke Sampling Truek.

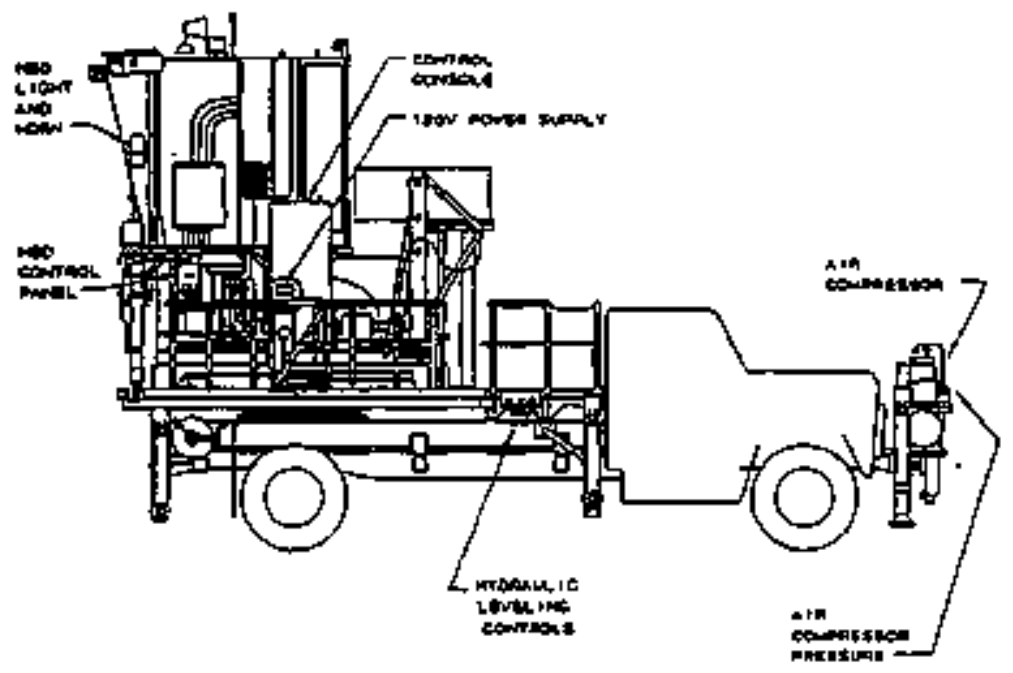


The dnil sting is detached from the drill unit after the core semple is obtamed The

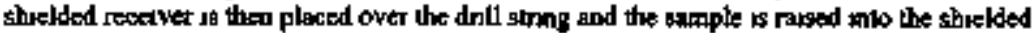

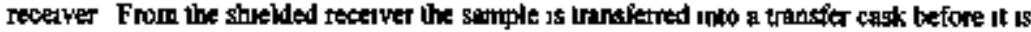
seat to a laboratory for analyses

\section{B1.3.3 Optoo 3 - Laitok Stopter}

Thes opuon uses the cancoptunl degogn done for the Grout Disposel Propran that locales a

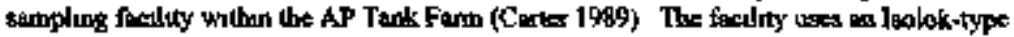
sampler syskem that en obtan representerive samples of the conilenis of any lank in the AP Tent

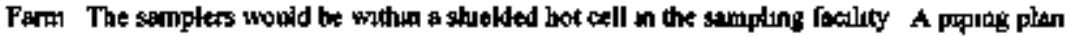
strowing the location of the samplang farcinty is shown in Figure Bl.3

The AP Tank Farm sompling facilny would consis of a vestabule, ckean disrabng and survey area, two arrocks, solked laundry slorage, supply stonge, soled disrobung and survey

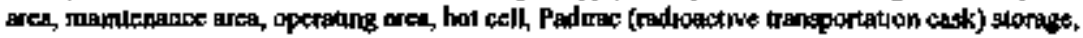

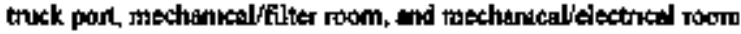

\section{HIA DECISION CRITERA}

Decusion crterta consists or informalion used ko distingash preference among the options

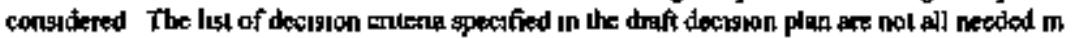

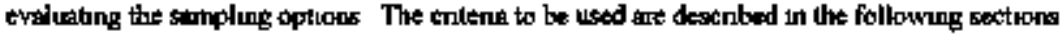

\section{BuA.I Cent}

The systems will be evaluated with respect to developmental costs, project espital costs, operahng costs. and dopposal cosis.

\section{B1.4.2 Schedole}

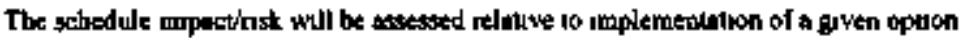
The DOE has developed a pletunng schedule with the glart date of June I, 2002 for the operatuans of Phase I facilnues and feed staging wall begin Oclober l, 2000 (Ceria 1996) 
Figute B1-3 Groux Samping Fuclity

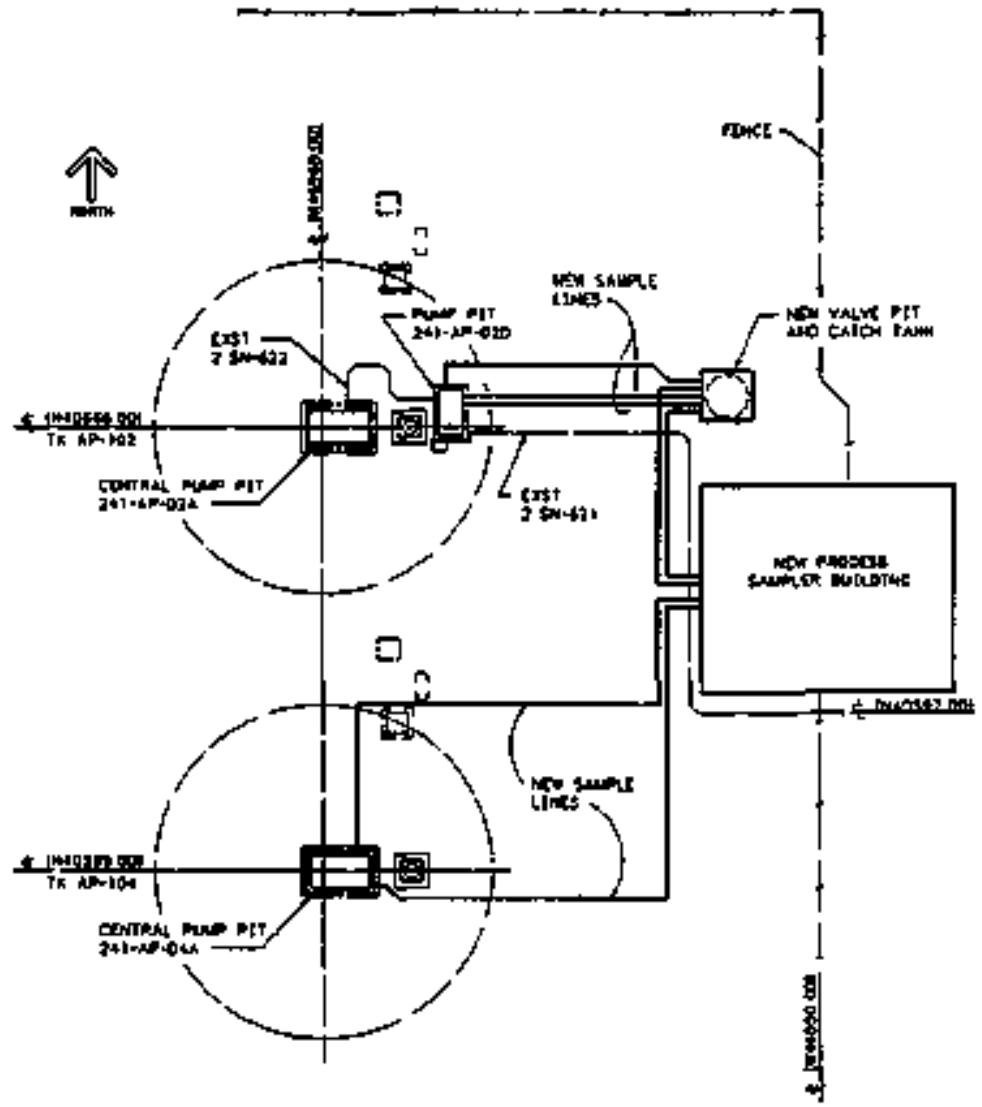

PLAN 


\section{B1.43 Maindaimability}

The maintansbility of a system will be ascessed by evaluatang the complexity, reluability, and reparability of the associated equpenenl and components Complexuly will add ress any trumng requirements for operation pertonnel, the need for epechil kols or procedures, and.

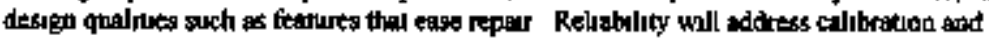

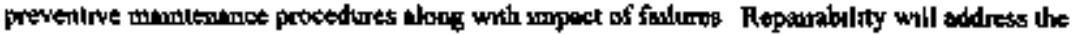
lexation of the equipment, the means of reparr, and the nurbter and type of personel requered to support ropars

\section{B1.4.4 Testand Maturity}

The lechuical maturity of the syytera will be assegsed as to welher the system has been applied at the Henford Sine or comenercul indugtry, and of the sysiem has been lested experimentslly by beteh scale experments

\section{B1.4.5 Performanca Regulirementa}

The saraplang gystem must be able io perform the followyng (Certe 1996)

- Insure thal the wastr composhon mest envelope requirements

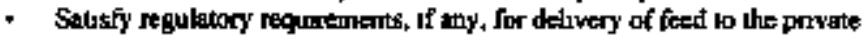
contractors

- Sahrfy the opapitmp specticalion diocument (WHC I996a) and waste

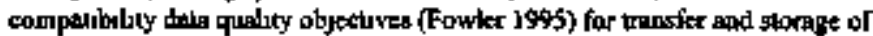
waste in the ГWFSTs

- Establish the oflickal compositjon of the waste for astessing the private comtrattor's performance

- Establish the quantity of sodium deliveted to the privale corrotactor

The tume needed to obtan camples and deljuer them ko the laboratory should raquire to

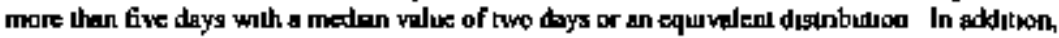

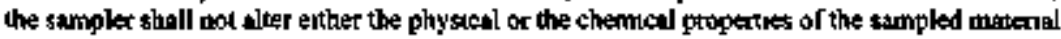

\section{B1.S OFTION EVALUATION}

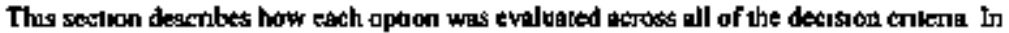

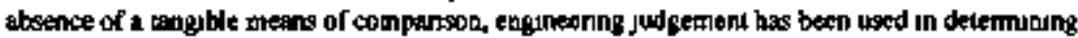
haw well a cntenon has been mel by the optrons The inalyseg of the thexe tamplang system opuons have beta summanzed in a tabuler form in Table BL-I

The cosi estmates are provided in Section Bo of The operaing costs for the grib and core

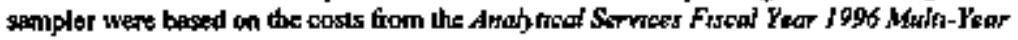




\section{HNF-SD-TWR-AGA-001 \\ Revision I}

Propran Plow (Spahr 199S) The ICF Kaser Egaimaing Department developed a sampling

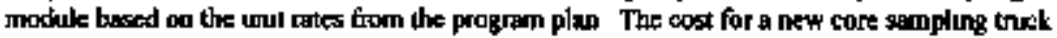
was based on Fiseol Year (FY) 1994 and FYI995 cost for Trucks 2, 3, and 4 (Prekett I996) The cost for the [solok sampler was besed on the cost from the Grou Drsposal Progritm sonceptual design repont [Carta 1989) wrth on escalatuon factor of $25 \%$ for curent dollars

The arab Samples, Optron I, is the dominand opton Opinon 1 mocts all of the centerna 501 for the eampinge system In addition, the cost of Option I is approximately 57,000,000 lese than the next lowrog opluon

Table BI-I Matrix of Sempling System Opions by Docisson Cinteria

\begin{tabular}{|c|c|c|c|}
\hline \multirow[b]{2}{*}{ Dectsyom Gatoma } & \multicolumn{3}{|c|}{ Option } \\
\hline & $\begin{array}{c}\text { Option } 1 \\
\text { Grab Sampler" }\end{array}$ & $\begin{array}{c}\text { Optoon } 2 \\
\text { "Cote Sampler" }\end{array}$ & $\begin{array}{c}\text { Ophon } \$ \\
\text { "Lbolok Sampler" }\end{array}$ \\
\hline $\begin{array}{l}\operatorname{Cos}{ }^{n} \\
\text { "Well-muxed" } \\
\text { ("Nol-mix:d") }\end{array}$ & $\begin{array}{c}53,860,000 \\
(\$ 9,840,000)\end{array}$ & $\begin{array}{c}\$ 12,670,000 \\
(\$ 18,540,000) \\
\text { Note } \$ 57 \$ M \text { of thus } \\
\text { is for a flew cone } \\
\text { sampling unck/skıd }\end{array}$ & $\begin{array}{l}\$ 12,970,000 \\
(\$ 16,900,000) \\
\text { Whet This is based on } \\
\text { wh estingte in FY } 1988 \\
\text { with } 25 \text { percent } \\
\text { escalation }\end{array}$ \\
\hline Schedule & 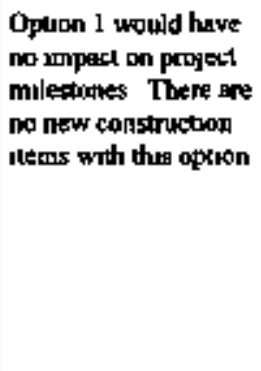 & 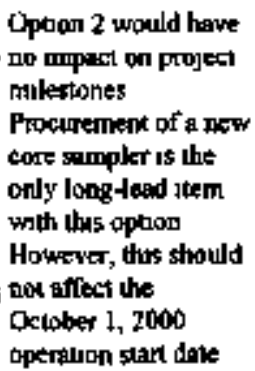 & 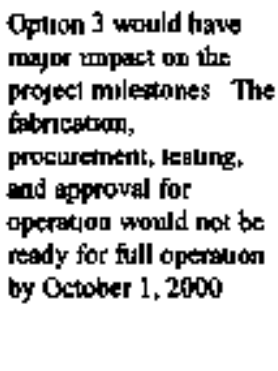 \\
\hline
\end{tabular}


Table B l-1 Manx of Samphng System Optons by Decusion Cinterta

\begin{tabular}{|c|c|c|c|}
\hline \multirow[b]{2}{*}{ Deçıыon cnicna } & \multicolumn{3}{|c|}{ Opune } \\
\hline & $\begin{array}{c}\text { Opton I } \\
\text { "Grab Swapler" }\end{array}$ & $\begin{array}{c}\text { Optuon } 2 \\
\text { "Coce Sampler" }\end{array}$ & $\begin{array}{c}\text { Optron 3 } \\
\text { "Tsolok Sampler" }\end{array}$ \\
\hline Maimlannabylity & 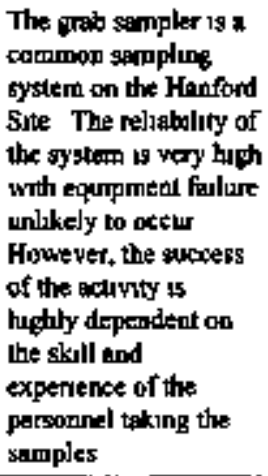 & 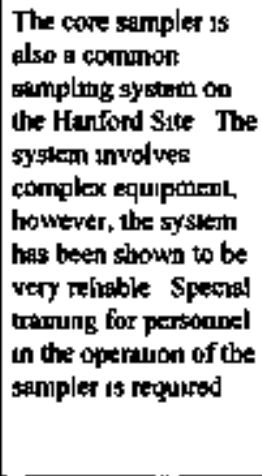 & Same $x$ Optran 2 \\
\hline $\begin{array}{l}\text { Techarkal } \\
\text { molurity }\end{array}$ & $\begin{array}{l}\text { Opion I has been } \\
\text { effectively appired at } \\
\text { the Hemfond Sile }\end{array}$ & Same ag Opın I & Same op Option I \\
\hline $\begin{array}{l}\text { Performunce } \\
\text { requrements }\end{array}$ & 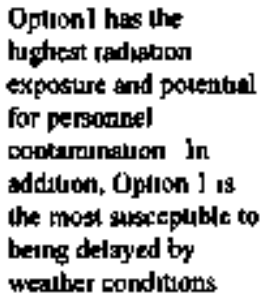 & 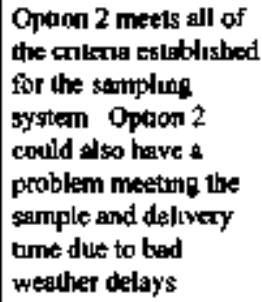 & 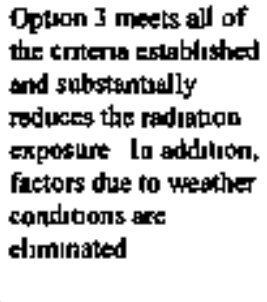 \\
\hline
\end{tabular}

The costs wo tased on the average number of samples at the romunal estumake of 2 percenl golıds Iabit B4-] prowdes the cost breakdowns for capptal, operatung, and anglysis 


\section{HNF-SD-TWR-AGA-OOL}

Revisition I

\section{B20 PROBLEM STATEMENT}

The objective of this AOA report is to detentine the best option for sampliag the IWFSTs The I'WFSTs will deliwer LAW foed to the privatization contrastors' staging lants. A statighical confhmetion of the feed bakh's chemical and physteal characierissics will be neated to support

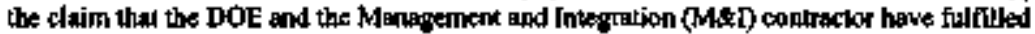

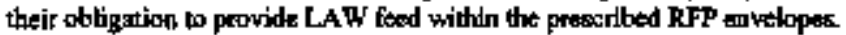

Thís AOA will iavestigate oplions for the sampling of the IWFSTg and doternine the moditicrtions required to install these sygtoms. Previous analysis and work op gampling systems will be used to sereen options and a preferred option will te sedected. The criteria for detamianting the best optious will be based primarily on coss and texhnical maturity of the sampling system. 


\section{HNP-SD-TWR-AGA-0OL}

Revision I

Thís page intentionally left bomk 
Revision 1

\section{B3.0 CONSTRAINTS AND ASSUMTTIONS}

The JWFST sampling system would be constidined pan of the Siare Managed Tank Wasts Function 42 I I (WHC 1996) Ths includes the moblizalion/stospartson of tank waste golids, mon chemical adjutrotents, and un-tank blendung and foed staping

The performance requiremeats denlified in Function 42 I that pertan to the samphng 5ysken are as follows

- Estunited YWRS Project Schedule The gampling systen must suppost the TWRS project schedule Proof-of-concepd aperailuons will be from bene 2002 through hane 2007 with DOE's option to extend processung through bune $20 \mathrm{~L} 1$

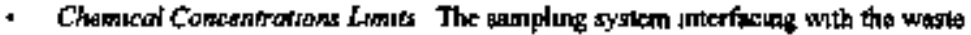
sources must be capable of handling waste with the chencel conctentrations specified in OSD-T-151-0LOA7 (WHC 1996a)

- Tank Duwe Sratac Luadug The wetghic of any portoon of the sampling system instalied on a tank nes will be limiled by the stakic dome looding design Imis ppeefied in OSD-T-15i-00007 (WTHC 19964)

- Tant Ventitation System - Pressture The samplang system wil not ovet- or underpressunze the tanks tased on the lumits specified in DSD-T-ISI-00007 (WHC. 1996a)

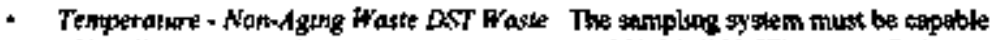

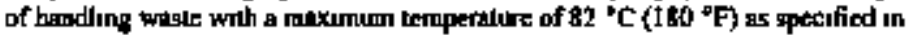
WHC-SD-WM-OSR-016, LCO 322 (WHC 1996)

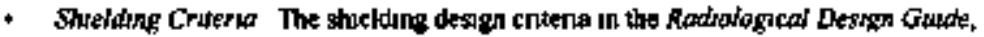

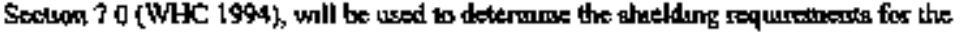
samplong system Shiding shail be designed to limit the tolal whole body dage to less thin 5 answ pet year

\section{B3.1 CONSTRAINTS}

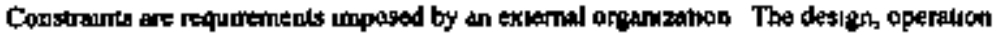
and mantenance of the IWFST samphig syaden are affected by stati and fodaral regulatronch, agreements, DOE Orders, and WHC requirments In wdhlion, there tre purdelines and apecificauont that set forth engineenng requirenuenls docmed necessary for safe destgn and

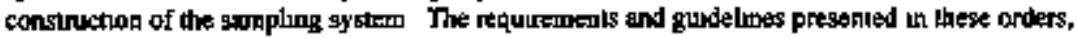




\section{HNF-SD-TWR-AOA-001}

Revison $]$

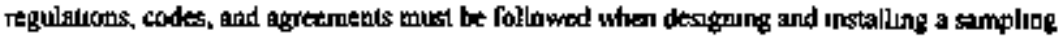
system The formal below establashes a heratchy into the listed docinents to be used danng defimtive the deppn stape of the IWFST upgrades

- DOE Orda 5480 23, Matural Phemowema Hasards Mtrigation

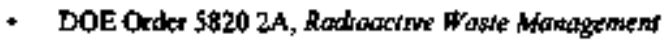

- DOE Deder 6430 1A, Genenof Desigh Crirernor

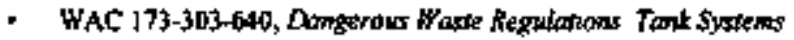

- WHC-IP-1043, WHC: Uccuparional ALARA Progrant

- WHC-SD-GN-DCS-30011، Radrolagcar Design Gende

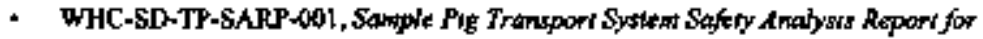
Pactaging (Ohrike)

- WHC-SD-WM-SARR-031, Syfory Amatyrrs for Pusts and Rorary kode Core Samping

- WHC-CM-2-14, Respontibitures and Procedure for all Hazardous Materat Shypuerts

- WTHC-CM-4-46, Safety Classuficatrom of Structures \$ystems and Camponenss

- ASME B3l 3, Process Ponnd

Other design constraints on the samphing sysem are as folkows

- The gystem must be able to abtinn the requrrod samples through tomk-top ngers wilh duatinters of benwer 10 and $30 \mathrm{~cm}$ (4 and $12 \mathrm{kh}$ nominal)

- Retrueved samples ind associated hardwat must fit in the exusting Hanford Site bot cell fochlines 


\section{HNF-SD-TWR-AOA-001}

Revision I

\section{B3.2 ASSUMPTIONS}

The following assumptions have been modt in the malysis of the IWFST sampling system options:

- Botch samples will be laken from a single riser on each IWFST. This is because the variability in supemant composition is assumod w be very kow.

- The pumber of simples nequited is based on a nominal estimate of 2 percent solids for the "well-mixed" and "not-mixed" wuse scentanios. This comesponds io an average of 7 and 25 samples per banch, respectively. The average number of sampdest at a low cotimate of I percert solids for the "well-plixed" wrase sceantio also was seven. However, the avenge titmber of agmples a a high estimate of 5 percent solids for the "nol-mbed" waste scenario was 29.

- The sample dize is ausumed to be so larger than $100 \mathrm{ml}$ (See Section 3.4).

- It is usgrmed that the operaing cost for sampling the waste has hot changed significantly aince FY 1995. This allowis the use of the cost numbers from the Anatyticol Services Fiseal Yow 1996 Mviri-Year Progrwe Plan (Spahr 1995) for the gtab and pusta mode sempling.

- The exposare detrimant for the grab samplet is based an a lotal persan-rem of exposure of 0.12 per sample.

- The total exposuse detriment was dokernined vaing Equation (2) from the Couthenefit Anatysis at Westinghoure Hanfard Company (Brown 1992). 
ENF-\$D-TWR-AGA-(0)]

Revision 1

This page intemtiontally lef bork. 
HNP-SD-TWR-ACA-OOL

Revbion I

\section{BA. ANALYSIS OF OPTIONS}

This section documents the methodology used o genterte the optlous and diocungeats any options thal were anporath In addition, this section determines how wetl at option satisfies cach belection cittería.

\section{B4.I GENLRATTON OF OFTIONS}

The optlons for the sumpling system were developed by informin trainatoming and

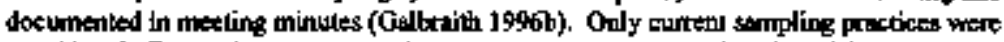
congidered. The options penerralod for the ganpling system consist of the fillowing: Grab Sampler, Core \$arnptor, and the lsokok \$antpler. A descrigion of cach option is provided in Seclion B1.3.

\section{BAI SERECNING OF OPTHONS}

The options generaled conld be initially gecreened againgt the criteria of schedule. Option 3. the Lodol Sampler, is hibhly unlikely to be able to moet the operrational start date of

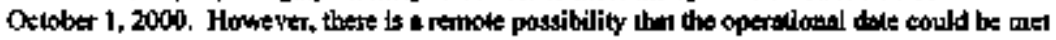
with a very apgressive schedule. Therefore, each option is evalualod against the decision criterita and no options are screctuod.

\section{B4.3 ANALYSTS OF SAMPLING OPTIONS}

The ardityses of the thre sampling oplions have beet summarized in a labular form in Table B1-1. This seclion addresses how well each option aldigfies the decigion criterion. The main driver in selecting the preferet option will be based on coul. Therefore, this acetian provides a destiled descriplion of the cost associoled with each option-

\section{B4.3.1 Cost}

Table B4-1 shows the cost breakdowns for ewch opthon. The cost estinates are provided in Section B6.0. The costs apa based on perforising ? amples per betch for the "wrill-mixed" wagte scenario for both the nominal (2 perceil solkds) and low (1 pencent solids) estimales. The costs for the "normiked" wasce scentrio are based on performing 25 and 29 soraples per batch for both the nominal (2 pervent solidy) and high (5 percenl solids) estimates, respectively. The cutrent schedule is to send 12 brichers to each contrackr for imuobilization (Certi 1996). The costs shown ane for the nominal 2 percenl solvis estimate with the cosis for the high estimalt of 5 percenl solids sown in portentheses. 
Table B4-I Cogs Sunmory of Phase I Sampling System Opunns

\begin{tabular}{|c|c|c|c|c|c|c|}
\hline \multirow[t]{2}{*}{ Cents } & \multicolumn{2}{|c|}{ 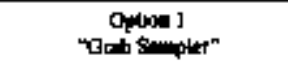 } & \multicolumn{2}{|c|}{ 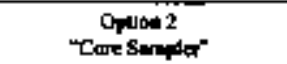 } & \multicolumn{2}{|c|}{ 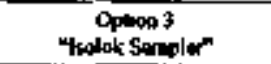 } \\
\hline & Wal-munod" & $\mathrm{Nat}=\mathrm{axpos}^{3}$ & Pretmous" & Notonimed & Welphaned" & Nath maxed \\
\hline Total enpind & \multicolumn{2}{|c|}{ so } & \multicolumn{2}{|c|}{$53,750,000$} & \multicolumn{2}{|c|}{ II $1,350,000$} \\
\hline \multicolumn{7}{|l|}{ Oparing } \\
\hline S- & \multicolumn{2}{|c|}{$\$ 1,320,000$} & \multicolumn{2}{|c|}{$\$ 1,900,000$} & \multicolumn{2}{|c|}{5600000} \\
\hline Somplme" & 5130000 & $\begin{array}{l}\$ 1,500,000 \\
(\$ 1,560,000)\end{array}$ & $1,160,000$ & $\begin{array}{c}5 s, 000,000 \\
(\$ 5,360,000)\end{array}$ & 5170,000 & $\begin{array}{c}\$ 300,000 \\
15930,000\}\end{array}$ \\
\hline Tronapontriose & $\$ 60000$ & $\begin{array}{l}5130,000 \\
(\$ 200,000)\end{array}$ & 560,000 & $\begin{array}{c}5100,000 \\
{[\$ 200,000)}\end{array}$ & 560000 & $\begin{array}{c}\$ 1 \$ 0,000 \\
1 \$ 200,000)\end{array}$ \\
\hline Exposyred & $\$ \$ 0,000$ & $\begin{array}{c}\$ 1,150,000 \\
(52,140,000)\end{array}$ & 50 & so & 跳 & 虭 \\
\hline Tosed Dptriturs: & $52,430,000$ & $\begin{array}{c}54,710,000 \\
(55,2,0,000)\end{array}$ & $55,120,000$ & $\begin{array}{c}57,000,000 \\
4 \leq 7,460,000\end{array}$ & 2990,000 & $\begin{array}{l}3540,000 \\
(2610,000)\end{array}$ \\
\hline \multicolumn{7}{|l|}{ Andyas: } \\
\hline 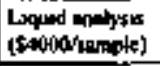 & $\$ 670,000$ & $\begin{array}{c}32,+0,000) \\
(52,+10,000)\end{array}$ & $56 \times 0,000$ & $\begin{array}{l}=, 400,000) \\
(\$ 2,790,000)\end{array}$ & \$270,000 & $\begin{array}{l}52,400,000 \\
(52,1+0,000)\end{array}$ \\
\hline 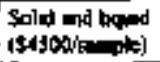 & 5760,000 & $\begin{array}{l}12,710,000 \\
(59.1+0,000)\end{array}$ & 5760,000 & $\begin{array}{c}5,710,000 \\
(53,140,000)\end{array}$ & 5760,000 & $\begin{array}{l}52,310,000 \\
(\$ 3,100,000)\end{array}$ \\
\hline 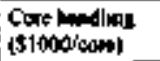 & . & v & $5] 34, \infty 00$ & $\begin{array}{c}3600,000 \\
(\$ 700,000)\end{array}$ & $\cdot$ & - \\
\hline Tolal Andysts & $51,430,000$ & $\begin{array}{c}\$ 5,1] 0,000 \\
(55,920,000)\end{array}$ & 51.6000000 & $\begin{array}{c}55,+710,000 \\
(\$ 6,620,000)\end{array}$ & 51,490000 & $\begin{array}{l}55,110,000 \\
(51,920000)\end{array}$ \\
\hline Toted Cast & $5,860,000$ & $\begin{array}{c}59,140,000 \\
(\$ 11,140,000)\end{array}$ & $512,670,000$ & $\begin{array}{c}\$ 18,140,000 \\
(\$ 14,450,000)\end{array}$ & $\$ 12.970,000$ & $\begin{array}{c}516,900,000 \\
(\$ 12,7 \$ 0,000)\end{array}$ \\
\hline
\end{tabular}

"The costs for the "wedl-raixec" waske scanaro are based on an average of stwen samples por batch The number of samples requered is the same for both the nominel estmate of 2 peareal soluts and the low estumate of I percent solids

"The costs for the "not-mixed" waste scentano are baged on an averaye of 25 sampies per

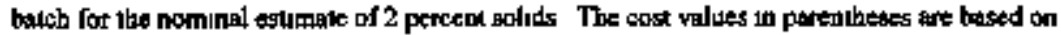
mol average of 29 smiples per balch for the hogh esimale of 5 percent solids

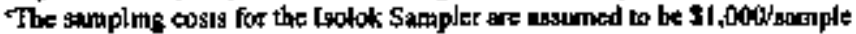

The exposure detnment for the grab samiples us based at a kotal person-rem of exposure of

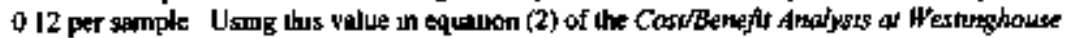
Haruord Compary, wHC-8A-1533-FP, the total deinment par grab somple is 53,080 


\section{Revisiog $]$}

The operalug costs for the grab and core sampter were based on the cost nambers fram the

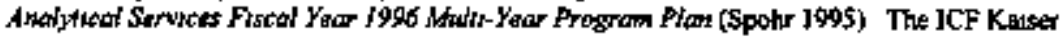
Estumiung Dopartunent developed a samplung module based on the tant rates firm the propran

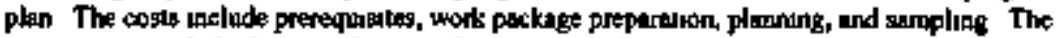

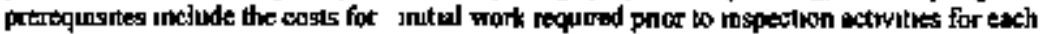

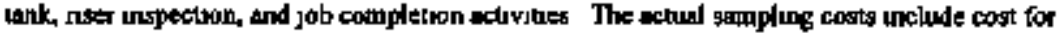
mobilizing crew and squipment, prepaning to sample, perfocming thrmpling uncluding ptacing the

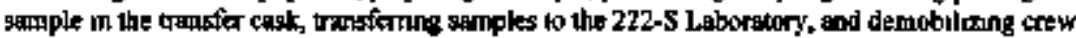
and equpareral

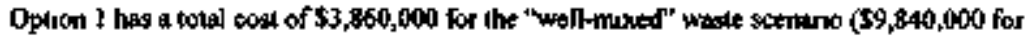

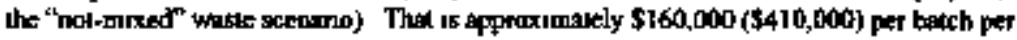
ГWFST

Optkon 2 has a total cosh of $\$ 12,679,000$ for the "woll-muxed" waste scenano (\$) $4,540.000$ for the "not-muxed" wiste scenario) Thus meludes the cost for a new eore samping truck of 35,750,000 (Pieket1 I995) The cost of the semping and atablys is approxumarely $\$ 290,000$ $(\$ 530,000)$ per batch per IWFST

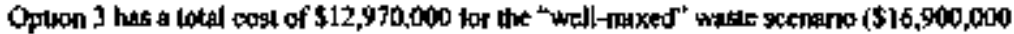
For the "noHmiked" waste scenenio) The includes \$I 1,250,000 for the cast of the Grout Disposal Program sampling system unth an escalation fictor of 25 percent for currem doilars (Carter 1989) The cagl of the sampliag and analyses is epproximately $\$ 70,000(\$ 240,000)$ per batch per IWFST

\section{B43.3 Seltedule}

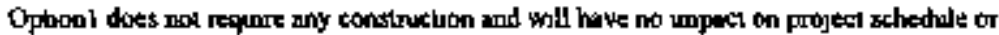

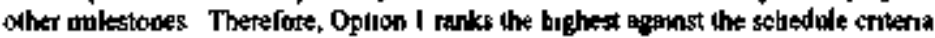

Optron 2 requires protureentent of a new core sempling truck or a skid mounted anupler The procuremenl and operumonsl approyal of the stuppler should hawe no Impact on projecl

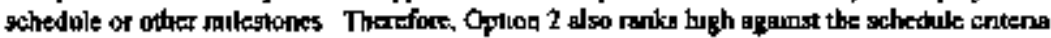

Optron 3 requres the design and consuructino of a complex sarmplang facility The facility consists of long-lead procurement ikens such ab kend glats thndows and remore menipulators The umplemerilation of this opion may cause schedula delays siace in is unlikely that Optoon 3 could be fabricated, procured tested, approwed for use, and reaty for full field operatan by June 1, 2002 For these reacong, Opwon 3 rank s poorly against the schedule cruterif 


\section{B4.3.3 Malntalabbllly}

Optoon I us a fanty sumple sysem. bul in does requre a high dedee of skull and expertence

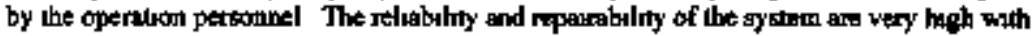

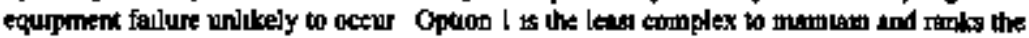
highest aganngat the mauntaunabilicy cnterta

Ophom 2 unvolves complex sampling equmpertit that requins specufically traned personael to operale The core stompling system has been teluble ut other applications on the Hinford Site Also, access to the equipment for repairs is readily avalabte However, high expertise is required by personnet ko sopport reparrs of the equpprionl Option 2 does not rank ts hugh as Optoan 1, but performs well aganst the mamiamabulty cnteris

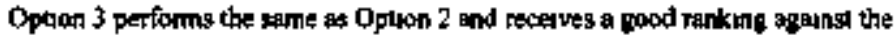
movrtsonsblity criena

\section{B4,3,4 Technied Maturity}

All three optious hove been applied succeserfilly on the Hanford Site, and, therefore, fark high apaunst the cnivena of kechnical maturty

\section{BA_3.s Performabe Requirtanents}

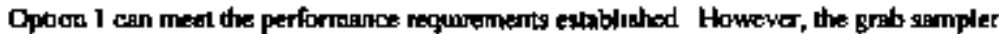
has some unduced bus as descussed in Section 131 ln addiuron, Optwon I has the hughest rodiation exposare and poiential for contiomination Dpiron I could hove a problem meetimg the

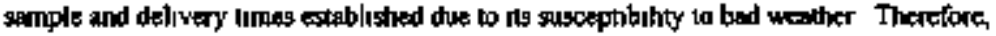

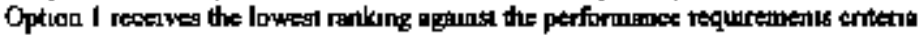

Opton 2 meets all of the performance requrements establashed Optoon 2 also could have a problem meetting the sample and delivery tome due to bad weallher deleys This option

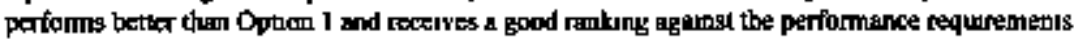
enterie

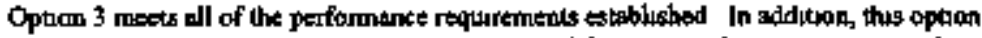
substanisally reduces the radialion exposure and potemial for personnel contammainon Also, my

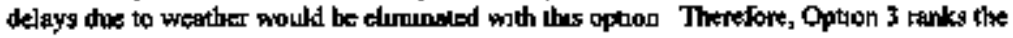
hughers agamst the performance tequrements critena 
HWF.SD-TWR-AGA-OOH

Retrision 1

\section{ISO REFERENCES}

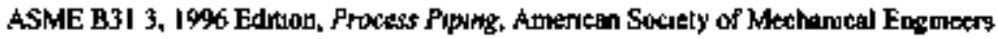

Brown, K L, 1992, CastiBengfit Anatyses of Westmphause Hayford Company, WHC-SA-1533-FP, Rev 0, Wralanghure Hanford Company, Ruchland, Warhipgton

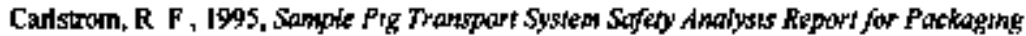
(Ongrte), WhC-\$D-TP-\$ARP-001, Rev OG, Wesunghoure Hanfond Company, Ruchland, Washugion

Carpenter, K E , 1996, TWRS Functurs and Requmenews Docmment, WHC-SD-WM-FRD-020, Rev 0, Wegtophousc Hanford Company, Ruchdand, Wrahnglon

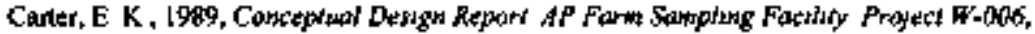
SD.W006-CDR-001, Rev 0, Drafl, Westmghouse Harford Company. Ruchland, Washngion

Certa. P J, 1996, Low-Lewed Warte Feed Sagung PJat, WHC-SD-WM-RPT-224, Rey 0, Weslunghouse Hanford Company, Rechland, W'ashington

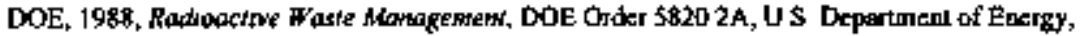
Wabungton, D C

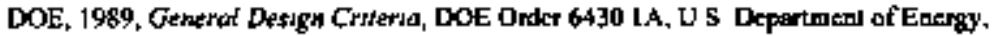
Wabungion, $\mathrm{DC}$

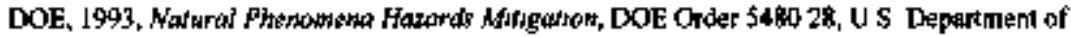
Energy, Washington, DC

DOE, 1995. TWRS Priwotization Reghesss for Proposols - Drafi, Solacitation Number DE-RP06-96RL 13308, U S Departimeni of Energy, Rwenland Operstions, Ruchland. Washngion

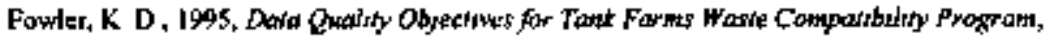

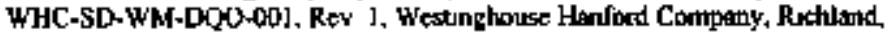
Washmglon

Galbrath, J D, T B Sapizan, and I R Nwchalson, 1996a, Dacosvon Document for Phase f

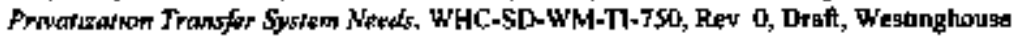
Hanfond Company, Richland, Weshungton 


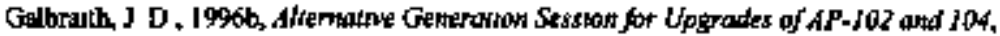
Metung Mnutes, dated June 13, 1996, Westanghouse Hanford Company, Ruchland, Washungigton

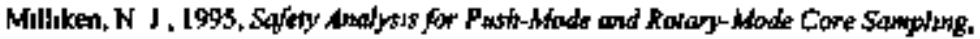
WHC-SD-WM-SARR-031, Rov 2, Westenghouse Henfoct Compeny, Rutilend, Washimgton

Prekell, W W, 1996, Electrous mal to T B Salemo, Re Cast of RtfCS, Augusi I5, 1996, JCF Kayer Hortord Compiny, Rudland, Washingion

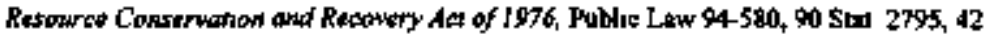
USC 6901 el seq

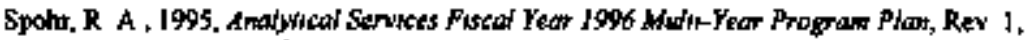
Westinghowe Hanford Company, Fuchlard, Whangion

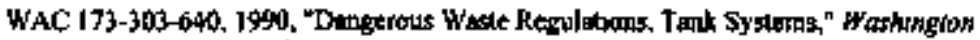
Adinimstratiwe Codk, as anmended

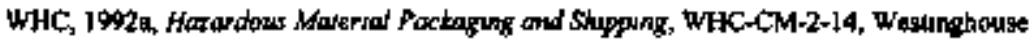
Hanford Company. Richland, Washmgton

WHC, 1992b, Safety Clasufication of Structures. Systems aud Compenthts, WHC.CM-4-46, Westanghourse Hanford Company, Rochland, Washungtor

wHC, 1994, Rodhotogted Desgn Gurde, WHC-SD-GN.DGS-300II, Rev 0, Westinghoust Harford Company, Ruchlond, Wadangipn

WHC, 5995, WHC Oceupathand ALARA Prograw, WHC-JP-1043, Rev 0, Westlighouse Hanford Company, Ruchlemd, Westungion

WHC, 19964, Opwraing Specsfacatrons for she 2AI-AN AF, AW, AY, AZ \& SY Tank Furrs, DSD-T-15]-00007. Westmghouse Honfơd Compary, Ruchand, Washagton

WHC, 1996h, Dowble-Shadl Tanks Mienm Operationd Safery Requremests, WHC-SD-WM-OSR-bI6, ReY OA, Wesunghouse Hanford Company, Ruchland, Washungton

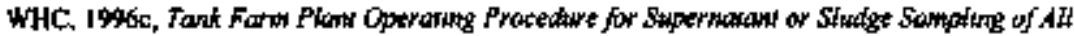

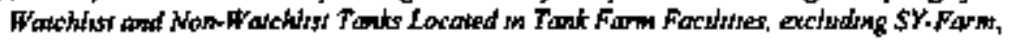
TO.080-493, Westunghouse Haniond Company, Rrchland, Waghington 
HINF-SD-TWR-AOA-OBI

Revisuon I

WHC, 1996d, Tavik Fans Plan Operaing Protedture for Phsh Made Sanplung of

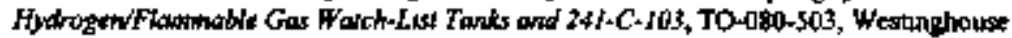
Hanford Cosmpuny, Rechland, Wasbangion 
HNF-SD-TYR-AGA-TOL

Revision I

This page iutentionsly kff blank. 
HNF-SD-TWR-AOA-001

Revision I

H6.0 COST ESTMMATES 


\section{TWA8 CHARACTERZATION SAMPUMG MODULE}

\section{General Noles inattucinans}

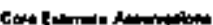

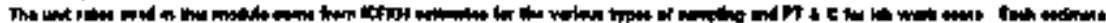

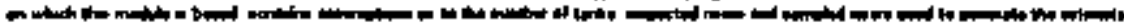

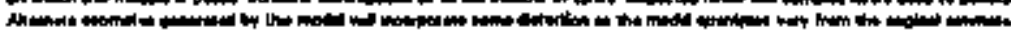

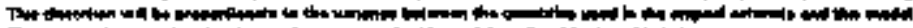

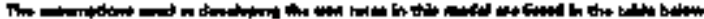

\begin{tabular}{|c|c|c|c|c|c|c|}
\hline & & & & & Im & $17=10$ \\
\hline & & ] & & netstet & $E_{-}$ & 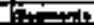 \\
\hline لمطشت & 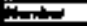 & Dan & The & t5 & |rint & ب \\
\hline B-wy & PdHEF & 대날 & II & 4 & 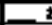 & IF \\
\hline =h & fartist & 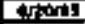 & 13 & $\underline{2}$ & $I$ & 8 \\
\hline 管 & TARPT & 군다 & 1 & 4 & 5 & I \\
\hline LE. & 1ditis & dristis & 1 & 2 & 1 & $I$ \\
\hline$=$ & Tाग & totitis & 1 & 7 & 1 & 1 \\
\hline
\end{tabular}

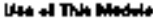

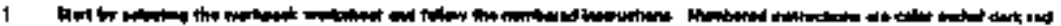

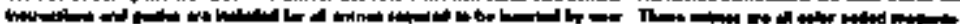
(1)

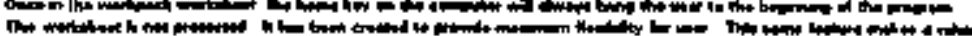

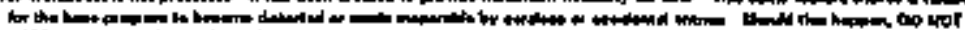

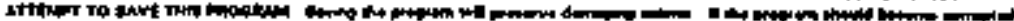

Nowit

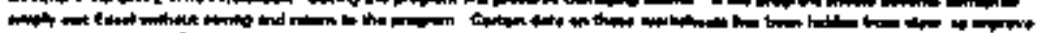

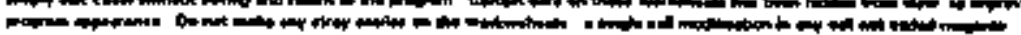

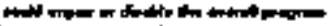

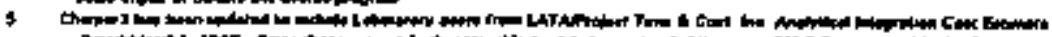

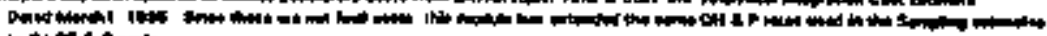

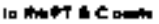

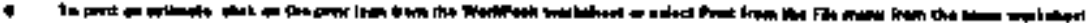
Pa

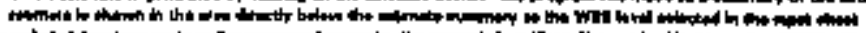

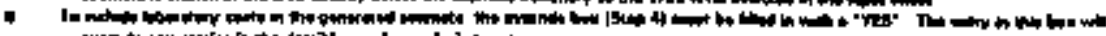

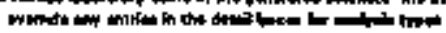




\section{TWAS CHARACTERzATIOH BAMPLHB MODURE}

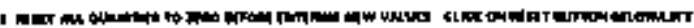

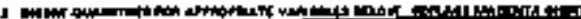

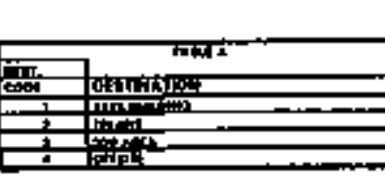

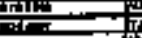

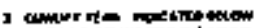

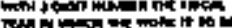

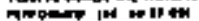

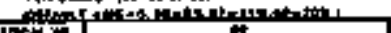

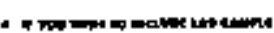

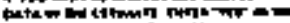

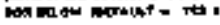

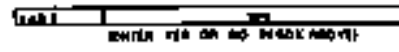

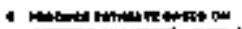
4hinb
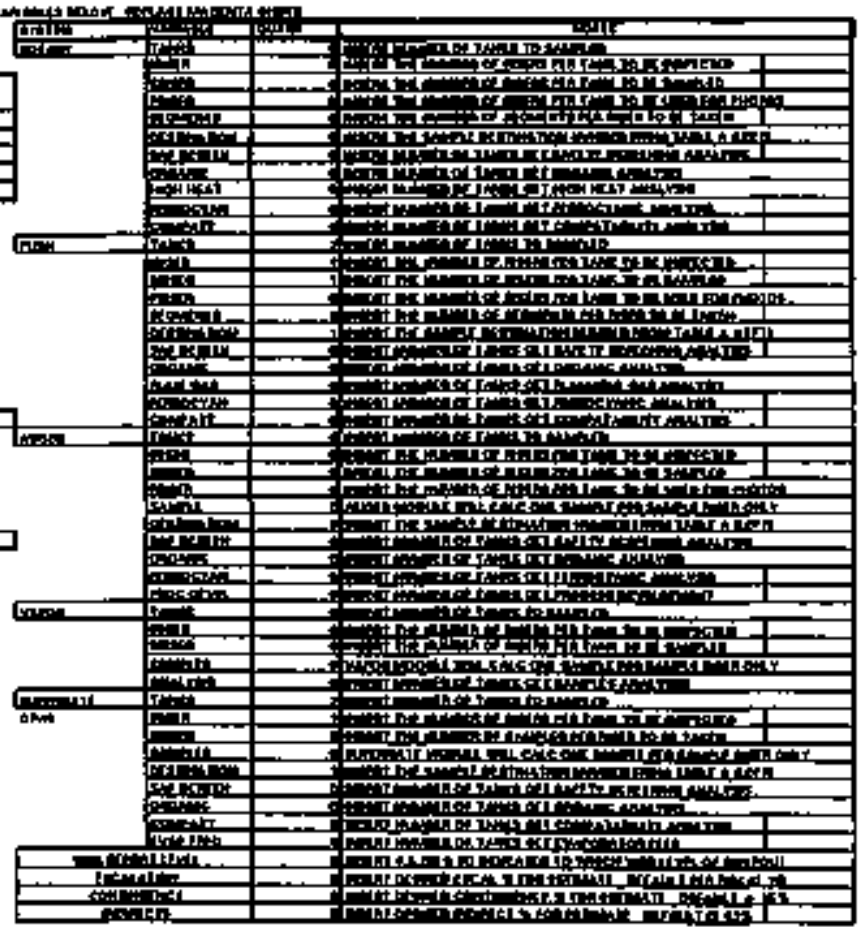
TWRS CHAGACTEFIATON sAMFume moothe

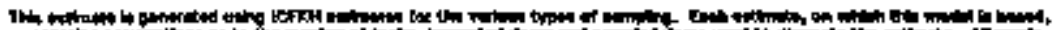

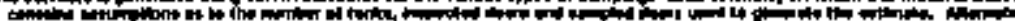

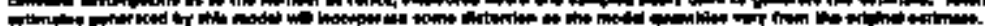

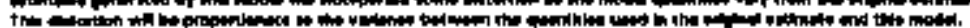

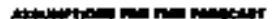

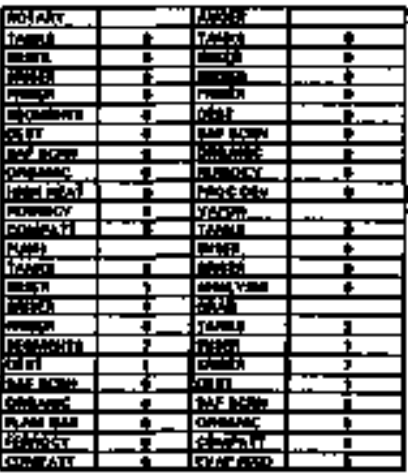

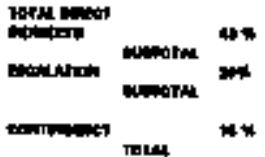

- mas

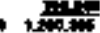


"Well-Mixed" Waste Scenano WhS Report (I and 2 Percent Soluds)

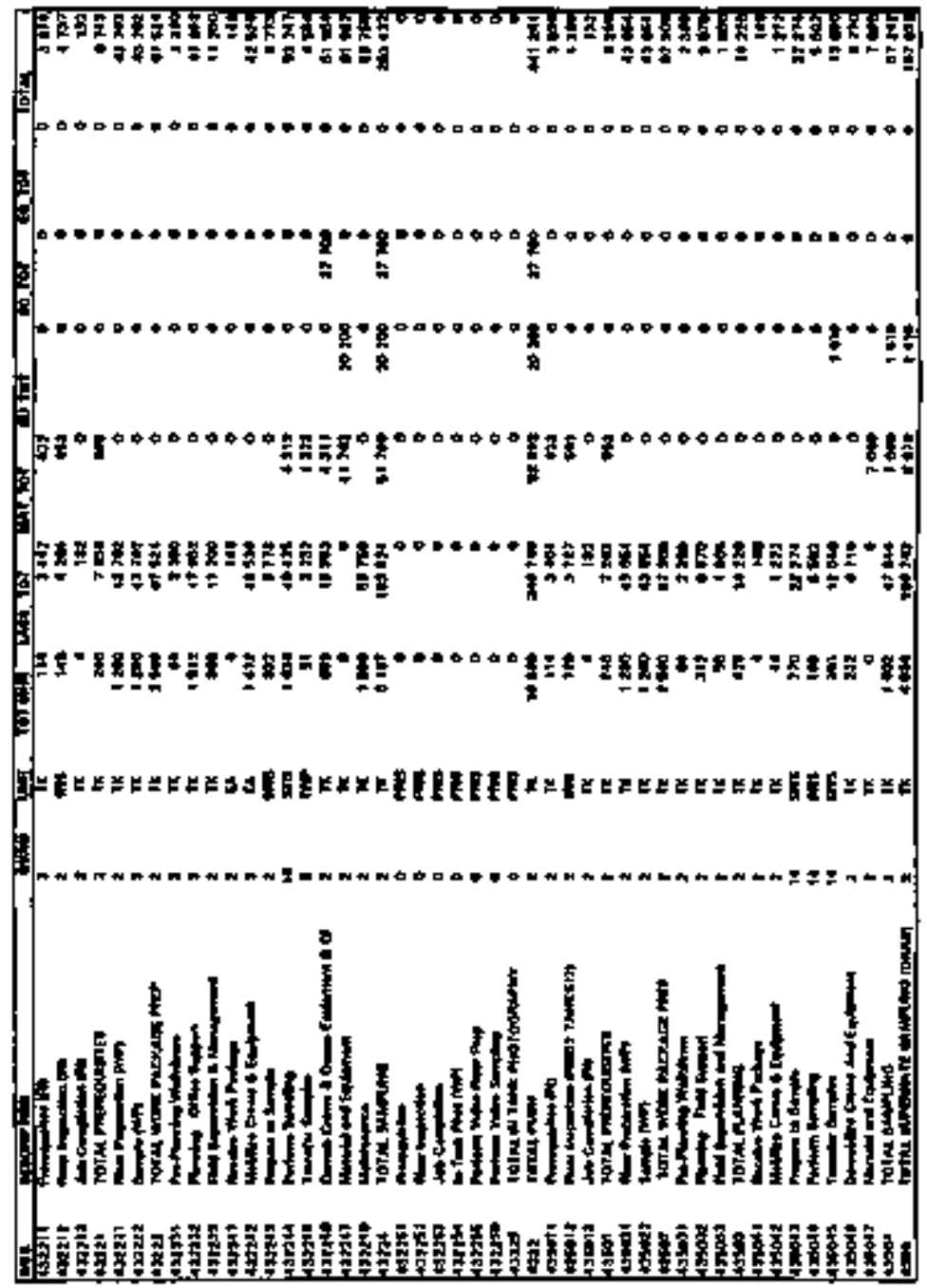




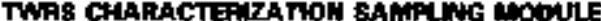

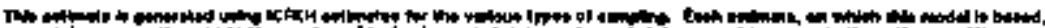

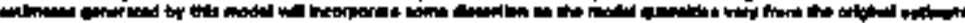

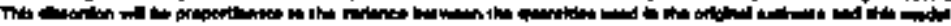

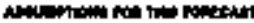

里

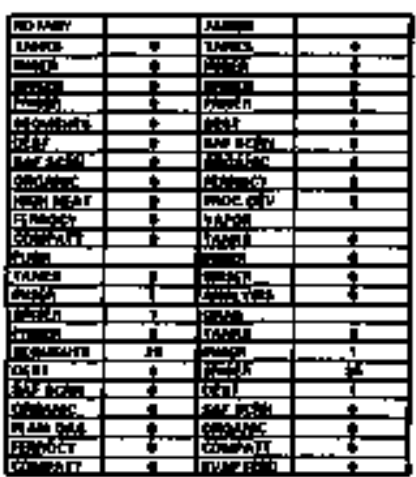

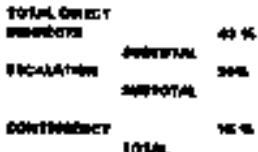

$1 \quad \mathbf{m a t}$ vise

19.

I4)

It)

Ioth

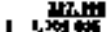




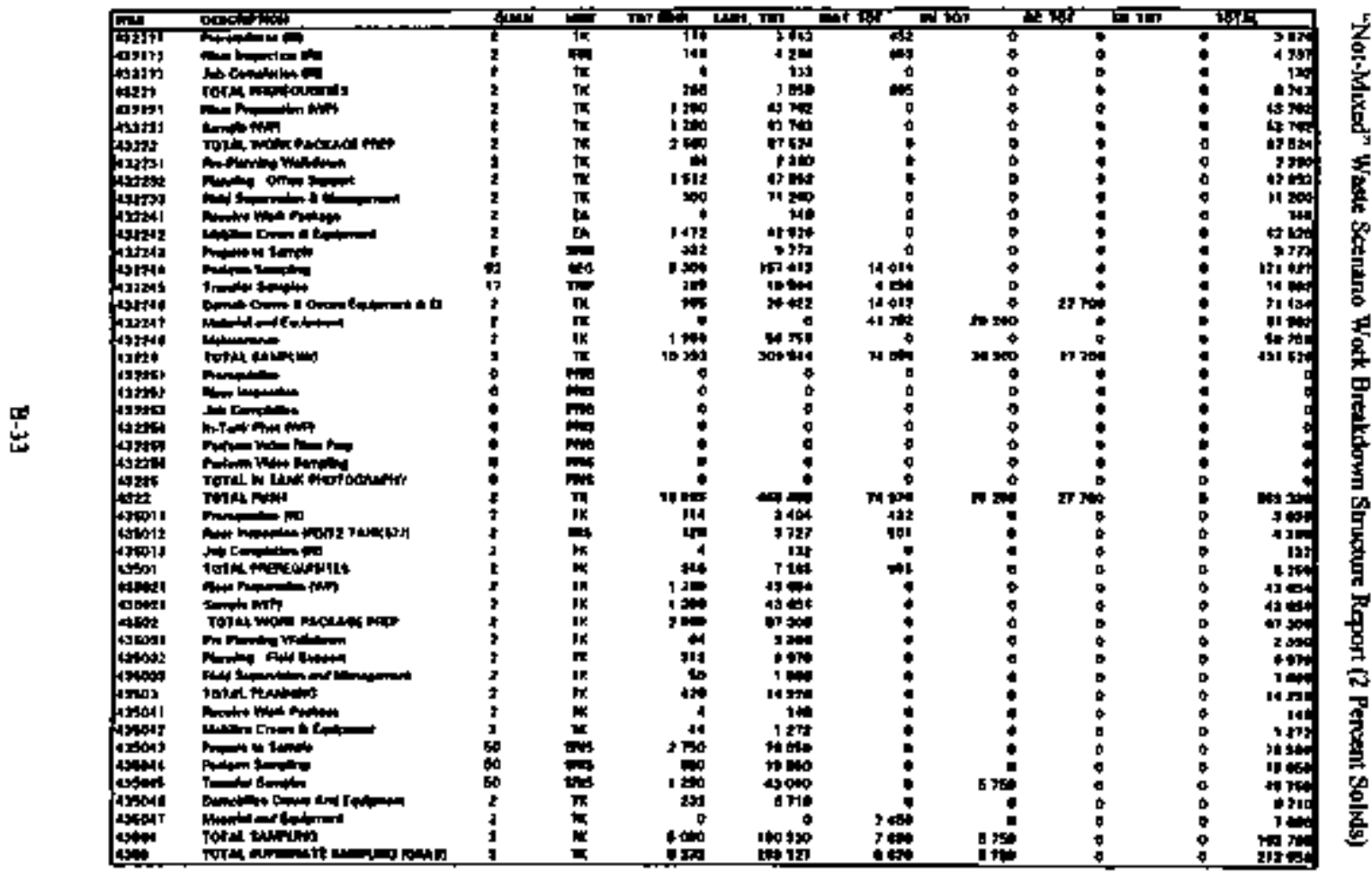




\section{TWRS CHAAACTEREATHOH SAMHLHE WOOULE}

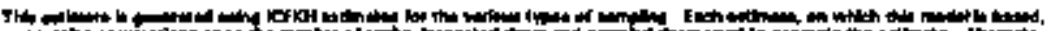

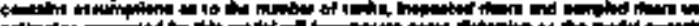

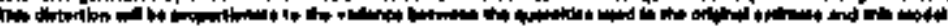

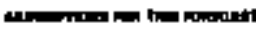

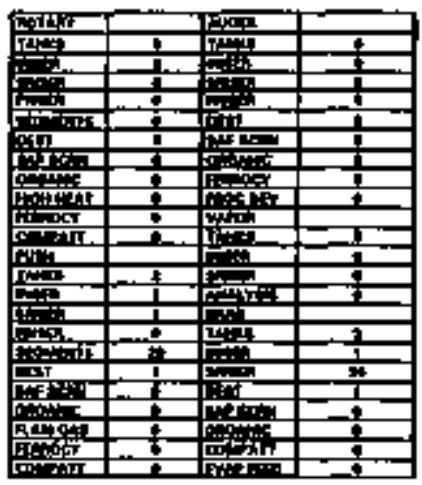

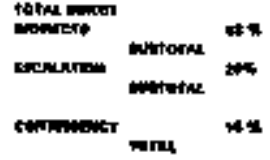

1 mats ond inting

res? 


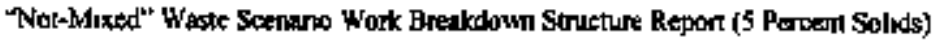

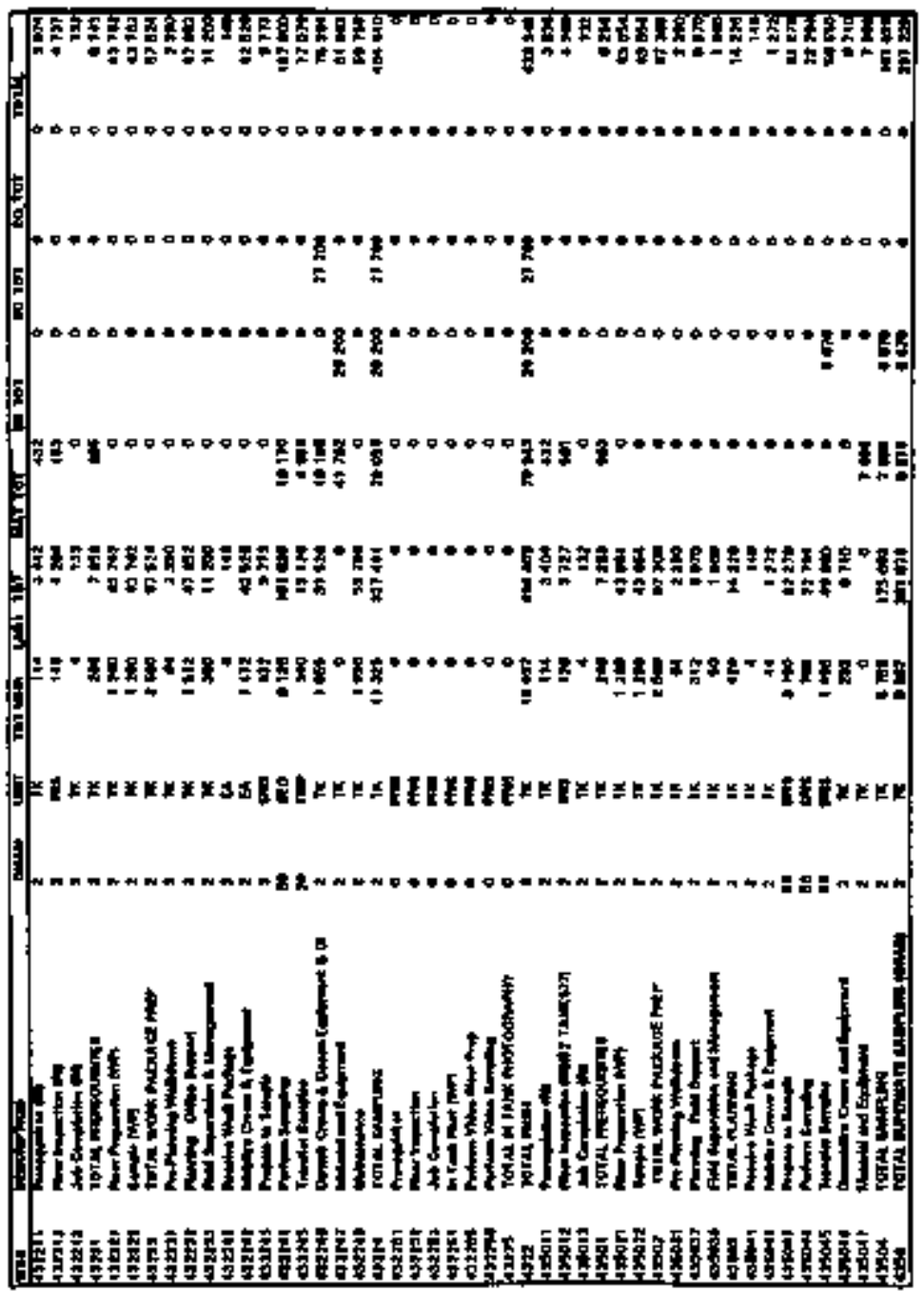




\section{HNF-SB-TWR-AGA-001}

Revision 1

This pare inkentionally kft blank. 
HNF-SD-TWR-AOA-001

Revigion ]

APPENDIX C

\section{VENTILATION ANALYSIS \\ LETTER REPORT}


HNF-SD-TWR-AGA-001

Revioion 1

This parge intentionally lef blank.

C.2 
HNF.SD.TWR-AOA-001

Revision I

APPENDIX C

VENTILATION ANALYSIS LETTER RERORT

\section{C1.0 INTRODHCTION}

This repoet analyzes the existing AP Tank Form vendaldion system In portecular, the analysis detormines the capabuity of the syghen to reanove heal created by muxer pumpe that may

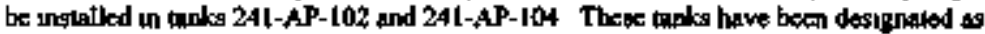
Inlemeduate slaging tanks for waste to be provided to 4 private vendor for vitufication Knowiwg the permissible twine of operaicon of the pumps that will not overbeal the tants is necessary

\section{C2.0 SUMMARY, CONCLUSTON, AND RECOMMENDATIONS}

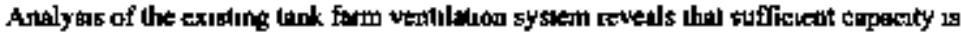
avalable to mamian paste conditrons wilhn operatoonal sofety requirmenus (OSR) limiss with

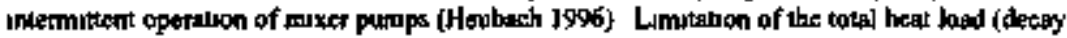

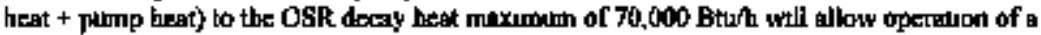
$300 \mathrm{hp}$ muxer pump for $4 \mathrm{~h}$ wik in a tank having dectay heal or 50,000 B Burh The average butk whete temperature wrould be approximately 106"F under these condnions if the bulk temperature is allowed to reach the OSR lint of $180^{\circ} \mathrm{F}$ the purmp may be operated tor $75 \mathrm{~b} / \mathrm{wh}$

The maxumitm rats of eemperianire nse calculated for operatuou of ine muxer pump for

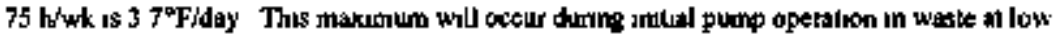
temperature This resull agroes unth analysis performed by the W-2I l proyect (Ruack 1985), eonosdering differankes in punop power and waske characienstics

If intermittent operation of muxer pumps (as defined) is scioquale to achlyeve the degree of muxing required, no modjfication to the exustung ventalalion systern is noeded However, the to uncertanues concetnmg future operations and elassificanons of the tank farms, the existint

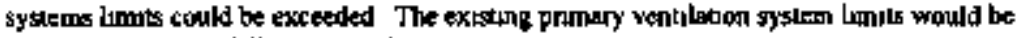
excesded under the folliowng contions

1 The toted primary anrlow rato is increased by more than 25 percent

2 One (or more) of the AP tanks so added to the flanmeable gus walchlust

3 The safety classafication of the vesulation systen is upgraded 
If the exisung syglem of judged nonsunable (for whakewer reason), sudies have beth

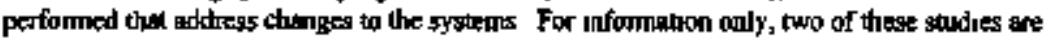
addressed in the following ponteresphs

Mod,fication of the Exughing system to increase capacty by 50 pervenl has ten recoummended (ICF XH 1995) The duract cost of the modeficathon was estmated at $\$ 221,000$

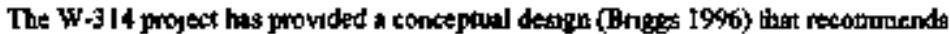

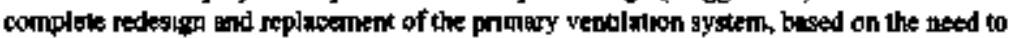

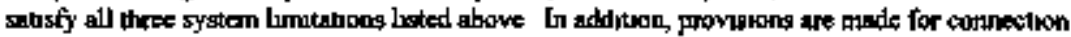

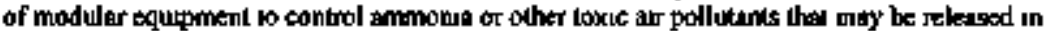

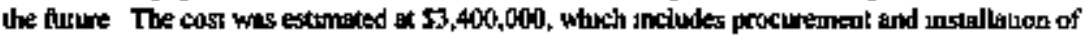

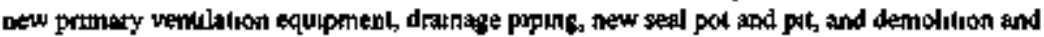

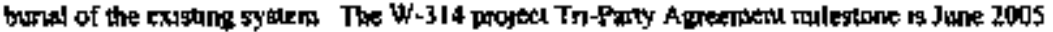

\section{C3. APTROACH / EVALUATJON}

Ansalysts of the exasting AP Tank Farm ventalaion system was perfocmied of determine tank temperatures with vanitions in thennd loading caused by the sdithon of muxer pumps A compulter todte developed for Projed W.236 was used to model the waste tant heat removal syMems

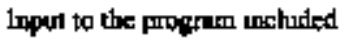

I Mixer pump heat

2 Radioniclide decay heat

3 Inlet anr ternperature and humitity

4 Vapor supprestom factor

5 Tank dimensions

6 Annulus flow condrions

Outputs from the propram theluded

I Waste vemperiature ard vipor pregsure

2 Nel eveporation

3 Pnmany arflow required

4 Vapor spoce kemperalure and humbdry

5 Andulus exhouss lemperature

6 Annulus heat loss

7 Condurtuon heal loss 
The expults urere graphucally presented to show the relalionshup berween radolytec decay bora and maxer pomp heat uhat would gatosfy two separile criteria

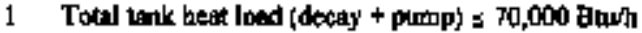

2 A verage bulk waste temperature $\leq 100^{\circ} \mathrm{F}$

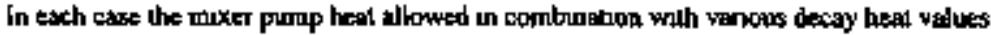

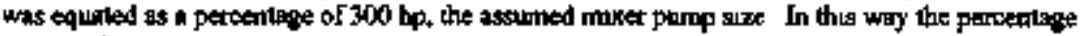
of lume atlowed at full powret was derermoned

\section{C40 UNCBKTAINTLES}

I The capacity requiromonl of the mixor pumps is noi certan Higher power pumps will requer thorter aperahng pernods.

2 The exrsting undergiound sungle wall veniluducon pipine has not been mapecled to determine remalning Jufa

3 I1 is uncerian whether oue of more of the AP unks may be placed on the flemantble gas watchlos The venalalion system degan would be affeciled

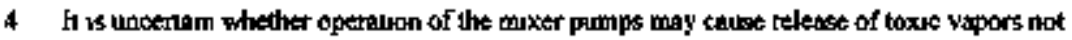
eurrently 1denufied

\section{CS, PFFERENCES}

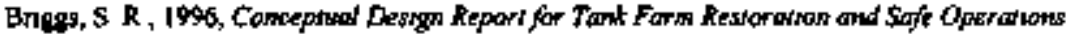
Projest W-3/4, WHC-SD-W314-CDR-001, Rev 0, Wesimeflouse Hantord Company, Richland, Waghingion

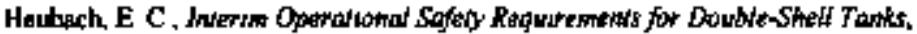
WHC-SD-WM-OSR-0I6, ReV OB, Wesundbouse Hanford Company, Ruchand, Wathungign

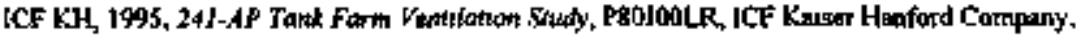
Rechland, Washingtorn

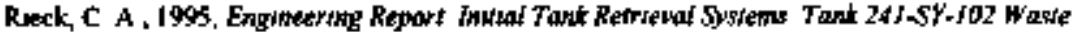
Cooleng Enatuorion Proyer W-2Is, WHC-SD-W21 i-ER-002, Re4 0, Westunghouse Hanfoud Company, Rushlond, Waskinotop 
HNF-SD-TWR-AGA-001

Revision 1

This pags intentionally left blank.

C.6 
HNF-SD-TWR-AOA-001

Revision 1

\section{cat calculation}

AF TANK FARM FEATING, VENTILATION, AND AIR CONDITIONING THERMAL ANALYSIS 
HWF-SD-TWR-AGA-OHI

Fievișion 1

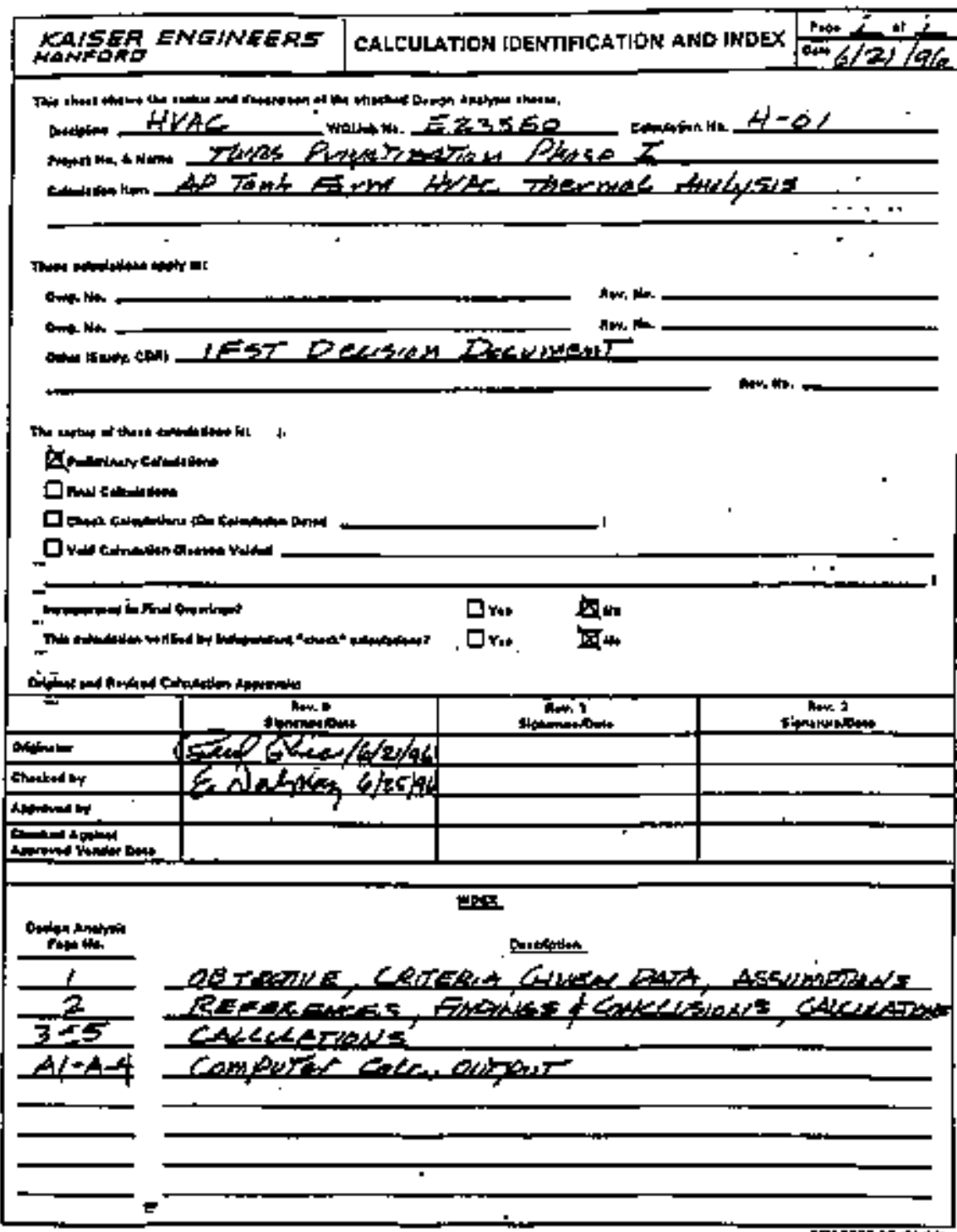

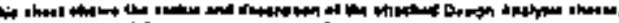

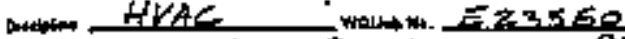

inatin He $A-\dot{0}$

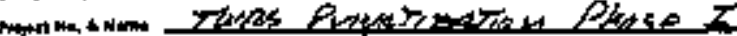

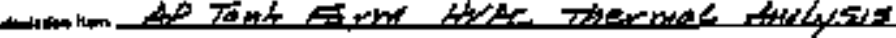

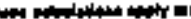

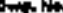

Non.

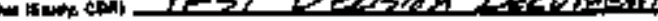

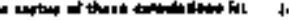

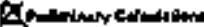

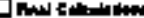

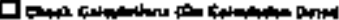

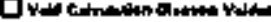

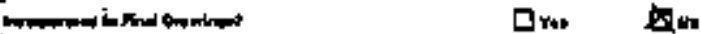

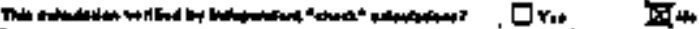

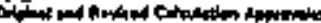

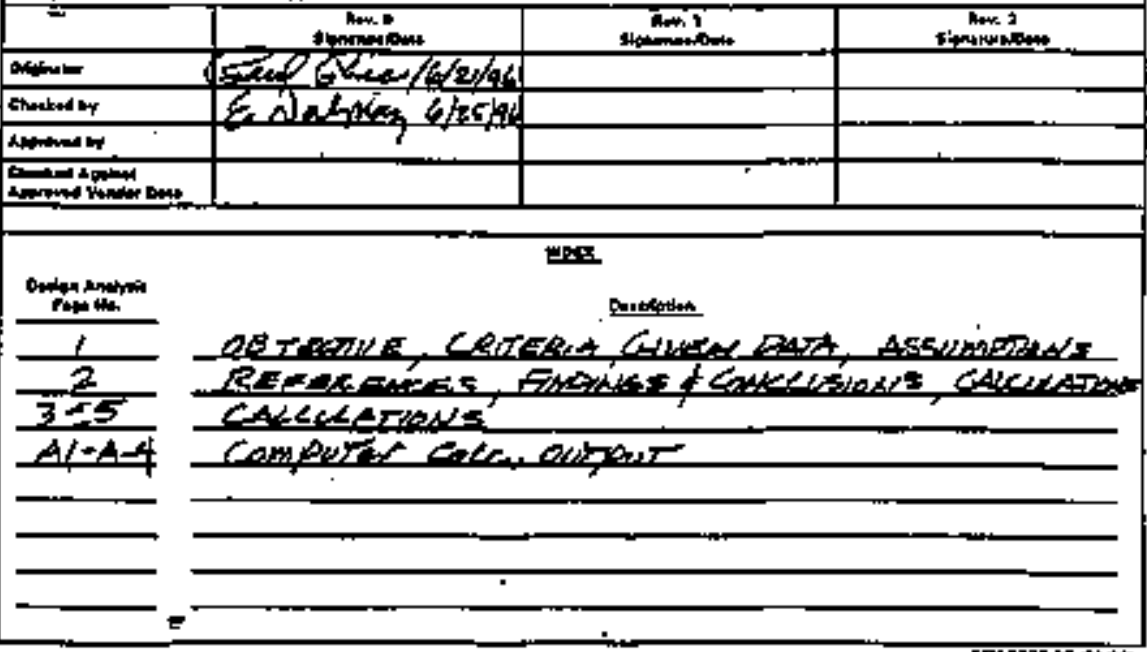

$C \cdot B$ 
HNF-SD-TWR-AGA-00I

Revison I

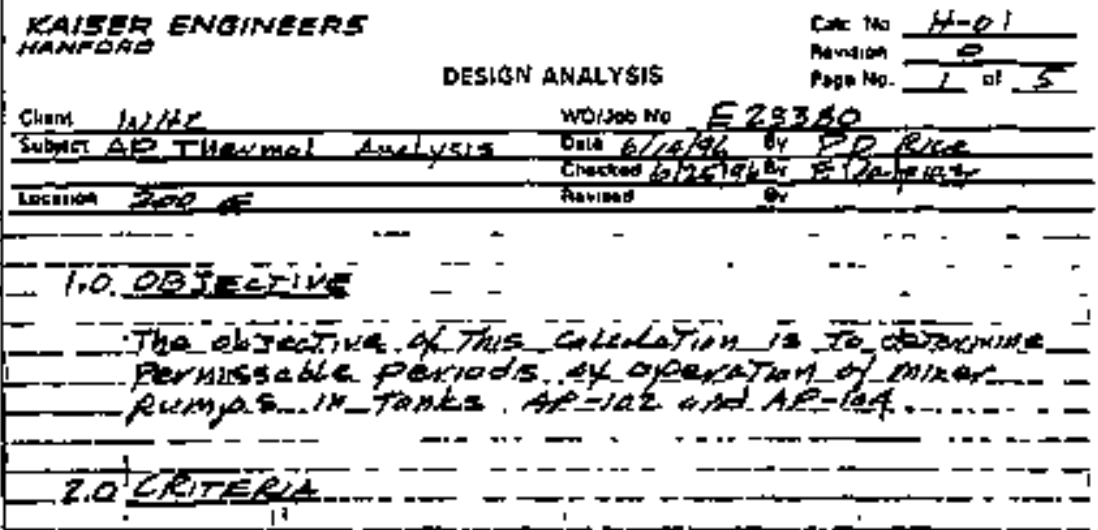

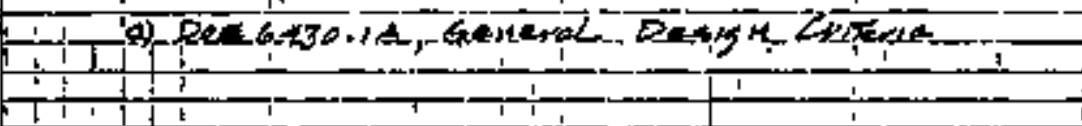

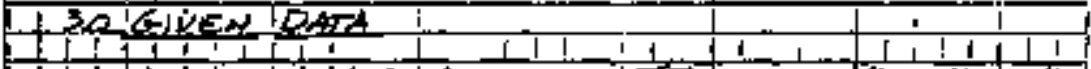

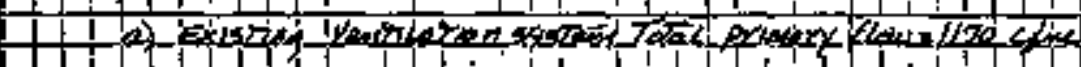

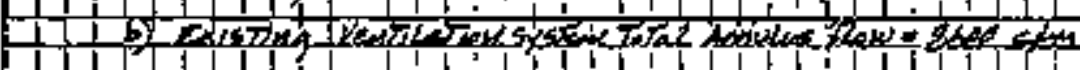

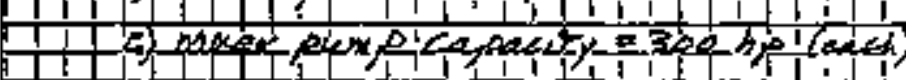

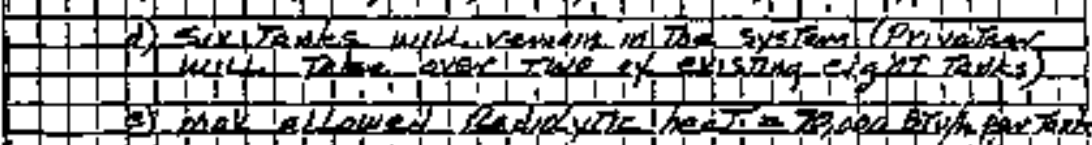

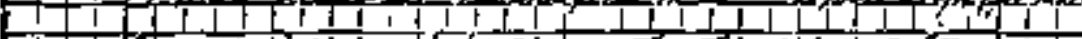

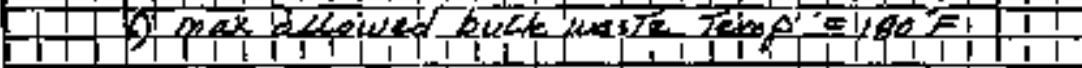

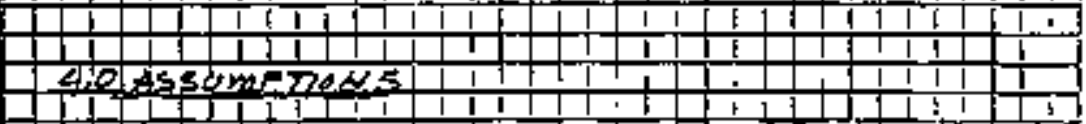

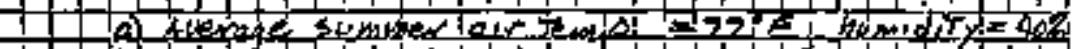

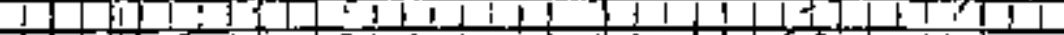

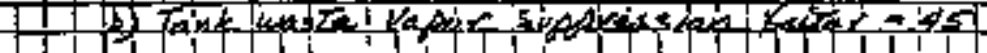

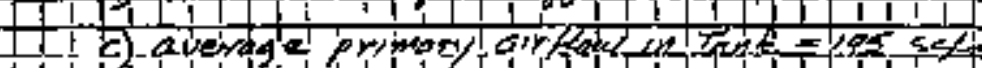

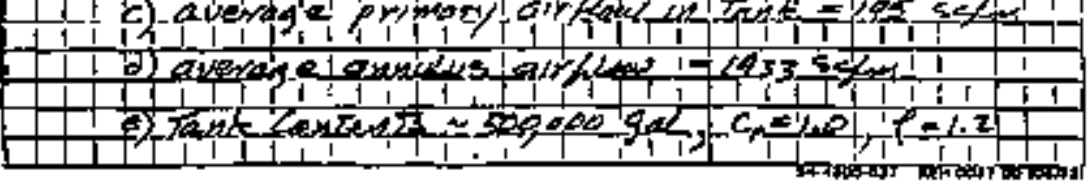
C-9 
HNF-SD-TWR-AGA-DO]

Revision I

KAISIA ENGINAGRS AMANOAB

DESIGN AMALYSIS

Dוm

wors in te 23360

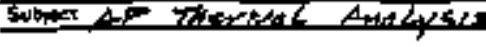

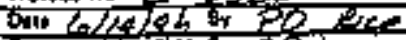

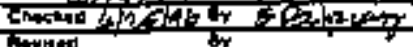

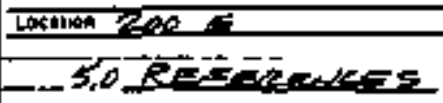

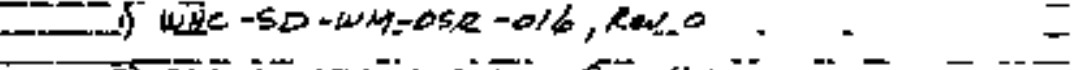

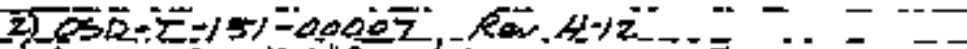

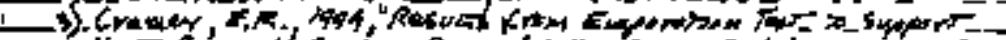

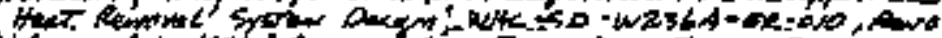

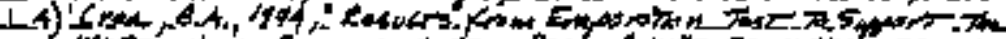
I.

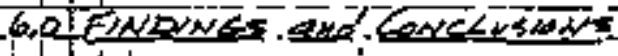

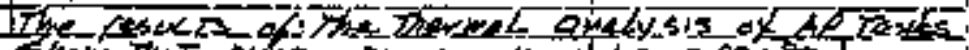

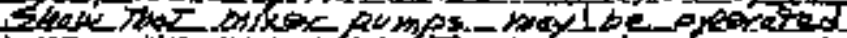
1
1

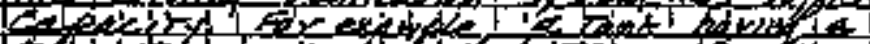

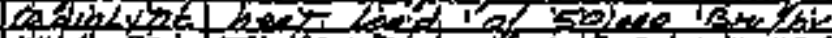

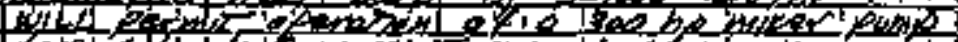

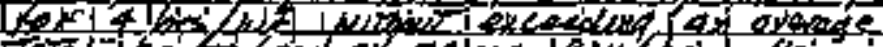
K

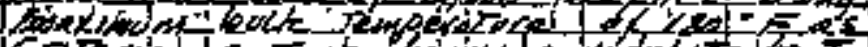

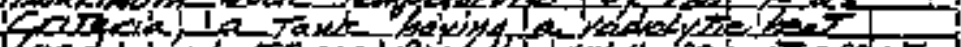

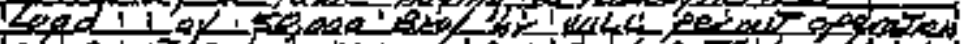

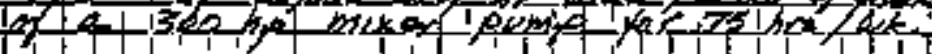

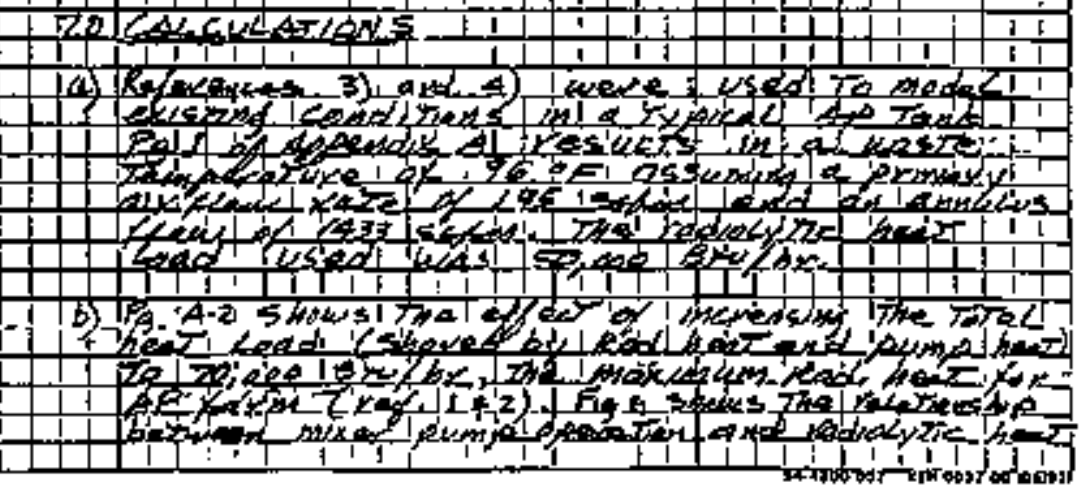


HNF-SD-TWR-AGA-0O-I

Revision 1

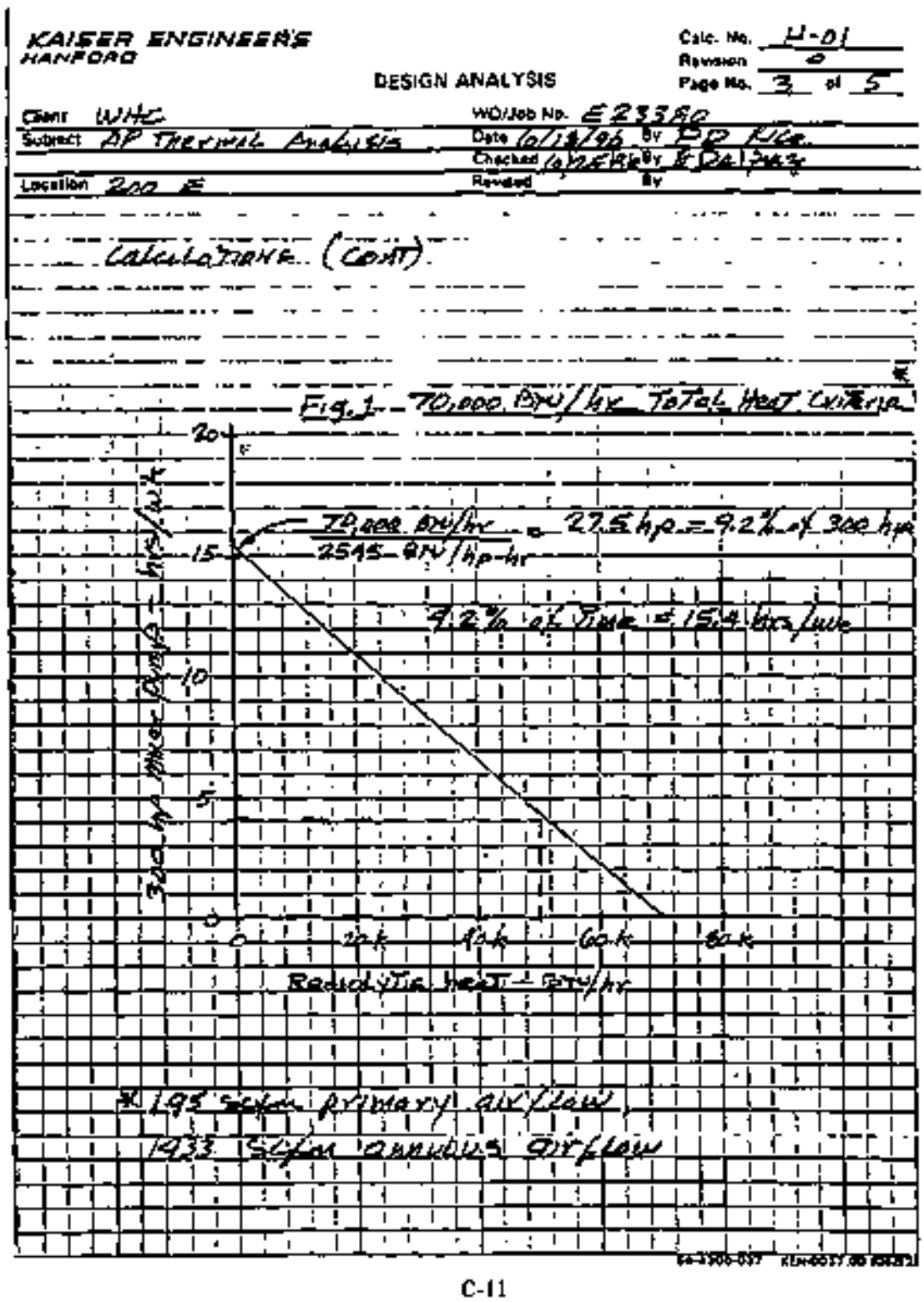


HNF-SD-TWR-AGA-00I

Revisló I

NAISER ENGINIER'S HANTORO

DESIGN AHALYSIS

Cinin $A c H C$

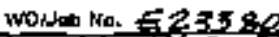

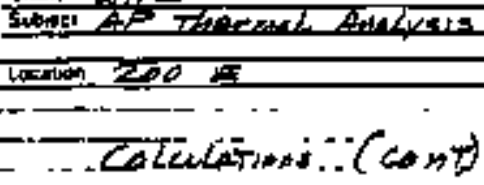

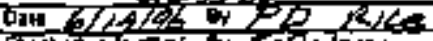

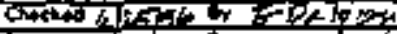

howred on

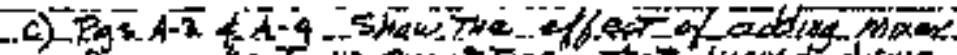

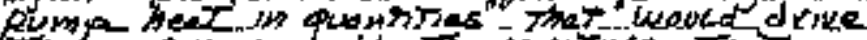

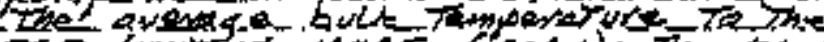

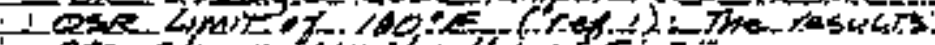

-1

$1-112$

'd 7 a

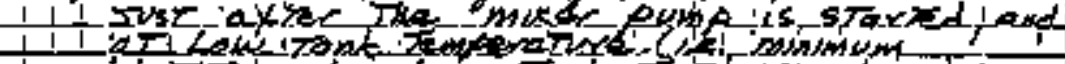

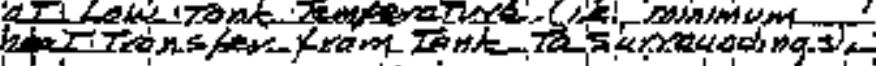

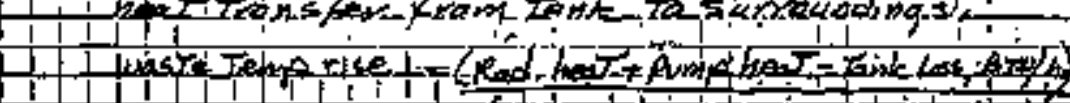

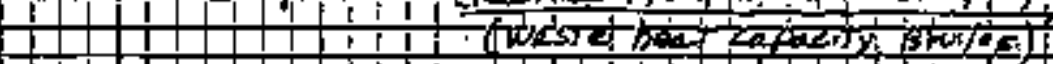

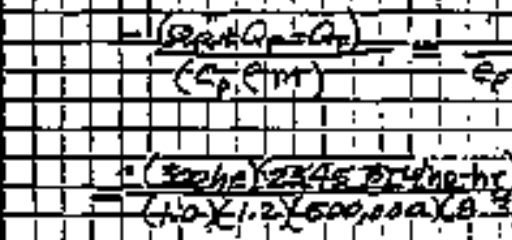

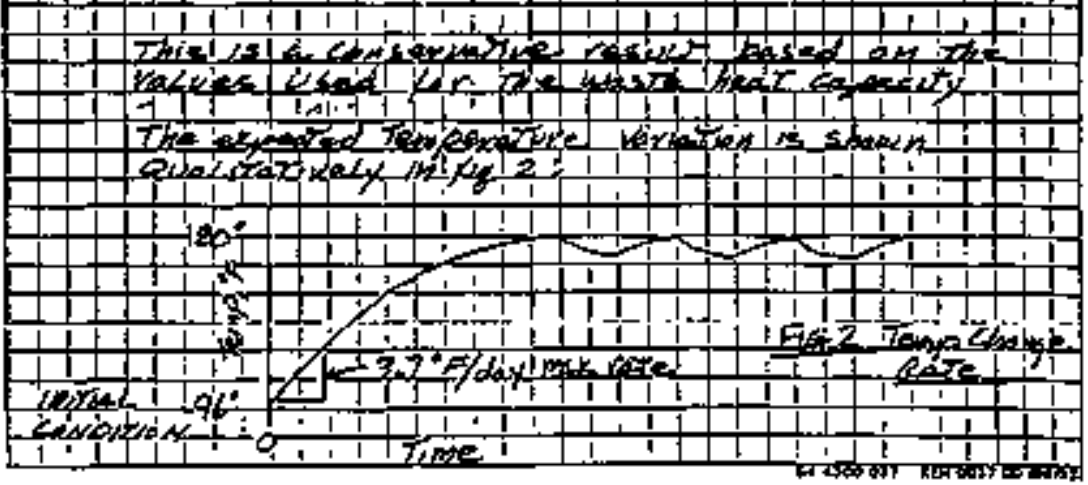


HNF-SD-TWR-AGA-COI

Revison 1

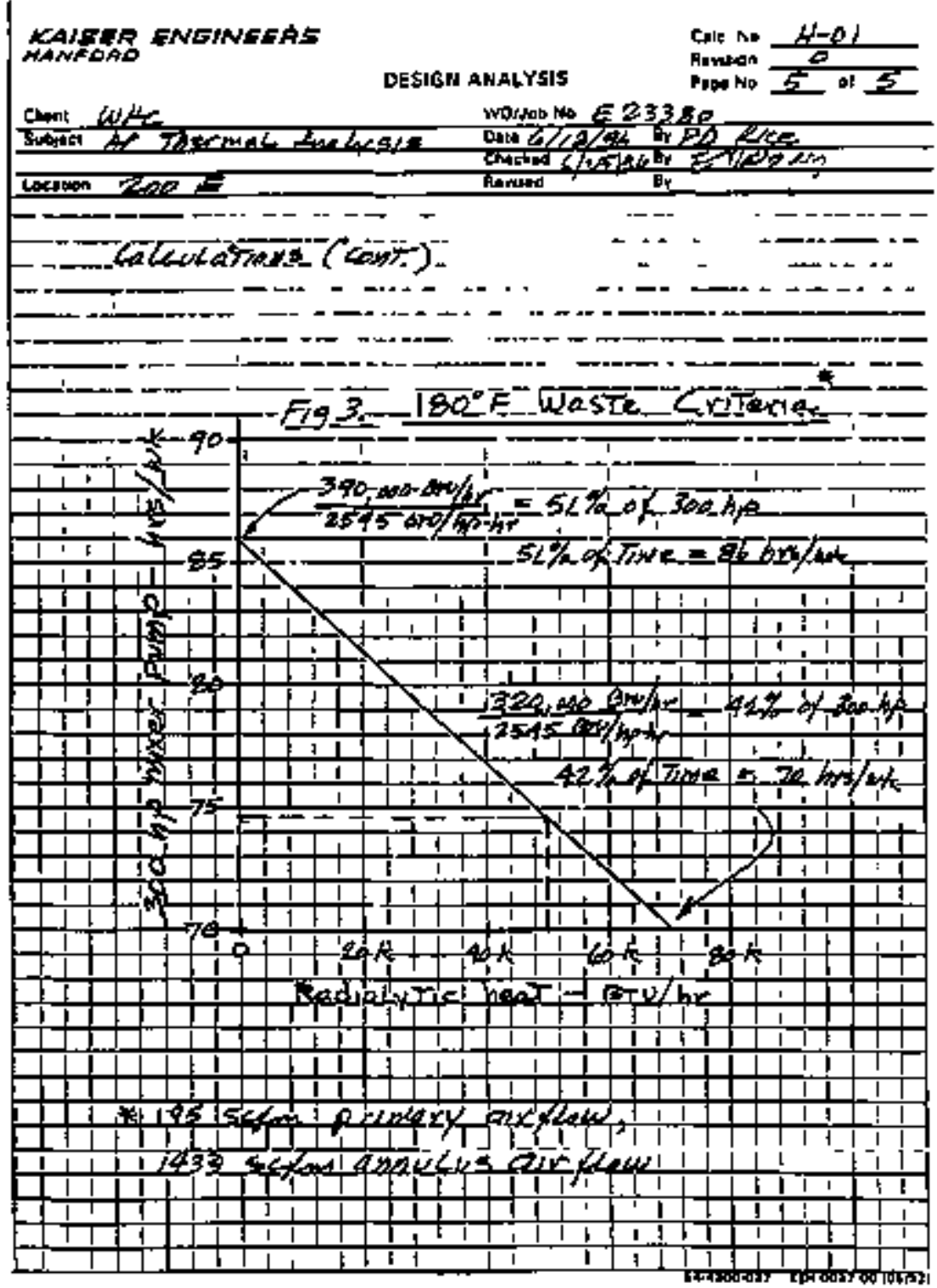

C.13 
HNF-SD-TWR-AGA-00I

Revision I

Initiol Condition

Puep Heat a 0 Btu/h

Inlet Air Temp = 7f F

Suppress ion factor -45

MC Flow Rate = O sefi

Tank Oituteter - $75 \mathrm{ft}$

Tank Thicknass - 1 in

Concrete Depth $=1+25 \mathrm{ft}$
Radionuclide Heat - 50000 Btw/h

Ref ative Howidity $=40 \mathrm{x}$

Inlet Air Tene it Anmulus - $77 \mathrm{~F}$

Annolus Flow Rate - 1433 scfi

Tank Heigbt - $35 \mathrm{ft}$ Ann Gap $=30$ in

$50 \$ 1$ Depth $-10.5 \mathrm{ft}$

Ousts 1de Afr Telop. $77 \mathrm{f}$

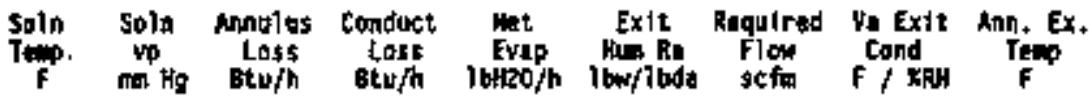

Waste tomerature 15 too high. Whll try next temperatare stup(A).

109.0 $29.5 \quad 37147.6567 .22 .37$ 0.025 30.68 101.6 $56.8 \quad 100.6$

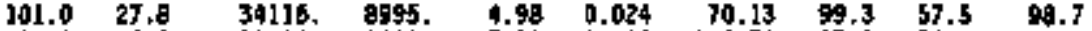

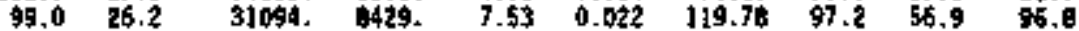

$9707.6 \quad 28003 \quad 7862$. $10.05 \quad 0.020100182 .09 \quad 95.0 \quad 55.3$

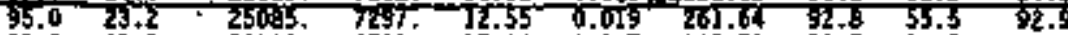

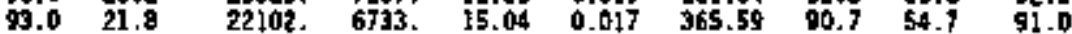

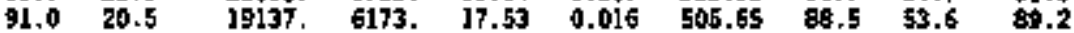

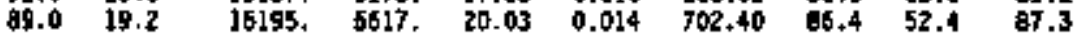

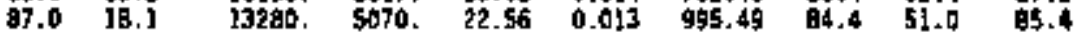

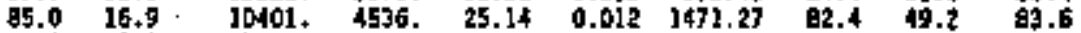

$\begin{array}{llllllllll}03.0 & 15.9 & 7573 . & 4025 . & 27.74 & 0.011 & 2353.20 & 00.6 & 47.0 & 91.8\end{array}$

$81.0 \quad 14.9 \quad 4320.3559 . \quad 30.00 \quad 0.009 \quad \begin{array}{llllll}351.93 & 79.1 & 44.4 & 01.1\end{array}$ 
HNF-SD-TWR-AGA-60:

Reviston I

70,000 BTU/h Total

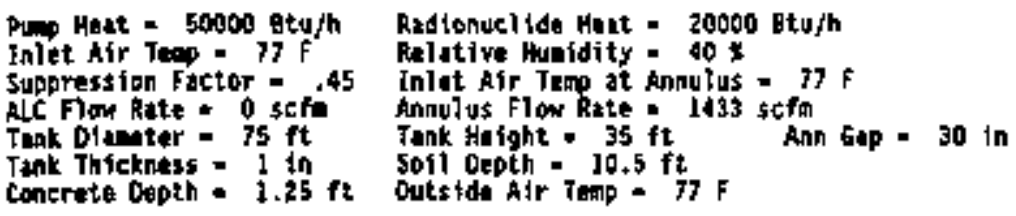

Soln Soln Anndilus Conduct Ext Raquired Ya Exit Ann. Ex.

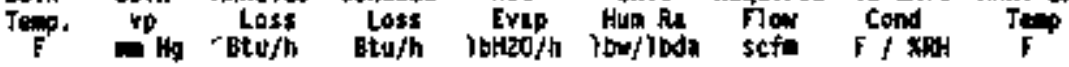

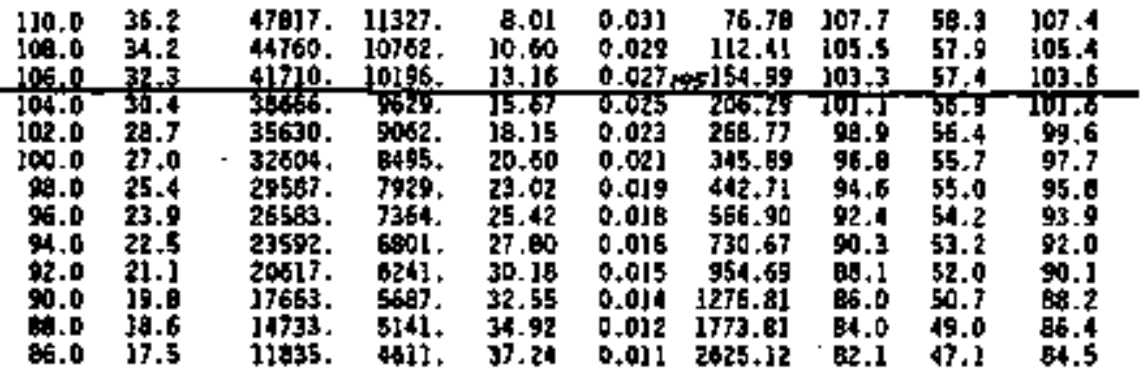


HNF-SD-TWR-AGA-00J

Revision 1

$390,00 \mathrm{BTU}$ T Tow

Plop Heat = 340000 Btu $/ \mathrm{h}$

Inlet Air Temp - $7 \mathrm{~F}$

Suppression factor $=.45$

ALC. Fion Rate - D scfu

Tmk 0ianeter - $75 \mathrm{ft}$

Tont Thickness - 1 in

Concrote Depth $=1.25 \mathrm{ft}$
Radianuclide Heat = 50080 Btu/h

Relative Huadity $=40 x$

Inlet Afr Teno at Annulus - N $F$

Annulus Flow hate - J433 stft

Tank Haight $=35 \mathrm{ft}$ Anח Gap $=30$ in

Sot1 Depth - $10.5 \mathrm{ft}$

Outside AIr Temp = IT F

\begin{tabular}{|c|c|c|c|c|c|c|c|c|c|}
\hline $\begin{array}{l}501 n \\
T=0 .\end{array}$ & $\begin{array}{c}501 \pi \\
\mathrm{VP} \\
\operatorname{mig}\end{array}$ & $\begin{array}{l}\text { Annolus } \\
\text { loss } \\
\text { etcis/h }\end{array}$ & $\begin{array}{c}\text { Conduet } \\
\text { Loss } \\
\text { Btuph }\end{array}$ & $\begin{array}{c}\text { Hat } \\
\text { Evap } \\
\text { lbH20/h }\end{array}$ & 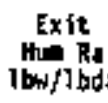 & $\begin{array}{l}\text { Pend } \\
\text { Fin } \\
\text { sct }\end{array}$ & & & $\underset{\text { Timp }}{\text { Ann: }}$ \\
\hline $\begin{array}{l}180.0 \\
178.0 \\
176.0 \\
174.0 \\
172.0 \\
170.0 \\
169.0 \\
166.0 \\
164.0 \\
162.0 \\
160.0 \\
156.0 \\
156.0 \\
154.0 \\
152.0 \\
150.0 \\
148.0 \\
146.0 \\
144.0 \\
142.0 \\
140.0 \\
138.0 \\
136.0 \\
134.0\end{array}$ & $\begin{array}{r}213.5 \\
204.2 \\
195.3 \\
185.7 \\
179.4 \\
170.4 \\
162.7 \\
155.3 \\
148.2 \\
141.3 \\
134.8 \\
124.5 \\
122.4 \\
115.6 \\
111.0 \\
105.7 \\
100.6 \\
95.7 \\
91.0 \\
66.4 \\
62.1 \\
70.0 \\
74.0 \\
70.3 \\
66.5 \\
63.2\end{array}$ & 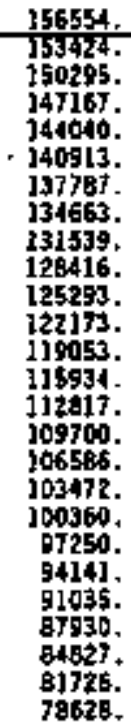 & $\begin{array}{l}29343, \\
21775 . \\
28208 . \\
27638 . \\
27057 . \\
26495 . \\
25921 . \\
25346 . \\
24770 . \\
24192 . \\
23613 . \\
23033 . \\
22451 . \\
21858 . \\
21193 . \\
20697 . \\
20110 . \\
19521 . \\
15930 . \\
18338 . \\
17744 . \\
17149 . \\
16552 . \\
15953 . \\
15352 . \\
14750 .\end{array}$ & $\begin{array}{l}1 B 5.15 \\
113.11 \\
190.74 \\
192.95 \\
195.12 \\
197.23 \\
199.29 \\
201.29 \\
203.23 \\
205.12 \\
206.94 \\
20.70 \\
210.40 \\
212.04 \\
213.60 \\
215.10 \\
216.52 \\
217.87 \\
219.14 \\
220.34 \\
221.44 \\
222.46 \\
223.38 \\
224.21 \\
224.92 \\
225.53\end{array}$ & $\begin{array}{l}0.22415 \\
0.2015 \\
0.195 \\
0.283 \\
0.172 \\
0.151 \\
0.151 \\
0.141 \\
0.132 \\
0.124 \\
0.116 \\
0.106 \\
0.101 \\
0.094 \\
0.098 \\
0.062 \\
0.077 \\
0.071 \\
0.0656 \\
0.062 \\
0.057 \\
0.053 \\
0.049 \\
0.045 \\
0.042 \\
0.038\end{array}$ & $\begin{array}{r}790.75 \\
20 \% .65 \\
224.22 \\
242.95 \\
243.17 \\
285.01 \\
309.64 \\
394.23 \\
361.98 \\
392.12 \\
424.90 \\
460.63 \\
499.63 \\
542.29 \\
599.09 \\
640.53 \\
697.26 \\
759.99 \\
929.61 \\
907.19 \\
993.97 \\
1091.55 \\
1201.63 \\
1327.26 \\
1470.67 \\
1636.60\end{array}$ & $\begin{array}{l}171.5 \\
169.5 \\
167.1 \\
164.5 \\
162.7 \\
160.5 \\
138.2 \\
156.0 \\
153.7 \\
151.5 \\
149.2 \\
146.9 \\
144.7 \\
142.4 \\
140.1 \\
137.7 \\
135.4 \\
133.1 \\
130.7 \\
126.4 \\
126.0 \\
123.6 \\
121.2 \\
113.8 \\
116.4 \\
134.0\end{array}$ & $\begin{array}{l}62.5 \\
62.6 \\
62.6 \\
62.7 \\
62.9 \\
62.8 \\
62.9 \\
62.9 \\
62.9 \\
62.9 \\
62.9 \\
62.9 \\
62.9 \\
62.0 \\
62.6 \\
62.7 \\
62.5 \\
62.4 \\
62.2 \\
62.0 \\
61.7 \\
61.4 \\
61.0 \\
60.6 \\
60.1 \\
59.5\end{array}$ & $\begin{array}{l}176.4 \\
174.5 \\
172.5 \\
170.5 \\
168.5 \\
165.5 \\
164.5 \\
162.5 \\
160.6 \\
158.6 \\
156.6 \\
154.6 \\
152.6 \\
150.6 \\
148.7 \\
146.7 \\
144.7 \\
142.7 \\
140.7 \\
134.9 \\
136.9 \\
134.8 \\
132.9 \\
130.9 \\
126.9 \\
126.9\end{array}$ \\
\hline
\end{tabular}


HNF-SD-TWR-AQA-DOt

Revision I

390,000 ETU/ Tod

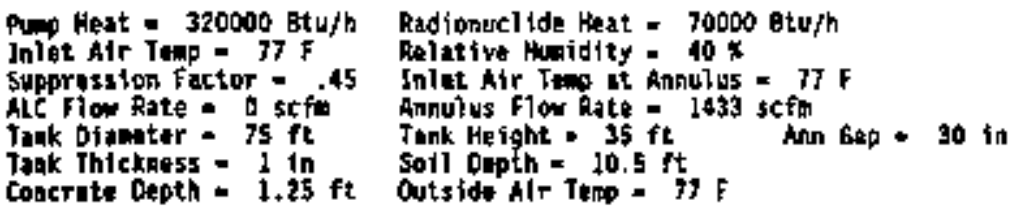

\begin{tabular}{|c|c|c|c|c|c|c|c|c|c|}
\hline Soln & $\begin{array}{l}\text { Soln } \\
\text { vip }\end{array}$ & $\begin{array}{c}\text { Anntulus } \\
\text { Loss } \\
\text { Btufh }\end{array}$ & $\begin{array}{l}\text { Conduct } \\
\text { Loss } \\
\text { etoph }\end{array}$ & $\begin{array}{c}\text { Het } \\
\text { Evat } \\
\text { Johtofh }\end{array}$ & $\begin{array}{c}\text { Exit } \\
\text { Hom the } \\
\text { lowflod }\end{array}$ & $\begin{array}{r}\text { Rodvd } \\
F 10 \\
551\end{array}$ & & & Ex. \\
\hline $\begin{array}{l}176.0 \\
174.0 \\
172.0 \\
170.0 \\
168.0 \\
166.0 \\
164.0 \\
162.0 \\
160.0 \\
358.0 \\
155.0 \\
154.0 \\
152.0 \\
150.0 \\
148.0 \\
146.0 \\
144.0 \\
142.0 \\
140.0 \\
138.0 \\
136.0 \\
134.0 \\
132.0\end{array}$ & 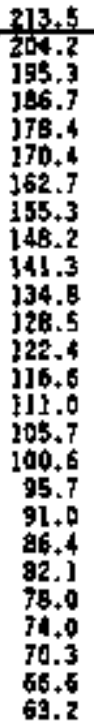 & 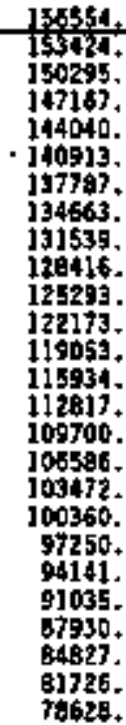 & $\begin{array}{l}79343 . \\
2877 . \\
29208 . \\
27654, \\
27067 . \\
26495 . \\
25921 . \\
25346 . \\
24770 . \\
24192 . \\
23613 . \\
23033 . \\
22451 . \\
21868 . \\
21283 . \\
20697 . \\
20110 . \\
19521 . \\
16930 . \\
19338 . \\
17144 . \\
17149 . \\
16552 . \\
15953 . \\
15352 . \\
14750 .\end{array}$ & $\begin{array}{l}186.16 \\
191.45 \\
190.74 \\
192.95 \\
195.12 \\
197.23 \\
199.29 \\
201.29 \\
203.23 \\
205.12 \\
206.94 \\
208.70 \\
230.40 \\
232.04 \\
213.60 \\
215.10 \\
216.52 \\
213.87 \\
210.14 \\
220.34 \\
221.44 \\
222.46 \\
223.38 \\
224.21 \\
224.92 \\
225.53\end{array}$ & $\begin{array}{l}0.2241 \\
0.2109 \\
0.196 \\
0.183 \\
0.172 \\
0.161 \\
0.151 \\
0.141 \\
0.132 \\
0.124 \\
0.116 \\
0.108 \\
0.101 \\
0.094 \\
0.088 \\
0.082 \\
0.077 \\
0.071 \\
0.056 \\
0.062 \\
0.057 \\
0.053 \\
0.049 \\
0.045 \\
0.042 \\
0.038\end{array}$ & 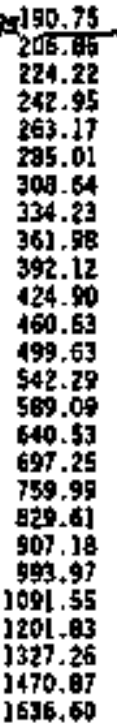 & $\begin{array}{l}159.9 \\
167.1 \\
164.9 \\
162.7 \\
160.5 \\
158.2 \\
156.0 \\
153.7 \\
151.5 \\
149.2 \\
146.5 \\
144.7 \\
142.4 \\
140.1 \\
137.7 \\
135.4 \\
133.1 \\
130.7 \\
126.4 \\
126.0 \\
123.6 \\
121.2 \\
118.8 \\
116.4 \\
114.0\end{array}$ & $\begin{array}{l}57.5 \\
62.9 \\
62.6 \\
62.7 \\
62.7 \\
62.8 \\
62.0 \\
62.9 \\
62.9 \\
62.9 \\
62.9 \\
62.9 \\
62.9 \\
62.1 \\
62.0 \\
62.7 \\
62.5 \\
62.4 \\
62.2 \\
62.0 \\
61.7 \\
61.4 \\
61.0 \\
60.6 \\
60.1 \\
59.5\end{array}$ & $\begin{array}{l}176.4 \\
174.5 \\
172.5 \\
170.5 \\
160.5 \\
166.5 \\
164.5 \\
162.5 \\
160.5 \\
158.5 \\
155.6 \\
154.6 \\
152.6 \\
150.5 \\
148.7 \\
146.7 \\
144.7 \\
142.7 \\
140.7 \\
138.8 \\
136.8 \\
134.5 \\
132.9 \\
130.9 \\
128.9 \\
126.9\end{array}$ \\
\hline
\end{tabular}


HNF-SD-TWR-AOA-AOI

Revision !

This past inkmitionally leht blank. 
HNF-SD-TWR-AGA-001

Revision 1

\section{APPENDIX D}

\section{WASTE TRANSFER SYSTEM ENGINEERING REPORT}


HNF-SD-TWR-AGA-001

Revison!

This grage irheduonally keft thark 
HNF.SD-TWR-AOA 4001

Reyiston 1

\section{APPENDIX D \\ WASTE TRANSFER SYSTEM ENGINEERING REPORT}

\section{D1.0 INTRODLCTION}

\section{HACKGROUNb}

Cleanup or the 177 underground hazardous waste sternge tanks is part of the current Handoxd Sile missions. The U.S. Departratenl of Energy (DOE) is changing the way that business is being performed at the Hanford Site. The DOE's new stuategy for treatuncent of the Henford Site tank waskes encompasset the use of privalization condrachors (Grumbly 1996)]. Under this. capcept, the DOE would privartze the ureatrient of the Hasford Sile lank wastes, including the design, parpiuing, construction, operation, decontamination, and decommissioning of equipment and fecilities.

The privalization couturelors will receive payment for low-Belivily wasie (LAW) tremmen services based upon the quanity of sodium incorporaled into the inmobilized LAW, consisten wilh the provisions of the Request For Proposal (RFP) (DCE.RL, 1996). To detemnine

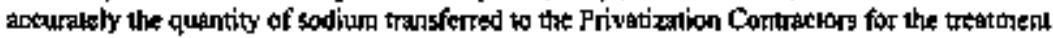
and to comply with the transfer condilions eqlablithed in the RFP, tarks 241-AP-102 and

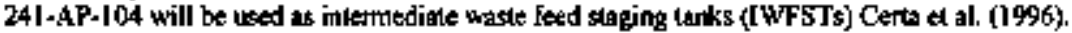

The dispogal propram asgumeg that one Privatizatios Contractor will process all of the high-kevel waste (HLW) oxikes from tanks 24I-AZ-101, 24I-AZ-102, and 24I-AY-102 (thal will be $\mathrm{n}$ mix of 241-AY-102 and 24]-C-106 tank combents). The wathed sluxigns will be uransferted from these three angite waste larks to the privatization contractor's High-[eve] Processing Facility. The privatization comusctor will provide a lank for receipt of the waghed sudges; an exigiting donble-shetled tank (DST) will not be uged for this funclion.

\section{D1.2 AKSUMPTIONS}

The folbowing agramptions have been made in the anglysis of the IWFSTs waske trasfer sytters oplions:

- Tarks 24I-AP-I06 and 24 I-AP-108 wijl be used by the privatizalion contraclorb for receipt sind lag storage of LAW feed solulion (DCE-R2 1996).

- Tanks 241-AP-102 and 241-AP-104 ajll be used as the [WFSTs (Certa et al. 1996).

- The waste feed solution will be transferred via the modified $5 \mathrm{~N}-650$ transfer line. 
- The HLW uamsfer lune will drals lroth the SN-650 to the pnvalzation conitacior's

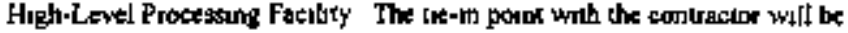
detemined upor completion of contract negotjalions

- The puping design temprature is $93^{\circ} \mathrm{C}\left(200^{\circ} \mathrm{F}\right)$ and dre ploing design presture is $28 \mathrm{MPa}(400 \mathrm{psc})$

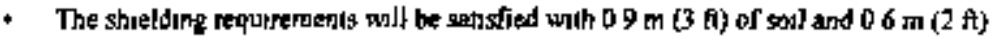
unck cower blocks

- Phase I privalization will be finished June 2011

- The HLW whll not be stored in tanks 241-AP.102 or 241-A.P-104 


\section{Revı\$়ı̣n 1}

\section{D2.0 SUMMARY}

The objectuve of this report was 10 complate optlons for transfinng LAW via the SN-650 Ine to tank 24)-AP-102 or 24I-AP-104 Tank and transfernng HL W va the SN-650 lune directly to the privatazalion contractor's High-Level Procesting Facility

Option 1 instailed a new valye pit north of tank 24I-AP-L102 wih a Jumper artangement lo provide the required moving capabylices Opuon 2 looked at usqug the excosung 24l-AP-O2D

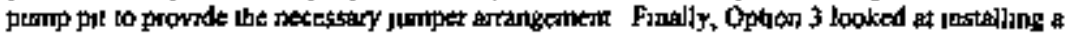

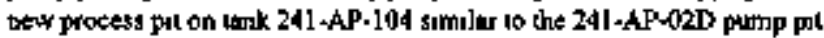

The analyges of the theee oplons have been surantarized in a labular form in Table D2-1 The crienou for detertaning the best option was based mimanky on cost and whelher the option met the topograpby requitements it Certa et al (1996)

Table D2.1 Matrix of Trassfer Bystetn Optoots by Decision Critenta

\begin{tabular}{|c|c|c|c|}
\hline Decuston antena & Optoon 1 New valvepit & $\begin{array}{c}\text { Oplion } 2 \text { 241-AP-62D } \\
\text { pump put }\end{array}$ & $\begin{array}{l}\text { Opuoin } 3 \text { New pt } \\
\text { on } 241-k P=109\end{array}$ \\
\hline Told cost & $\mathbf{s 2 , 8 0 0 , 0 0 0}$ & $S 1,900,000$ & $52,750,000$ \\
\hline Leak detection & 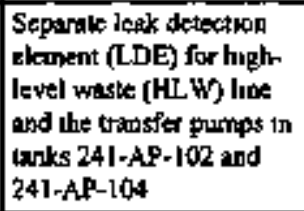 & $\begin{array}{l}\text { Corrmon LDE for } \\
\text { HLW line and the } \\
\text { urmsfer purmp on tank } \\
241+A P-102\end{array}$ & $\begin{array}{l}\text { Soperate LDE for } \\
\text { HLW Wure and the } \\
\text { transfer pumps in } \\
\text { tanks 241-AP-102 } \\
\text { Jand 241-AP-104 }\end{array}$ \\
\hline $\begin{array}{l}\text { Meeis altemsuve K } \\
\text { topopraphy } \\
\text { requirements }\end{array}$ & Yes & No & Yes \\
\hline Maintaumabslity & Easy acress & Tighl axcess & Eagy access \\
\hline 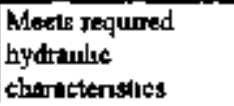 & Yes & Yes & Yes \\
\hline
\end{tabular}

Optiong 1 and 3 tre almost idenical in each of the dectsion enileria used All of the requirentetits of the iransfer system, incloding the lopoenphy are mel; and the cogls are siralar However, Option 3 is the preferted opton because the new prl on tank 241-AP-104 would allow

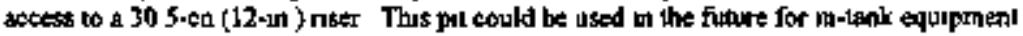
where as the pit in Option I could only be used for the seope of Phase I prvatization 
HNF-SD-TWR-AGA-ODI

Reyrsion 1

The page ustenlonnally left beank 


\section{D3.4 PURTOSE}

The purpose of this report is to define the design requrements for implensenuing upgrades

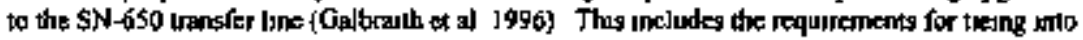

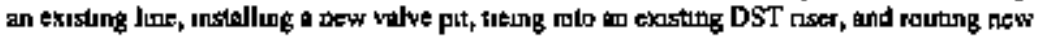
waste uransfer and dran lites

Three opteos nere considered for traysfeming $\mathrm{LAW}$ va the $\mathrm{SN}-6 \$ 0$ line lo the tanks 241-AP-102 or $241-A P+104$ and transferning HLW yat the SN-650 line dirnely to the privalizalion contracior's Bigh-Levei Processing Facility Thest ophions we presented to allow the best chouce for the final desugn Option I is the ongunal requested melhod, whue Ophions 2 and 3 werre coassdered for possable cogt sayungs The engineenng report shows piping plans, jumper arrangements, poping and instrument didams (P\&lD), and hydealic diagroms for the sygtem opuons In addition, cost estumales for the three different options are included 
HNF-SD-TWR-AGA-00]

Revision J

This page inlendionally left blank.

\section{D.8}




\section{HNF SD-TWR-AGA-60ㅏ \\ Revision I}

\section{D4.0 DESCRIPTION}

\section{DA.1 TRANSFER LINE FUNCTIONS AND REQUIREMENTS}

\section{D4.1.1 Safety Fancbon}

The tearsfer line shall be capable of ctonficung tank waste during trajifers The desgn. construction, and operalion of the transfer lunes stall estab]ısh mulipile berners that protecl public and fextrty persodinel from hazards associsted with the use of radroactive and other hazardous materials Releases of hamandous materials postulaied to occur from design basis eccidents (DBAs) shail be funned by designing the transter lineg so at lasst ond confinemeni

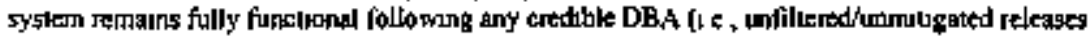
of barridow levels of such mokerals shall not be allowed followigg such acejdents) The urantifer line desgign shall provide attenuation features for postulaked accidenis (up to and including DBAs) that preciude afisite releases that would cause doses mote than the DOE 5400 seeres limets for public exposure Ia addition, to the extemi practicil, such releases shall be

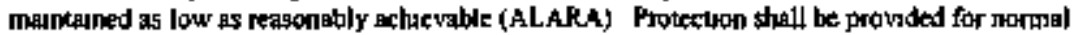

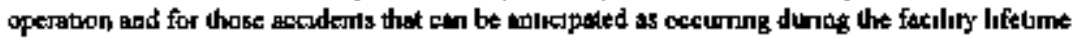
such as radidactive malental sptls

\section{D4.12 Qperational Foncting}

Gravily traned piping shall be installed with a slape thet results in a Erguld velocity of at

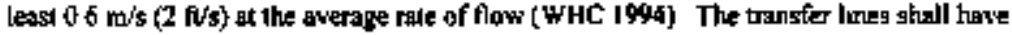

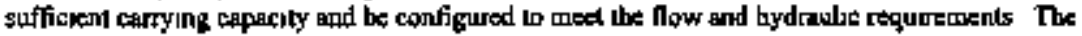

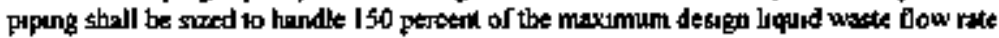
(WHC IO94)

The uaste purpabulity rule requires that the Reynolds aumber be greater than 20,000 with volure percent less than 30 peroent soluds for ann-roulune transfers (Fow]er 1995b) For the wriste propartes rviluated in Galbruth et al (1996) ths would requare a muimum vellocity of

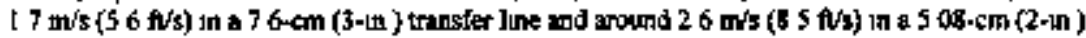
trathsfier Jube

Following a waste transforr through a transfer pripeltut, the wats gejeracor shall flush the uranter pipelune onth 2 volume of waler ibat is equal to the transfer pipeline volume (Galbrarth et al 1996)

The spectic gravity of the solution must be less than I 4I SpG If 1he specific granty is

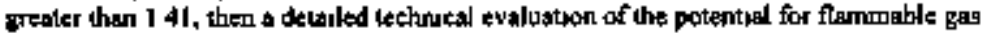
accumulation in the commingled wrote shall be performed (Oalbrath et al 1996 and Fowler 1995a) 


\section{D4.1.3 Physical Charncleristict}

The transfer lines thall be underground double-s:alled pupe (I e, primary pupe whthu an encasebent pipe). The transfer lines stall be supported apd potocted agannst phygical damage end excessive stress obe to settlemem, vabjation, expention of contracion The trangfer lines shall Ietminate al gozzles in the new irangfer valye put

\section{D4.1.4 Retitubility}

The dagign life of the urangfer lines shall be 25 years (Folules 1995a) The system desion shall provide for retundancy or diversity of componeals io meet rejiabalily requirements

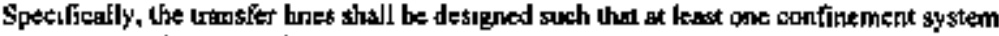
remains fully functional following any credible DBA

\section{M4.1s Maintaipntult'ty}

The design stull provide for roubne mejalenance and repur oc teplacencent of equpmen1 subject to fallure The transfer lines shall be dessgined co allow uspketrom, mantenance, and testag to ensure their continued finclionng and readiness for operation The design of equpment that must be located writun confinement systems shall allow for in-place mainvenance

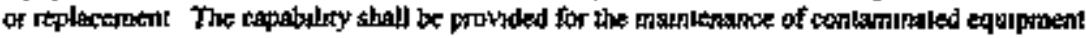

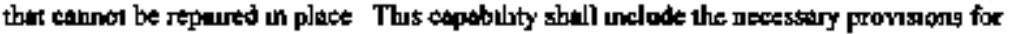
coufinement, veutilation, and waste control The design of process equpment sball unklude

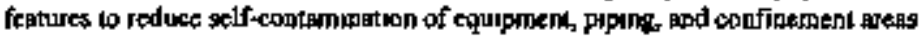

\section{D4.2 PIPING CONSTRAINTS}

\section{D4.2.1 Design Requireneats}

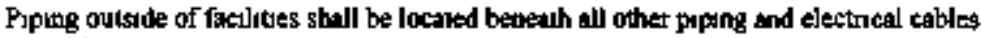

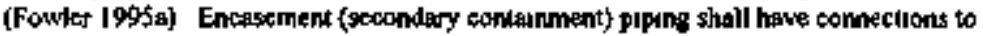

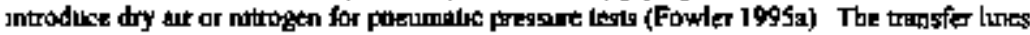
shall be of fully weldad construxion Taps for instrumendalion, kest cormechons, and similar sinall demeter pupe shall be made on top of the pipe (Fowler 1995a) All components of the

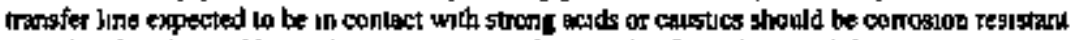

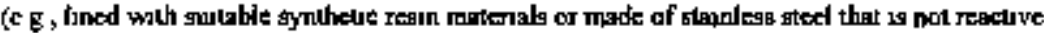
with the wasles\}) The use of traps in radioscure liqud waste lites should be avended and the

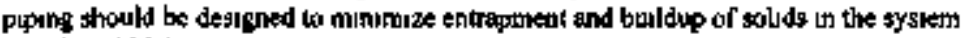
(Fowiter ly95a) 
HNF SD-TWR-AGA-0O1

Revision 1

\section{D4.22 Design Lapda}

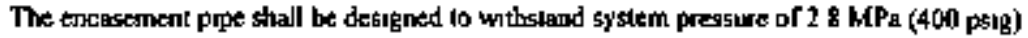
The secothdery pipe thall be evaluated for the design lemperanure of the pormatry pipe unless lower lemperatures are fistified by thermal analysts The pramary and secondary pipees shall be dessgned for dead loads aggociated with the self-ureghl of the prpes and the soll overturden as applicable The trangfer lores ghall be desugned for an Amencen A s5ociatonn of State Highway Transportation Officuls (AASHTO) H20.44 whetl loadmg, and Amencan Rulway Engineers Assocsaunon (AREA) Cooper EB0 rasl koding at ral crosings, and a 100,000 th crate loading in the tank farm area (Wagentlagl 1995) Promery and seconkary preses shall be desugned for the interation and transfat of losds beiween the primary and secondary pupts at the reacuon sorpport poknts of the purintry papes

The transfer lwes shalt be designed for the applicable response spectue of CCLOAD-0I The 5 percent daripung tesponse specunum shall be used wheth dynamic evalations are performed Prpes exposed lo son] shall be desigred for seismic induced stesses resultug from selsric wrves Peak ground velectly shall be caleulated io GCLOAD-0] SessanIC wave velocities for the determination of selsmic stran shall nat be kess than $610 \mathrm{~m} / \mathrm{s}(2,000 \mathrm{ft} / \mathrm{s})$ The

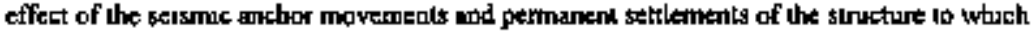

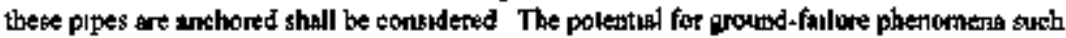
as soil liquefacuon, land slides, gross surface settlement, collapse of wolds, and instabliny of soll sloper shall be considerred in the deargo of urdergroubd prosess propes

\section{D4.2.3 Burnat}

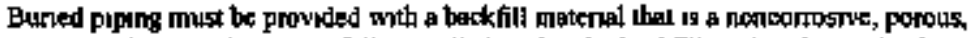
homegeneous gubgiance that is carrfully unsualled go that the bockfill is placed completely around the piping and cormpacted to ensare that the pupeng is fully and undfocmly supported

\section{D4.2.4 Cothodie Protecilon}

The dagign of cathodic proteston for the thew transfer ltes shall use the prectices described un NACE Standiond RP-02-s5 as gudelines un providong corrosion protection The exhodic provelion sysien shall be installed at the same troe as the piping system Connecuprs

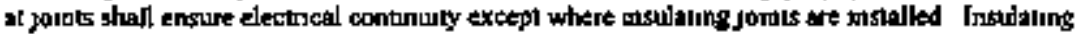
fornts shall be used to electneally isolate protected sections from non-protected gections and from neidhboring melollic structures Tegt slatwons shall be powided at safficient indervalg along the mping system to evaluate the performance of the calhodic protection system after installation

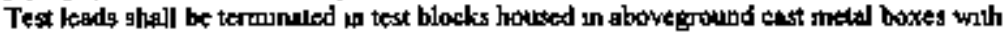
removible covers Thete kest stalions thall be kecated in areas nol exposed ta iraific or grass muswers and properly idenuified 
HNF-5D-TWR-AOA-OOI

Revision 1

D4,3 VALVE PTT FUNCTIONS AND REQUIREMENTS

\section{D4_s.1 Vake Pit}

The valve pit shall be constricked of reinforced conkrete and designed in accordance with ACl-349. The valve pit shall be painted with a protective coating or lined with 30dL stainless sket. The liner shall be designed to confine contamination tin accordance with WAC-173-303-640.

\section{D4,3.2 Vave Pit Centing}

Valye pits shall have coalings to ensure the inlegrity of containgend the of decontamination. Access penctrations ghall be sea|cit to provide containnent. The prolectve coating is specified as os installation location, corrosion resistance, substrate eleaning and preparatton, method of application, and other parameless. This is in direct conmpliance with DOE Oriter 6430.1/ that stales that where tadioective maletials are handled and contamingtion car occur, washable or strippable finishes stall be used on walls and floors. The primary furctional intertace for the pit coatings is to protect the valve pil that eristighes a secondary containmenl required for the trangfer lines and connections. The coatings enable the secondary coaling to be

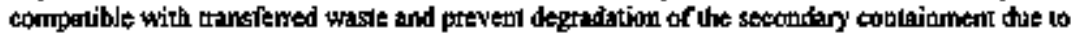
pbystcel coulact with the waste (40 CFR Part 265 and 40 CFR Part 280).

The prolective caoting stall hove the following physical characteristics:

- Contheous. The layer of protective coatias shall got contain any holes, seams or defects Applicestion of the coating shall be done witheut any breaks in the application process that would lead to a seam between sel and uncired material.

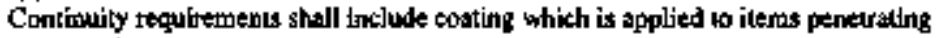
into the pit.

- Appliretion Hright. Protective costing shall be applied to a kevel equal to or above where the thozakes enler the pit.

- Corroslos Resiatinece. The prolective caating shall be resistant to the randard decontamination solutions lissed in ASTM D-3912, Figura I. Chernical resistance testing shat be in wecordanoe with ASTM D.3912 or an equivalent stonderd. Test samples stall be prepared in accordance with ASTM D-5139. Exposure of the coating to the service conditionss shall not nesult in pitting, soughing, peeling, or any other darage. 
Ręviekn $]$

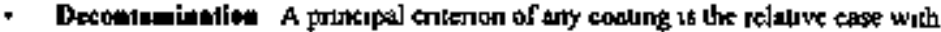
whicb radioactive conlasination can be removed, lypically meataned by the decontamination factor (DF) A coatung that demonstrates a mommum DF of 50 as detemiped by ASTM D-4256, Method A The DF after an initial wash will 120 io 160 pto dionical agent sprays should be arotind 20

\section{D4.3.3 Vake Pit Leak Deterbios}

Valve put sumps shell have nsialled letk detedors Legk detection instrumentation is required to derect leaks and display leak dekecuom status information (WAC-173-303, 40 CFR 265, DOE 3820 2A) Leak detecton systerts that will be used to alert operviors of leals or 10 activate aubmantc ghut-off or alam systems stual be capable of detectuge a minimian leak of 3 gallons per hour al 10 pounds per square unch (psig) line pressure withn one bour (WAC-173-303, Seetron 350, 3)

The kak delection system stall be capable of deteetnis the fallure of the pnimary contangenl suruture or the presence of any release of dingerous waste or accumulaled liquid m

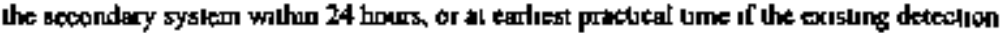
vechnology ot sile characteristics wy]l mat allow delection of a release within 24 hours (WAC-I 73, Secuon 640,4 and 40 CFR 265)

The kak detection system shall be eapsble of detectug the leak rate with a probablity of delection of of 95 and a probability of falce alarms of 0 os The gystems shall be designted to allow for perioduc catibrahon and ease of access for repetur and replacerment of comportents

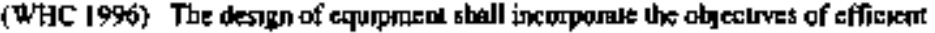

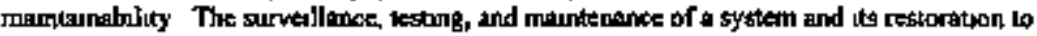
operational effecluveness shal] be achueved at minimur life-cycle cost whit a mubumuta level of support services LCRL 15673 shall be consudert for system desan (DOE 6430 IA 1300-12 4 10) The system shall provide capabylity for remote mantenance and ouher appropnate lechuruques to maqntan personncl rahalipn expogure ALARA (DOE $58202 \mathrm{~A}$ Clappler $1, j$ o(2)(p)

\section{D4.3.4 Valve Prin Cover glokks}

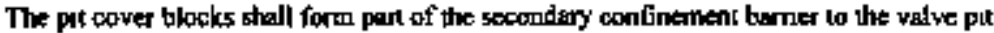
and are requed to confine any potentud release of hazadous molenal trom ibe prutuary confincmesil (DOE 6430 IA) They shall prowte protection from an ingress of forejgn matier into the pit enclogure The pil cover byocks shall be designed as an indegral part of the pot struche to gan access to equipment within the prt for operitional or mantentake putposets (DOE 6430 IA) They shald be designed to sheld operalossimaumanners from radiation sources Wnithin the pit (DOF 6430 1A) The integnity of the socondary continement shall be mantamibte through all norctal operaluots, andicipaled operaional occurrences and for the DBAs they are 


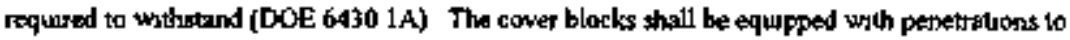
faciluace operallow and for montenanke of valves They shall te equipped whth legends to indreale rolling options and valve posilions The cover blocks ahall be equipped with lifting bolls of factlitate resrovel of the block by crane The cover blocks sthall have a spectal prolectuve coatung to prevent the migration of contaminadon and inprove the eage of decontamination

\section{DA.A PROCESS PIPING MODIFICATIOHNS}

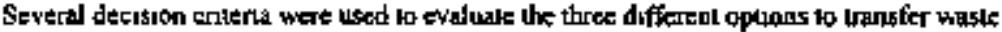

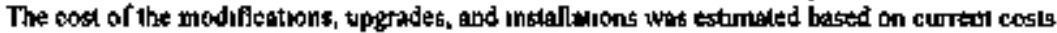
Manntanability was based on ease of access and spare room in the pit The abulity of the lines to dran by gravity to the tank for LAW or to the pnvate contractor for HLW was a condriton of desagn acetplanse The abihty to perform sumultaneous inangfers of LAW from tanks 241-AP-102 or 241-AP.104 and HLW from SN-630 to the prrvate contractor was designed as a

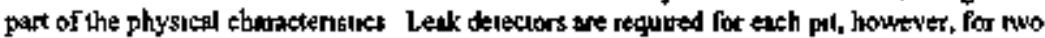
opt|cos the lask detectors are shared wnh another gystern to the put

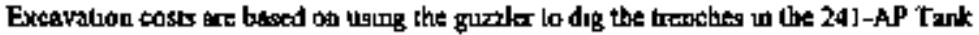
Farm These costs for using the guzpder are tesinated from those uncumbd by Project W-151 The estimale for the HLW' transfer line is tared on ternubaing the line 10 feal outsode the

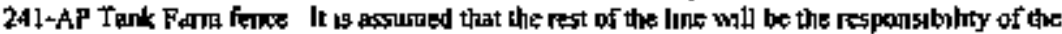
HLW prrvatization contracior The proposed roulmg of the HI W transfer Ime from the val ye pt to the provatizanon contractor is stown in Sectoon ? 0, Figure D?-17?

\section{D4.4.I Option One}

Option 1 would locale a riew valye pal on the SN-650 line proc to $n$ feeding into tank 24]-AP-102 Tark A plas vew and a P\&ID for Opton 1 are shown In Section I D. Fugures D7-1 and $07-2$, respectuvely The new valve prt would be localed on the notheagl edge of tank

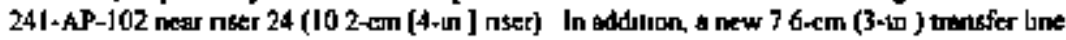

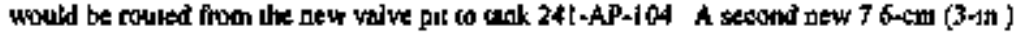
transfer lise would be rouled from the new valye pil to the HL W prvatizalion contrachor Algo, a gew 5 l-cm (2-w) dran line from the valve put floor dran would be routed to a gpare nser on lank 24I-AP-102 The jumper arrangentenl in the new valve phl would allow LA W to be gall to enther tank 241-AP-102 or 241-AP.] 34 and allow HLW w be couted directly to the HLW

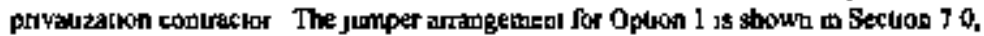
Figure D7-3, while hydraulic diagrams are shown in Figures D7-4 through D7-6 Option I is identical to Alternaluve K ag presented in Certs et al (1995) One of the key desdign features and

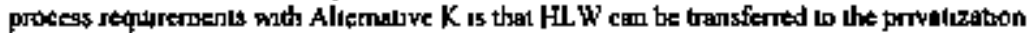
contractor's BLW Phocestitis Facilaly at the tame ture thal LA W is beine transferred from the

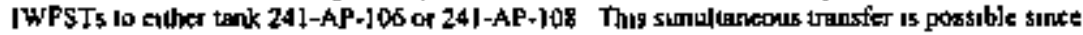
the two transfer routos do nol share any comrnon last detectors and, therefore, the routes can be 
isolaled in regardis to the masuer pump shuldown system. The tolil consuruetion cost for the work included in Option 1 is epproximately 32,890,000. This includes to coticrated cogt of excavatlon of \$432,000 using the Guzzler and a fabrication cost for the uew valve pit of 5350,000.

\section{D4.4.2 Option Two}

Oplion 2 would use the exising 241-AP-02D pump ph and alleviare the beed to build a new yalye pit. A plan vjew and a P\&iD for Option 2 are shown in Section 7.0, Figures D7-7 and D7.8, respoctively. The existing nozales is the purnp pil are all 2 in. and, therefore, all the jumpers would need to be 2 in. and the new transies lites wrould need to be redoced before tentering the pit. This would create additionat head losses corspared with that calculaled in Galbraith et al. (1996). In addition, to provide alt of the rouking requirements, the jumper arrangemert would be very congested and several contrections wauld nead to be firting-to-fining. This would not be a destrable arsargement when design loleronces of $\pm 1 / 32$ of at inch are required. The jumper arrangement for Option 2 is stown in Figure DT. $\$$, while hydradic

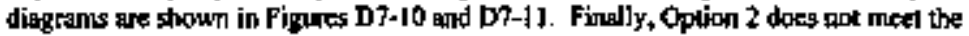
topagrapby requirements of Alternetfve $K$. The trentifer pump for tank 241-A.P.102 woutd ghave a leak detechor with the HLW routing. This would cause the master pamp shutdown system to stop both transfers if the leak detertor was alanied. The cosa estimane for this option includes returntug riser 24 on tank 24)-AP.102 to a spare riger condition. This riser was whete the existing SN-650 trangfer lincentered the lank. This is the least expensive of the three options

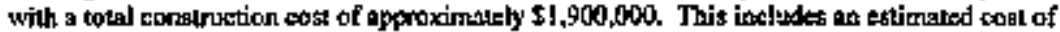
excavition of S354,000 using the Guzzler.

\section{D4.4.3 Optian Three}

Option 3 would locake a net prosess pil on 1enk 241 -AP-104 similur to the 241-AP-02D pursp pit A plan riew and a P\&ID for Option 3 are shown in Section 7.0. Figures D7-12 and D7-13, respetively. Stree this would be a new process pit, all of the problens mentloned in Option 2 would be elimineted. Primarily, the new pil would hove a watl that wowld separate the 12-in. riser for a trangfer pesmp from the valve arrangernen ko support the Phase $f$ transfer of LAW and HLW. Each section of the pit would hate a septralte leak delector to meel the requirements of Altemative $K$ and allow simulineous trassfers. The jumper arrangement for Option 3 is showm in Fipure D?-if, uhile hydraulic diagranes ane shown in Figures D7-is and D7.16. The todal construstion cost for the werk included in Option 3 is approximately $\$ 2,750,000$. The aturehed cosi estimare was based on fabricatins a pii similar in size to the

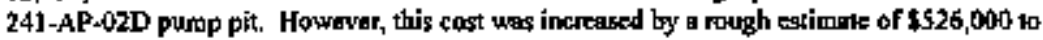
Pabticate a larper procesg pil with a separation wall. 
HNF-SD-TWR-AOA-OOL

Rev]s]on 1

Thes page unkentwondly kfi blenk 


\section{DSD CONCLUSIONS ANT RECOMMENIRATIONS}

Opton 1 has the bentefit of adequste foom is which to install new equipmenl Thus also transtales undo room for mantenance and repals work walbun the pit is the future Also, the valve pit would be new and upcontapinaled However, the opton would add a new struclute nithon the $6 \mathrm{l}-\mathrm{m}$ (20-A) exchusion $200 \mathrm{ne}$ of the latik In adduon, the only purpose of the new valve pnt would be wo support Phase I privatuzation Thes opiton meets the logography requerements to allow for ymul|artecus iransfers as diseussed in Certa et al (1996) the colal construcition cost of Opton I is appeoxmonately $\mathbf{5 2 , 8 0 0 , 0 0 0}$

Opton 2 would regmere a scan of the put walls before coce dryling to find the tetar and other possible obstruetions It will allow kess flexibality for desagn mod:fiegtions In additoon,

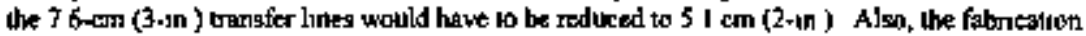

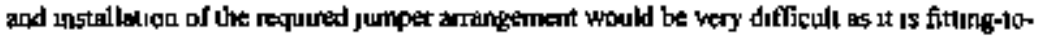
fitting, is ilt in the pit The purmp pit will tequre decondamungton before constructron work inside the put can star Lo additon, the jumper amangemenl would make the ponp pat very

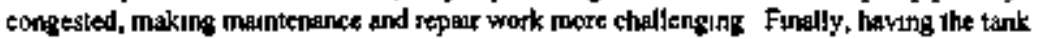
241-AP-102 transfet pump and the HL W routung on the same pal would mean that they use the

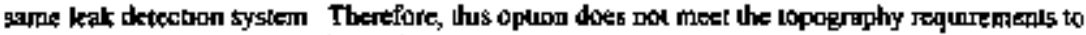
alkw for sumuluseous transfers. The lotal consinection cost of Option 2 is oppraxmittely st $, 900,000$

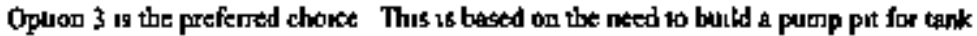
241-AP-104 (sere Appandix A), the pu coutd exstly be edlarged to accommodele the transfer line valves and jumpers By combuning lasks, constructaon costs conuld be reduced over builder a new valwe pit (0plion 1) In addition, adequite room for mantitenance and repaur work can be epcorporated unto the degign of the new pump put instead of using a crotwded existing pump pat (Ophoo 2) It also provides a cleaner routing of the transier lines A wall separaling the HLW rouling and the transfer purng meets the topography requiremedis of Ahemaluwe $K$ Finally, the

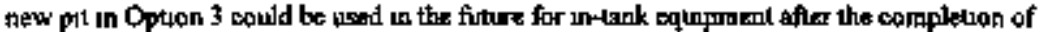

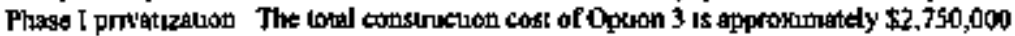


HNF-SD-TWR-AGA-DOI

Rev15109 I

This page intent|onally left blank. 


\section{D6.0 REFERENCES}

40 CFR Pan 265, 1996, Inierm Siolus Brandards for Ohwers and Openators of Hazardous Waste

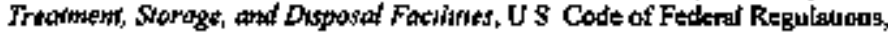
US Nuctear Regulalory Comrnisson, Washington, DC

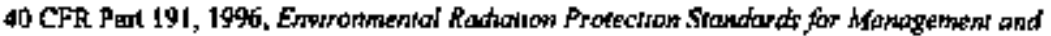

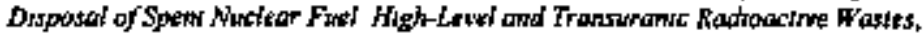
US Code of Fedteral Regulations, US Nucletr Regulatary Commitson, Washington, DC

40 CFR Part 280. 1996. Techwicol Shandards and Correctrue Action Regumewents for Ohemers and Operatarg of Uadergroutt Storage Tankt, U S Cade of Fedenal Regulations, U S Nuclear Regulatary Commresom, Washagion, DC

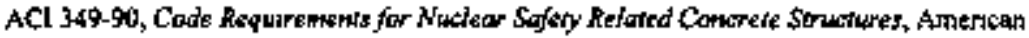
Concrete Intitutule, Detroul, Minchigan

ASME B31 3, 1996 Edrtion, Petroleum Refinery Pipung, Amencan Soctely of Mechatica] Engiaters, Farriekl, New Jersey

ASME B31 1, 1996 Edrtion, Chemead Plant and Petralew Refinary Pppmg, Amencen Soctery of Mechanneal Enquneers, Fanfield, New Jersey

ASME, B 16, I996 Edition, Finngs, Flanges, and Valves, Amerkan Seciety of Mechanucal Enguteers, Farfield, New Jersey

ASME B16 9, 1996 Edition, Factory Made Wrought Steel Boll Weldong Futtmgs, Amencan Sociely of Mechankal Engomets, Farrield, New ketsey

ASTM D-3843, Practice for Oualty Assurance far Provectue Coatergs Applsed fo Nuclear Focutenes, ASTM, Phladelphur, Penusplvamia

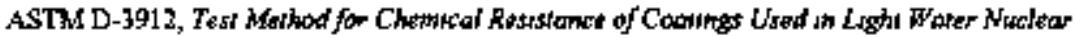
Power Plants, ASTM, Pthladelphia, Penssy]vania

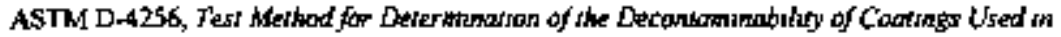
Light Fater Nisilear Power Piants, ASTM, Phuldeliphut, Pennsylvatis

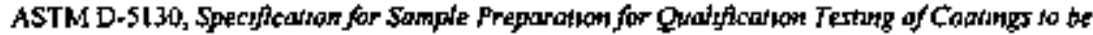

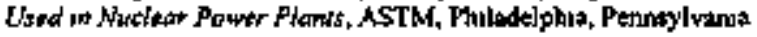




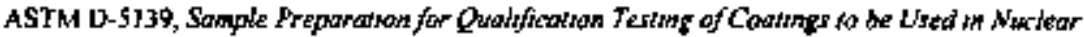
Power Plants, ASTM, Pholadelphia, Penmsy]vamis

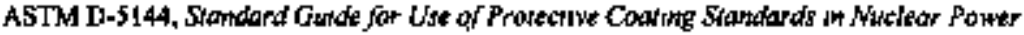
Plank, ASTM, Pholedelphua, Pennsylvanla

Certu, P J, 1996, Prelinenary Lonw-Level Wate Feed Statgrng Plan, WHC-SD-WM-RPT-210, Rev 0, Weglinghouse Hanford Company, Ruchland, W/ashingtont

Certa, P J, W H Grams, C M MaConville L W Shelon, and E J Slathauge, 1996, Low Lebel Waste Feed Soging Flon, WHC-SD-WM-RPT-224, Rev 0, Westughoulse Handord Compsuy, Ruchland, Waghingion

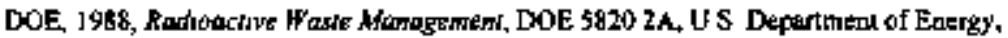
Washunglon, D C

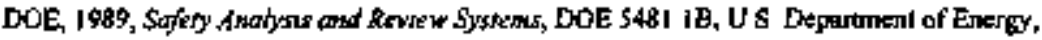
Washinglon, DC

DOE, 1989, Gemeral Degrgn Cruterna, DOE 6430 1A, U S Departmen of Exergy, Waşhaglon, D C

DOE, 1992, Radologrcal Protectian for Occapattont Warkers, DOE 5480 11, US DepartmenI of Energy. Washungton, D C

DOE. 1990, General Emyronmentol Pratecthon Program Requirements, DOE S406 1, US Department of Earrgy. Washerginn, D C

DOE-RL, 1996, TWRS Privenizatron Requesr for Proposal Solıchtatum Number

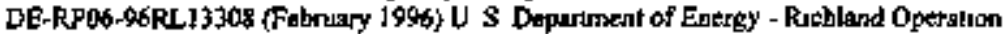
Office, Ruchland, Washngion

Evens, R A, 1994, Redilogical Desrgn Gunde. WHC-SD-GN-DGS-3001 I, Rev D, Wesunghouse Hanford Cormpany, Ruchlent, Washungton

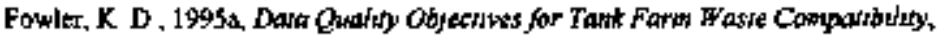
WHC-SD-WM-DQO-001, Rev I, Weslunghouse Hanford Company, Ruchland, Wathington

Fouler, K D, 1995b, Tank Farm Waste Transfer Compatibltiy Program, WHC-SD-WM-OCD-015, Rev 1, Westonghonse Hanfard Comptry, Rechland, Washungion 
Galtwaquh, J D, T B Sadzane (ICF KH), and J R Nicholson (ICF KH), I996, Decision

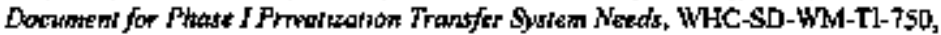
Rey 0, Westinghouse Hanford Company. Ruchland, Washungton

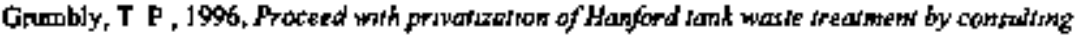

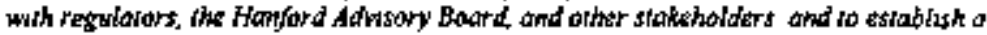

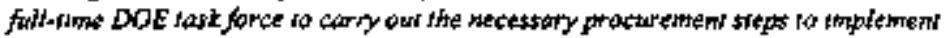
priwatization, letier to the Department of Energy Secretary. US Departraent of Energy. Washongton, D C

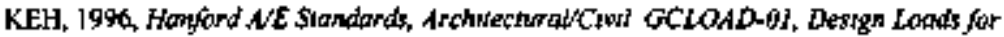
Facritstes, KEH-MA-22, Kasser Enguneers Henford, Rechland, W'bshington

Mitluken, N J, 1993, Dopble Shell Tank fnktum Sajoty Egrarpment Lust, WHC-SD-WM-\$EL-026, Rev 1, Westughouse Hanford Company, Ruchtand. Washspron

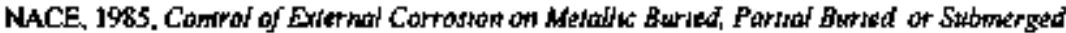

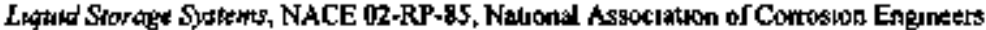

Smuh, G L , 1994, Hanford Site Tank Form Fachitses Bwersm Safery Basts, WHC-SD-WM-ISB-0OI, Rey 0, Westunghouse Harford Company, Ruchland, Waghington

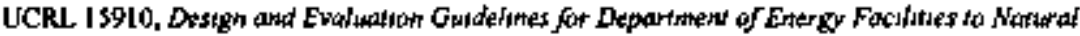
Phenomena Hazads, Lawrence Livermore Natonal Laboralory, Liyermore, Callifomua

WAC 173-303, Washengron Dengtrous Wase Regulateons, Washungton Adminustralive Code, ts anmended

WAC 173-360, Undergroumd Sorage Tonk Regwations, Washungton Admumtoraive Codk, as ammended

Wagenblass, G R, 1997, Desıgi Landy for New Linderpround Double Sheth Tanks and Asrociated Undergrowutd Process Psphtg, WHC-SD-GN-DGS-30008, Rev 0. Wesinghtouse Hanford Conpany, Ruchland, Washington

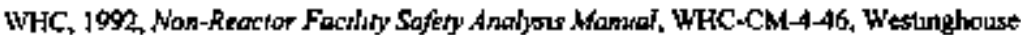
Hanford Company, Ruchland, Washington

WHC, 1994, Radrologrod Destgh Gude, WHC-SD-GN-DGS-30011, Weslinghouse Henlord Company, Ruchland, Washungion 


\section{HNF-SD-TWR-AGA-00I}

Revision I

WHC, 1995, WHC Oecupotiont' ALARA Progpan, WHC-IP-1043, Wegtigghouse Henford Company, Richland, Washingoru

WHC. 1996, Evvironmentaf Compliance, WHC-CM-7.5, Westinghouse Hanford Company, Richland, Washinglon. 


\section{HNF-SD-TWR-AGA-DO]}

Revision 1

DT. FIGURES

D.23 
Figure D 7 AP Tank Farm Site Layourt Opton I

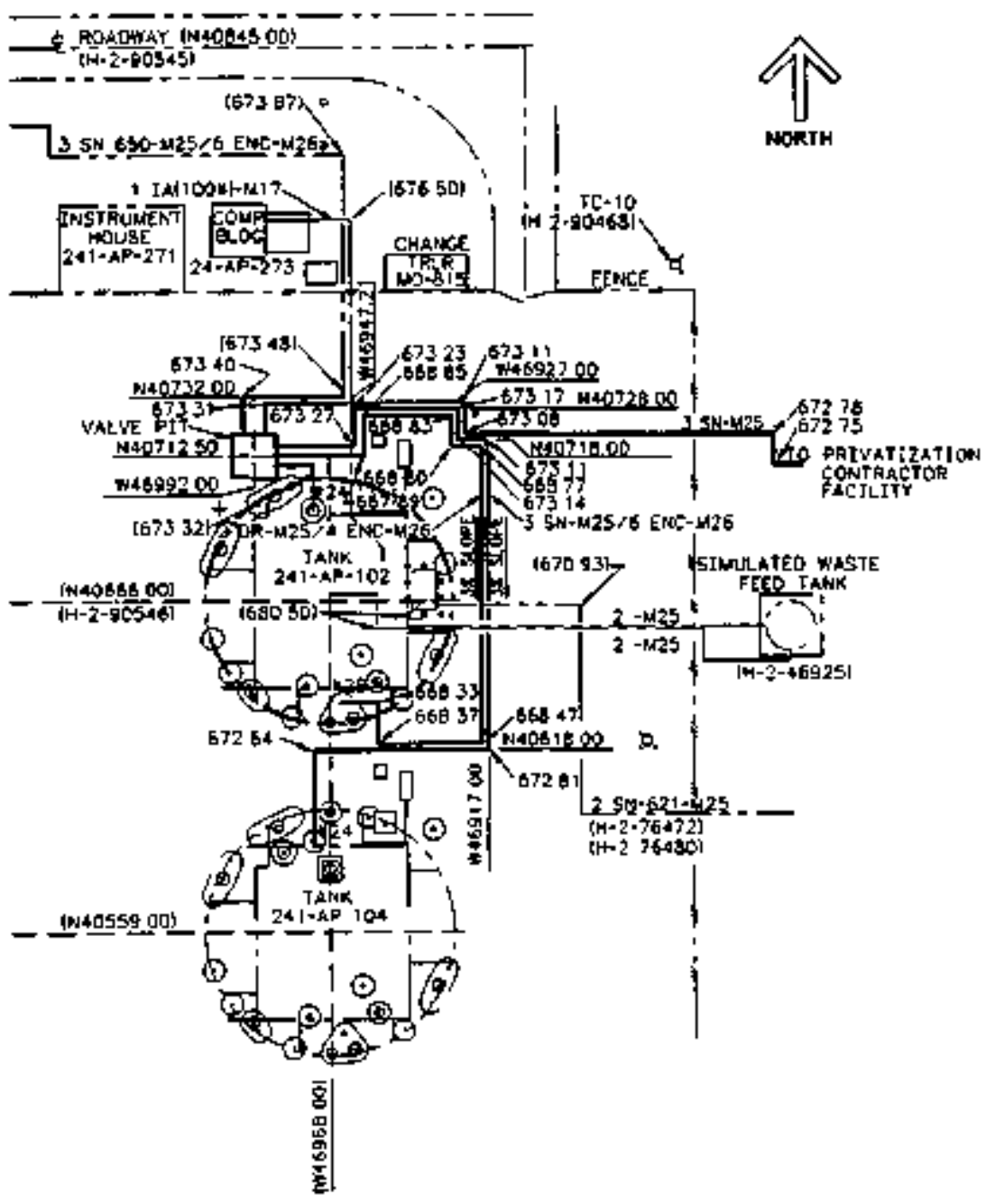


Fięure D7.2. Piping and instrumentation Dikgram: Option I.

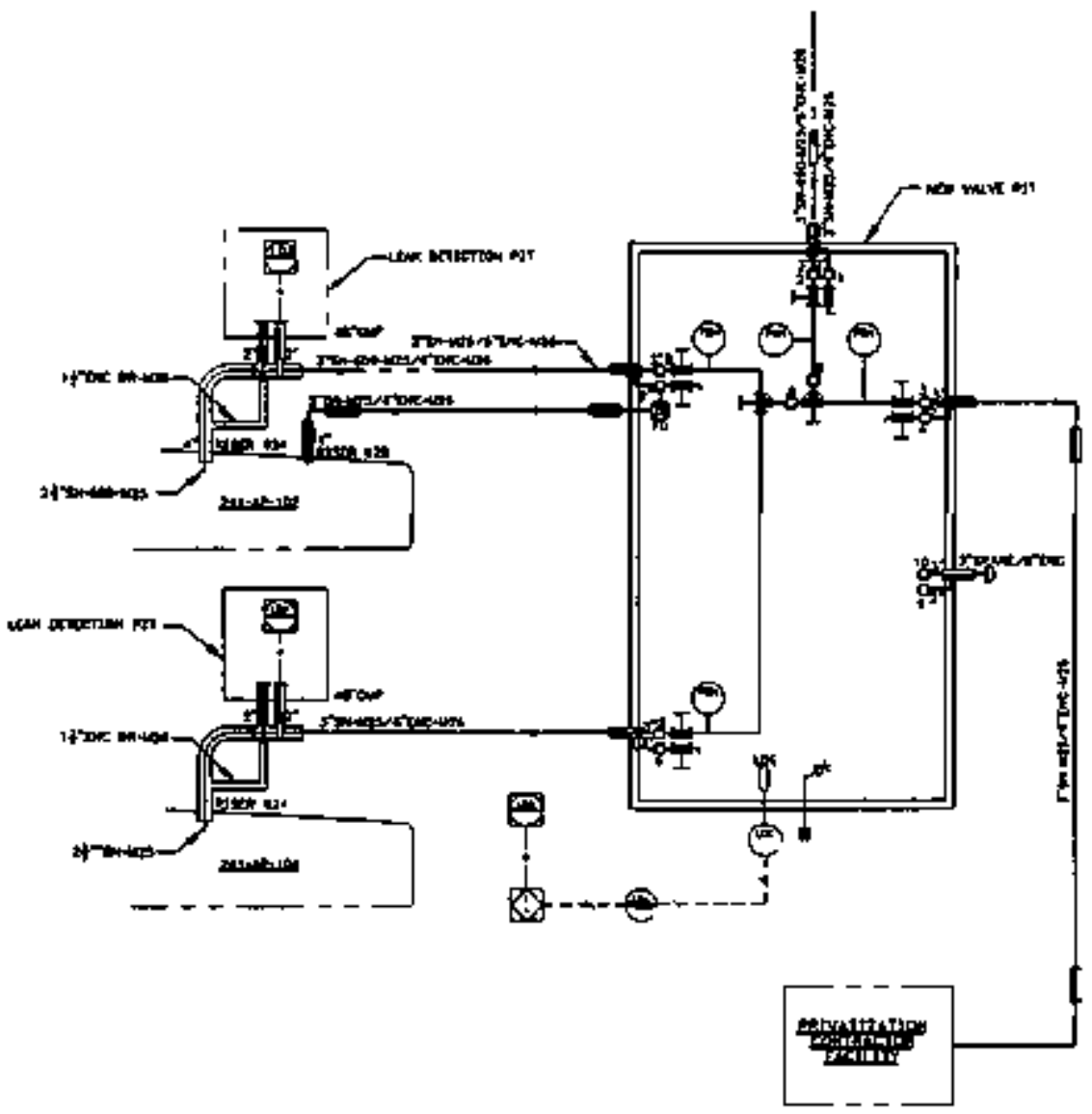




\section{HWF-SD-TWR-AGA-COI}

Rev15100 I

Figure D7.3. Valve Pal Jumper Arrangemeox: Option 1.

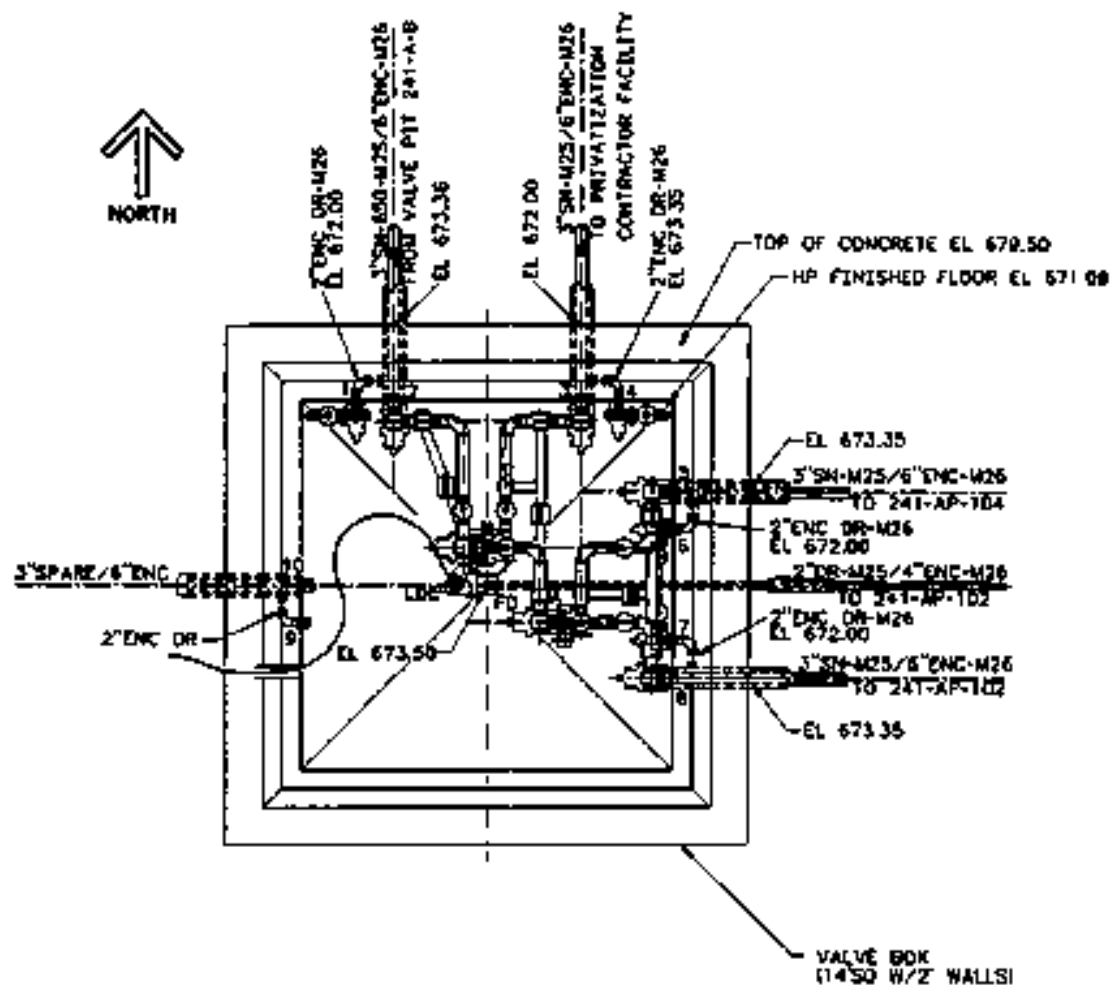

TRRADE EL GTO OOI 
Figure D74. Valve Pit ka Tank 24I-AP+102 Hydraulic Diagrant: Option 1.

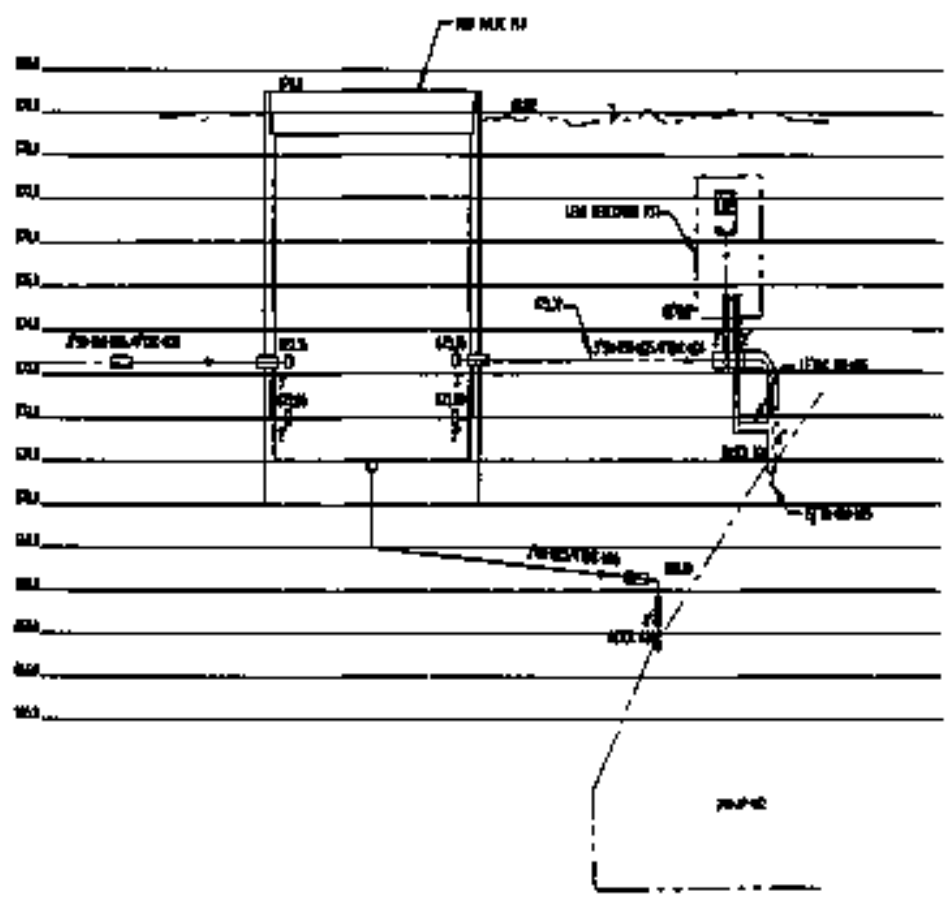




\section{HNF-SD-TWR-AOA-COI \\ Revision I}

Figure D7.5. Valve Pit to Tank 241-AP.104 Hydraulic Diagram: Option I.

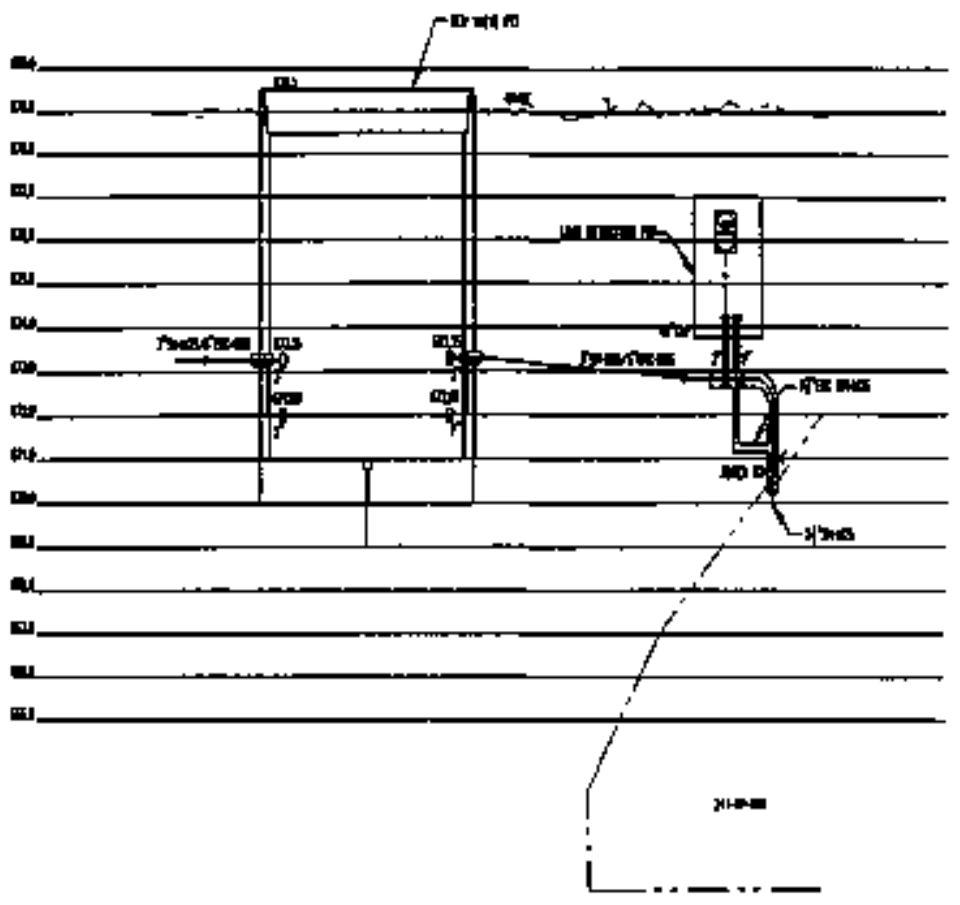

.

D-28 
Figure D7-6. Hiph-Levẹ Waste Transtiter LJne Hydraulic Diagram: Optipn l.

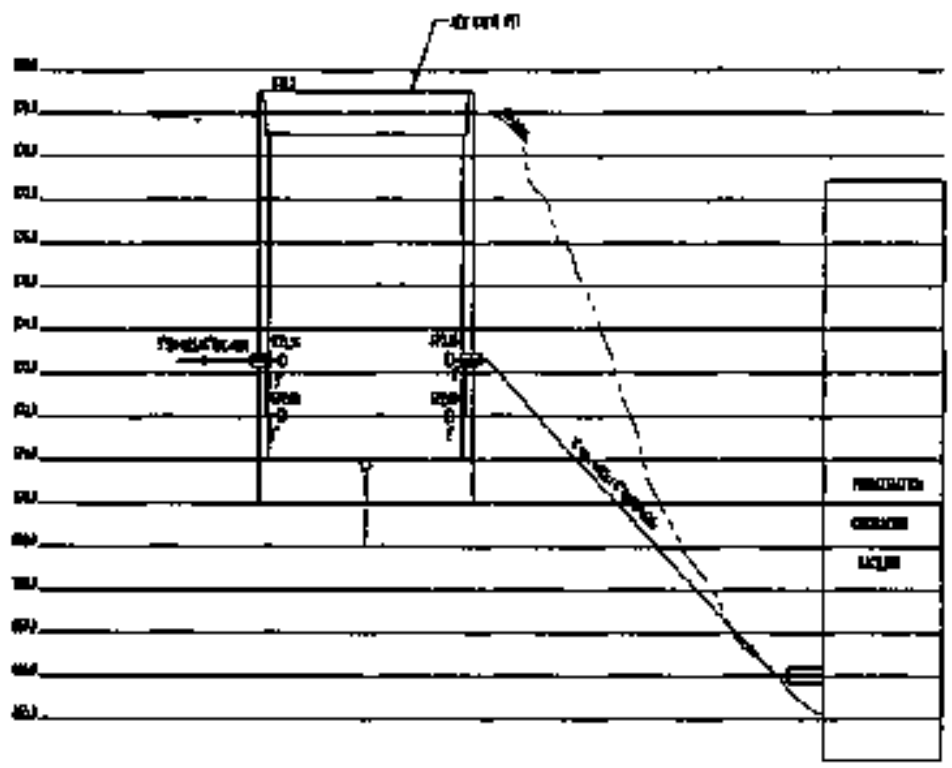




\section{Revision I}

Figure D7.7 AP Tent Farma Site Layout Dption 2

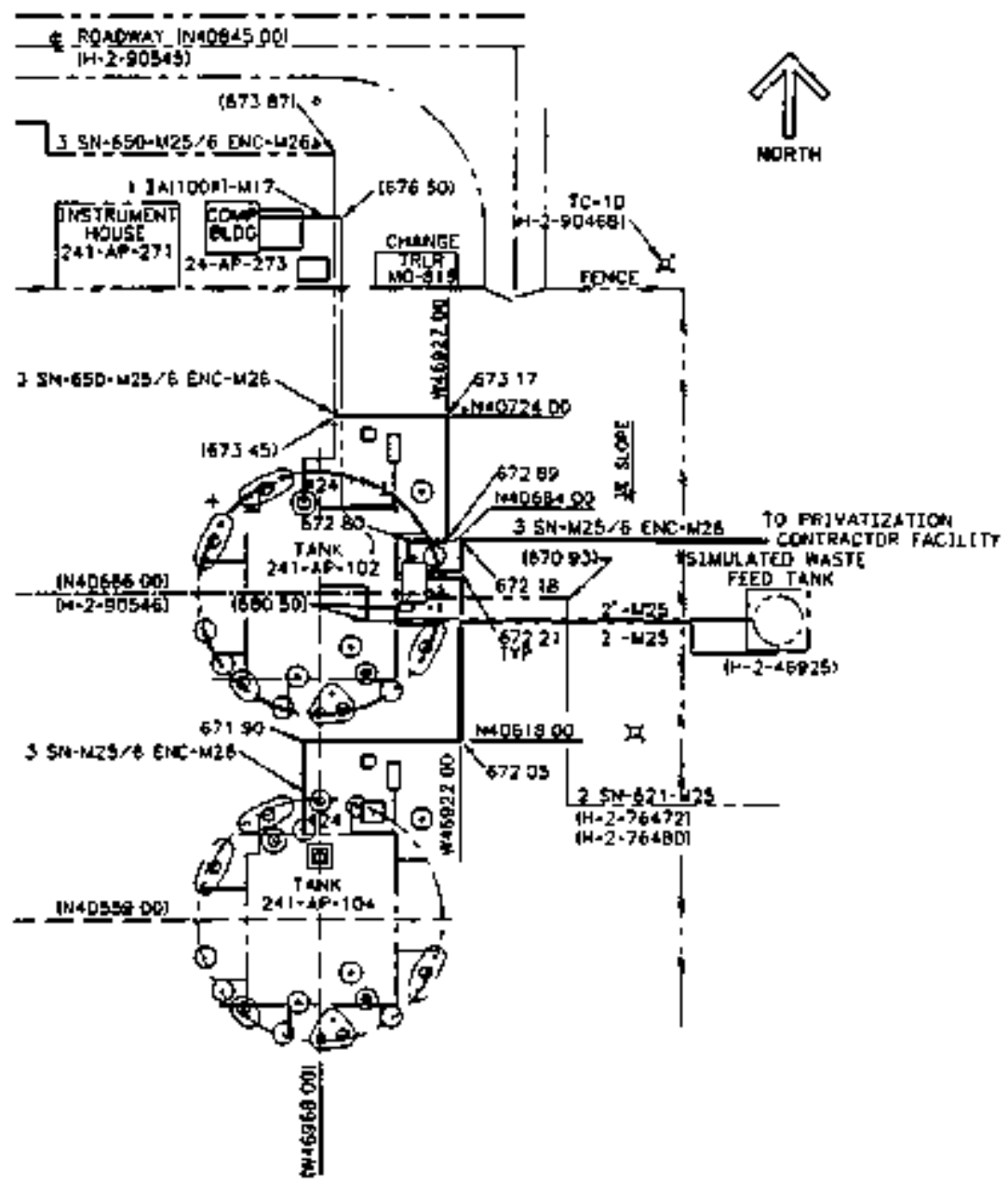


Figure D7-8. Piping and lostrumentation Diatgram: Oplion 2.

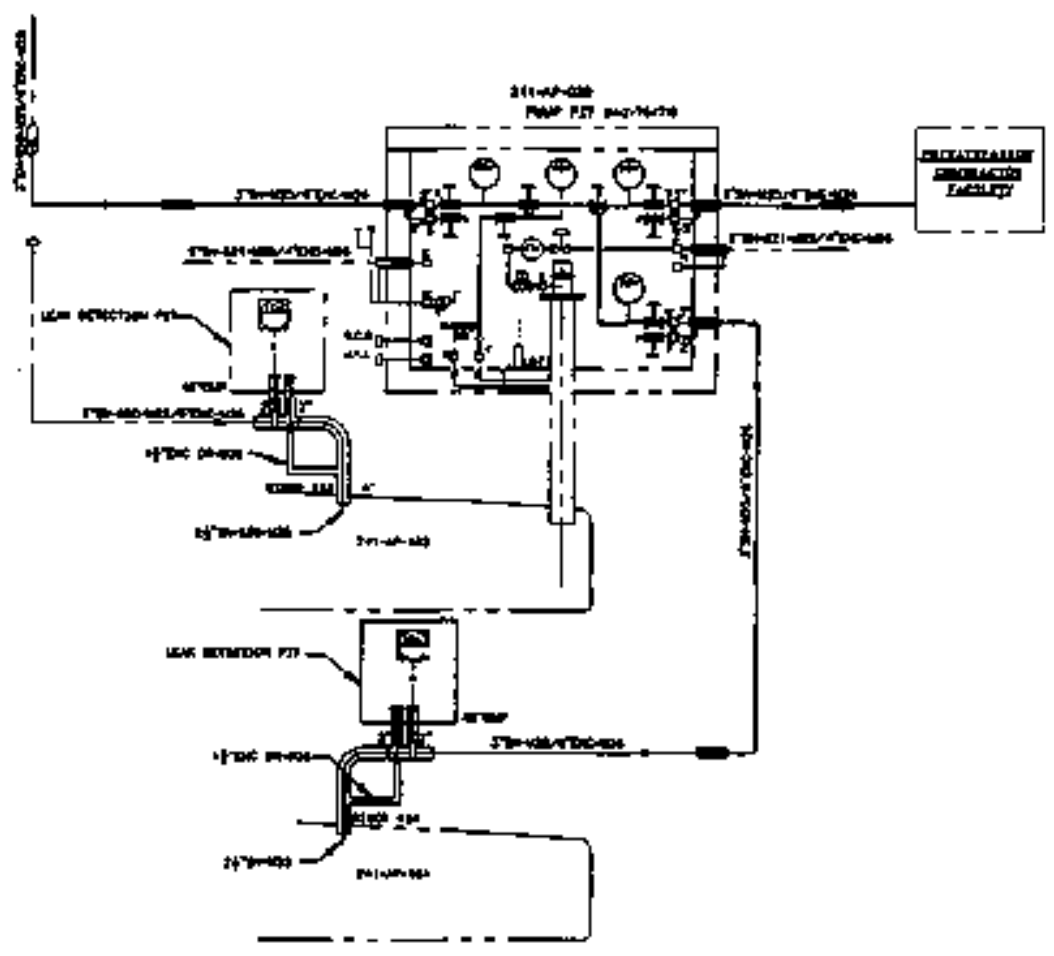


Figure D7-9. Pump Pit Jumper Artangenejal: Optión 2.

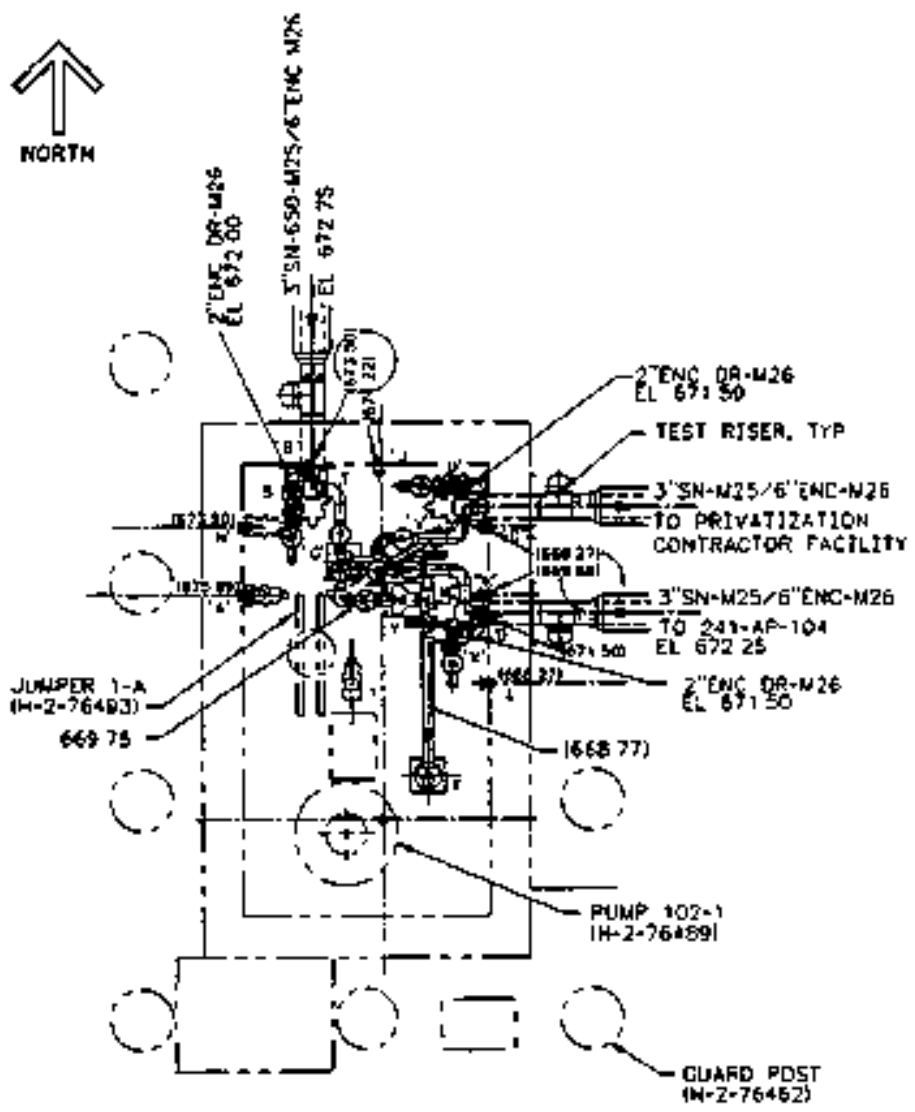




\section{HNE-SD-TWR-AGA-001}

Revision I

Figure D7-10. Panp Pil to Tanks 241-AP·102 and 241-.104 Hydnutic Diagran: Option 2.

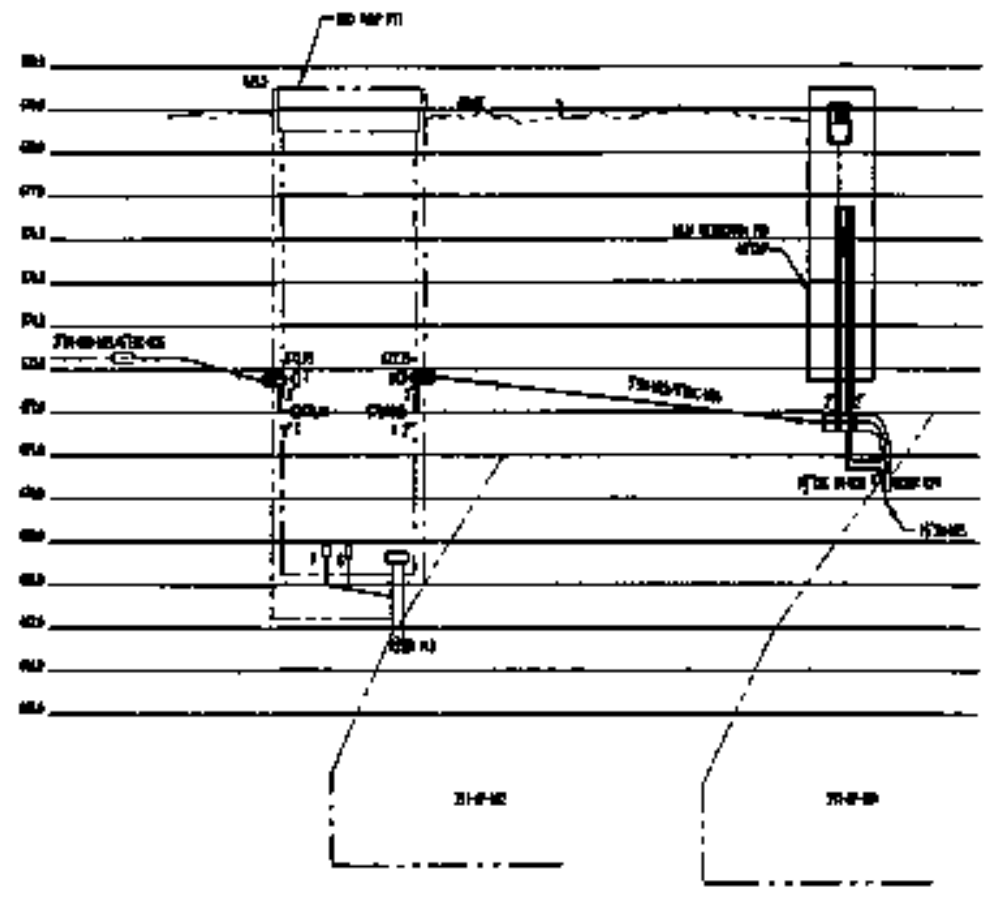

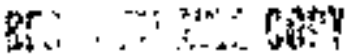

D-33 


\section{HNF-SD-TWR-AOA-601 \\ Ravision I}

Figure D7-1 I. High-Level Waste Transfer Lloe Hydraulic Diagram: Opion 2

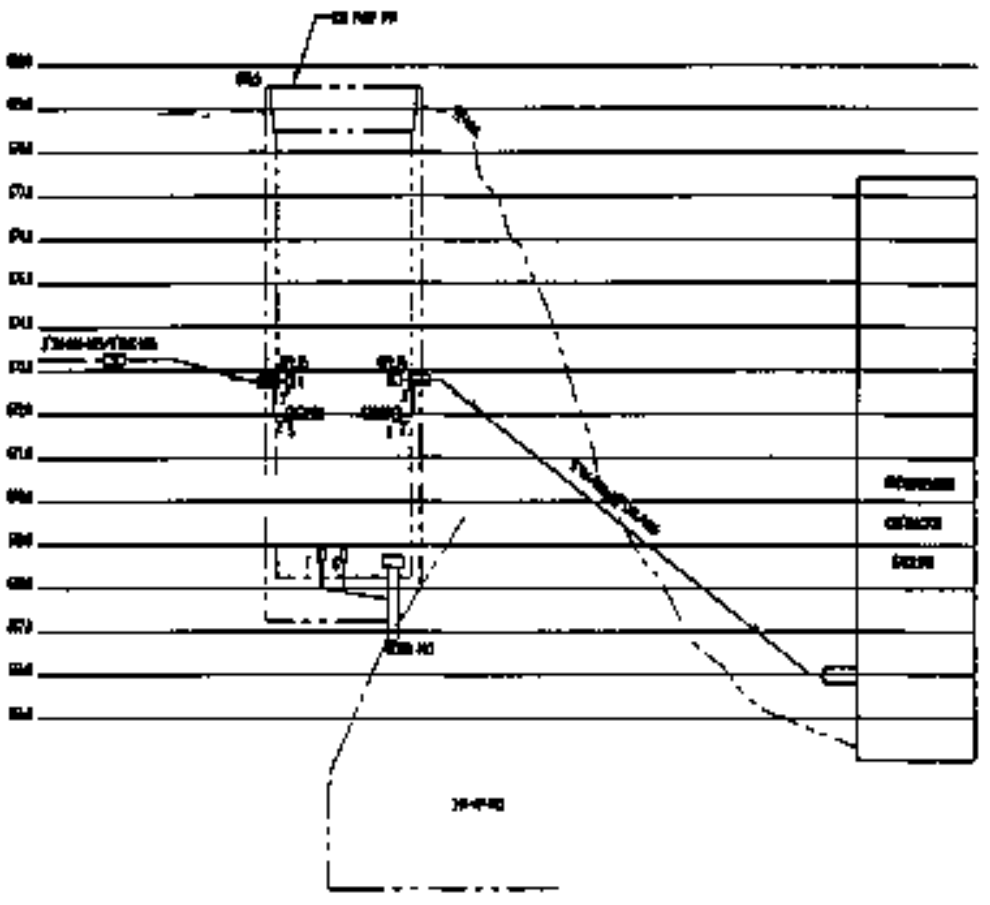

j: i ....... 
Figure DT.12 AP Tank Fanm Site Loyoul: Option 3.

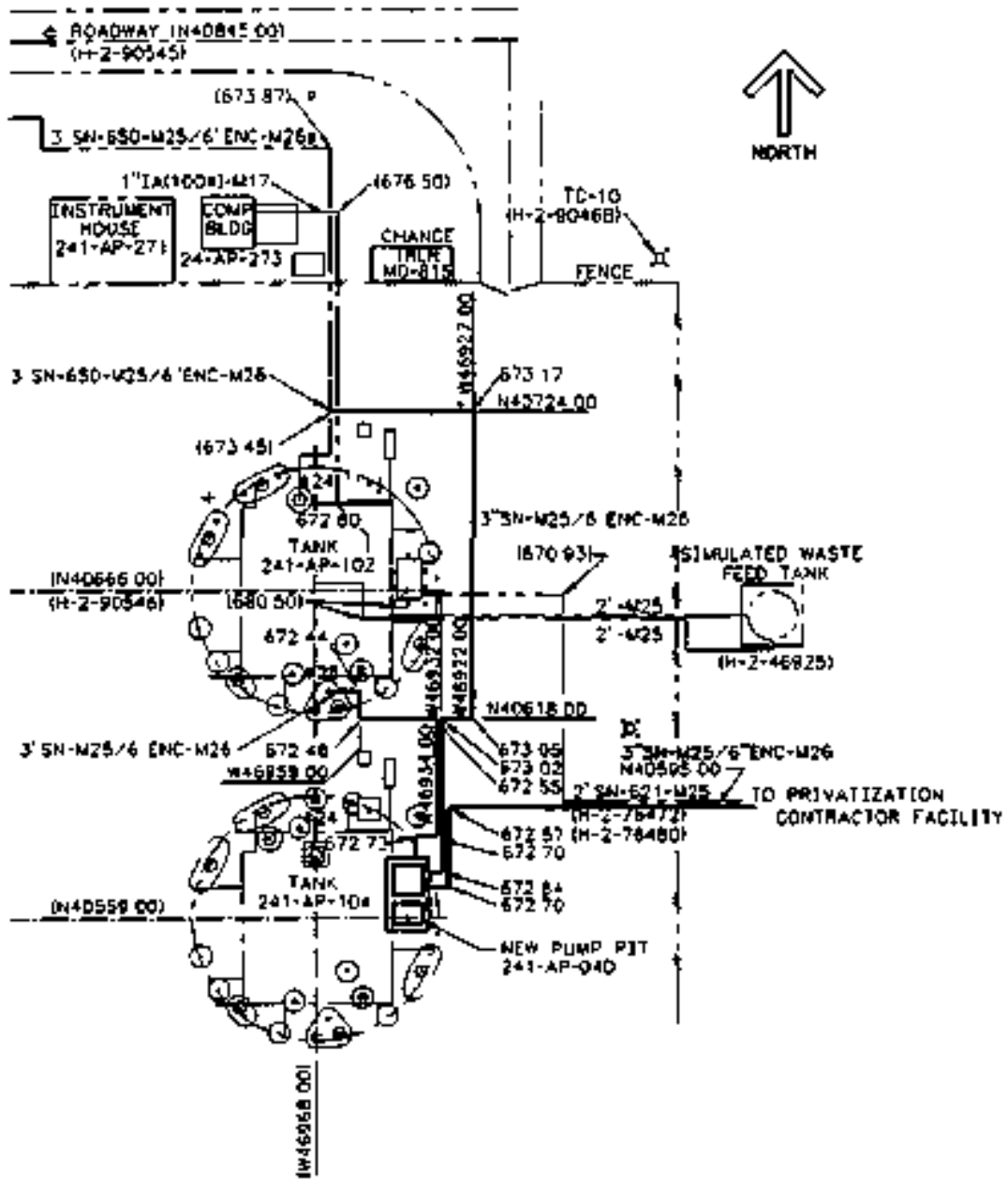


HNF SD-TWR-AGA-OOH

Revision I

Figure D7-13 Piping and Instrumemiation Diagram Option 3

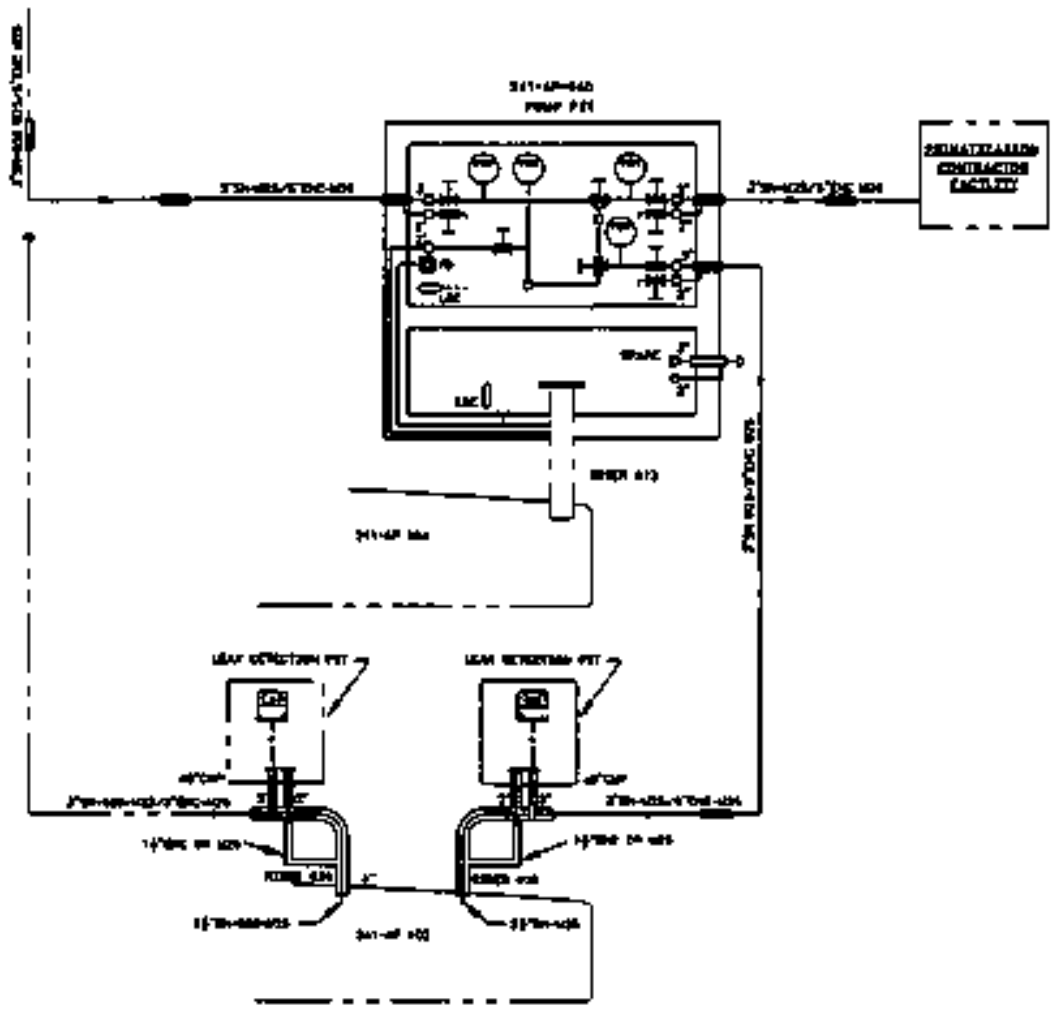


HNF-SD-TWR-AGA-ODI

Revision J

Fégure D7.14. New Protess Pil Jumper Arratgement: Option 3.

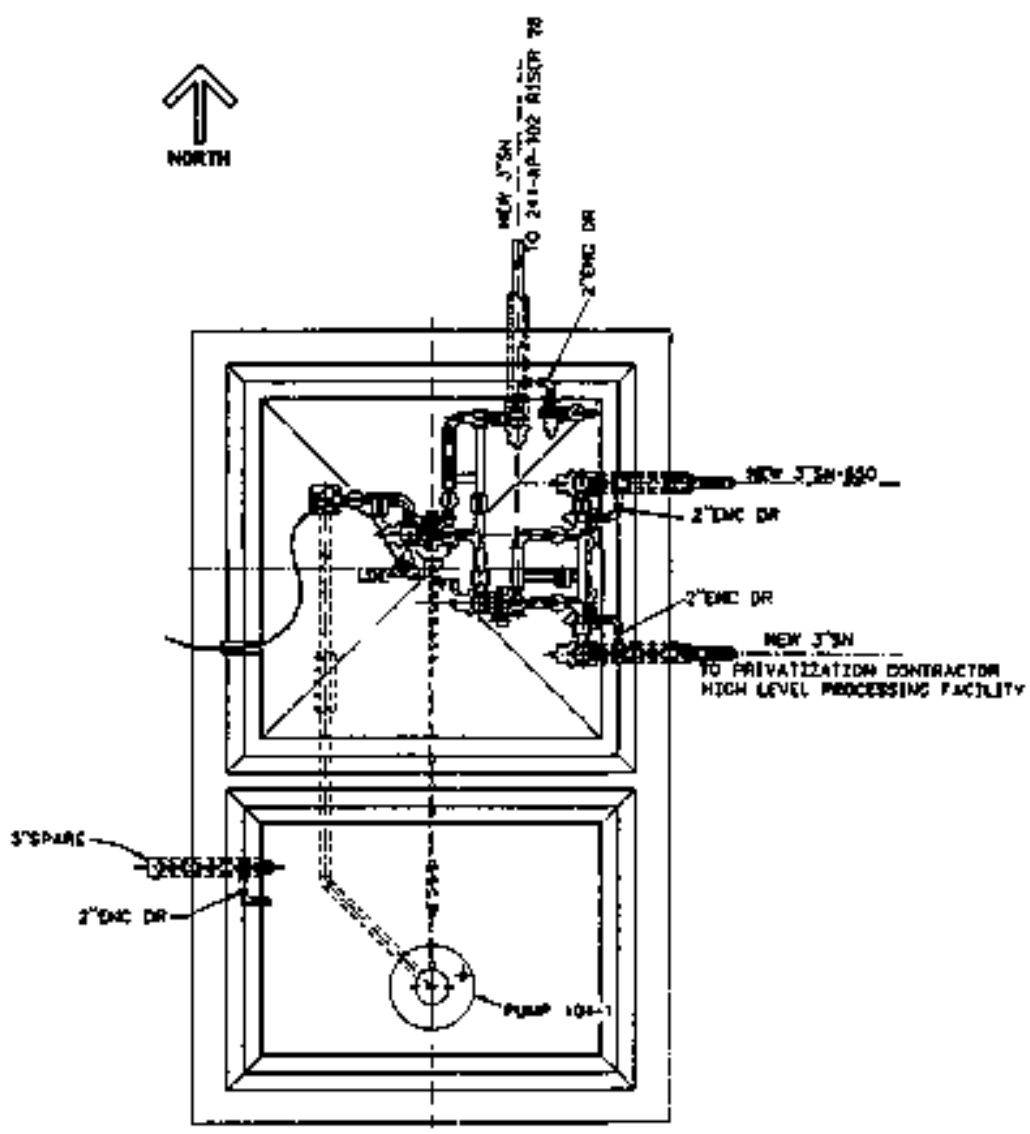




\section{HWF-SD-TWR-AGA-D01}

Revision 1

Figure D7.15. New Process Pil io Tanks 24I-AP-102 and 24I-AP-104 Hydraulis Diagram: Option 3.

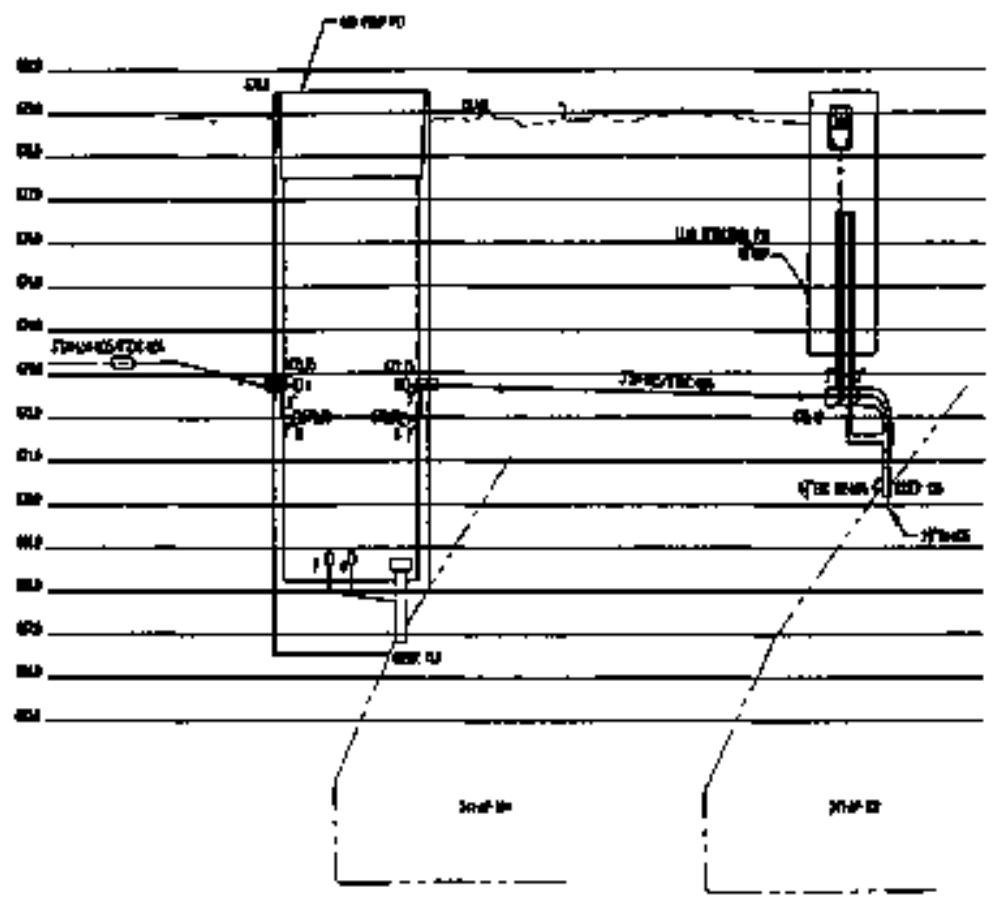

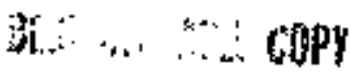




\section{HNF-SD-TWR-AGA-0O] \\ Revision $]$}

Figure D).16. High-Level Waste J ransfer Line Hytratic Diagram: Option 3.

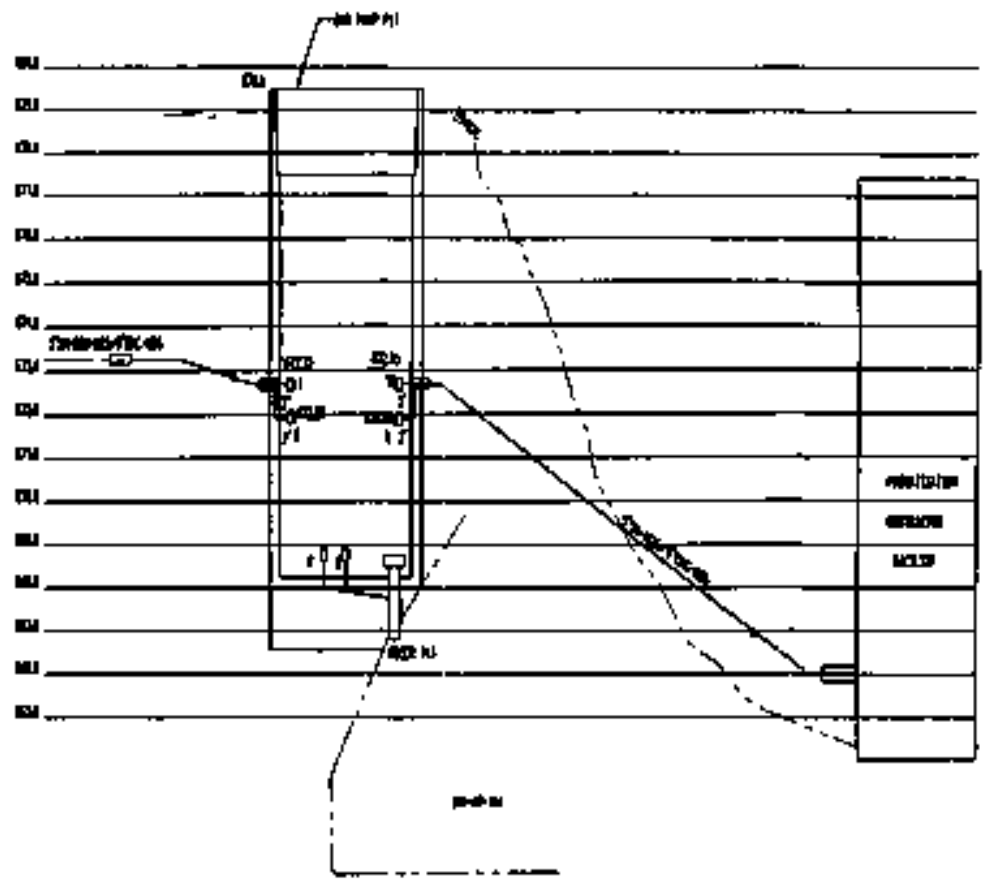

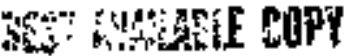

D.39 


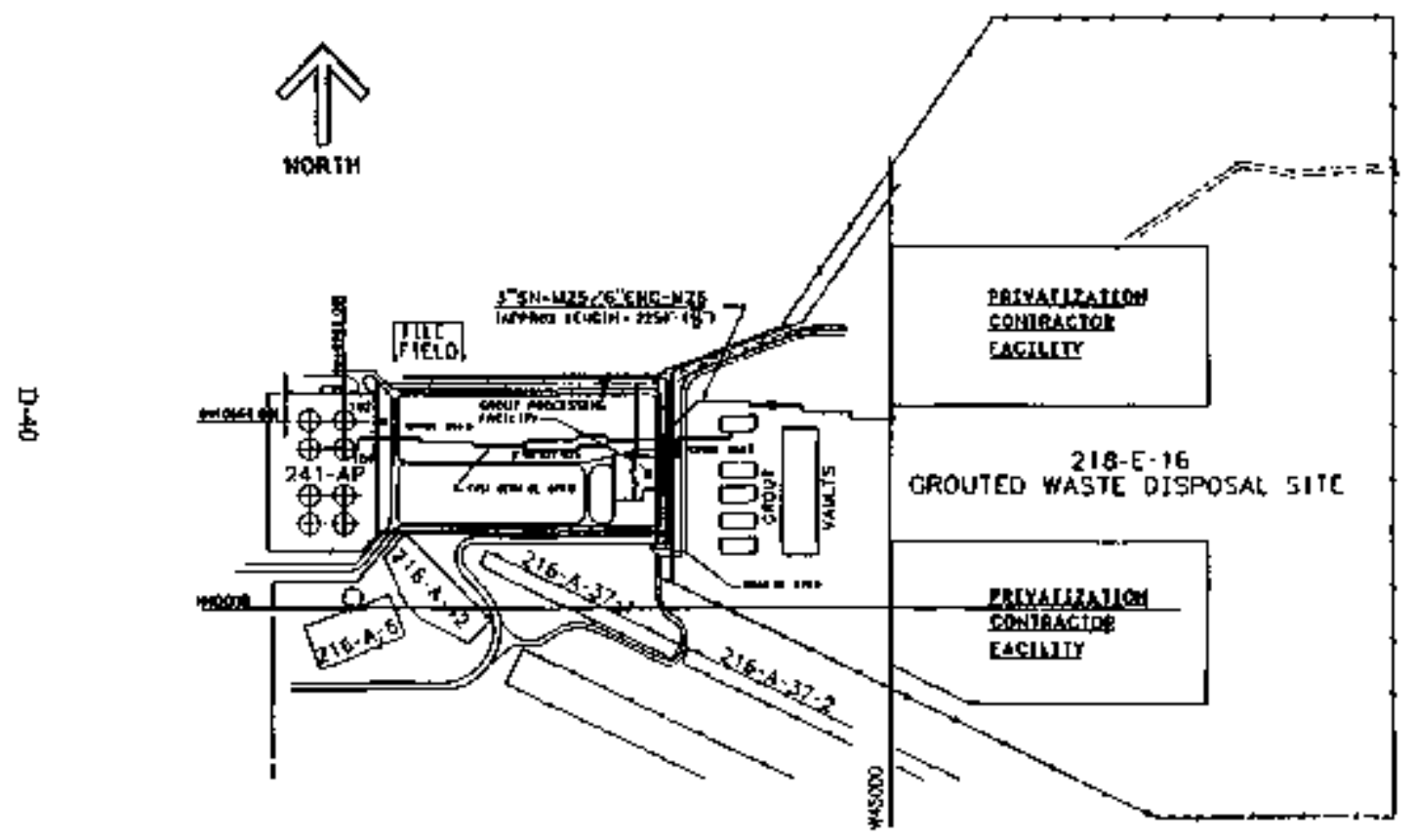

물 
HNF-SD-TWR-AGA-DOI

Revision I

DB. COST ESTIMATES 
HNF-SD-TWR-AGA-QDI

Rersision 1

DG.1 OPTION 1 COST ESTIMATE 


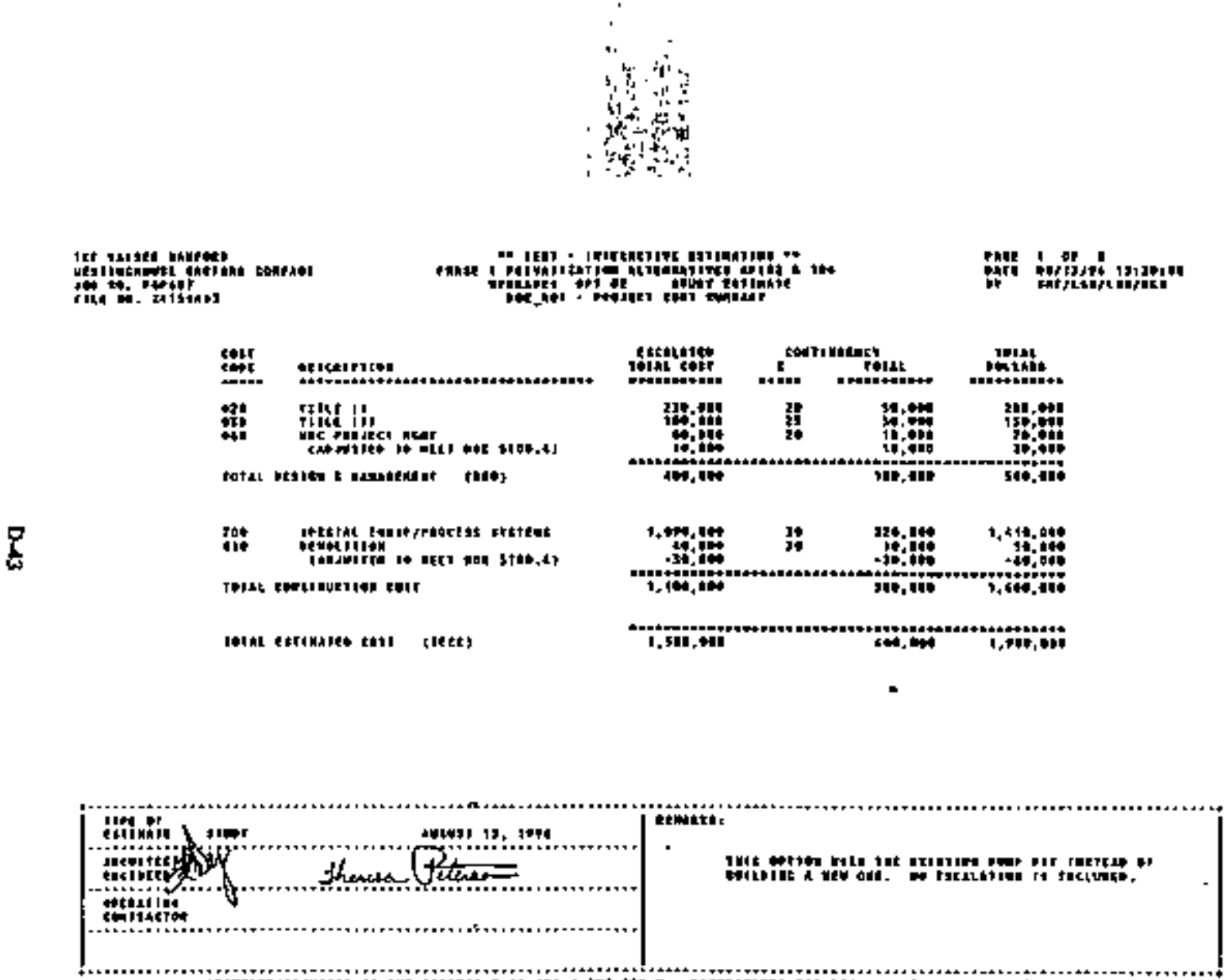

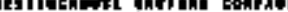

Ielol etramales toti glett
I. 5 II.

cta, tow

1, ont, ob 


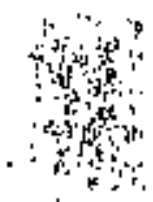

15t chint wathor

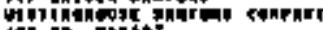

19.19.

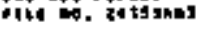

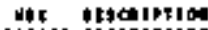

thets oteinitre ortith

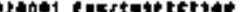

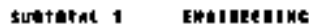

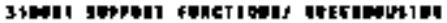

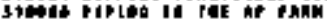

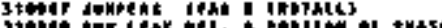

storth the ceak te

†

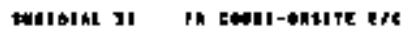

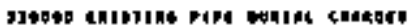

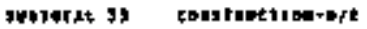

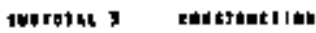

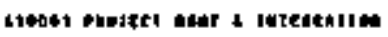

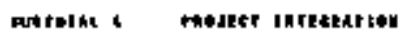

valest thing

DAMI DF

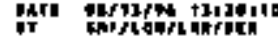

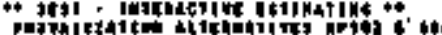

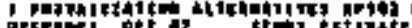

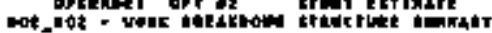

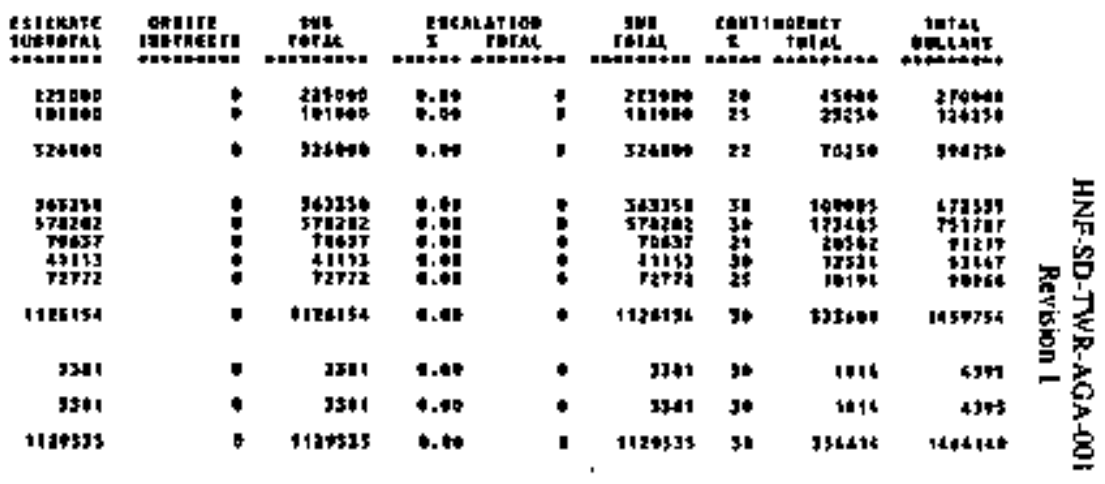

\begin{tabular}{|c|c|c|c|c|c|c|c|}
\hline 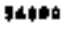 & t & Istoth & 1. 10 & ! & 54tad & 71 & 11246 \\
\hline gatet & 1 & gatet & 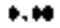 & ॥ & Strted & 21 & $11 k 40$ \\
\hline
\end{tabular}

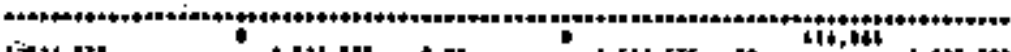

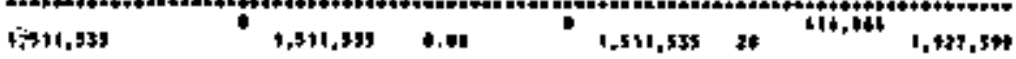




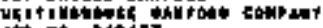

40.707

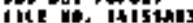

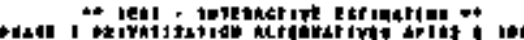

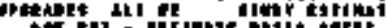

Phe 3 is

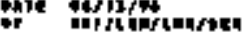

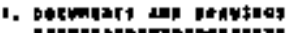

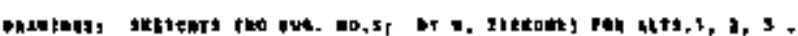

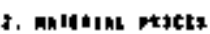

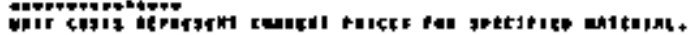

1. Hatod matrt

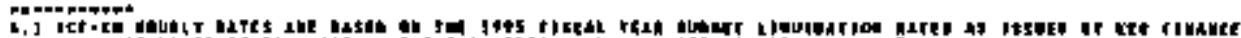

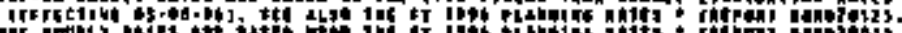

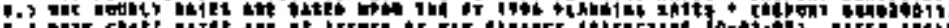

F

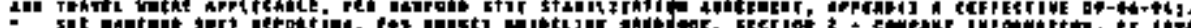

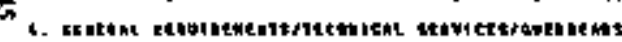

tomentents

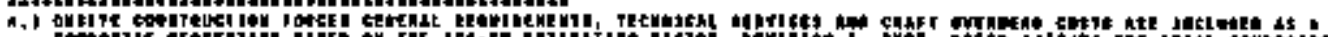

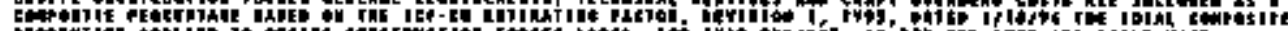

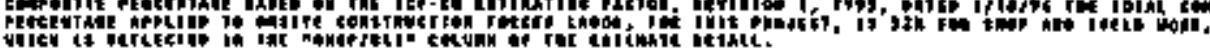

5. Etestalion

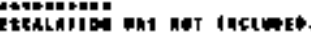

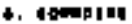

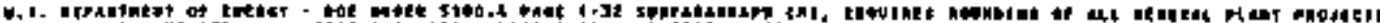

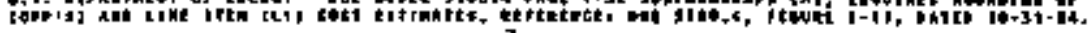

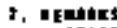

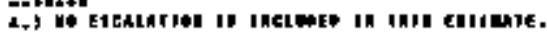

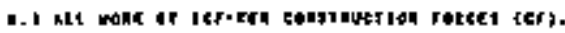




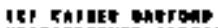

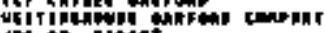

$1040.040 \%$

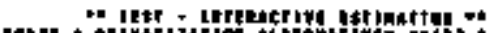

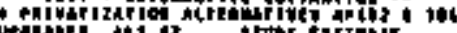

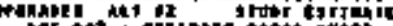

ant 1 or

or virtintionrert

c.) pipes

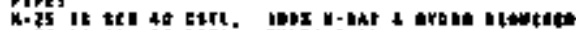

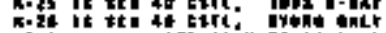

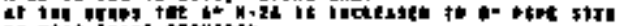

it otat linit tewieto.

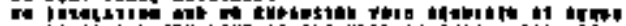

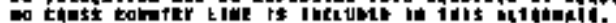

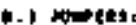

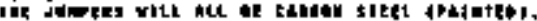

e.1 tulehthilon.

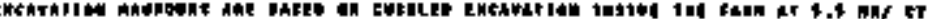

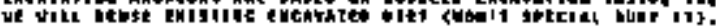

$\frac{1}{d}$

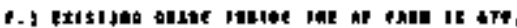

c.) heiblaw contilions!

Mo Whic He

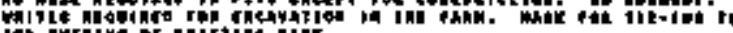

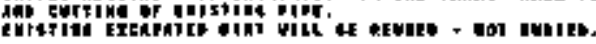

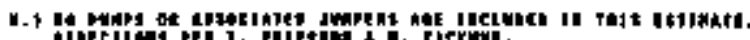

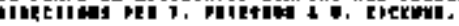

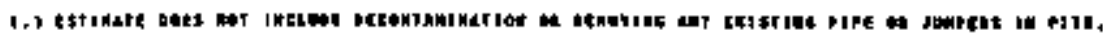

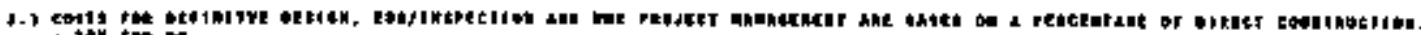

Tay tow

: to the tal on 
Mr enitcis whareng

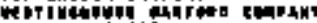
14. opent

Fits. Th, rishes

Casi

cantions Lesclut I It

Q2e risk i

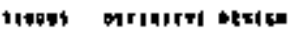

Teras ess rate is

ost titie in

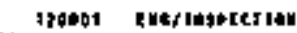

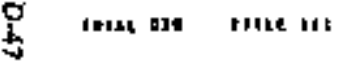

16* Whe whatetr whr

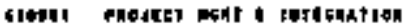

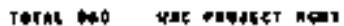

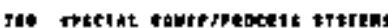

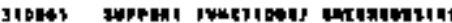

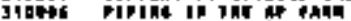

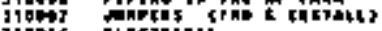

ग10\%16 Etectuient

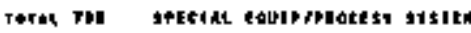

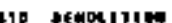

J19en

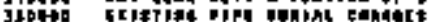

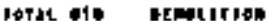

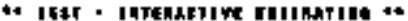

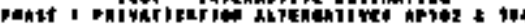

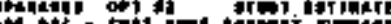

Whel tor

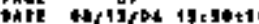

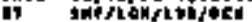

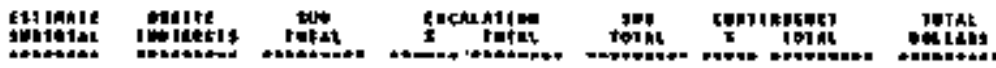

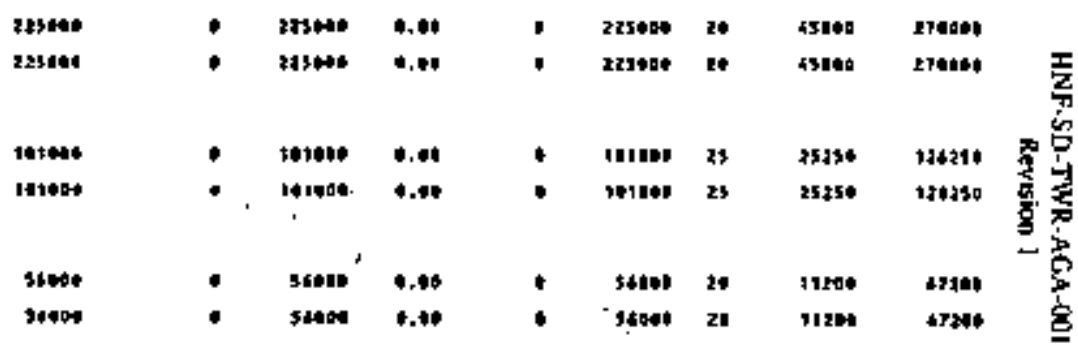

MHOHAT taI AL,

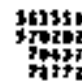

tomste

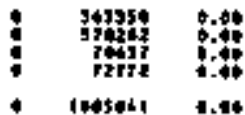

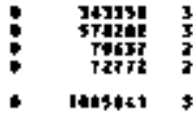

Inoses ty351 i3t) 7317 tori

tiras latist

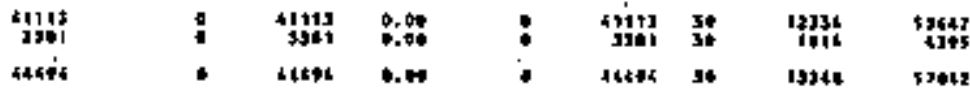

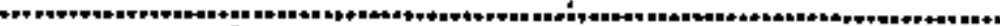




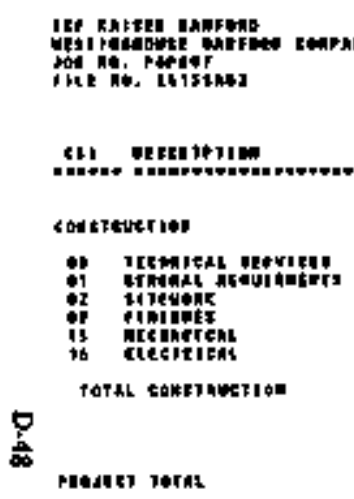

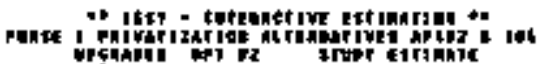

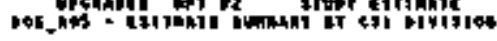

Pate onfigin

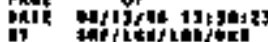

\section{Ixt indra}

tor 1oint

Intitit:

sult

portis.

Etestarier

I. 1014L.

tap chnituseres

19the

terat

cochata

(1,

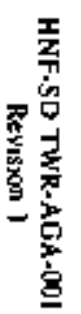




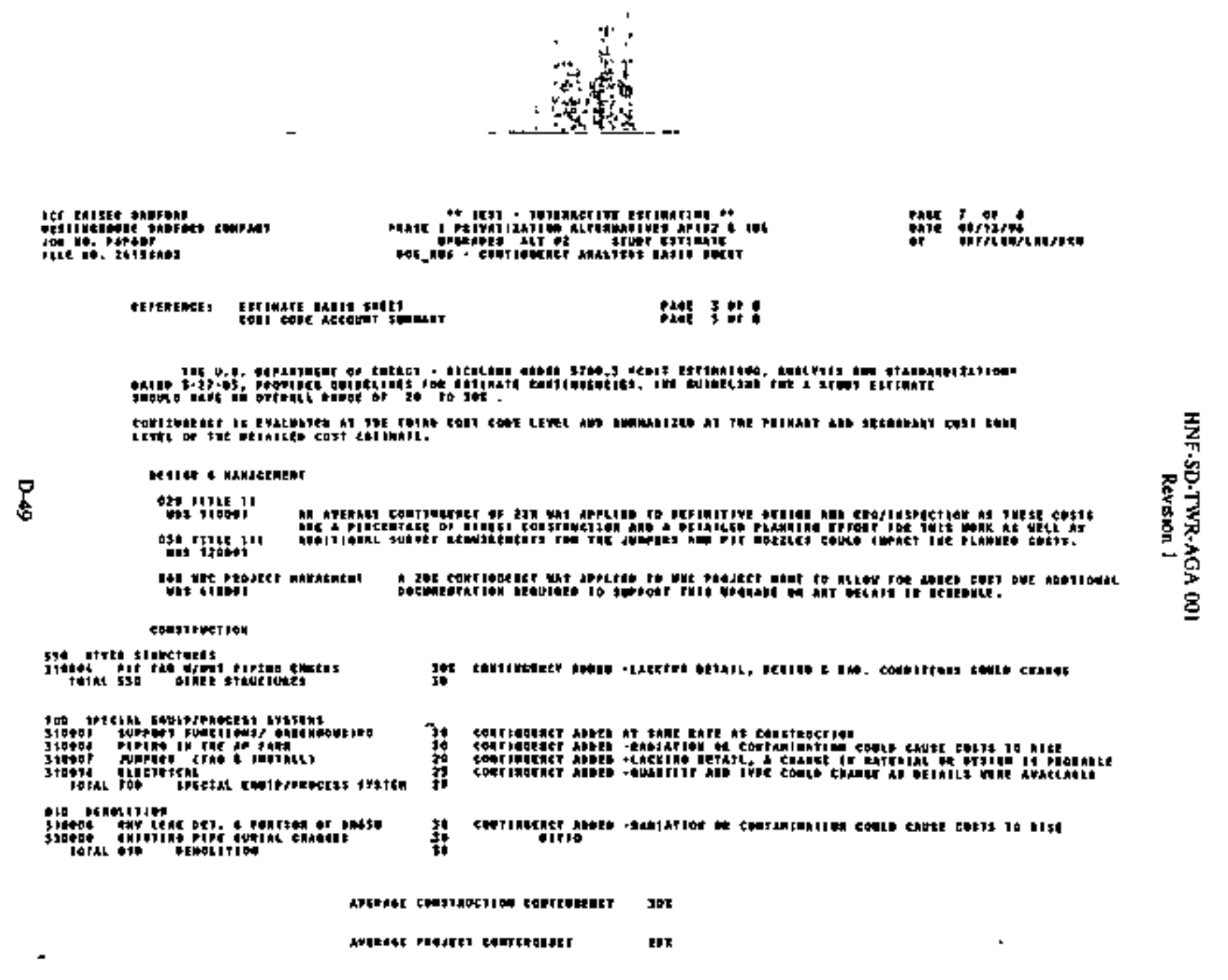




\section{Ittr ratioth vaveont}

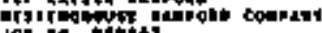

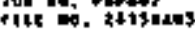

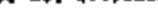

Hat Hetreipilay

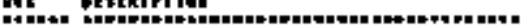

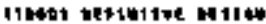

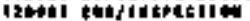

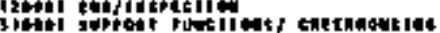

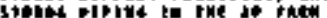

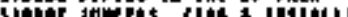

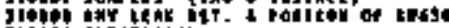

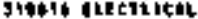

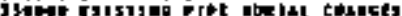

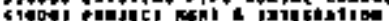

P

+kojre, 19T4L

炙

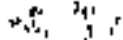

'is is

(4)

-

$=1_{1}^{2}$

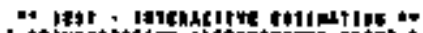

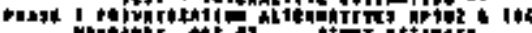

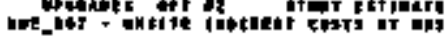

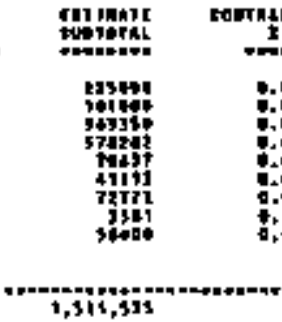

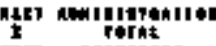

i.t.

Q.i.

a.1.

.1.

G.

2

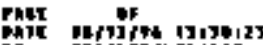

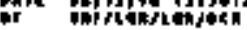

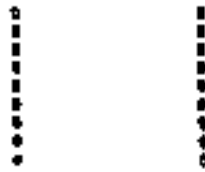

DIhet tardt initerts

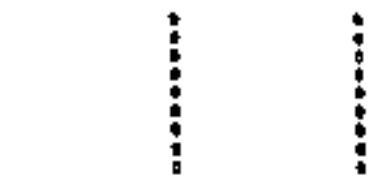


HNF-SD-TWR-AGA-QN]

Revision 1

IR.2 ORTION 2 COST ESTIMATE 


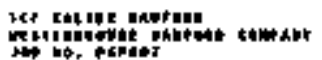

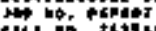

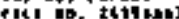

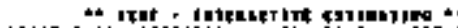

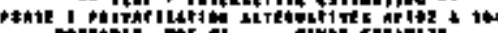

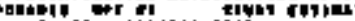

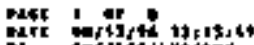

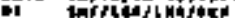
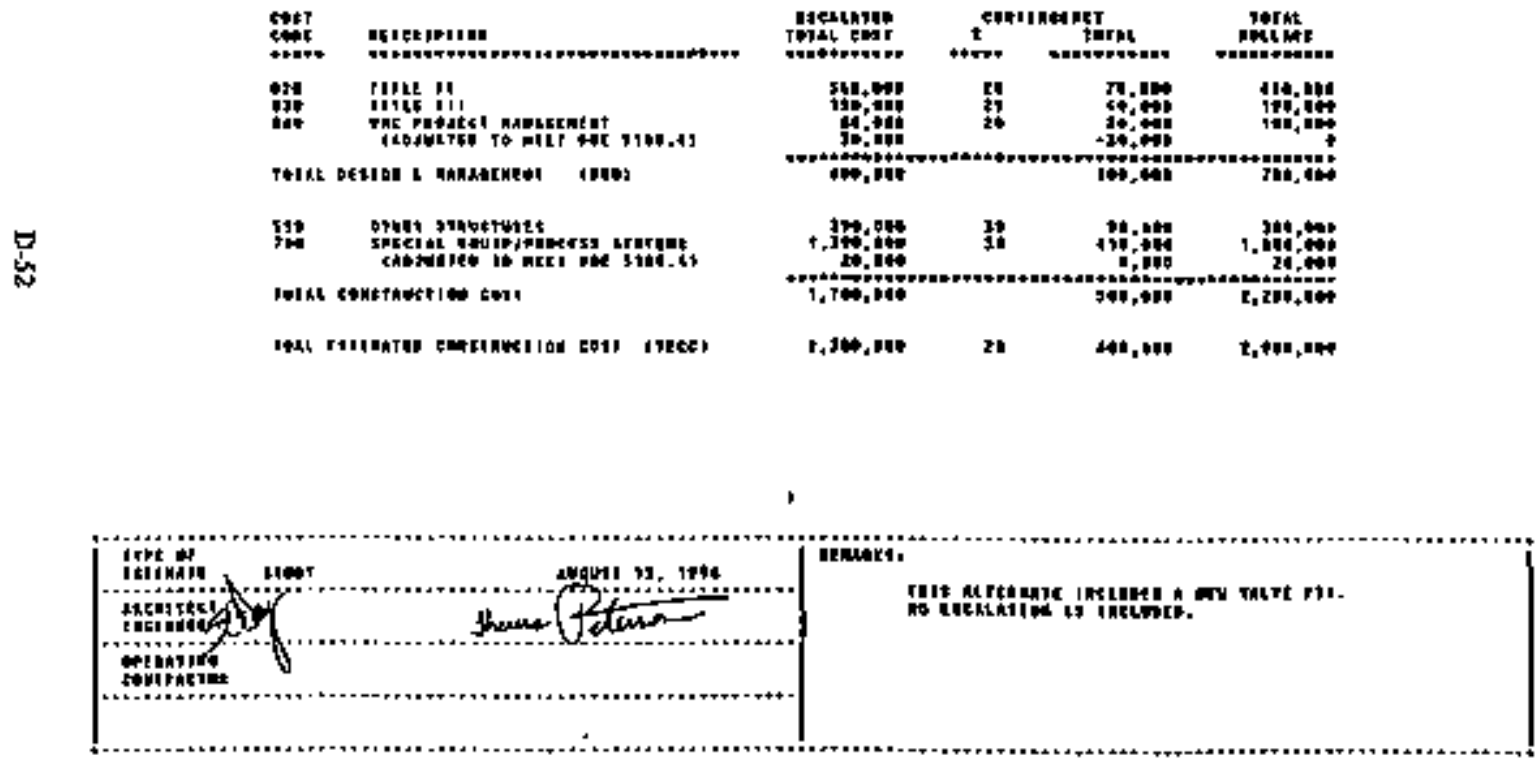

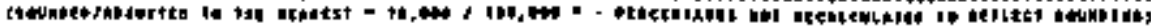




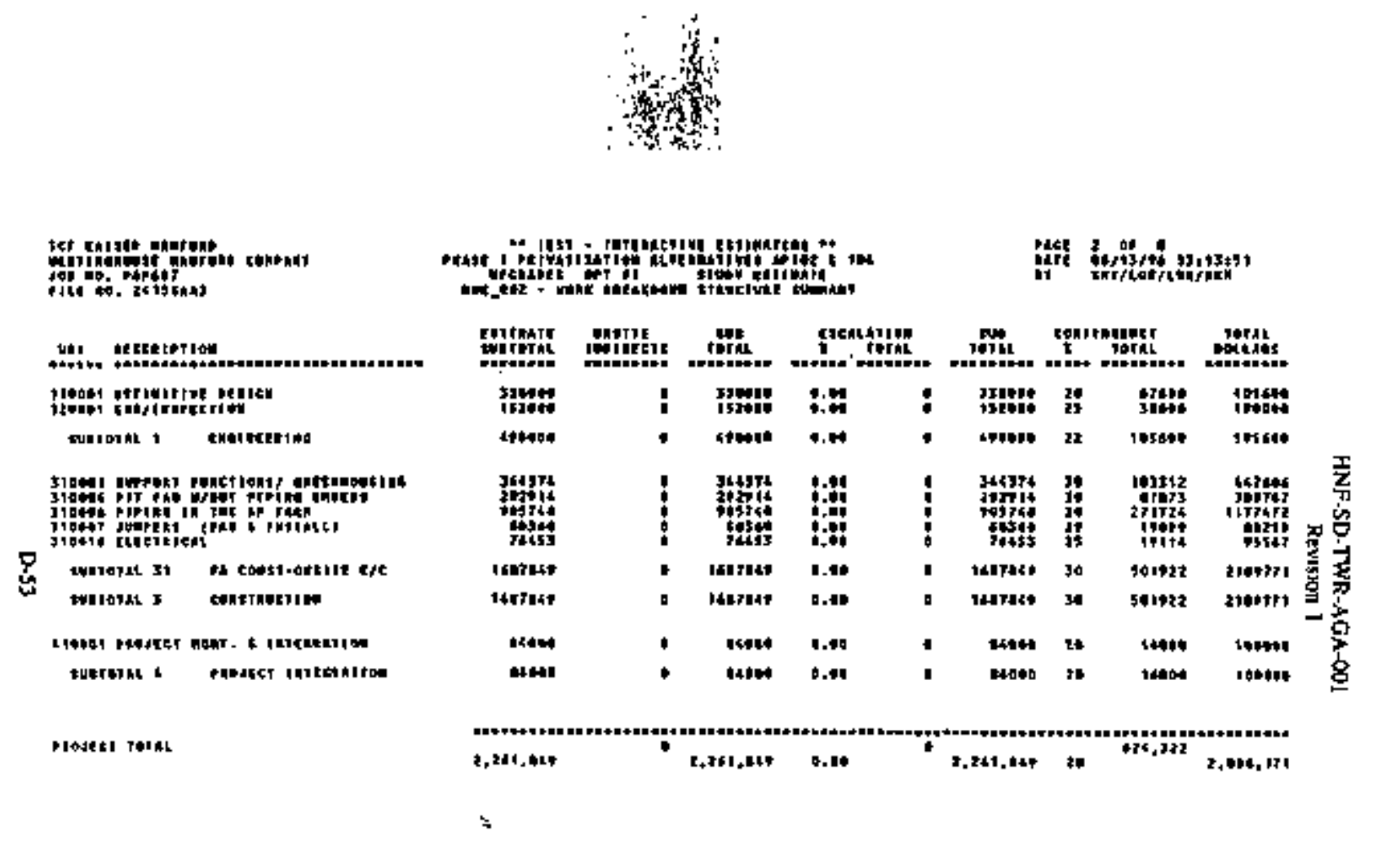


ICr Galizh manean

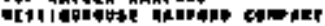

$\rightarrow$, M topt

rite Mo, jitions

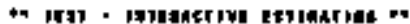

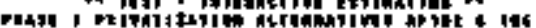

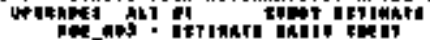

onst at a

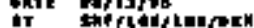

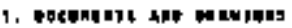

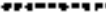

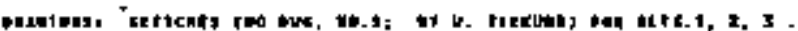

P. nutrald onitet

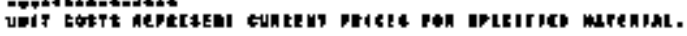

1. Laba nate:

antomes

L. IFF-E⿰亻⿱

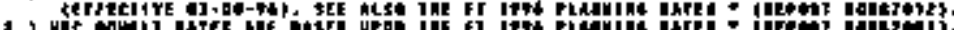

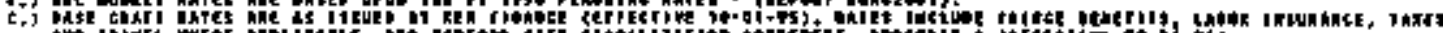

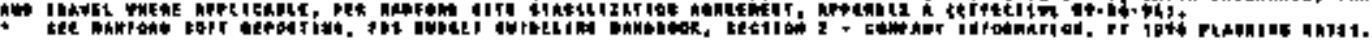

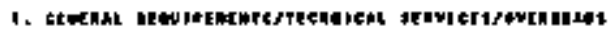

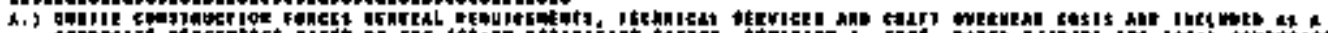
cghof Mccerice

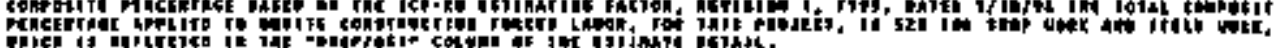

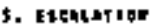

Eterintion abt ant pecbets.

6. Neurlitith

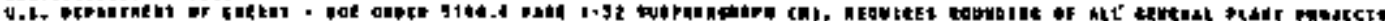

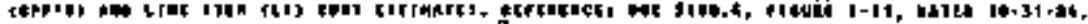

7. MEwhHC:

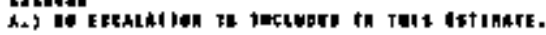

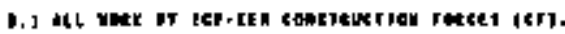


Iro Kentith Malrion

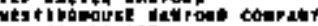
Ned 14 . tote?

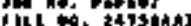

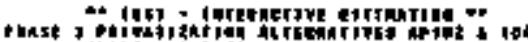

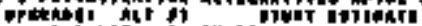

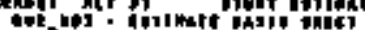

inte

E.] pIr:

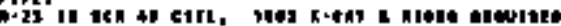

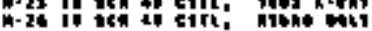

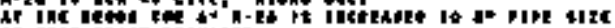

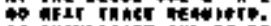

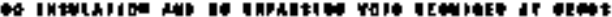

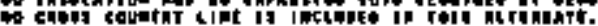

1, , splets:

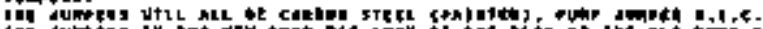

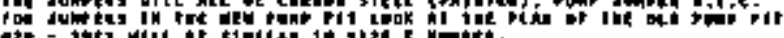

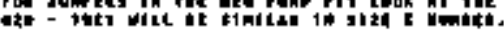

e.) tratarnife:

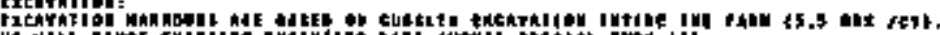

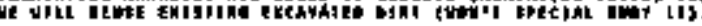

1.) PIrA

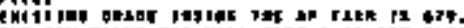

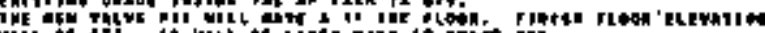

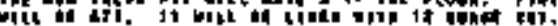

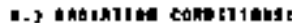

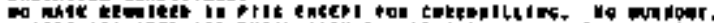

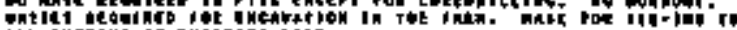

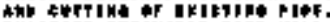

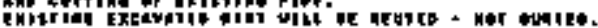

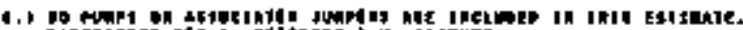

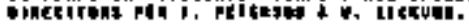

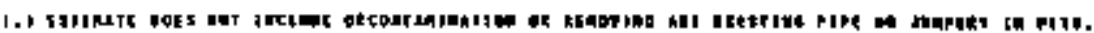

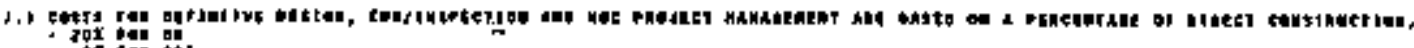

prit the the

- 31 ret vie no 
IEf kagen wawronf

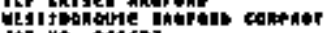

Jof Mo. Thest

plat wa. 24tsthlo

c4)

copising

TEtchiat ion

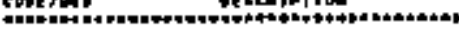

424 112⿺ 11

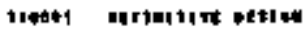

torth equ vite 11

130 T110 111

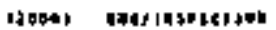

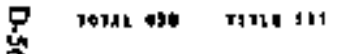

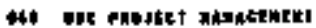

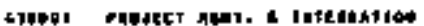

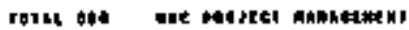

554 Hrial spawt rutert

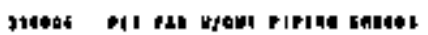

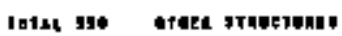

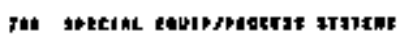

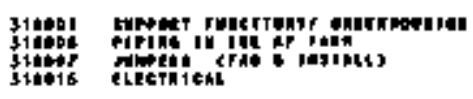

jite16 CLethieht

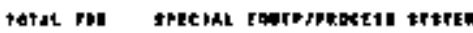

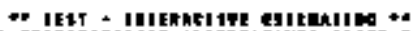

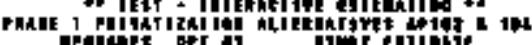

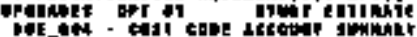

Dhe s ol

Hit afiste $13,13,5$

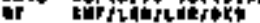

a1 1enst

cuptetil

artits

IT⿰亻丨⿰丨三⿻

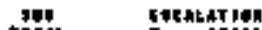

Thatitian

T⿻肀口

Fentoraters

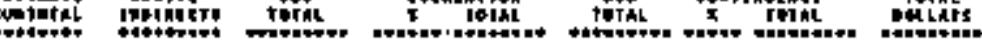

THTLL

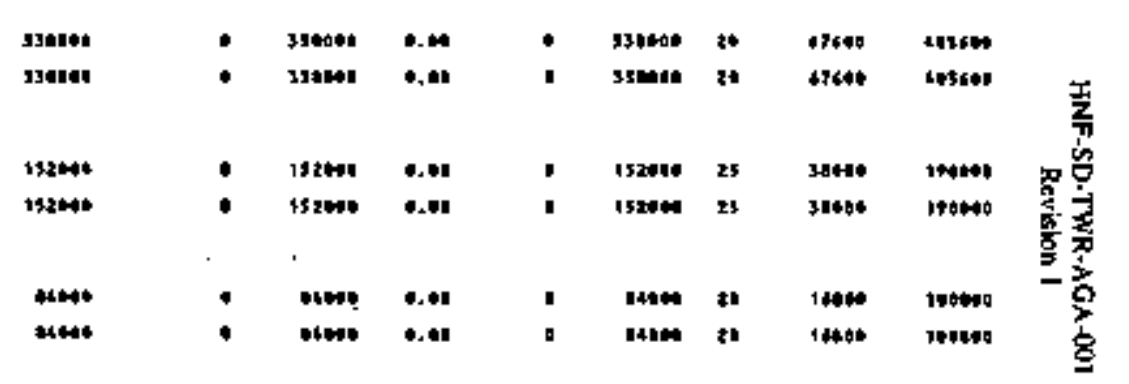

$2+11,46$

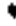

- 2*t+14

4.

เ

xoxa 31

urars jobtet

24r\%14

- $2+2+14$ a.

202t 14

$3 \mathbf{n}$

1345

doetat

$i$

144176

4194

1944755

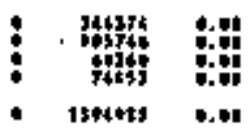

3it3ry

Fistat

7453

3

In3s12

tifit:

14i:

ititit

anzit yss?

- 15\%4t

1304015 3

c1446)

Iอกเอน

\section{bodici teina}

$t, 201,464$

๑. 1

$2,261,464$ to

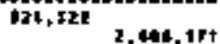


Ite ralsth yayfote

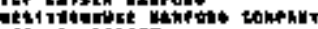

200. Dater

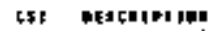

contring itan

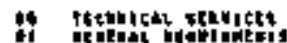

of siotivent

if renctite

i) morhon

is orevinictic

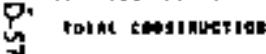

-Resctl latal

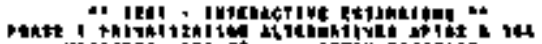

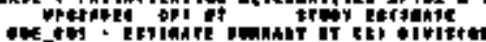

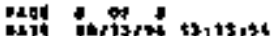

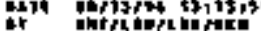

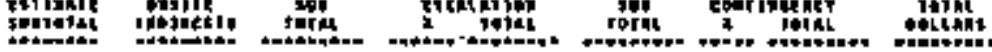

\begin{tabular}{|c|c|c|c|c|c|c|c|}
\hline 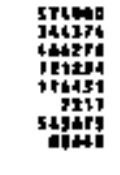 & 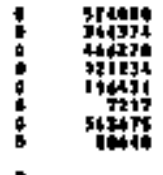 & 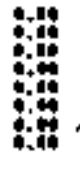 & 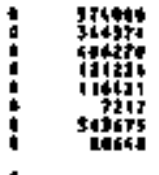 & 点 & 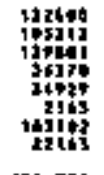 & 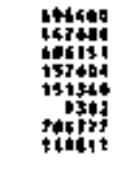 & 希 \\
\hline $1,261,064$ & E, rel, 40 & $\bullet+\mathbf{t}$ & $2,201,447$ & $\mathbf{z}$ & & $2,04+, 121$ & \\
\hline
\end{tabular}




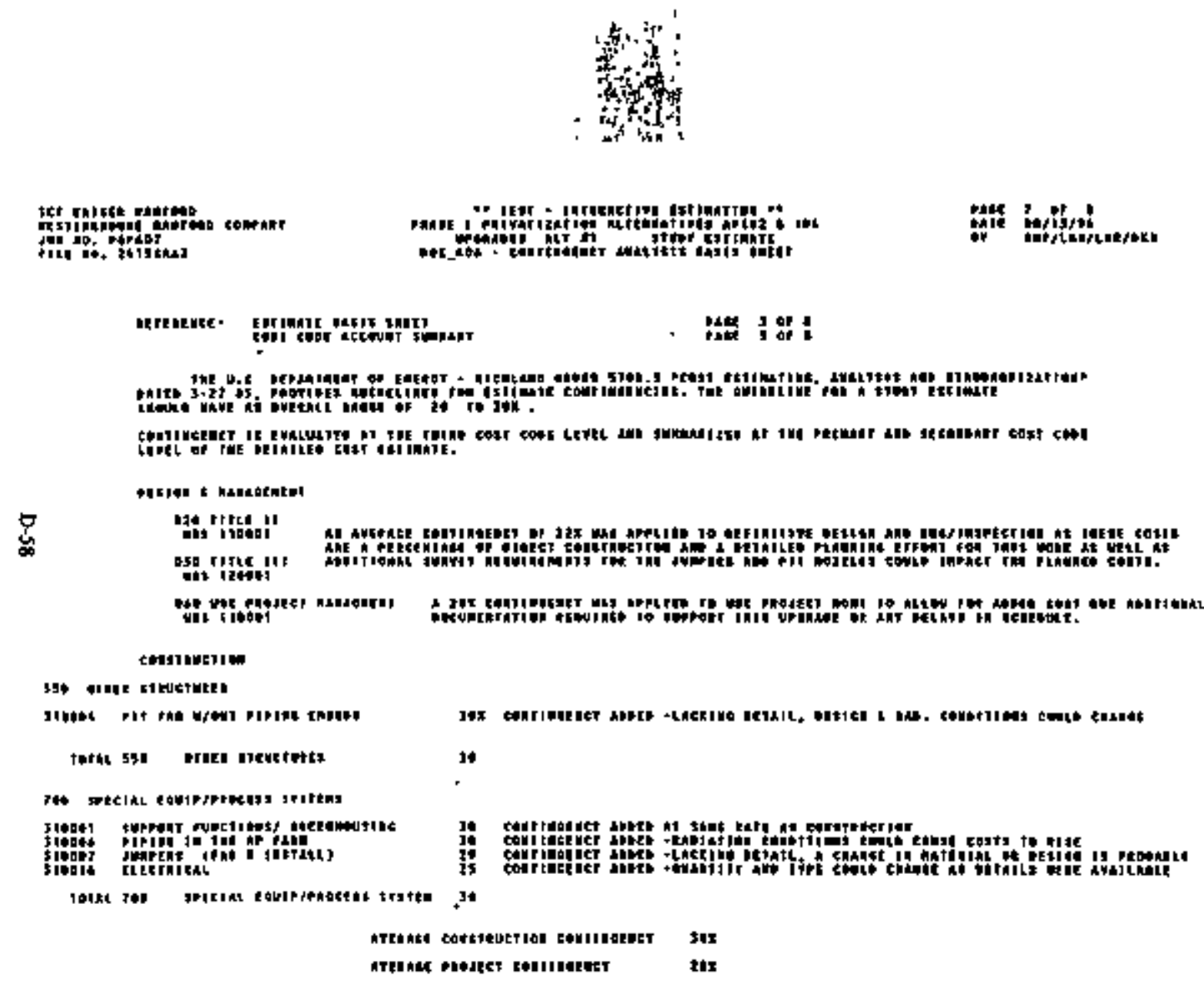




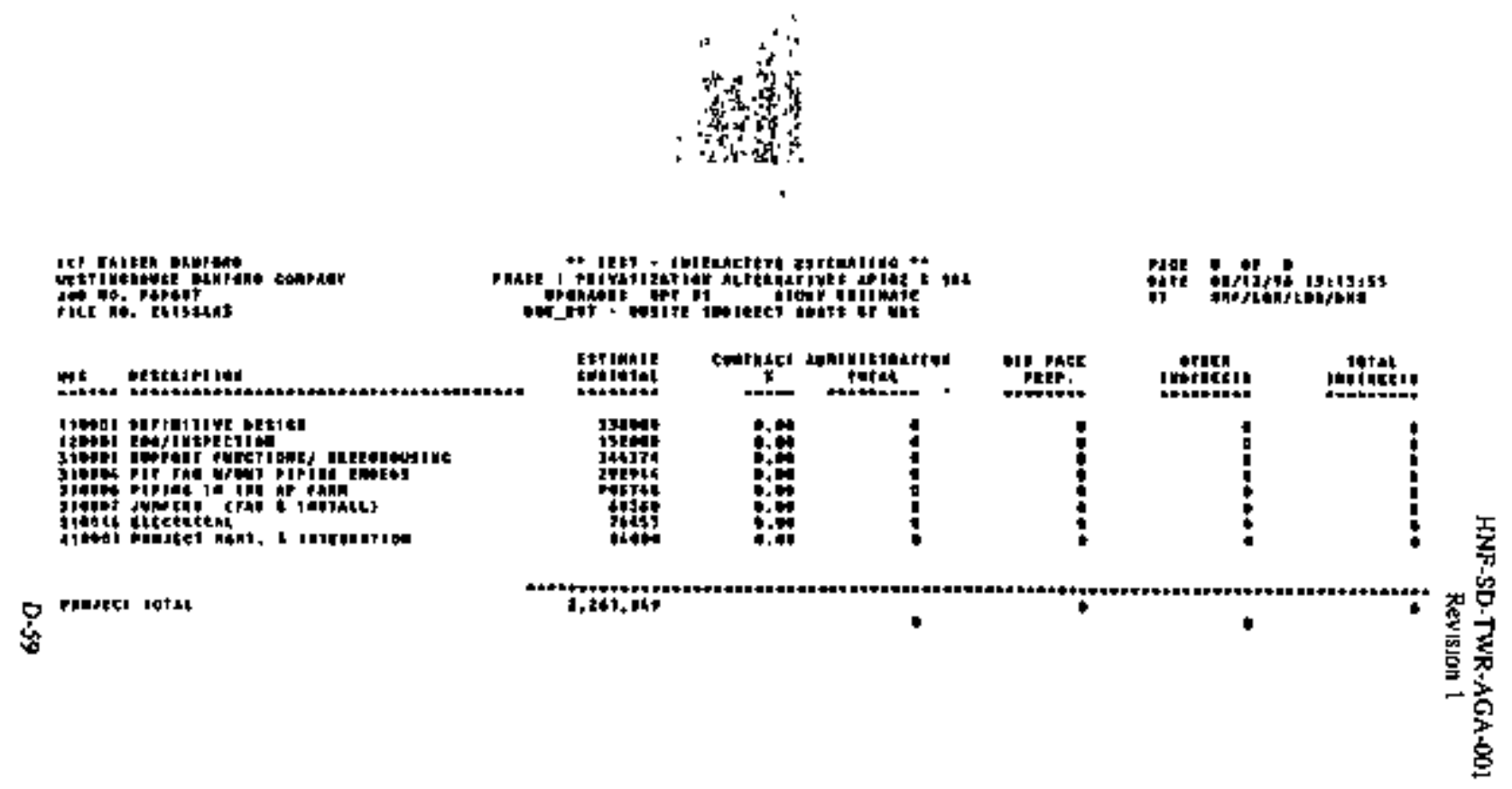


HNF-SD-TWR-AGA-00]

Reyision 1

D8.3 OPTION 3 COST ESTIMATE 


\section{Eer Karten mantes}

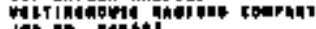
der a. put $m$. Lttsiets

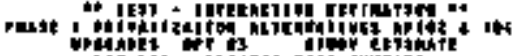

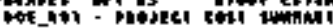

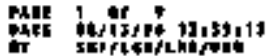

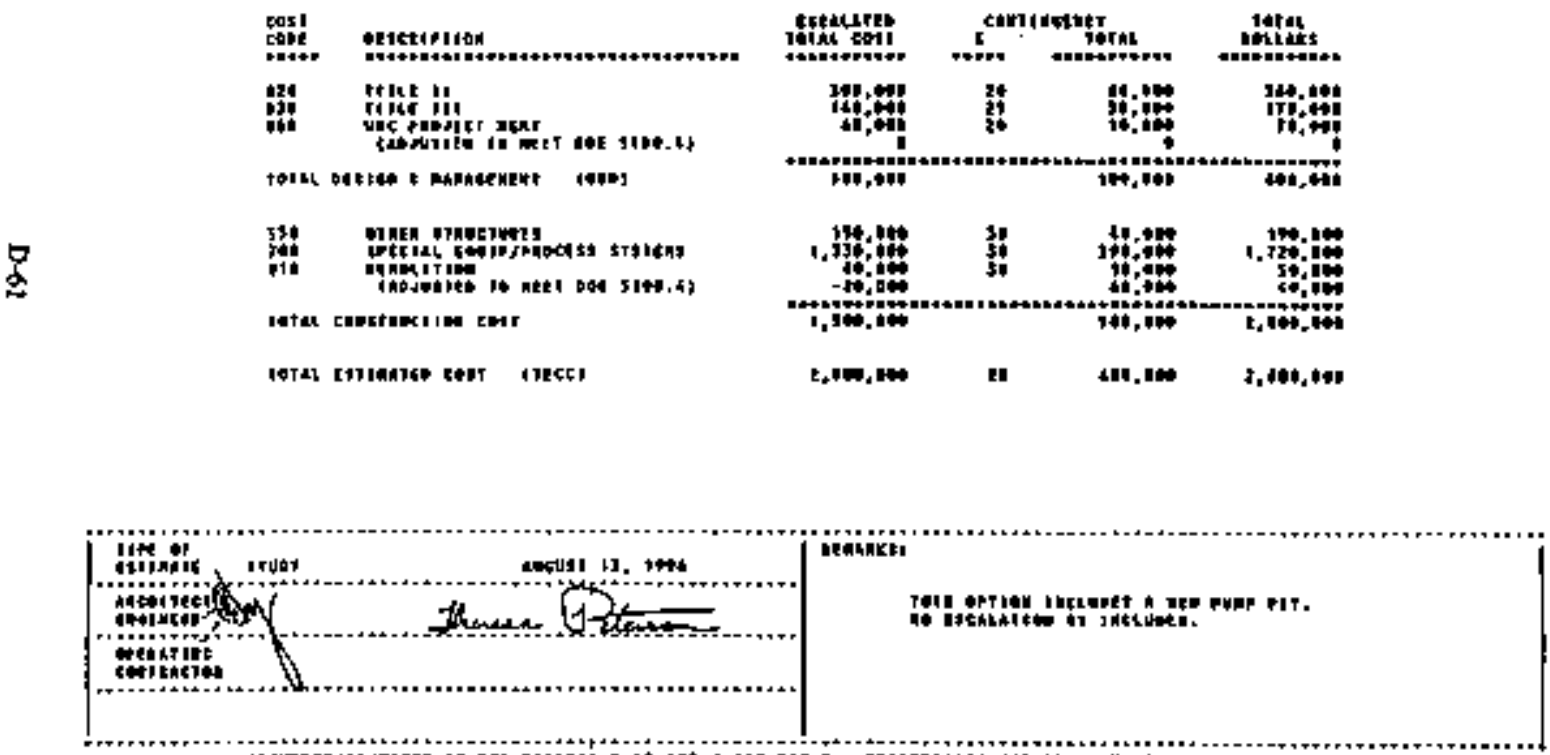

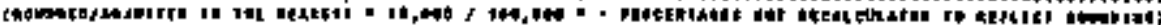



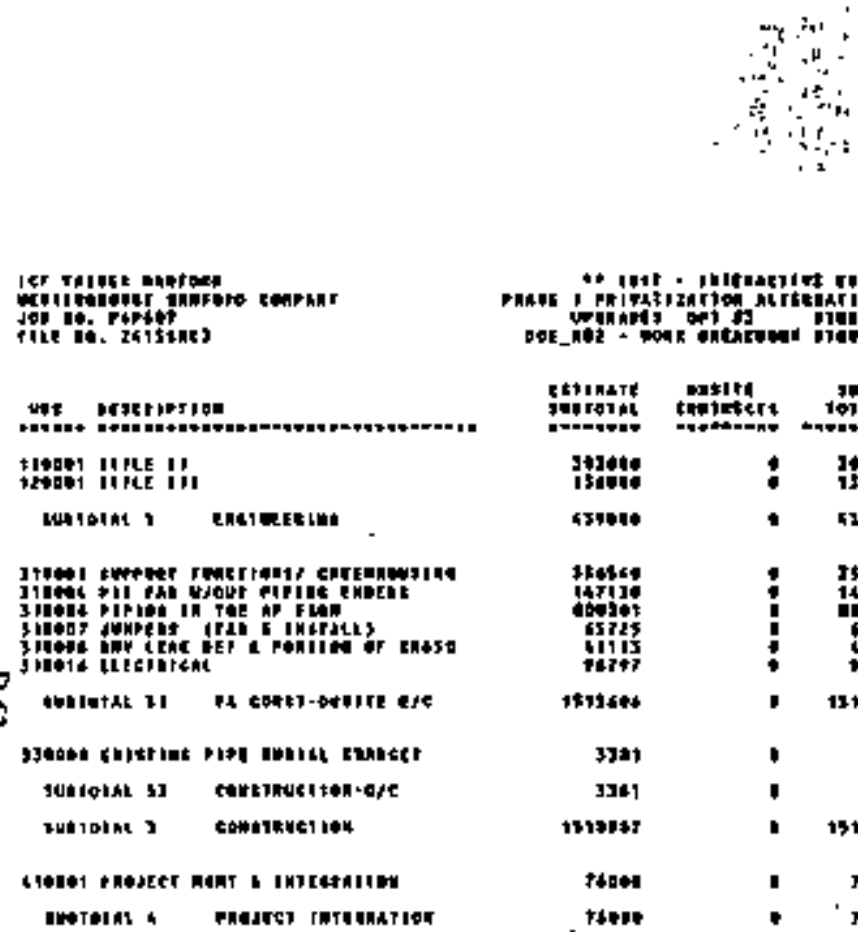

Peajger Tatat

van 2 or 7

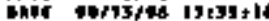

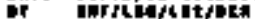

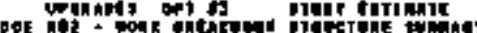

\begin{tabular}{|c|c|c|c|c|c|c|c|c|c|}
\hline 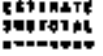 & 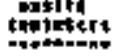 & 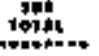 & 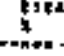 & & repule & 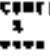 & 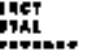 & $\begin{array}{l}\text { prit } \\
\text { rotind }\end{array}$ & \\
\hline $\begin{array}{l}\text { joythe } \\
\text { istente }\end{array}$ & 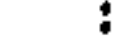 & Ityote & 0.40 & 4 & itstht & is & jected & It5eth & \\
\hline 435006 & - & $537+40$ & 0.10 & $\bullet$ & tyent & tz & 74648 & 337404 & \\
\hline 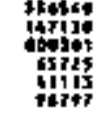 & 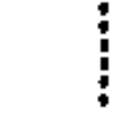 & 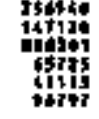 & $\begin{array}{l}1.10 \\
0.84 \\
0.84 \\
4.86\end{array}$ & 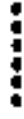 & 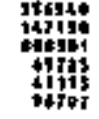 & $\begin{array}{l}10 \\
30 \\
30 \\
j\end{array}$ & 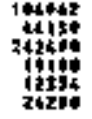 & 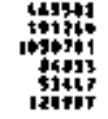 & \\
\hline 1571646 & - & $13+5646$ & $\bullet .04$ & a & 1915646 & 94 & $4+725\}$ & 1764034 & 줄 \\
\hline 3)at & 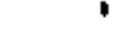 & 3501 & 4. & 1 & 3]1 & 50 & IaIt & 1343 & \\
\hline 31 & ॥ & 3501 & $\bullet .14$ & औ & 5J81 & 30 & 1414 & t3ts & \\
\hline thists? & ! & 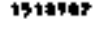 & $\omega *$ & 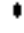 & 1314bit? & De & 45+24] & 1040735 & \\
\hline 76801 & ॥ & Jallell & 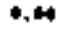 & $\varphi$ & rean & to & 13200 & कान्या & \\
\hline THEDP & $\bullet$ & TStab & $1+11$ & 1 & Thter & 20 & 15216 & 11>44 & \\
\hline
\end{tabular}

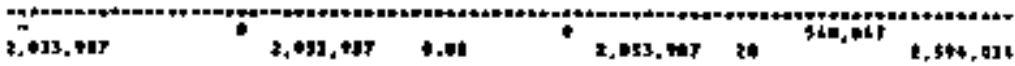


IEf ralden mingent

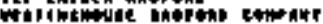

Jol 1 .

live 26 istenes

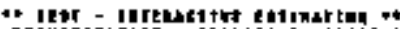

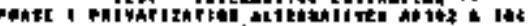

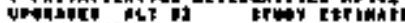

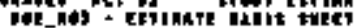

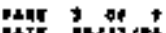

ir infortionate

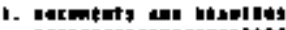

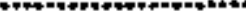

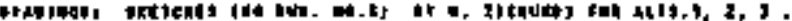

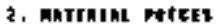

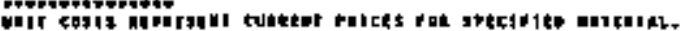

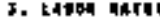

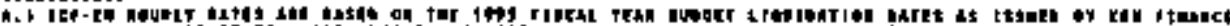

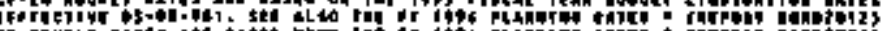

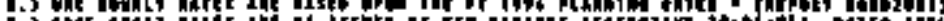

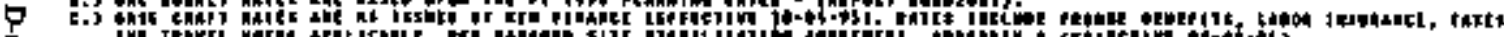

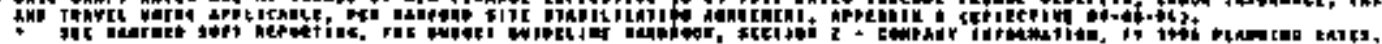

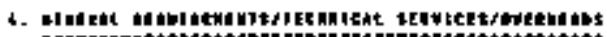

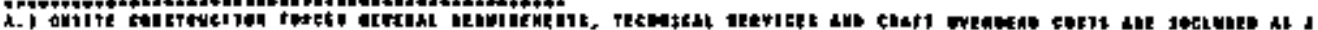

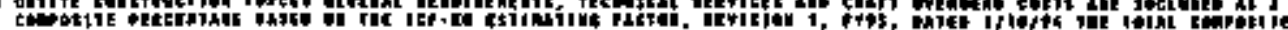

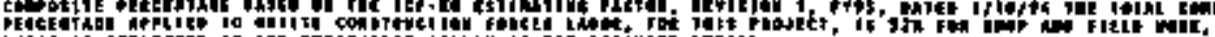

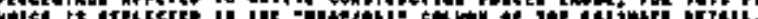

5. etedititis

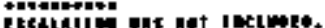

4. Favie

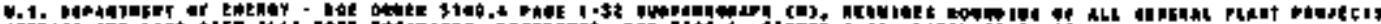

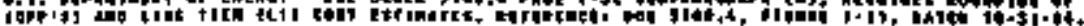

7. HFrant

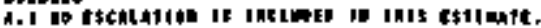

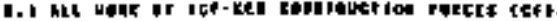




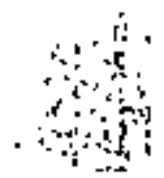

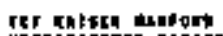

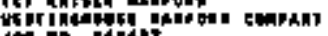

riic 10, Jissars

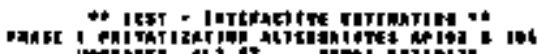

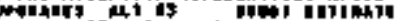

c.3 rig

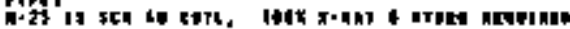

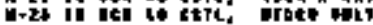

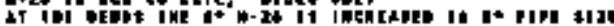

at ITh TEhet mavikes.

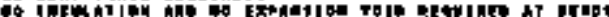

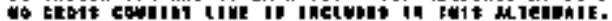

1 I demprot

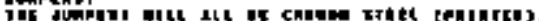

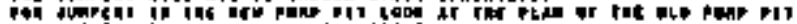

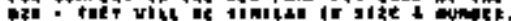

T Jrenvittet:

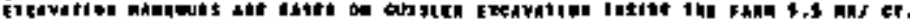

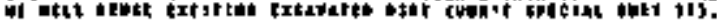

r) ritt

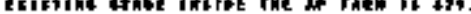

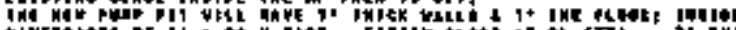

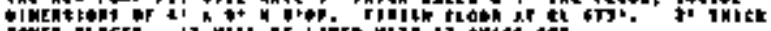

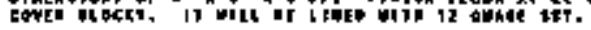

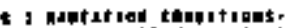

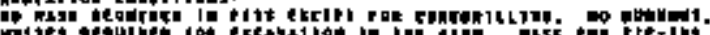

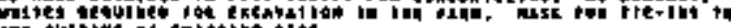

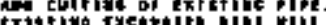

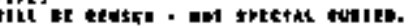

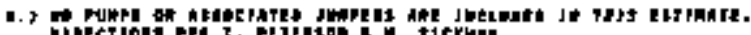

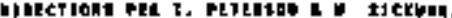

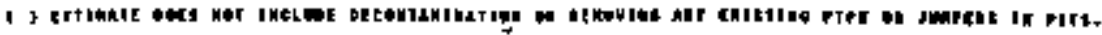

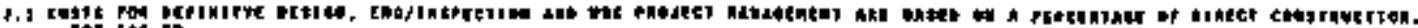

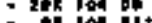

: 5 ion vine 


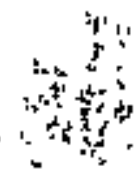

\begin{abstract}
MET KAITSK MANAOAR

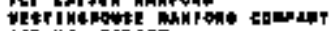

rick. Mater.
\end{abstract}

cerp

cent riwas

Th nesper 100

209 $110 \mathrm{~T}$ II

flathl titst it

TETRL +20 NITL It

bu ITL I1I

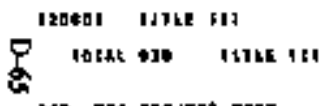

76) vise matret ant

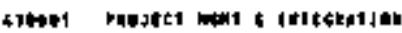

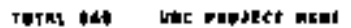

390 noth ileuctorat

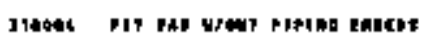

Teral sot prane zigescenas

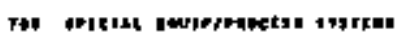

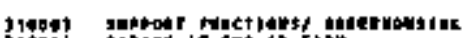

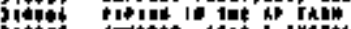

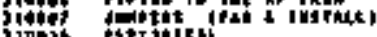

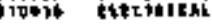

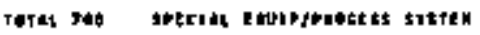

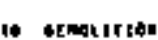

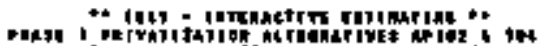

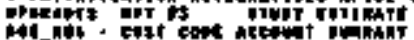

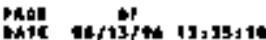

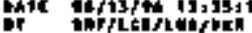

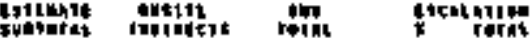

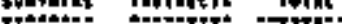

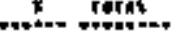

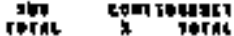

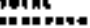

5014.

cotat

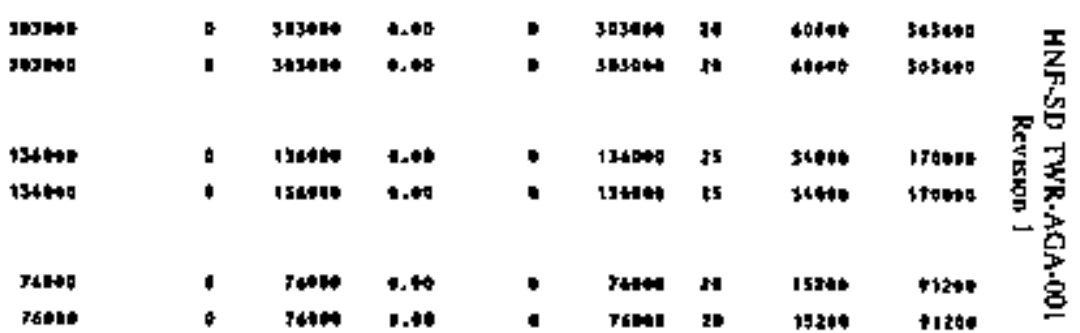

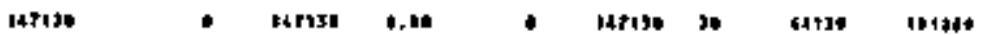

147130

- 46risa

1.14

14715

41110

141206

35436:

4and

45F⿱日十)

- j3454

1323343

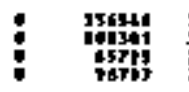

- 1717367
34 rostet

arzto:
145502

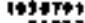
1t453

172t15] 


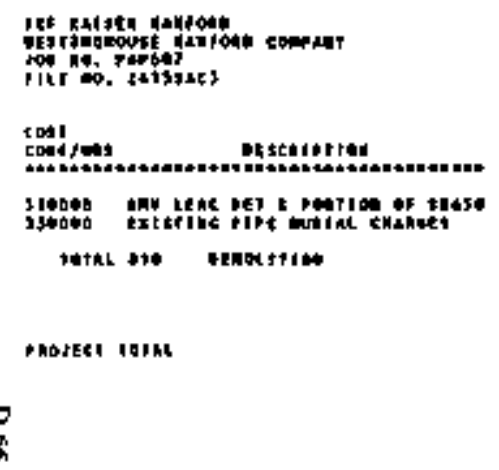

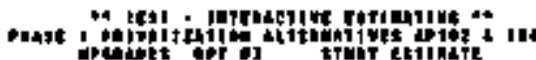

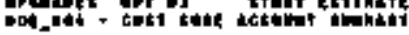

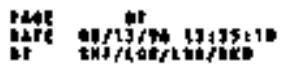

\begin{tabular}{|c|c|c|c|c|c|c|c|}
\hline 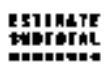 & Initixter| & rys & 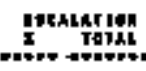 & PHz & t & IErey & . \\
\hline lisis & 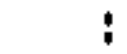 & nyis & i:th & ayde & st: & & ssats; \\
\hline 64676 & 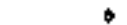 & tutet & $\bullet, 4$ & 44619 & jo & 1314: & t thes: \\
\hline
\end{tabular}

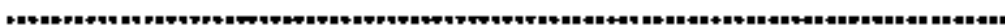

$2,03 x_{1}+1 t$

$t_{t+2 s_{+}+4 t+\infty}$

I

sen, 17

$2,5+6,034$ 


\section{IE) THIOEE Wharbe

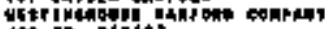

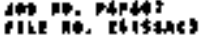

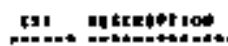

\section{cou ntwertite}

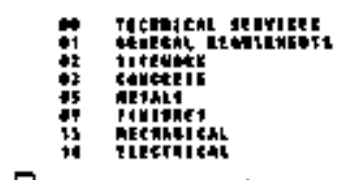

官

pated renht

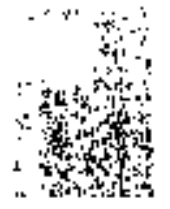

,

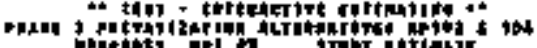

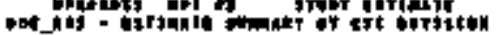

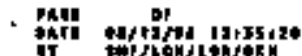

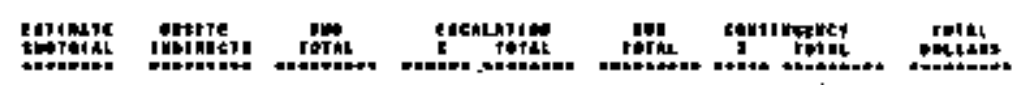

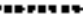

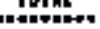

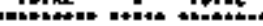

intans

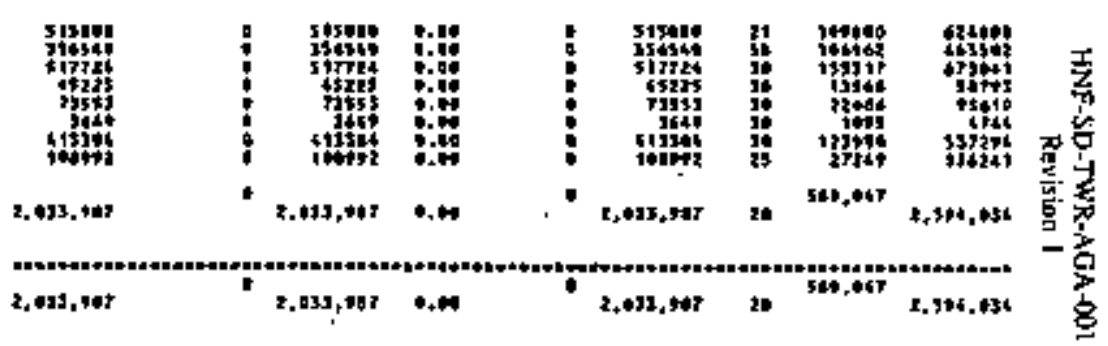




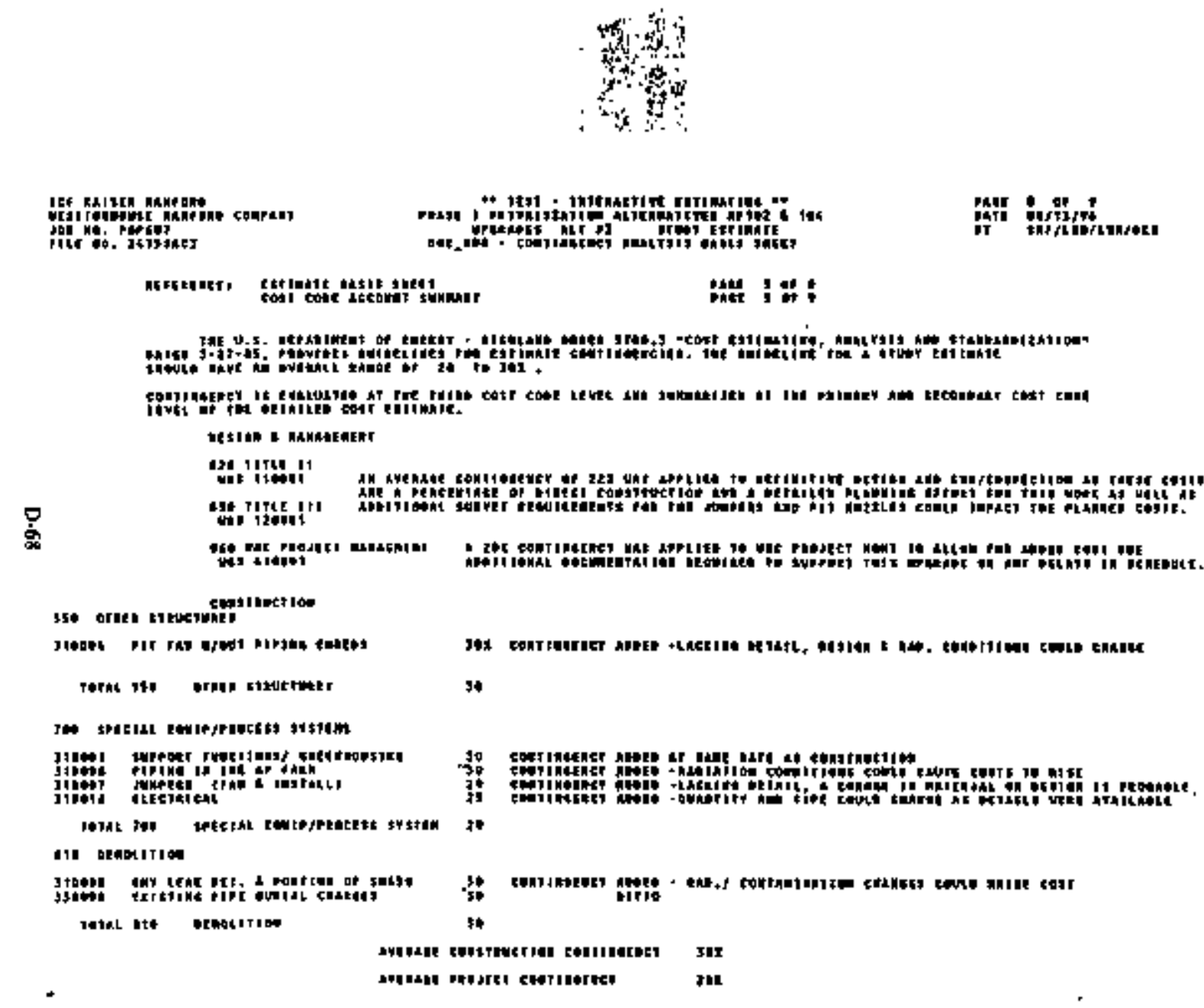




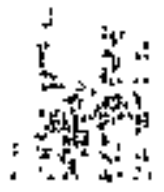

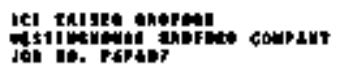

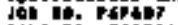

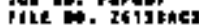

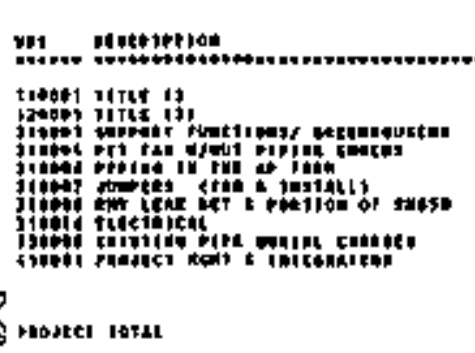

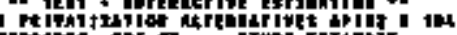

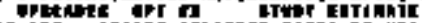

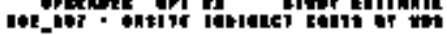

Itirwit:

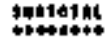

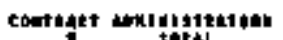
itidet

nit piez atmen.

rojed.

1stete

353

14713

19.

aris

111

isil

+十

$+4$

$+4$

$+4$

$+4$

$+4$

ritis

$+4$

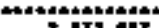

z.แ31.งเT out

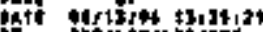

tet

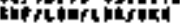

:

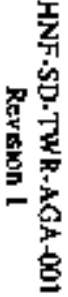


HNF-SD.TWR-AGA -DOI

Revișion 1

This paye imennionatly left blank. 
HNF-SD-TWR-AGA-002

Revition 1

\section{APPENDIX E}

\section{PULSAIR VENTILATION ANALYSIS LETTER REPORT}




\section{HNF-SD-TWR-AGA-001}

\section{Revision I}

This page imentianally left blank. 


\section{APPENDIX 2 \\ PULSAIR VENITLATION ANALYSIS LETTER REPOAT}

\section{E1.* JNTHODUCTION}

Thus report analyzes the effict of a inoposed tank waske mining stratery known as Puksar of the 241 -AP Tank Farm exhaust vedulation systerr

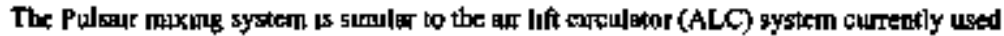
to agtates waste in the 241-AY ind 241 AZ tanks The primary differmse in operation ig that the

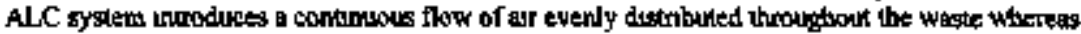
the Pulsair sybatent depends of relatively wioknt local spargang at one of 1 wo sites wilhen the bink Air is aidmitted al a frequenty of ftom 5 to 12 pulsesimin

It tis tecessary to know the effect of Pulsalr on the followith

- Wabte tank thermodynamics

- Thk head space pressure vatiainons

- Arosol generabon and exhaus HEPA filter life

\section{E7. SUMMARY, CONCLUSION, AND RECOMMCNDATIONS}

Calculatung have beet performed to malyze the efiect of the Pulsart bystem on temperature, pressure, and eerosol generaton withun the 24I-AP larks

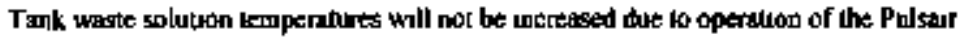
mixing syblem This is th contras to the elevaled waste temperanue created by uge of moxer pumps

Tank hatd apdoe pressure will vary less thap 4 percent as a drect recult of Pulsalr operallot

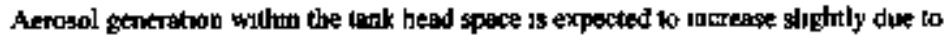
Pulsarr operation. Under these conctiong, HEPA filter iffe in the ventilobon exbause system has been calculated as 2 B yeors or more Insialation of a protreatment device upstream of the HEPA fifters may be warranted if exiended filter changeon intervals ane watued for companson, the 
Existing HEPA filkers have shown kess than 0.25.in we. pressure differential increase per year of operation.

A cost estimate has been prepaned for installotion of a fluddic vartex serubber to oxiend HEPA filter life. Performanes and operating principles of the gerubber ate described in the referenced journal article (AEA 1993). The efficiency of the Eluidic gerubber is nearly 99 percent

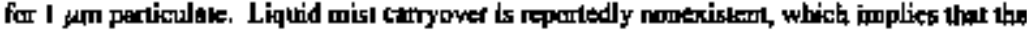
deentrainet in the tank farm ventlation system could be eliminded if a fluldic serubber with full system crapucity $\left(34 \mathrm{~m}^{3} / \mathrm{min}\left[1,200 \mathrm{ft}^{\mathrm{t}} / \mathrm{min}\right.\right.$ ) were installed. The extintated toted project cost of a $11,3 \mathrm{~m}^{3} / \mathrm{min}$ ( $400 \mathrm{f}^{2} / \mathrm{min}$ ) scrubber (to treql exhaugt from Pulsair tanks anly) is $\$ \mathrm{~s}, 000,000$ (ree Section E7.0). The cost tstimale includes a conkrete enclosure (missile athd naliation shielding) around the scrubber, and a large anount of "bumnout" expense to perform hoot lie-ins wo the existing wertilatian piping.

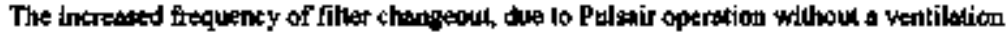
system pretreatment device, will iprrease tant fanm maintenance costs. The hiftesycle cost for

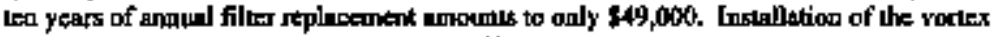
scrubber for the sole purpose of extending tilter life is, therefore, nor cost eflective. Howevers, if the coupplete exhaugs system were to be replaxed (as rocomirended by Project W.314). installation of the serubber may be coet effoctive, and should be given serious consideration in light of its unique capobilities.

\section{E3, APPROACH IEVALUATION}

A thermal analysis of the 241.AP lanks was performed to determine the effect of using the Pulsoir mixirig system. A compuler code developed for project W-236 was used to modet the waste ink heat removal systems. The Pulsair system was modeled using the provision in the colde 10 allalyze the effect of ALCS.

Itoput to the program included the followine:

- Rationuclide decay heat

- Inlet air tempesature and humidity

- ALC flow rate

- Vupor suppression factor

- Anutus fow conddions

- Tenk timentions. 
HNF-SD-TWR-AGA-001

Revision 1

Outpux from the progran included the following:

- Waste temperthure and vapor pressure

- Net evaporation

- Supply air nequired

- Vapar space kemparature and bumidity

- Courection and conduction bea losses.

Pressure variations in the lank herad space caused by digcrele pulsed air adilitions wo the

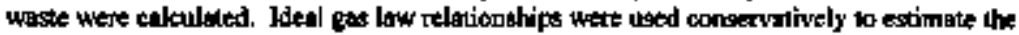
change in pressure assuming the volune and temperature to be flked, with a varibble gas masto

Aerosol generation due to Polsair operatios was assumed to be equival tat to the effect of AlC's in existing aging waste tanks. Aecosol mexsuremends have been made in the vertilation syglems for the aping watser tanks and for the AP Tank Farm (Ligotke et al. 1994). Calculations were mode to detemime the projected HEPA filter life in AP Tank Farm assuming fiker change out at a particulate kad of $2,000 \mathrm{~g}$ in a $28.3 \mathrm{~m}^{1 /} \mathrm{min}(1,000 \mathrm{ft} / \mathrm{min})$ HEPA Elter.

The additional coas for a wetreatrent device to extend fiher life was compared with the filter changeout costs that would be incurred without the device. Fitter changeonl and disposal costs used (from persongl communicalion with J. T. Ross) were as follows:

- $\$ 2,600$ per cubic metcr (\$3,500 per cutic yard) burial 009

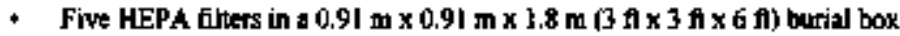

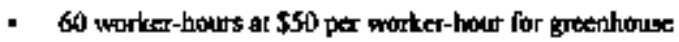

- Each HEPA fiher cosi \$250.

Assuming ontly two filters are changed oul for ench greenhouse set up, the average cost of meptaceaneml is approximately \$3, IS0 each. Changeoull of two fihers per yetre (congidered excessive, based on the calculaved lite of 2, B years) wonld lecur an antul expense of 36,300.

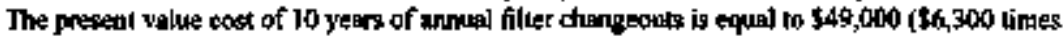
7.76) (Polersen I990). 
HNF-SD-TWR-AOA-D01

Rerigion J

\section{DA.* UNCERTALNTIES}

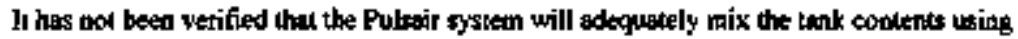
the given gir quentities.

\section{ES.0 RDFERENCES}

AEA Technology Engimesting Serwlces, "Solvend Recovery. Try Power Fluddies," The Chetrien' Enginest, December 9, 1993, Huntsville, North Carolina

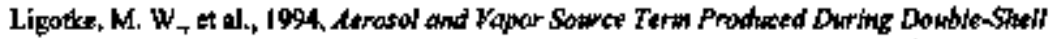

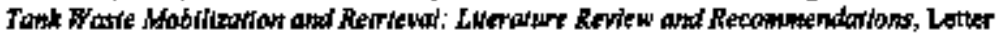
Repon, Pecific Northwest National Laboratory, Richlent, Waghirgion.

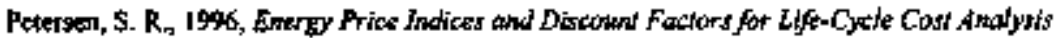
1996, NISTLR 85-3273-10, U.S. Department of Commerce, Washington D.C. 
HNF-SD-TWR-AGA-OOI

Revbskon 1

\section{E6.0 CALCULATJON}

\section{PULSAIR VENTILATION}


FINF-SD-TWR-AGA-OOI

Revigion I

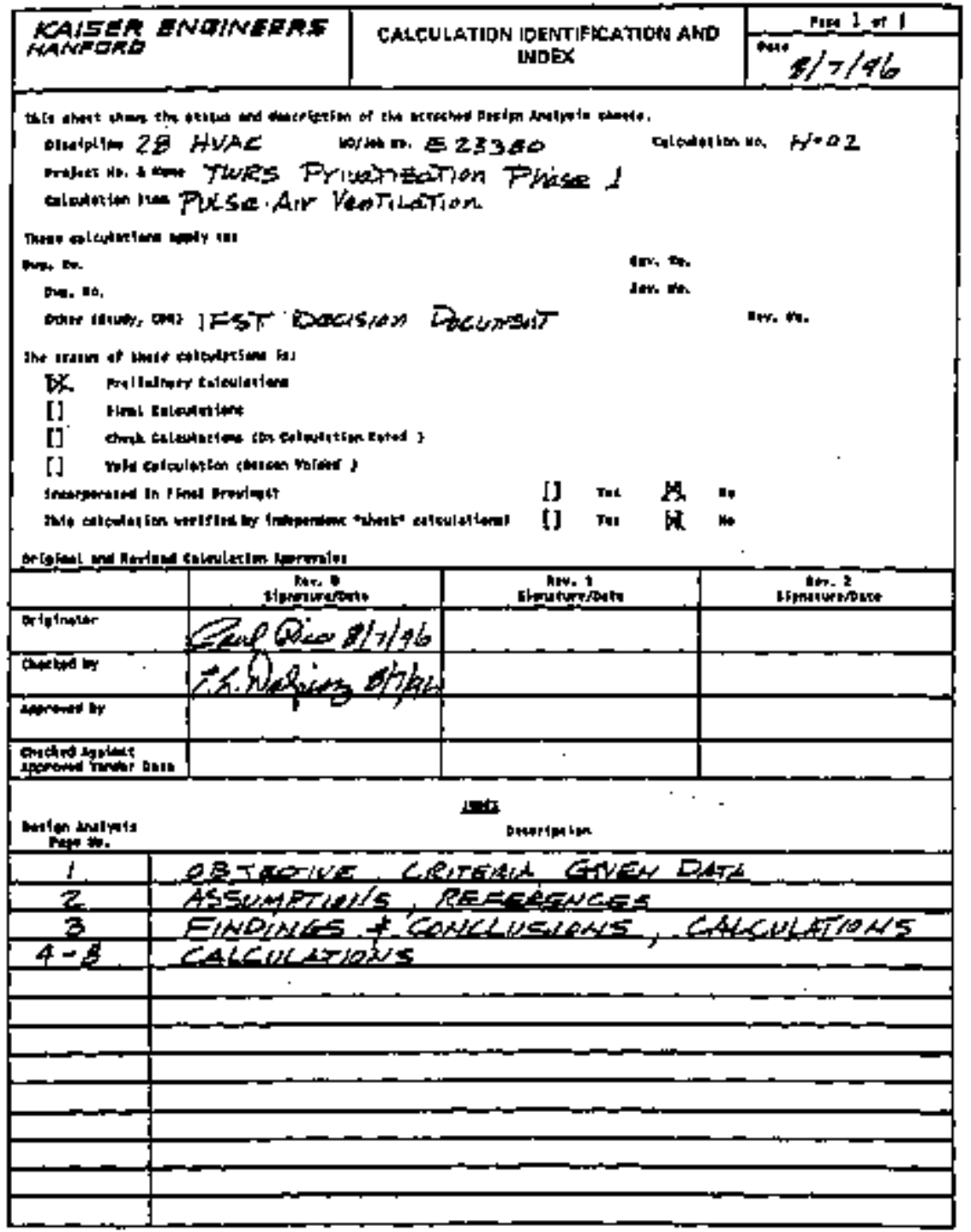

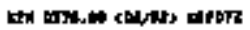


HNF-SD-TWR-AGA 001

Revision I

KAYAGR INOINEERS

DESGH ANALYSIS

c1.pof Whe

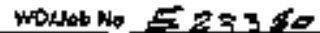

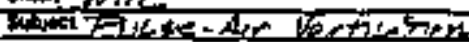

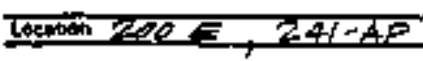

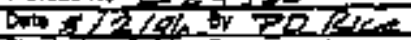

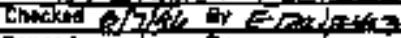

tove ins

Anriogen

Prov kp

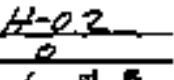

Rembind

아

- $=$

- Yo getratrese

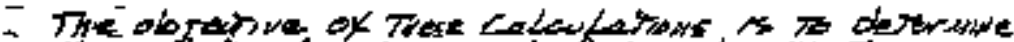

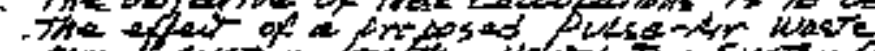

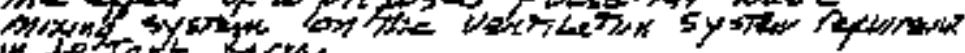

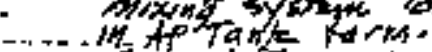

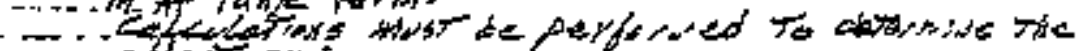
- oflect on :

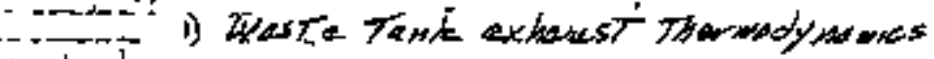

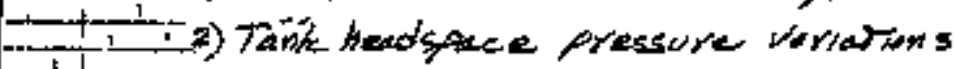

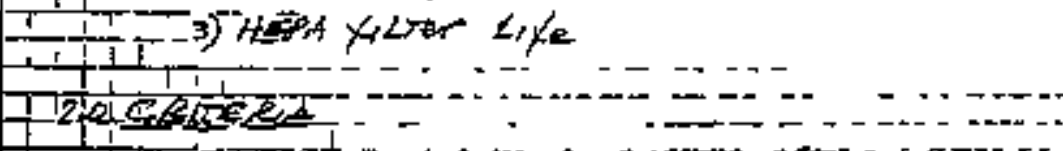

. 1 1

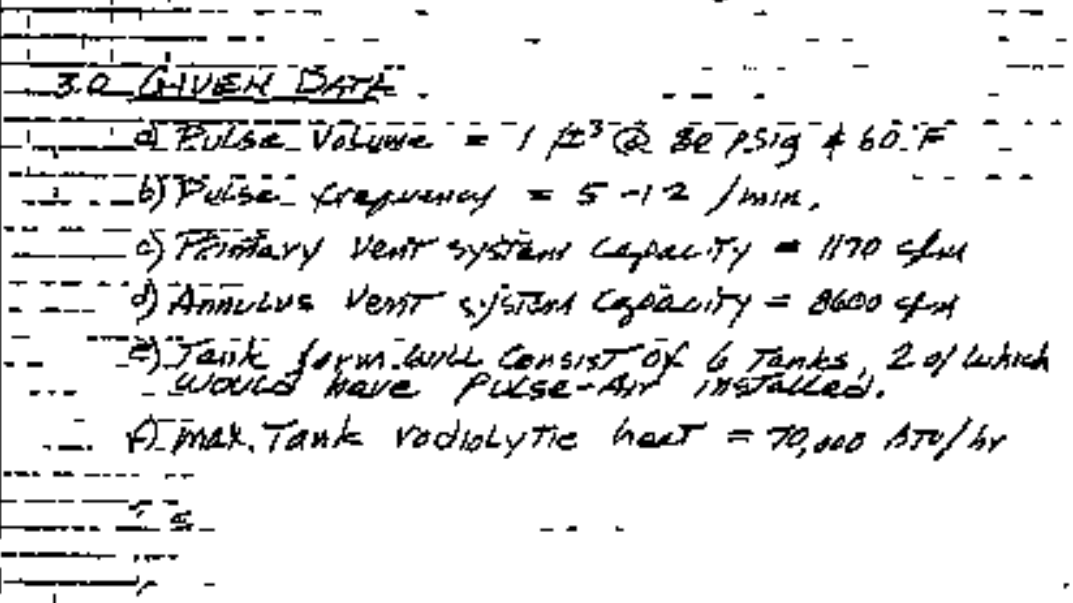

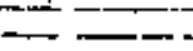


HANF-SD TWR-AGA 001

Revison?

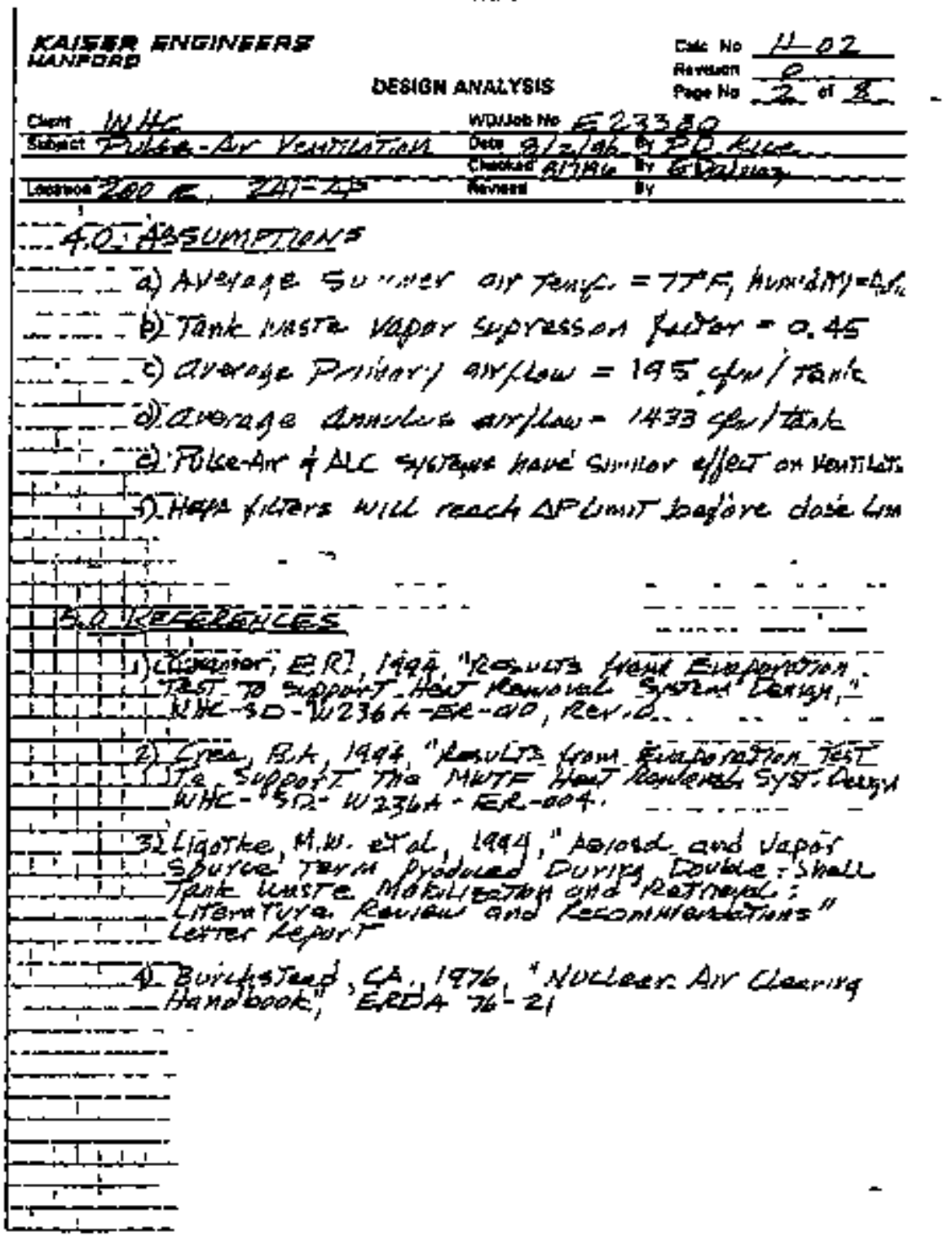

E-10 
HNF-SD-TWR-AGA-001

Revision I

KA/7FR ENONEEAS

HANFARO

Emin WL

DESION AKALYSHS

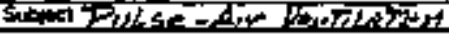

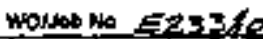

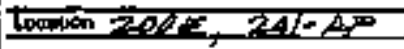

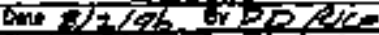

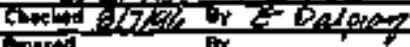

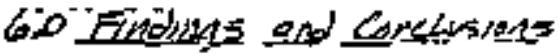

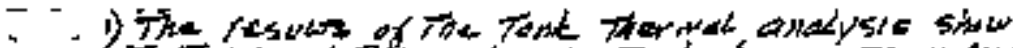

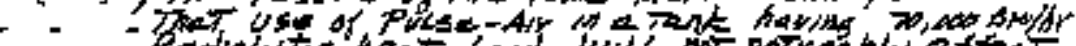

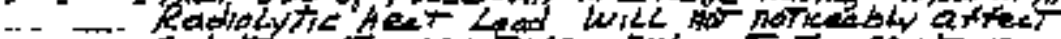

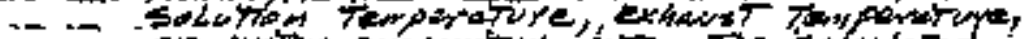

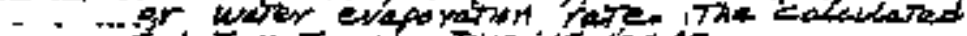

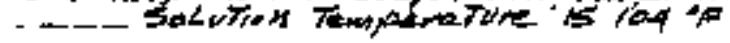

- $\cdots--_{1}=$

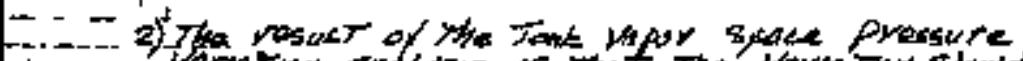

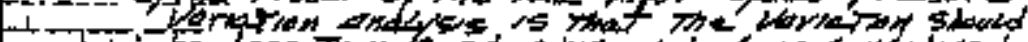

F-

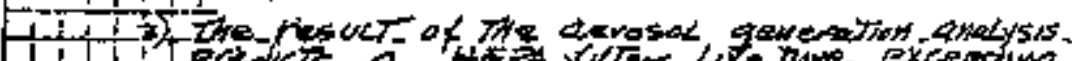

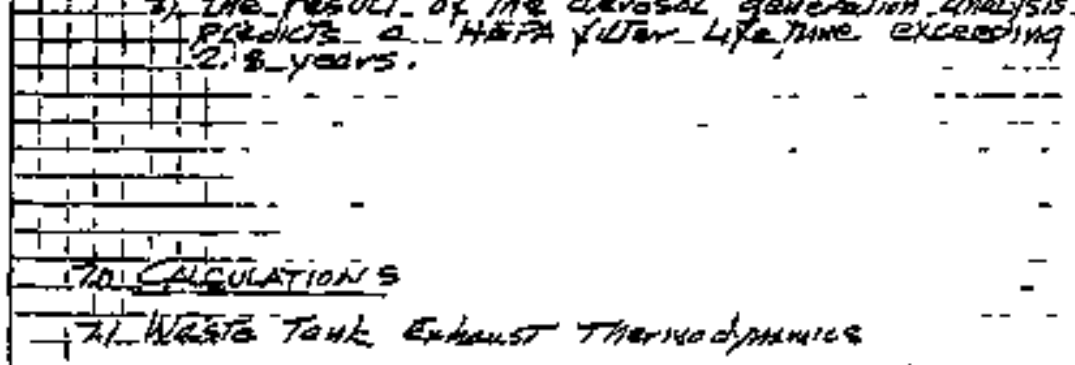

-

-

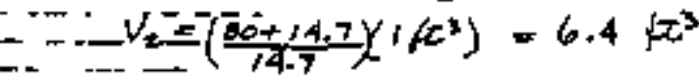

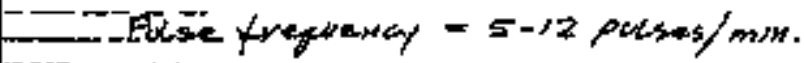

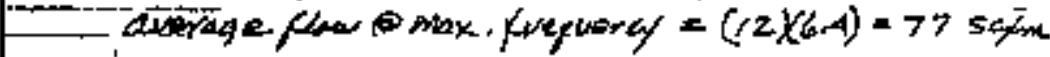

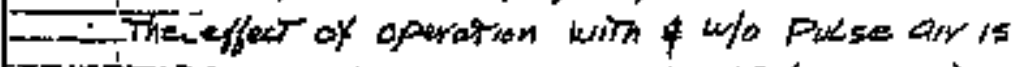

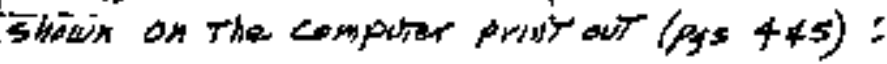


Revision I

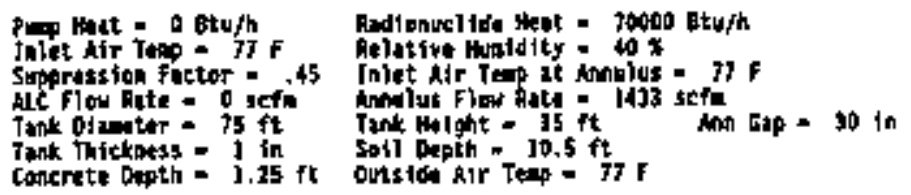

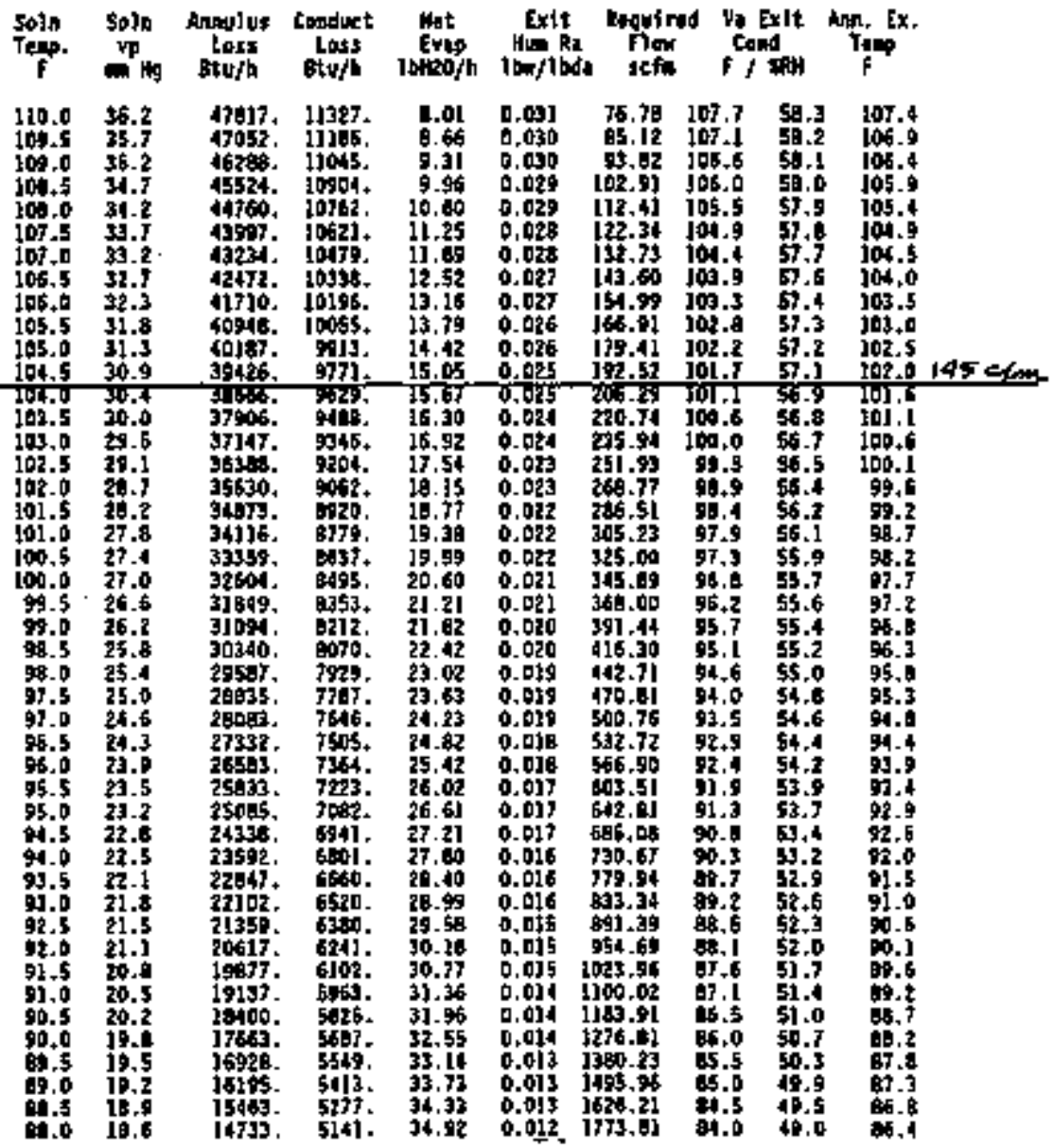

E-12 


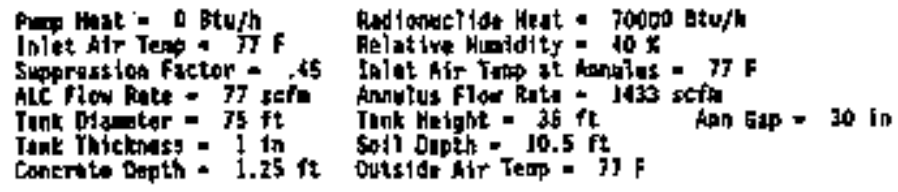

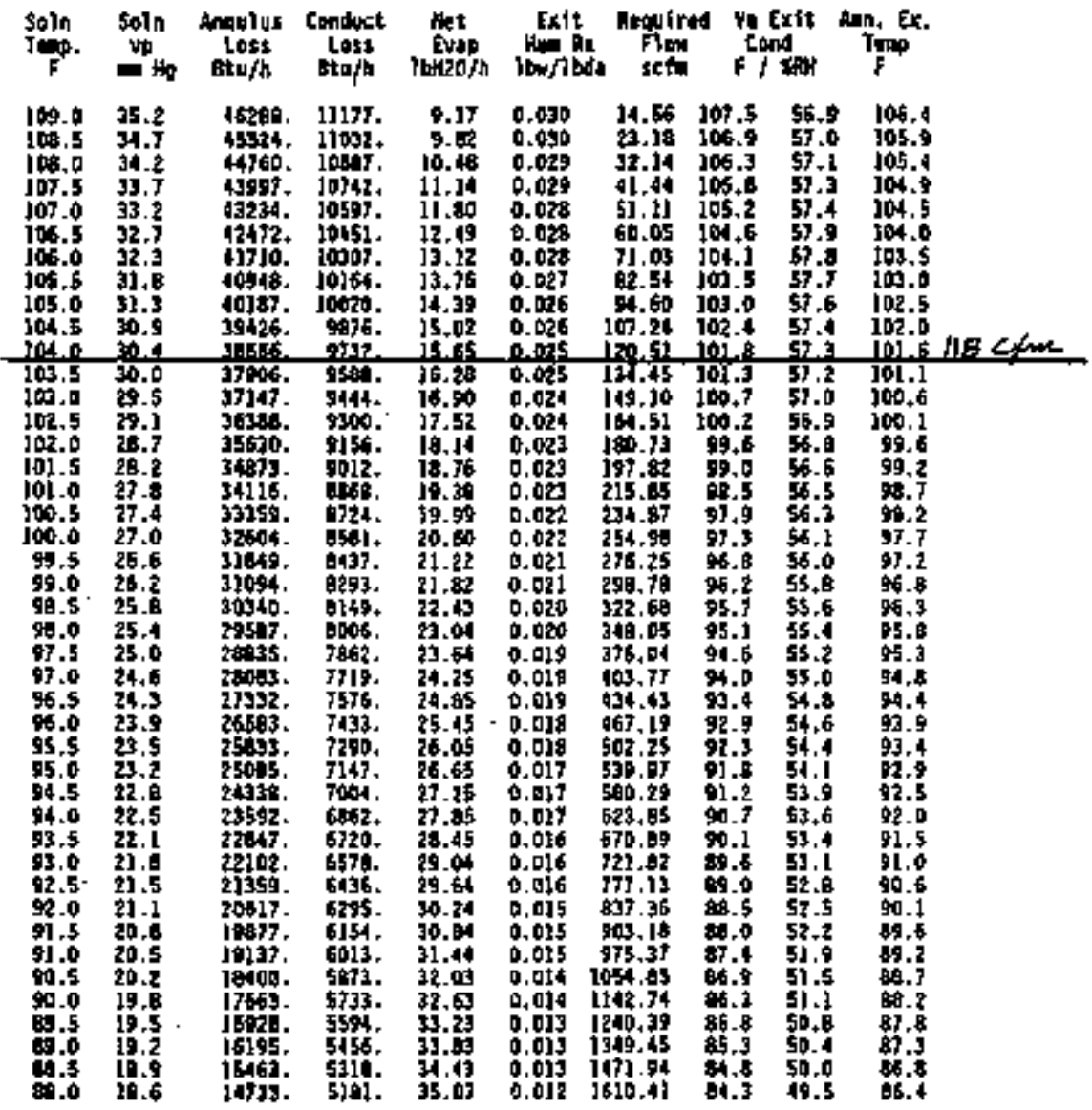


HNF-SD-TWR-AGA-OOU

Revoron 1

KAMCA ENGINEEAS

HANOAS

than

DEFIGN ANALYSAS

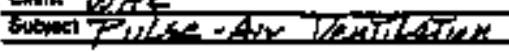

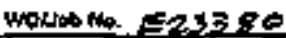

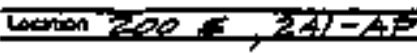

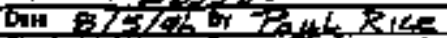

chend

Cac. No. $\mathrm{H}-\mathrm{OZ}$

nintom $\mathrm{O}$

$\tan$ No. 7 . lonem

calevialows (conr)

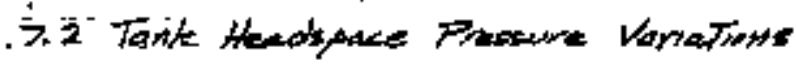

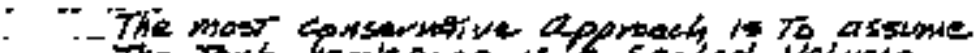

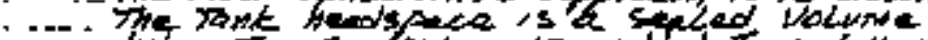

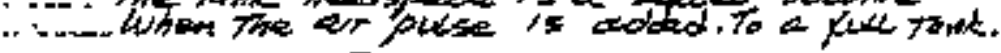

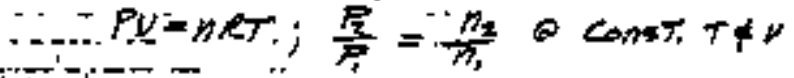

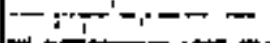

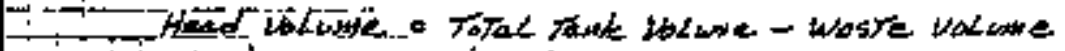

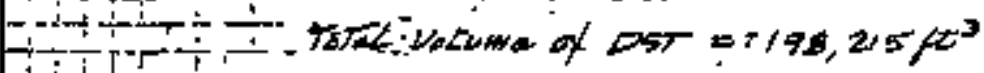

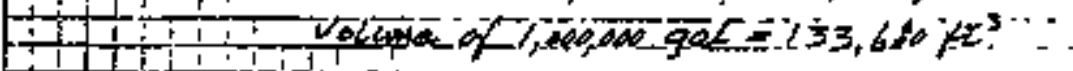

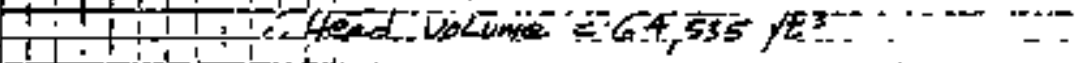

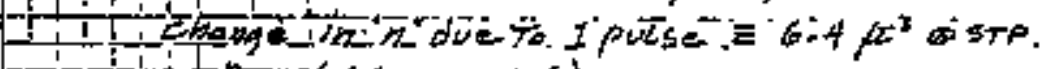

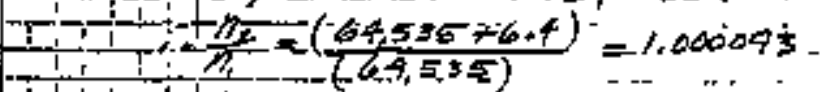

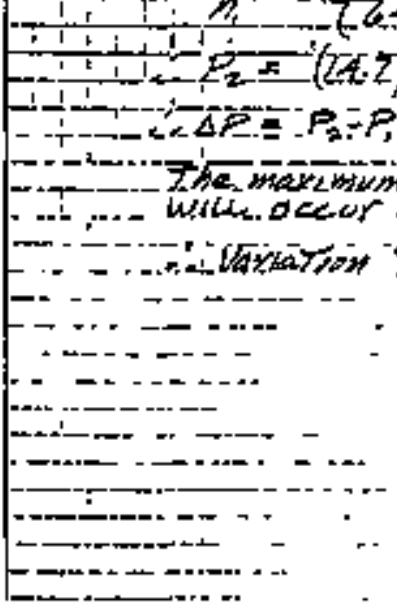


HNF-SD-TWR-AGA-OOI

Revision 1

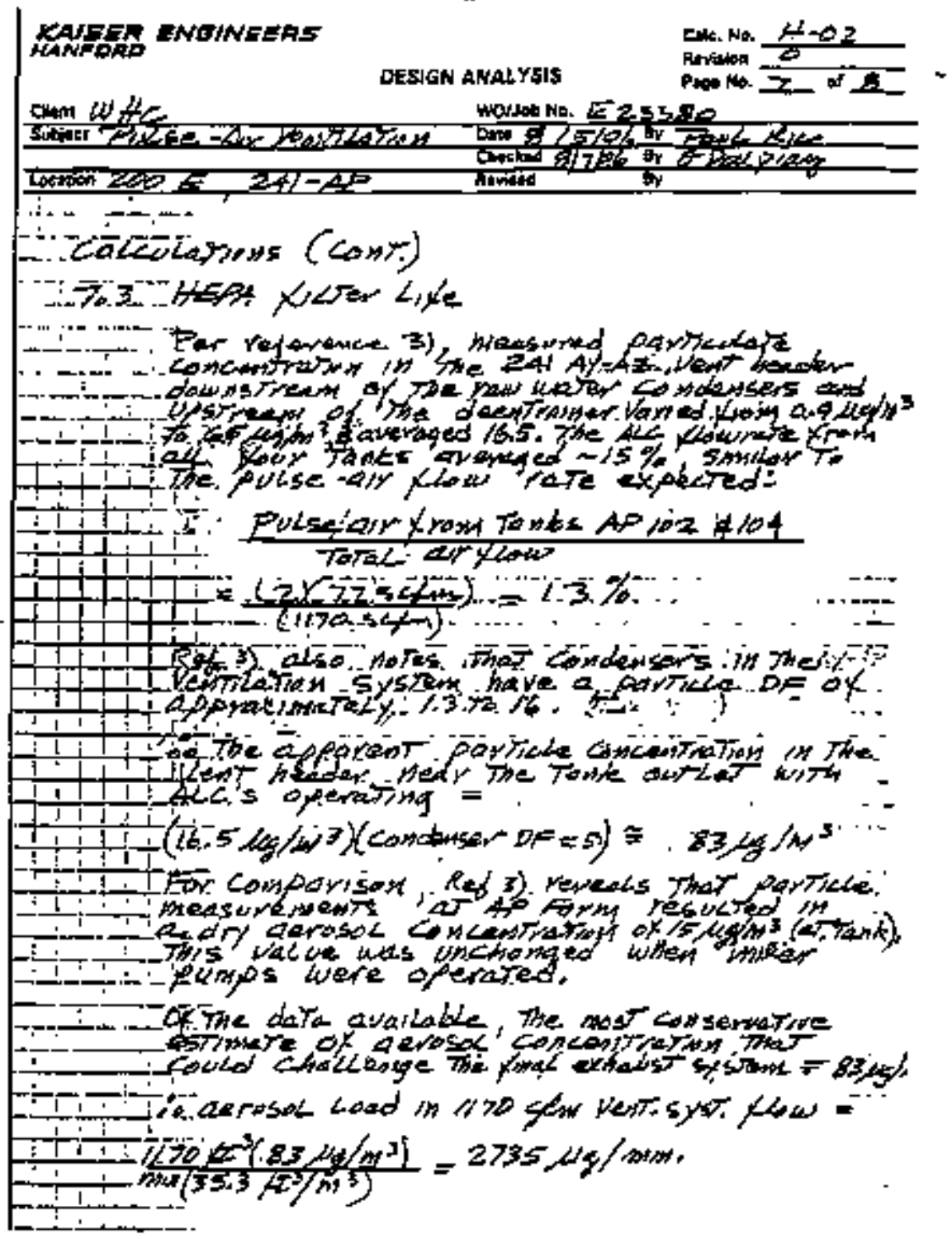


HNF-SD-TWR-AGA-001

Revision I

CAITER ENGINGERS andreno

Cann als

DESICN ANALYSIS

Cole tho $H-6 ?$

Minvion

Pagr No. $\bar{f}$ of $\bar{g}$.

in

work H. E 23380

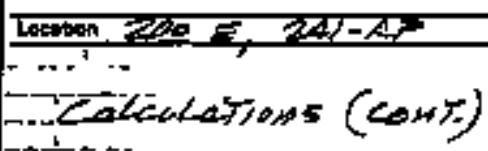

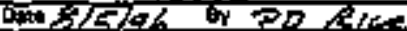

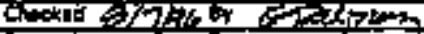

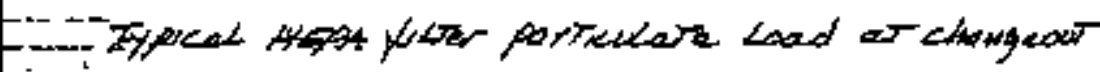
E

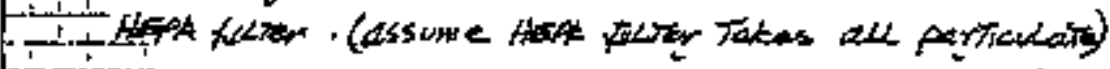
$=\frac{2000 \mathrm{gm}}{2735 \times 6 \mathrm{gm}^{2} / \mathrm{wh}}=73 / 400 \mathrm{mw}-508 \mathrm{days}$

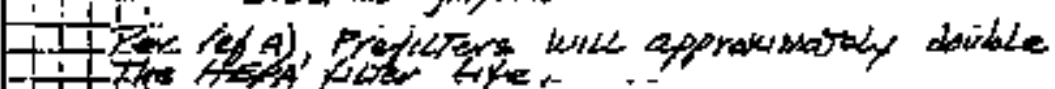
$1+1$

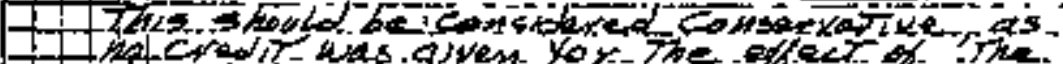

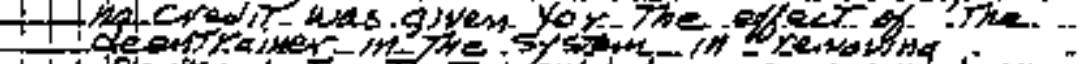
11 bay

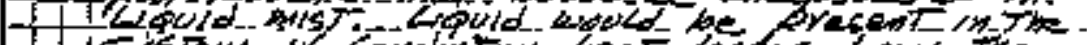

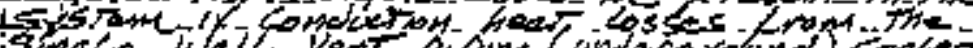

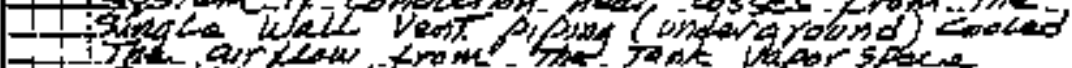
1 1

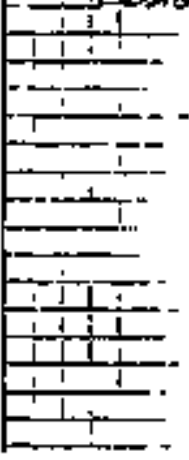


HNF-SD-TWR-AOA-0OL

Rertston I

E7. COST ESTIMATE

YORTEX SCRURBER 


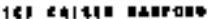

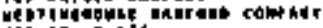

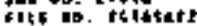

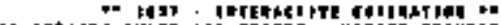

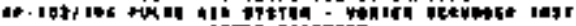

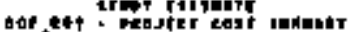

rant I B it

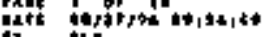

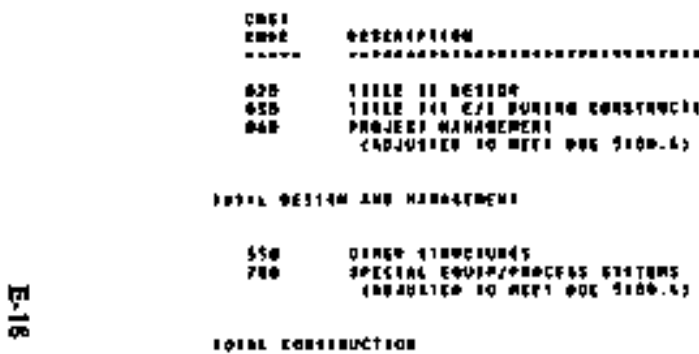

1 o1 be rentinuttian

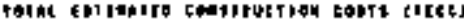

ots oldte petrert cons

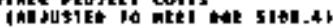

(2)

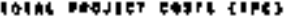

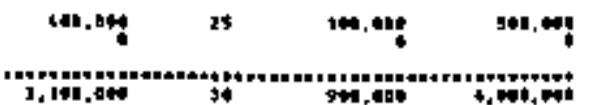

$\because$

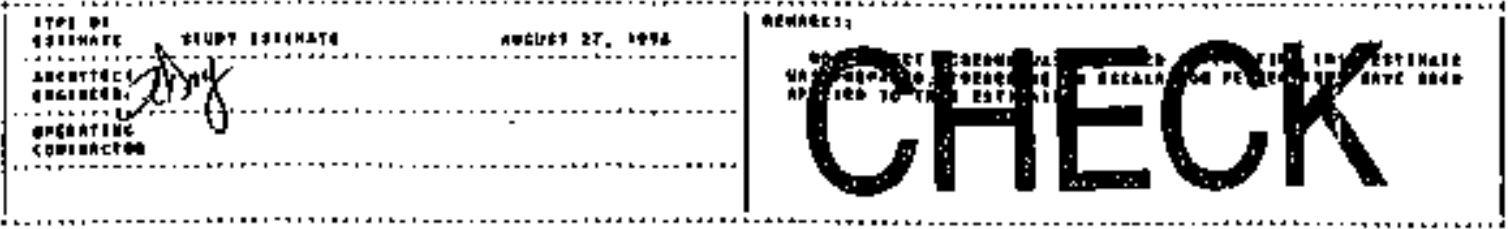

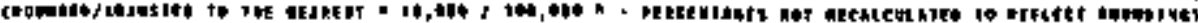




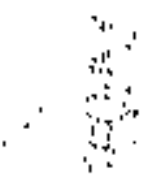

IES k1175t therbot

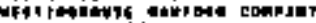
bal It. risid

int an. to idshe?

We betration

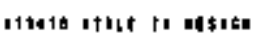

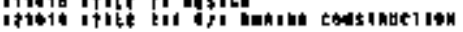

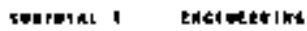

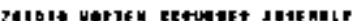

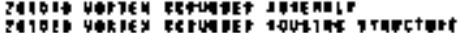

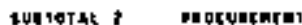

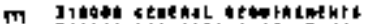

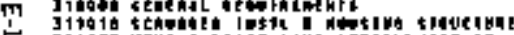

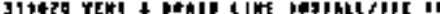

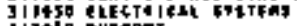

(1)

gettolite 31 contingtilon fotces

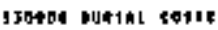

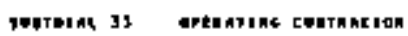

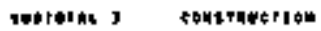

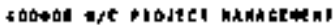

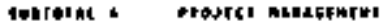

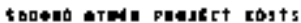

Hodete Tolind

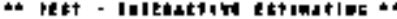

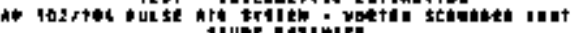

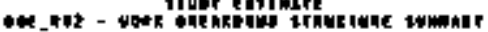

What 2 or 1 .

thite corzitionstist

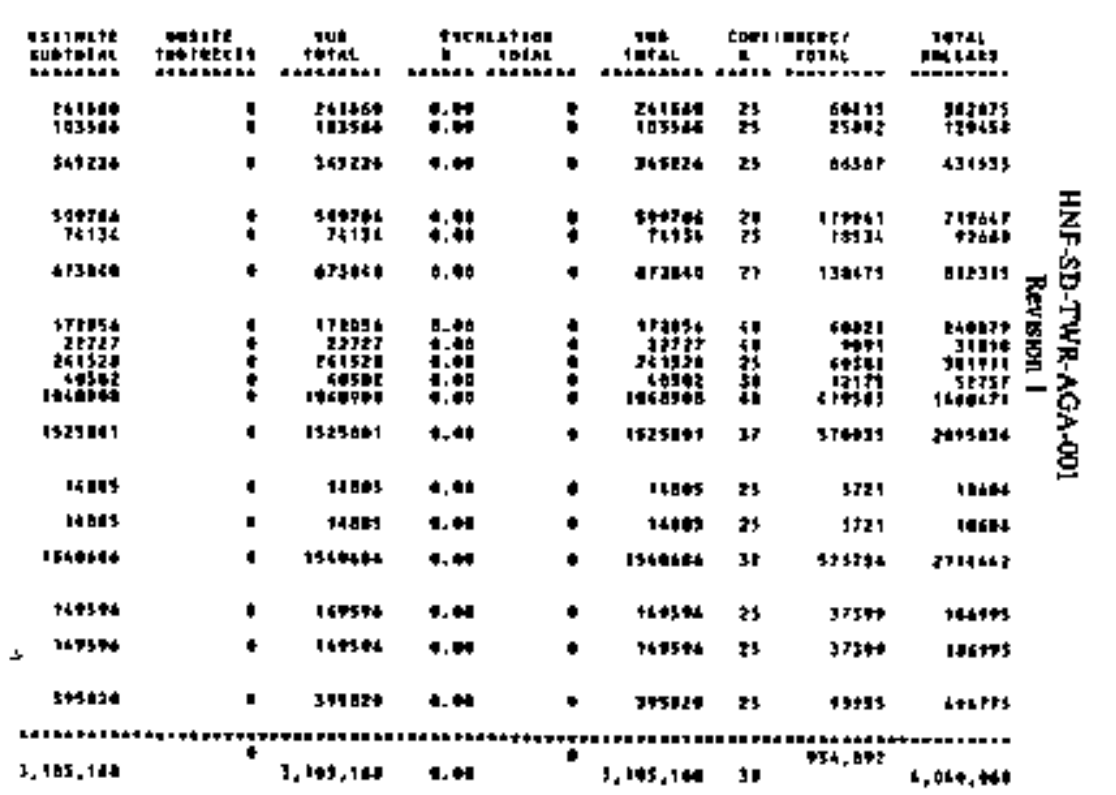




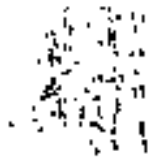

1c1 ratuth alufone

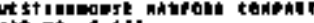

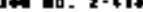

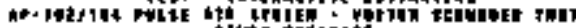

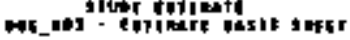

DeIf $1 \%$ it

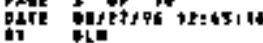

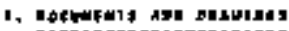

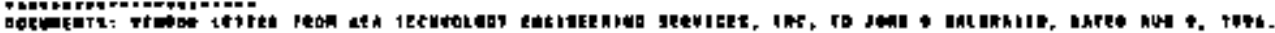

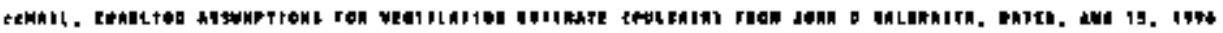

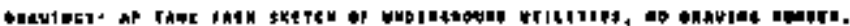

2 mathind pareft

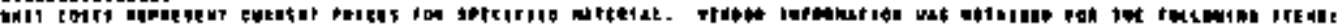

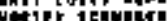

3. LJedn חLT5

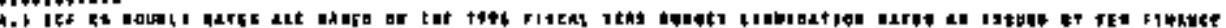

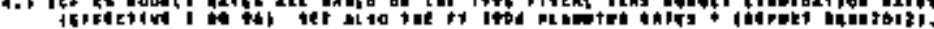

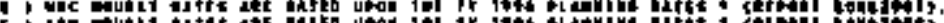

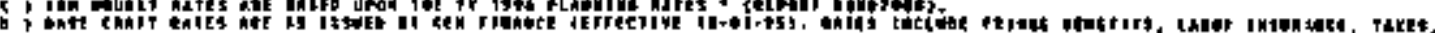

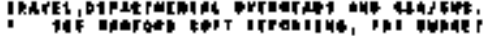

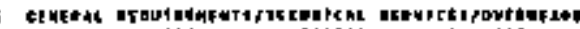

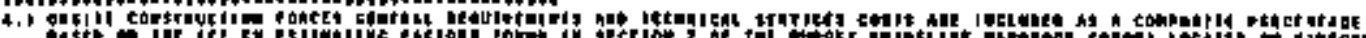

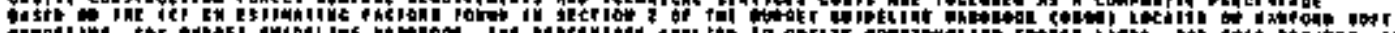

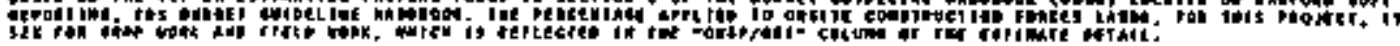

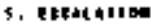

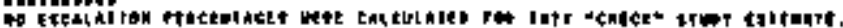

+ nquatime

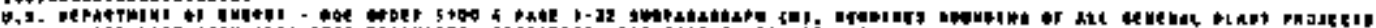

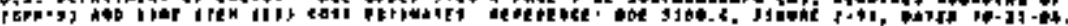

1 utuhlers

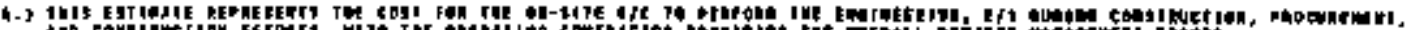

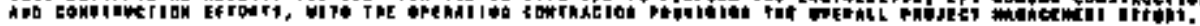

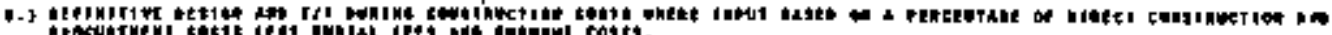

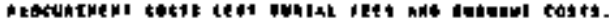

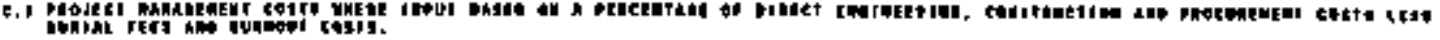




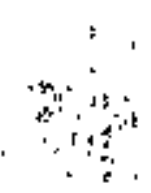

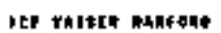

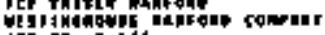

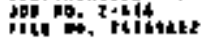

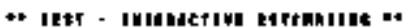

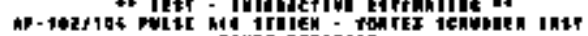

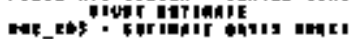

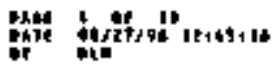

7. Hening to ton I,

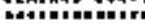

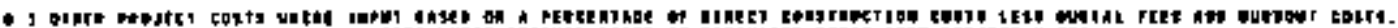

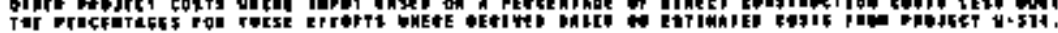

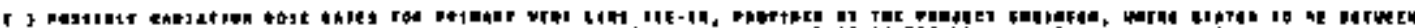

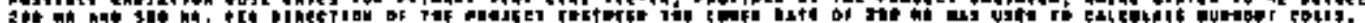

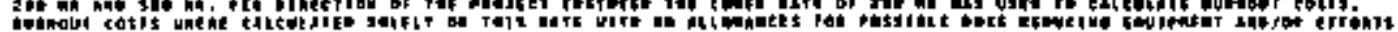

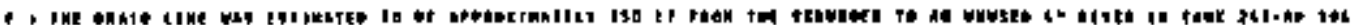

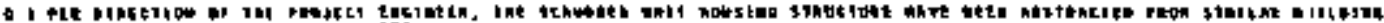

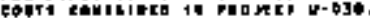

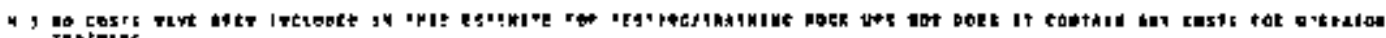
Turatere.

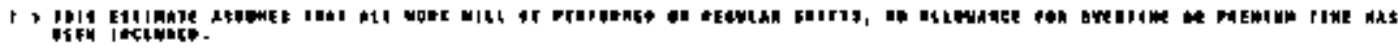

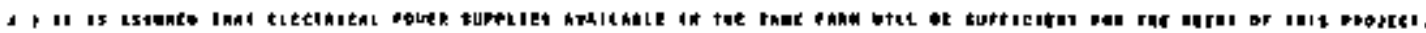

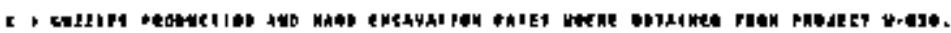

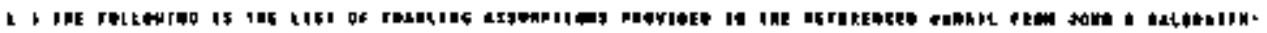

IMETHent shawict:

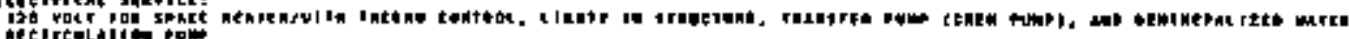

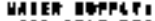

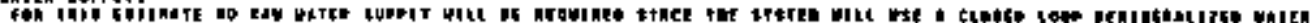

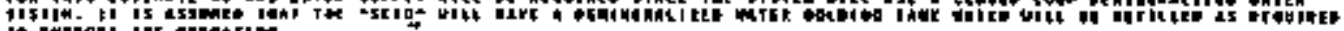

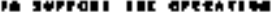

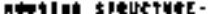

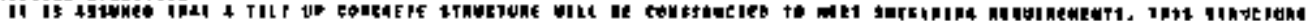

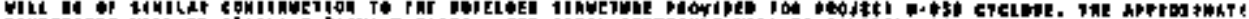

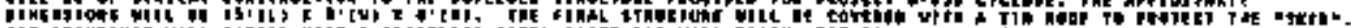

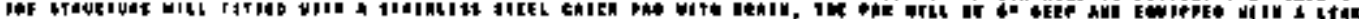

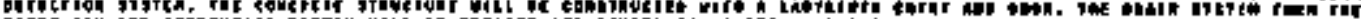

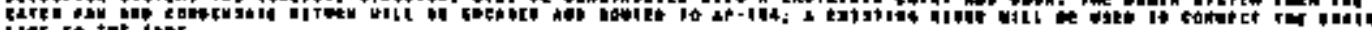
itex re ter intr.

Thel 1 ind

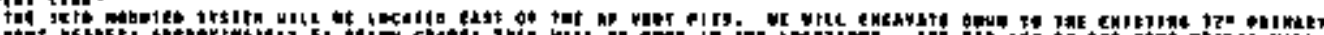

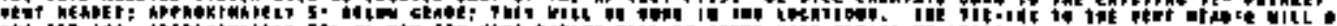

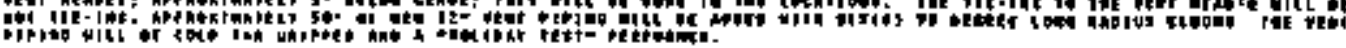




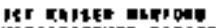

oput conser

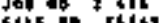

Cotil fow

nerantica

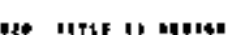

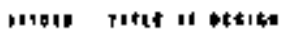

terms of rile il velitt

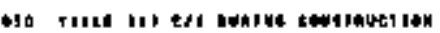

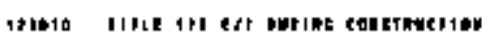

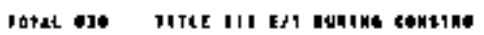

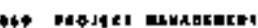

choute are bestel Phwermenl

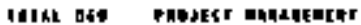

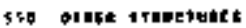

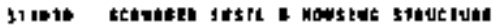

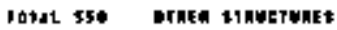

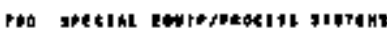

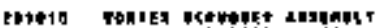

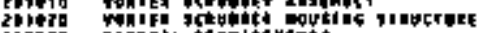

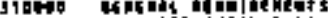

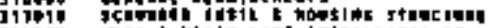

vel to the cine irstalete is id

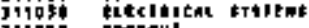

ग197\%

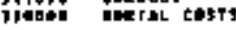

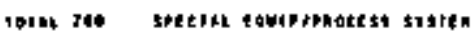

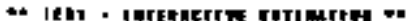

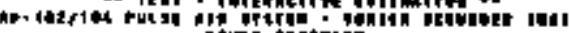

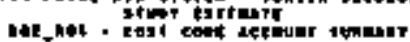

FaLd 5 ar 10 84-19t5t or th

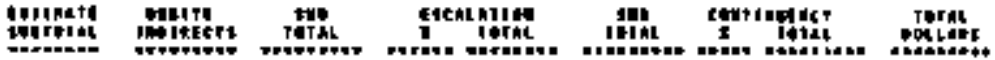

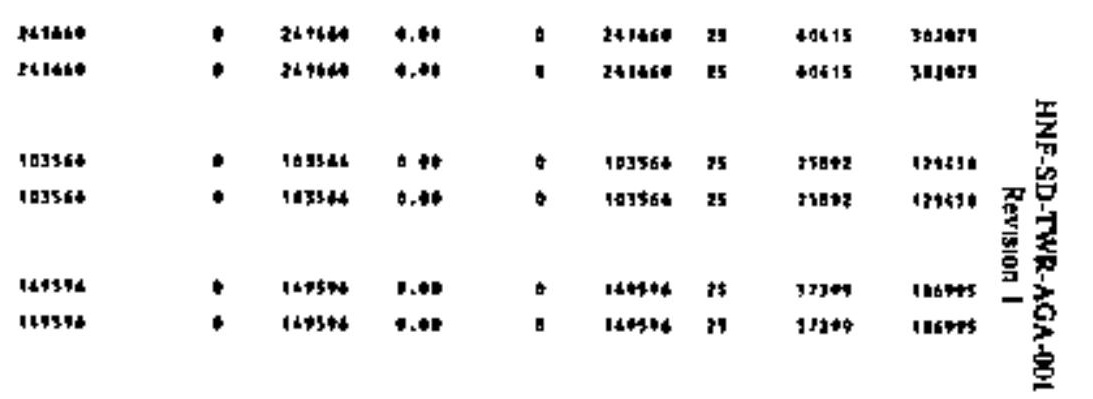

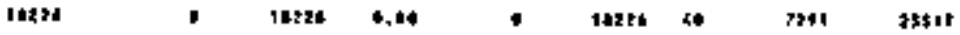

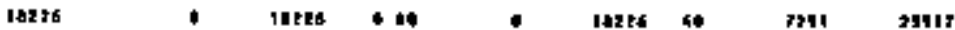

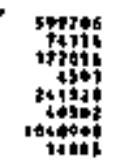

174get

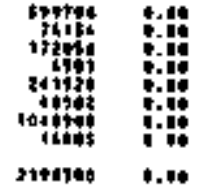

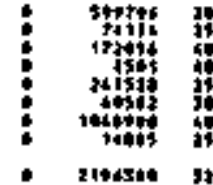

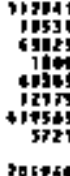

ritu? 2140 ring 3191; 32 ris iftert inder 24+124 
ItF rainer aheibra

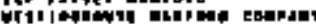

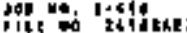

\section{tors}

cotistion

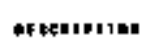

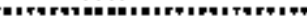

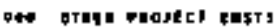

dotbeg Dinkt thesect casit

pothl wo ginet proser ceily

tkostel netal

ب.

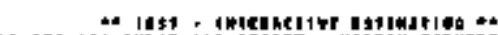

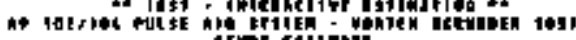

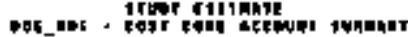

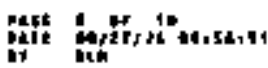

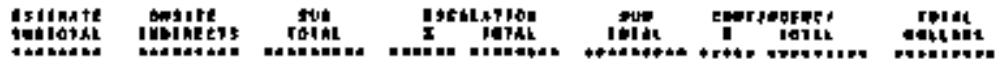

\begin{tabular}{|c|c|c|c|c|c|c|c|}
\hline$\$ 0507$ & a & Joldet & 1.0 & $\nabla$ & IV1*2* & 21 & 73053 \\
\hline & B & 301024 & 6.00 & $\phi$ & $5+1020$ & 25 & P4553 \\
\hline
\end{tabular}

(1)

1. 163, 1t:

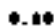

(1)

1.195 .14

$1 *$

9131, 442

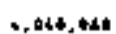




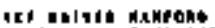

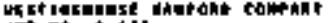

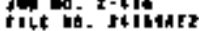

(4) AF netionima

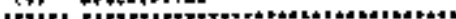

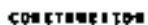

* ircatras diterites

- 514 and $r$

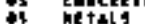

13 Metunhien

16 thicluith

14 Codzei mowhet meny

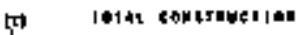

?

phestel Iolnt

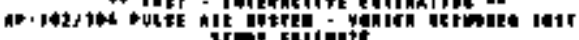

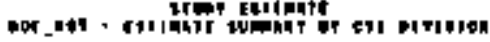

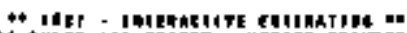

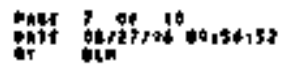

etiunte

dustoind

watite

chiketst

Totrat

TลT2L

Ettind hild

J Torinc

tบ1

Iorith

Cawingeter

laling

rolint

od Lint:

\begin{tabular}{|c|c|c|c|c|c|c|}
\hline 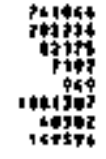 & 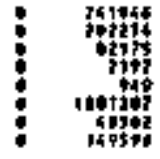 & 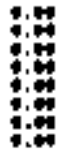 & 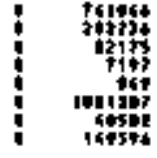 & $\begin{array}{l}51 \\
45 \\
45 \\
41 \\
51 \\
5\end{array}$ & 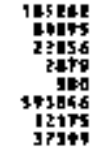 & 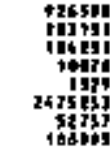 \\
\hline t.141.14t & $, 0,101,161$ & 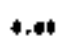 & T 5.109 .120 & 91 & $\$ 34,8+2$ & $d, * a, d t$ \\
\hline
\end{tabular}

5. 141. 140

,10T, 14E 1.t5

3, 119. IAt

I.

$4,46,46$ 


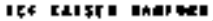

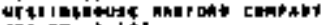
Jod me pid to

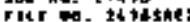

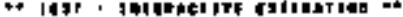

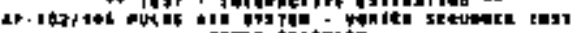

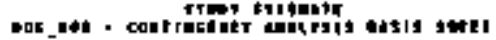

rati 10

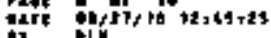
artarect; ;

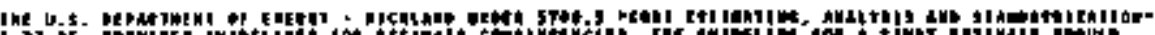

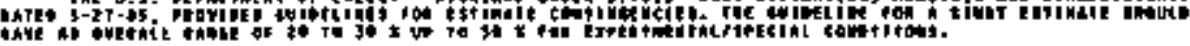

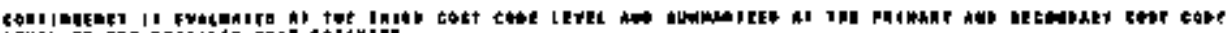
irtat or ier acrsicia roif etiande.

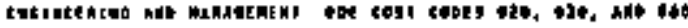

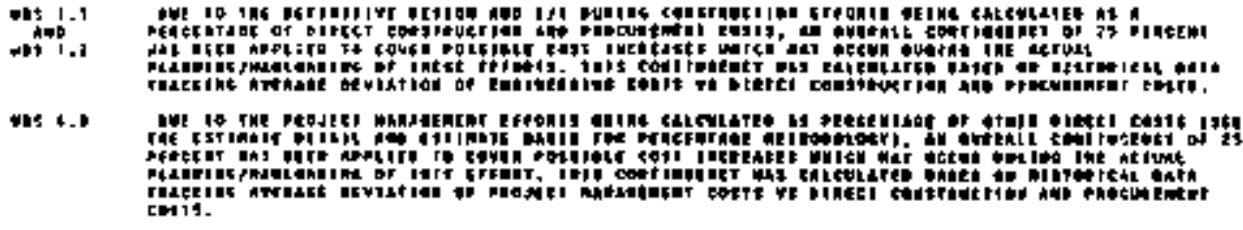

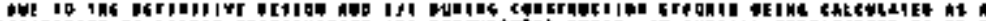

1. 1.

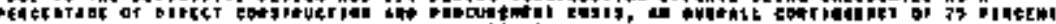

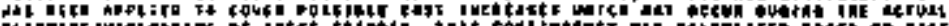

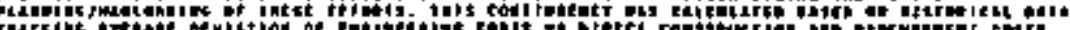

vits 4.

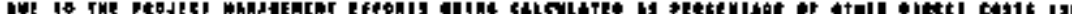

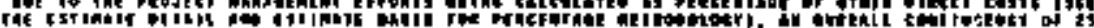

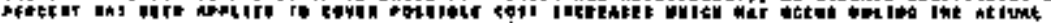

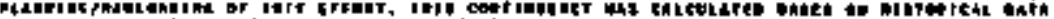

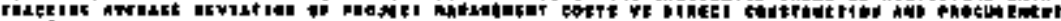
coris.

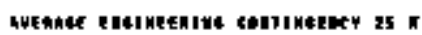

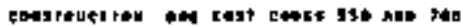

vits 1.

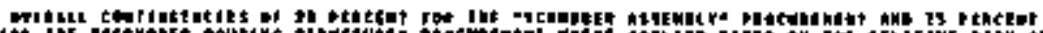
IHEkE

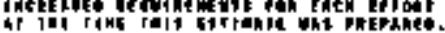

UaI I. 1

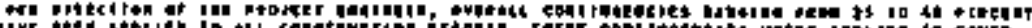

ing

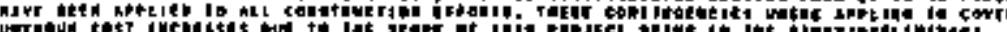

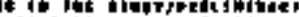

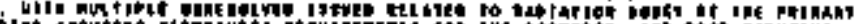

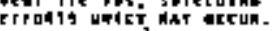

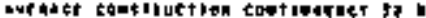




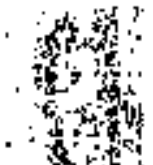

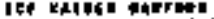

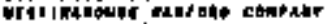

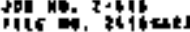

\author{
a IraI - Maphedetivn EtT1hilite at

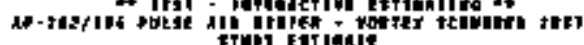

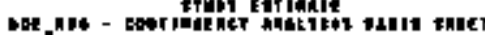

- that to to

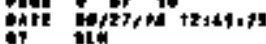

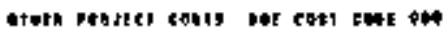

yte t,

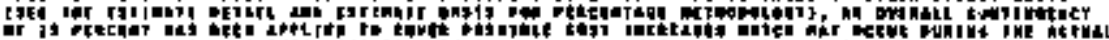

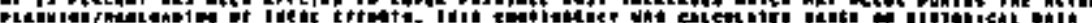

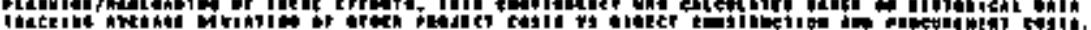

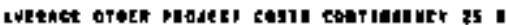

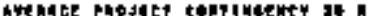




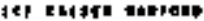

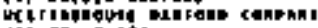
Iot an. $2+5$ th

riuc ab. pluket

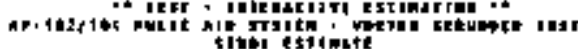

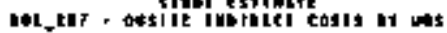

inte in

wh prietioriat

linte lint ti neticn

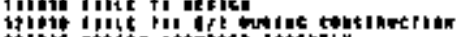

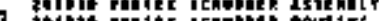

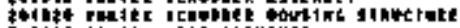

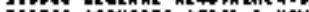

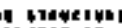

3115s renker

40.0

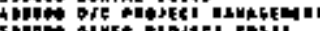

IU⿴囗十) 14

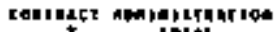

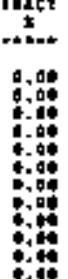

ipinis

24164

107546

547\%:

76134

1 Trets

itist

tod that

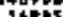

Intas

$1695 \%$

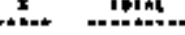

G. of

4.

4.60

4.94

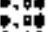

4

4.4

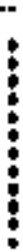

PAOJESI IOTAL

\section{$3,103,1+18$}

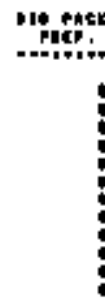


HNF-SD-TWR-AGA-COI

Revision 1

This page bicencionalty left blank 
HINF-SD-TWR-AGA-00I

Revision ]

APPENDIX F

SAMPLING SYSTEM ANALYSIS 
HNF-SD-TWR-AGA-001

Revision 1

This page irontionuly left blank. 
HINF-SD-TWR-A[DA-OA]

Revisian I

APPENDIX F

SAMHLJNG SYSTEN ANALYSLS

This appendix provides sampling aesumpriong and analysis used in determining requiratueals for the tabsysans of the Intementiate Waste Feed Staging System (1WF\$T).

\section{F1.0 PROJXCTED IEED BATCFES}

\section{W.I PROJECTED FEED BATCH SUPERNATANT COMPOSITIONS}

The feed bach supomatant sompasitional masses (as they will exigt in the internediele waste feed staging lagaks) are baked on Shelbon (1996) and ware calculated for, although not published in Certe et il. (19\%). Tobles F-1 and F-2 show the compositional ruagses (as prijected in 2002) for each butch for Controctors $I$ and 2, respectively. The chemical componerls are listed in metric vons (MT) and the radionuclides are listed in becquerels (Bq). The value for the total transuranics (TRL) is the sum of neptunium, plutonium, and americium isolispes.

Table; F-3 and F-4 show the projected IWFST foed bathoh supematant compositiong' for Contractors $l$ and 2, respectively. The concentrations, shown in molarity (M), for each

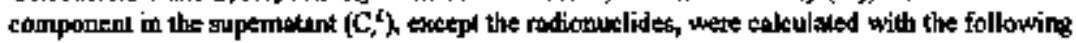
equation:

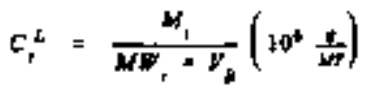

where:

M, = Mags of component i (excheding rodionuclides) in the botch (MT)

MW, - Molecular welgh of compuneal $f(g / \mathrm{grol})$

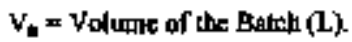

'Ths is the projected composition of the feed baches as they will oxist in the staging lankg, nol as they will exists in the conlroctors' tanks. 


\section{HNF-SD-TWR-AGA-DOI}

Revision I

For this calcolation, the molsculur weight of the tolal opanic carbon (TOC) was assumod to be 12 gimote. The concentralions of the radionuclides (in $\mathrm{B} 4 \mathrm{l}$ ) in the supernalant ( $\mathrm{C}_{r}$ ) ware calculated with the following equation:

$$
c_{r}^{+} \cdot \frac{M_{r}}{V_{0}}
$$

where:

$\mathrm{M},=$ Activity of nationonlide $r$ in the betch $(\mathrm{Bq})$. 
Táble F.I Projected Feed Bunch Supernalapr Magaes for Coptrator I (Tark 24I-AP-102)

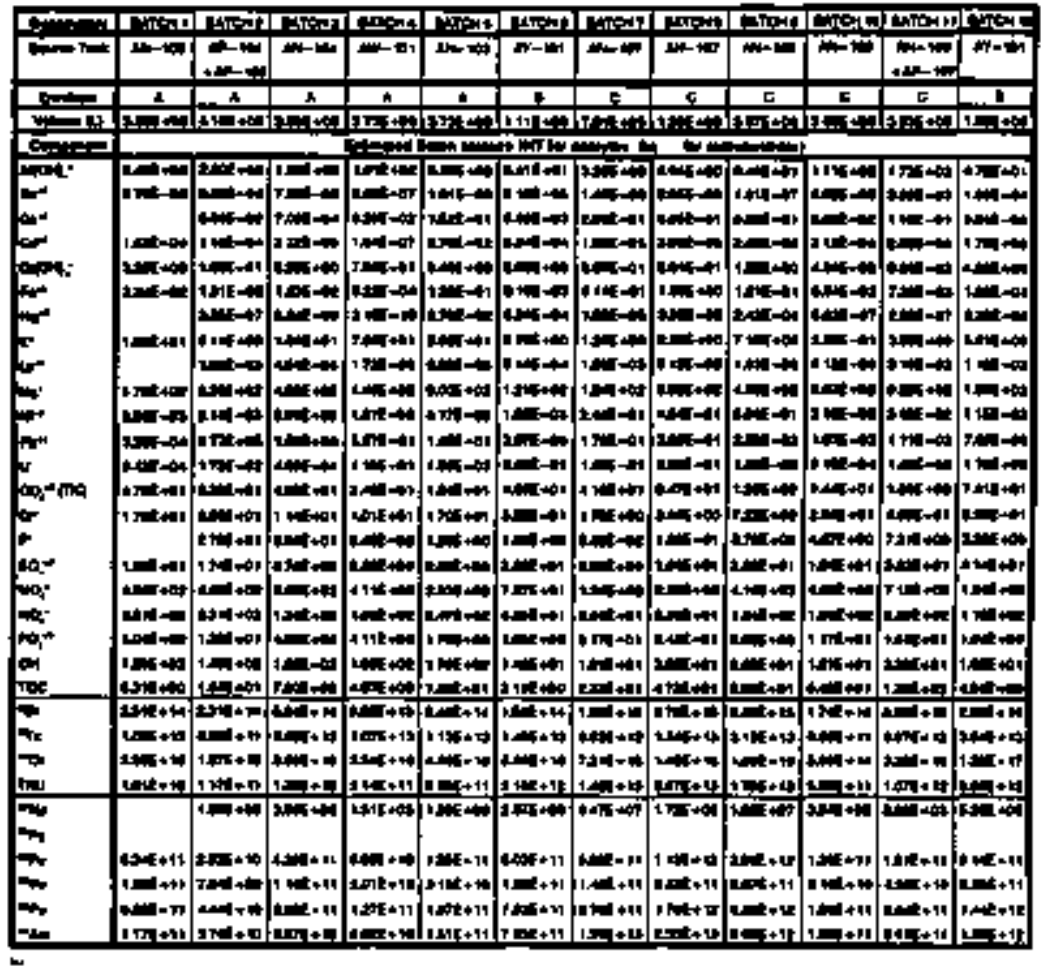


Table F-2 Projecled Feed Batch Supcrnatent Mnstes for Contrator 2 (Taml 241-AP-104)

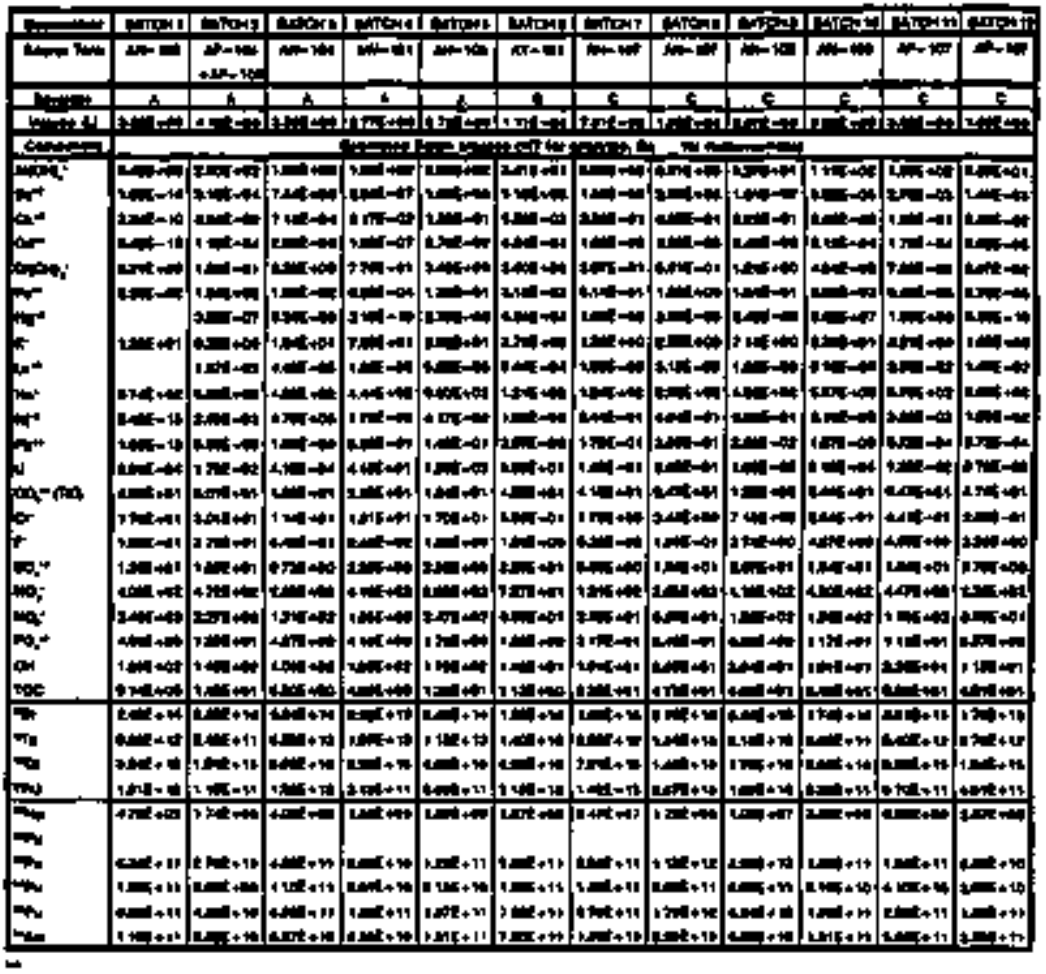




\section{HNF-SD-THR-AOA-00I \\ Revision 1}

Table F-3 Projected Feed Batch Supenrtant Compositwas for Combrachor 1 (Tunk 241-A.P-102)

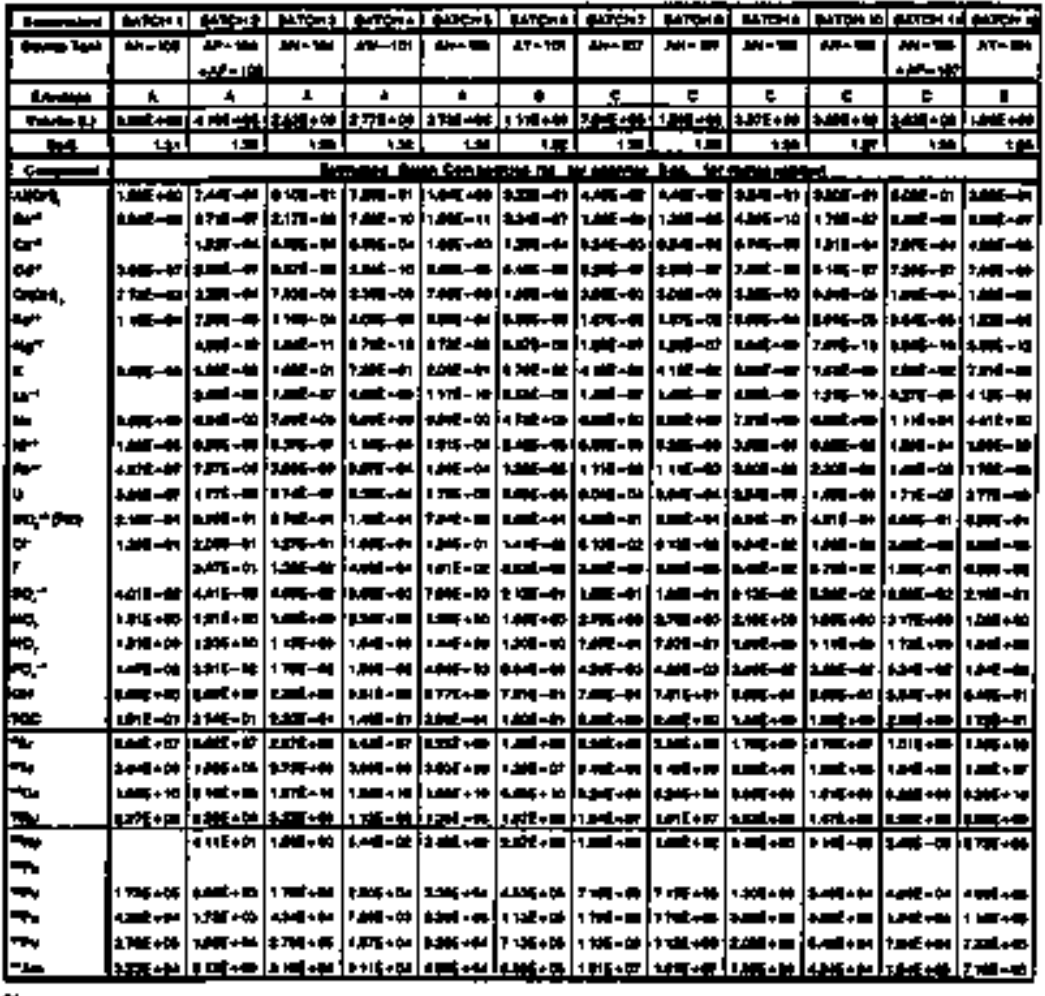




\section{HNF-SD-TWR-AGA-[0] \\ Revasuon I}

Table F-4 Projecied Feed Botch \$upematunt Compositoms for Contracter 2 (Tink 241-AP.104)

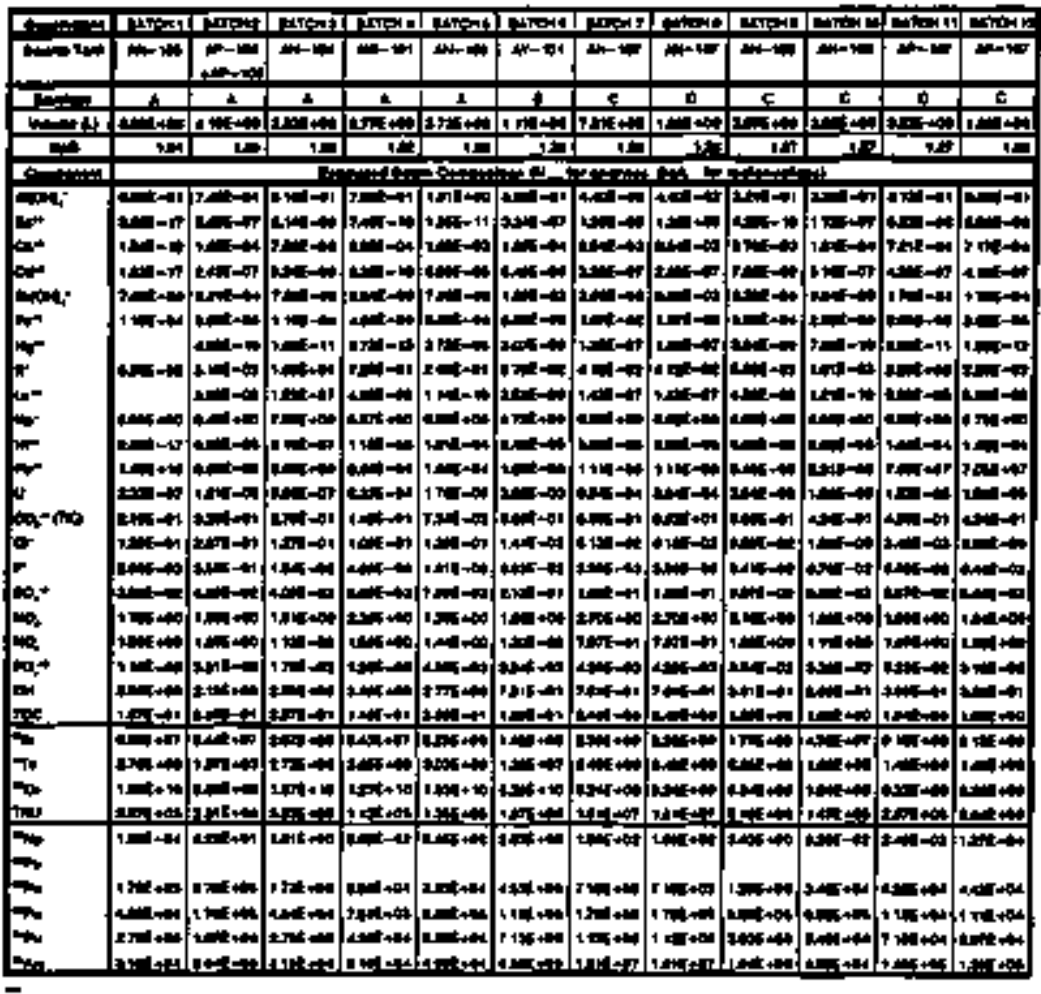




\section{F1. I POTENTLAL FOR INGOLUELE SOLIIS ENTRAINMENT}

In utde to assess the potential effects of entramuing insohuble solnds from compacted shidge layers ip sourse lanks donng retreval and the subsequenl effect on the percenl settled soluds in the staped foed betches in the stagur tark, the followng assumptions are made

- The maximum permusaible percentage of the setled soluds laytr volume to the fioed

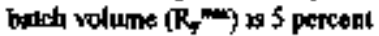

- The percenlage of the actual sohds volume kr the total volume in the compacted

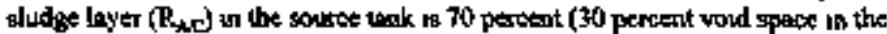
source tank studge byer)

- The percentrge of the acinal sohds volume ke the total vohume in the sethled solids

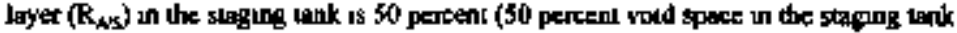
sectled solpds)

- The robo of the staged feed volume to the ongand volume of the waste before retineval is the dilution factor (D) and is desenbed in Cetia el al (1996) for each source lank waste retneved

Table F-5 bekow lists the low-level waste (LL W) Phase I privatualion source tanks which contain a sludge layer excluded froen the plannod netneved wasto by Certa ct al (1996)

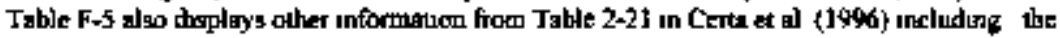
volume of retreved waske, the diluicon Fackor, and the locel shudise that is thouthal to be layered at the bottom of the source lank. The maxamum permissitle volume nuto of compacled sludge

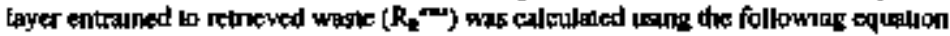

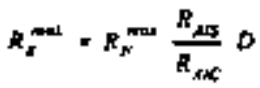

where

$R_{r}=$ - Maxamism permigable ratio of gettled achads layer volume to faed batele vol\%

$R_{\text {hec }}$ - Parcenlaye of achual solds volume wo wal volume in the contipacied sludge layer (percent)

$\mathbf{R}_{x y}=$ Percedioge of octual solids volume to lotal volume int the sebled solids layer (percent)

D = Delalion facior, ratio of staged feed batch wolurae to retrieved wagae volume 


\section{Revisian 1}

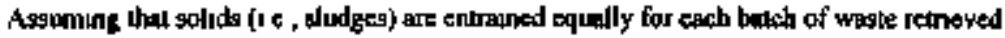

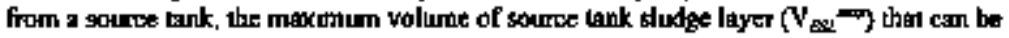
entranced foum each source tank can be calcwaved by the followng equainon

$$
V_{\mathrm{FS}}^{\mathrm{Fr}}=V_{k} \frac{f_{*}^{+1 x}}{100 \%}
$$

Whete

$V_{n}=$ Volnme of wagle potricued from the gourse lank (ML)

Table F-3 shows that enough sludge exists al the bothom of tanks 24]-Al-102, 241-AN-104, 24l-AN-107, 24I-AY-101, and 24I-AW-101 berced that wolume pencent settlet

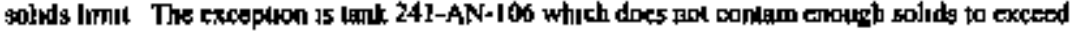
Ihas lımit

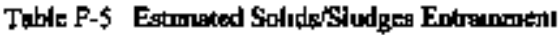

\begin{tabular}{|c|c|c|c|c|c|c|}
\hline $\begin{array}{l}\text { Sounce } \\
\text { Tankst }\end{array}$ & $\begin{array}{c}\text { Baich * for } \\
\text { Condraclots } \\
182 \\
(12)\end{array}$ & $\begin{array}{c}\text { Woste } \\
\text { volume } \\
\text { reincuet } \\
\left(V_{R}\right)\end{array}$ & $\begin{array}{l}\text { Dolution } \\
\text { moter (D) }\end{array}$ & 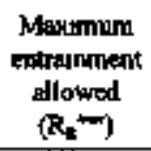 & $\begin{array}{l}\text { heximom } \\
\text { entranned } \\
\text { gludge lajer } \\
\text { (ven }\end{array}$ & $\begin{array}{c}\text { Tołal slurige } \\
\text { in source } \\
\text { bank }\end{array}$ \\
\hline$A N \cdot 104$ & 33 & $302 \mathrm{ML}$ & 171 & $610 \%$ & 0 IS ML & $100 \mathrm{ML}$ \\
\hline$A W-101$ & 44 & $394 \mathrm{ML}$ & 143 & $511 \%$ & $020 \mathrm{ML}$ & $092 \mathrm{ML}$ \\
\hline$A Y-101$ & 6,126 & $416 \mathrm{ML}$ & 100 & $3 \sin x$ & $015 \mathrm{ML}$ & $031 \mathrm{ML}$ \\
\hline AN-JW & $7,8 \quad 7,8$ & $368 \mathrm{ML}$ & 131 & $469 \%$ & $017 \mathrm{ML}$ & $051 \mathrm{ML}$ \\
\hline$A N-102$ & 99 & 3 B山 ML & 162 & $\$ 78 \%$ & $022 \mathrm{ML}$ & $034 \mathrm{ML}$ \\
\hline AN-106 & $10 \quad 10$ & $400 \mathrm{ML}$ & 231 & $825 \%$ & $033 \mathrm{ML}$ & $005 \mathrm{ML}$ \\
\hline
\end{tabular}

"Data from the Certa et al (1996) 


\section{FI.3 PROJECTED FEED BATCH ENTRAJNED SOLJDS COMPOSITLON\$}

The folkwing is an chabling assumption used to estimule the composition of the solits entrainted in the feed betch thuring netrieval and transfet.

- The entrained solids have the same composition as the setlled solida (i.e., shuidges) in the source tank.

Nox all of the of the courtes thriks have hag solide characterization complent. The currently availabte oolids data were collected Kor, although not puthished in, Shelion (19\%6) and the Cefta e1 A. (1996), and are shown in Tables F-6 and F. 7 .

'Tabie F-6. Projected Feed Basta Entrauned Solids Compogitions for Contracker I (Tort 241.AP-102).

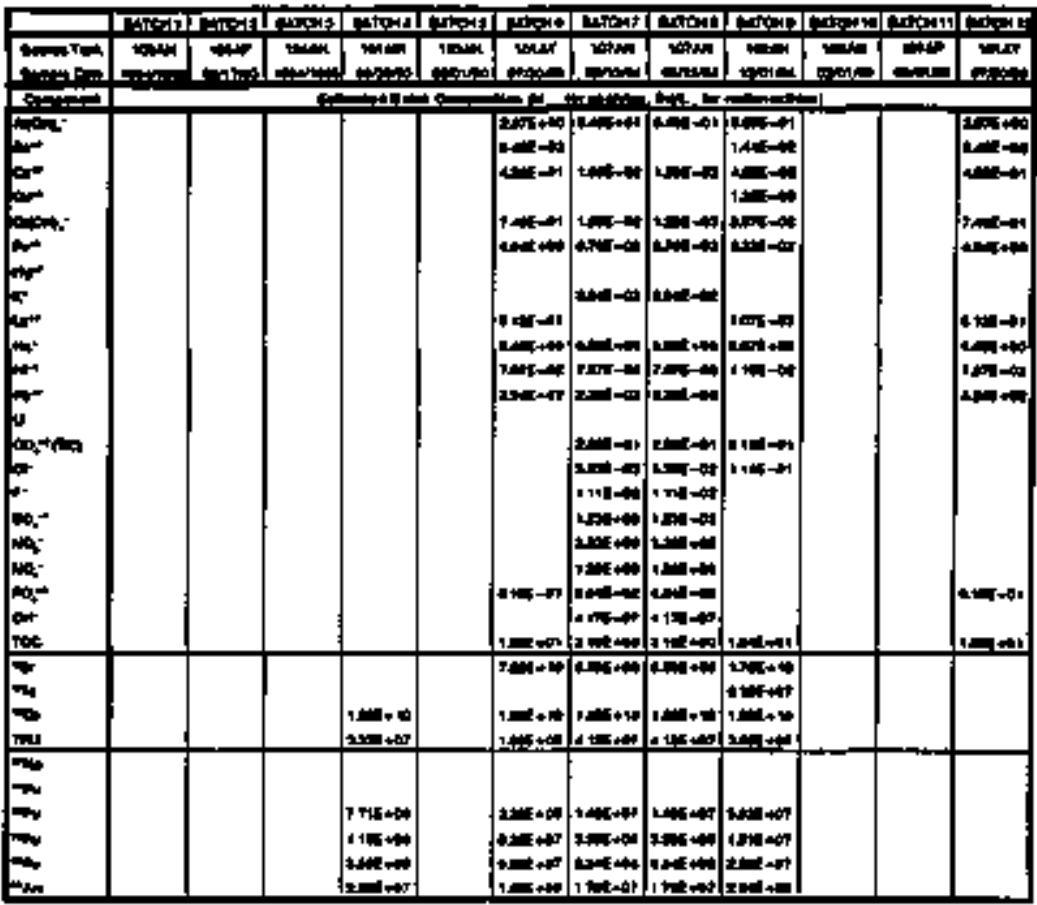


Teble F-7. Projeclod Feed Batch Enirained Solids Composittons for Contractor 2 (Tank 241-AP-104).

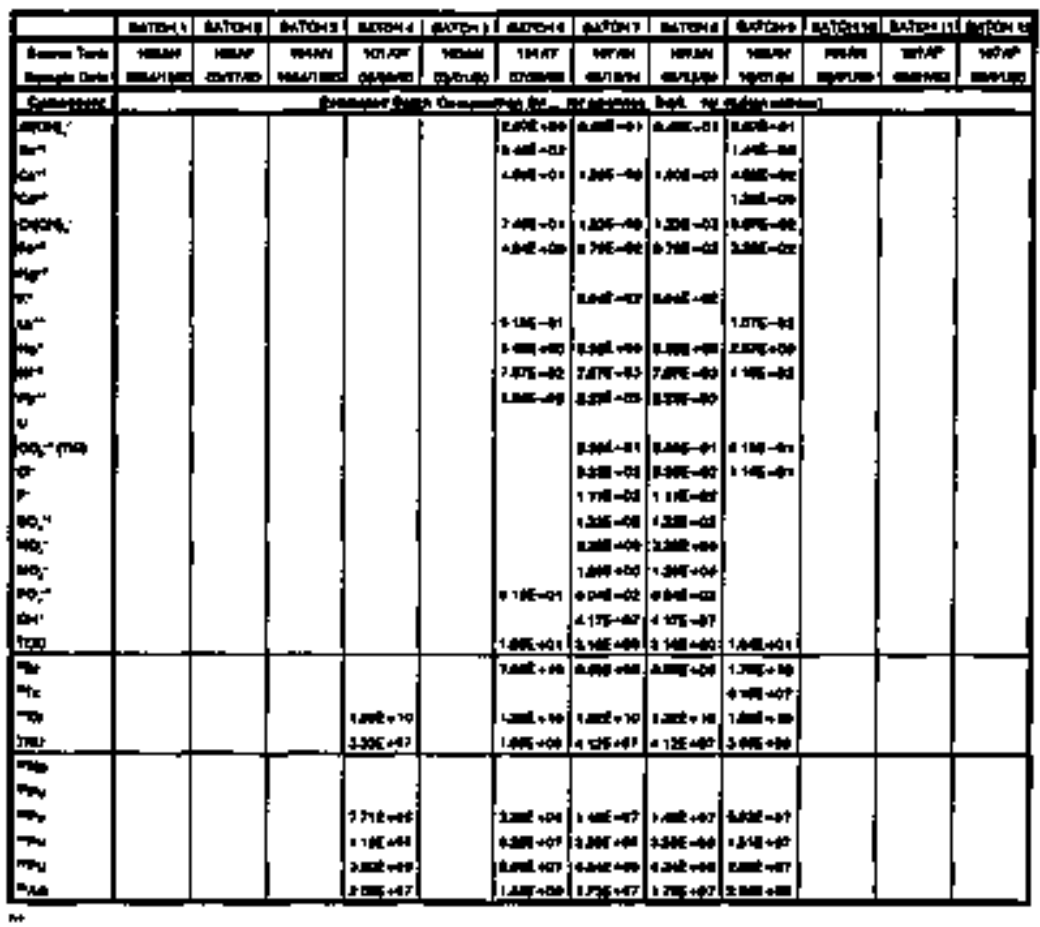




\section{F1.4 PROJECTED COMBINED FEED BATCH COMPOSITIONS}

The followter enabling assumptions were used in calculatmg the feed batch compositions as a sum of the projecled supernatant and antrained solids compagitions.

- The modified Reques for Propasal (RFP) feed tavelope criterio vefer to the total composition of the feed banch includiag the entrined solids.

- The ratio of the actual solids volume to total volume in the setched solids layer is asquand to be $\$ 0$ pertetel

- The volume of the supemalanl displaced by solids is neqligible.

- Wherre no solide compasition dala is available, the solids composition is astumed to have ne effect on the feed batch composistion.

The compositions (in $M$ ar Bg/L) for the superastant and the entrained solids were combined to calculate the tots feed betch compositions (C, ${ }^{7}$ ). These were galeulaled with the following equalion:

$$
C_{1}{ }^{r}=C_{1}{ }^{L}+R_{F} R_{N S} C_{1}^{s}
$$

where:

$C_{1}^{1}=$ Total conkentration of component $i$ in the combined supomatant and entrained solids phases ( $M$ or Bof $L$ )

$C_{i}^{*}$ - Coacentration of componend $i$ in the entrained solids phase (Mf or BqL)

$\mathbf{R}_{\mathbf{f}}=$ Ratio of seluled solids layer volume to the total fred batch vol\%

$R_{N A}$ * Ralio of the sctual solids volume to tatal wolume in the setiled solids layer (percert).

liables F 8 through F 13 show the projected loal foed batch compositions for Contrackors I and 2 for the zero, tuo, and live percent sentied solidg cases. 
Table F-8 Projecked Feod Batch Combiped Compostions o Pereent Settled Solids, Contractor I (Tank 24i-AP-102)

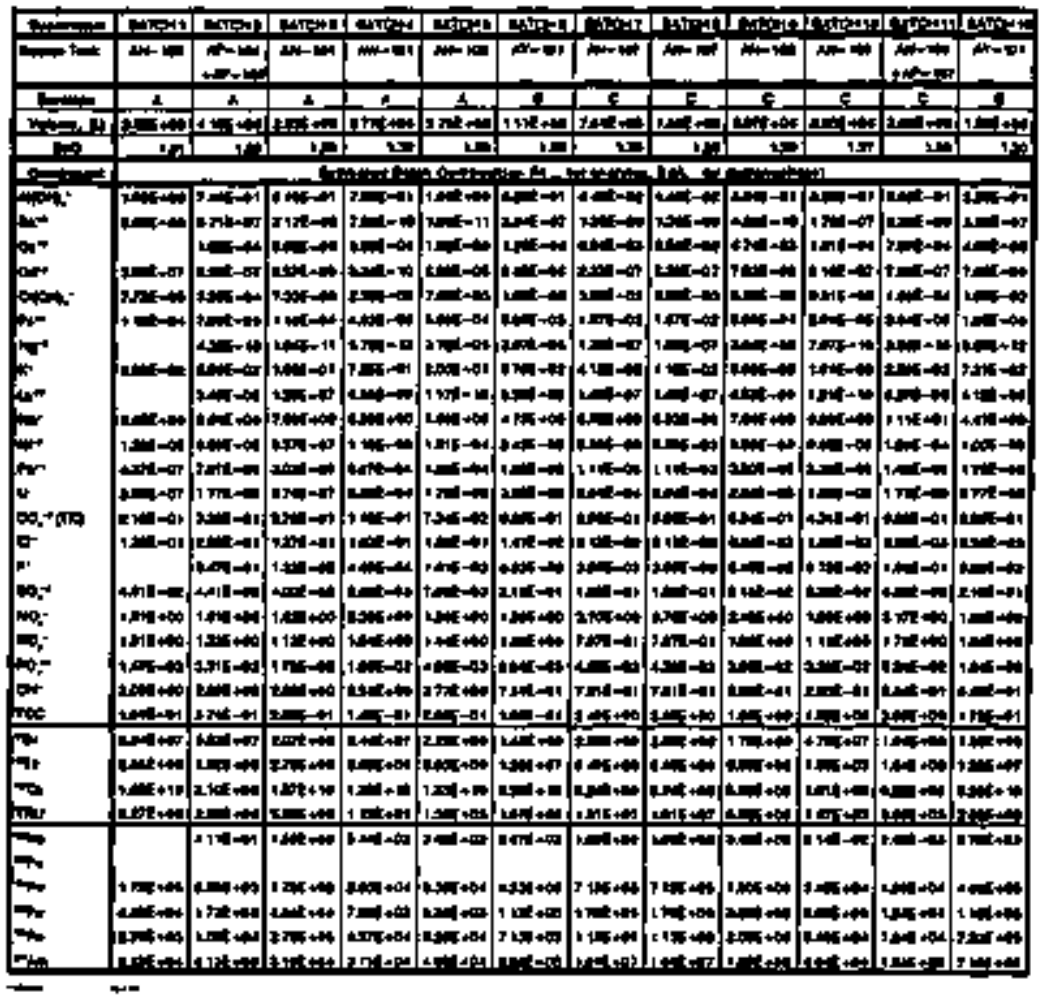




\section{HNF-SD-TWR-AGA-001 Reviswan I}

Toble F-9 Projecled Feed Balch Combured Compositrons 0 Pereent Seuled Solkds, Contractor 2 (Tank 24l-AP-104)

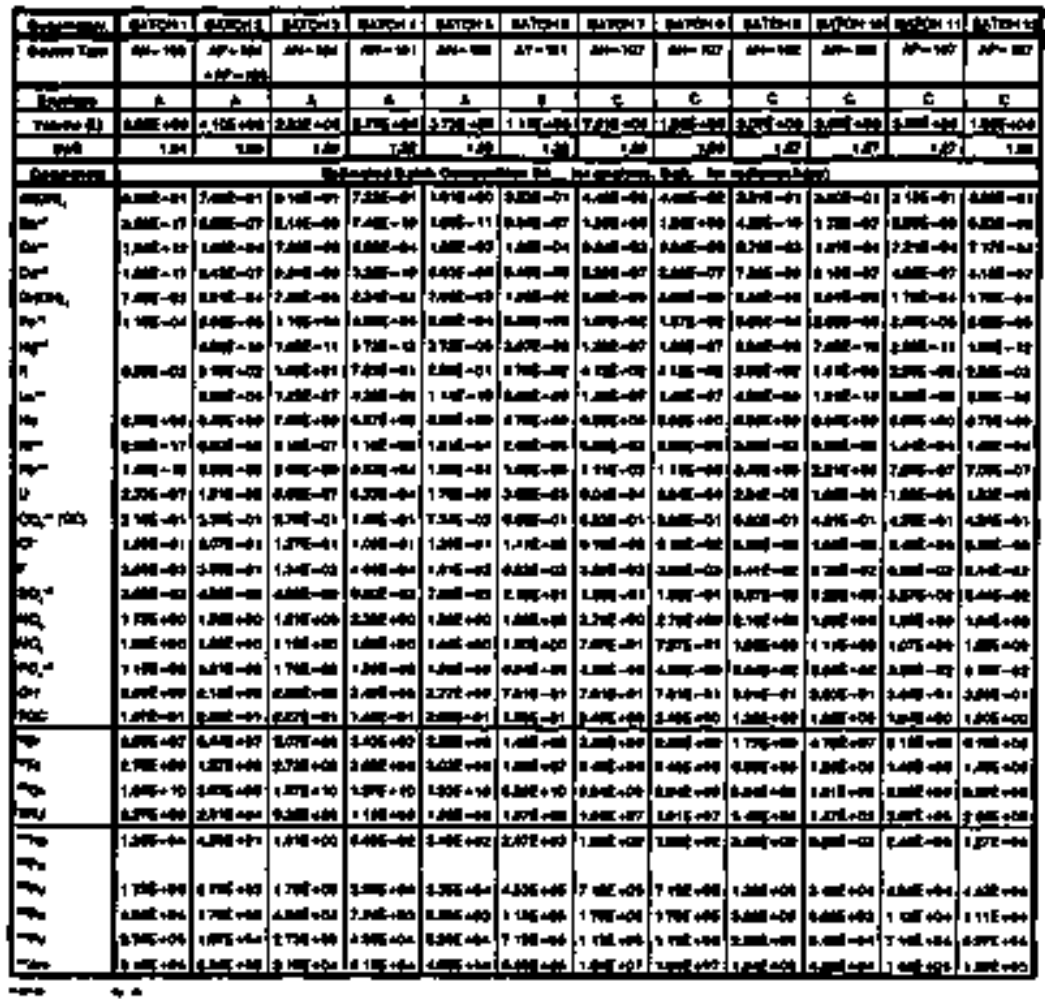




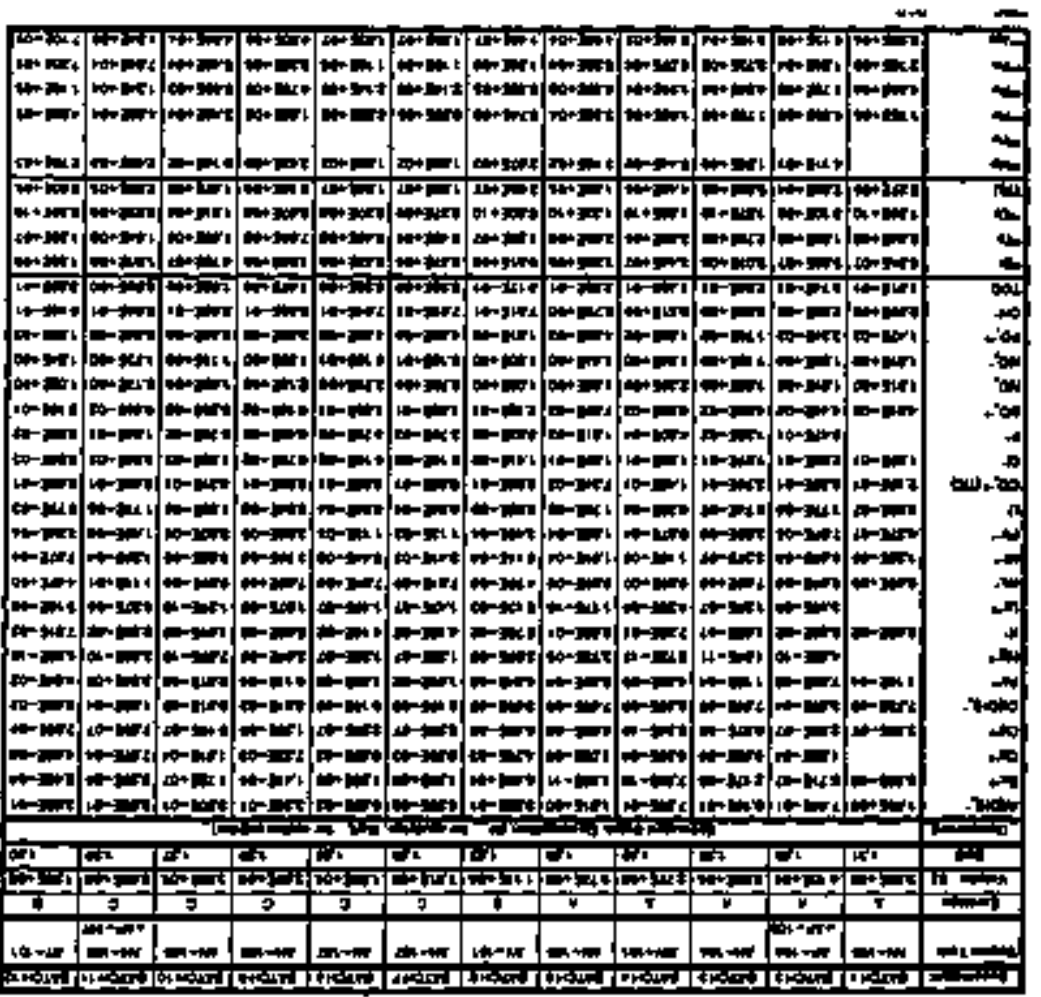

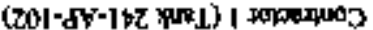

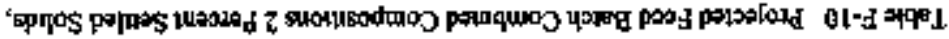




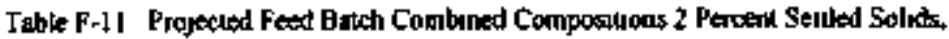
Contractor 2 \{Tmk 24\}-AP-144)

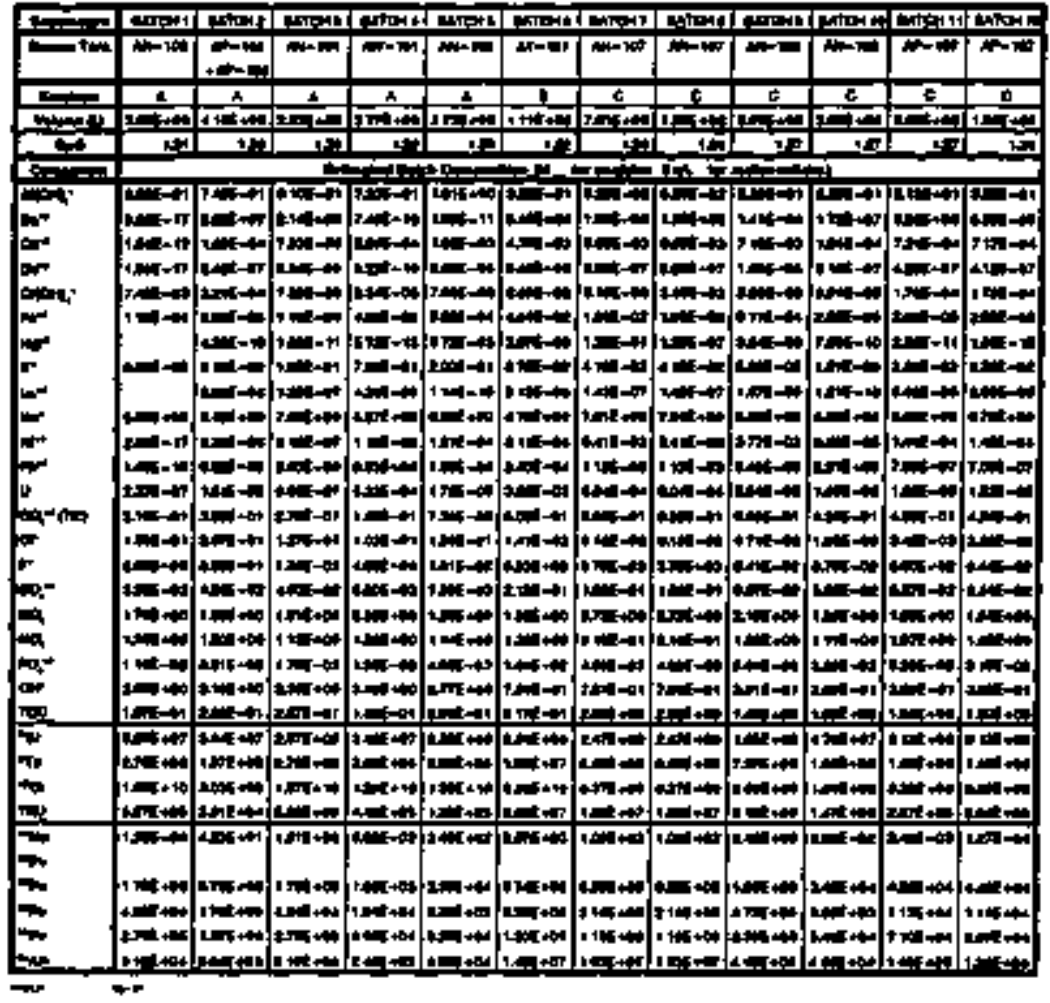


Tab]e F.12. Projectad Feed Butch Combined Compositions S Percent Sortled Soluds, Contraclor ] (Tark 24]-AP-102).

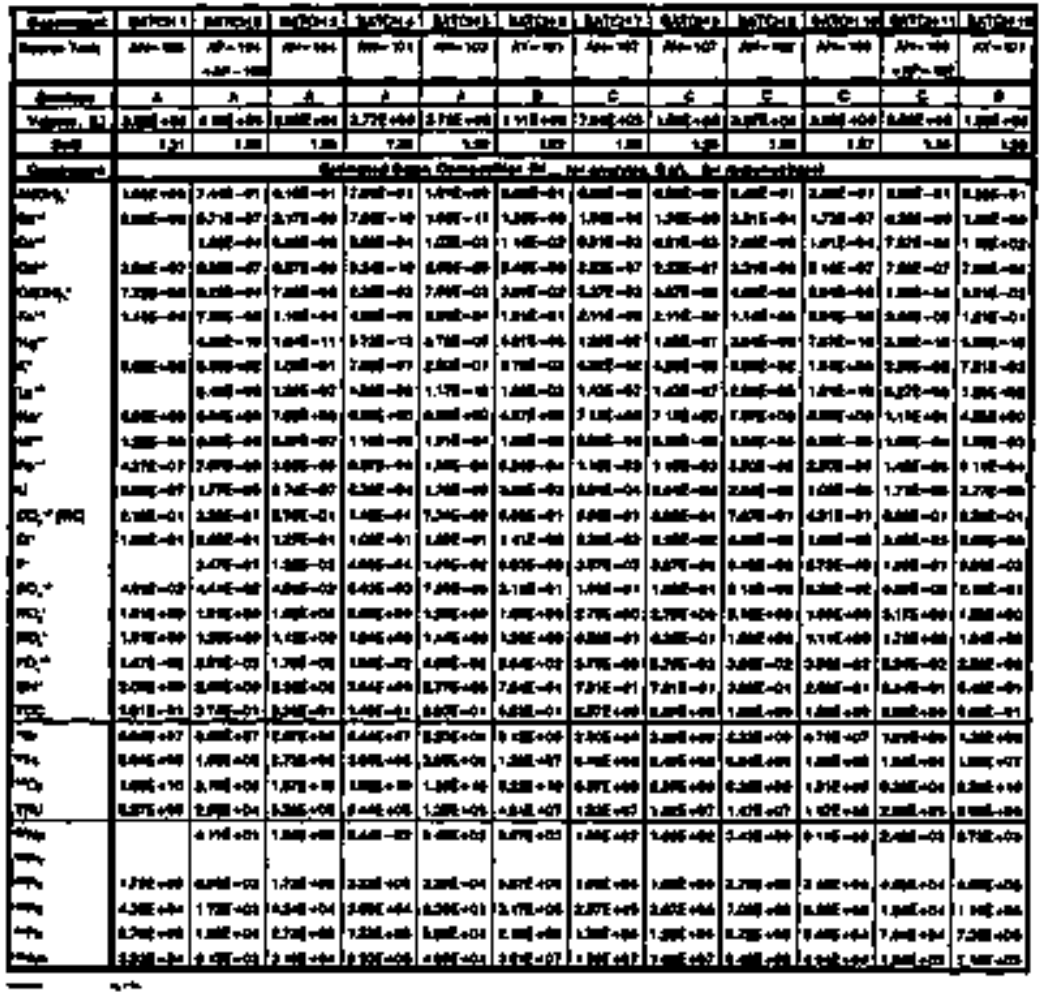




\section{Revision I}

Table F.13 Projected Feed Gatch Combened Composiluous 5 Pencent Settled Salrds, Contracker 2 (Twik 241.AP. 10A)

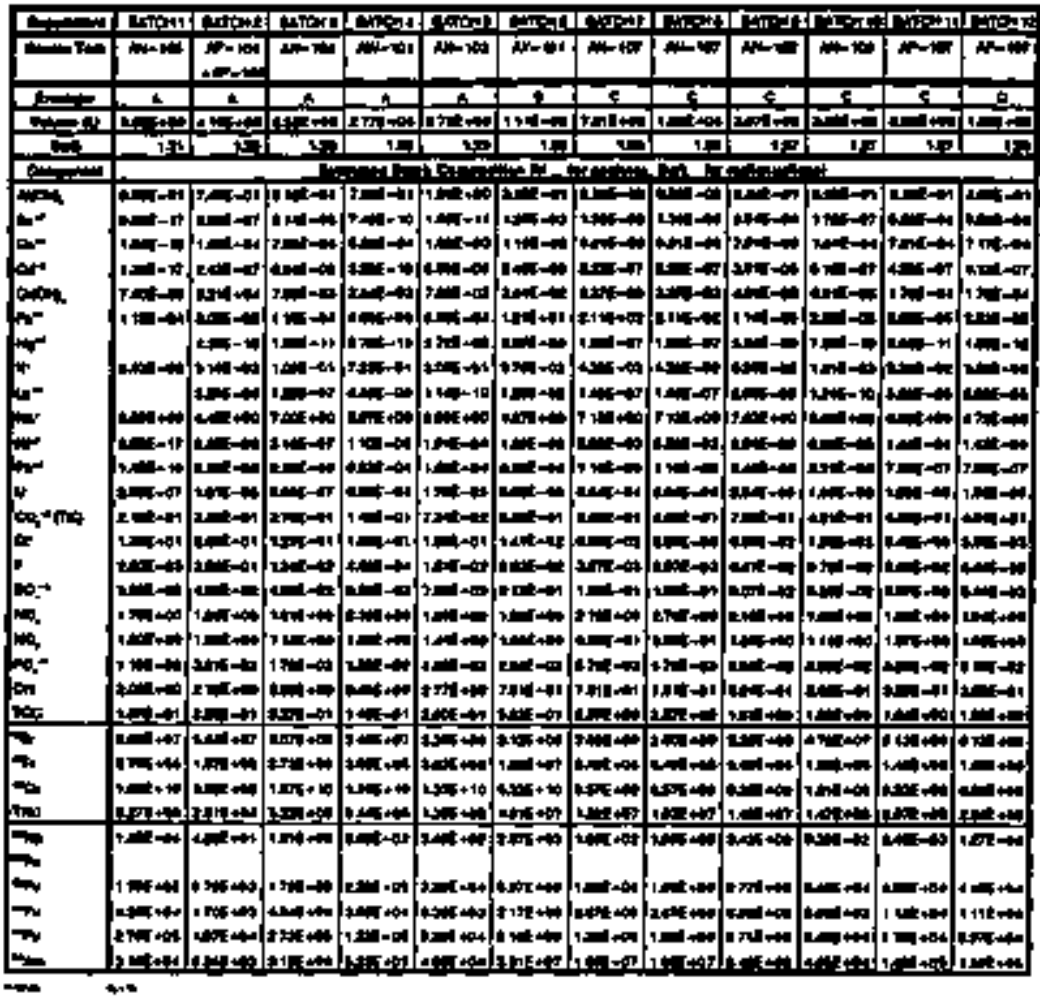




\section{FI.5 PROJECTEO FEED BATCH RATIOS}

Since the feet envelope lisig the concentralion limits as mios of the component concentration to the soding sopcentralion. The component consentrations wert canverted w sodtum ratios $\left(R_{1}\right)$ with the following toution:

$$
\text { n, - } \frac{c_{r}^{\top}}{C_{\mathrm{in}}}
$$

wher:

$R_{1}=$ Sodium Rativ: Ratio of the companent i concentration to the sadium concentcation (mokes i moles wh of Bq $r /$ moles $\mathrm{Na}$ )

$\mathrm{C}_{\mathcal{N}}=$ Jotal concartuation of godium in the combined sapernotant and entrained solids phinges (M)

Tables F-14 drough F-19 show the projected lool feed balch sodiun tains for Contractors 1 and 2 for the zero, nwo, and fiwe percenal setdod golids cases. The value listed for sodium bs the soditum concentration in mokerl. 


\section{Reunsian I}

Table F-14 Proyected Foed Batch Sodium Raluos 0 Percent Senled Solds, Contractor I (Tank 241-AP-102)

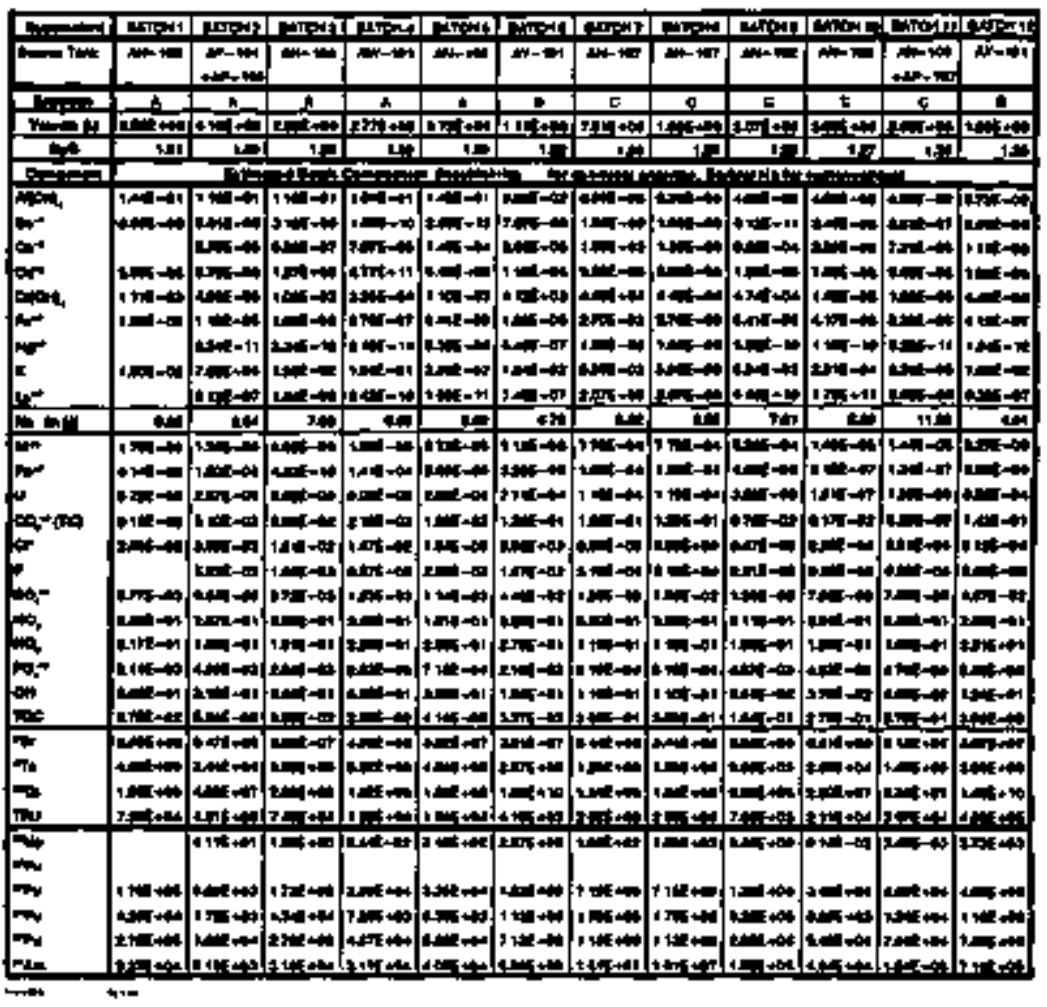




\section{HNF-SD-IWR-AGA-00] Revisal I}

Table F-15 Proyected Fred Balch Soduun Ralkos O Percent Seuled Solvds, Contractot 2 (Tank 24)-A.P-104)

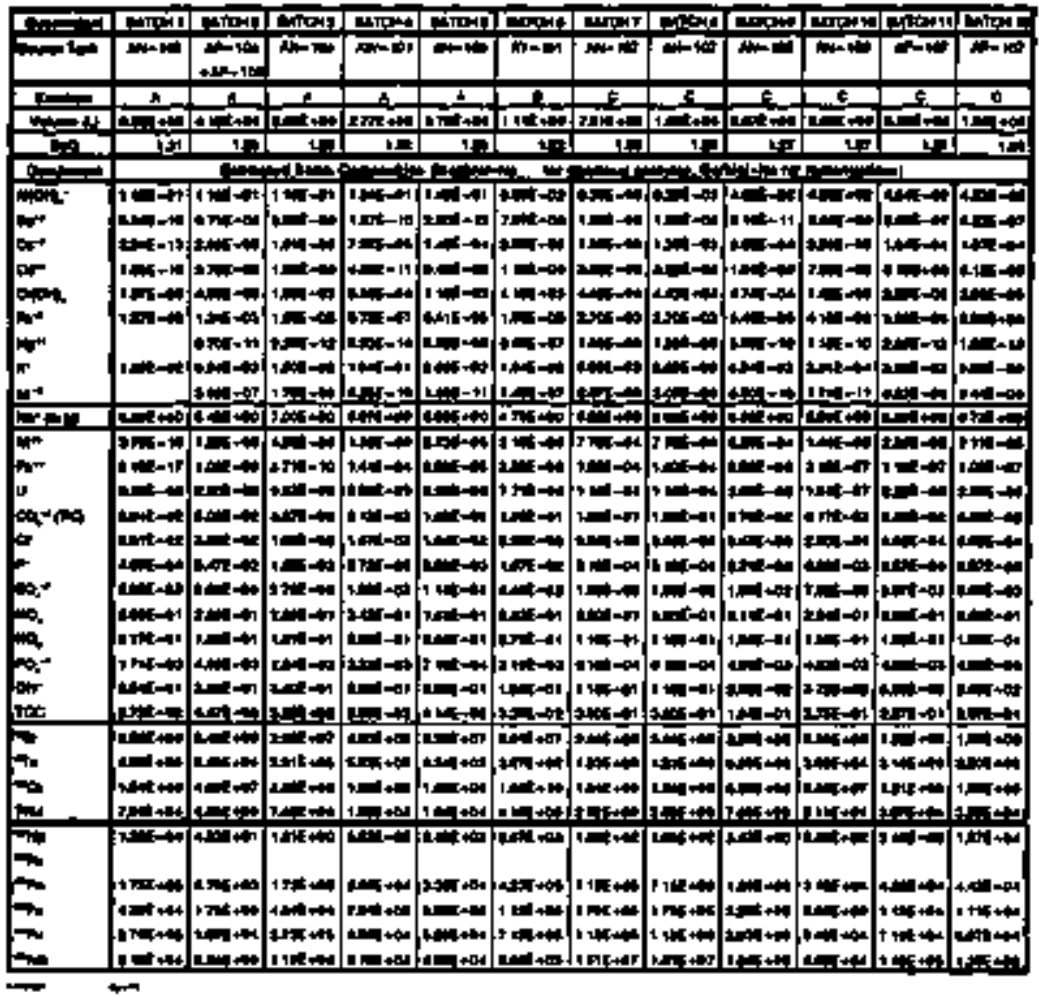


Table F.16 Projected Feed Bach Sodian Ratag 2 Percend Settled \$odids, Contractor I (Tank 2AI-AP.IDZ)

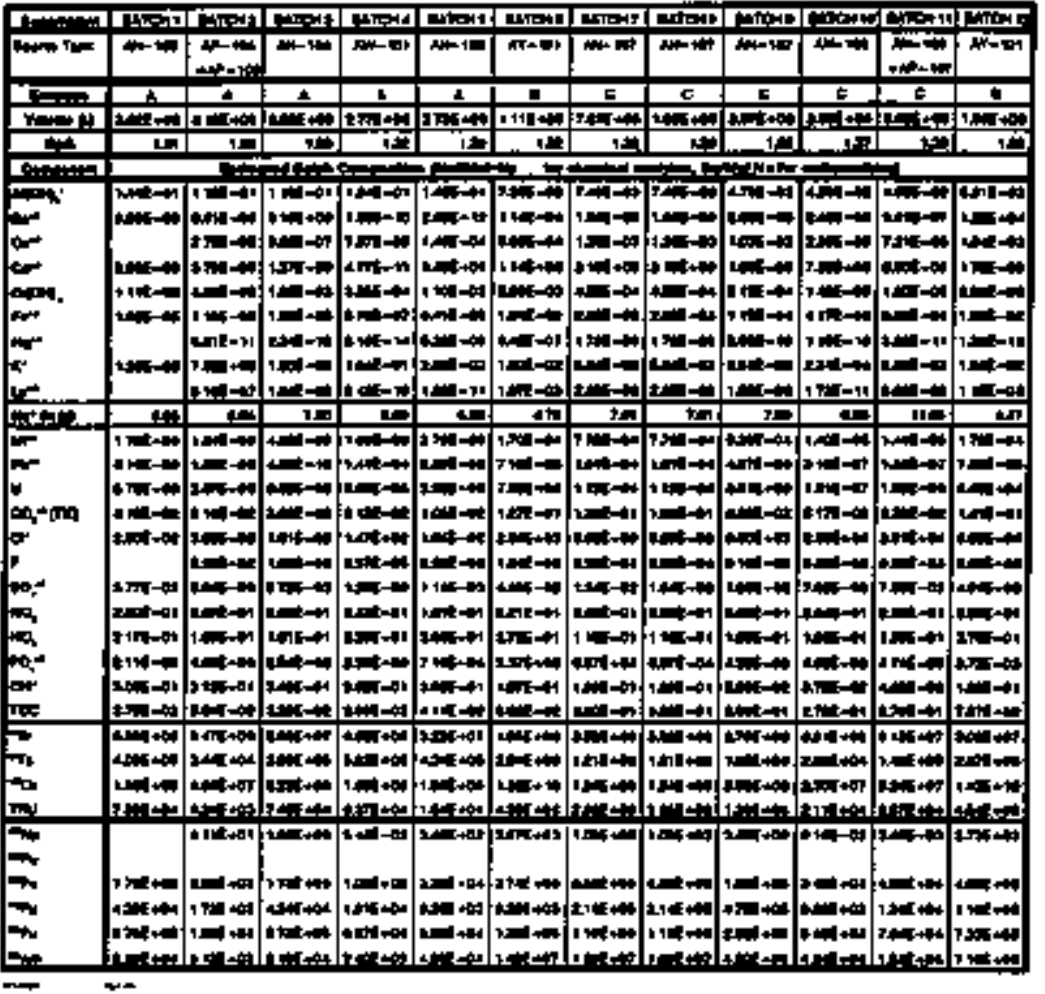




\section{HNF-SD-TWR-AGA-00I \\ Reviston!}

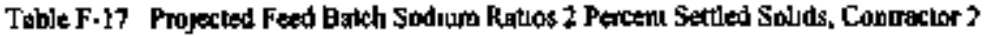
(Tanle 241-AP-104)

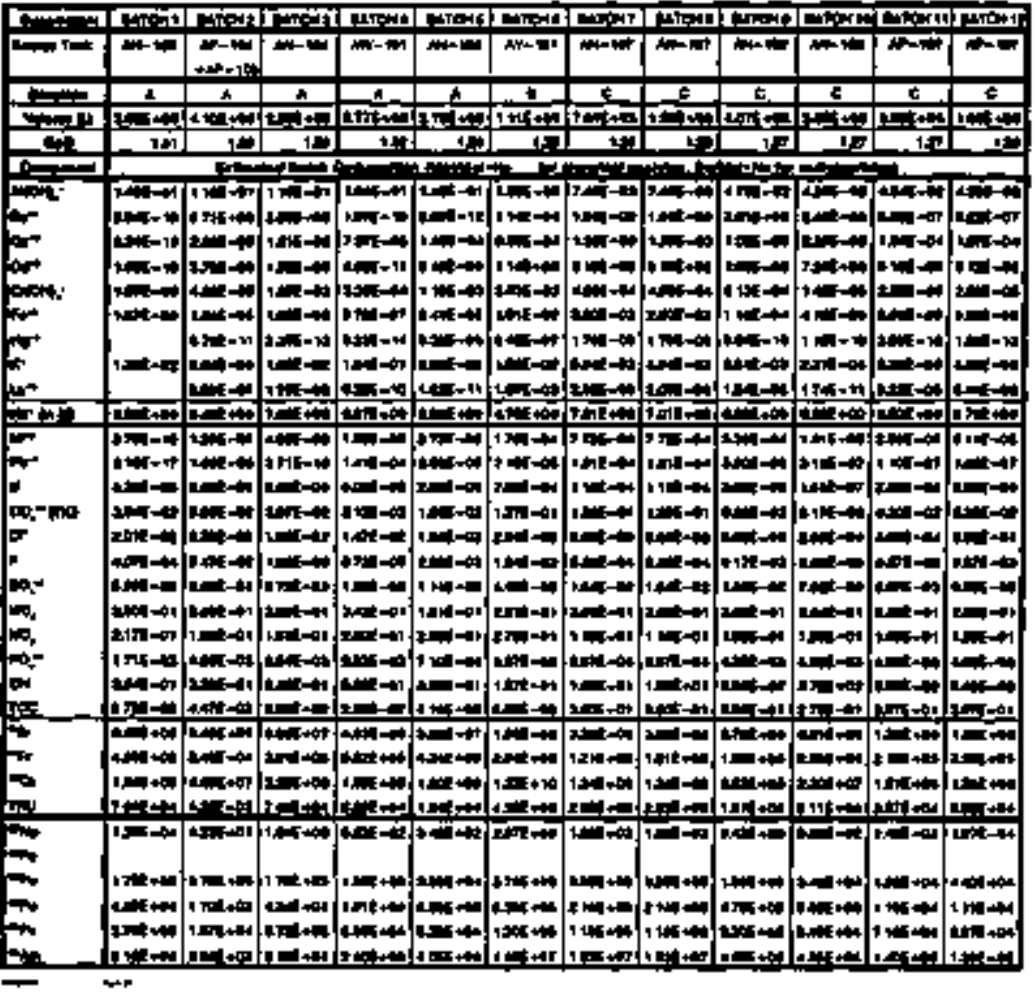




\section{Revigion I}

Tabje F-18 Projeciod Feed Batch Sodum Rutuos 5 Percent Settlad Solids, Conuracor 1

(Tank 241-AP-102)

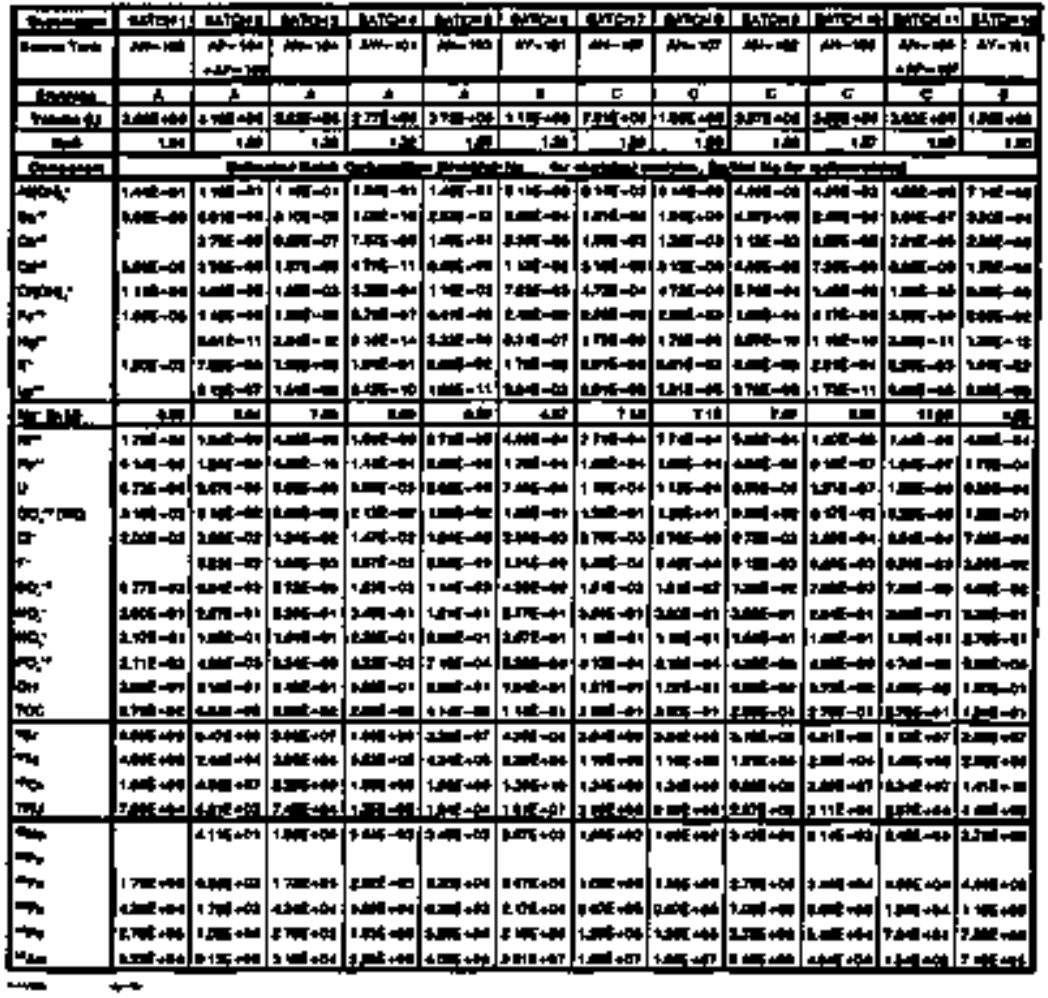




\section{HNF-SD-TWR-AGA-001 \\ Revision ]}

Table F-19 Projecked Feed Batch Sontum Ratios 5 Percend Seallod Solids, Coulracior 2 (Tank 241-AP+104)

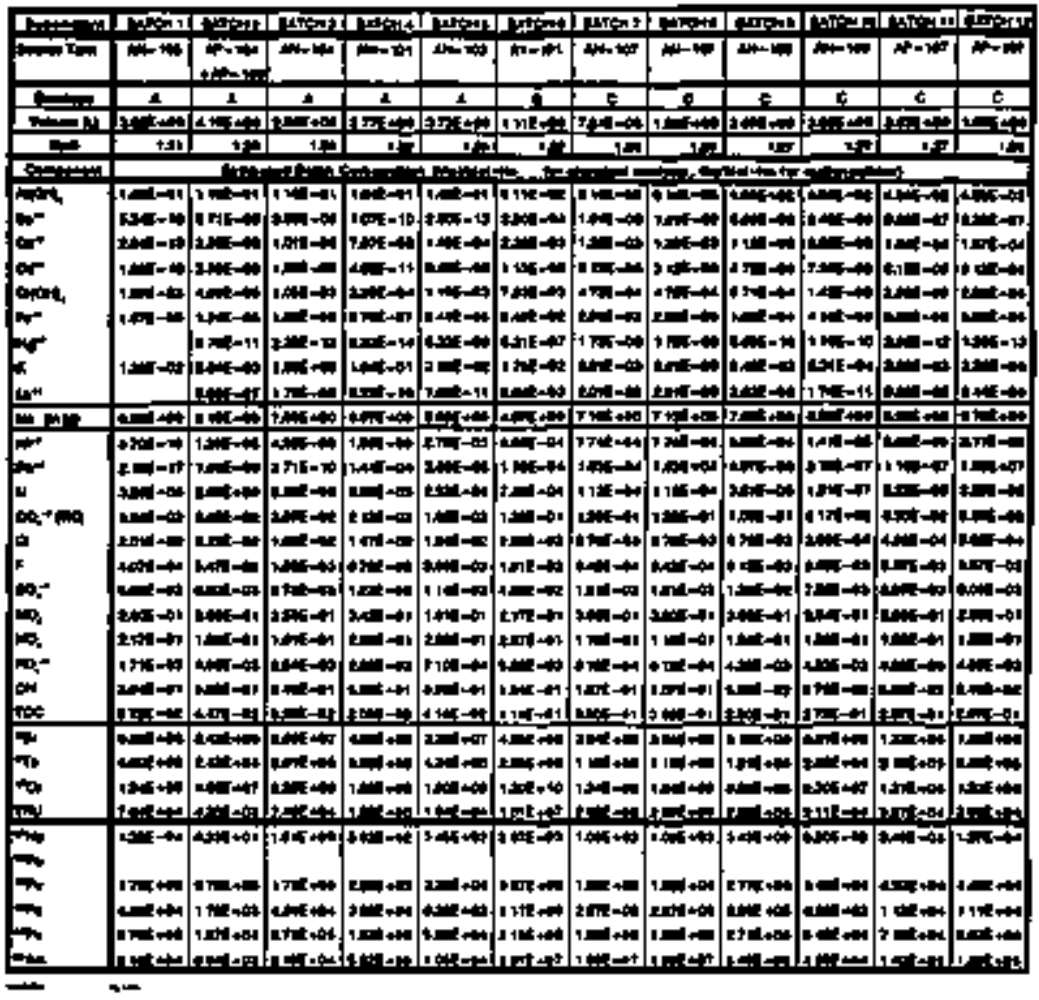




\section{FI.6 PROJECTED FEED BATCH DENSITIES}

Densties ( $\rho$ ) or speciftc gravlties (SpG) for the projecred foed balches (in grants per

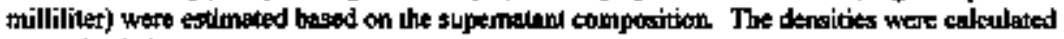
using the following equation:

$$
\begin{aligned}
& p=1+0.2\left[a[A T]^{3}+b[\mathrm{AI}]+a[\mathrm{Na}]^{3}+d[\mathrm{Na}]+t\left[\mathrm{NO}_{2}\right]^{2}+\right. \\
& \left.f\left[\mathrm{HO}_{2}\right]+g\left[\mathrm{NO}_{3}\right]^{2}+h\left[\mathrm{NO} \mathrm{O}_{1}\right]+f[\mathrm{OH}]^{2}+/[\mathrm{OH}]\right)
\end{aligned}
$$

(A plew and Walkin 1994) where the components in trackets are fied bach concentrations of the componeat in molarity. The coeflicients in this equation tre as follows:
$*=0.0955$
$f \quad-0.373$
b $=0.383$
$\mathrm{g}=0.00046$
c $=0.0054$
h -0.201
d -0.1096
il -0.0197
e - -0.073
j - 0.0077

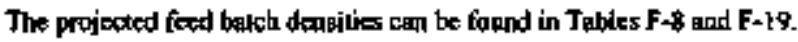




\section{F3,0 SAMPLING NUMEER CALCULATIONS}

\section{F.I WASTE VARIABIITIY AND SAMPLENG LOCATIONS}

The untentiou of sampliag is to obtar a get of samples that we representalive of the enlire

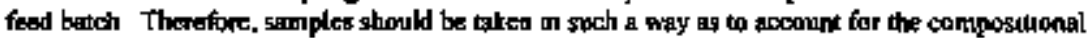
vanabthty berwoen slupernotint phuses

Limeral Varlabinty. The lateral vansbulity is the vanability in the compostion of samples

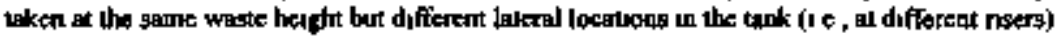
For supernatunts the following is asumed

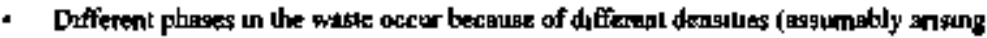
from different composiluons)

- Each phase has a smgle source and is hamogeneous

- Each phase is level throughanal the tark.

From thes, the following is excoloded

- The lateral varsbibity for supernedants is very low (below andyucal amor)

Therefore, the followng requriencent of samplung is decived

- All the bach samples unll be isken from a gingle fiser on each stapng tank

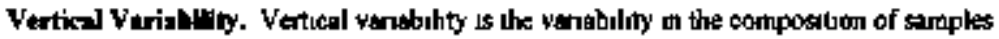
taken as the some laveral locauon (1 e, nser) bu al different waste depths If Inquds with duferent densitues (and assunnably defferem somposituons) are added togother in a feed batch, straluficed supermitant phases may form unkess there is adegunte mexung Potental sources of strolufied phases tomes froun

- Adding a new batch to the berl from a previous bolch

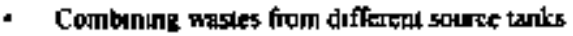

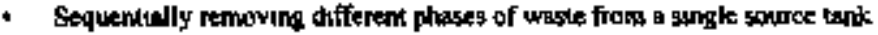

- Adting chemicells to adusi a foed batch compositiog 


\section{Revision I}

Becouse it is quitic probable then strabified surpernalemis will appear without adequale mixcing vertical variability is considered to be the most probable source of sample viriability Therefore, the following requirement is derived:

- Samptes will be taknh all goveral diffierent heidth in the waste.

\section{F2.2 ESTTMATED SAMFLING AND ANALYSAS VARABILTY}

Io calculating the aumber of sanples required to valjate that a feed back tosts the fecd envelope crikcia, an estimate of the analytical emor and sampling variability is needed. The cakulations in this study nse delative glandand deviation (RSD) yalues that combine the analytical error and sappling variabilities. These RSDs wect determined from the mean concentrotion, the variathe of the men, and the mumber of sinple loctions reprorted in previous sampling and andysis reports for appenialant characteriadion (Simpsob 1994a, Weksh 1994a,

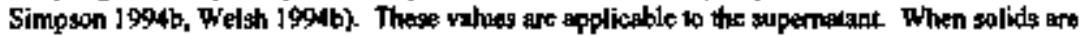
added to the feod balch camposition, the fallawing is gastumed:

- The RSD vahues tor the sopermatants are valid for the kptal feed batch composition, which includes the composition of minined tolicts (i $c_{4}$ sturbes).

The RSDs arere calculated with the following equation:

$$
\text { kSO, }=\frac{\operatorname{Var}[\vec{y}\} \cdot 1}{y_{1}} \cdot 100 \% \quad \text { Eqn } 8
$$

where:

RSD, = Relative slandard deviation for the concenlibation of tampotienli i (percedt)

$V_{\text {atf }}\left(Y_{1}\right)$ - Veriance of the menc concentration of componem $d(M$ or BqL $)$

I = Number of stmple locations

$\bar{y}_{I}=$ Mesh coukenteatlon of component i (M or B- $/$ L).

The RSD values used repretent two difiereal scentrios in the staging lanks, "urell-mlxed" and "not-mixed," and are showh in Table F-20. 
Table F-20. Rdalive Standard Devialions.

\begin{tabular}{|c|c|c|c|c|}
\hline Component & 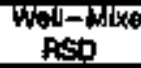 & $\begin{array}{l}7 \text { scingono } \\
\text { ARso }\end{array}$ & 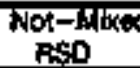 & $\begin{array}{c}\text { S seanars } \\
\text { pisso }\end{array}$ \\
\hline & $\begin{array}{l}\operatorname{sim} 2 A \gamma \\
\text { F5D (\%) }\end{array}$ & $\begin{array}{c}\text { rntis } \\
\text { Rso (*) }\end{array}$ & $\begin{array}{l}\text { hom StA } \\
\text { RSD ( }\end{array}$ & $\begin{array}{c}100 \\
\text { RSD (x) }\end{array}$ \\
\hline (OF & son & 5,49 & 10.88 & 13.72 \\
\hline B & 2293 & 23.04 & 43.69 & 44.49 \\
\hline & $\begin{array}{r}10.60 \\
6.60\end{array}$ & $\begin{array}{r}1028 \\
7.08\end{array}$ & $\begin{array}{r}20.00 \\
7.39\end{array}$ & $\begin{array}{l}21.68 \\
11.15\end{array}$ \\
\hline$(\mathrm{OH})^{-}$ & 3,49 & 4,09 & 10.11 & 13.12 \\
\hline 3 & 28.20 & 2029 & 218 & 20.42 \\
\hline & $\begin{array}{l}8.30 \\
3.00\end{array}$ & $\begin{array}{l}8,00 \\
4,48\end{array}$ & $\begin{array}{r}1500 \\
721\end{array}$ & 17.17 \\
\hline +3 & 1000 & 1025 & 2000 & 21.8 \\
\hline & $\begin{array}{l}2.27 \\
8.00\end{array}$ & 3.76 & $\begin{array}{l}\text { Q.38 } \\
\text { B.893 }\end{array}$ & 12,16 \\
\hline & $\begin{array}{r}9.10 \\
10.00\end{array}$ & $\begin{array}{r}4.0 \% \\
10.25\end{array}$ & $\begin{array}{l}16,24 \\
17.50\end{array}$ & 1027 \\
\hline & 6.00 & 723 & 2098 & 24.43 \\
\hline & $\begin{array}{l}5.80 \\
8.10\end{array}$ & $\begin{array}{l}6.07 \\
6.51\end{array}$ & 24.18 & 25.59 \\
\hline & 7.72 & 205 & 41.71 & est \\
\hline & 5.68 & 6.10 & 14.99 & 17.16 \\
\hline & 5,49 & 5.94 & 10.62 & 13.52 \\
\hline & 7.00 & 7,36 & 24,23 & 2503 \\
\hline & 2,00 & 3.0 & 2.50 & 8.73 \\
\hline & 3.05 & 4,47 & 10.04 & 13.06 \\
\hline & 9.10 & 8.41 & 13.44 & 1583 \\
\hline & e.e0 & 8 & 1239 & 14.25 \\
\hline & 5.10 & 5.58 & 9.66 & 1278 \\
\hline & & & & \\
\hline & 17,60 & 1804 & 20.60 & 268 \\
\hline & 10.00 & 105 & 20.00 & 21.69 \\
\hline & 10.00 & 10. & 1223 & 14,81 \\
\hline & 10.00 & 10 & 20.00 & 21.60 \\
\hline & & & & \\
\hline & & & 44 & 4 \\
\hline
\end{tabular}




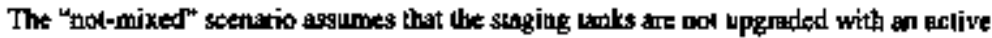
mixing system. In this situation it is posstble for straliffed layers of liquids huthing diffierent densities and cherrical concentrations to exist in the ank. For this scenario, the component KSD valuog used were those values determined for the sampline wnd analysiz of tank 241-AP-105 (Simpson 1994b and Welsh 1994b). This wak wo determined to bave two on more layers in the superanlanl phase and its RSD values give a good indicalion of expected variahilities for unumixed tanks.

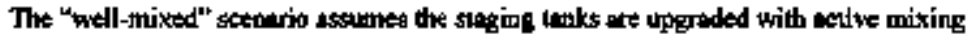
systems capable of mixing stratifed liguid lnyers inta a bomopenous mixture. For this scenario, the RSD values used were those values determinod for the sampling and andygis of tank 241-AP-102 Simpoon 1994a and Wekh 1944a). This lattl was deternined to have a homogentous supernatnt phose and its RSD values give a good indication of whe expected variabilities for well-rixed tanks.

Becenuse the fred entelopes tre based of component concentrationt ratioed to the sodiun concentration, the component RSDs are converted to component natio relative standerd deviaions (RRSD) using the following equation:

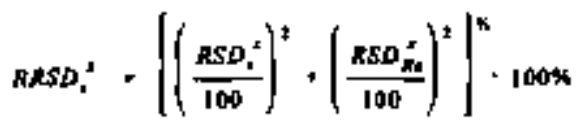

rither:

RSD $_{1}^{x}=$ Relotive standerd deviation of the component $i$ coecentration for the $x$ scenario.

RRSDi - Ratio of the component i to sodium concenturtion RSDs.

$x$ - Either lhe "sot-mixed" of "well-miked" scenario.

These values ante shown in Table F-20 for both the "wetl-nilxed" and "hod-mixed" scenarios.

Using the falkewing equalion, composent standard devidions (0,) were calculated for eich aet of balth, coatracior, mixing scenario (avell-miked or ant-paixed), and volume of settled schids.

$$
0_{1}=R \cdot \frac{R R S D_{0}^{2}}{100}
$$

Where:

$\mathrm{R}$ = Sodium Ralib: Rotio of the componeme i concendration to the sodium concentrotion (moles / incles $\mathrm{N} \mathbf{2}$ or $\mathrm{Bq} r /$ moles $\mathrm{Ne}$ ) 


\section{HNF-SD-TWR-AGA-DO1 \\ Revision I}

The fed envelope erileria for sodium is a concentration nuther then a ratio, so the standand deviation for sodium is calculated with the following equation:

$$
\mathrm{J}_{\mathrm{Na}}=C_{\mathrm{No}} \cdot \frac{28 D_{\mathrm{N}}^{\prime}}{100}
$$

whene:

$O_{x_{p}}=$ Standard devistion in the sampling and amalygig for sob sum $(M)$

$\mathrm{C}_{\mathrm{M}}=$ Conoentration of sodium (M)

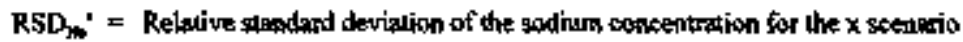
(percent)

Toe stondard deviation for each transuranic ndioauclide (b) can be calcolaled with the following eqnalion:

$$
a_{1}=c_{1} \cdot \frac{R S D_{i}^{A}}{100}
$$

where:

$\mathrm{C}_{r}=$ Concenintion of transuranic tadionudide ? (Bq/L)

$R S D_{r}^{\prime}=$ Reflative stonitand deviation of the tranguranic radionuclide if for the $\mathrm{x}$ scenario (percent)

One = Strondand devisuion in the gampling and amalygig foe sodion (h/).

The feed envelopes linit the total amount of tranguranics nather than each transusanic fodionuclide individually. The standard deviation of the enmbined trangurtevic composition (c mard is calculated with the following equarion:

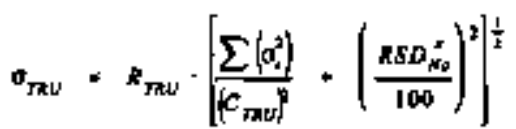

where:

$\mathbf{R}_{\text {तwy }}$ - Ratio or the IRU concendration to the soctium cancentration (Bq TRU/mole Na)

$\nabla_{1}=$ Standard devidiou in the stmpling and analysis for the transuranic radtonuclide !

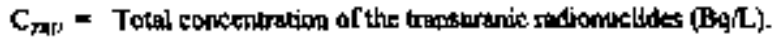

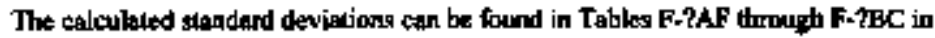
Section 5.0 for the zero, two, und Give percend setled solids coses. 


\section{HNF-SD-TWR-AGA-00J \\ Revision I}

\section{MH CONFIDENCE LEVELS}

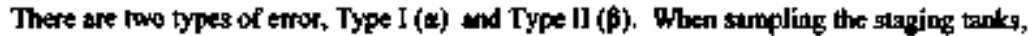

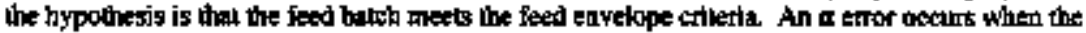
foed bakch is within the fead envelope limils but gampling and anabysis indicate that it is nol (Le., false regative). The B etror becturs when the faed betch is not within the feed orvekpe limits but garmpling and analysis indicate that it is (Le., folte postitive). To ronbling further calculations, the following is sesmed:

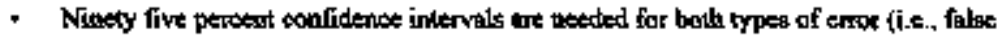
positive and fake nefalive) io validate that a feed batch meets the feed etlivelope criterin

The following is also assumod:

- The component concentrations ate inampilly distribuned anound the mean.

The sodinm concentration is evaluated apgingi both upper and lower limits and the twosided l-critical valos of 1.959964 (which corrosponds to a 95 percent canfidearce interval) is used in the sodiun calculations for both ertor types. Becouse all of the other contiponenters are evaluated against concentration ratio maximums, a singke-sided t-critical value corresponding to the 95 percent confidence interval is used. This value is 1.644854 ,

\section{T24 SAMPLING NUMBER}

The number of samples roquired to validere a specific foed tatch (sampling number) for couponent $f$ was calculated with the following equition.

$$
\left.s_{d}=\frac{\left(\sigma_{\sigma}+\omega_{0}\right)^{2} \cdot \sigma_{1}^{2}}{\left(n_{r}-\Sigma_{d}\right)^{2}}+0.5-\psi_{d}\right]^{2}
$$

whera:

$\mathbf{S}_{1}=$ Sertupling unmber for componed I

1. - 1 critical value for the Type [ (a) emor

4. 1 critical value for the Type [l (\$) error

$E_{2}$ × Feed envelope concentrotion limh for component $i$. 


\section{Revision !}

This component sampling number is tolways rounded to the nearest whole number.

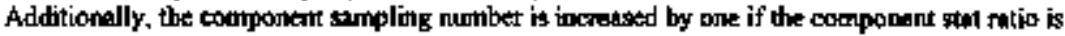
equal wo or greaner than 6.5. The componen stat ratis is a messure of the camponeat ratio's proximity to the feed envelope limil and is determined by the folloxing equation:

$$
s R_{2}=\frac{\left|E_{1}-R_{r}\right|}{\theta_{1}}
$$

where:

$\mathrm{SR}_{1}=$ Stat ratio for componemol $t$. mumbers.

The sompling mumber for the feed betch is thet the lergest of the component sampling

Tables P-AAF thoughF-79BC in Sextion 5.0 shew the sodium ratio, the 6 , (Signa), the maxdmum and minimum feed envelope ctiteria, and the number of samples tequired to validale the feed bench for each component for the zero, two, and five percepl settled salkds cases. In the top lefthand comer of these ables is an indiralion of the conditions the calkulations werre preformed for including which controcior (CNTR I o CNTR 2), the miking scenario (wellmixed or bot mixed), and the percent senked salids $\left(V_{E}\right.$ ). Also inofeated in the lop lefthand cormer of these lables is the assomed ratio of actugl solids volume to tolal volume in the settred golidy leyer in the staging tanks $\left(V_{\xi}\right)$ and the confidence interval used (CI). The ratio and gigma yalues for sodium tre in moles per like and those for the mansurteics (isolopes of Np. Pu, and Am) are given in becqueness per liter. An up or down amow in the "H. of Samples" cohumn indicales a expmponent that has exceeded its feed envelope limit.

Table F-9 lhrogih F-9 summarize the number of samples requined for each liced balch walidation for contractors I apd 2 for the ztrw, ane, two, three, four, and five percent seftled solids caser 


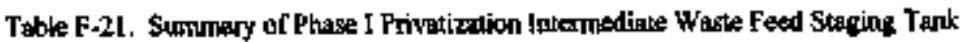
Stmples with o Pencern Stiled Solids.

\begin{tabular}{|c|c|c|c|c|}
\hline senipho & WEl- & & $|k|=$ & \\
\hline conractor & 1 & $\frac{1}{2}$ & 9 & 2 \\
\hline seth & sent & & $5=\pi$ & \\
\hline 9 & 3 & 3 & 7 & 7 \\
\hline $2^{\circ}$ & 8 & 5 & 47 & 34 \\
\hline 40 & $\begin{array}{l}3 \\
3\end{array}$ & 3 & $\begin{array}{l}7 \\
4\end{array}$ & 7 \\
\hline 5" & 3 & 3 & \$ & 5 \\
\hline B & 3 & 3 & $\mathbf{g}$ & 9 \\
\hline 7 & 18 & 19 & $\Rightarrow$ & 80 \\
\hline 8 & 19 & 19 & an & 89 \\
\hline$\theta$ & $\mathbf{3}$ & $\mathbf{3}$ & 10 & 10 \\
\hline 10. & 3 & 3 & 4 & 4 \\
\hline $11^{*}$ & 3 & 3 & 5 & 4 \\
\hline $12^{ \pm}$ & 4 & 3 & 15 & 4 \\
\hline bु-可F & 74 & 70 & 85 & 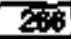 \\
\hline Fotr & $1 \overline{4}$ & & 557 & \\
\hline
\end{tabular}

- No wolida data mallabile for these betates.

- No sollds dest owarieble for Cont 2's Batth 12.

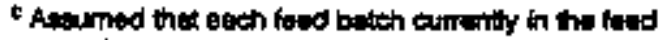
oteging pten that would trit, is replaced by :

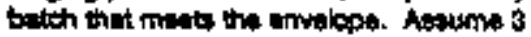
enteles tor each new feed botich. 
Table F-22. Sumruary of Phase I Privatization Indemmediate Waste Feed \$slaging Tent Sarmples with I Pecend Settled Solids.

\begin{tabular}{|c|c|c|c|c|}
\hline scentaio & \multicolumn{2}{|c|}{ Wateriond } & \multicolumn{2}{|c|}{ 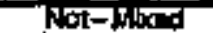 } \\
\hline Contrectar & 1 & 2 & $1=$ & 2 \\
\hline EI & \multicolumn{2}{|c|}{ Samplos } & \multicolumn{2}{|c|}{ Somplot } \\
\hline $1^{2}$ & 3 & 3 & 7 & 7 \\
\hline 24 & B & 5 & 47 & 34 \\
\hline 3 & 3 & 3 & 7 & 7 \\
\hline 4" & $\begin{array}{l}3 \\
3\end{array}$ & 3 & 4 & 4 \\
\hline 6 & Fariled & Ftibed & foriter & Falled \\
\hline 7 & & 30 & 8 & 8 \\
\hline 8 & 20 & 20 & Eg & 85 \\
\hline 8 & $\mathbf{3}$ & $\mathbf{3}$ & 10 & 10 \\
\hline $10^{\circ}$ & 3 & 3 & 4 & 4 \\
\hline $11 \%$ & & 3 & 5 & 4 \\
\hline $12^{\circ}$ & Foilad & 3 & ftillod & 4 \\
\hline Sub-Toter & 7 & 72 & 285 & 372 \\
\hline Tot & 147 & & 57 & \\
\hline
\end{tabular}

- No soolicts deta available for thew betches.

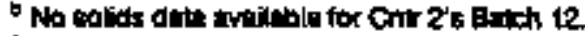

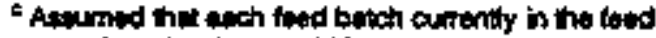

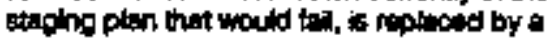

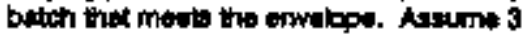

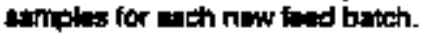


Table F-23 Summary of Phase I Priviluzelpon Intermediate Waste Fed Slaging Tank Samples whth 2 Pencent Setiled Solvds

\begin{tabular}{|c|c|c|c|c|}
\hline "Sctiong & \multicolumn{2}{|c|}{$W_{\theta} \mid-K_{10<0}$} & \multicolumn{2}{|c|}{ 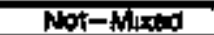 } \\
\hline Confractor & 1 & 2 & 9 & 2 \\
\hline Exth & \multicolumn{2}{|c|}{ stomplpan } & \multicolumn{2}{|c|}{ Simplest } \\
\hline 71 & 3 & 3 & 7 & 7 \\
\hline $\begin{array}{l}2: \\
3:\end{array}$ & $\begin{array}{l}8 \\
3\end{array}$ & 5 & 47 & 34 \\
\hline $4^{*}$ & 3 & 3 & 4 & 4 \\
\hline $5^{*}$ & Faltan ${ }^{3}$ & Foliad & 5 & Foting \\
\hline 7 & 21 & 21 & 102 & 100 \\
\hline 8 & 21 & 21 & 102 & 102 \\
\hline 8 & $\sqrt[3]{ }$ & 3 & 10 & 10 \\
\hline 104 & 3 & 3 & 4 & 4 \\
\hline $11:$ & & 3 & 5 & 4 \\
\hline Sub-Tot & 莎 & 74 & $2 \%$ & 28 \\
\hline Tot & 5151 & & 58 & \\
\hline
\end{tabular}

- No solits cha aveilable for these botthes.

- No solids coto wivito tor Cnt $2=$ anteh 12

I Ausmed thet wach faed bitch curnently in the foed stioghe plan that woult fill, a ropteced by a bench that moets the envelope. Asautie 3 semples for excth newr fow balth 
Table F-24. Sumnay of Phase I Privalization Intermediate W'aste Feed Staging Teark Stonples with 3 Peisent Sevilod Solidt.

\begin{tabular}{|c|c|c|c|c|}
\hline seangerio & \multicolumn{2}{|c|}{ Whal-Maced } & \multicolumn{2}{|c|}{ NGT-Mond } \\
\hline contector & 9 & 2 & 1 & 2 \\
\hline Eatth & \multicolumn{2}{|c|}{ Sarneles } & \multicolumn{2}{|c|}{ Semplas } \\
\hline 17 & 3 & 3 & 7 & 7 \\
\hline $2 \%$ & g & $\$$ & 47 & 34 \\
\hline 3. & 3 & 3 & 7 & 7 \\
\hline 5. & 3 & 3 & 5 & 5 \\
\hline 6 & Fanlad & Fatled & Failed & Fatilad \\
\hline 7 & 20 & 22 & 110 & 110 \\
\hline 8 & 22 & 22 & 110 & $t 10$ \\
\hline 9 & 3 & $\mathbf{3}$ & 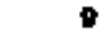 & 9 \\
\hline $10=$ & 3 & 3 & 4 & 4 \\
\hline $11^{\bullet}$ & 3 & 3 & & 4 \\
\hline $12^{\circ}$ & Folland & 3 & Fallad & 4 \\
\hline 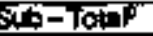 & -78 & 76 & 374 & 301 \\
\hline $\operatorname{tot}^{2}{ }^{2}$ & 13 & & 6i5 & \\
\hline
\end{tabular}

- No sollas date oweilable for thase bitthes.

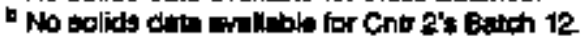

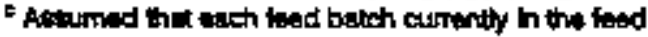
staping plan that would farl, is repleced by a batsh that meets the envilope. Alsumin 3 semples tot woch new lood balch. 


\section{HDF-SD-TWR-AGA-OROI}

\section{Revision I}

Table F-25. Sumuary of Phase I Privatizotion Jntermediate Waste Fed Staging Tank Samples with 4 Pertent Settled \$olids

\begin{tabular}{|c|c|c|c|c|}
\hline Scthtip & \multicolumn{2}{|c|}{ Well-Mnod } & \multicolumn{2}{|c|}{ 14at-ribed } \\
\hline Contractor & 9 & 2 & 1 & 2 \\
\hline betch & \multicolumn{2}{|c|}{ Samplos } & \multicolumn{2}{|c|}{ Sempos } \\
\hline 7 & 3 & 3 & -7 & 7 \\
\hline 24 & B & 5 & 47 & 34 \\
\hline 30 & 3 & 3 & 7 & 7 \\
\hline 5. & $\begin{array}{l}3 \\
3\end{array}$ & 3 & 4 & 5 \\
\hline 6 & Failed & Fallod & Fallod & Fallod \\
\hline 7 & 24 & 24 & 118 & t18 \\
\hline 8 & 24 & 24 & 118 & 118 \\
\hline 9 & (3) & 3 & & 9 \\
\hline $10 *$ & 3 & 3 & 4 & 4 \\
\hline $11^{\circ}$ & 3 & 3 & & 4 \\
\hline $12^{\circ}$ & Fatied & 3 & Fralled & 4 \\
\hline$S \omega b-T o t h$ & 83 & 80 & 30 & 317 \\
\hline $30 h^{2}$ & 163 & & 67 & \\
\hline
\end{tabular}

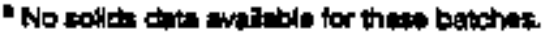

- No solids deta arallable for Cnto Z's Boten 12

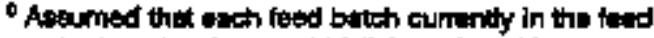
string plan thet woul fall, is repleced by a beth that meets the envelope. Absume 3 samples tor acch aew foed both. 
Tabie F-26. Sumnary of Thase I Privalization lotermethale Waste Feed Staging Tank Samples with 5 Percent Settled Solids.

\begin{tabular}{|c|c|c|c|c|}
\hline scanto & WDIF- & Ibed & $\mathrm{NOA-}$ & Stox \\
\hline Controtor & 1 & 2 & $1-$ & र \\
\hline Ention & seln & 106 & SEN & 906 \\
\hline 10 & 3 & 3 & 7 & 7 \\
\hline $2=$ & 8 & 5 & 47 & 34 \\
\hline 34 & 3 & $\mathbf{3}$ & 7 & 7 \\
\hline 4* & 3. & 3 & 4 & 4 \\
\hline $5^{\circ}$ & & 3 & 5 & \\
\hline $\begin{array}{l}6 \\
7\end{array}$ & $\begin{array}{c}\text { Failod } \\
28\end{array}$ & $\begin{array}{r}\text { Follod } \\
26\end{array}$ & Falled & $\begin{array}{l}\text { Falled } \\
120\end{array}$ \\
\hline g & $\mathbf{2 6}$ & 26 & 120 & 128 \\
\hline 9 & 4 & 4 & $\theta$ & 9 \\
\hline $10^{\circ}$ & 3 & 3) & 4 & d \\
\hline $11 \%$ & & 3 & & \\
\hline $12^{b}$ & Fellod & 3 & Ftided & 4 \\
\hline 5b-Totf & 88 & क5 & $3+5$ & 37 \\
\hline$T \overline{T^{\prime}}$ & 173 & & 687 & \\
\hline
\end{tabular}

- No sollds date waileble for these butchus.

- No eofids deta malieble for Cnt 2's Beteh 12.

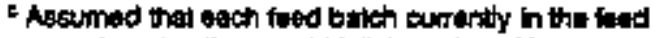

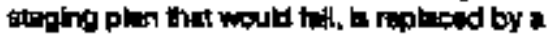
bitch that mets the ermebop. Aopume 3 samples for anch now lood bach. 


\section{F3. EFFECTS OF SOLIDS ON THE SAMPLING NUMBER}

\section{F3.1 EFFXCTS OF SOUDS ENTRAINMENT}

Tabte F.27 thowg the effecl solids antrainment has on the sampling number for the cheses of zero to six percert seteled solids. The "Toul Smaples" column lists the lotal ("life-cycle") mumber of samples required for Phese I. This incluxks the samples for all twelve batches for both contractors. The right column lists uhe curnenty planoed feed tatches baled in Certa el al. (I996) that will not moet the modified RJP feed envelopes (i.e., tailed bakches) if the specified amount of solids'shudges anc entrained In calculating the total aamples, it is assumed that the potentigl of these firiked balches would be anticipeted and Certa et al. (1996) would be revised to replace them with batches that meet the ited envelope citeria and only requires thres samples for validation.

Tabto F-27. Sampling Number and the Effects of Emturined Solids.

\begin{tabular}{|c|c|c|c|}
\hline \multirow{2}{*}{ Percent Settled Solids } & \multirow{2}{*}{ Total Sinples } & \multicolumn{2}{|c|}{ Elalches Excesding Freed Enwelope Criteria } \\
\hline & & Contracker 1 & Contracter 2 \\
\hline \multicolumn{4}{|c|}{ Well Mixed Scethetio } \\
\hline $0 \%$ & 144 & & \\
\hline $1 \%$ & 147 & 12,6 & 6 \\
\hline $2 \%$ & 151 & 126 & 6 \\
\hline $3 \%$ & 155 & 12,6 & 6 \\
\hline $4 \%$ & 163 & 12,6 & 6 \\
\hline $5 \%$ & 173 & 12,6 & 6 \\
\hline $6 \%$ & 183 & 12,6 & 6 \\
\hline \multicolumn{4}{|c|}{ Nol Mixed Scenatio } \\
\hline $0 \%$ & 557 & & \\
\hline $1 \%$ & 557 & 12,6 & 6 \\
\hline $2 \%$ & 585 & 12,6 & 6 \\
\hline $3 \%$ & 615 & 12.6 & 6 \\
\hline $4 \%$ & 647 & 12,6 & 6 \\
\hline $5 \%$ & 687 & 12,6 & 6 \\
\hline $6 \%$ & 740 & 12,6 & 6 \\
\hline
\end{tabular}

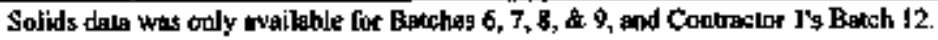




\section{F3.2 EFFECTS OF THE TRANSURANIC LMITT}

Table F-28 legtg the totel (d,fe-cycle) muniber of samples thes woukd be requered in the Feed Enveloje C TRU Imil was morrersed for solud cutrannment sceasmos between zero and 5 percent The eurrent TRU limil is 3,000,000 Bexquerels for TRU per mode af andımin Figures F-29 and

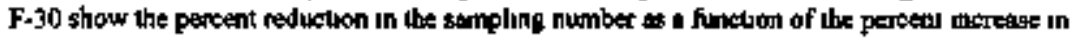
the Fred Envelope C TRU Limit for the wel-puixed and not-nixed soenanos, tespeelively

Table F-28 Sampliag Number as a Fonchon of the Tranguranc Limn with Respect to Muxcro Sreenano and Percenl Setuled Soluds

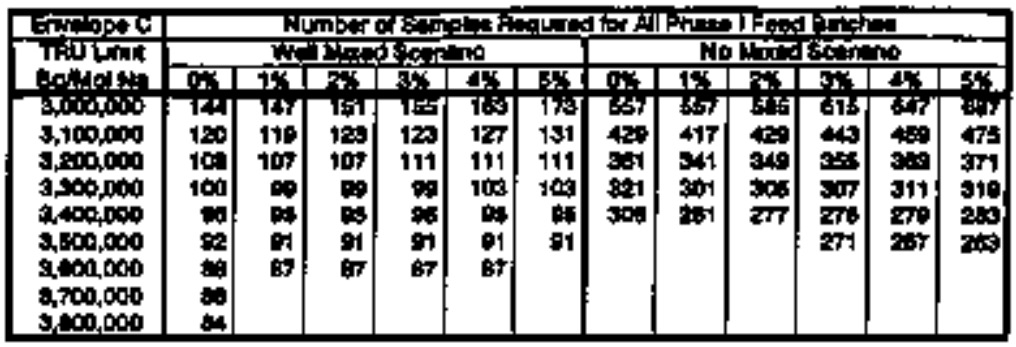


Figure F-29. Sampling Number Redaction versus Tranerpanic Limil Inkrease: Well-hixed Seenerio.

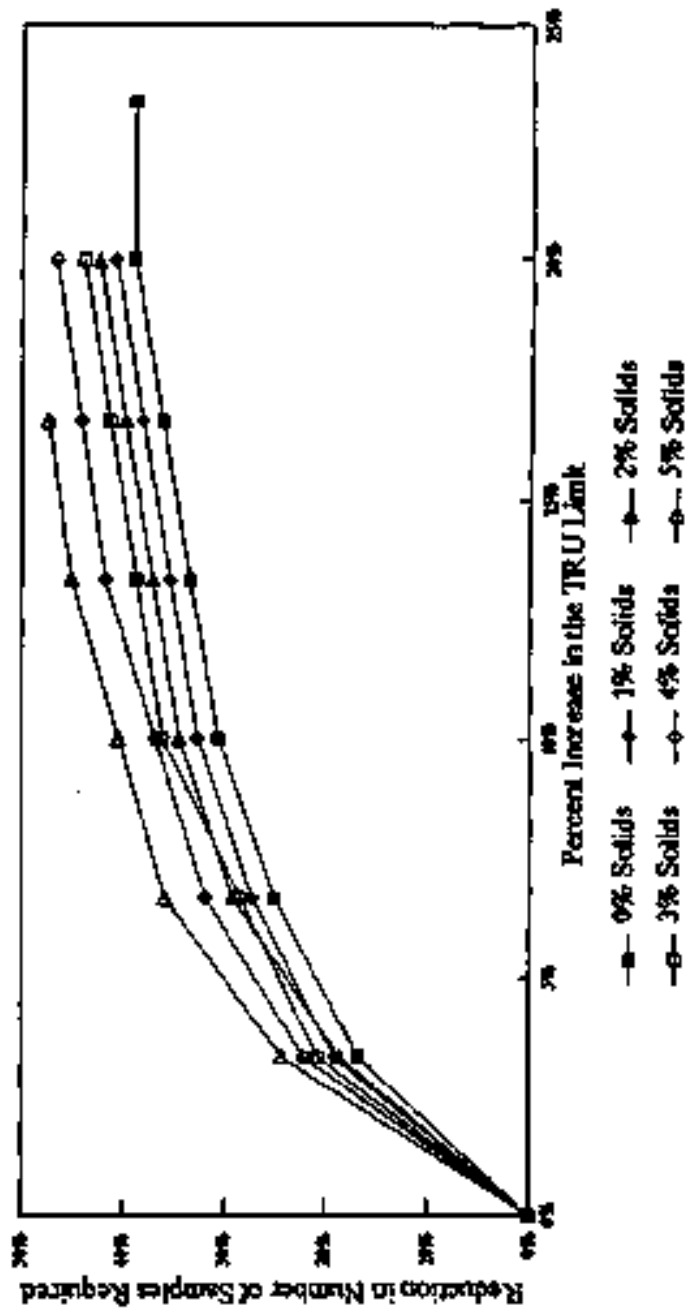


HDNF-SD-TWR-AGA-00I

Revisiono 1

Figure F-30. Sampling Number Reduction vergts Tranguranic Limil Increase: Not-Mixced Scarario.

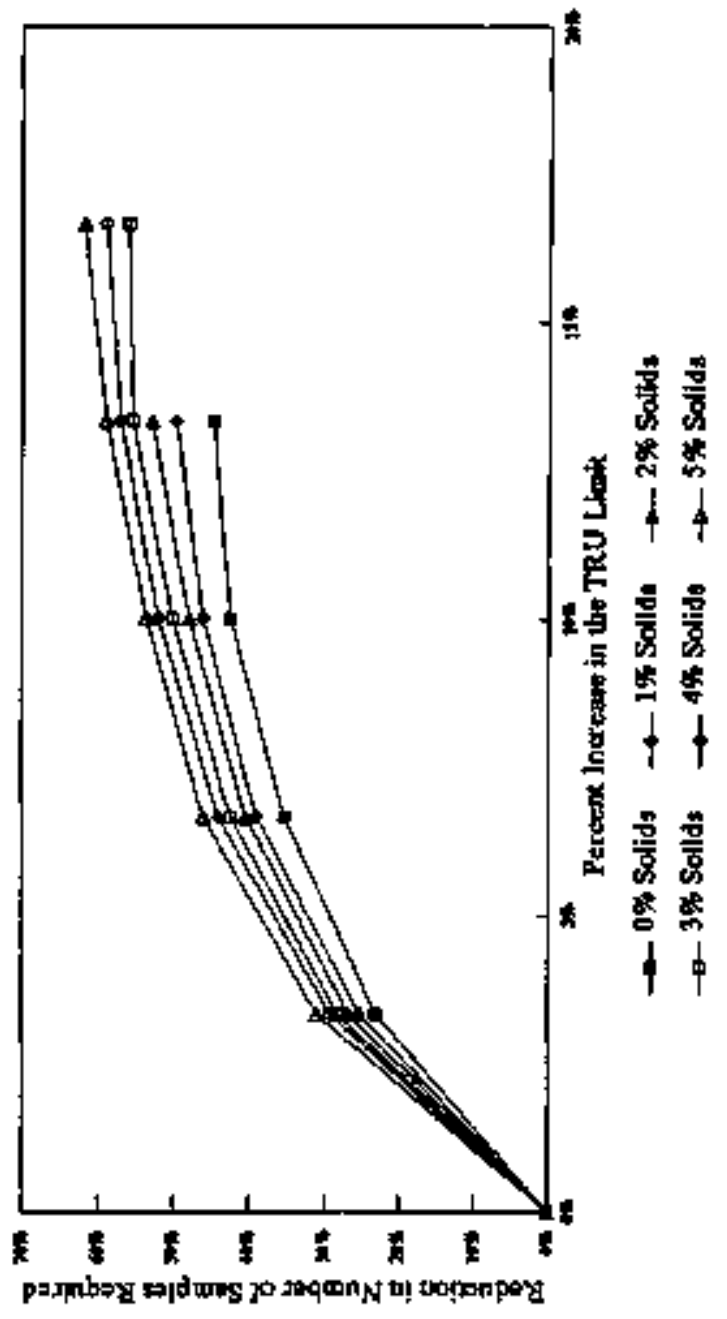




\section{F4.0 SAMPLE AND ANALYSIS REQUIREMENTS AND COSTS}

\section{F4.1 ANALYTICAL RLQUIREMENTS}

An analysss of the staging tank samples will be noekd for each of the tandyces and madornuchdes listed in the feed envelope critern Table F.31 lists the analytical method and procedure nambers for the requered analyss

\section{F4,2 SAMPLE \$IZE REQUIREMENTS}

Tabk F-3I alto luts the volume of sumple required for atalyss When received, the bulk samples are keted for several physical chacacienetics The bulk sample is then separaied uto laquid and sofsds frachons whuch are tosted scperately The sample volume requred for the bulk

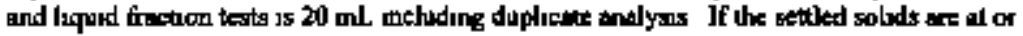
below Exwe volume percen1, a sample vohame of 100 to $120 \mathrm{~mL}$ may be requred to ensure ewough solvds are separated oul to perfom the roqurzed an:alysss Also, gampie volumes maller that 100

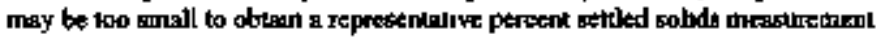

\section{F43 SAMPLE ANALYSIS COST ESTIMATES}

The cuts for rample analyas has been separaled unto (I) the cogl for Inquid fraction analysis, which includes the tests on the bulk onpples, and (2) the cost for the solds fracunas analyas Thesc costa adso undude the costa of dupheak anatysis The cost for lequid fiaction

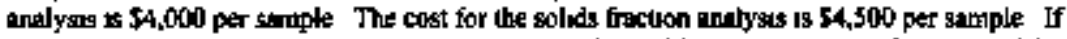
samples art taken with a care samplex, thene is an adihuonal \$1,000 per sample foe agsossed for exirusion of the gample from the core sampler (Ruce 1996) 


\section{HNF-SD-TWR-AGA-001 \\ Revision 1}

Table F-31. Intermetiatt Wabke Foed Staging Sysken Feed Botch \$anple

Antalysis Requiremenls, (Sheet 1 of 3)

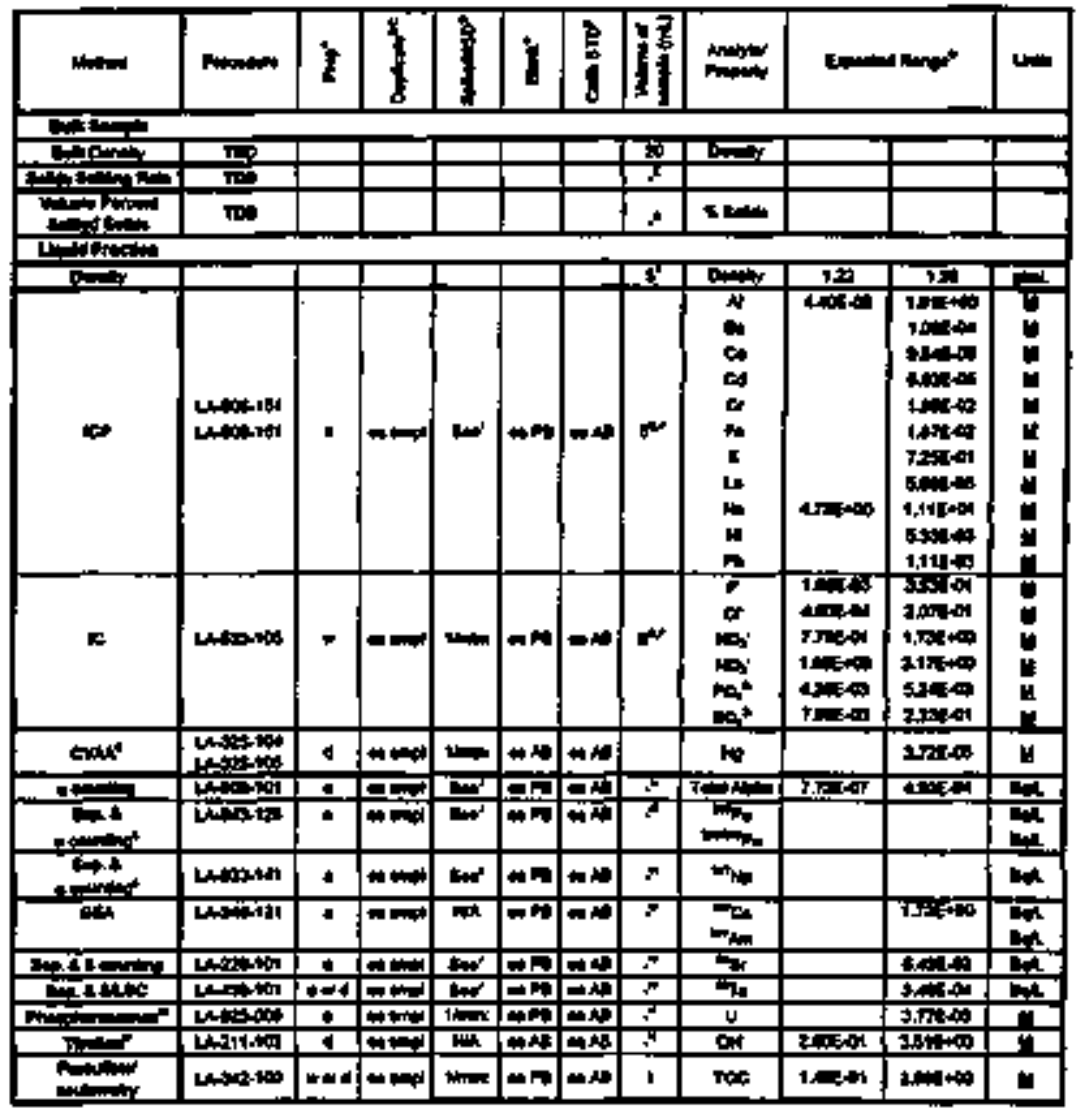




\section{Revision I}

Table F-31. Imternediate Waste Feed Staging Systen Fred Banch Sample

Analysis Requirements. (Shest 2 of 3)

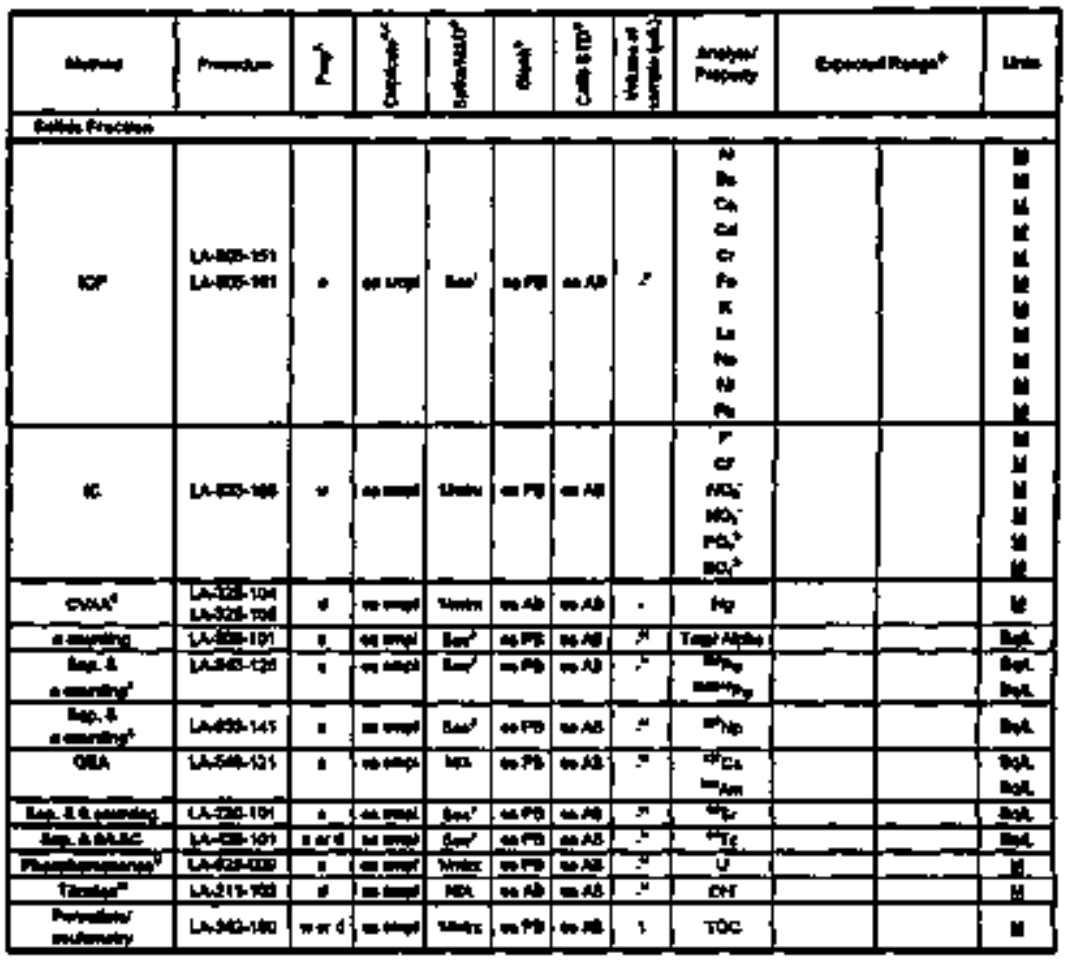


Table F-31 Intermedrate Waste Fexd Staging System Feed Banch Sample Atralysis Requrements (Sheet 3 of 3)

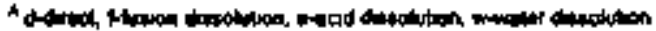

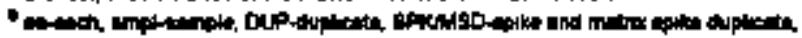

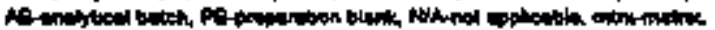

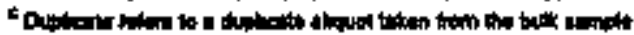

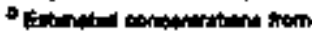

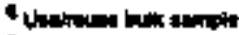

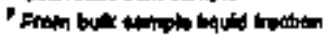

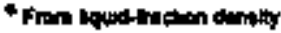

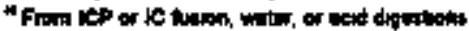

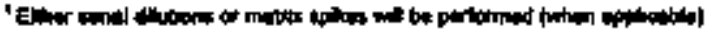

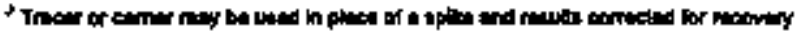

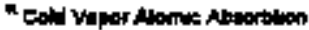

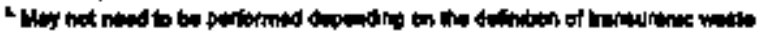

marimay

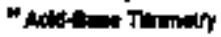




\section{HNF-SD-TWR-AGA-D0]}

Rerision I

\section{F50 TAFLES}

This ection conlesins the tables used to calcukale the minimuna pumber of samples required ko validale that he feed betches meet the food envelopes. 
HNF-SD-JWE-AGA-O01

Revision I

Table F-32 Sample Number Calculationts for Conuractor 1, Weli-Maxed, 1) Percont Setaled Solnts (Sheat I of 3)

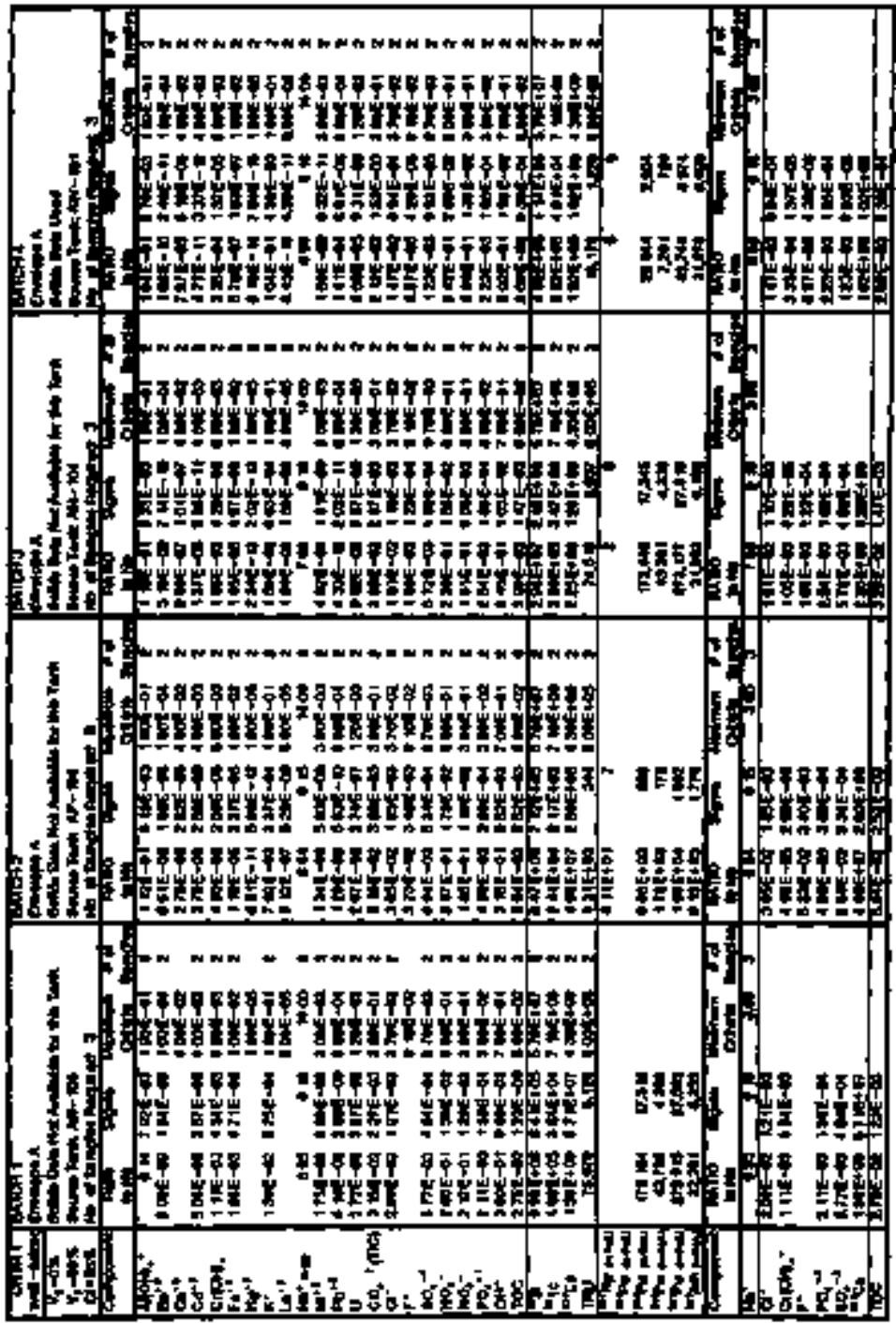




\section{HNF-SD-TWR-AGA-OOP}

keveron 1

Tabk F-32 Sample Number Cakculaluons for Contractor I, Well-Mixed, 0. Perven Sertiled Solids (Steed 2 of 3)

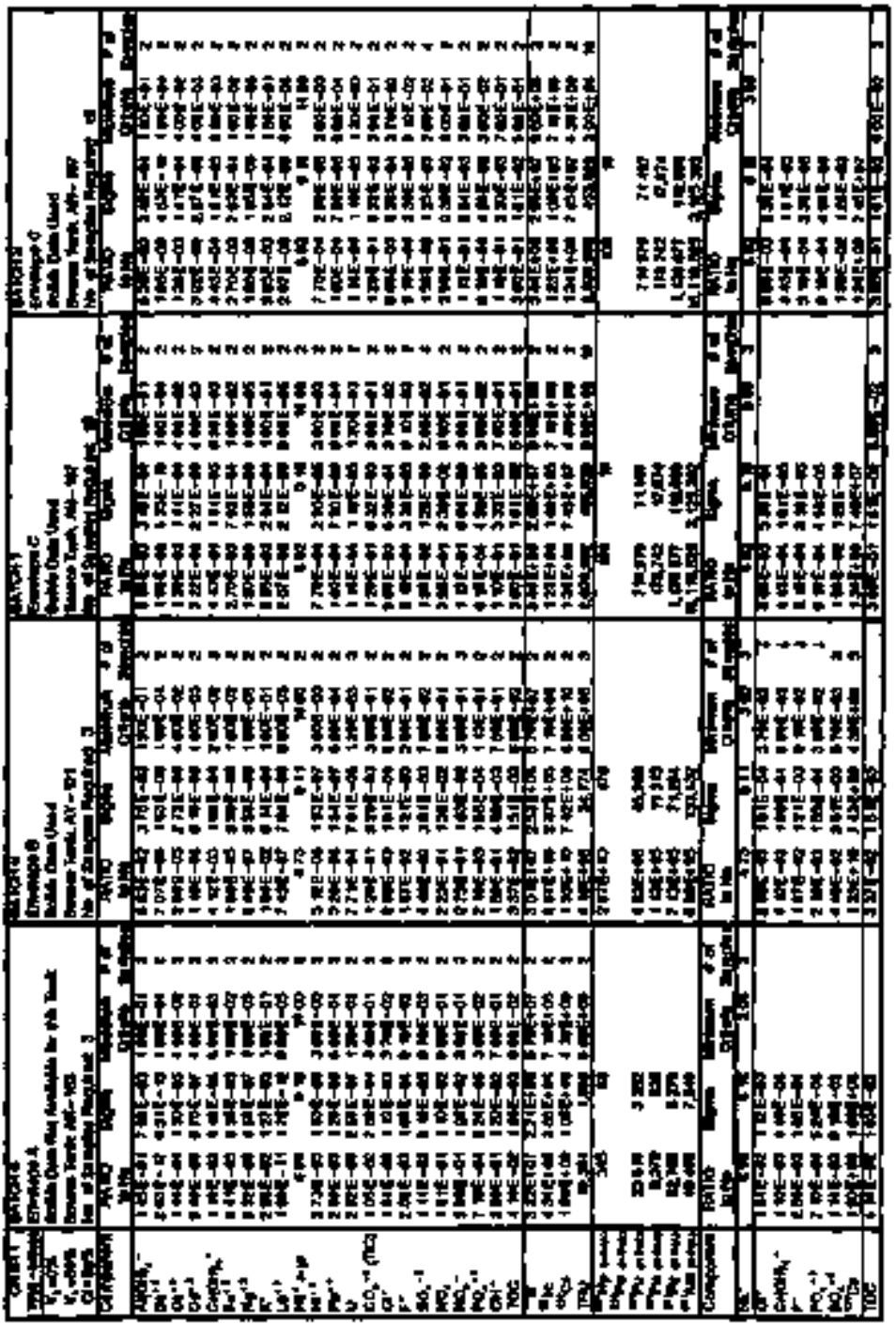


Table F-32 Sample Number Calculairons for Contractar I, Well-Mixed. 0 Percent Setaled Solkds (Sheet 3 of 3)

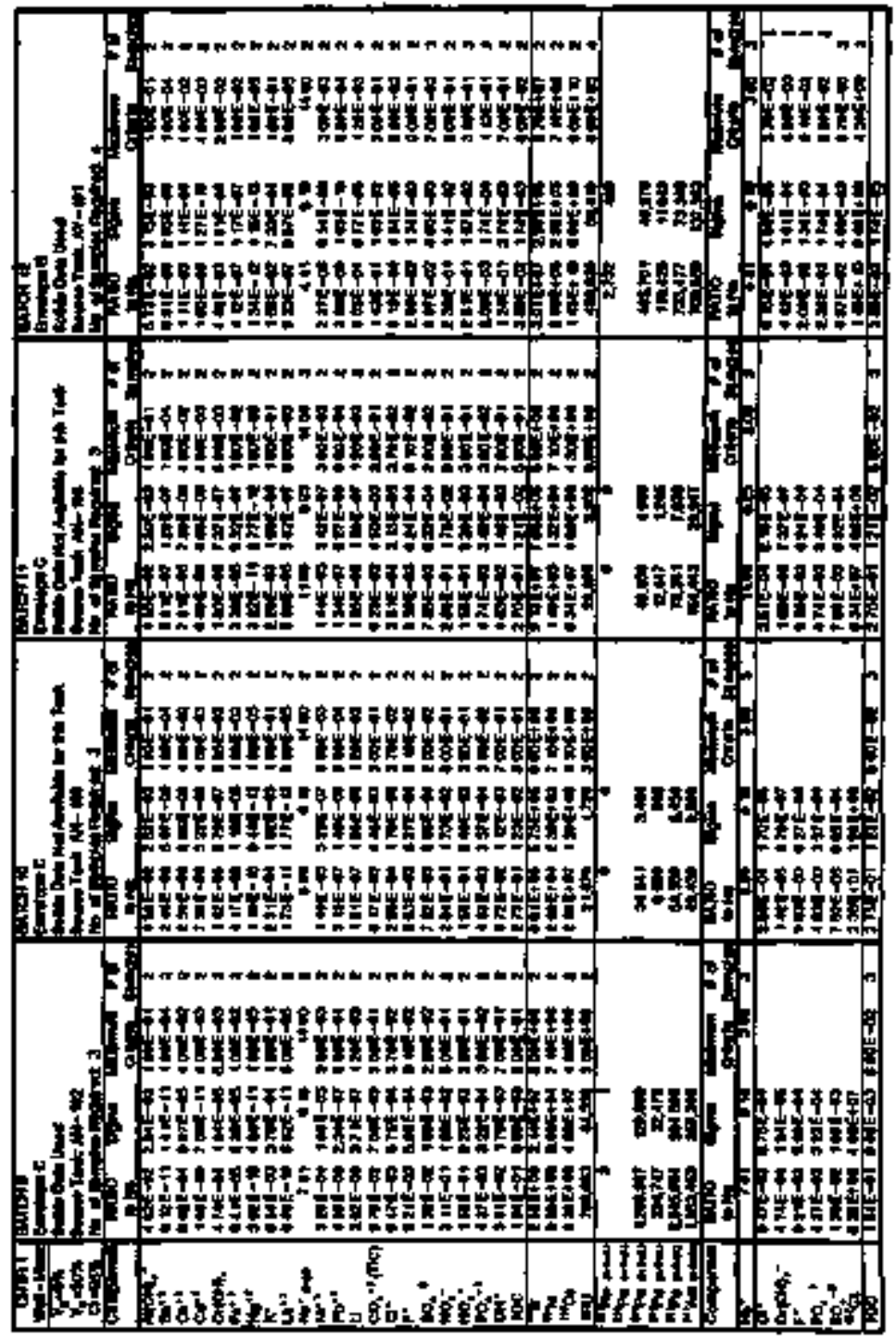


Table F-33 Sample Number Calculaluous for Cootrictor I, Nor-Mixod, o Parcan Senled Soltds (Sheet 1 of 3)

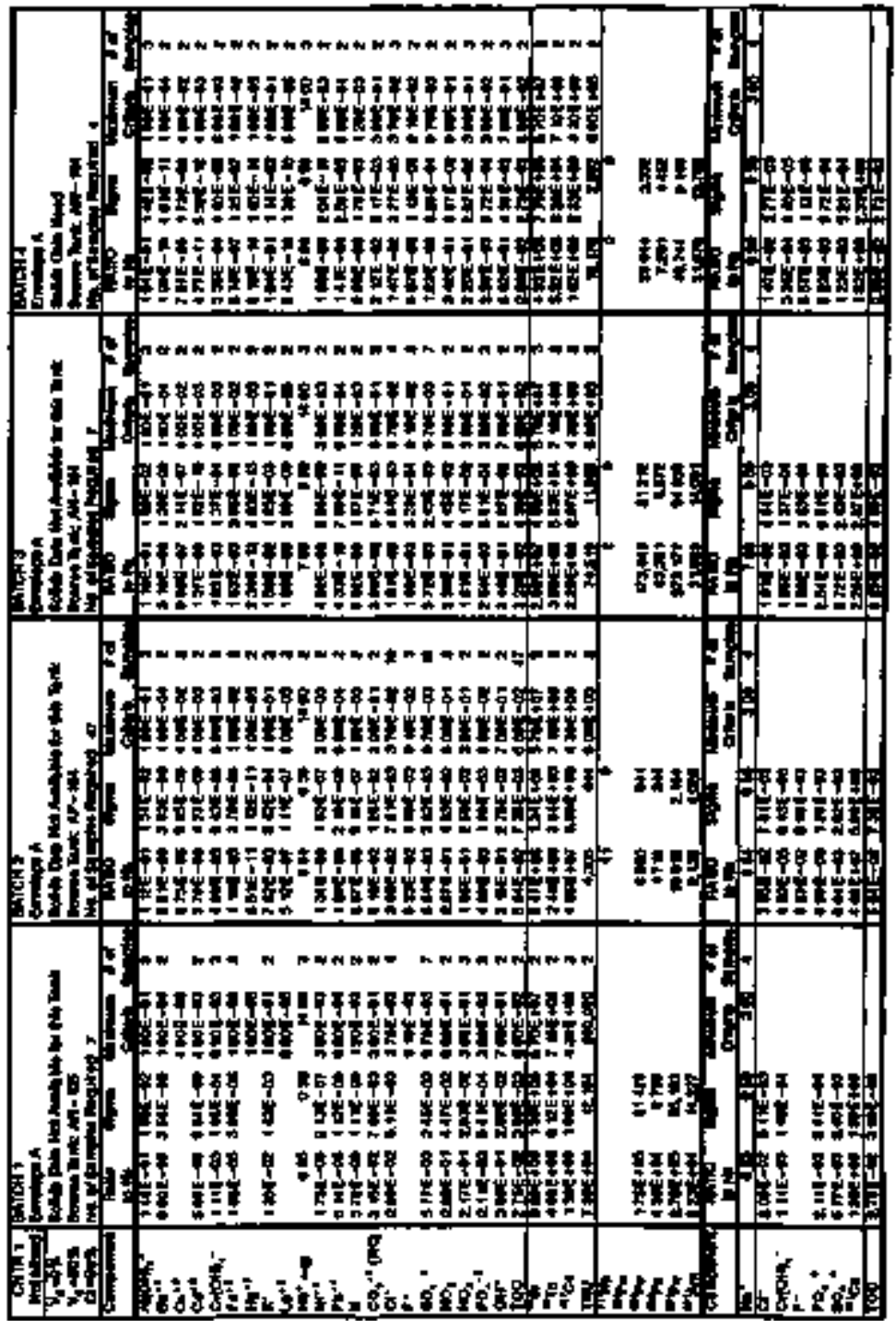


Table F.33 Stmple Number Colculadsoms for Contractor 1, Not-Mixed 0 Perent Sented Soulds (Shett 2 of 3 )

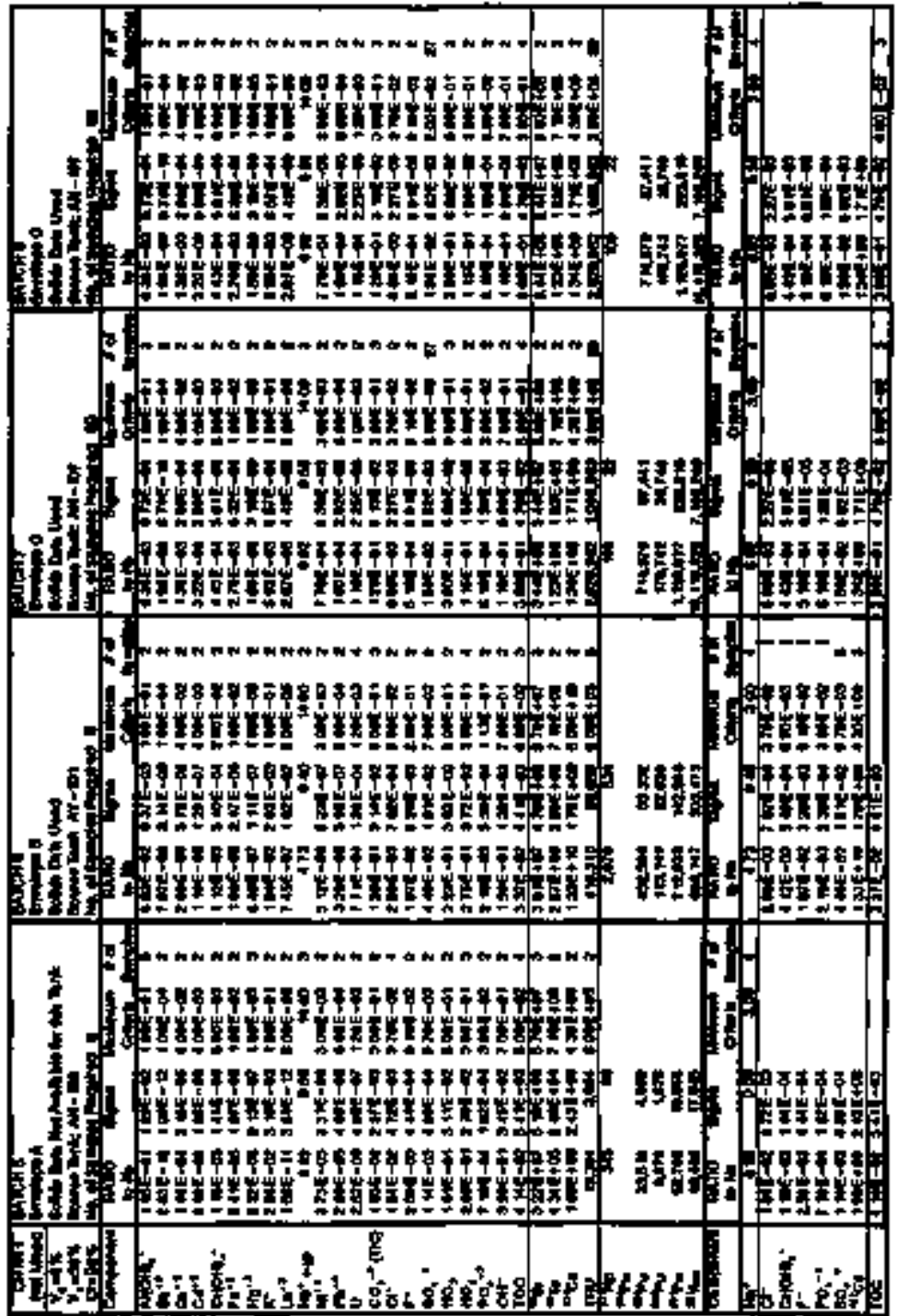


Table F-33 Sample Number Calculsuopis fox Contractor 1, Not-Mixed, 0 Poremt Sented Solndy (Sheat 3 of 3)

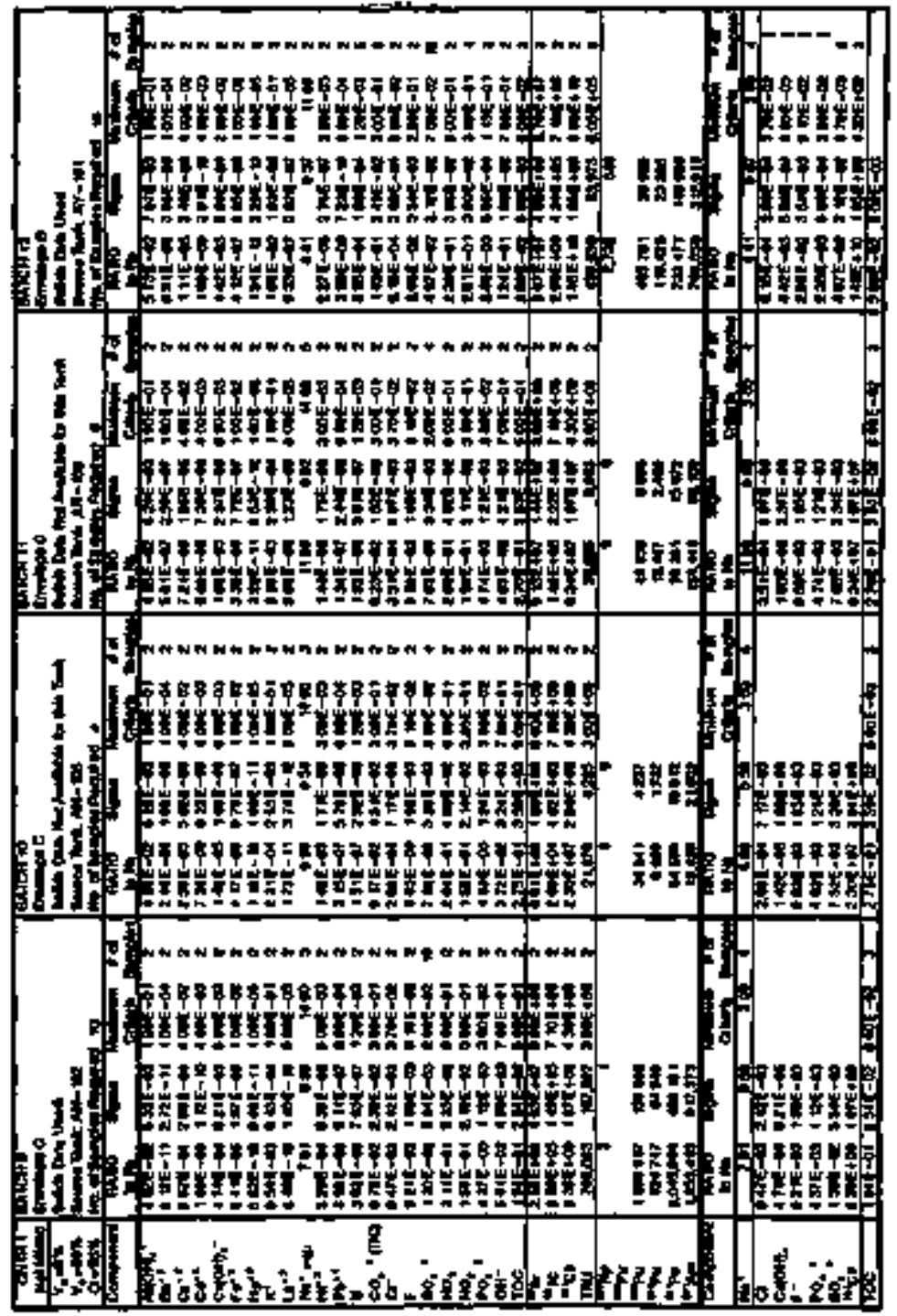




\section{HNF-SD-TWR-AGA-DOI \\ Revisian I}

Table F.34 Srimple Number Calculations for Contracior 2, Well-Mexed, 0 Perceral Setaled Solds (Sheet l of 3 )

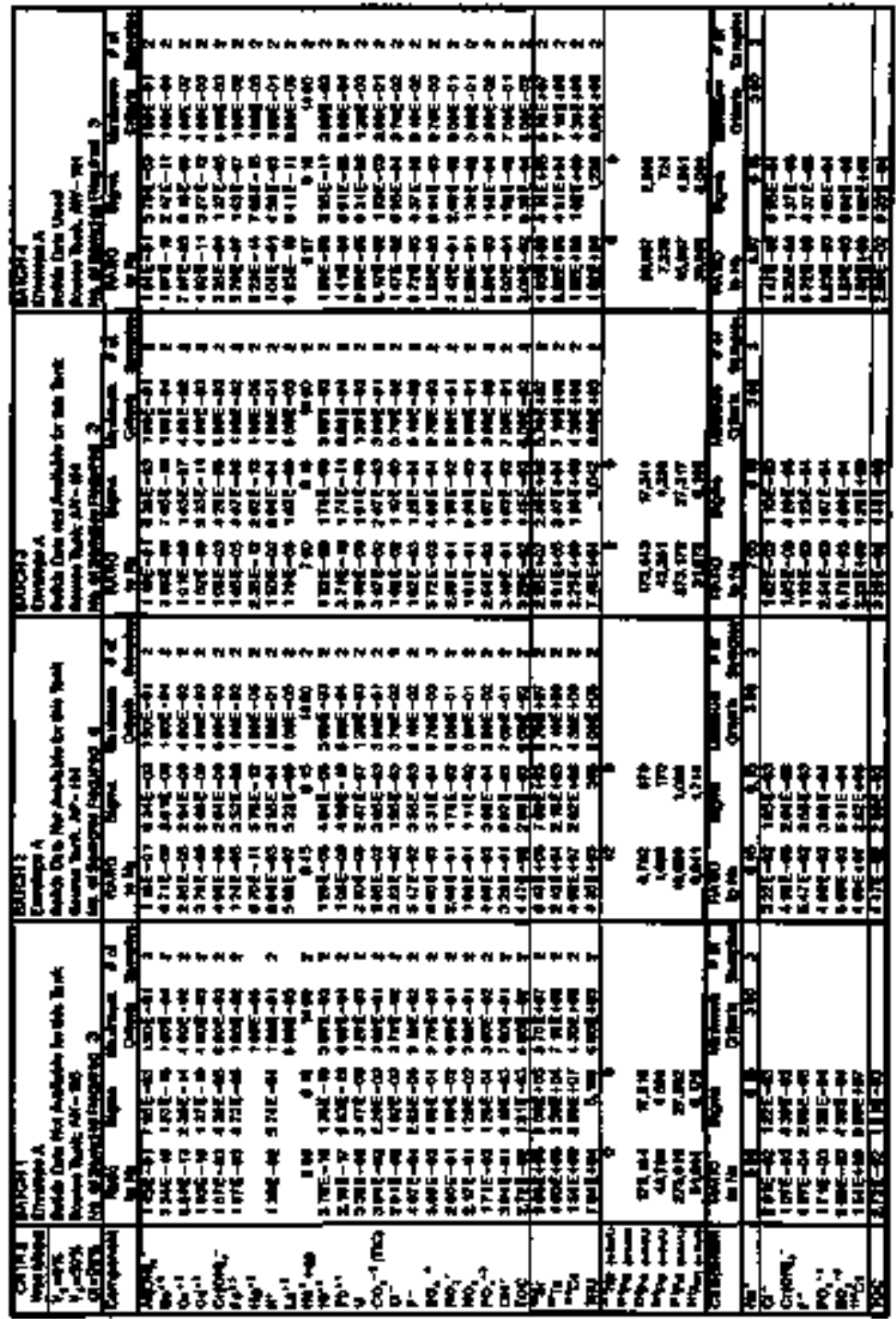


Table F-34 Sample Number Calcularons for Contractor 2, Well-kuxed, 0 Percent Sertiled Soluts (Sheet 2 of 3)

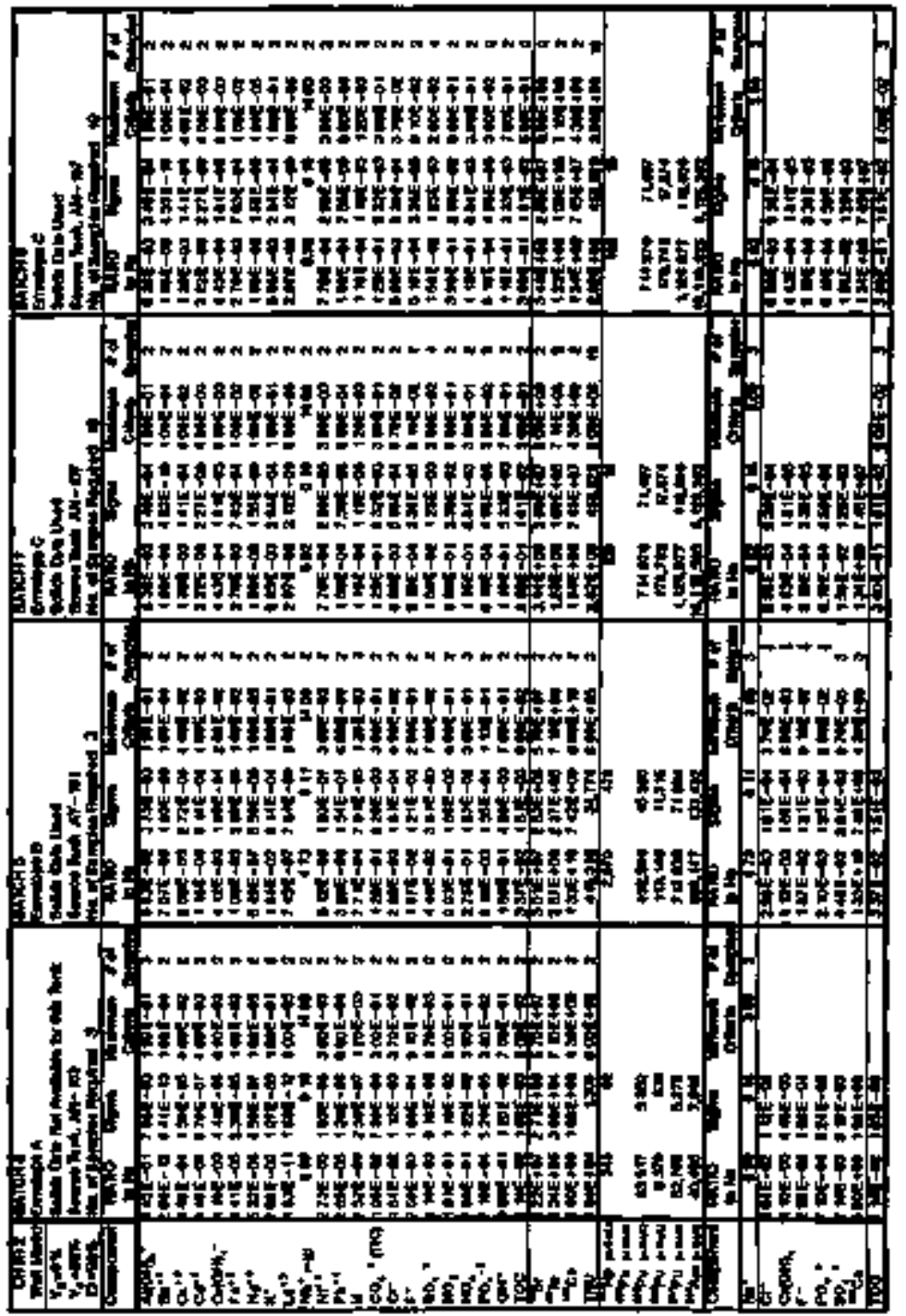


Table F-34 Sample Nuraber Calculations for Conlnekr 2, Well-Maxad, 0 Percent Setiled Solvis (Sheet 3 of 3)

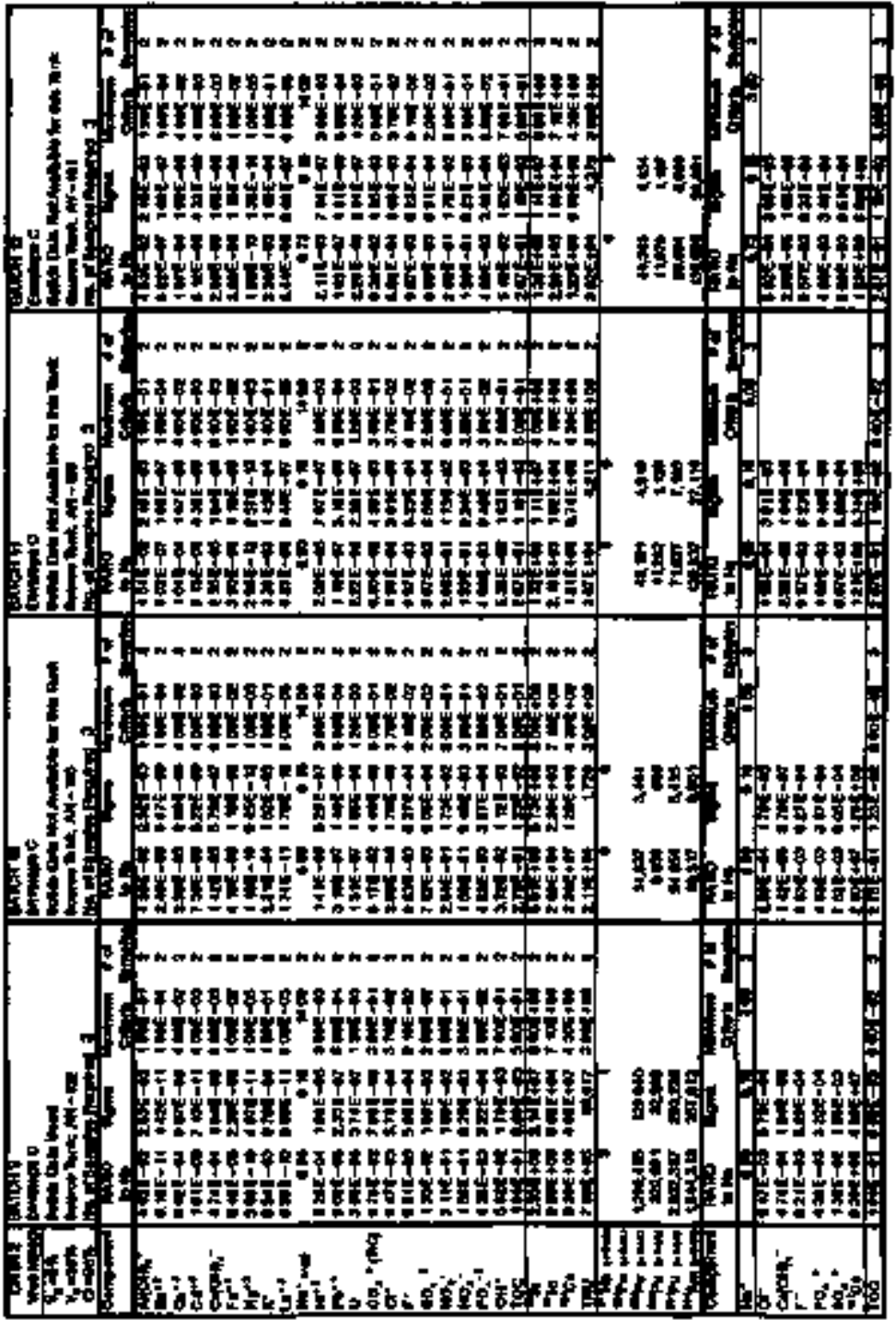




\section{HNF-SD-TWR-AGA-001 \\ Revision I}

Table F-35 Sample Number Cakulairons for Contractor 2, Not-Mixed, O Percent Sertled Solds (Shaet 1 of 3)

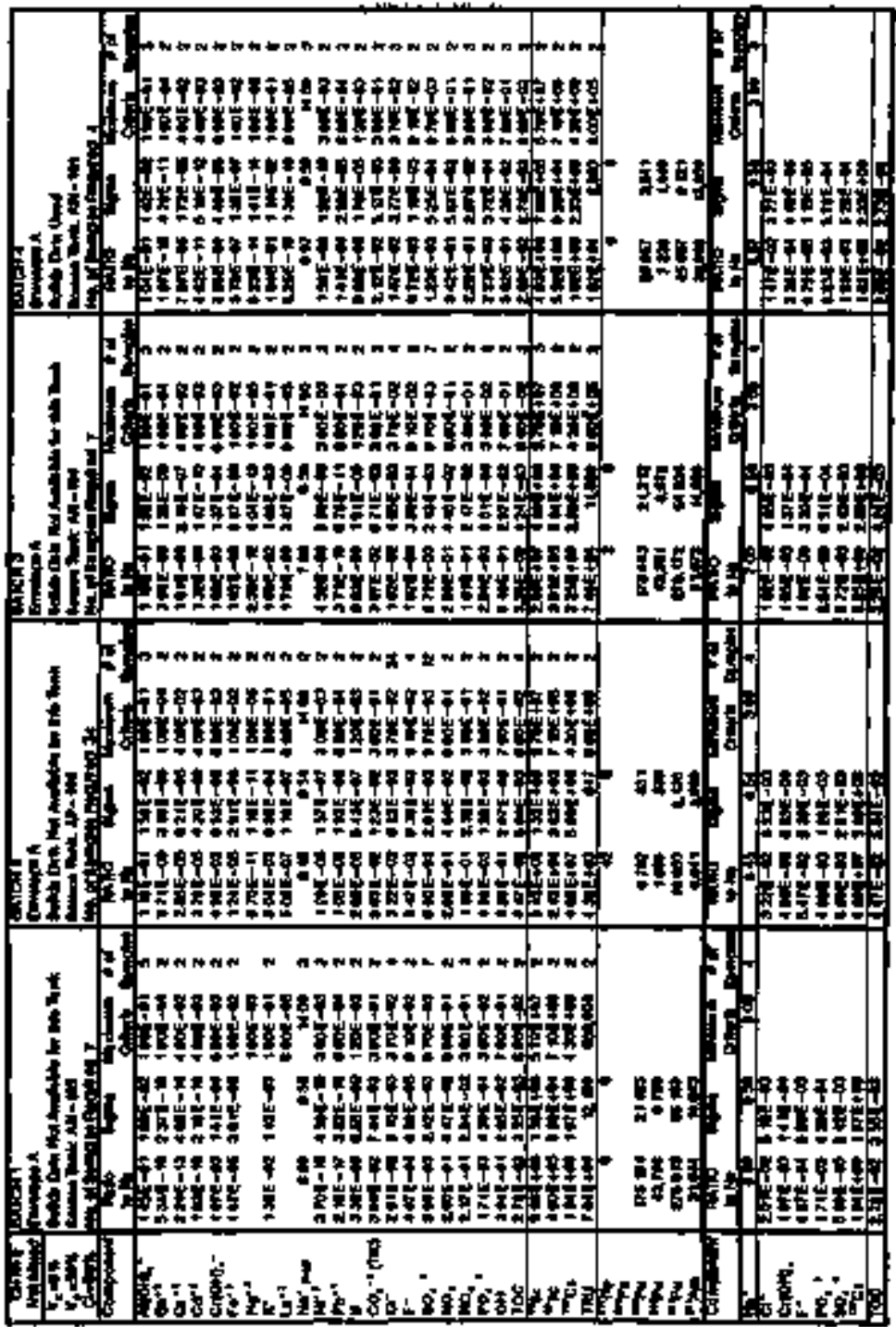


Tabic F-35 Sample Number Calculalions for Contractor 2, Not-kuxed, o Percend Settled Solıds (Sheed 2 of 3)

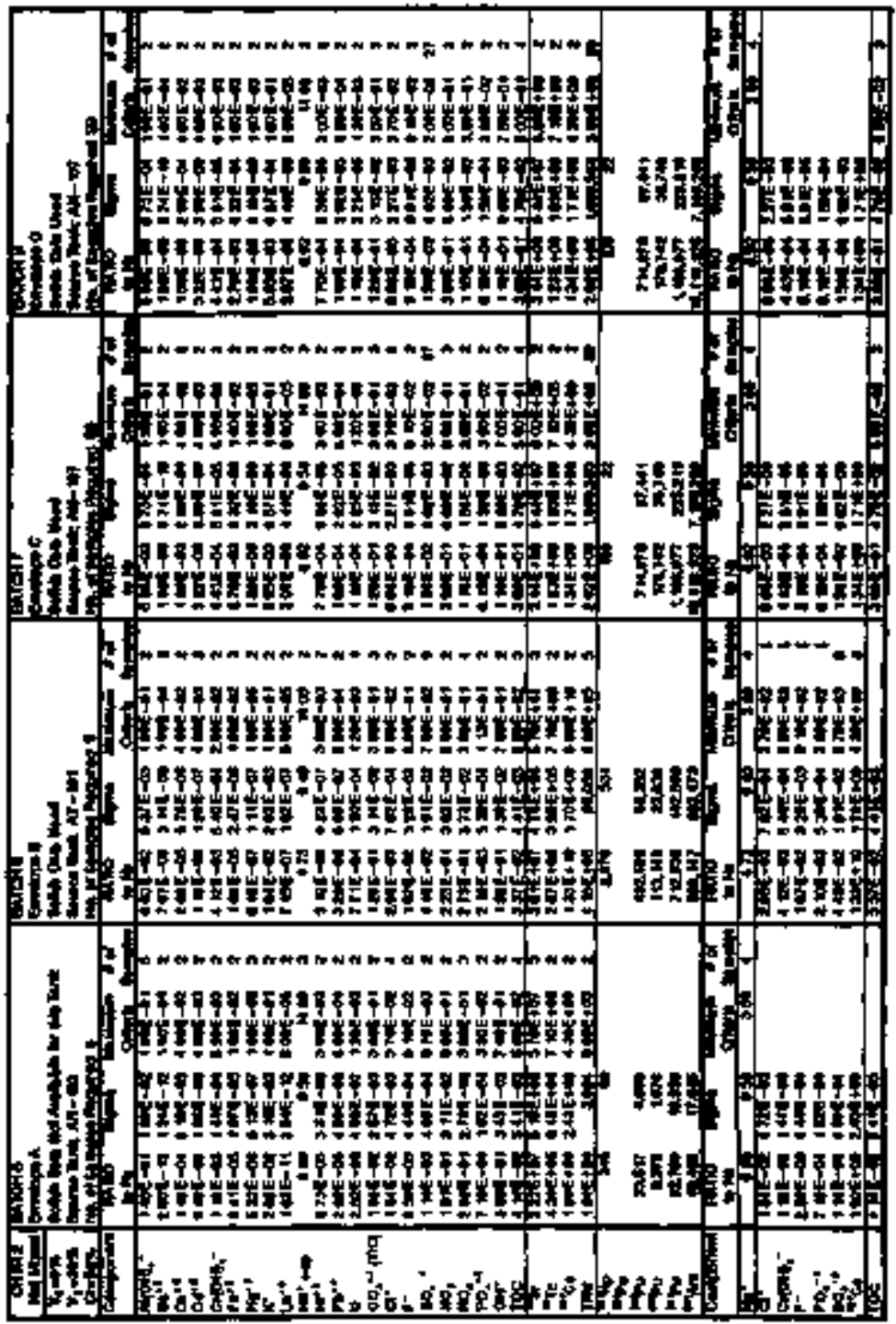


Table F-35 Sample Number Calculabons for Contratelor 2 Not-Maxed, 0 Percenl Senled Solds (Sheet 3 of 3 )

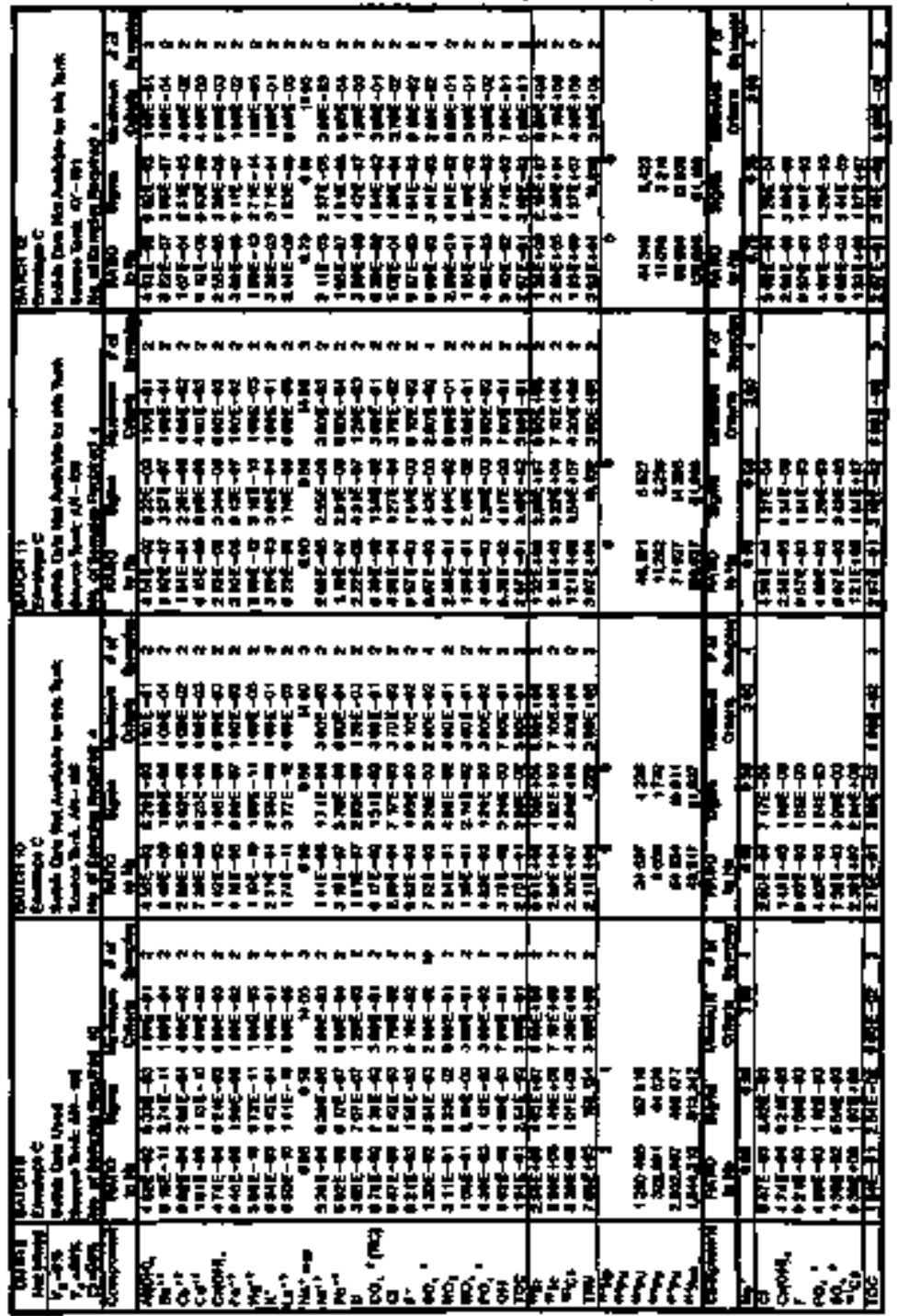


Jable F-36 Semple Number Calculabons for Contractor 1, Welt-Maxed, 2 Percem Setlied Solids (Sheed I of 3)

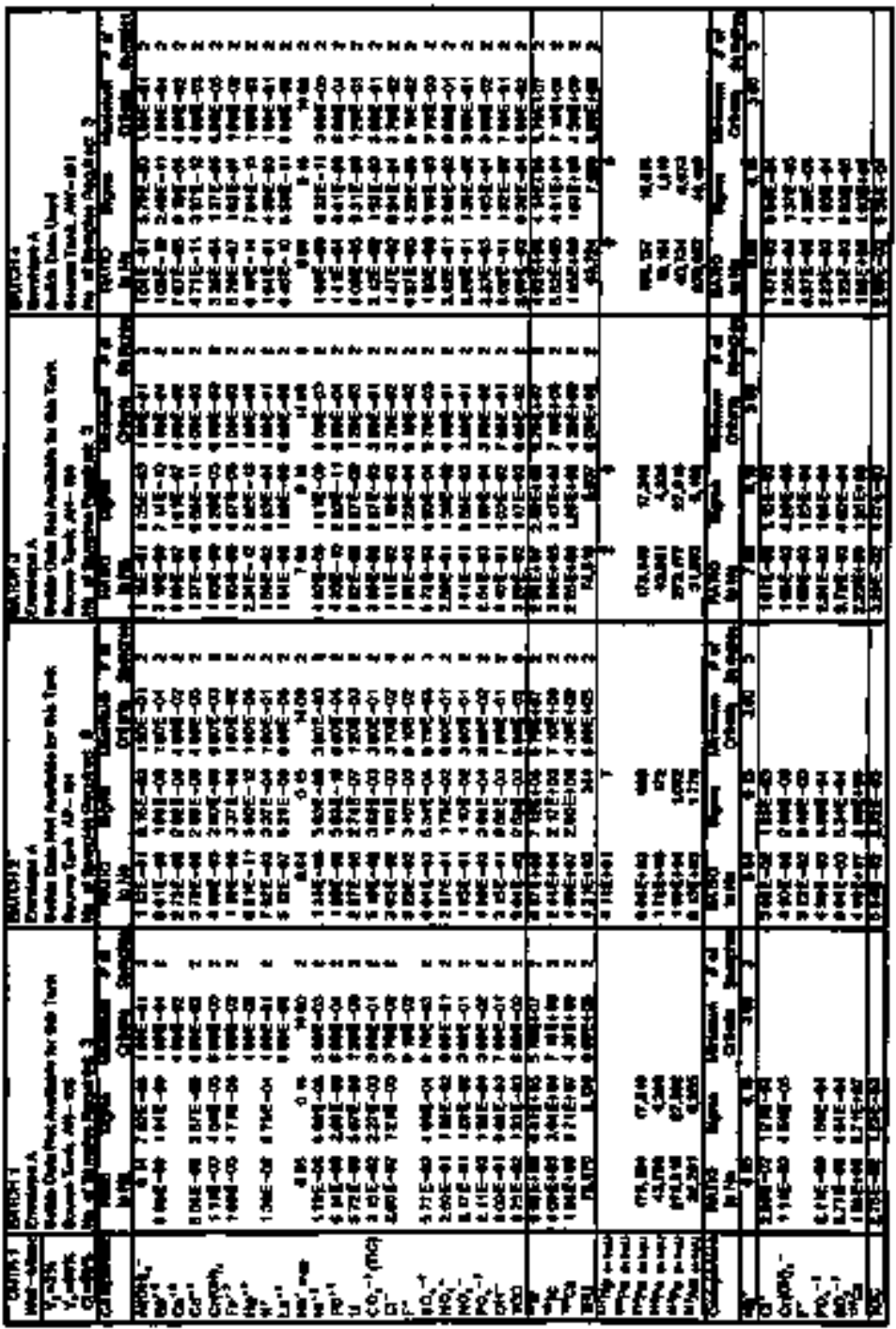


Table F-3̧6. Semple Number Celcudarons for. Contareloc 1, Well-Mixod, 2 Percent Stated Sollds (Shen 2 of 3)

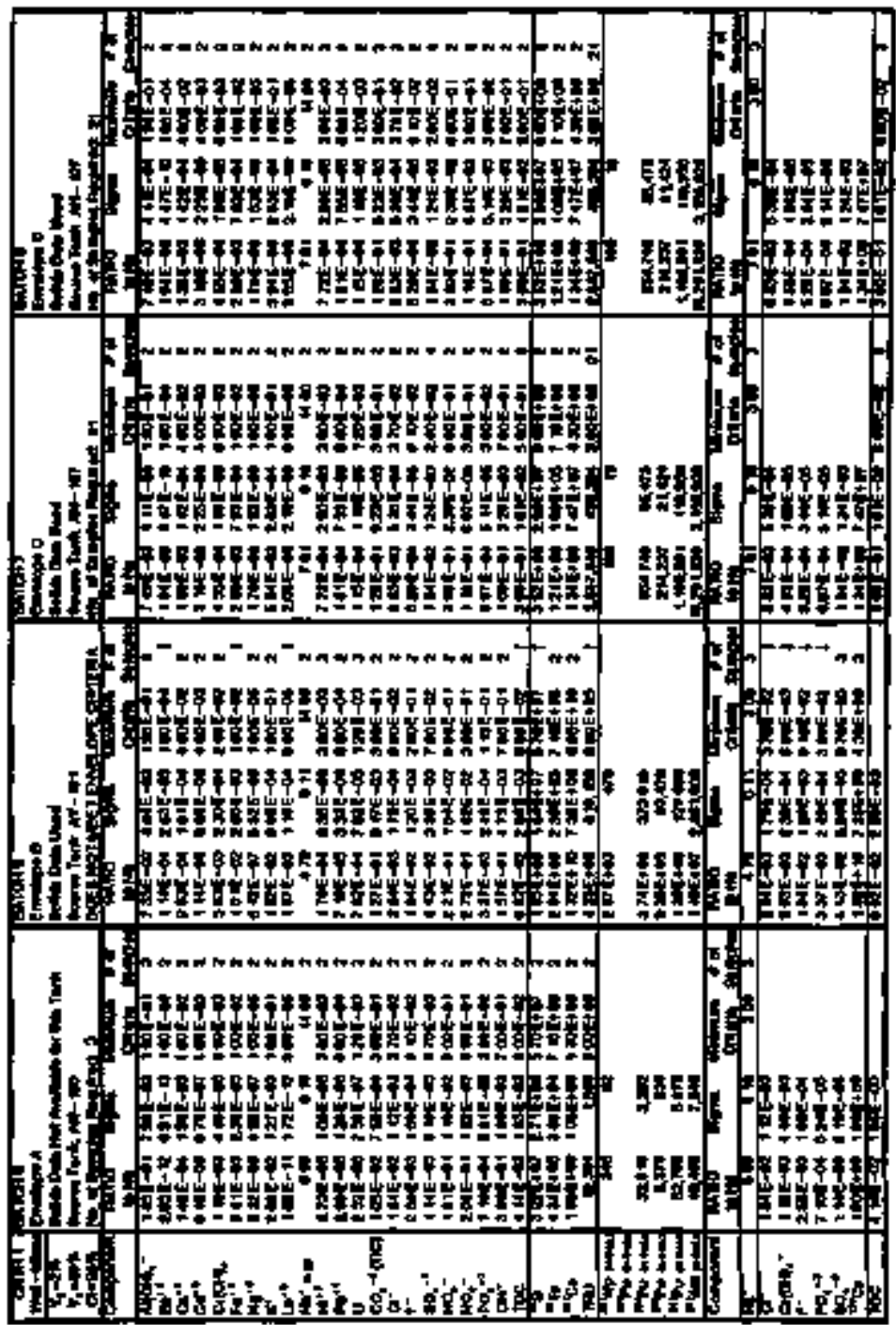


Tshk F-36 Sample Number Cakculauons for Contractor I, Niet|-Muxed. 2 Percent Settled Sollots (Shoet 3 of 3)

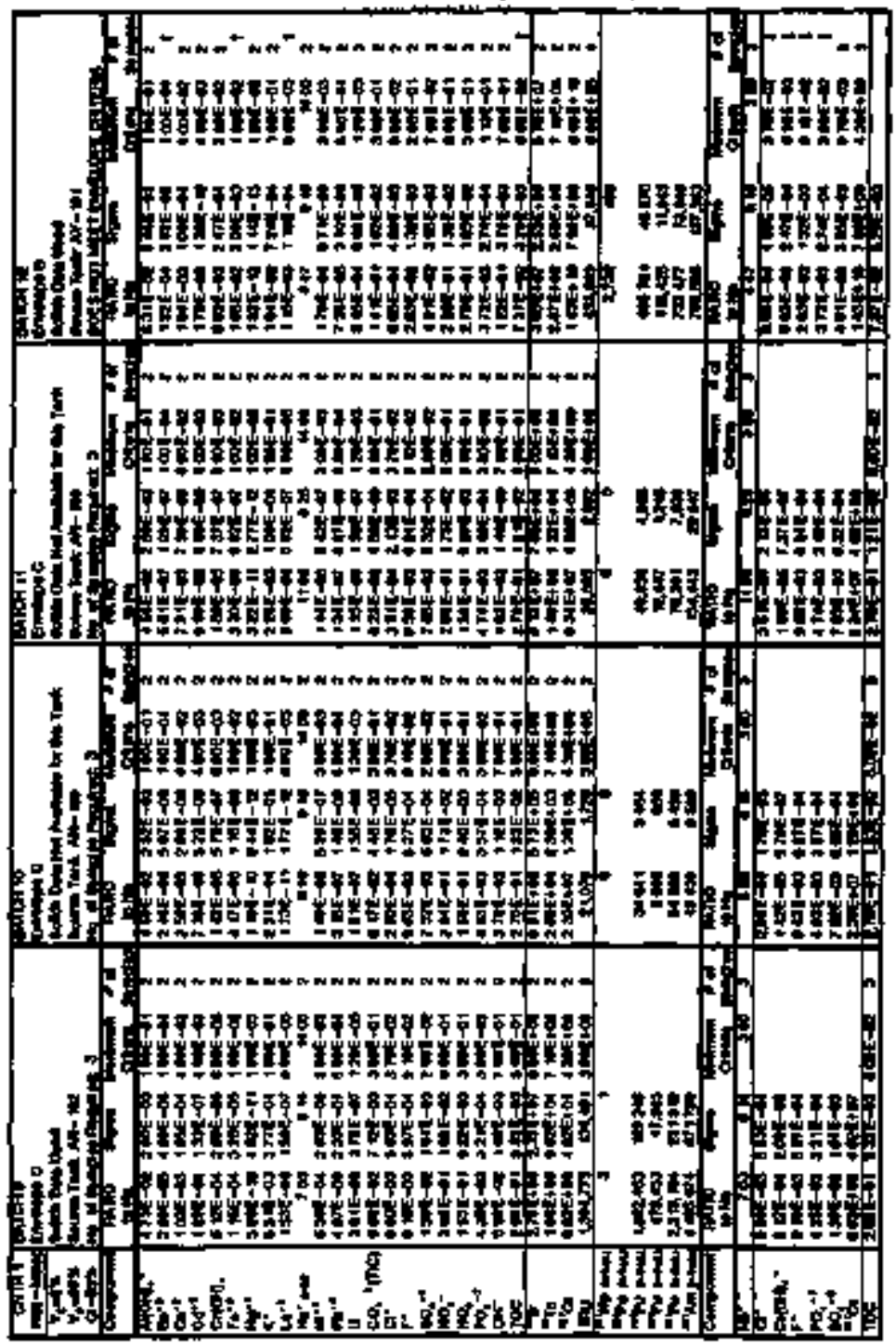

F-64 
HNF-\$D-JWR-AGA-OOI

Revitmon I

Table F-37 Sample Number Calculatans for Cophactor 1, Nal-Mexed, 2 Pacent Seviled Solvds (Sheel 1 of 3 )

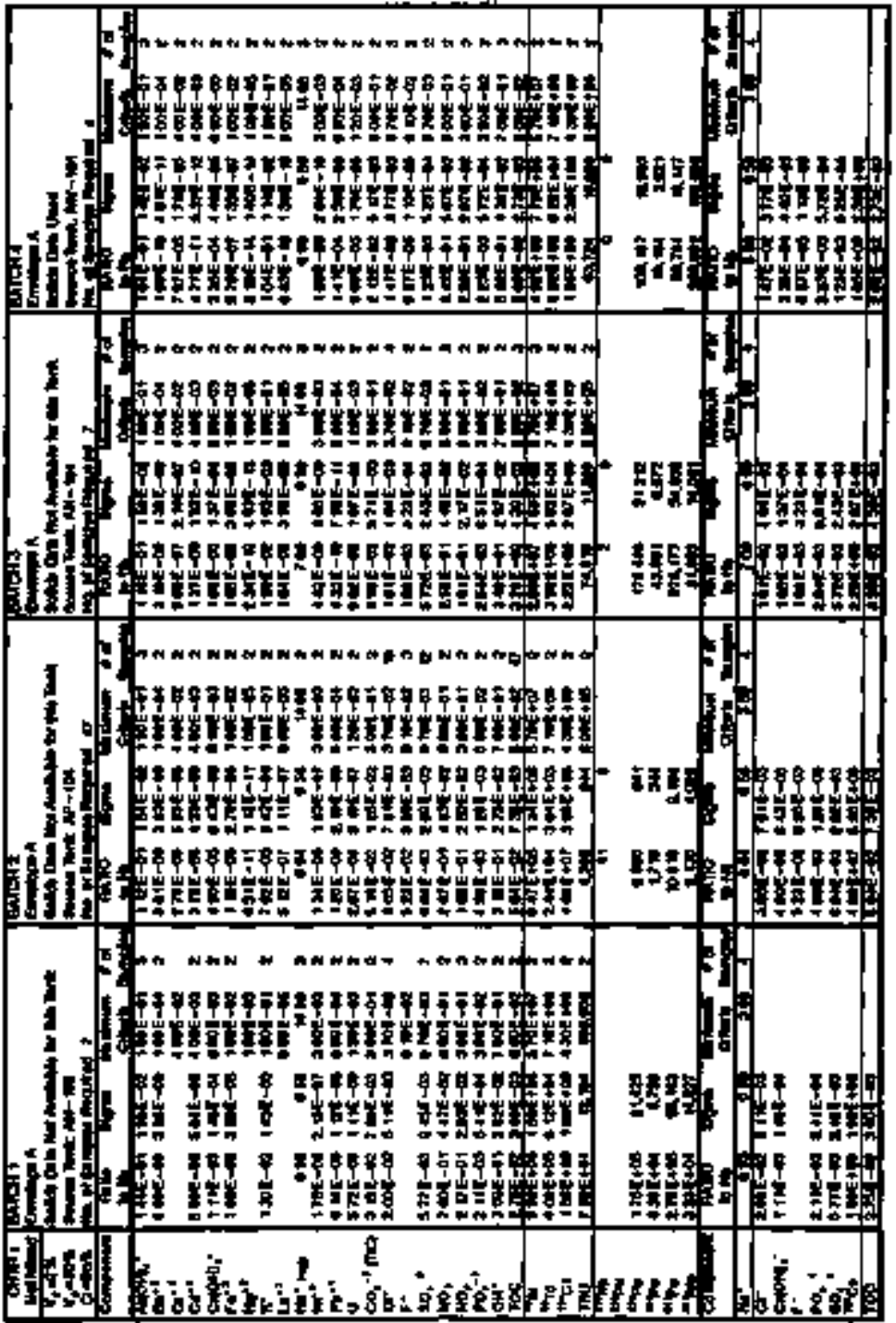


Table F-37 Sample Number Calculaikns tor Contractor I, Not-Muxed, 2 Percent Setted Soldes (Sheet 2 of 3)

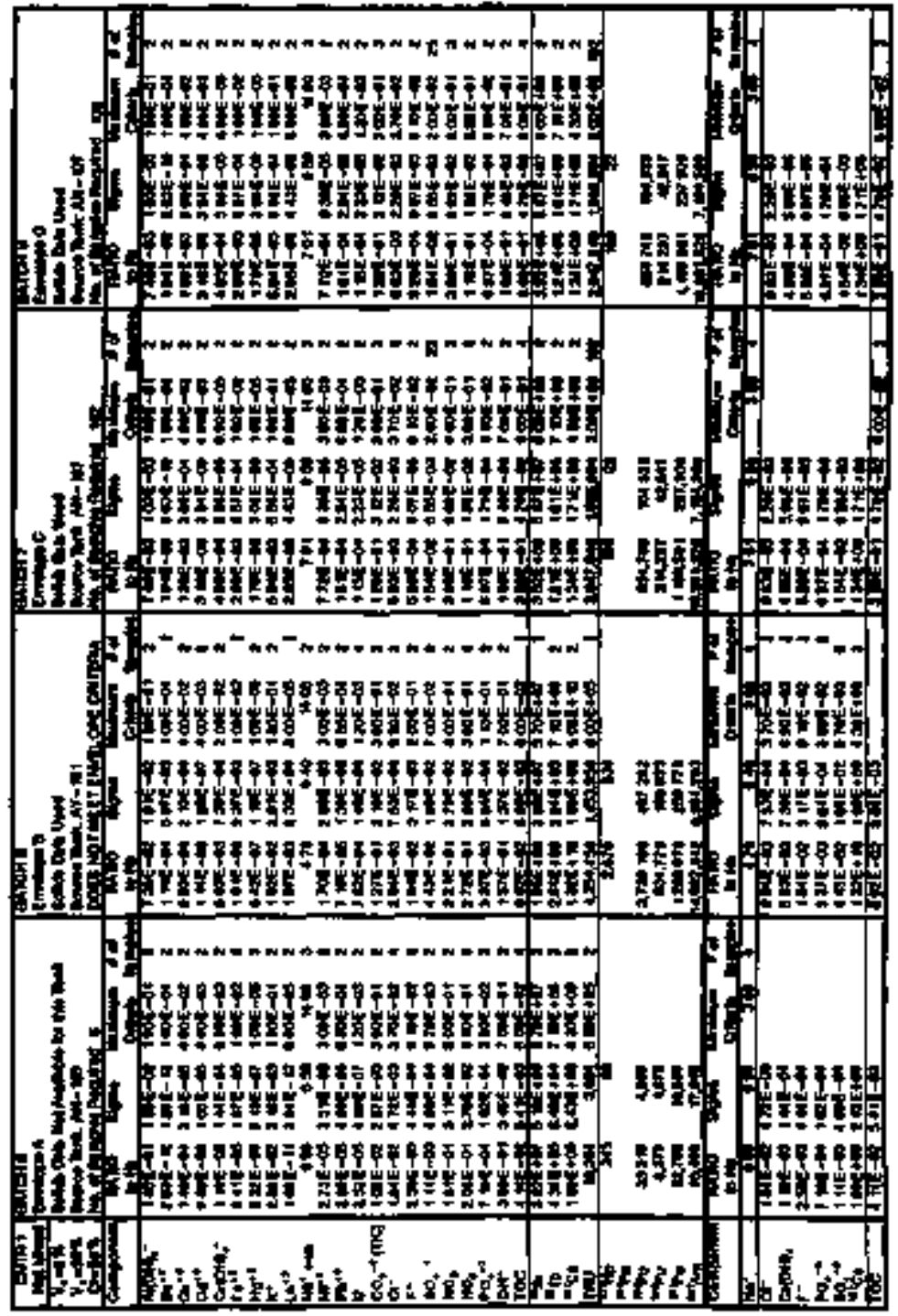




\section{HNF-SD-TWR-AGA-OOOI \\ Revison 1}

Table F-37 Semple Number Calculelions far. Controctor I, Not-hoxed, 2 Percent Setled Solids (Shret 3 of 3)

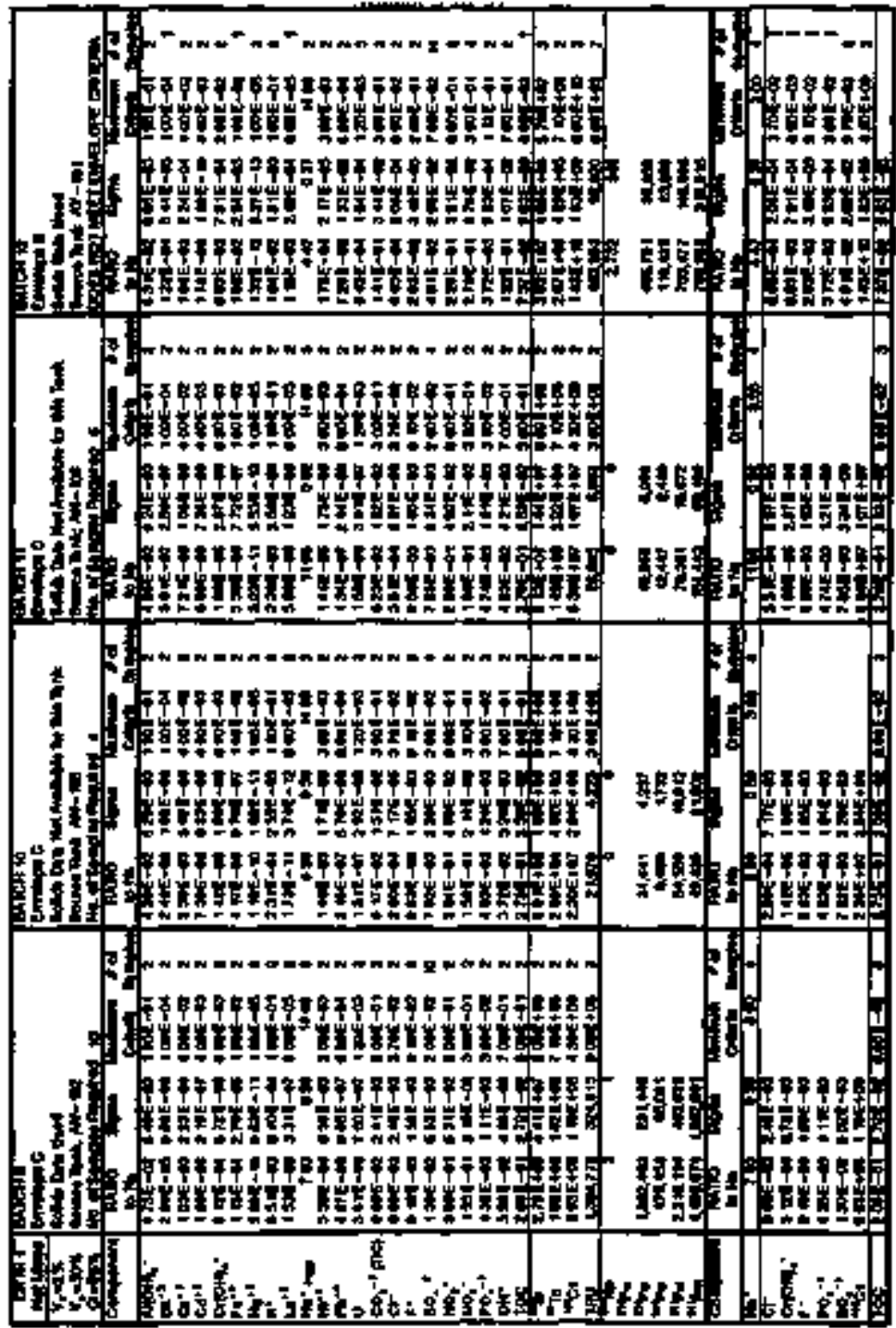


Table F-38 Sample Number Calculations for Conuractor 2, Wetl-Mixed, 2 Percent Selled Solids (Sheet I of 3)

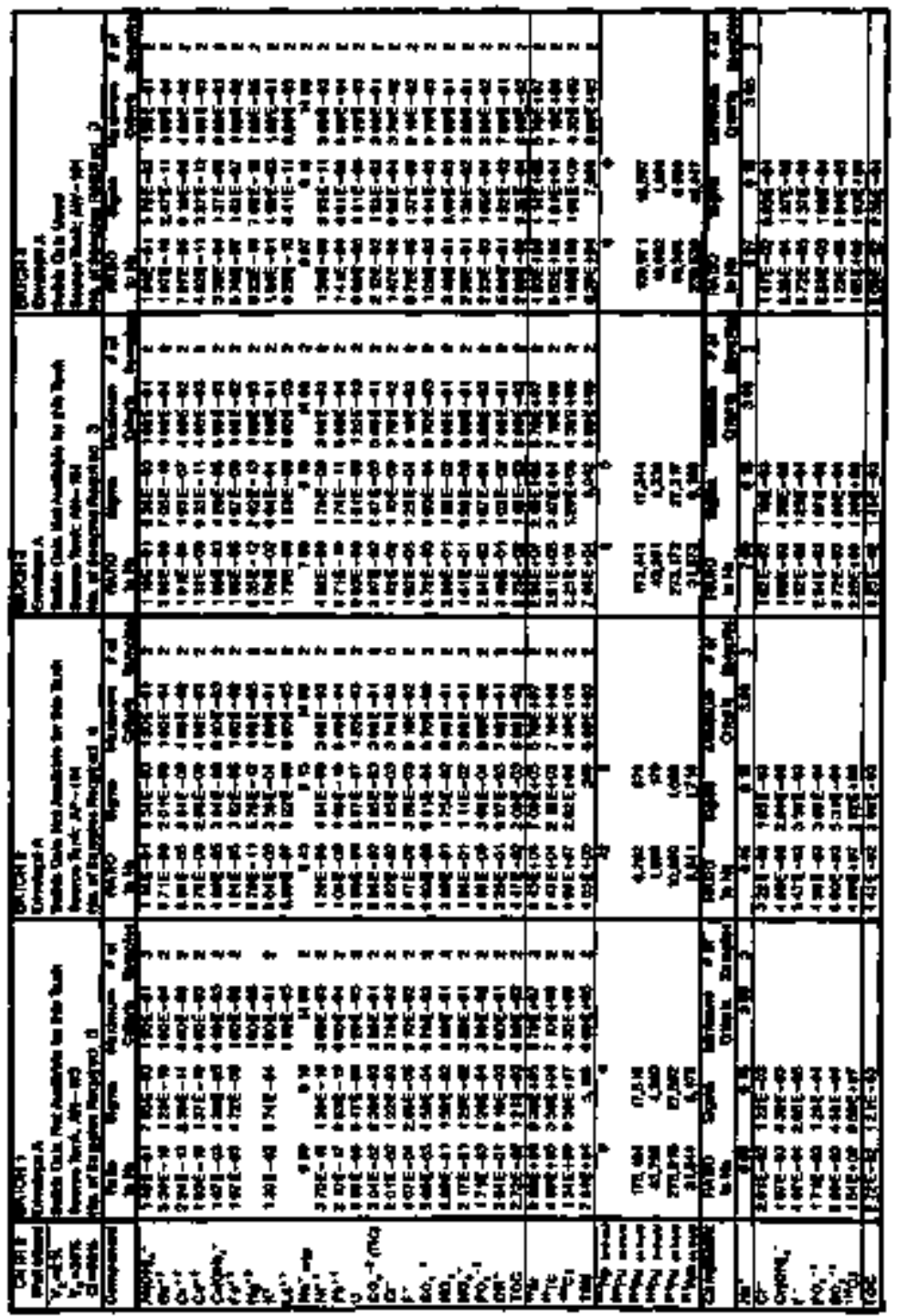


Table F-38 Sample Number Calculabons for Comtnator 2, Well-Mbxed, 2 Pereeul Setuled Soldds (Shen 2 of 3)

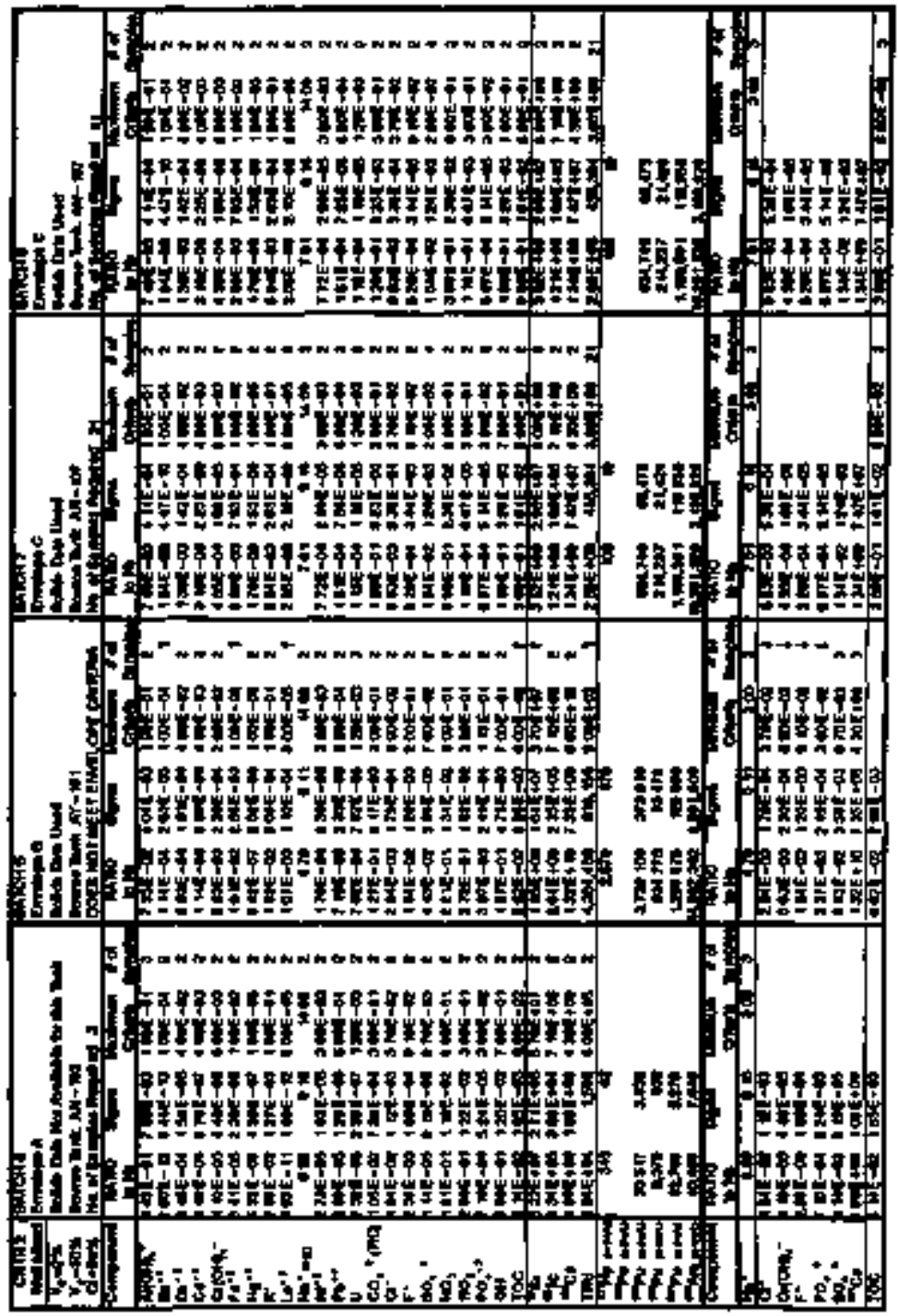


Tabie F-38 Sample Nanter Calcudaions for Contracior 2, Well-Mixed, 2 Pertent Settled Solıds (Sheet 3 of 3)

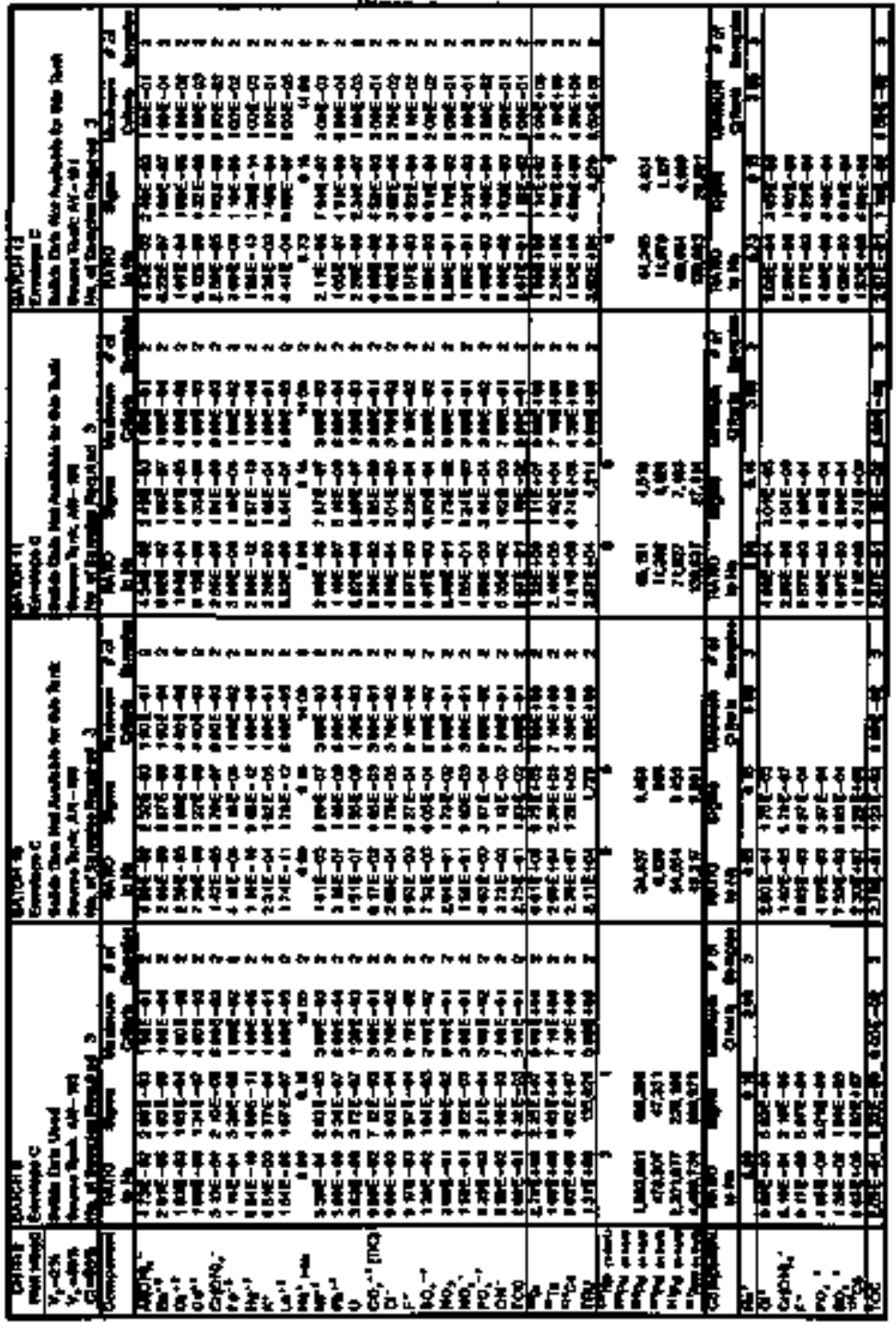




\section{HNF-SD-TWR-AGA-DOI \\ Revison 1}

Tab]e F-39 Sampte Number Calculations for Contractor 2, Not-Mixced, 2 Petrent Setiled Solds (Sheed I of 3)

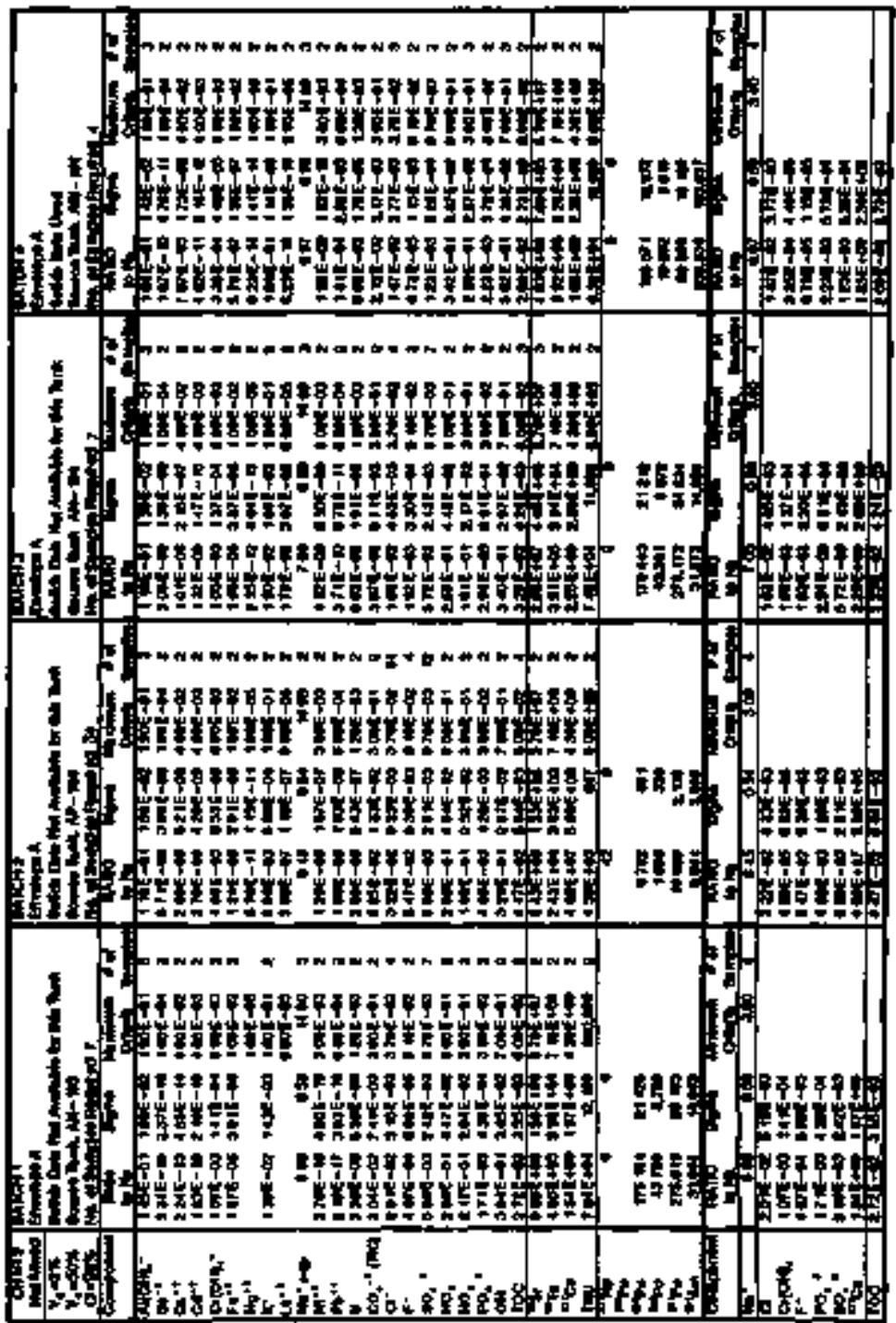




\section{HNF-\$D-TWR-AGA-00] \\ Revisuon 1}

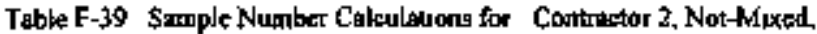
2 Parent Sertked Soluds (Sheet 2 of 3)

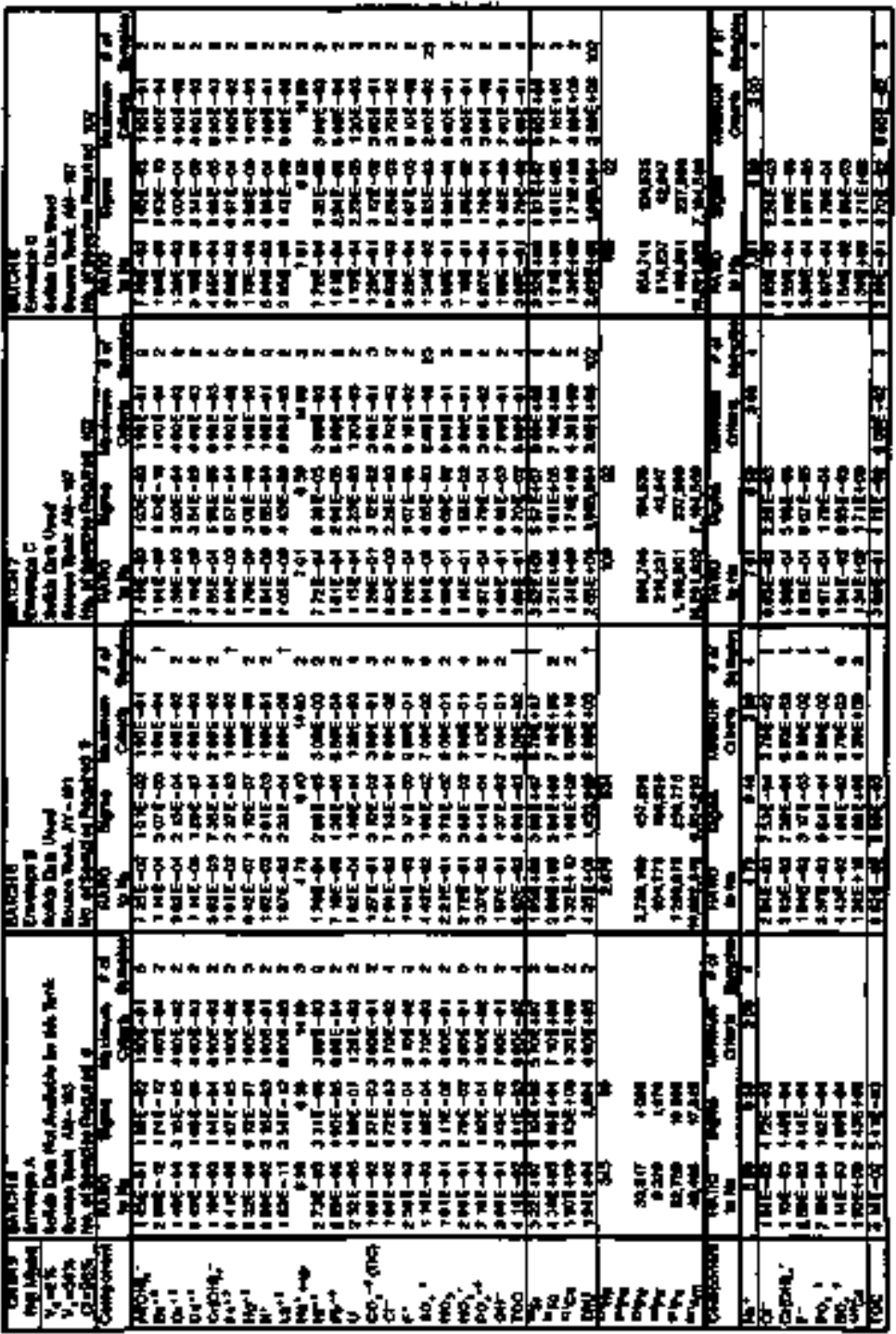


Table F-39 Sample Number Cakulatang for ConLrantor 2, No1-Mrxct, 2 Percent Setiled Soluds (Shetet 3 of 3)

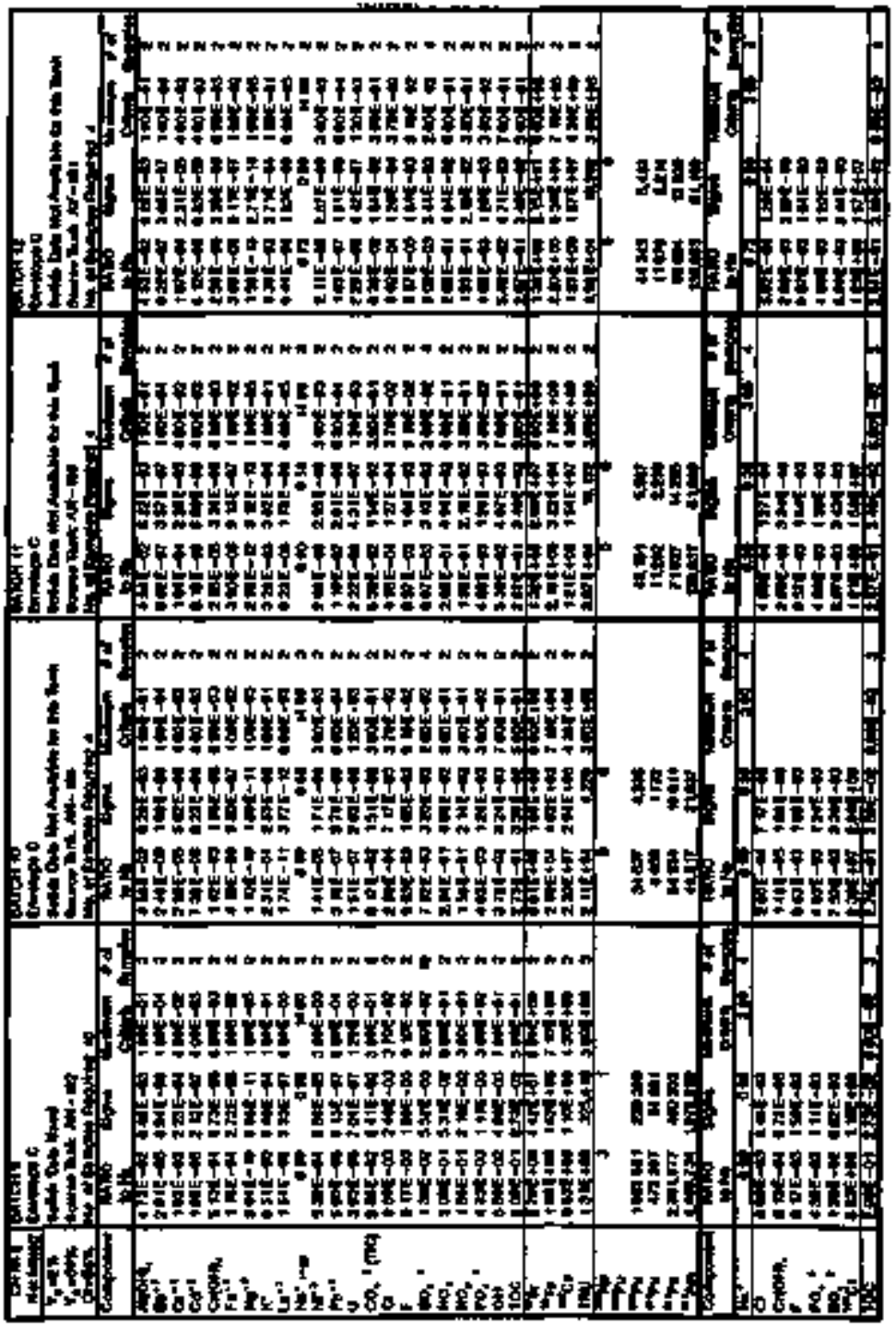


Table F-10 \$ample Number Calculairons for Contractor J, Well-Mixed, 5 Percent Settled Soluds (Sheet 1 of 3)

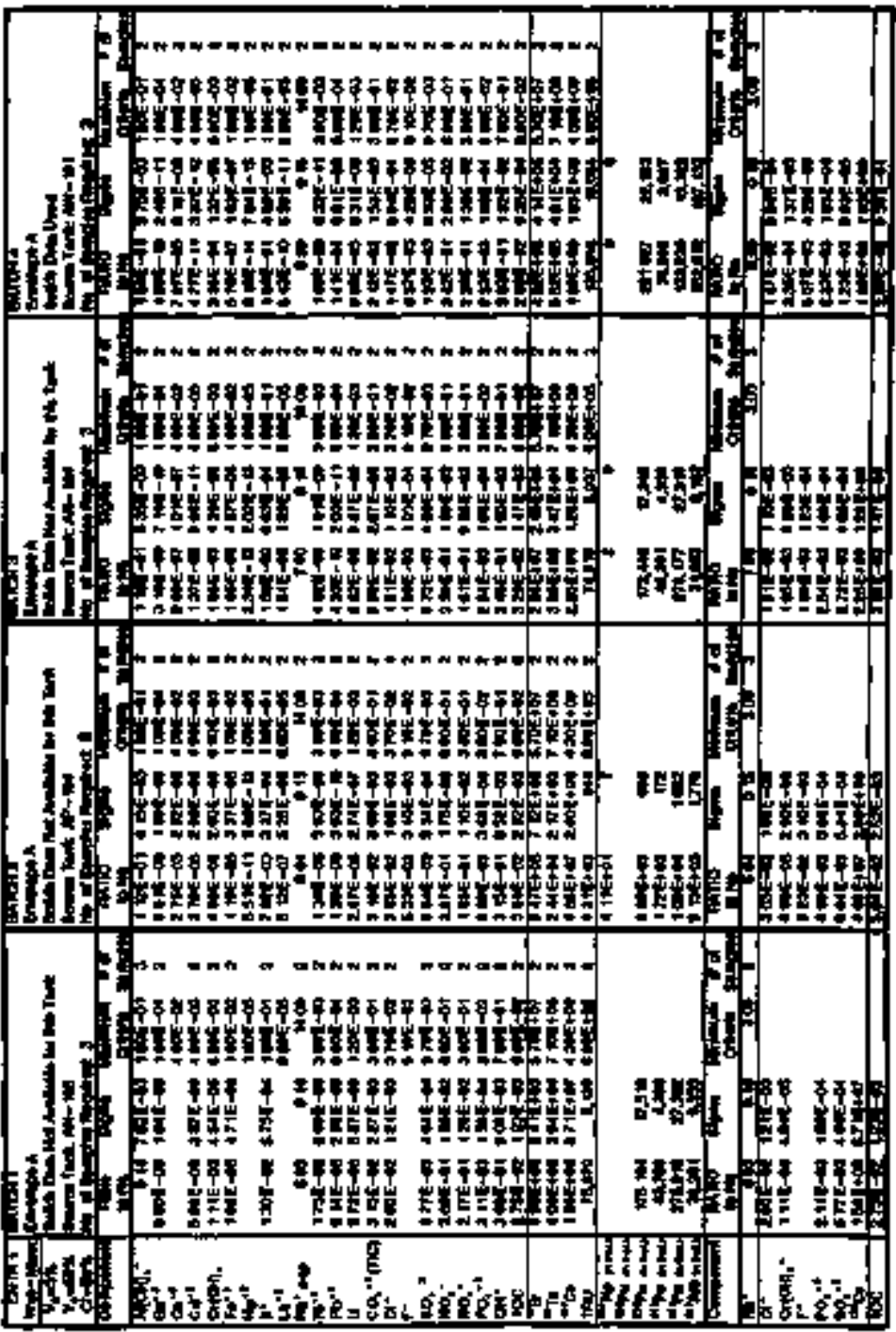


Table F-40 Sample Numiber Coikulauons for Contracler 1, Welt-Muxed, 5 Persent Senled Solnds (Shete 2 of 3)

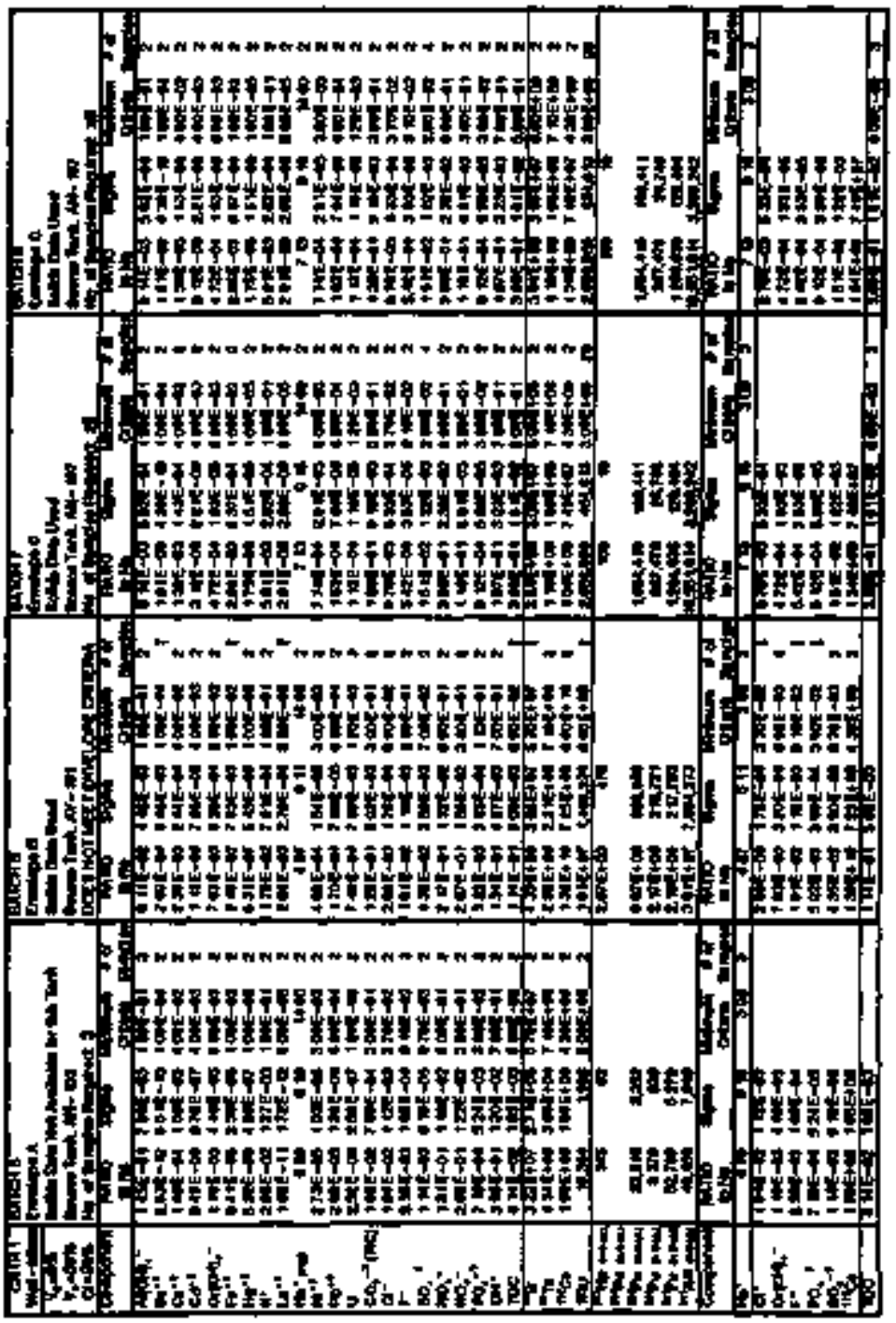


Table F.40 Sample Numbet Calculatrons For Contractor I, Well-Muxed, 5 Percent Settled Saluds (Sheet 3 of 3)

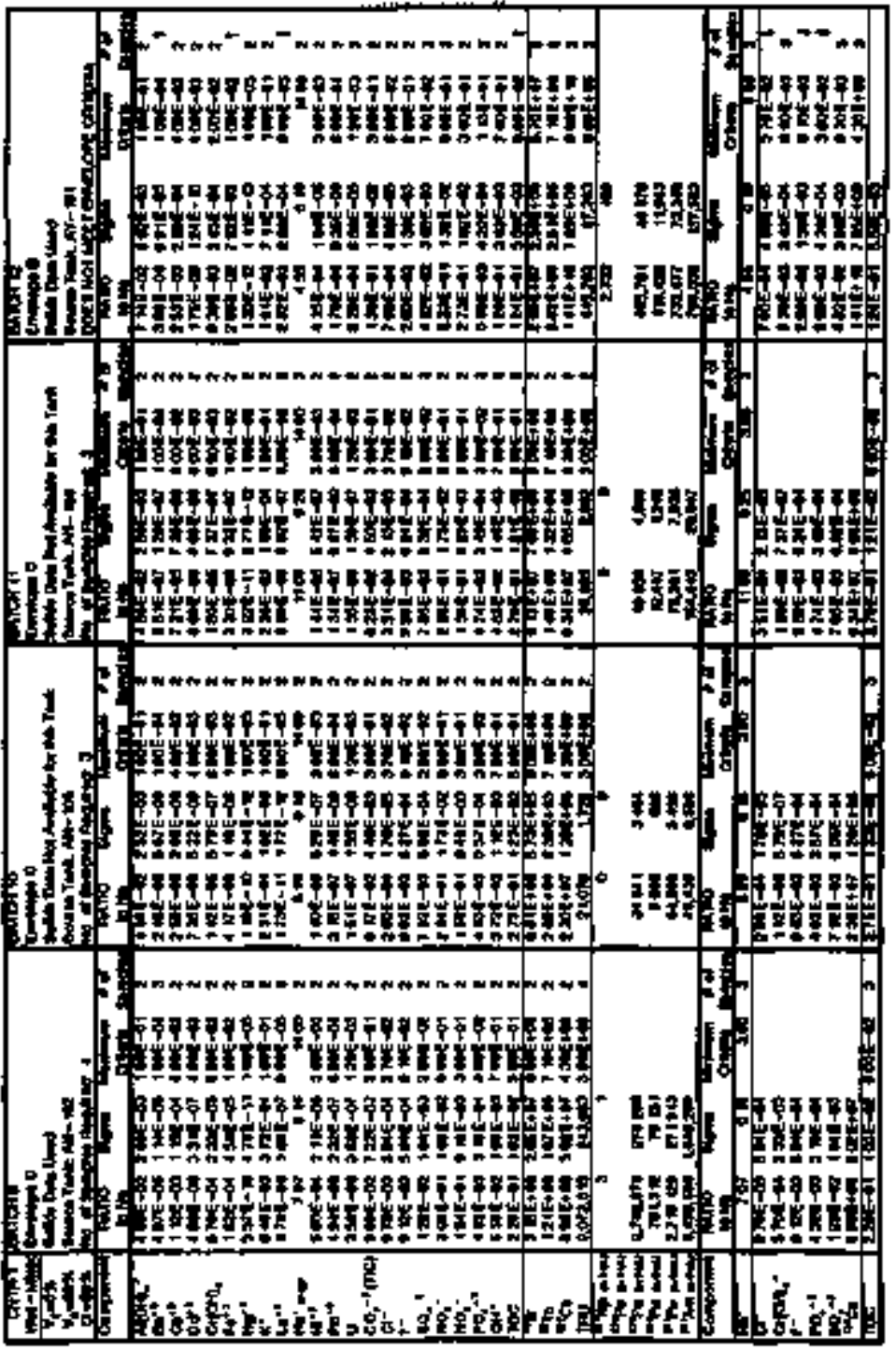


Table F-4I \$ample Number Cakutuonits for Coniractor I, Not-Mix=d, S Percent Settled Soldes (Sheet I of 3)

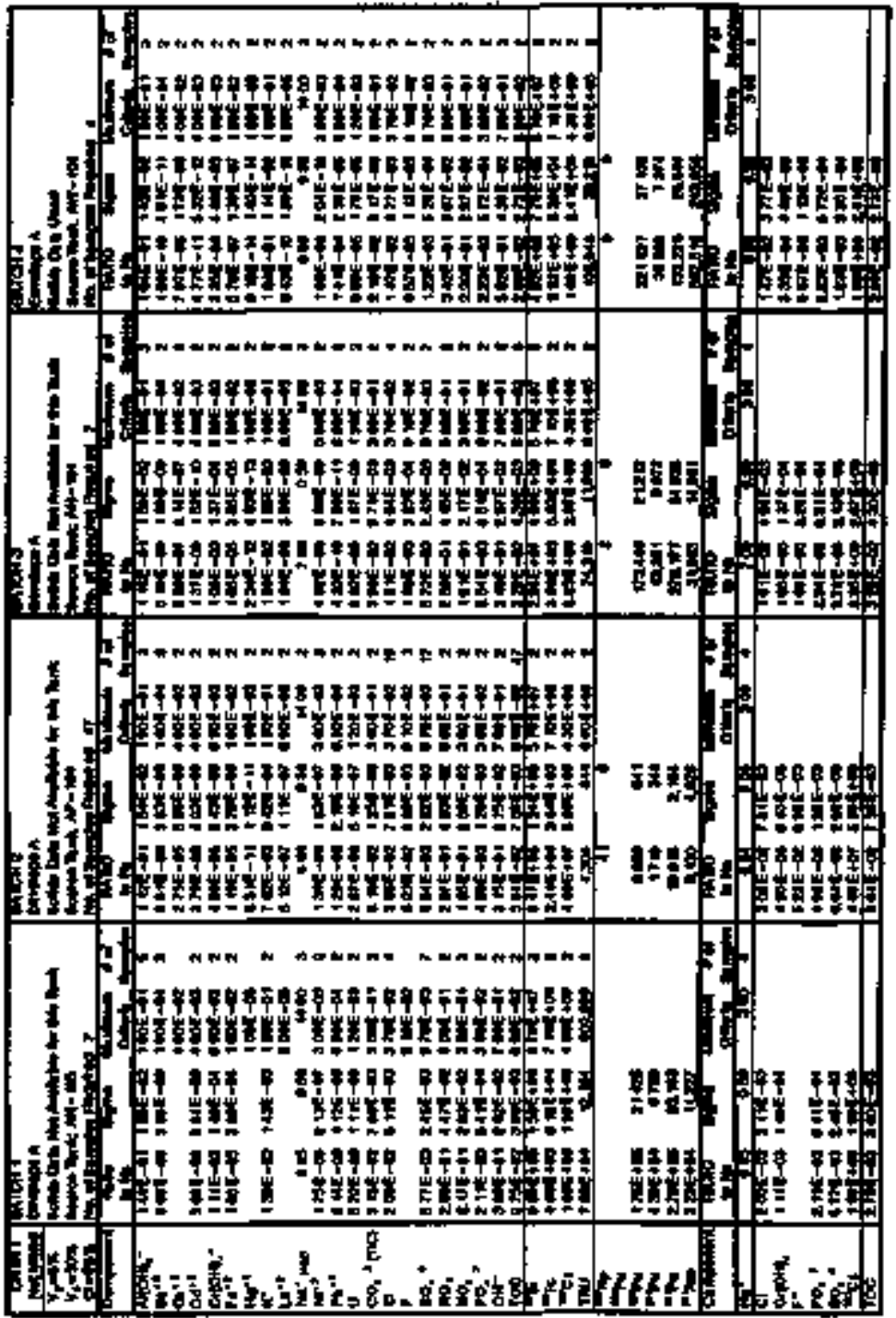




\section{HNF-\$D-TWR-AGA-00I \\ Revasaon I}

Toble F-4I Sarpple Number Cakculaulans for Contractor I, Not-Mened, 5 Pereend Settlent Solids (Sheat 2 of 3)

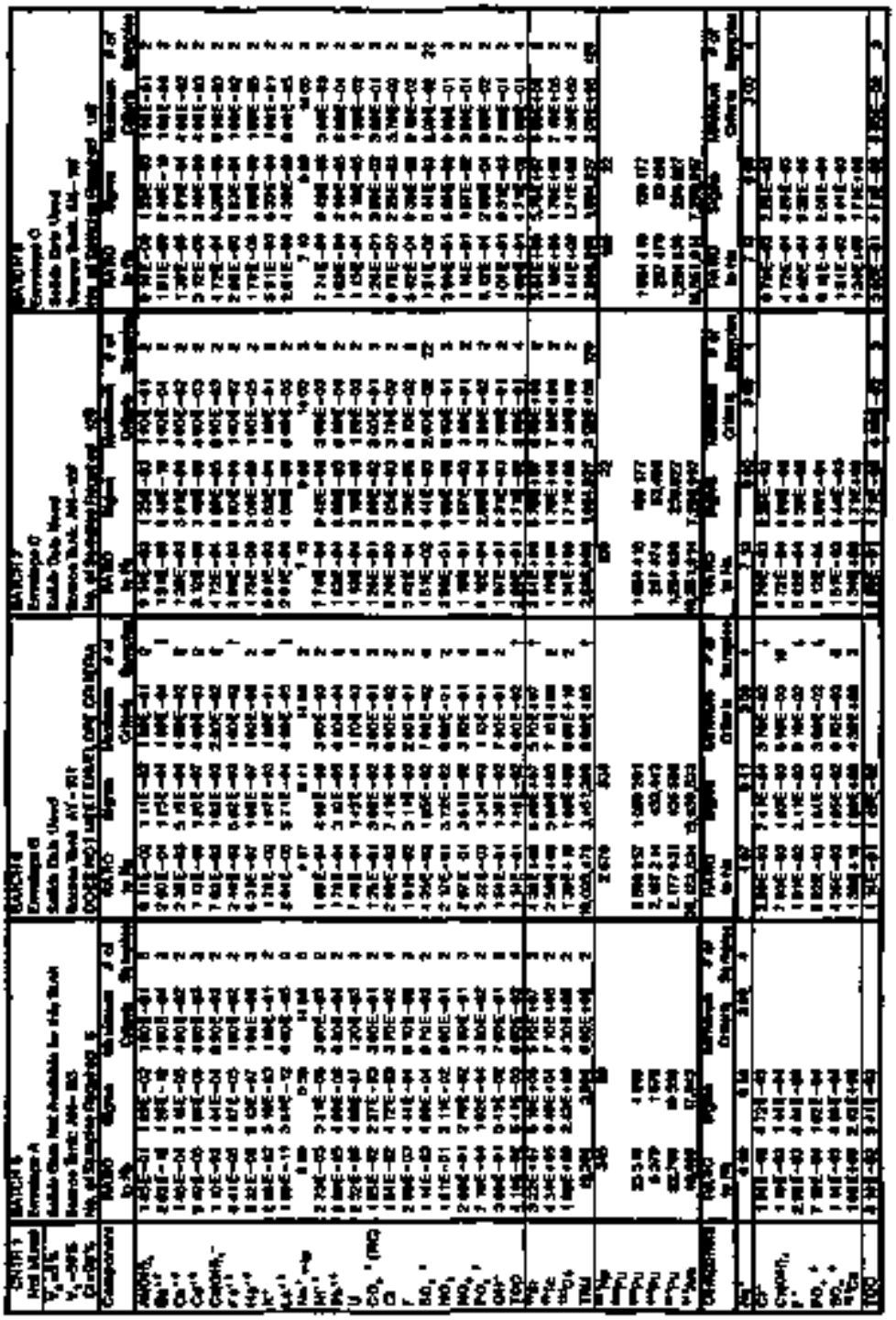


Table F-41 Sempte Number Calculations for Contractor I, Not-Muxed, 5 Percent Setuled Soluds (shoes 3 of 3 )

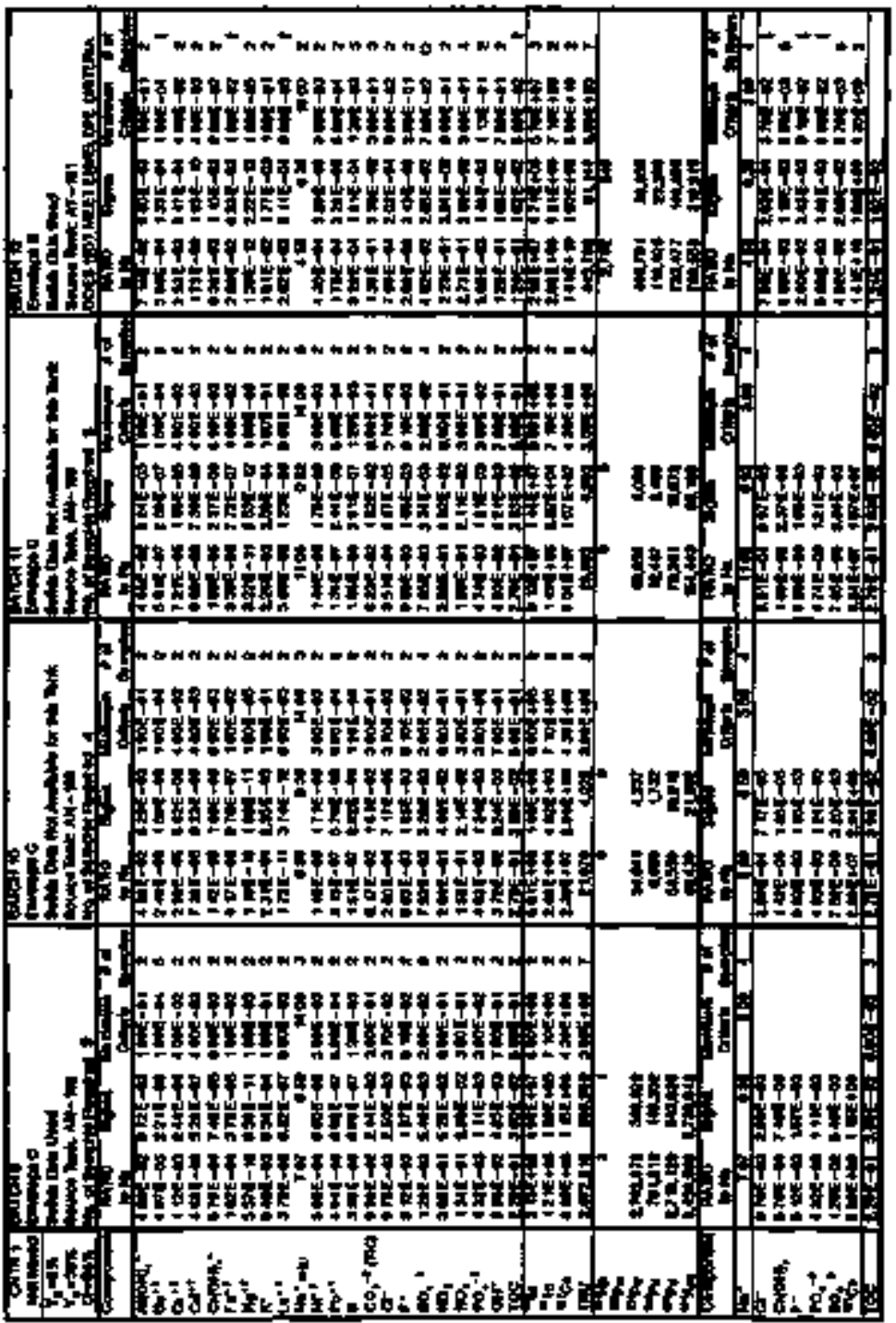


Table F-42 Saruple Number Calculnurons for Contractor 2, Well-Mixed, 5 Peroert Sonted Solids (Sheat 1 of 3)

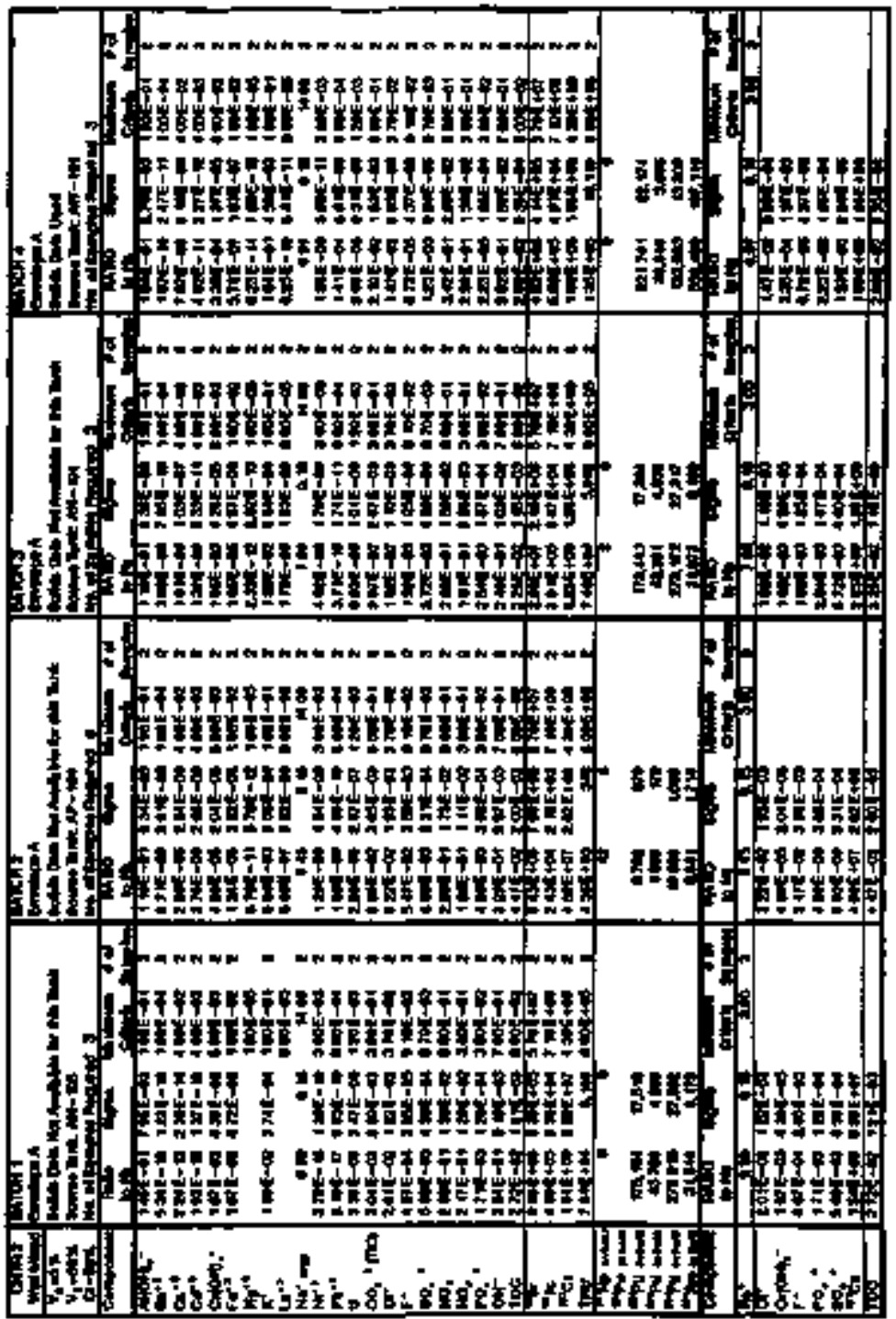


Table F-12 Sumple Number Caleulatons for Contricion 2 , Well-Maxed, Percent Sottled Solids (Sheet 2 of 3)

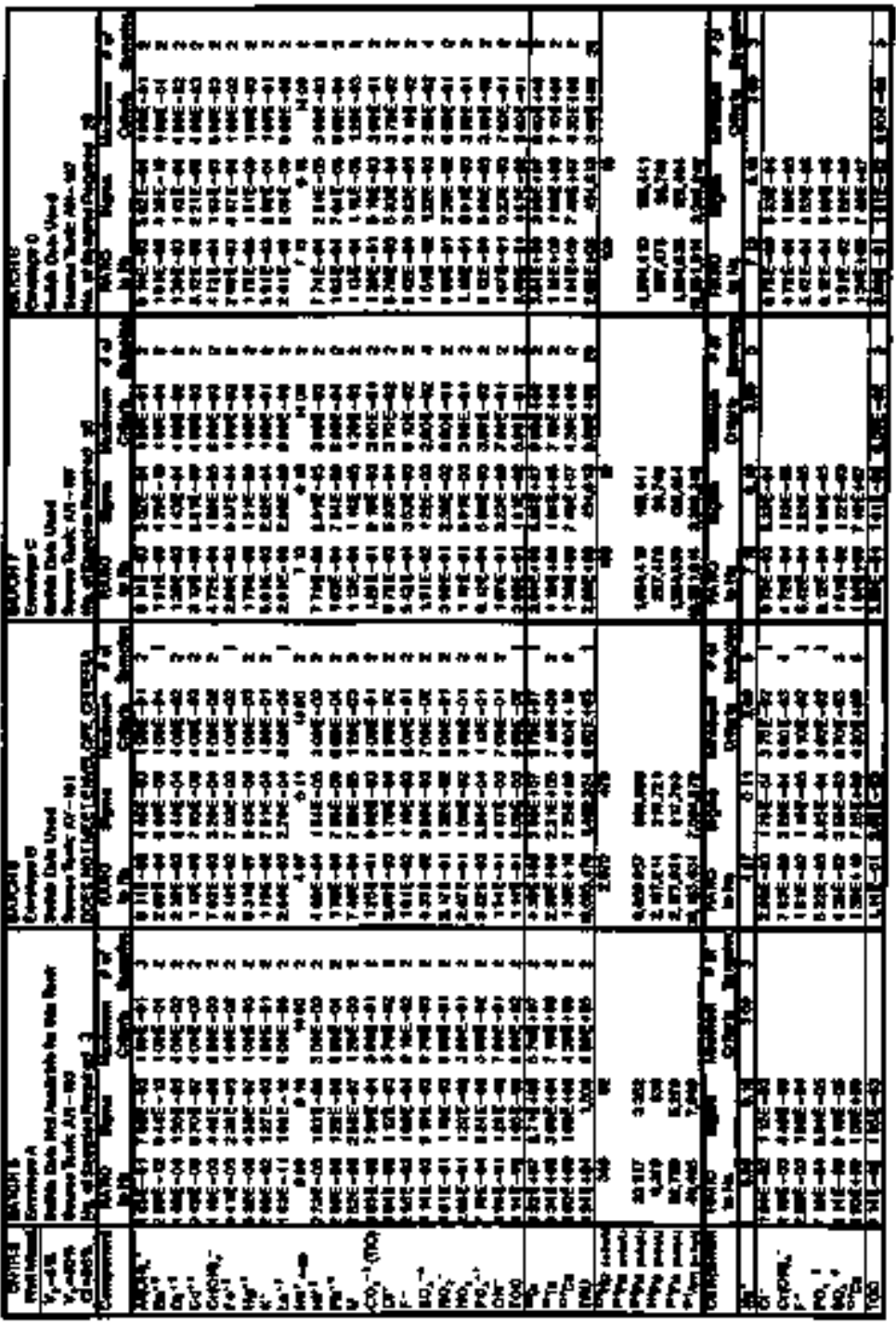


Tabie F-42. Sampde Number Calculaions for Contricton 2, Wetl-Mıxed.

Percent Settled Solids (Sheert 3 of 3)

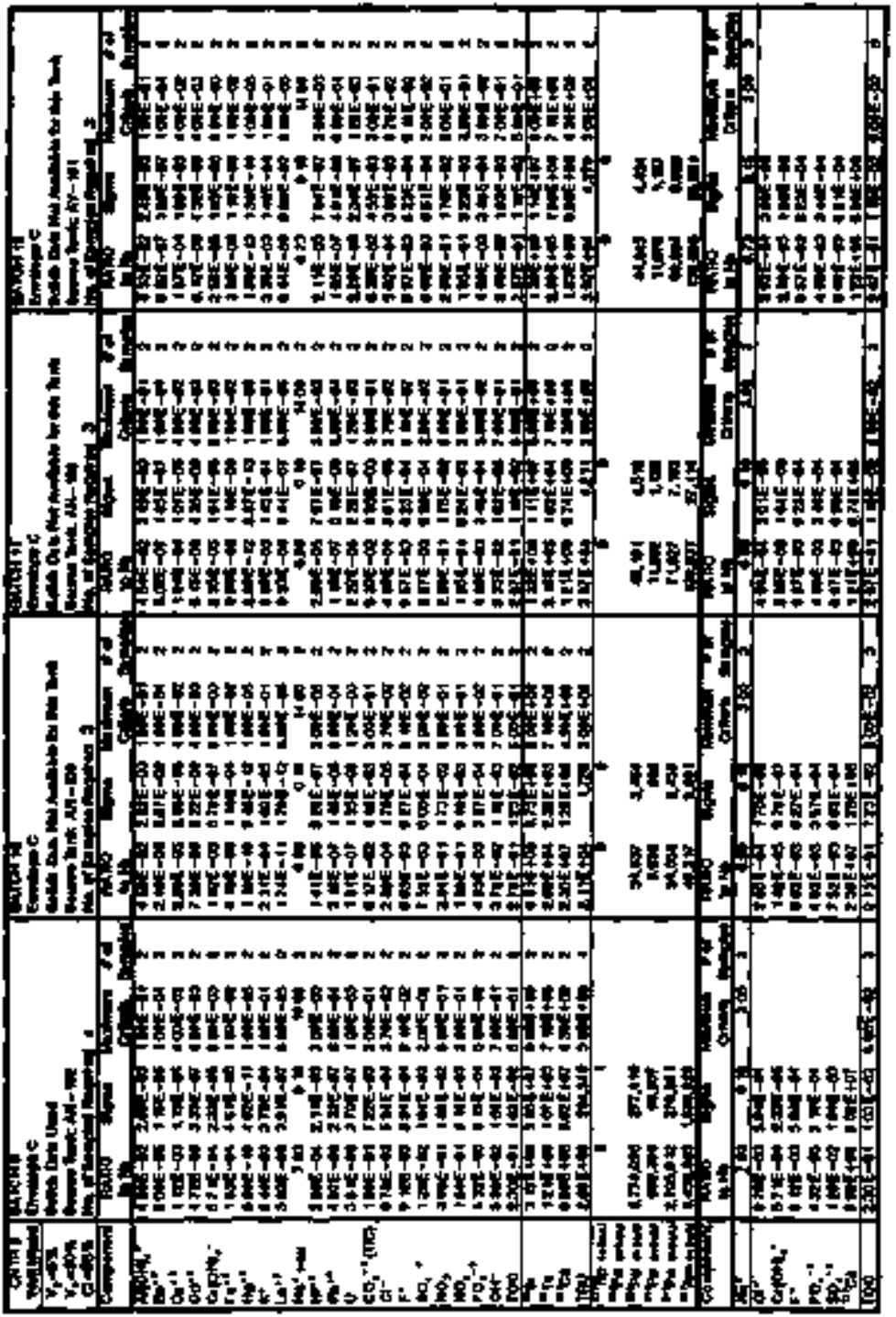


Tabte F-43 Sumple Number Calculatons for Contustor 2, Not-Mexed, 5 Percent Settied Solvas (Sheet I of 3)

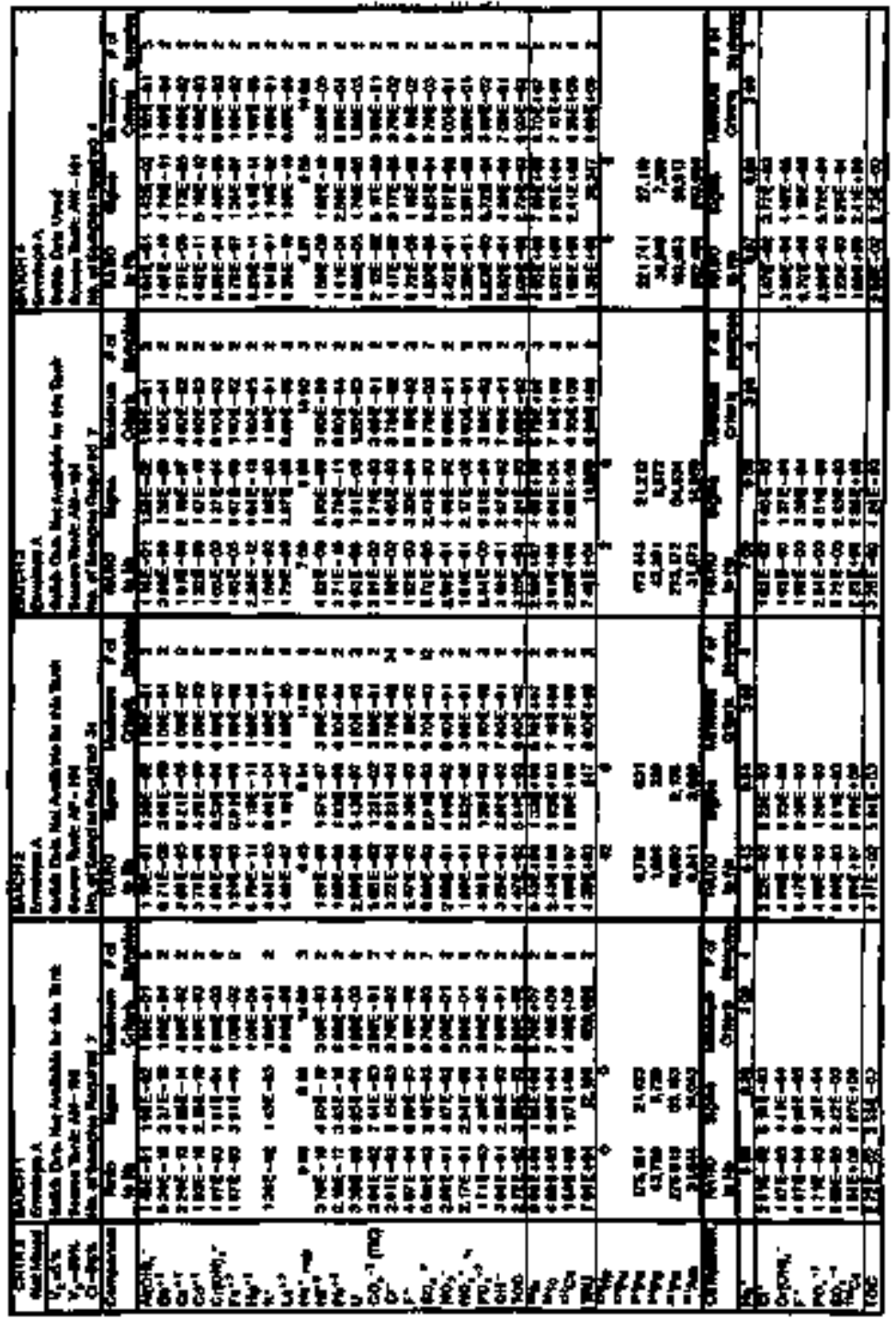


Table F-\$3 Sample Number Calculanong for Contractor 2, Not-Huxed, 3 Percem Setiked Soldss (Shee1 2 of 3)

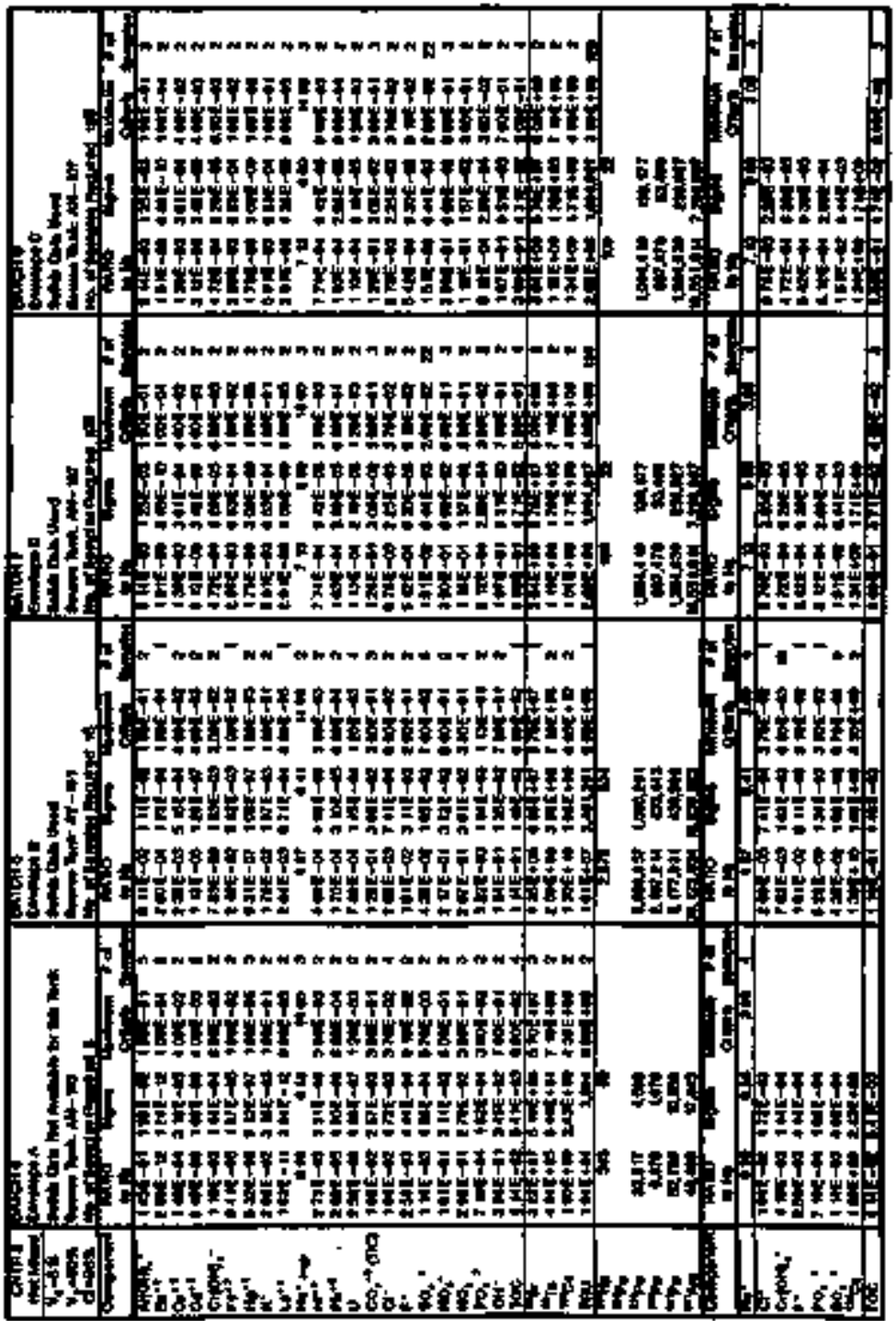


Table F-43 Stmple Nomber Calculatongs for Contractor 2, Not-Mlxed, 5 Ptounl Settled Solıds (Shoet 3 of 3)

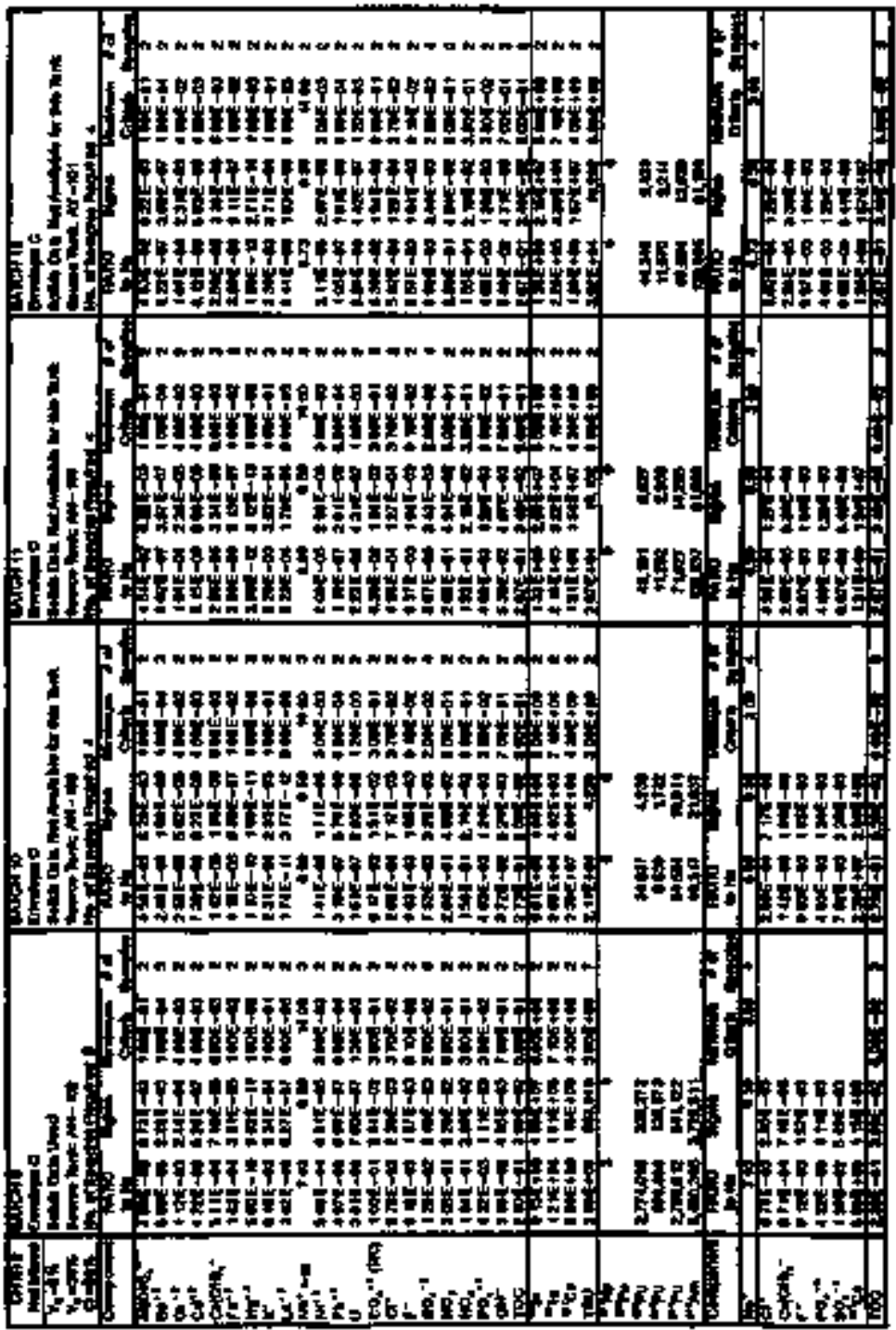


HNF-SD-TWR-AGA-001

Revision I

This parse intenlionodly lefi biank. 
HNF-SD-TWR-AGA-OOI

Rovision 1

P6.0 NOMENCLATURE

\begin{tabular}{|c|c|}
\hline $\begin{array}{l}C_{r}^{y} \\
c_{r}^{r}\end{array}$ & 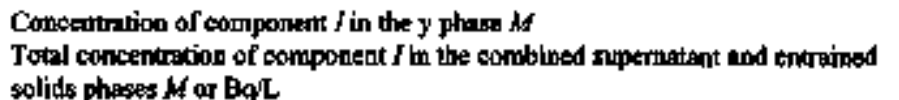 \\
\hline & Comsentrition of corsporvent / in the supersatant phase $M$ \\
\hline & 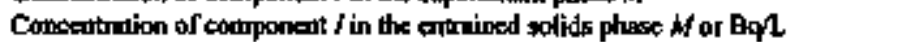 \\
\hline $\mathbf{C}_{r}^{L}$ & Concentration of ndionuclide $r$ in the supemainet phese $\mathrm{Bq}$. \\
\hline & Consertitution of sodium $M$ \\
\hline $\mathrm{E}_{1}$ & 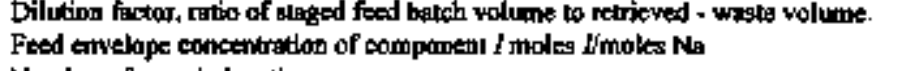 \\
\hline I & Number of sample beotions. \\
\hline$M$ & Mass of companem I in the batch MT \\
\hline M. & 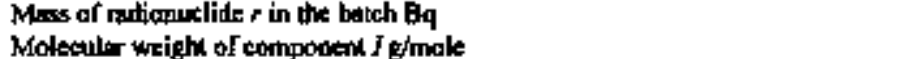 \\
\hline & 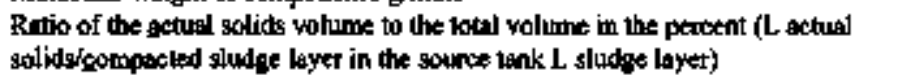 \\
\hline os or $V_{s}$ & 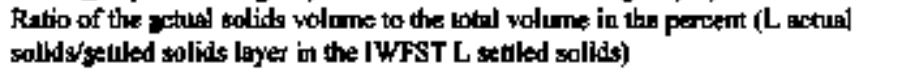 \\
\hline $\mathbf{R}_{\mathbf{T}}$ & $\begin{array}{l}\text { Ralio of the componenl I cupcentration to the sodium naoks Himoles } \mathrm{Na} \text { or } \\
\text { conceptration. Be rimoles } \mathrm{Na}\end{array}$ \\
\hline & $\begin{array}{l}\text { Maximum pernissible nutio of the settled solids leyer volume persent (L gettled } \\
\text { solids/lo the feed beteh valume L Feed) }\end{array}$ \\
\hline & $\begin{array}{l}\text { Ralio of the setliced solids layer volume to the feed betch percent (L setlled } \\
\text { solids'volume } 1 \text { Feed) }\end{array}$ \\
\hline & 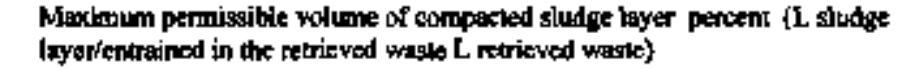 \\
\hline BD; & Ratio of RSD, to RSD \\
\hline & Relative Sandard Deviation of the launcentration for the $x$ scensrie percetit \\
\hline & Sample Nunker samples \\
\hline & Stal Ratio for component $f:$ \\
\hline$v_{E S}=$ & Maxisum yolume of sudge iayer that can be entrained MR \\
\hline $\begin{array}{l}V_{\pi} \\
V_{a r j}\end{array}$ & 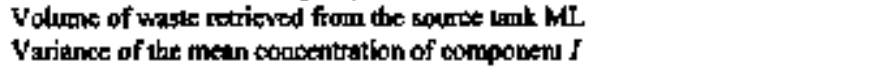 \\
\hline & Meain conkentration of componeat I S or BqL \\
\hline
\end{tabular}




\section{HNF-\$D-TWR-AGA-001}

\section{Revision 1}

\section{Greek Lettera}

a Type l trrox, single-sided tesd

* Type I error, double-sided logl used for sodium

f Type 2 error, singlesided tegt

d. Standard deviation in the sampling and analysis for component I.

\section{Subsertipt}

I Component / (arabyls, rudionaclide, or transuranic rafionuclide)

7 Raviomuelider

No Sodium

1 Transurtic radionuclide 1

TRU Tranguranics

Sipencriph

C Combined sapetrinut and entrained solids phoses.

L Superoatait (liquid) phase.

mar Maximum

now Not-Mixed Scetionio

$\$$ Entroined solids phase.

wh Wedl-Mixed Scennirio.

I Ejther the "Nor-Mixed" (nm) or "Well-Mixed" (wm) seenario. 
HNF-SD-TWR-AOA-601

Revision I

F7. ROTERENCES

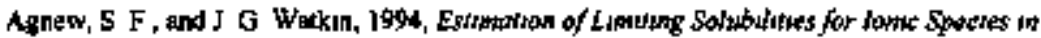

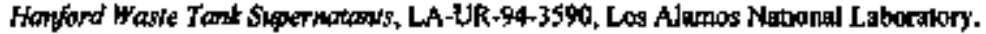
Los Alimos, New Blexico

Cerka, 9 J, W H Grams, C M McConvillo, L W Shehon, and E I Slanhaug, 1996, LowLevel Warte Feed Stagning Plar, WHC-SD-WM-RPT-224, Rev 0, Westenghouge Hanfond Company, Rehlout, Wachngion

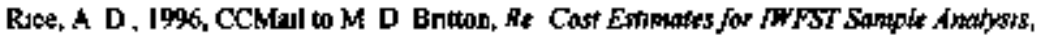
Augusı 8, 1996, Westmghouse Hanford Company, Ruchland Washupgton

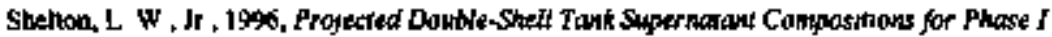

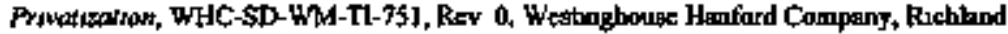
Washungton

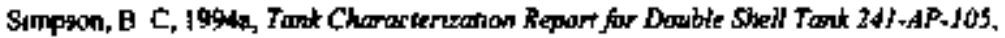
WHC-SD-WM-ER-358, Rev 0, Wetunghouse Hunford Company, Ruthlond Washington

Simpson, B C, 1994b, Tank Chavacterkattan Report for Double Shelf Tank 26/,AP-J02, WHC-SD-WM-ER-360, Rev 0, Wegunghoure Hanford Company, Ruchland Washngton

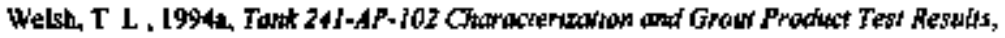
WHC-SD-WM-TRP-168, Rov 1, Wesunghouge Ganford Company, Ruchland, Wushngk

Welsh, T L , 1994d, Tauk 24I-AR-105 Charactertation and Graw Praduct Test Ressits,

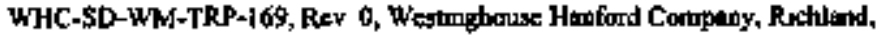
Wachupgton 


\section{HNF-SD-TWR-ABA-0OI}

Revision I

This page inkakiannlly keft blenk. 


\section{OISTAIBUTION SHEET}

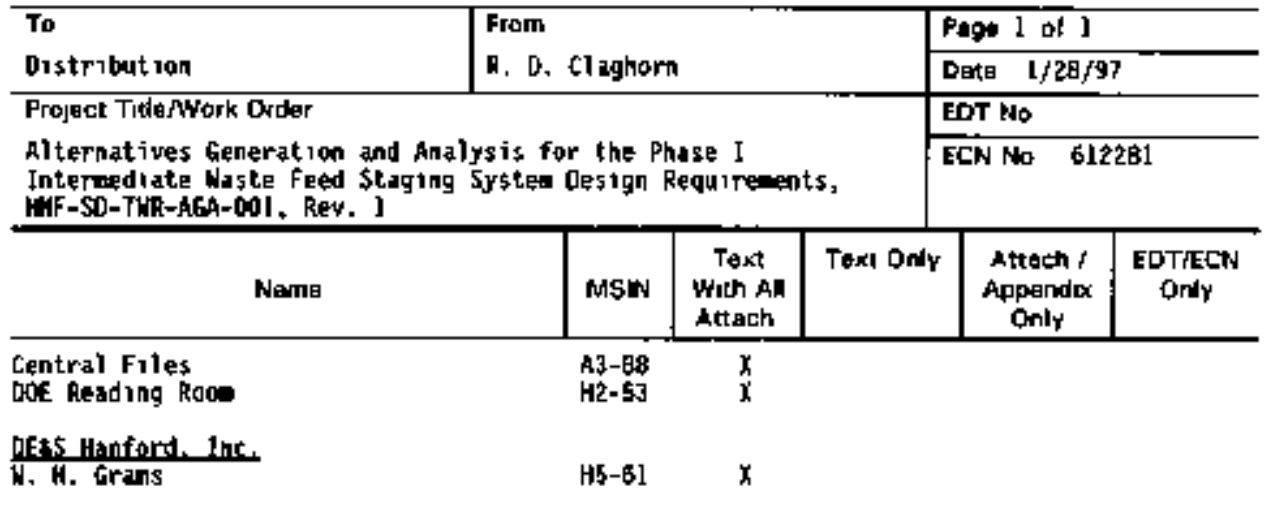

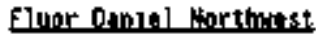

\$. K. Baker

P. Fellise

H5- $99 \quad x$

I B. 5alzano

B4-55

G3-12

$\stackrel{x}{x}$

Lockheed Martin Hanford Coraoration

D. C Balde

T W. trawford

$\$ 2-48 \quad x$

K. A. Gasper

A. F. Manue 1

H5- 49

63-21

H5- 61

G. A. Meyer

\$2-48

R. J, Murkowsk 1

w. J. Powell

H5- $-\mathrm{DJ}$

S? -48

E. J. Slaathang

H5-49

Humetec. Hanford Corrorstion

P. J, Certa

R. D. Ejaghorn

J. D. Galbraith

J. S. Garfield

Q. L. Lamberd

R. P. Marshal1

J. E. Yan Betk

H5-61 $x$

H5-49

H5-49 $\quad x$

H5-49 $\mathrm{x}$

H5-61

H5-61 $x$

S6y Eurdsys Seruaces tornorrtion

\begin{tabular}{|c|c|}
\hline $\begin{array}{l}\text { K. W. Eagor } \\
\text { C. E. Grenard } \\
\text { G. T. Macloan } \\
\text { D. E. Place }\end{array}$ & $\begin{array}{l}\text { H5-27 } \\
\text { H5-61 } \\
\text { H5-61 } \\
\text { H5- } 27\end{array}$ \\
\hline
\end{tabular}

U 5. Departent of Enemr-Richland Oostrituons

J] Daris

T R. Hoertkorn

B. L. Neoll

M. L. White

$57-53$

64-55

$57-53$

64-55

$x$
$x$
$x$
$x$
$x$
$x$
$x$ 